Fall 1984

\title{
1984 Miracle Yearbook
}

Cedarville College

Follow this and additional works at: https://digitalcommons.cedarville.edu/yearbooks

Part of the Higher Education Commons, Organizational Communication Commons, and the Public Relations and Advertising Commons

\section{Recommended Citation}

Cedarville College, "1984 Miracle Yearbook" (1984). Yearbooks. 58.

https://digitalcommons.cedarville.edu/yearbooks/58

This Book is brought to you for free and open access by DigitalCommons@Cedarville, a service of the Centennial Library. It has been accepted for inclusion in Yearbooks by an authorized administrator of DigitalCommons@Cedarville. For more information, please contact digitalcommons@cedarville.edu. 


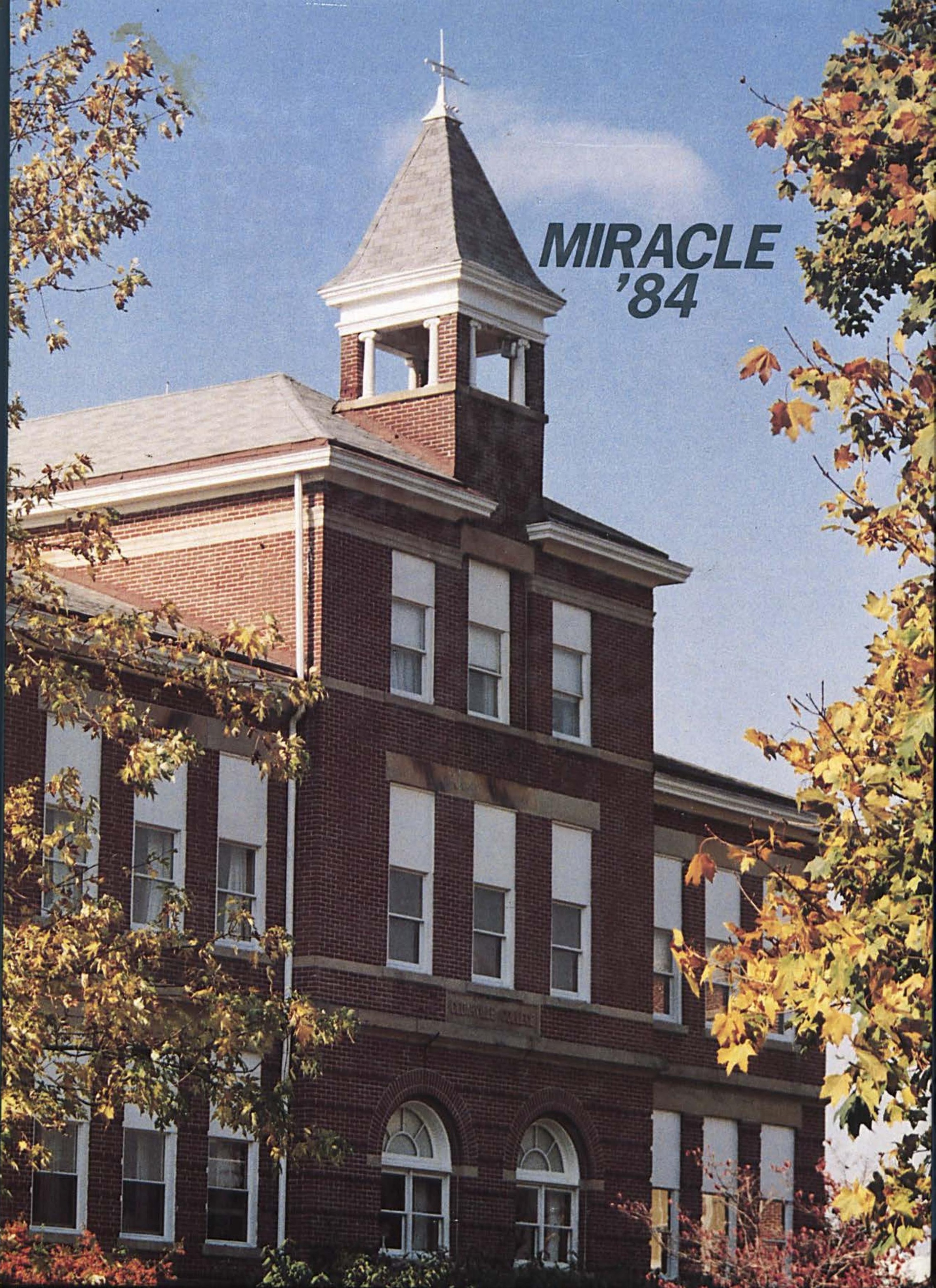





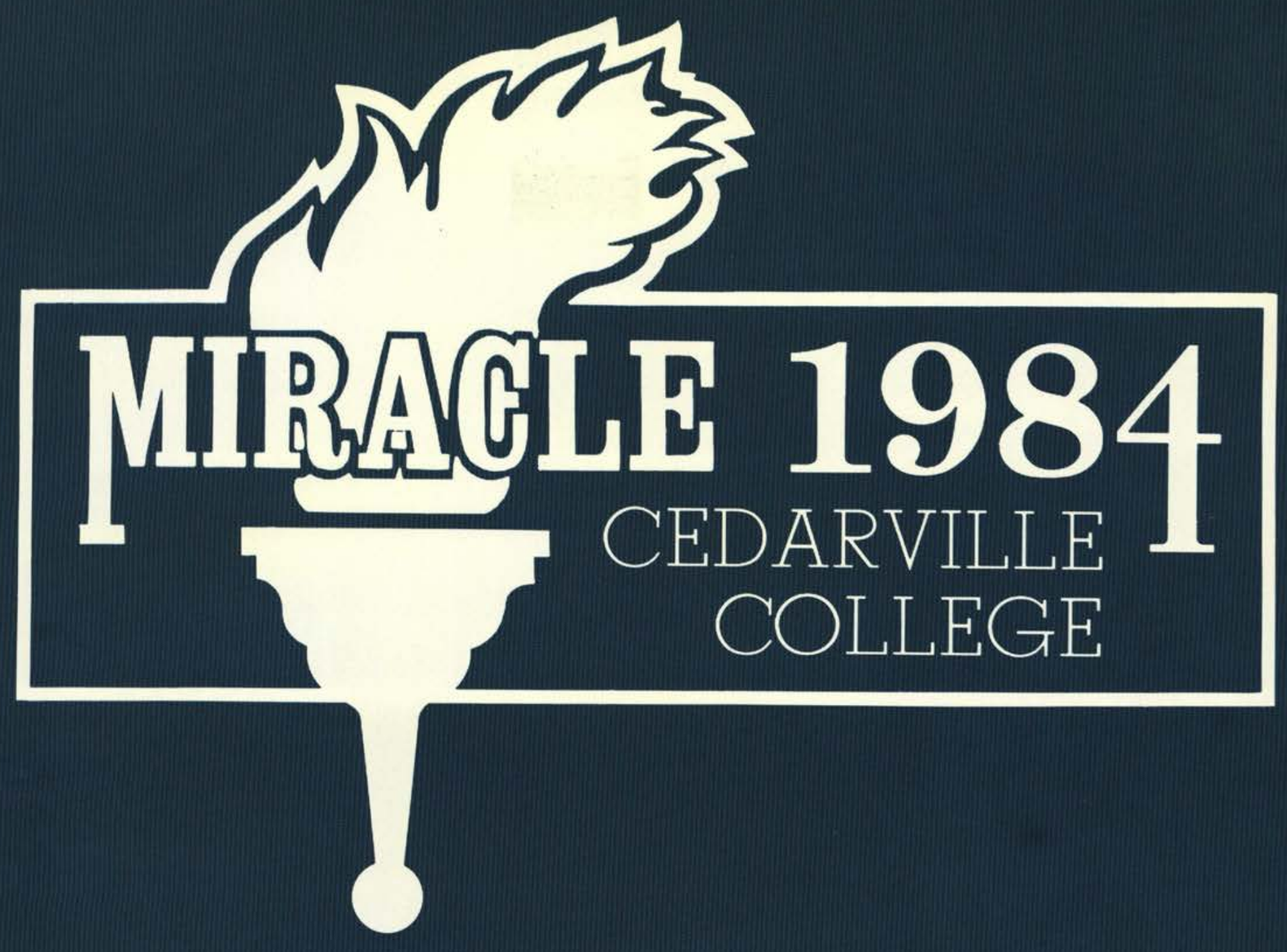




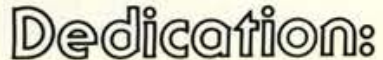

\section{Faithful Service}

$\mathbf{K}$ nown to some as husband and wife or Pastor and family, to others as Dean of Students and Director of Records and Registration, and yet to others as professor, deacon, colleagues, neighbors, and friends - for twenty-four years Richard and Barbara Mclntosh have served their Lord with a distinctive dedication to Cedarville College, its students, and the community in which it sits. Educated by Bryan College, reinforced by the Master of Theology degree from Grace Theological Seminary, the Mclntoshes came to Cedarville in 1960, following eight years of pastorate.

Not interested only in teaching specialities in theology, missions, and Bible study methods, Mr. and Mrs. Mcintosh have integrated these interests into their daily lives. Both have ministered long and faithfully through Grace Baptist Church of Cedarville in spite of extensive activity in pulpit supply. Much in demand as a popular, thorough, and caring academic advisor, Mr. Mclntosh, as well as Barbara, has counseled

\section{"Together, They Have Extended Warmly Christian Hospitality"}

and "pastored" hundreds of students seeking God's direction for their lives. Together, they have extended warmly Christian hospitality expecially to minority students and those from other continents, far from homes and families.

Mr. Mclntosh's commitment to quality of performance in Christian living has led him to lengthy service on the college committee guiding the Missionary Internship Service. Setting an example himself, Mr. Mclntosh taught for a term in Africa and, with Mrs. Mclntosh, toured and ministered under MIS in Australia.

Barbara Mclntosh has for the past

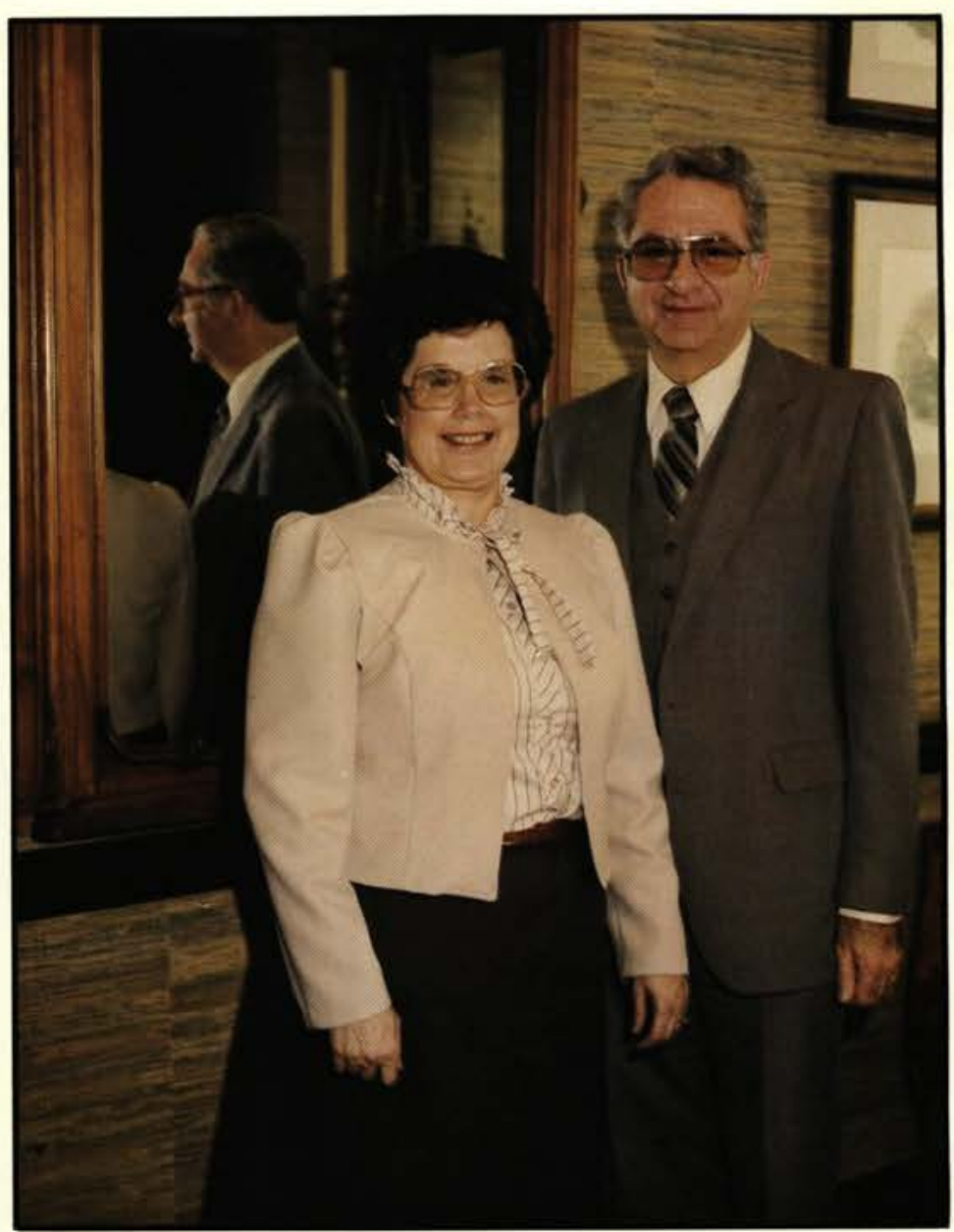

thirteen years aided and guided development of the comprehensive system of academic record-keeping and services so vital to a quality educational institution. Her tenure as Records Clerk and, since 1980, as Director of Academic Records, has coincided with the simultaneous rapid growth of student enrollment and the strenuous task of developing and installing computers and their programs to meet complex academic needs. And when the computers failed, Barbara didn't!

Both Mr. and Mrs. Mclntosh, displaying sacrificial committment of time and energy, have exhibited that careful stewardship of detail in their professions and ministries so necessary to achieving excellence. Trustee of the Kyle Medical Center, and hostess, extension professor to minority pastors and curator of student growth, grandparents, and now returning to the pastorate, the Mclntoshes leave a tradition of dedication to be fulfilled.

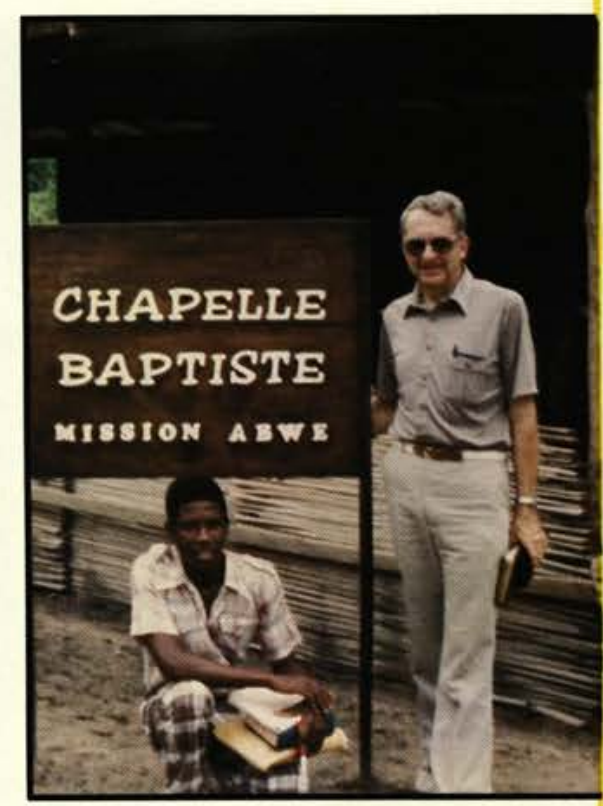

by Ronald M. Grosh 


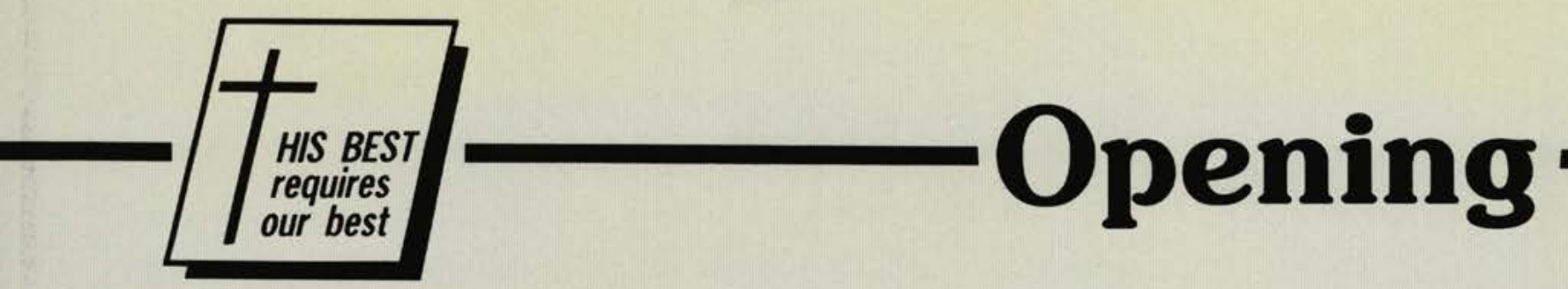

\section{"SPECIAL EDITION"}

The Cedarville College Yearbook staff presents the 1984 Miracle. Through the mediums of word and picture, the 1983-84 school year has been captured to preserve the memories of events, people, and accomplishments. This storehouse of the past allows us to reminisce and to visualize the fall quarter theme, "His Best requires our best," as it was demonstrated over and over again throughout the year.

As you pursue through this book, it is the hope and prayer of our hardworking staff that you consider what is behind to have been a learning experience and a time of development and maturity. May you look at the future as a challenge and confidently say to yourself, "I want this year to be even better!" When those feelings of "Where does the time go?" begin to press in, don't dwell on the past; use the urgency for redeeming the time as a springboard to motivate you for what lies ahead. Join us now as we review the previous three quarters of life here at the 'ville.

By Bill Thomas

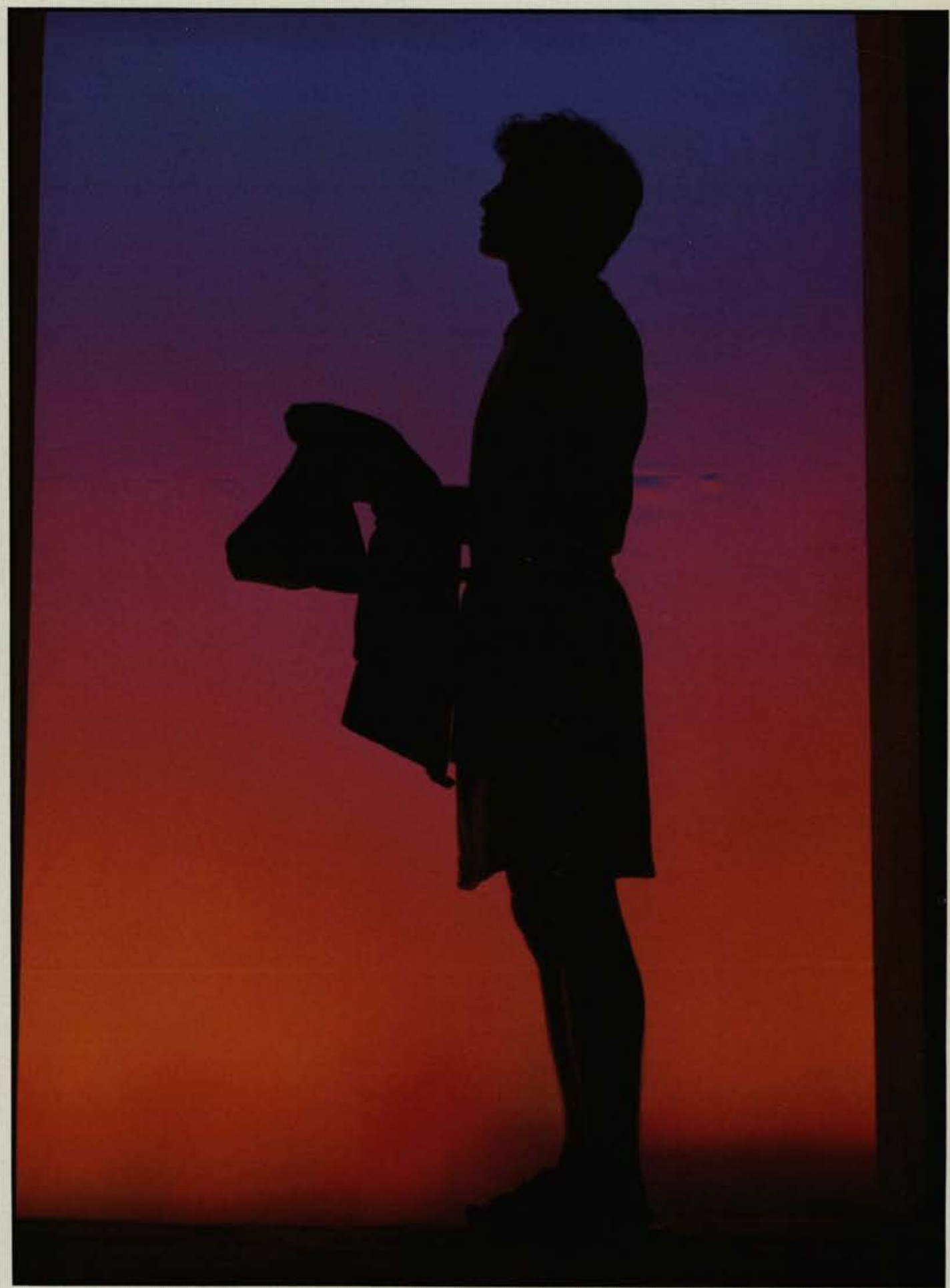

\section{Contributors:}

- Walt Fouch

- Jon Beight

\section{Layout By:}

Tracy Holtzman Jeff Wassenaar 


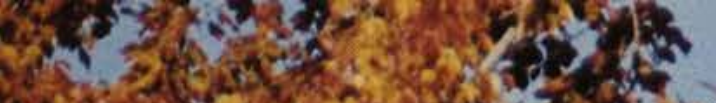

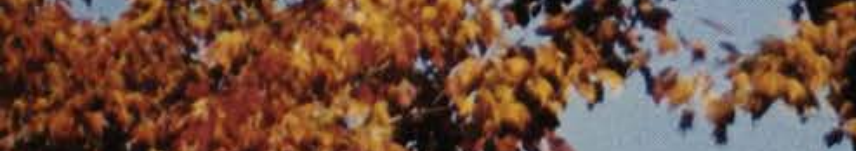

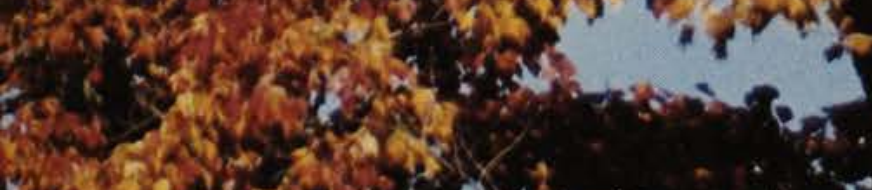

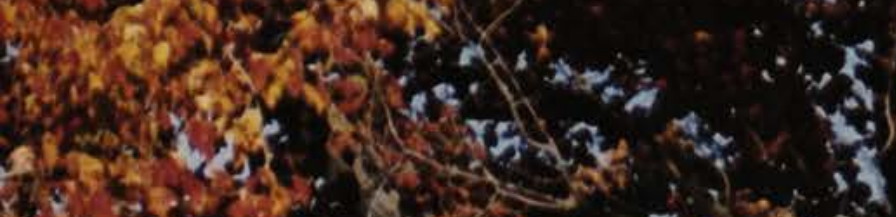
40 .

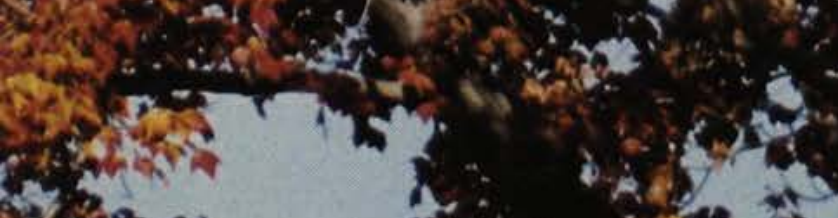
3) en a $3 x+2$

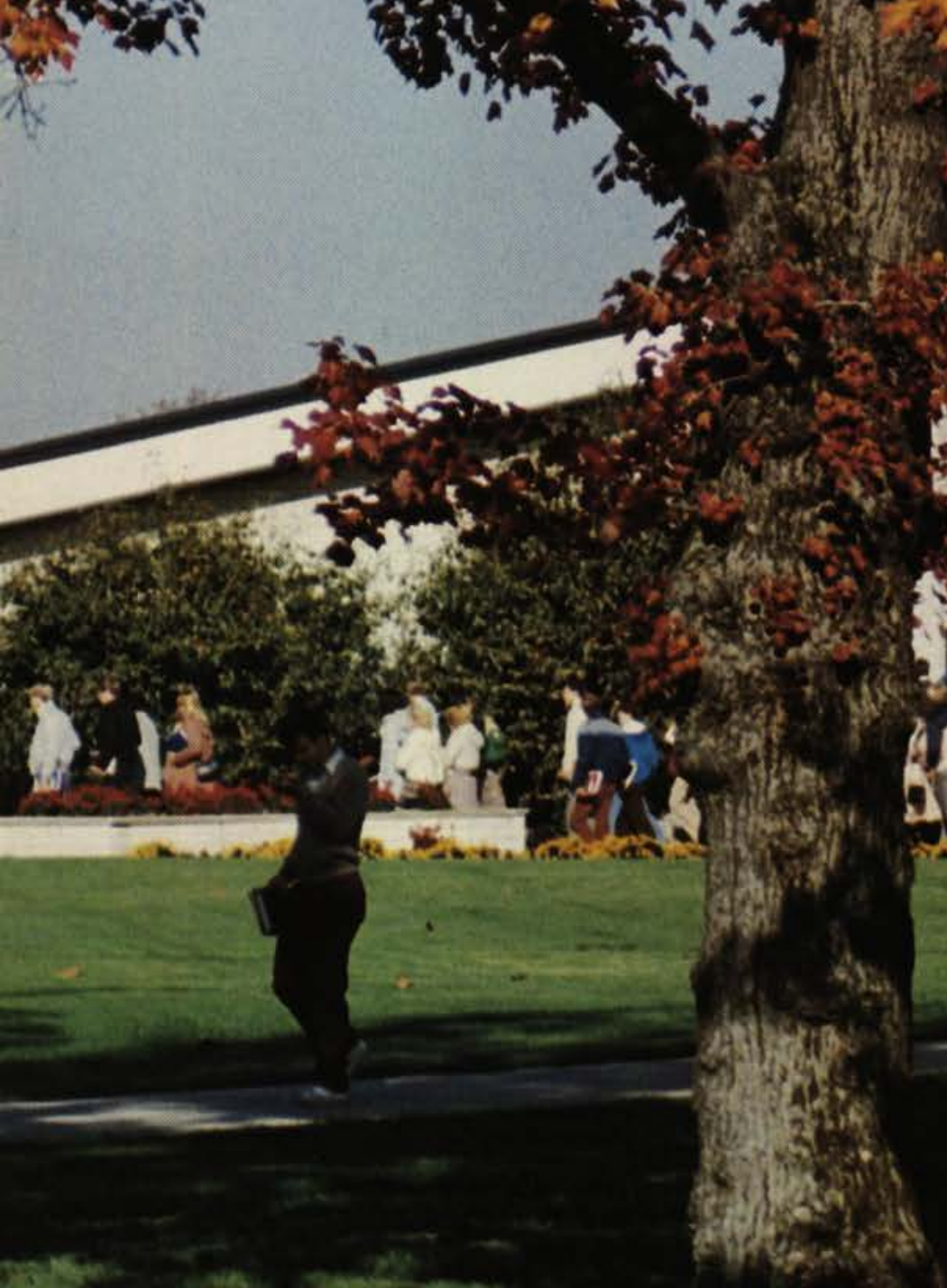

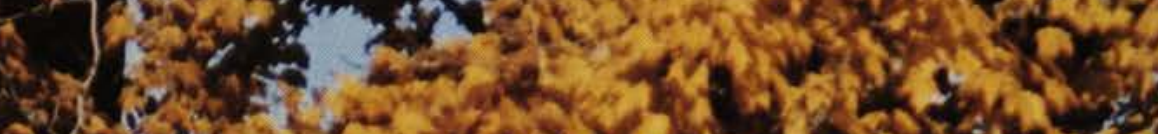
Fin

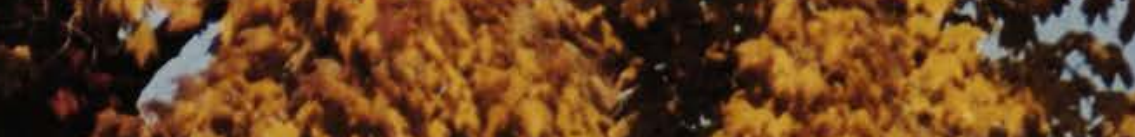

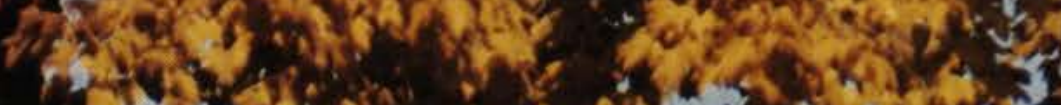

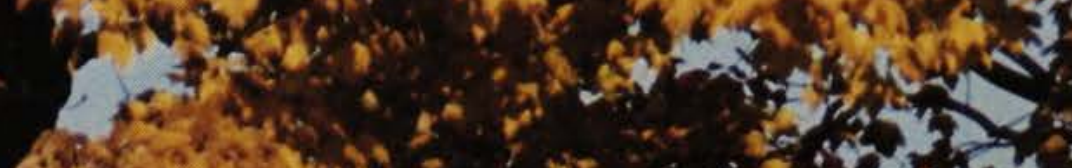

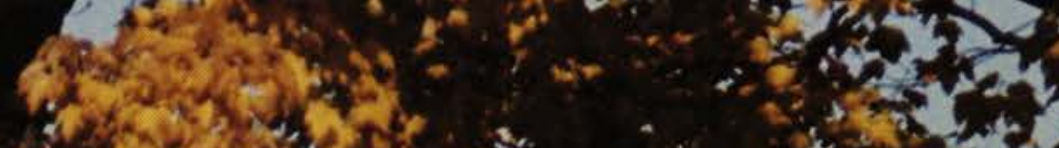
Q.

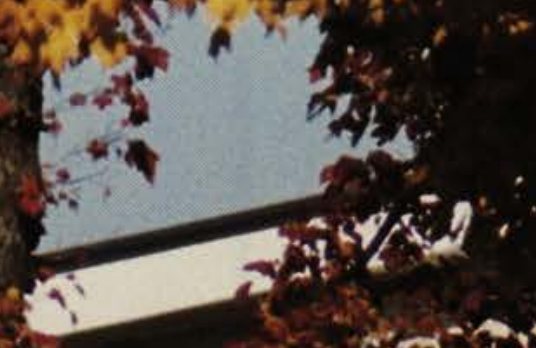

tet.

$\because n^{2}=$ $\sin 2=24$ 3) 1 (45)

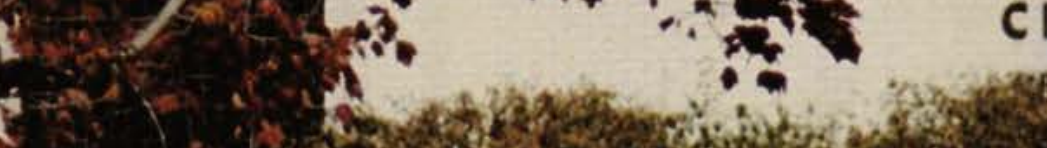

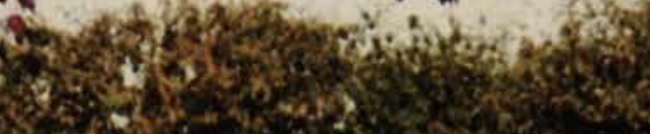

2

apditis

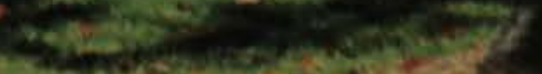
40 


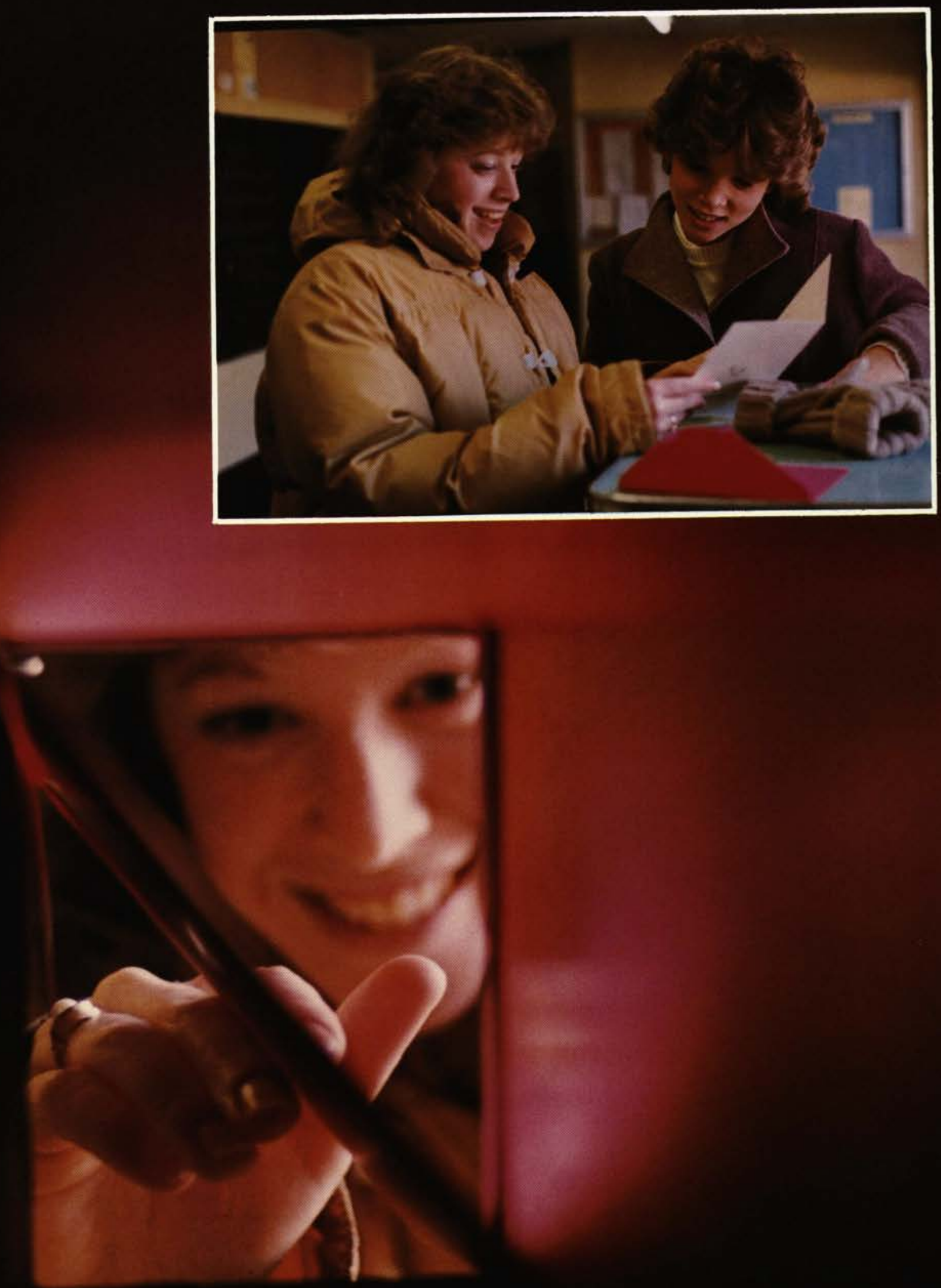


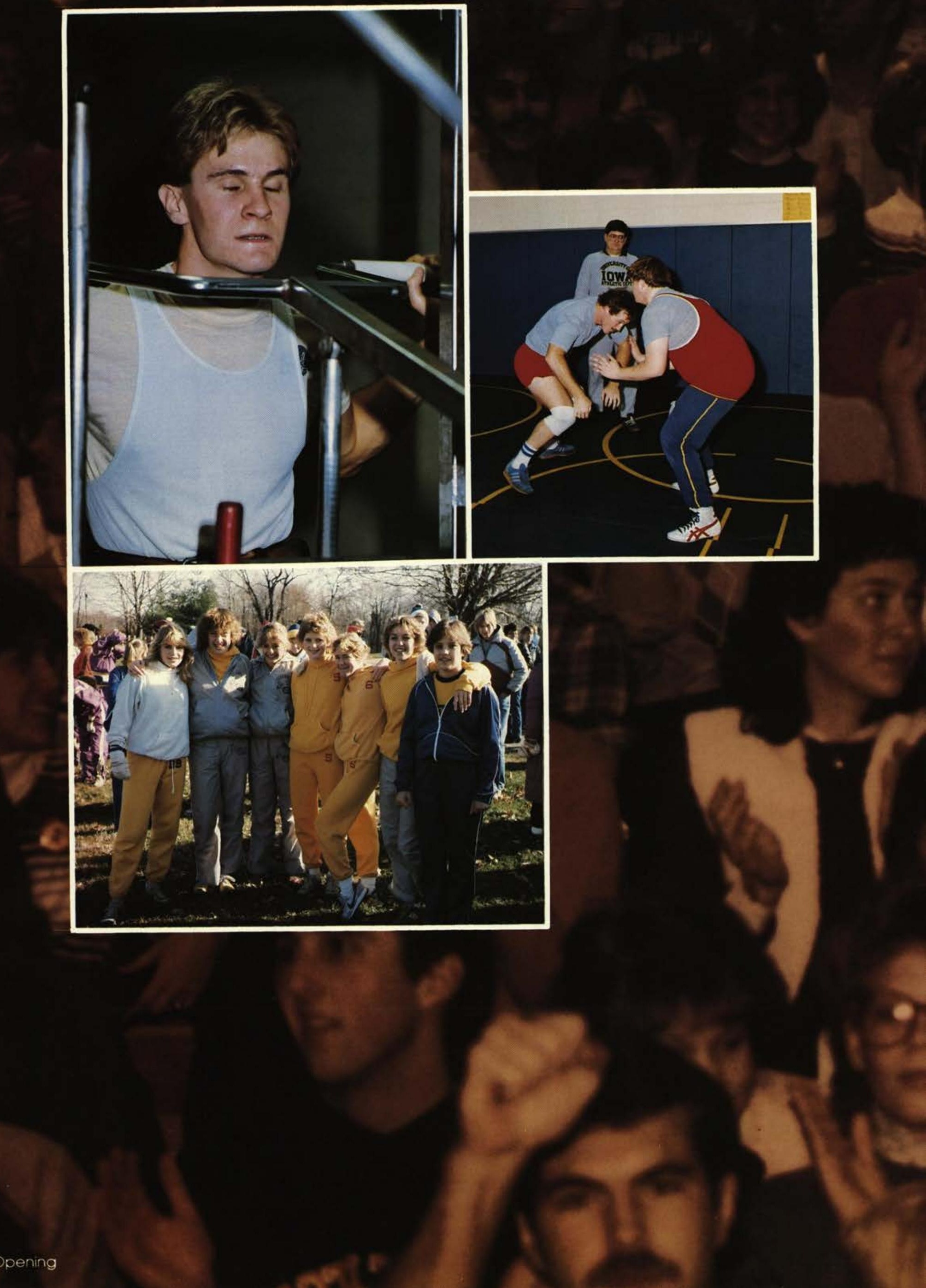




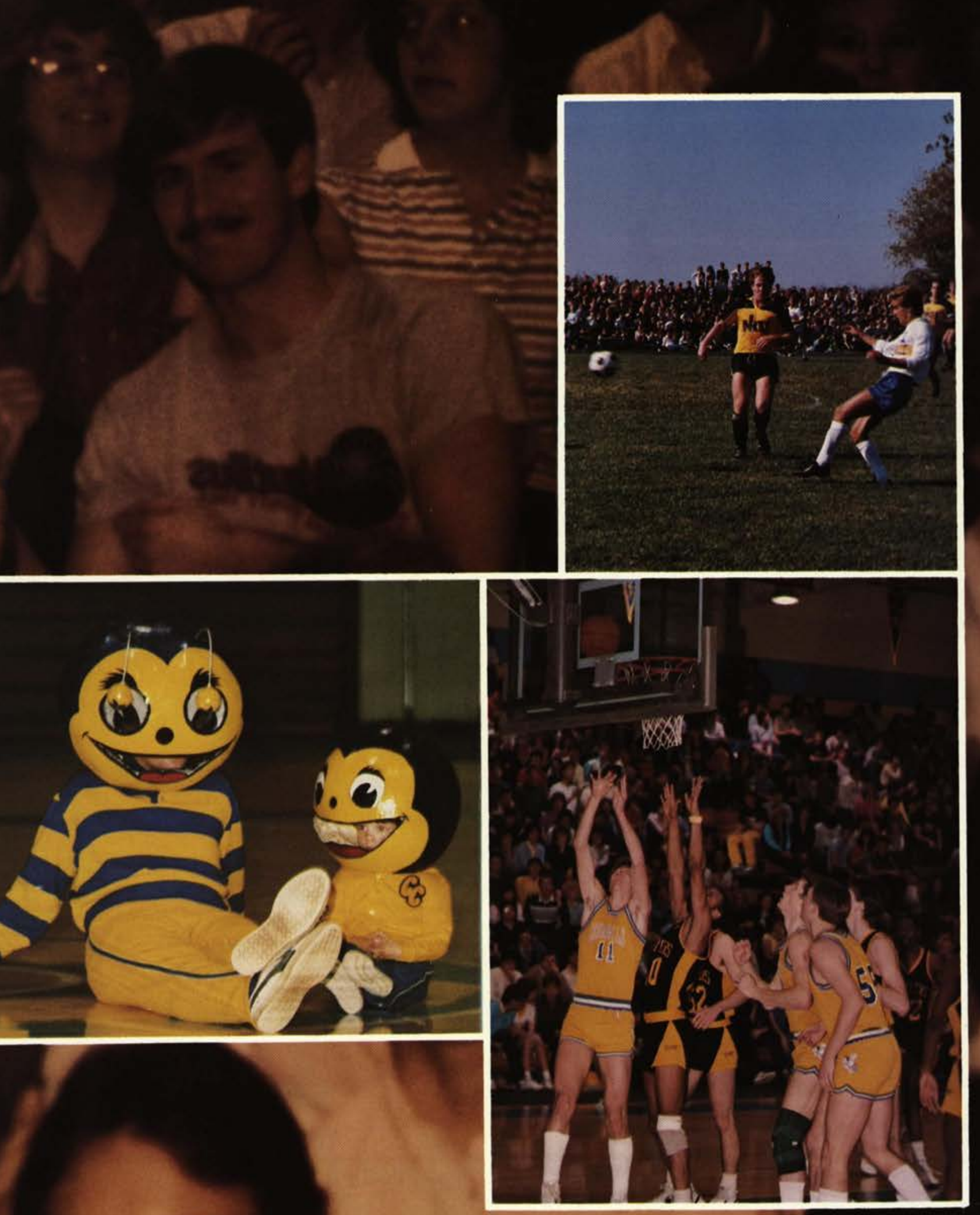



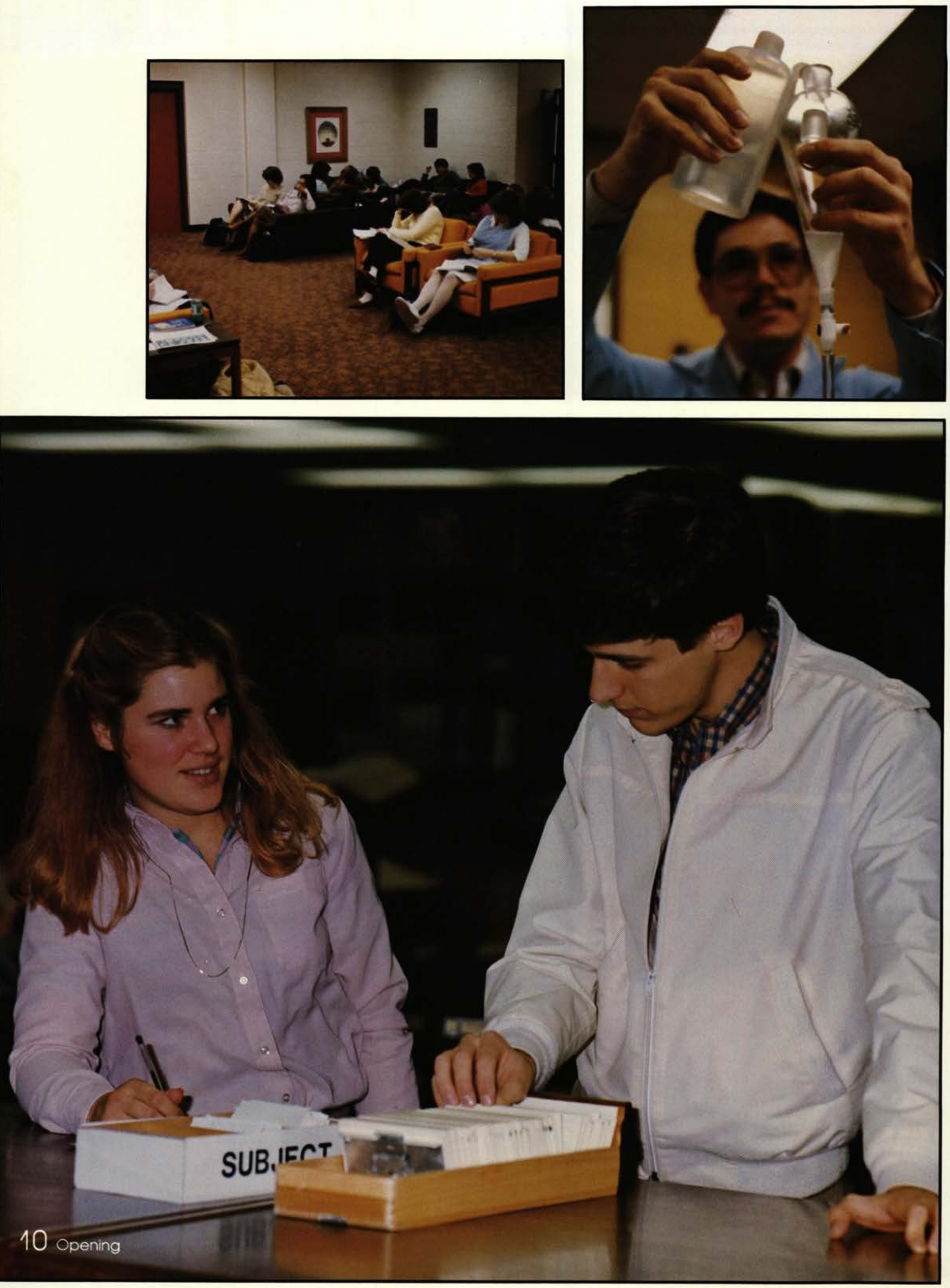


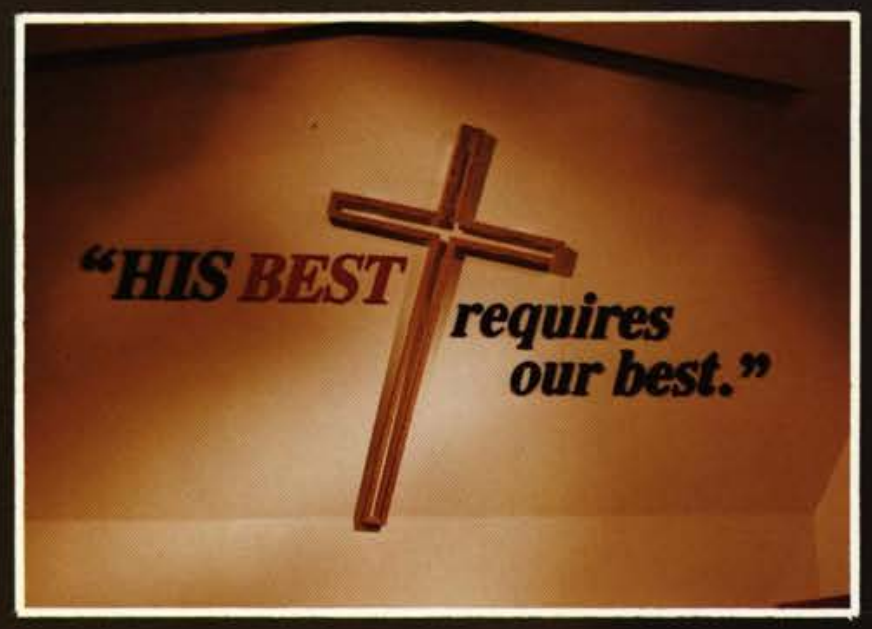

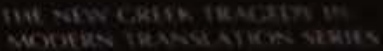

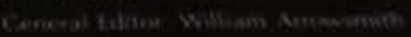

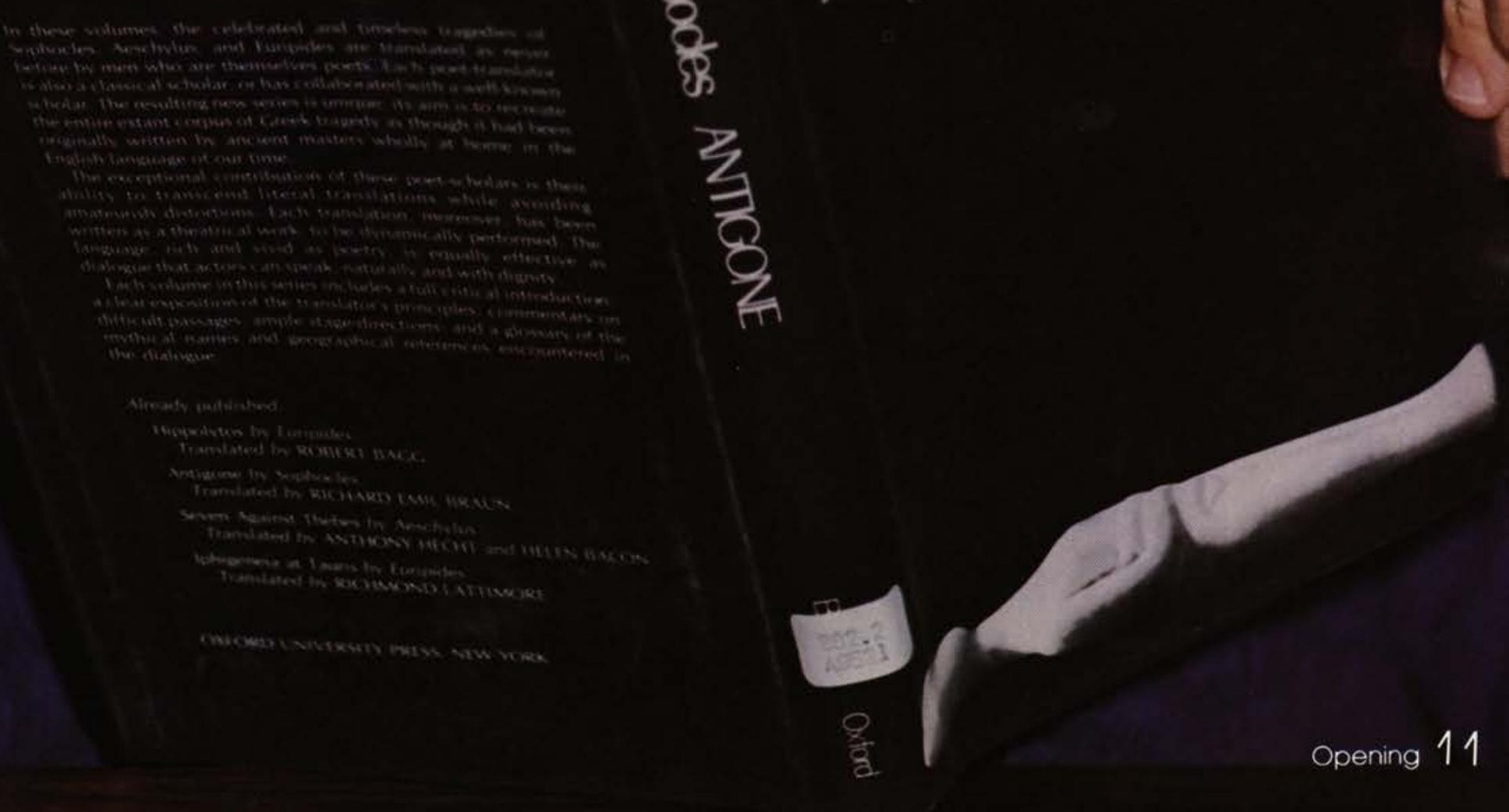




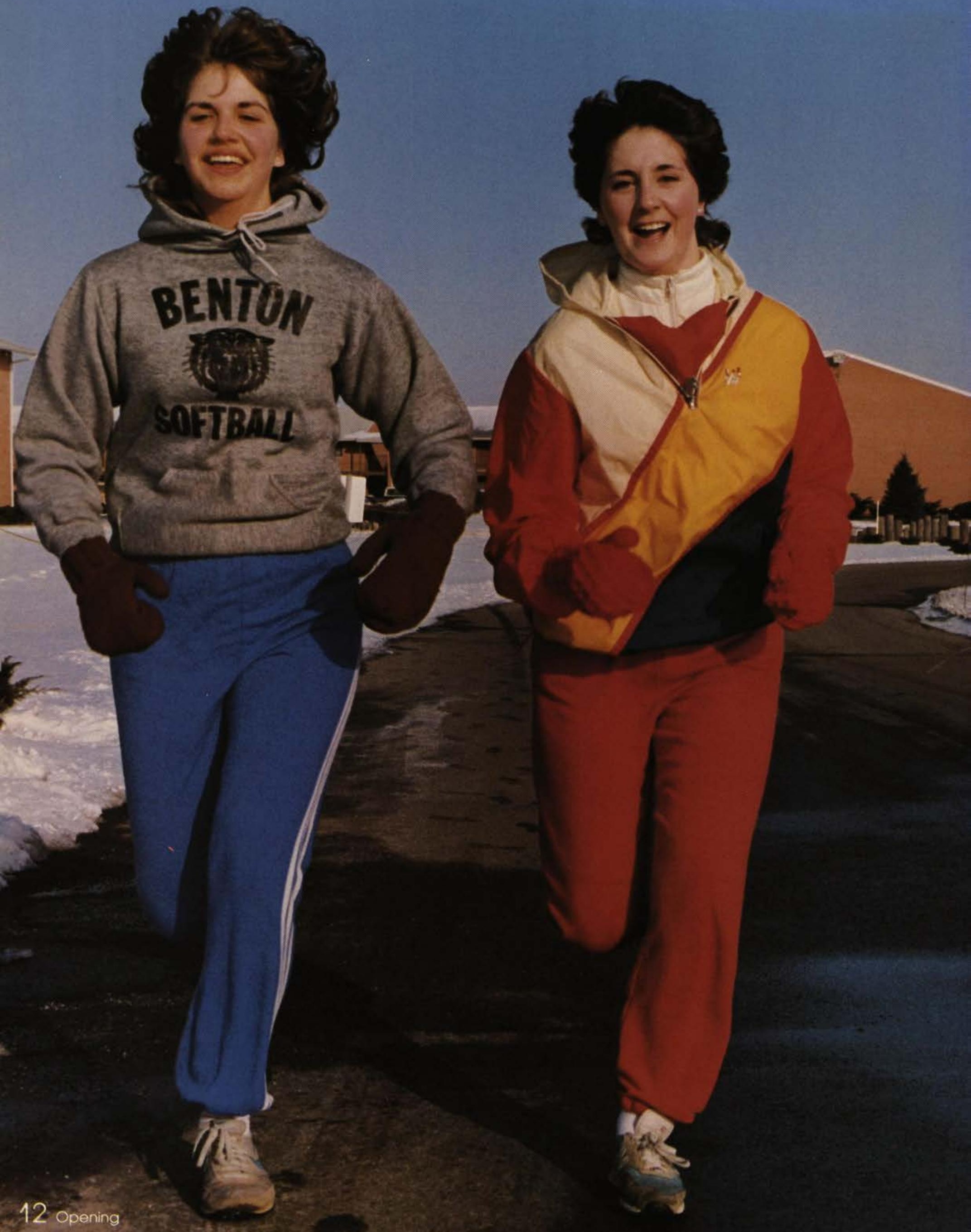



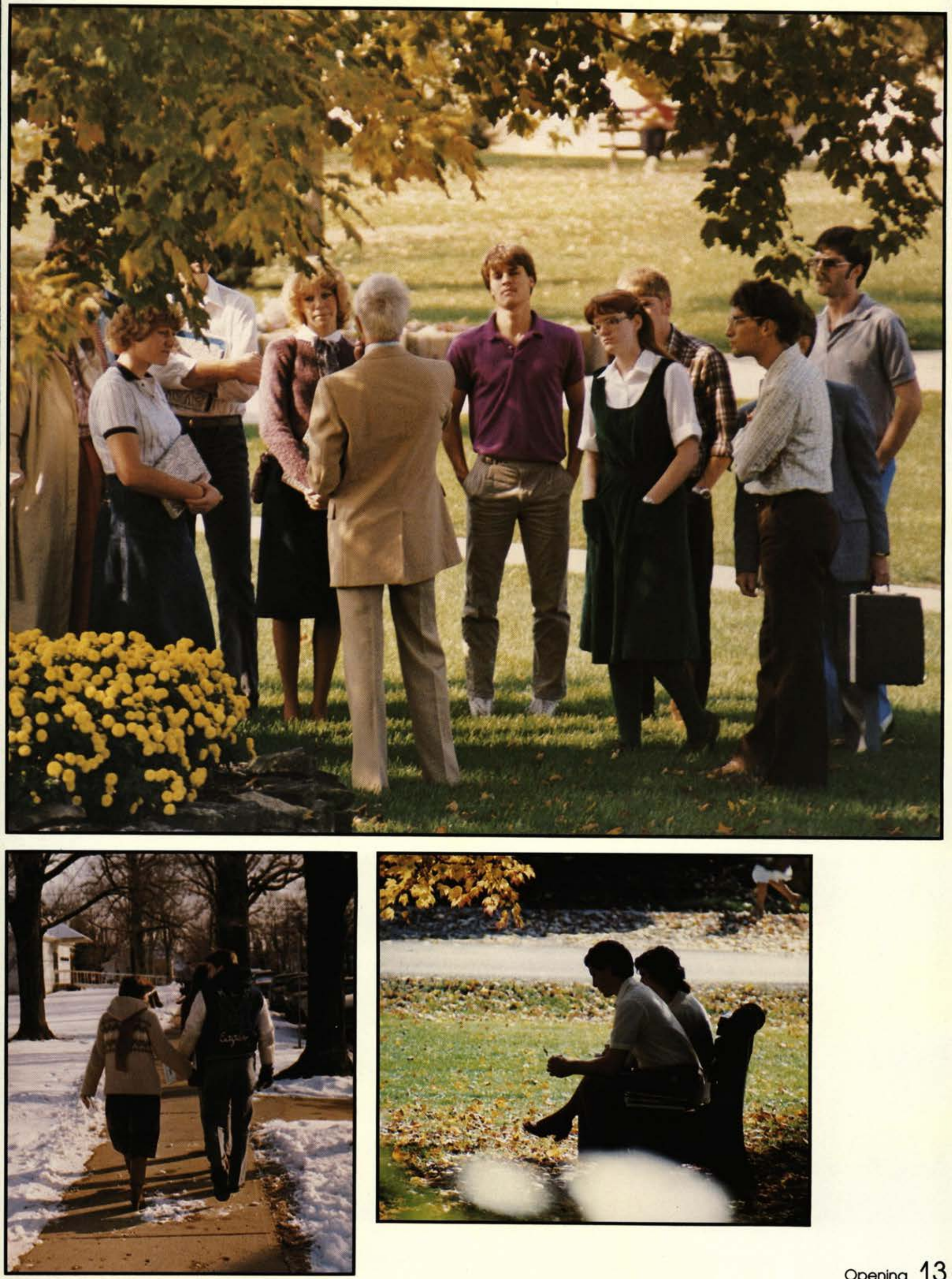


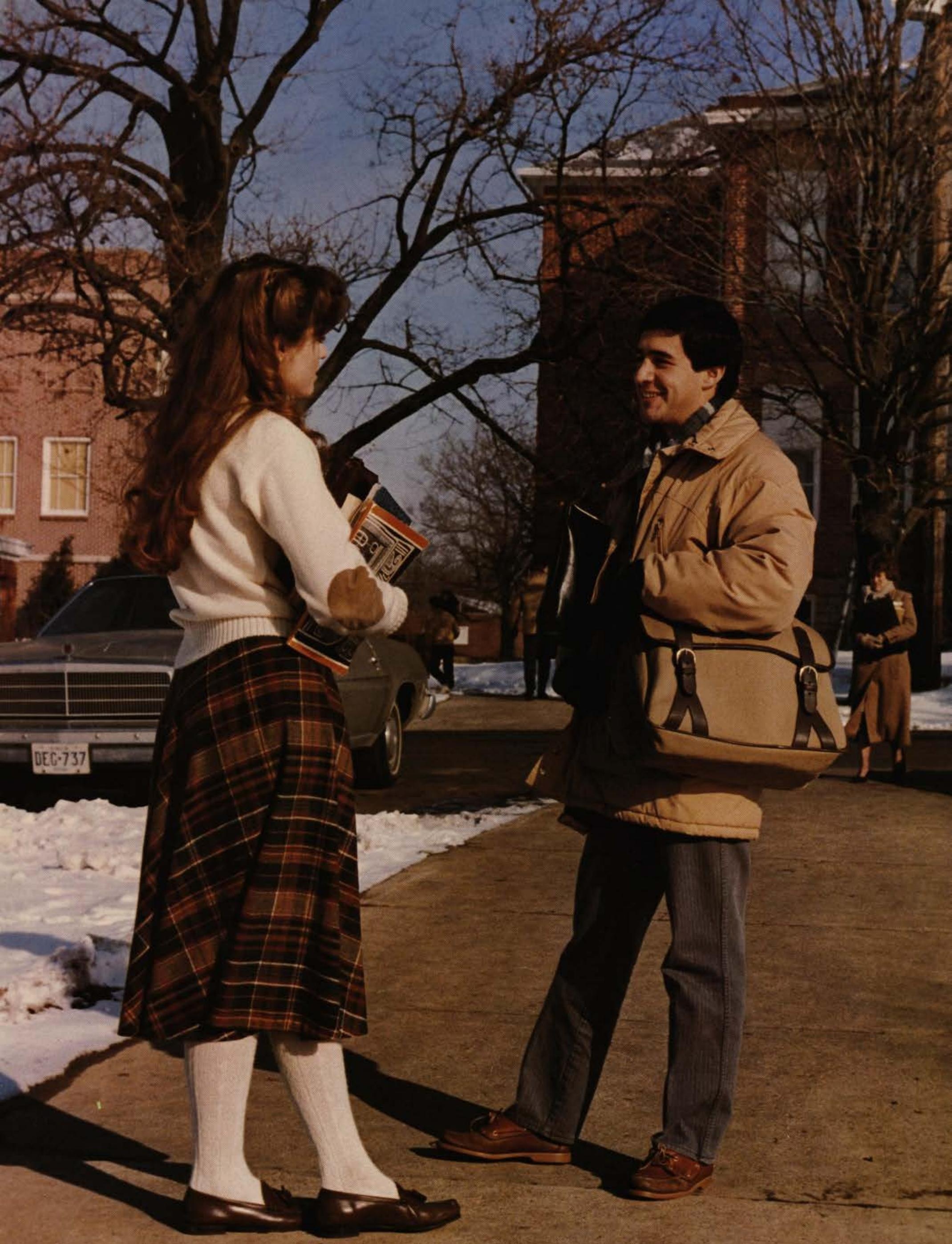




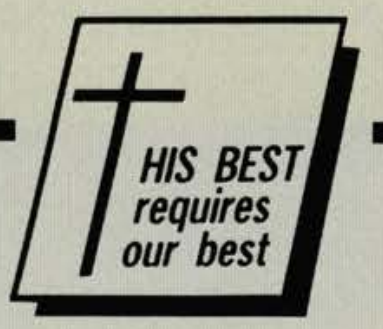

\section{"TOUCHING LIVES"}

D oes anyone work harder to make our experience at Cedarville College so profitable as the faculty, staff, and administration? How fortunate we are to have the opportunity to get to know some of these very special people. They are people, you know, sharing some of the same joys and struggles of life. These groups are the people who make Cedarville College tick, ad they deserve to be commended for the spendid work they are doing for this student body. Many of us will remember the way they reached out and touched our lives because we allowed them to be the human beings that they truly are. They have given us friendship and earned our respect. May we always remember them as playing a significant role in shaping our lives and in making our college days meaningful, enjoyable, and worthwhile. Please continue reading as the 1984 MIRACLE honors the Faculty, Staff, and Administration of Cedarville College.

\section{Contributors:}

- Amy Ames .............. 16

- Paul Dixon ............... 18

- Mike DiCuirci ...........21 21

- John Silvius ..........23

- Jim Phipps ............24

- Sandra Entner ........... 24

- Glenda Womack . . . . . . . 29

- Audrey Bergen ..........30

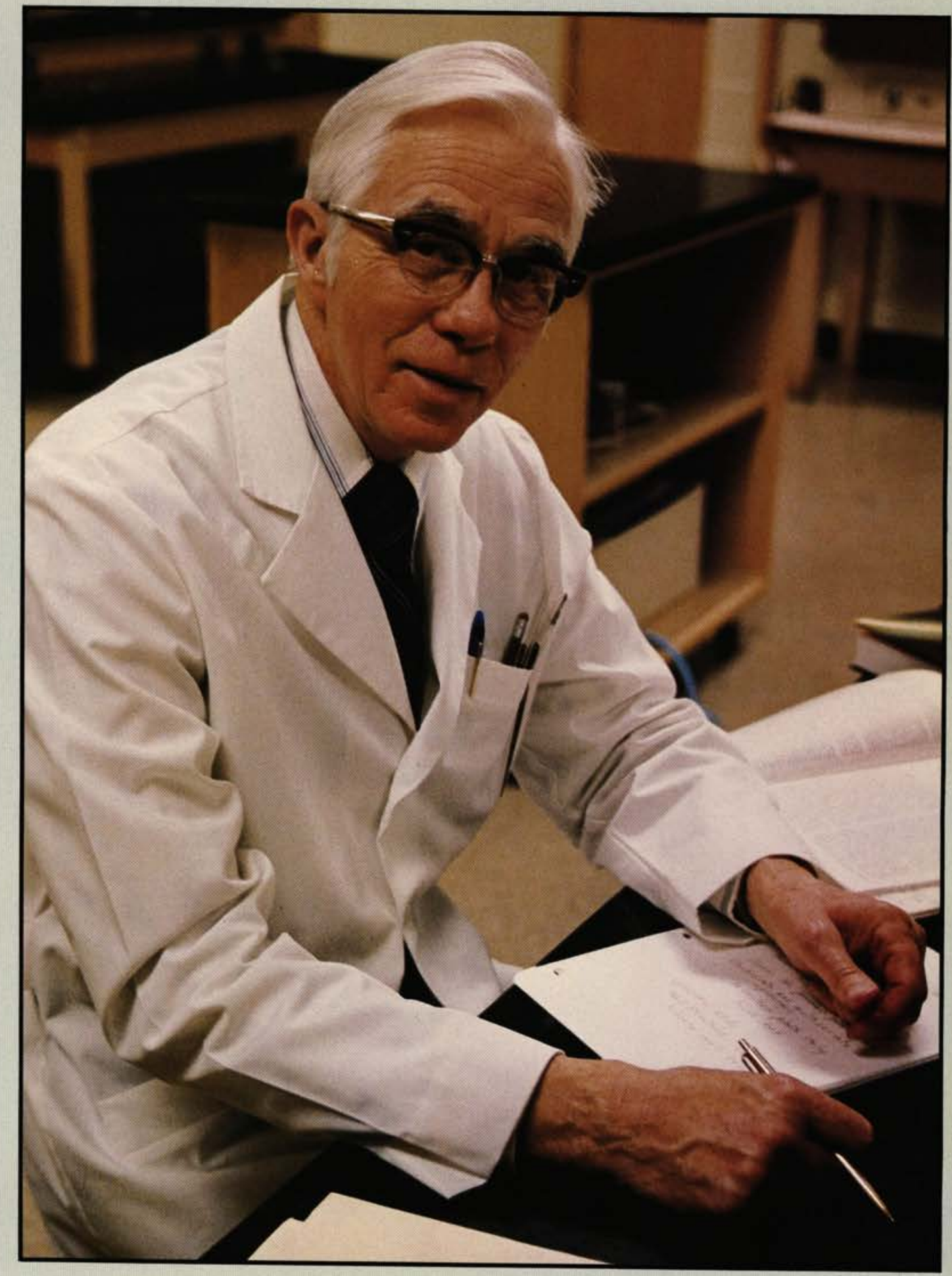

\section{Layout By:}

Karen Beattie 


\section{OUR PRESIDENT}

"He is not only a representative of the college, but also he is an ambassador of Jesus Christ."

A s a college president, Dr. Dixon $A$ has many qualities of a good leader. Coming to Cedarville College six years ago, Paul Dixon brought a certain freshness to the workings of Cedarville. Being a personable member of the village has strengthened Dr. Dixon's outreach as the president. His honest love for people and his ability to respond easily with many kinds of people has broadened the circle of $\mathrm{Ce}$ darville's influence. With his desire to make Cedarville known, Dr. Dixon still maintains a balance in priorities as he travels. He is not only a representative of the college, but also he is an ambassador of Jesus Christ. Having a background as an evangelist, Dr. Dixon has not lost sight of the importance of evangelism, which some hold to as his strong point. In his personal dealings he shows a consistency in his testimony. He does not just preach evangelism; he does it.

Organization and discipline go handin-hand as he leads the college, and these qualities evidence themselves in

"He does not just preach evangelism; he does it."

his own life. Melting into these qualities is his push for planning, not only shortranged but also long-ranged. He sets goals for the college family and takes the initiative as the leader to realize them.

"A man of ideas" is how Mrs. Dixon describes him. And he gets those ideas out. Inherent also in his nature is a contagious enthusiasm which, many agree, affects everyone from the administration to the student to some degree. "Dynamic" as a leader is how Dr.
Johnson describes him in one word. Because of his balanced lifestyle, Dr. Silvius describes Dr. Dixon as "a man of God." Seniors Beth Wieder and Rob Freeman agree that he is "committed" and "dedicated" and he "sets goals and meets them." The number one quality that senior Gillis West sees is his "foresight." Senior Marcia Golike named "organization" as his strength. Words such as "consistent - " "eventempered," and "... the most disciplined person I know" coming from Mrs. Dixon reveal the qualities so many people see Dr. Dixon applying in her personal life as well as in his role as a college president.

By April Ames

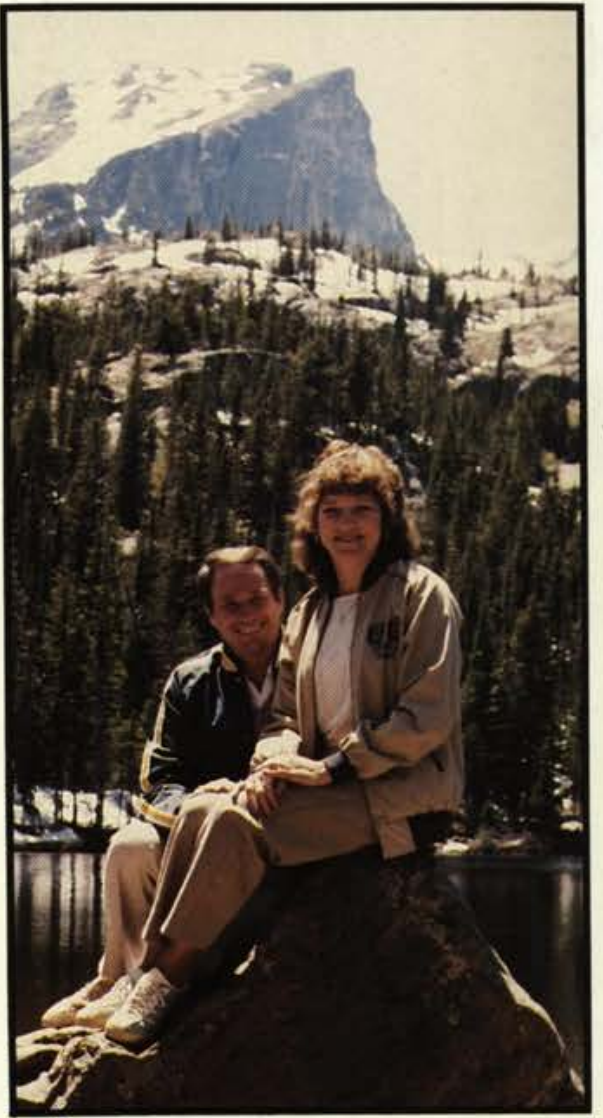




\section{The Executives}

ne of the strengths of Cedarville College is the five vice presidents whom God has placed in key positions of leadership. Working with these men, learning from them, and having them as friends give me intense pleasure and joy. We do function as a team and all of us lean very heavily upon each other.

The longevity of their leadership is significant. Any growing, quality organization needs individuals who commit major portions of their lives to that organization. Ken St. Clair has completed 25 years as a vice president of business; Cliff Johnson has been academic vice president for 22 years; the vice president of student services, Don Richard, began that ministry 14 years ago, and Harold Green started his role as a vice president of campus ministries 15 years ago. Our newest mem- ber of the executive team is Chuck Ross who has completed his fourth year as a vice president of development.

Each one of these men provided his own particular contribution to the college. While building an exceptional academic program, Cliff Johnson has always been full of vision, optimisim, and excellent spirit. Mr. St. Clair's

\section{"Each one of these men pro. vided his own particular con. tribution to the college."}

knowledge of financial matters and careful fiscal control has been key to the college's stability. Don Rickard is another individual with a great spirit. This is apparent in the attitudes of his staff and the success of his student services programs. Harold Green's appointment to his position was a major factor in the numerical and spiritua growth of Cedarville. His commitment to quality and hard work is apparent in all that he does. Chuck Ross has provided expertise in development anc his godly attitude has been appreciated by all.

This is a band of knowledgeable. faithful, committed, and spiritual men. count it a privilege to have them as friends and co-workers in this ministry of "... the same commit thou to faithfu men, who shall be able to teach others also" (II Timothy 2:2).

by Paul Dixor President

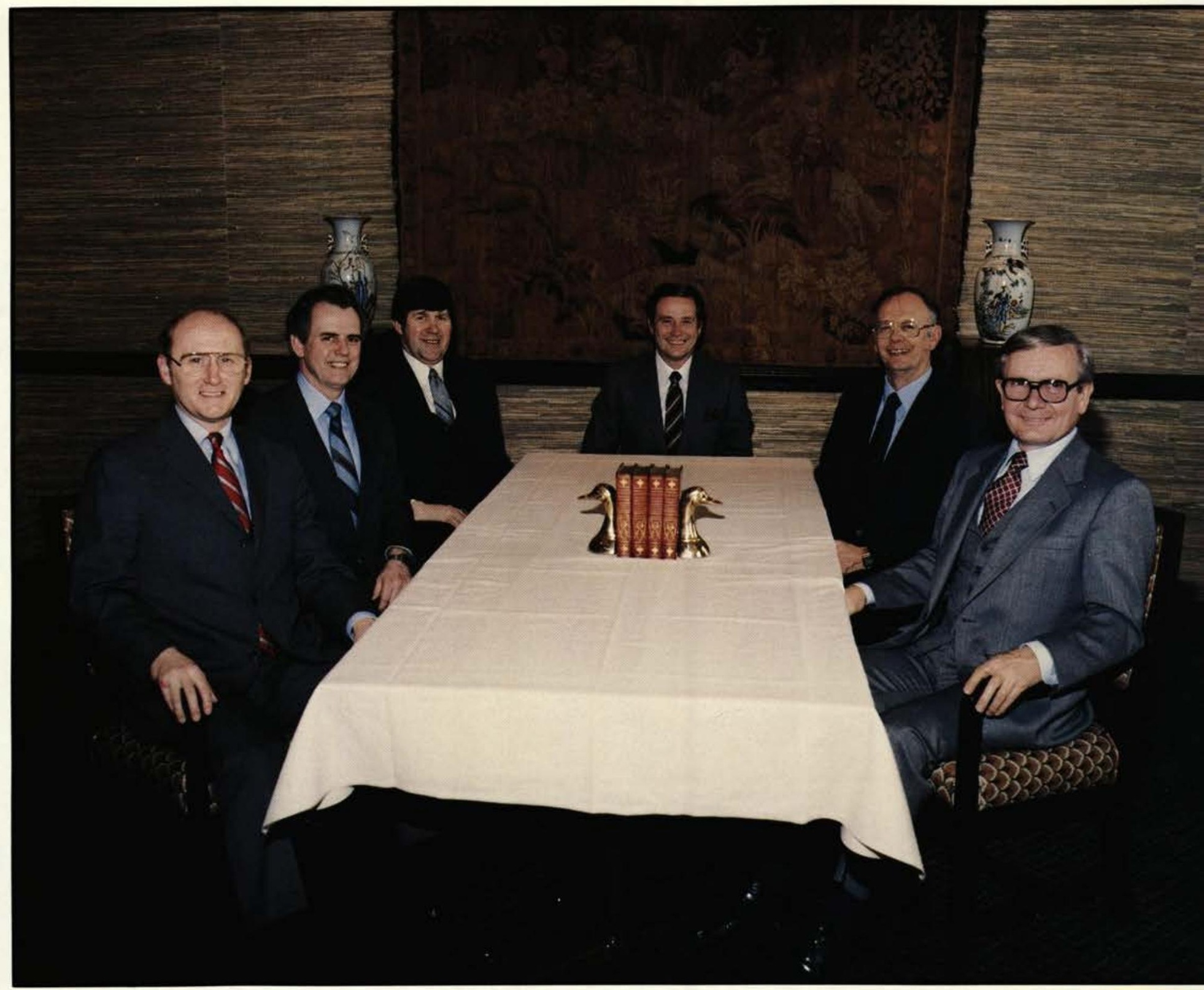



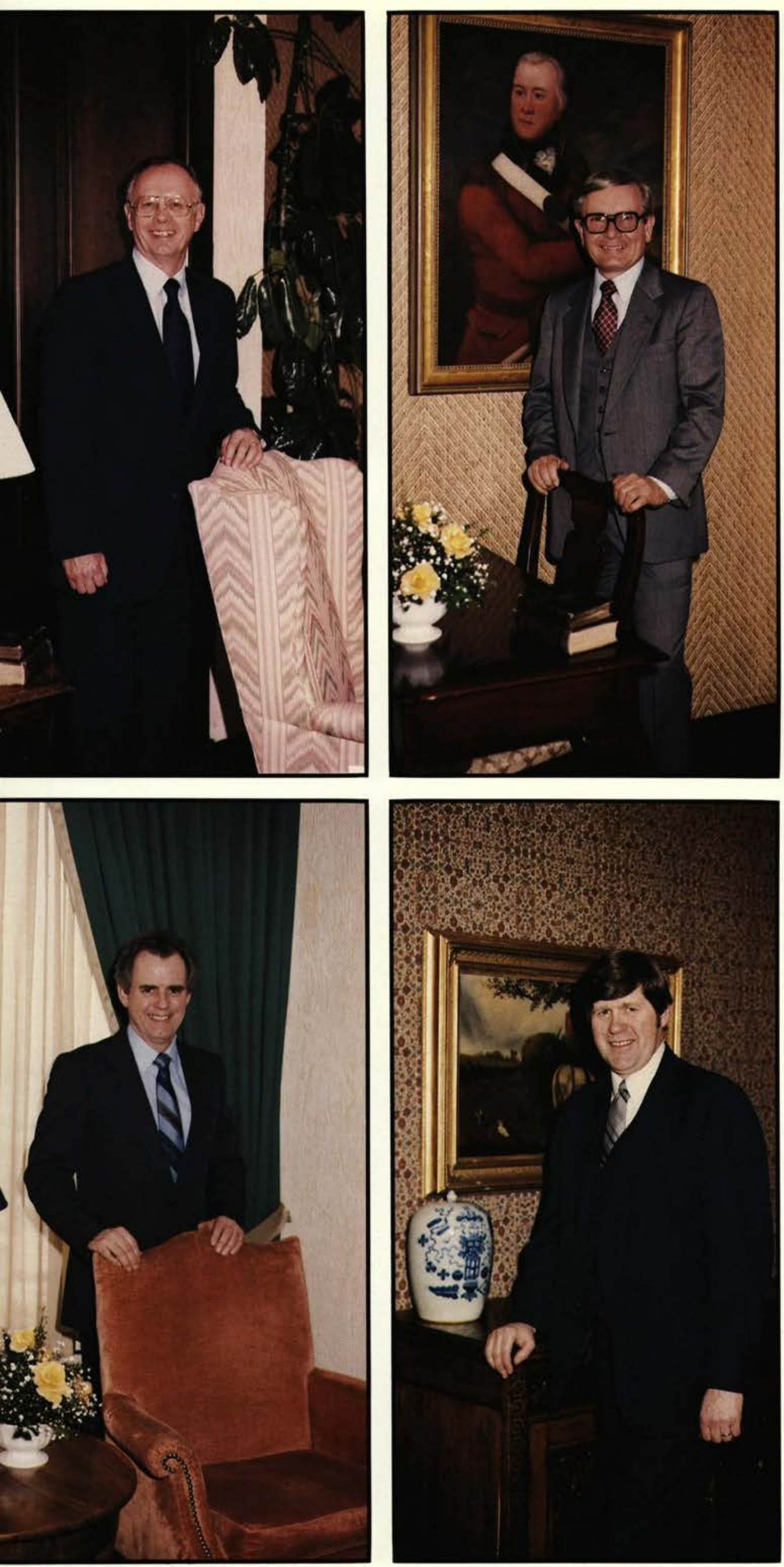

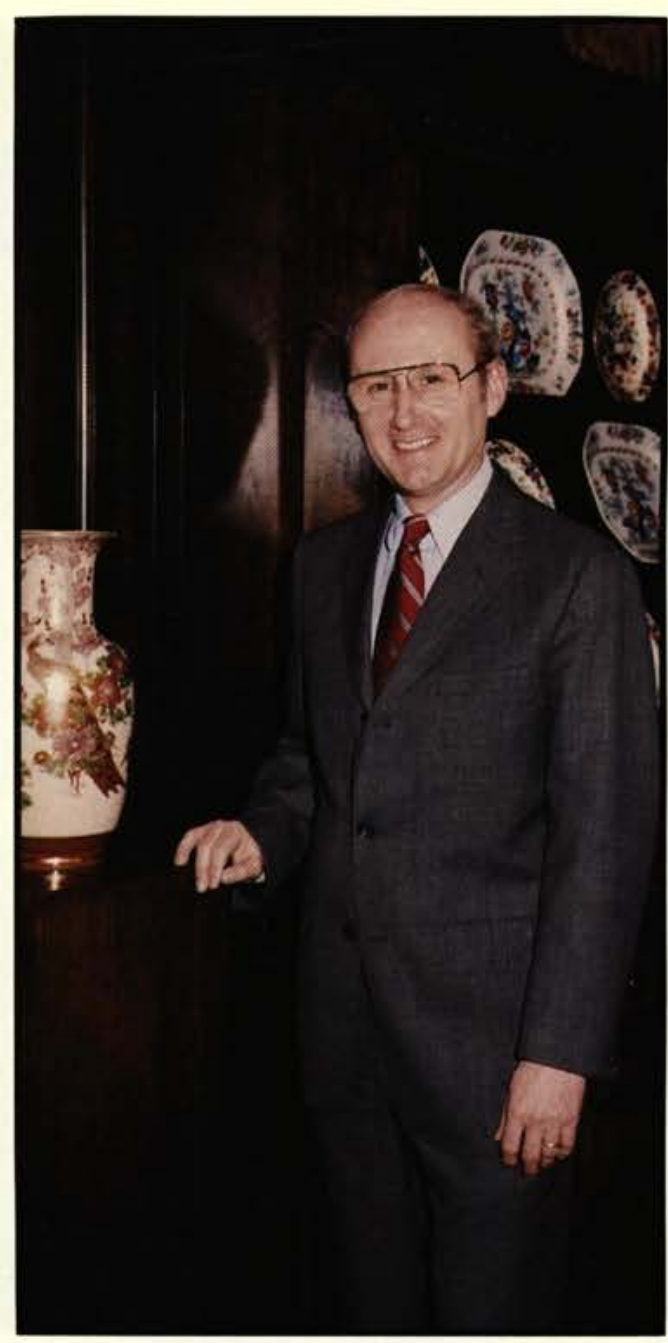

\section{The Executives:}

Cliff Johnson - top left Ken St. Clair - top middle Don Rickard - top right Harold Green - bot. left Chuck Ross — bottom right 
Robert Abbas, Ph. D Protessor of Psychology Merlin Ager, Ph.D. Professor of Education Irene B. Alyn, Ph. D. Professor of Nursing Lyle J. Anderson. Ph.D Associate Professor of Music

Ray E, Bartholomew. Ph.D. Professor of Language and Literature Patricia L. Bates, M.A. Dean of Women Janet A. Baver, M.S. Assistant Professor of Nursing Donald Paul Baumann, Ph.D. Professor of Biology and Chemistry Harmon Bergen. M.A. James R. Biddle, Ph.D

Professor of Education Sharon Biddle. Ph.D Associate Academic Dean Omer E. Bonenberger, D.Ed Associate Professor of Education

Jan M. Bosma, M.L.S Assistant Director of Library Edwin S. Braithwaite. Ph.D. Assistant Professor of Mathematics Lynn A. Brock, M.L.S

Director of Library Services Debra L. Brown. M.B.A. instructor of Marketing

Elaine L. Brown. M.S.Ed. Assistant Professor of Physical Ed Stephen P. Brown. M.L.S.

Associate Director of Library Donald E. Callan, Ph.D

Professor of Physical Ed. Martin E Clark, Ed.D. Director of Counseling Services

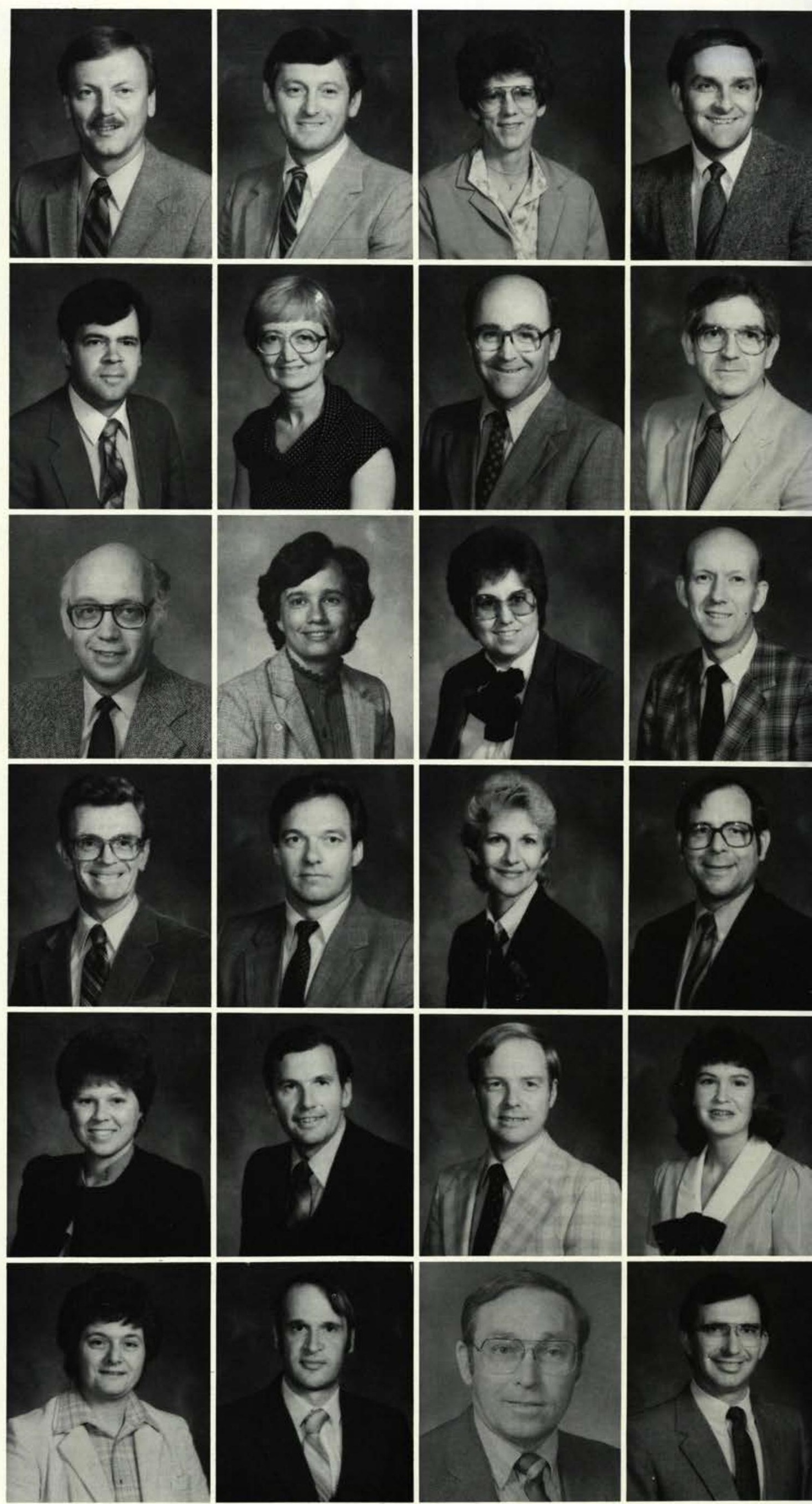




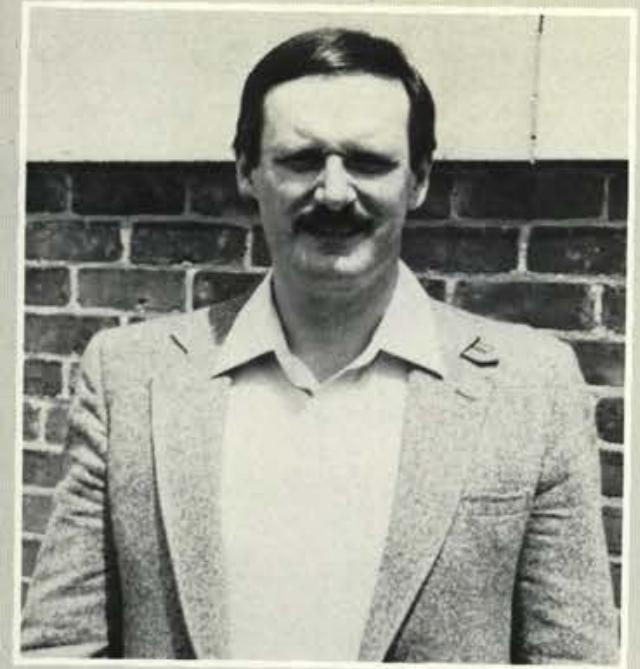

$n$ the summer of 1979 , my family and I took our summer vacation at Gull Lake Bible Conference in the great state of Michigan. (Go Blue!) The speakers of the week were Dr. John Whitcomb of Grace Seminary and Dr. Paul Dixon of Cedarville College. God truly used this time of retreat in our lives to minister to our souls and provoke us to explore the possibilities of further Biblical education and full-time Chris- tian ministry. We began to think seriously of attending Grace Seminary in pursuit of an M. div. degree. I was presently employed as a band director in Plymouth, Michigan, having earned a B.A. and M.M. degree from the University of Michigan.

At one of the conference's morning sessions, Paul Dixon and I had occasion to get to know each other. I found him to be an interesting and gracious individual. That evening, he inquired if I would be willing to submit a resume to his college, as he reported they were presently looking for a music teacher for the '79-80 school year. I complied and diligently wrote my resume out on a paper napkin. (It was a clean one!)

After our wonderful time at Gull Lake we journeyed back to our home in Livonia, Michigan. On our first Monday evening back home, I received a phone call from Dr. David Matson, head of Cedarville's Music Department. He mentioned a certain napkin and described to me a job which seemed most harmonious with my abilities and training. I was now interested, and acting on this interest I travelled to Cedarville and interviewed for the job which I accepted and have had for the last 5 years.

I believe God has blessed our ministry here: I enjoy it, and the results and victories have been beyond my expectation.

The Bible says: "Trust in the Lord with all your heart and lean not unto your own understanding, in all your ways acknowledge $\mathrm{Him}$ and $\mathrm{He}$ shall direct your paths" Prov. 3:5, 6

How simple, yet profound those verses are: I have experienced their truth.

Michael DiCuirci, M.M.

Assistant Professor of Music
Charles Clevenger, M.A.

Assistant Professor of Piano Michael DiCuircl, M.M.

Assistant Professor of Instrumental

Pamelo Sue Diehl, Ph.D.

Associate Professor of Phys. Ed. Charles Alfred Dillon, M.S.

Assistant Director of Library For Instructional Media

Pat Landers Dixon, M.Ed. Associate Professor of English Charles D. Dolph. Ph.D. Assistant Professor of Psychology 
Fichard D Durham, Th D Professor of Bible and Greek Lee Eimers. Ph D Associate Professor of Physics.

Sharon Lee Fimers Math Assistant Professor of Education Charles L Ellington. Ph D. Professor of Music

E Ellen Glanville. M.S.Ed Visiting Instructor in Special Ed. Edward L Greenwood. D.A Professor of English Robert Gromacki. Th D. Professor of Bible and Greek Ronaid M. Grosh. Ph D. Associate Professor of English

Helen L. Hall, MA Associate Protessor of Education Joseph G. Halsey. MEd Associate Professor of Political SCI Sandra W Harner. MA Assistant Protessor of English Larry S Helmick. Ph D Professor of Chemistry

Lawrence N. Killian. MS Associate Protessor of Biological Elvin R. King. MEd Associate Professor of Physical Ed Mark R. Klimek. M.S.N Assistant Professor of Nursing H. Mark Larson: MA Assistant Professor of Spanish

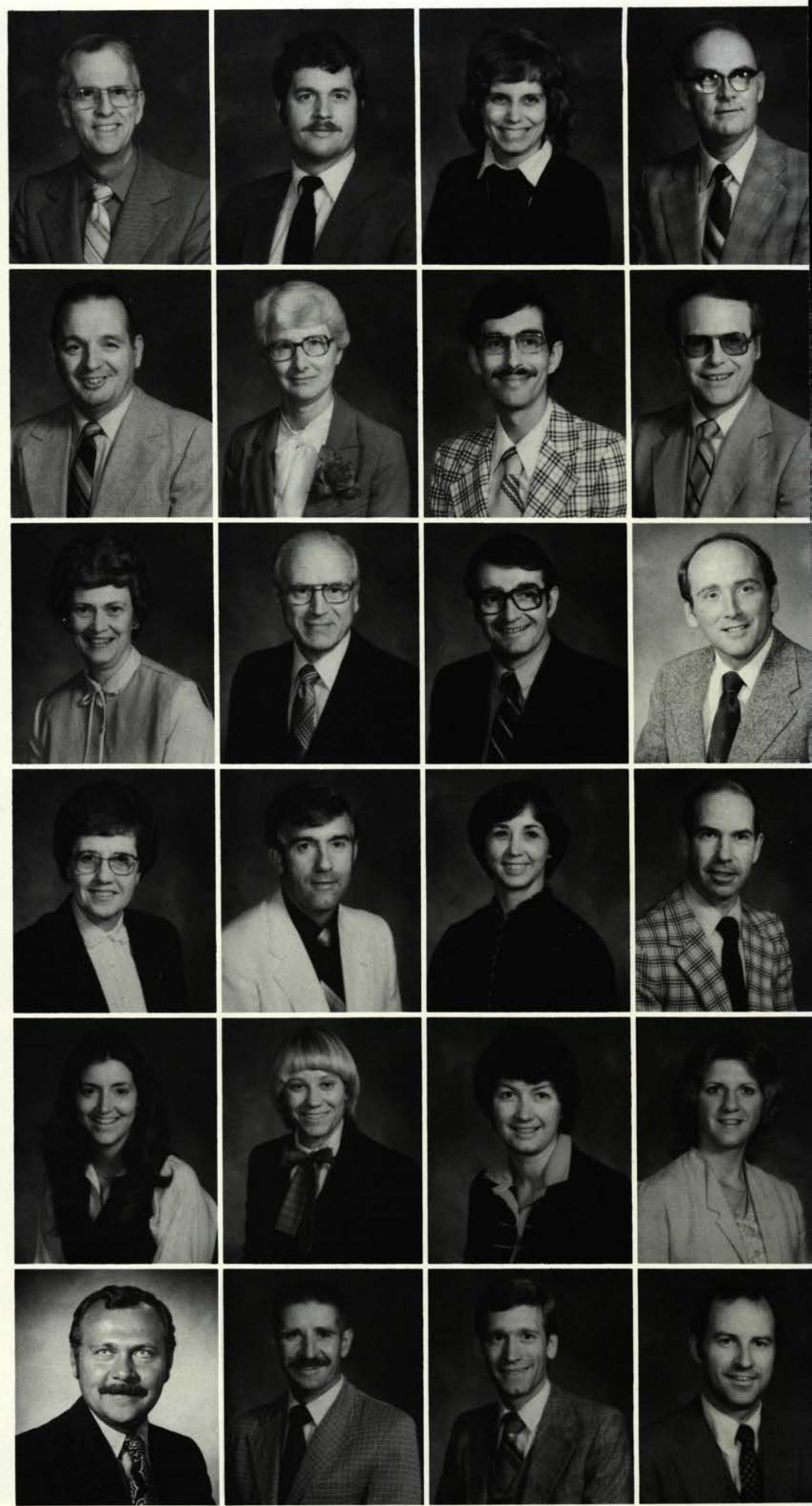




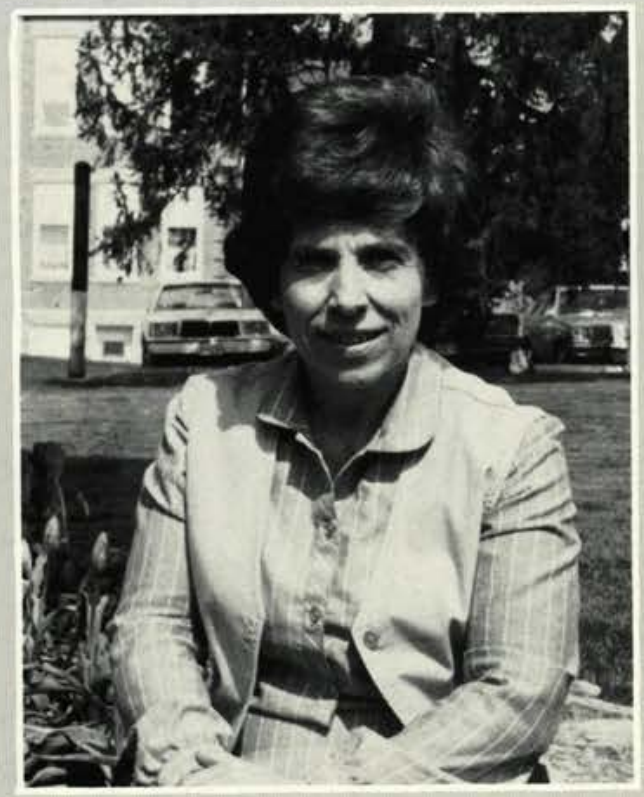

$\mathbf{W}$ hen I think of what Cedarville College is now compared to what it was when I first saw it, my first thought is, "How things have changed."

First of all there are many physical changes. Most of what is here wasn't here, and most what was here has been painted, sandblasted, cemented over, or drowned. My students are amazed when I tell them that at one time the whole student body sat down to eat together in what is now the post office, or that we all had chapel in the book-store, or that the third floor of Collins Hall was a dormitory.

Who would have dreamed in those years that the school was struggling to keep its head above water, that someday we would have our own lake, or who could look back from a season of championships to believe the "roar of the crowd" when the basketball team won its first game?

Would I want to go back to mudpaths, to sports events in Alford, to one hundred students in the student-body. or to the cook's favorite lunch being Spanish rice? Not on your life! I love cement walks, a beautiful new field house, the multitudes of students, and the salad-bar at lunch time.

Now I treasure the memories, I relish the thirty-year friendships, and I thank God for what Cedarville meant to a new Christian those many years ago. but I thrive on the excitement of watching the generation's students accept the challenge of a stressful society with hope and courage and faith.

Sandra G. Entner M.A.

Part-time instructor

Social Science Dept.
- t was not easy to capsulize twenty 1 years into several hundred words. Cedarville has been a way of life since arriving here as a student in 1964. It is here that I met my wife to whom I am very indebted for her willingness to put up with an often hyperactive schedule. It is from her that I have learned the Biblical concept of helpmeet.

Cedarville has provided opportunities, victories, and also, defeats. Certain quarters seem to rival eternity in length, yet others go more quickly than a box of cookies in a dorm. The reward comes, though, when a student returns after several years and relates how something that was taught is now useful to them. No words can adequately express the joy of seeing a student mature in spirit and mind.

The Lord has blessed. I remember when Williams Hall was a dorm, Alford was a chapel and the cafeteria was a gymnasium. The Post Office was in the basement of the $A D$ building and house trailers sat where the Chapel sits now. I remember knowing every student by name and having no I.D. cards.

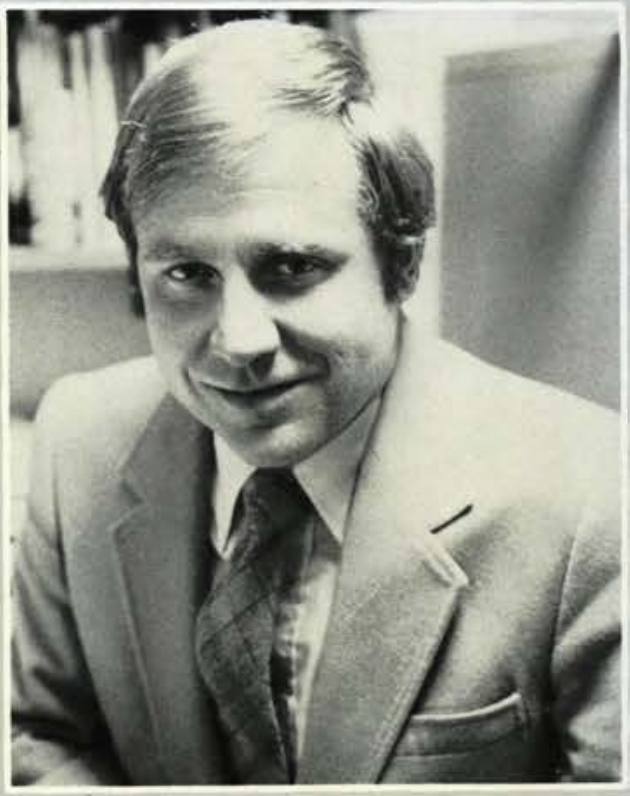

Yet, it is good to see the growth and though I might wish for quieter times once in a while, I cannot look at Cedarville and not see the handiwork of God.

\section{by James R. Phipps Ph.D.} Professor of Speech
James Edward McGoldrich. Ph.D. Professor of History Richard T. Mcintosh. Th.M Associate Professor of Bible

Allen L. Monroe. Ph. . Professor of Social Science Beverly S. Monroe. M.A. Associate Professor of Education

Kurt D. Moreland, M.A Assistant Professor of Communication Arts
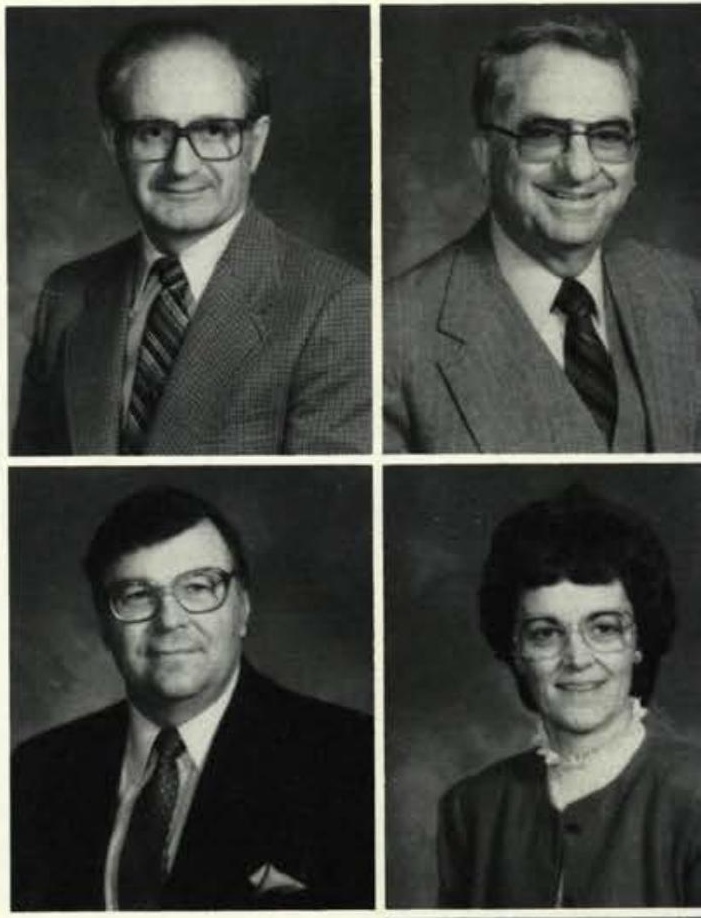

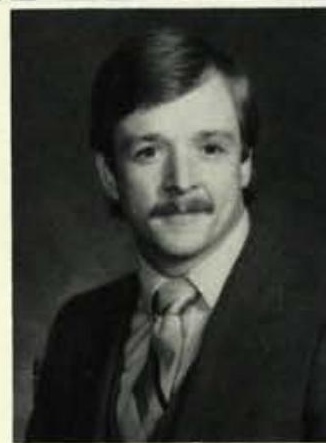




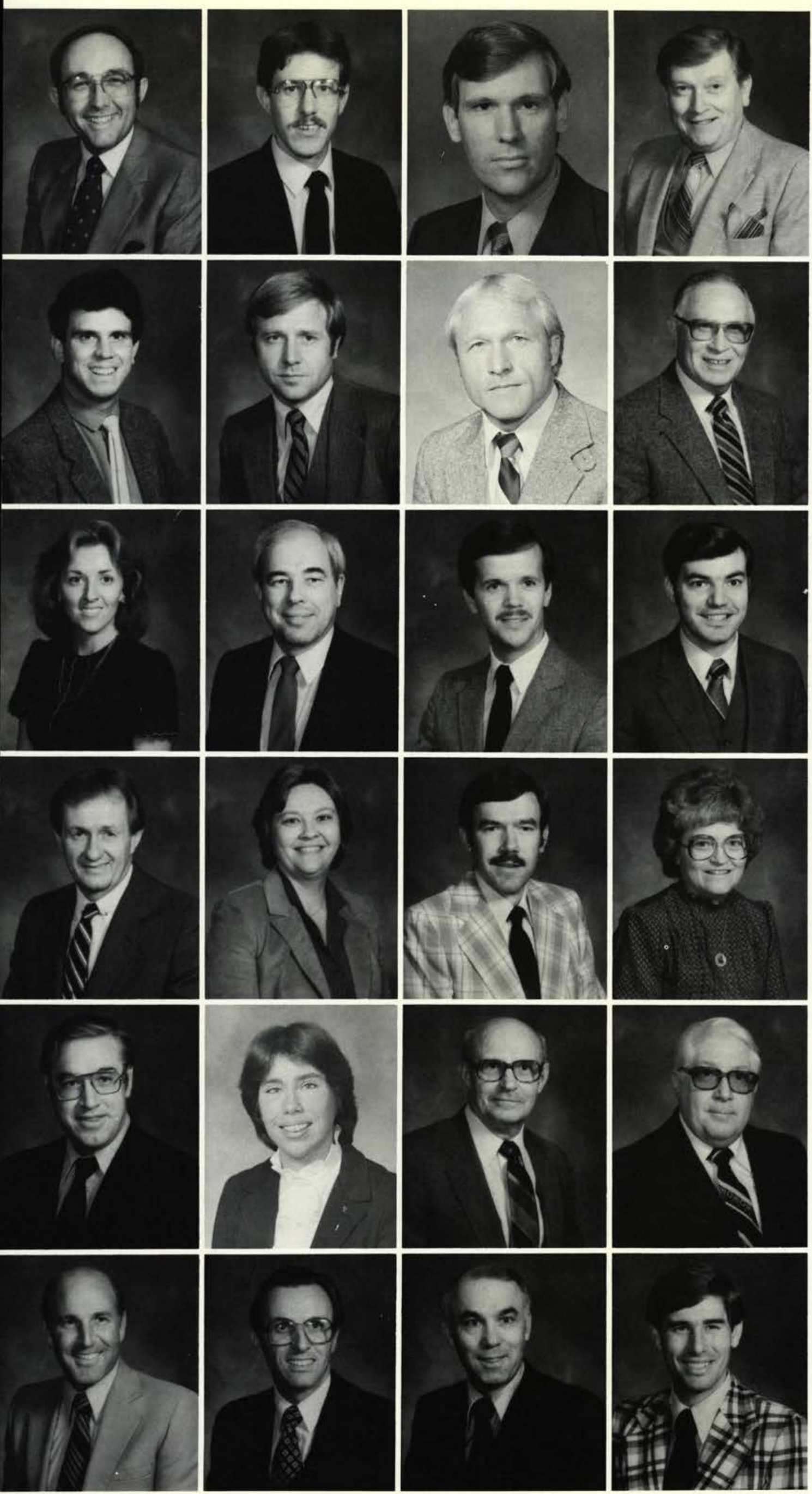

J. Murray Murdoch. Ph.D.

Professor of History

Chairman. Social Science

Department

Charles M. Pagnard. MM.

Assistant Professor of instrumental

Music

Robert Glenn Parr. M.A.

Assistant Professor of Sociology

Donald A. Parvin. M.Div.

Assistant Professor of Bible

Gary John Percesepe. M.A

Assistant Professor of Philosophy

James R. Phipps, Ph.D.

Professor of Speech

Chairman Speech Dept

Terry L. Phipps, M.S.

Assistant Professor of Science and

Math

Marlin L. Rayburn, M.A

Associate Professor of Speech

Anne N. Rich, M.Acct, C.P.A.

Instructor of Accounting

Jack R. Riggs, Th.D.

Professor of Bible

David H. Robey, M.A.

Assistant Professor of Speech.

Drama

Rex Martin Rogers, Ph.D.

Assistant Professor of Political Sci.

James Seaman, Ph.D.

Associate Professor of Marketing Management

Lila M. Seaman, Ph.D.

Administrative Assistant of Nursing

John Edward Silvius, Ph.D.

Associate Professor of Biology

Ruth Ellen Slocum, M.S.

Assistant Professor of Nursing

Galen P. Smith, M.S

Assistant Professor of Economics Sarah H. Smith. Ph.D.

Assistant Professor of Accounting

Edward E. Spencer, M.A.

Professor of English

Karl N. Stahl. M.A

Assistant Professor of Organ

Ronald J. Walker, B.A

Assistant Professor of Business

Chairman. Business Department

W. David Warren Th.M.

Associate Professor of Bible

Greek

Daniel E. Wetzel, Ph.D.

Professor Physics. Math

Stephen W. Young. B.A.

Coach and instructor of Physical

Ed. 

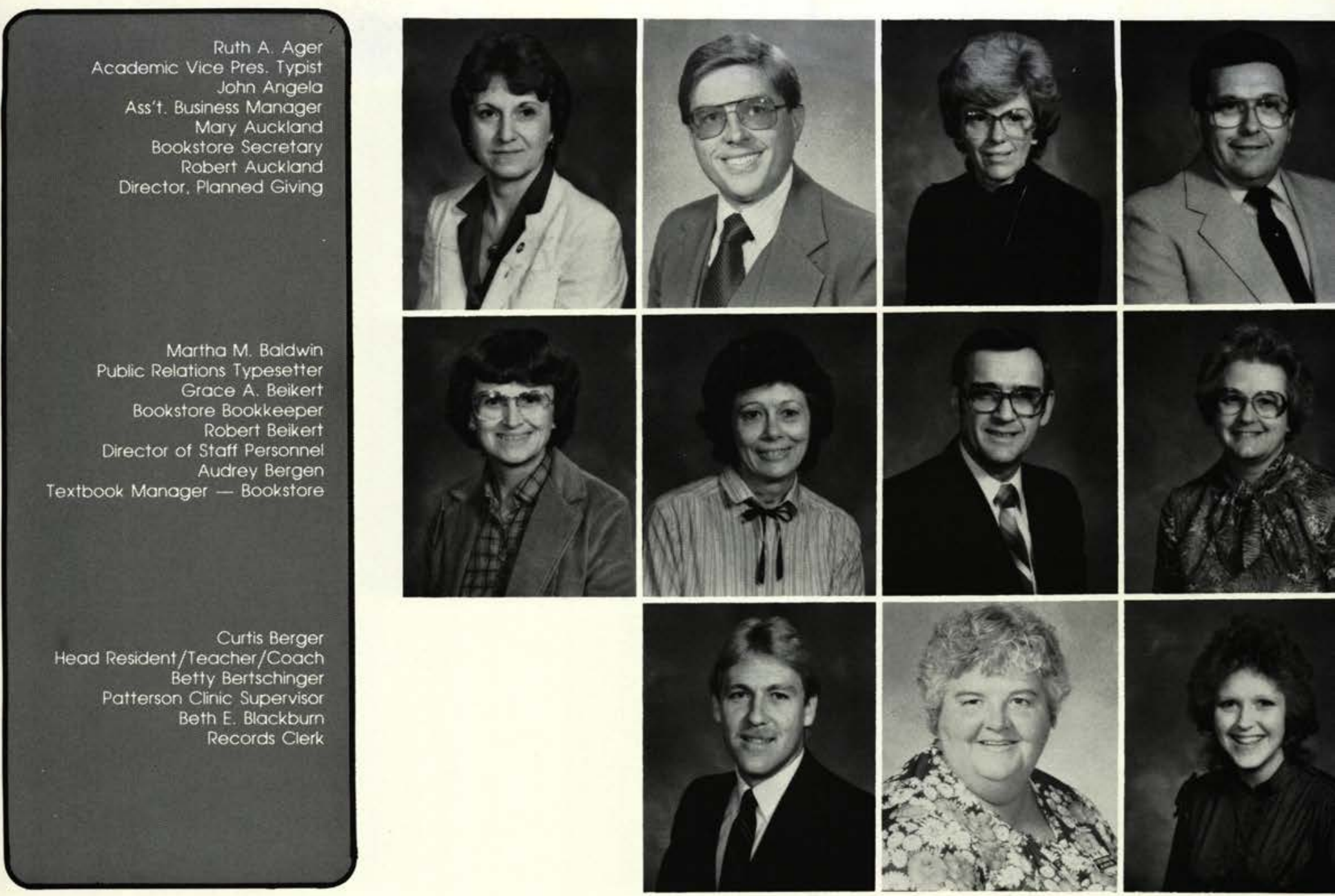

\section{David}

\section{Purrington}

\section{Staff}

\section{Member}

\section{Of The Year}

This native from New Hampshire I came to Cedarville four years ago. Having been graduated from the Wentworth Institute with a degree in buidling and construction, he came to work in the Maintenance Department as a carpenter. It didn't take the col- lege family long to realize they had a "master of carpentry skills." His masterpiece in the restrooms of Alford convinced them.

One of his colleagues in maintenance, Dan Orr, expressed his appreciation of Dave by saying. "Dave is well respected for his leadership and attitude by all of us men. He's the finest example of a believer giving his all to the Lord and his job. I've learned from him that a job is not just a job but a ministry. I've kidded him about his being a 'Klutzo,' but he truly has the finest skills of being able to take rough lumber and turn it into a beautiful cabinet. l'd do anything for him."

We salute Mr. Dave Purrington, Assistant Director of Physical Plant, for his being selected the "Staff Member of the Year."

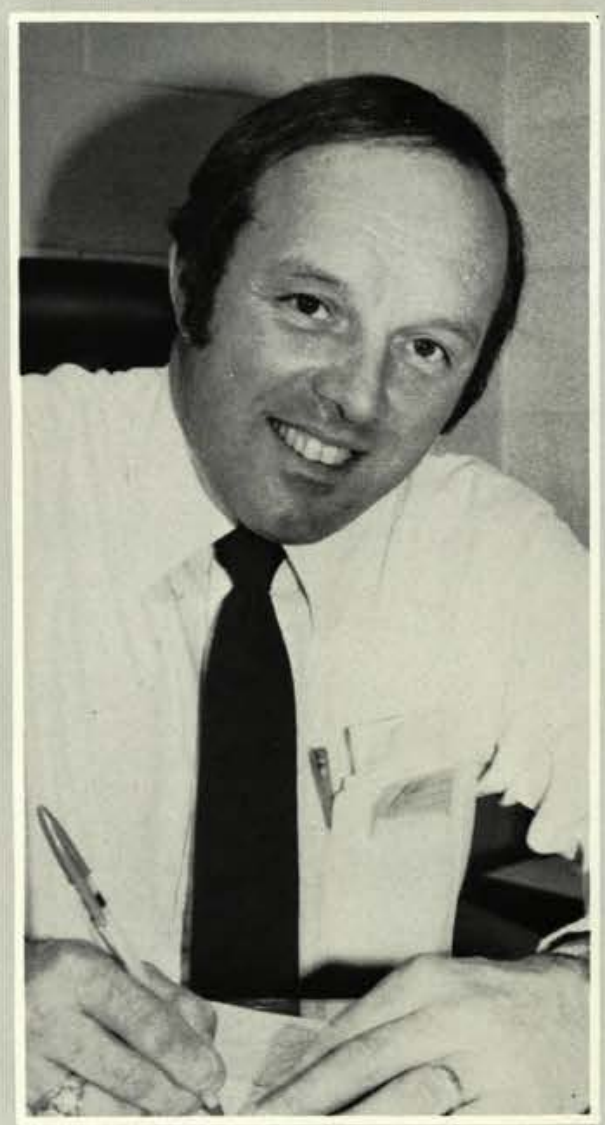




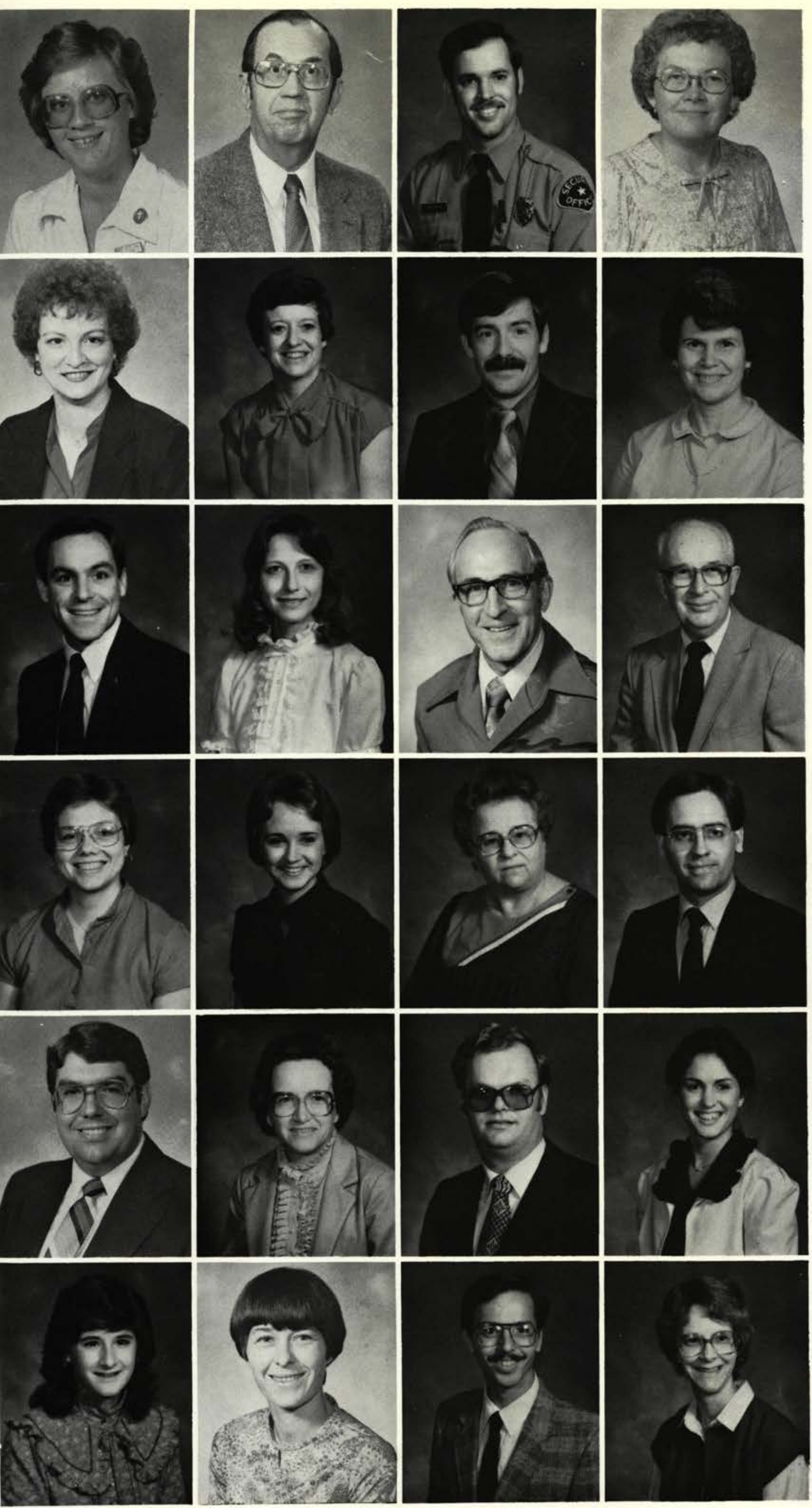

Brenda Boley

Staff Nurse

Richard Bowersox

Controller

Mark Andrew Brown

Security, Sargent

Margaret Burrichter

Business Office Staft

Deborah Cagwin

Accounts Payable Clerk

Fran Campbell

Secretary. Physical Plant

Jack N. Canpbell

Electronic Technician

Alberta Carr

Bookstore Clerk

James David Cato

WCDR Field Representative

Melody Cato

Bookstore Clerk

Stuart Chaffe

Bookstore Staff

Harry E. Cole

Ass't Bookstore Manager

Deborah Jean Compton

Records Clerk

Emily Carol Conklin

WCDR Secretary

Wilma J. Conklin

CRT Operator

Ron James Coriel

Director. Public Relations

Robert Couch

Ass't. Director of Financial Aid

Sherry G. Coy

Secretary, Student Services

Jeffery Cunningham

Electrician

Marie Daliey

Secretary. Placement

Derena Lynn Danube

Secretary Physical Plant

Jeannie Day

Bookstore Clerk

John DeMeester

Head Resident

Linda Anne Divan

Audio-Visuals Coordinator 
ence Department

Patricia A. Farrow

Head Resident

Judith Ann Fires

Secretary to the Vice President

of Development

Nancy Fissel

Business Office Staff

David Charles Gaffner

Director of Piacement

Paul H. Gathany

WCDR General Manager

David Gidley

Financial Aid Director

rene J. Gidley

Secretary to the President

ifies Office Manager

May E. Greenwood

Secretary to Academic Vice

President

Dewayne Grooms

WCDR Staff

Hugh T. Hall

Director, Church Relations

Lorraine Ann Halladay

Staff, Dept. of Nursing

Agnes C. Howell

Head Besident

Trish J. Huber

Staff, Social Science Dept.

Sherry L. Hubler

Bookstore Clerk

ephan Allen Hubler Plumber Helen Hunt

Secretary, Physical Plant Leigh Hunt

Director of Physical Plant

Judy Ann Johnson

Circulation Supervisor/Library

Horold Dole Kendal

WCDR Operation Director

JoAnne E. Kendall

Admissions Correspondent Toinette King

Staff. Education Dept.

Nancy A. Knouft

Student Services Receptionist
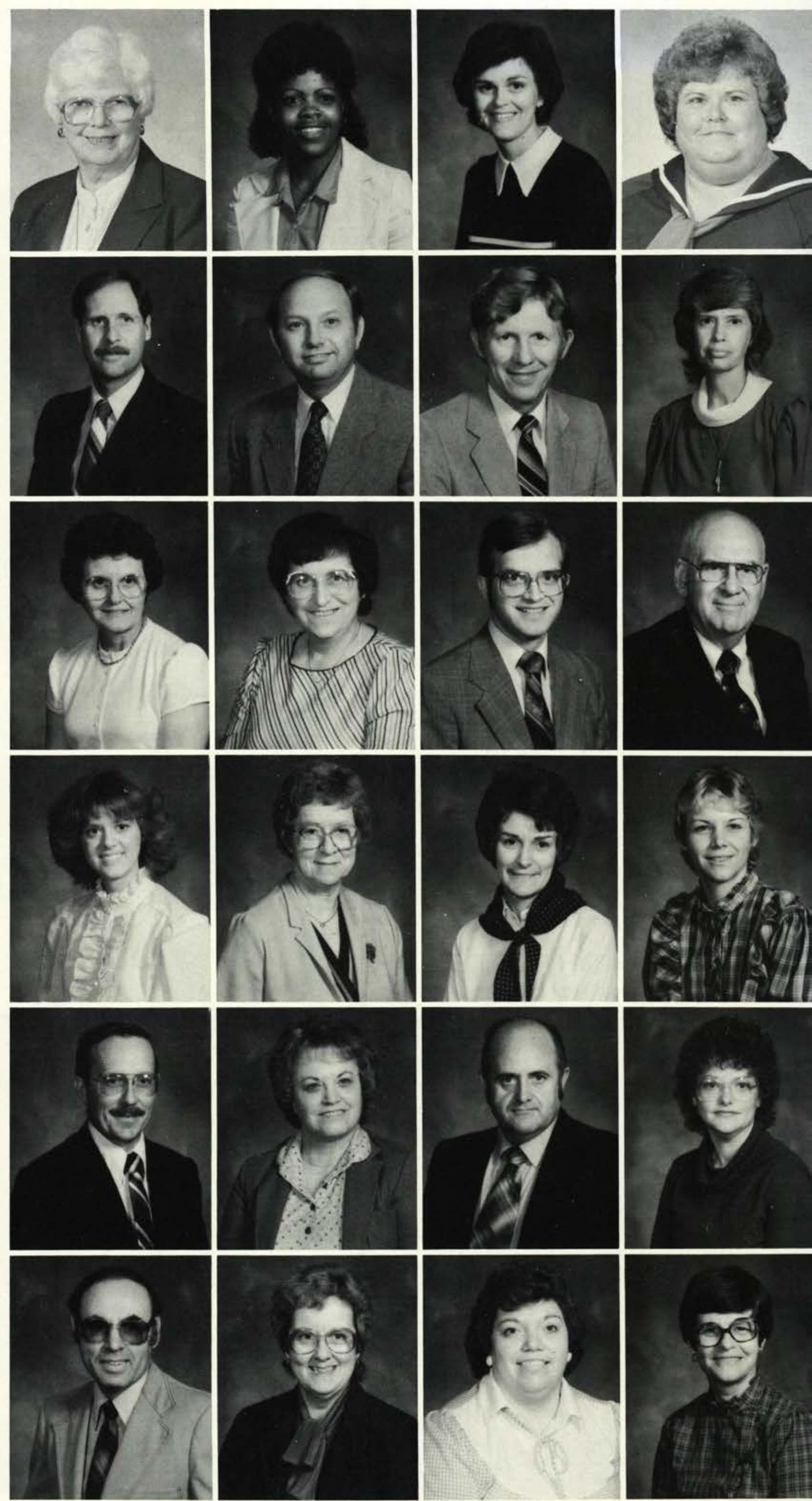


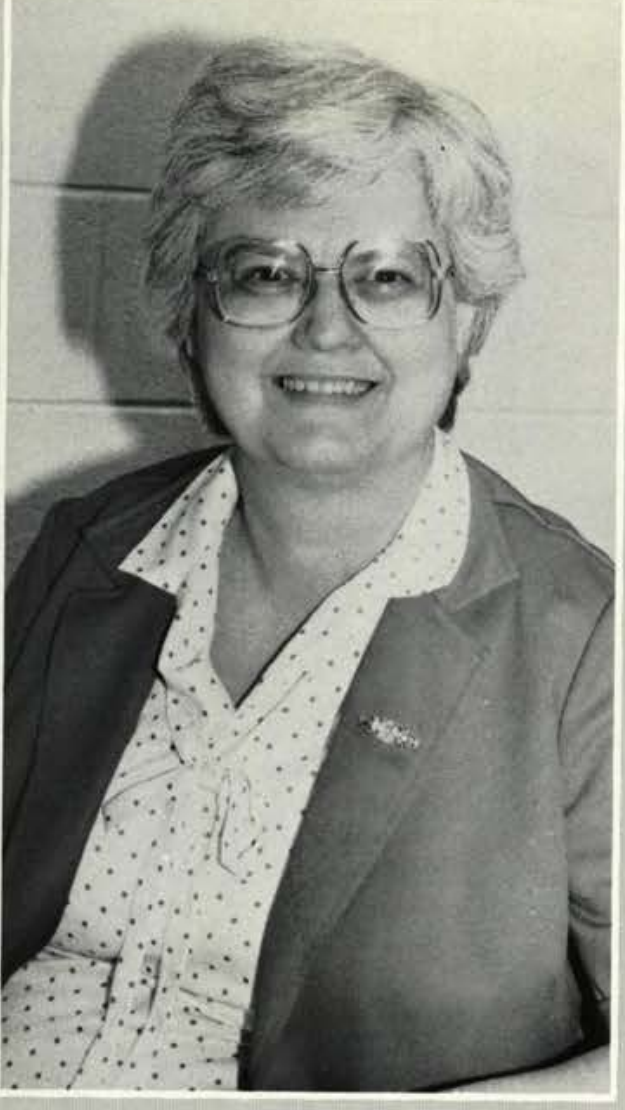

In the fall of 1980, we felt the Lord's leading to sell our service station. We then sought His guidance as to what $\mathrm{He}$ would have us to do. Our son and daughter, Mark and Carla, were attending Cedarville College at that time. The college and its people had always impressed us with its testimony and goals; we wanted to become a part of its ministry. After breaking the ties with operating a service station for twenty-two years, we applied and were accepted to work on the staff of the college.

We have always enjoyed young people and athletics. Cedarville College is a place where we can enjoy both at the same time. Working in the physical education department, I see a Christian balance in athletics. Winning is important; but I see there among the athletes and the coaching staff an emphasis in the athlete's responsibility to exhibit his or her Christian faith and to set an example before other visiting athletes with whom they come in contact.

One of my husband's special times is during the winter when he is called out early in the morning to plow snow and enjoy the quiet stillness of the campus before the activity of the day begins. He also appreciates the time of sharing he can have with different students who work in the maintenance department each quarter.

Cedarville College is a great place to work and it is rewarding to see the spiritual growth of the students who touch our lives. by Glenda Womack Secretary, Physical Education Department
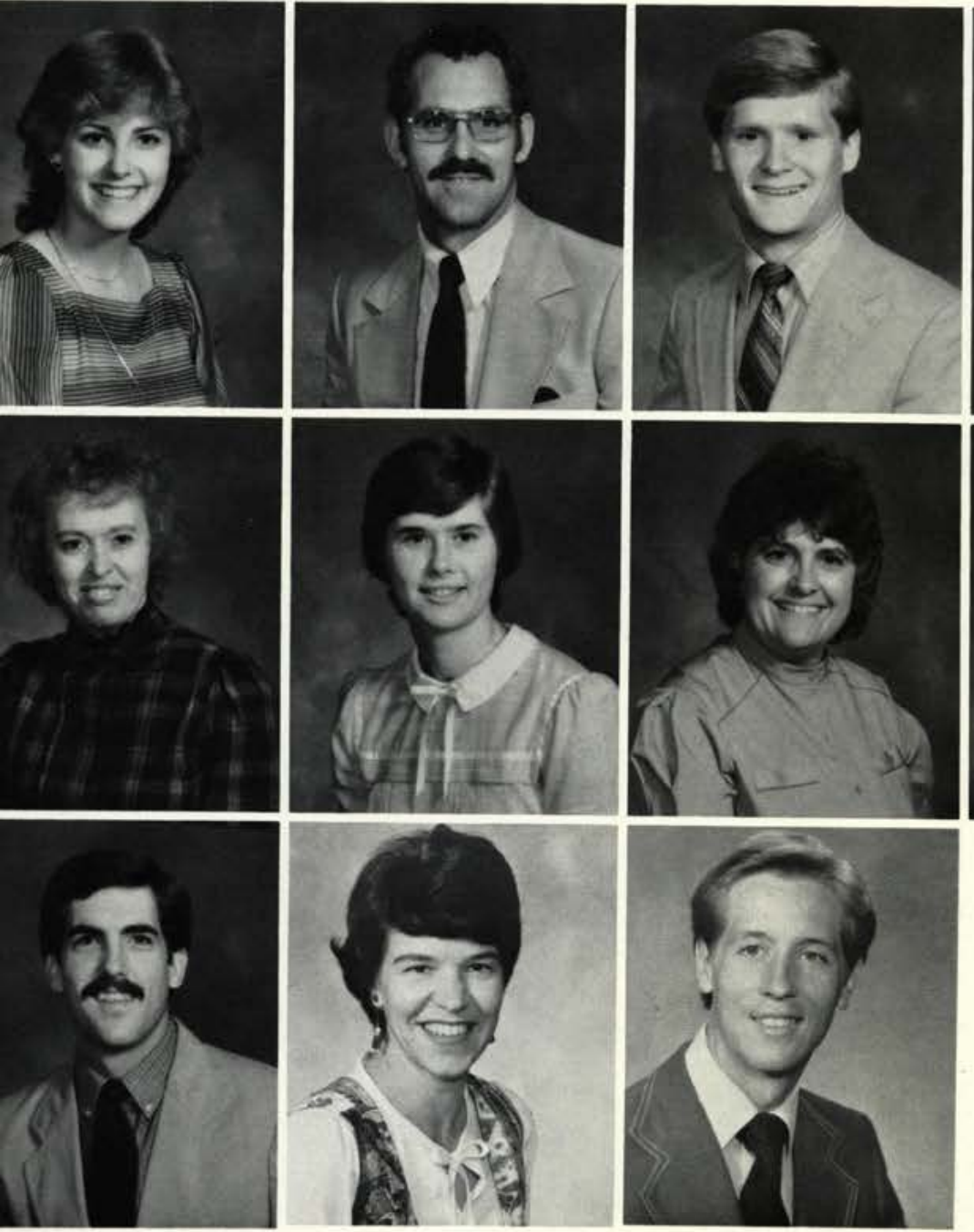

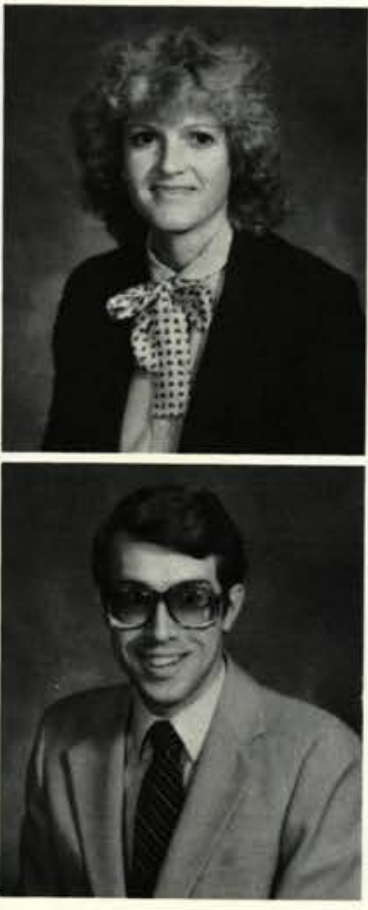

Michelle Lynn Kola

Church and Chapel Clerk Gary P. Kuhn

Director of Alumni Relations

Matt E. Kunkel

Head Resident

Susan Denise Larson

Graphic Artist, Public Relations

Patricia J. Lee

Payroll Clerk

Diane Lynn Lichtensteiger

Secretary. Business Administration

Dept.

Sheryl D. Liddle

College Photographer

Bruce Maddux

WCDR Electronics Technician

Mark Everett Mathews

Adjunct Instructor/Coach

Rebecca Matson

Library Clerk. Music Dept

Mark McDougal

Recreational Activities Director 
am thankful to be a part of Cedar1 ville College and for the evident blessing of God which I have seen and experienced. I am thankful for trustees with faith equal to their vision and for faculty and administration who love the Lord and care about their students. I am also thankful for dedicated staff members who are willing to do their jobs to the best of their ability and for students brought here by God with the potential of living their lives for His glory. I am thankful for the testimony of our graduates in their many spheres of activity: in the pulpit, in the classroom, in business, on the mission field, and in their homes. There have also been many answered prayers through the years that have increased our faith for future accomplishment.

I praise God that $\mathrm{He}$ rewards hard work. What greater visible evidence do we have than the beautiful campus with the multitude of cheery flower beds? God goes beyond that which we can do. He gives us, in addition, that delightful clump of wild violets, those breathtaking fall leaves, and the evening sunset. I am thankful for what the faithfulness and hard work of so many people have accomplished. Most of all, I am thankful that God goes beyond to add untold blessings and surprise delights. I am thankful for $\mathrm{Ce}$ darville College.

by Audrey L. Bergen

Bookstore Staff

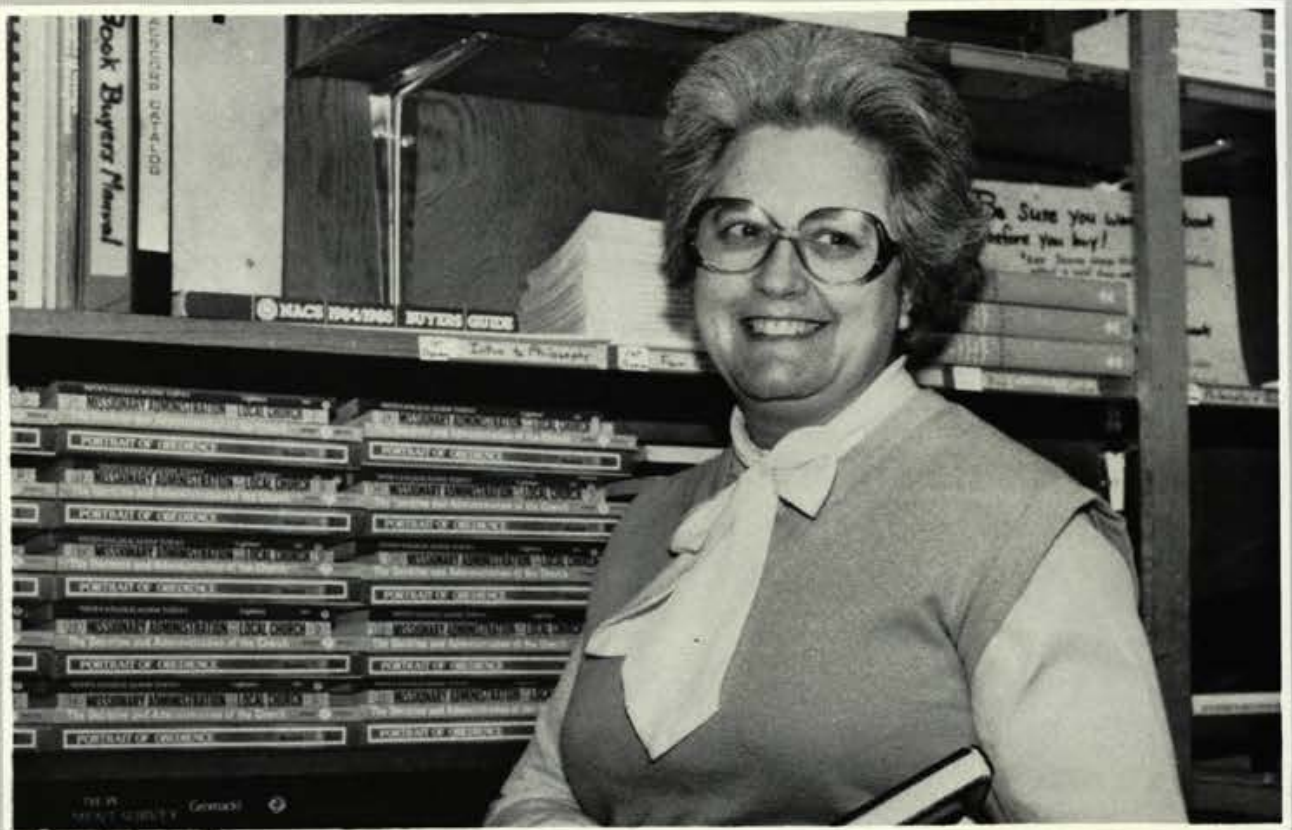

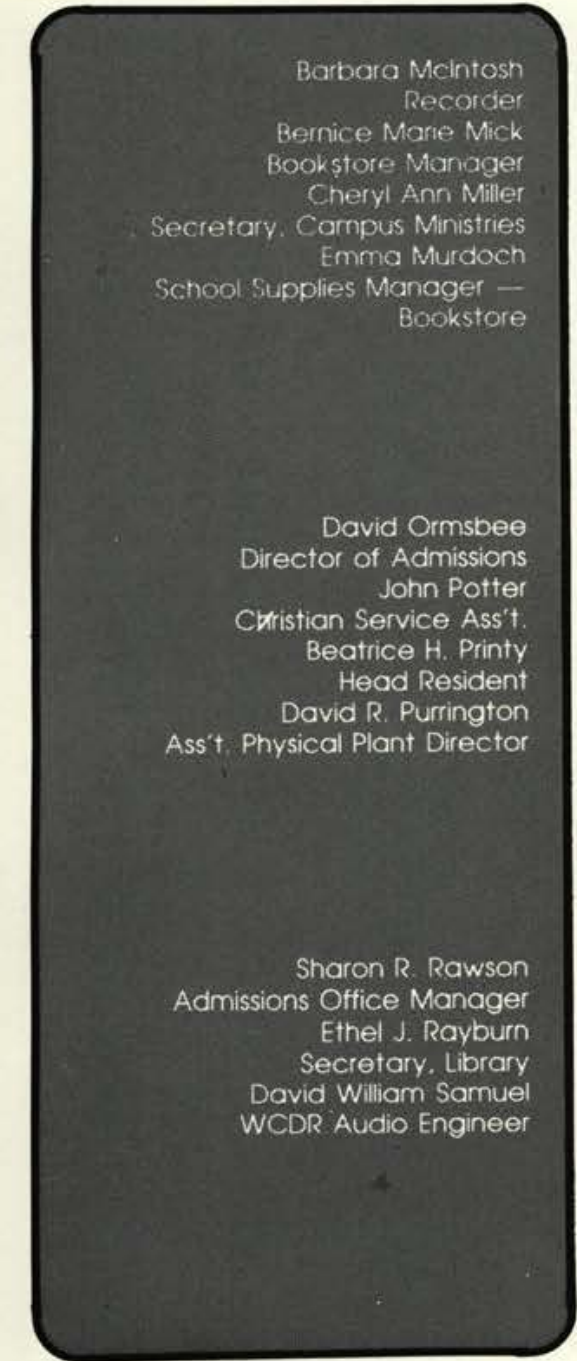
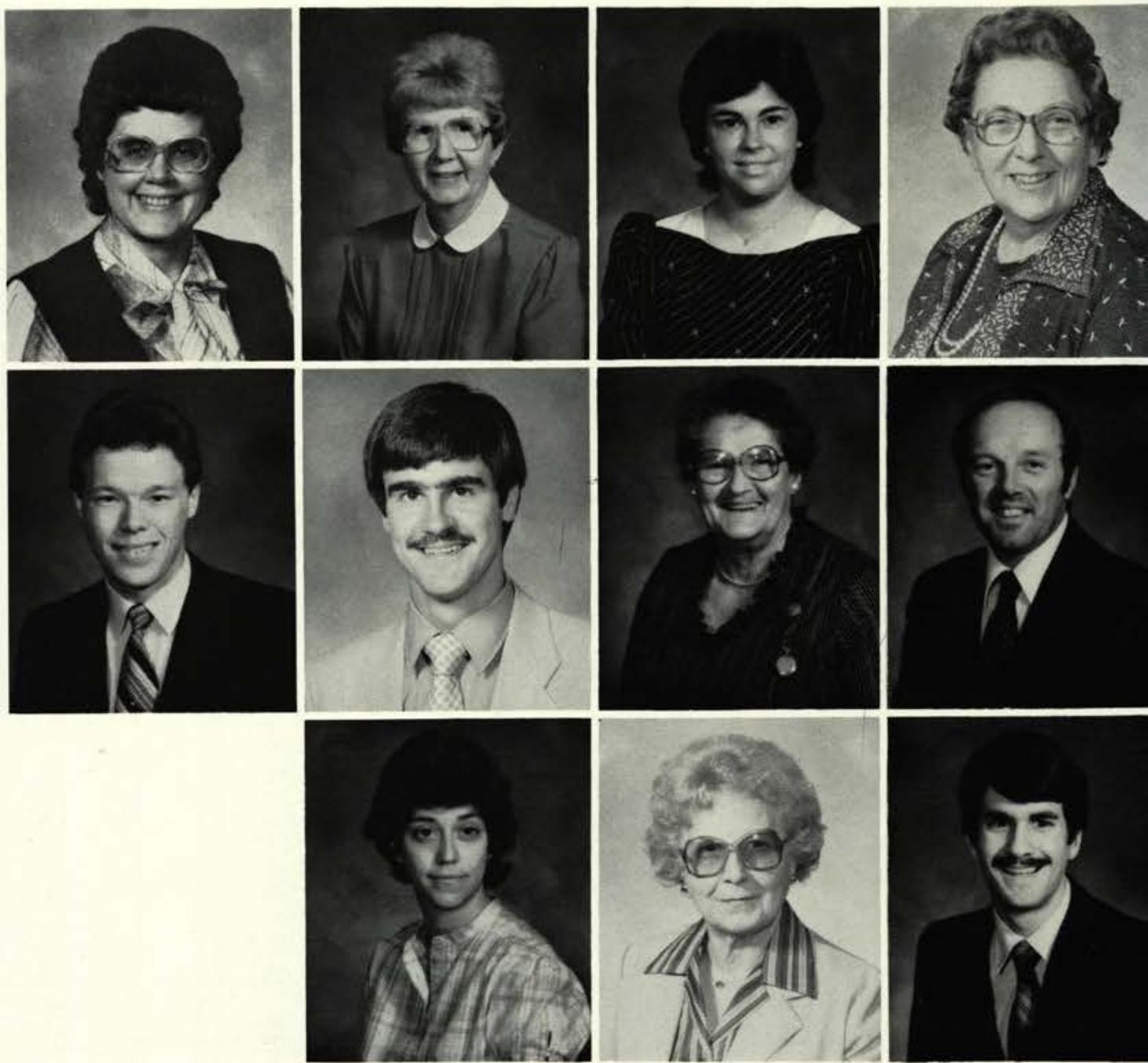
AU.DEL'S BEAUTY AND GIFT SHOP 80 N. MAIN STREET

CEDARVILLE, OH 45314

$766-4351$

\section{BANK ONE}

306 W. SECOND STREET

XENIA, OH 45385

376-2971

\section{CEDARVILLE COLLEGE BOOKSTORE}

P.O. BOX 32

3131 FISHWORM ROAD

CEDARVILLE, OH 45314

766-1781

\section{CEDARVILLE HARDWARE \\ MAIN AND XENIA STREETS \\ CEDARVILLE, OH 45314 \\ 766-1941}

\section{CENTRAL AUTO PARTS \\ 140 E. MAIN \\ XENIA, OH 45385}

\section{COLONIAL PIZZA}

87 N. MAIN STREET

CEDARVILLE, OH 45314

766-5779

\section{DICK'S GLASS AND MIRROR}

196 DAYTON AVENUE

XENIA, OH 45385

$372-8451$

\section{GERARD INSURANCE}

1 WEST WASHINGTON STREET

JAMESTOWN, OH 45335

675-9321 OR 372-2600

\section{GODFATHER'S PIZZA}

124 XENIA TOWNE SQUARE

XENIA, OH 45385

$376-8286$

\section{GOODYEAR TIRE CENTER}

213 W. MAIN

XENIA, OH 45383

$372-9254$

DAVID A. HAFFEY, MILLER, FINNEY, AND CLARK, ATTORNEYS AT LAW P.O. BOX 610

20 KING AVENUE

XENIA, OH 45385

$372-8055$

\section{HAIR LIMITS}

96 N. MAIN STREET

CEDARVILLE, OH 45314

766-5855 XENIA: $376-4303$

HOME FEDERAL SAVINGS AND LOAN
129 N. MAIN STREET

CEDARVILLE, OH 453

766-2141

\author{
HURLEY'S WALLPAPER AND PAINT \\ $\triangle 91$ W. 2ND STREET \\ XENIA, OH 45385 \\ $372-8435$
}

JOHN MEYER BUICK PONTIAC GMC

1213 CINCINNATI AVENUE

XENIA, OH 45385

372-6947

JOHNNY'S AUTO PARTS

51 WASHINGTON STREET

XENIA, OH 45385

$372-9286$

\section{LANG'S CHEVY TOWN \\ 127 E. MAIN STREET \\ XENIA, OH 45385 \\ 372-3551 \\ LEATHER BRITCHES \\ 57 N. MAIN STREET \\ CEDARVILLE, OH 45314 \\ 766-5531}

MC KINNONS FLORIST

$1336 \mathrm{~W}$. NORTH STREET

SPRINGFIELD, OH 45504

325-9826

MIAMI BANK

69 N. MAIN STREET

CEDARVILLE, OH 45314

766-2311

MORRIS BEAN AND CO.

CEDARVILLE PLANT

$154 \mathrm{~W}$. XENIA AVENUE

CEDARVILLE, OH 45314

766-2471

\section{OPEKASIT CENTER}

$\triangle 211$ TOWNSLEY

CEDARVILLE, OH 45314

766-1031

\section{PAM'S PLACE}

81 NORTH MAIN STREET

CEDARVILLE, OH 45314

766-2027

PIONEER FOOD SERVICE

251 N. MAIN STREET

CEDARVILLE. OH 45314

766-4211

PRO KUT HAIR STYLING

36 W. MAIN STREET

XENIA, OH 45385
$372-4333$

RAY'S AUTO TRIM

323 W. CHURCH STREET

XENIA, OH 45385

$372-2966$

RAX RESTAURANT

233 W. MAIN STREET

XENIA, OH 45385

$376-4418$

\section{SEAMAN REALTY SALES \\ AND CONSULTING \\ $88 \mathrm{~N}$. MAIN STREET \\ CEDARVILLE, OH 453 \\ 766-5674}

\section{STATE FARM INSURANCE}

BILL ROGERS AGENCY

$280 \mathrm{~N}$. DETROIT STREET

XENIA, OH 45385

$372-4429$

SUPERIOR LABEL SYSTEMS

BOX 42415

11405 GROOMS ROAD

CINCINNATI, OH 45242-1476

$513-489-3800$

THIRD NATIONAL BANK AND TRUST

co.

$120 \mathrm{~N}$. DETROIT STREET

XENIA, OH 45385

372-8035

\section{VILLAGE SUPER VALU}

360 N. MAIN STREET

CEDARVILLE, OH 45314

766-1201

\section{WEAD AND AULTMAN}

ATTORNEYS AT LAW

ALLEN BUILDING

$231 / 2$ W. MAIN STREET

XENIA, OH 45385

$372-4436$

WEBBER'S FLORIST AND GIFT

\section{SHOPPE}

75 N. MAIN STREET

CEDARVILLE, OH 45314

766-5768

W.R. HACKETT, INC.

99 W. NORTH STREET

SPRINGFIELD, OH 45501-1042

323-7541

\section{YOUNG'S JERSEY DAIRY}

6880 SPRINGFIEID-XENIA ROAD

YELLOW SPRINGS, OH 45387

325-0629 


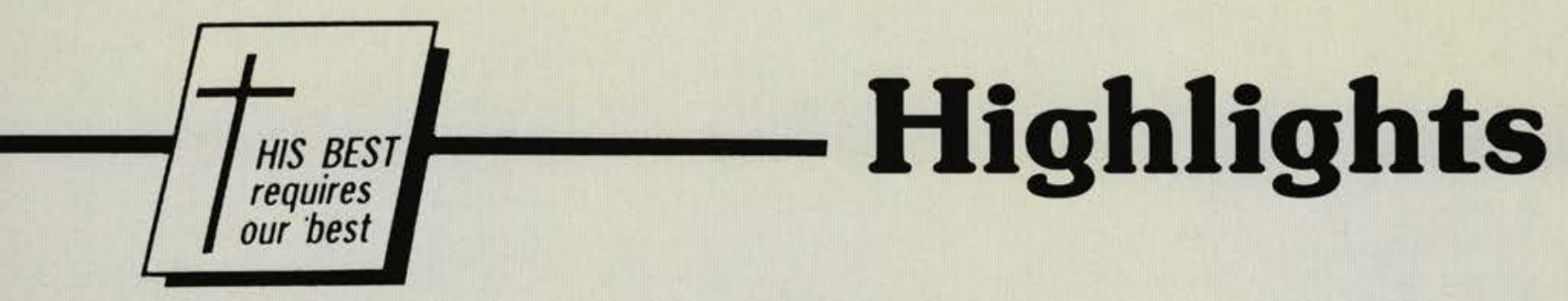

\section{REFLECTING}

\section{AN ERA."}

The Class of ' 84 . Four years

I further and wiser. MIRACLE aptured them for lifetime renemberence and congratuates them for their enduring acomplishment. This next section potlights these seniors and their pecial year.

Miracle captured the excitenent of Homecoming; relives he thrill of the banquets; and onors the Class of ' 84 upon heir graduation. Join Miracle as ve see the end of an era and inticipate the beginning of anther.

\section{Contributors:}

Susan Fields ...........36

Martha Baldwin ........38

John Sidle ............40

David Wright .........42

\section{ayout by:}

\section{Jeff Wassenaar}

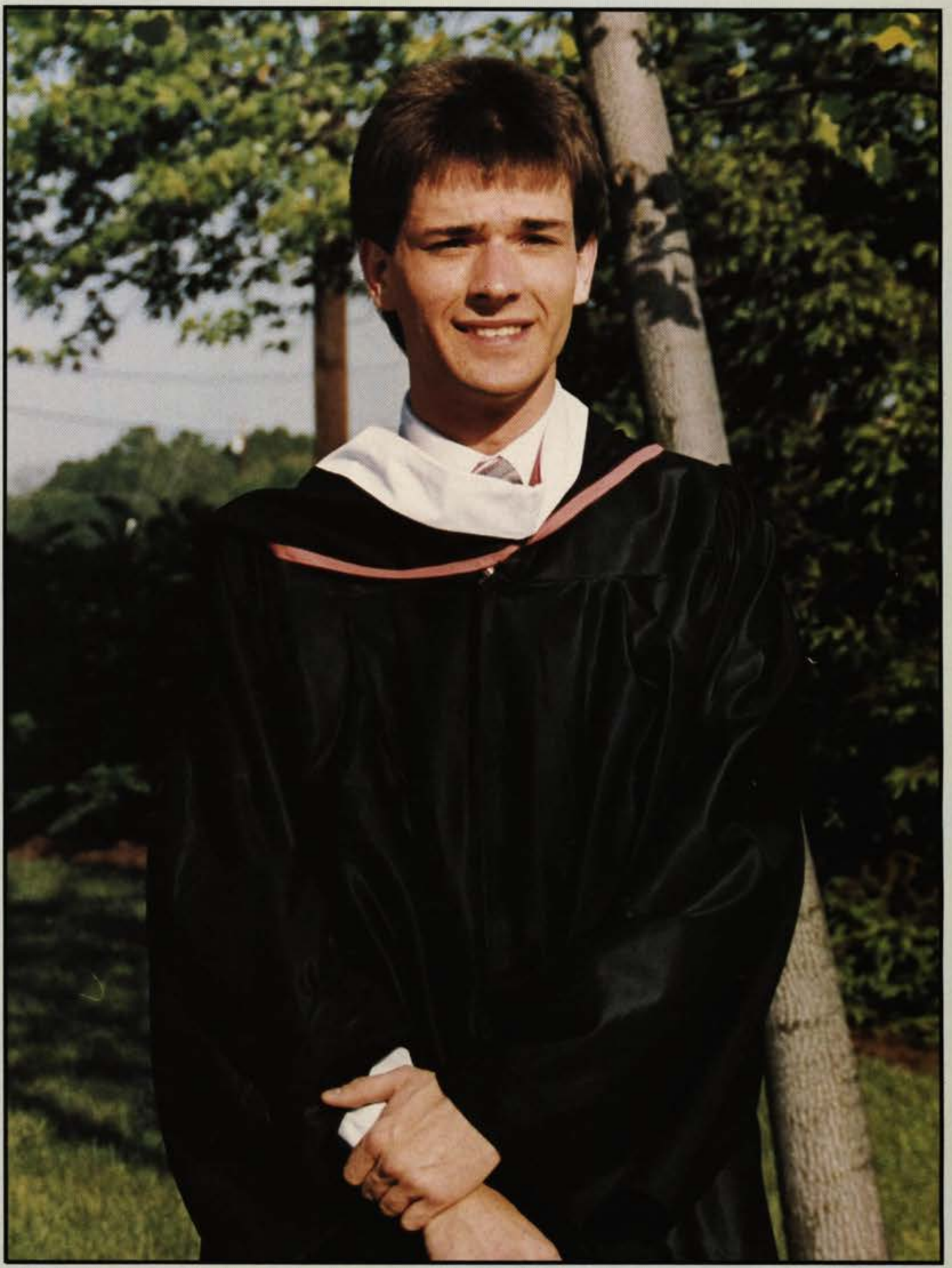




\section{Coming} Home In

\section{Style}

$\mathrm{n}$ the past it seemed like an enjoyable flurry of activities including reunions with families and old friends, the Homecoming banquet and court, and the parade all of which culminated with the soccer game.

This year, however, I received a behind-the-scenes look at Homecoming activities and what they involved. From the time that I was first notified of my Homecoming nomination to the ending of the soccer game weeks later, I found myself hurled into an exciting world of new acquaintances, activities, and responsibilities. I saw a little of the work that goes into events such as the Homecoming activities. I grew to appreciate the cheerful dedication of those individuals involved in long hours of planning and organizing and to respect Jim Barber and the other members of the Homecoming Committee, as well as Gary Kuhn and the Alumni Association. Their hard work and gracious examples truly reflected the theme, "His best requires our best."

Lace parasols, fans, and pink and white ribbons complimented the theme of the Homecoming Banquet, "A Celebration of Southern Style." Entertainment for the evening was provided by $\mathrm{Dr}$. and Mrs. Lyle Anderson followed by the annoucement of $\mathrm{Dr}$. and Mrs. Edward Greenwood as Grand Marshalls for this year's Homecoming activities. Next, came the presentation of the court: Freshman Valerie Baylock, escorted by Bill Lee: Sophomore Susan Olsen, escorted by Jim Reiter; and Julie Shellie Beaman escorted by Jay Benson. The Senior Homecoming court consisted of Sara Beattie and her escort Scott Dixon;

\section{"I grew to appreclate the cheerful dedication of those in. dividuals involved ...."}

Laura Coffman and her escort Tim Pryor: Angela Cooke and her escort Gillis West; and myself, escorted by Barry Kane. The court members proceeded down a staircase descending from the mezzanine to the cafeteria floor and over to the coronation stage.

Homecoming week brought such activities such as the President's Associates Dinner, the Heritage Alumni Reception and Dinner, and the Prism IV Concert. On Friday of that week was Homecoming chapel. It was a memorable one featuring not only a mes- sage in song by the Heritage Alumni. but also Rachel Kitchen and Harry Sinks' spirited testimonies of what life was like at Cedarville in 1938. Student Senate presented a silver tray to the Homecoming Grand Marshalls Dr. and Mrs. Edward Greenwood. Senate also recognized Dr. and Mrs. James T. Jeremiah for thirty years of faithful service to the college.

Saturday morning set the stage for all the activity; the sun shone brightly, and for once only a slight breeze moved through the air. The Lord blessed us with a perfect day for the parade and soccer game. Both events went smoothly. The parade provided enjoyment for both spectators and participants. A Yellow Jacket soccer victory over Northern Kentucky University put the icing on the cake. An all-school social completed the weekend's activities and provided a relaxing and enjoyable wind-down from the constant activity.

I saw the theme, "His best requires our best," exemplified countless time in the generous support and encouragement of my roommate, friends, fellow students, faculty and staff members who showed me so much about what it really means to be a part of $c$ Christian college family. All of these activities worked together to make this Homecoming a memorable success, one which will influence my life for years to come.

by Susan Fields

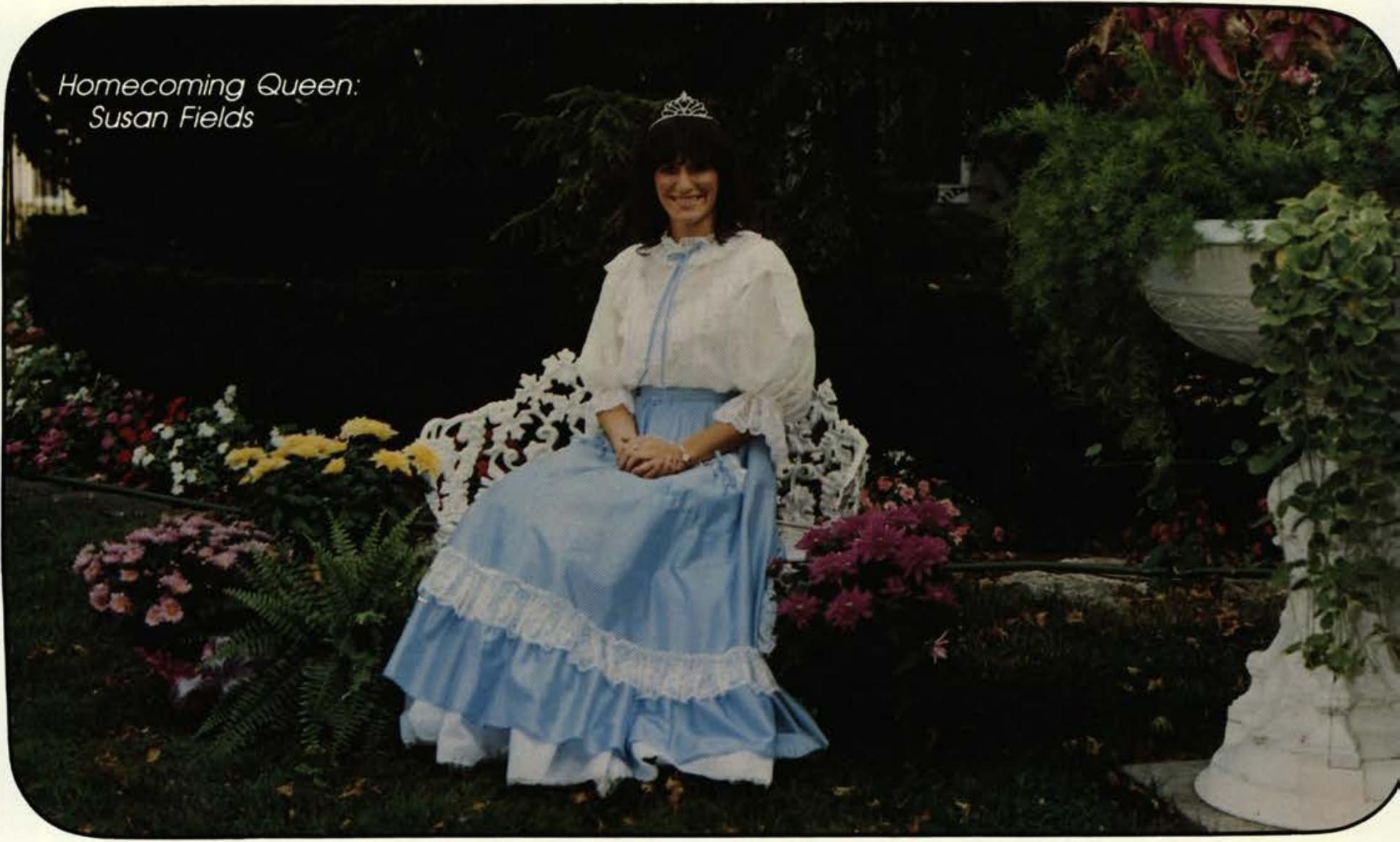




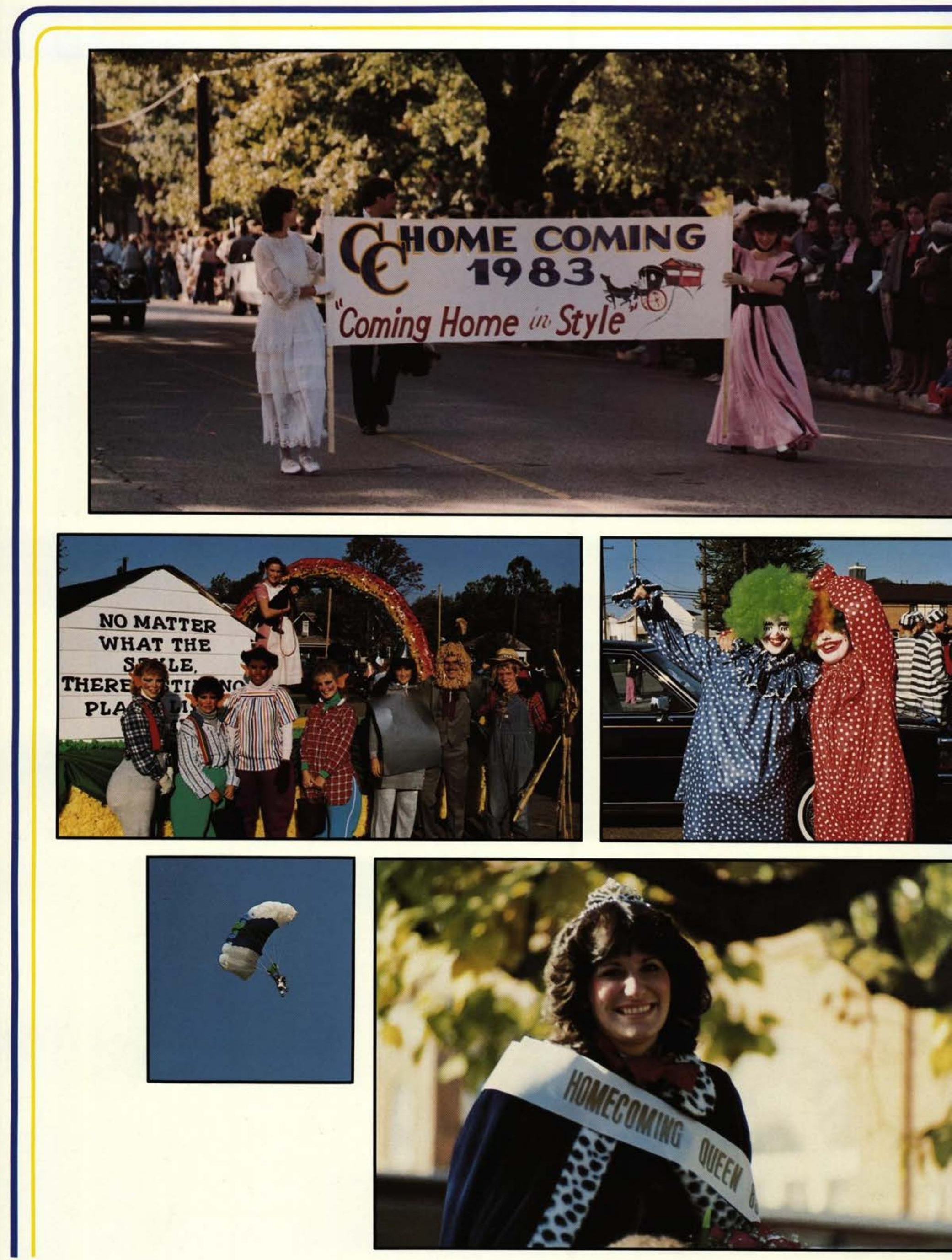




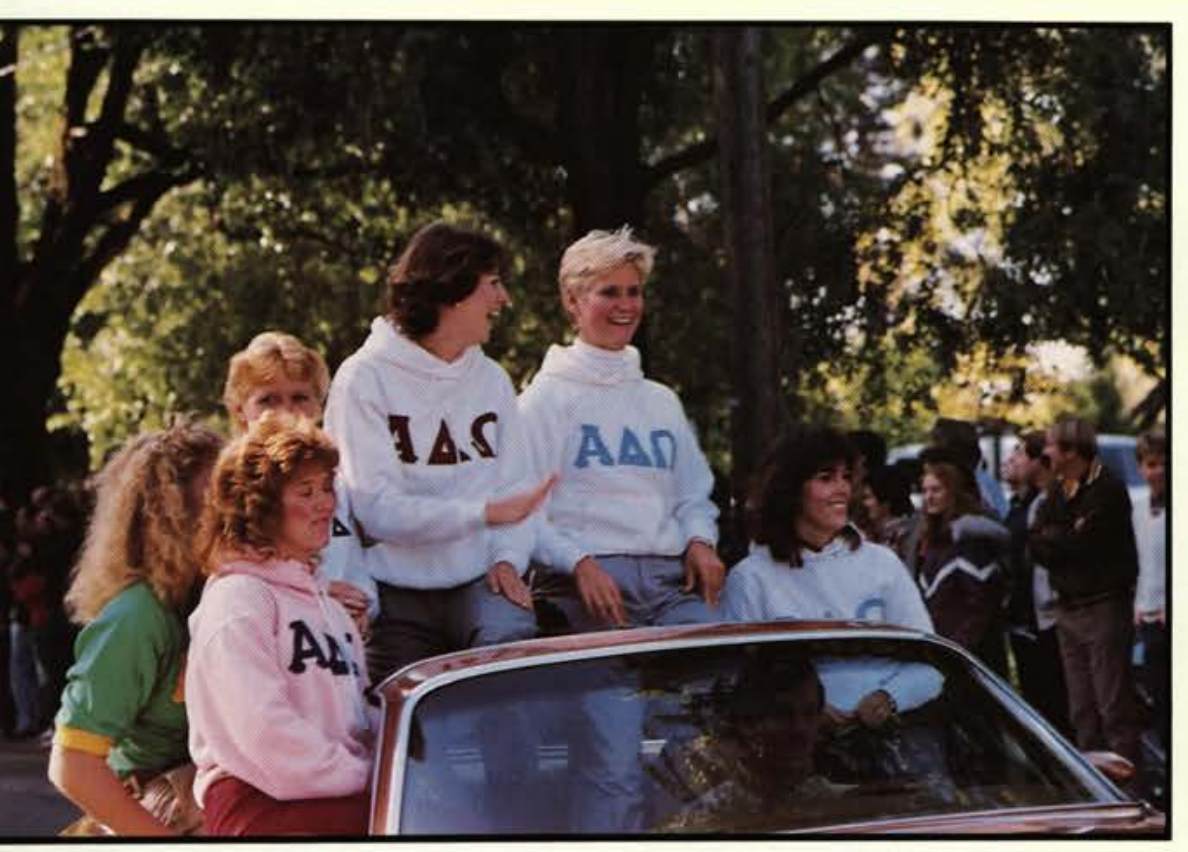

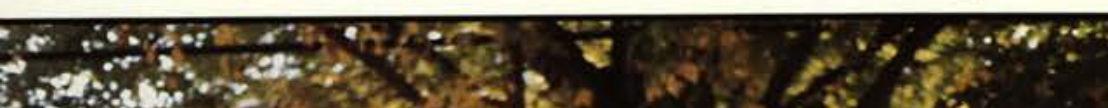

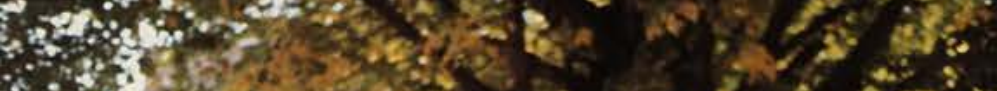

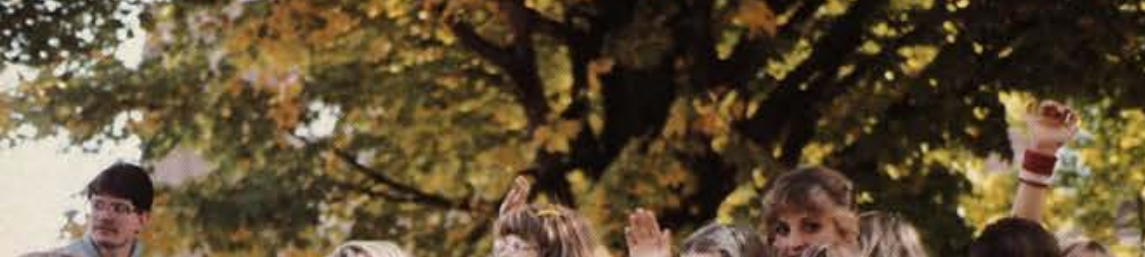

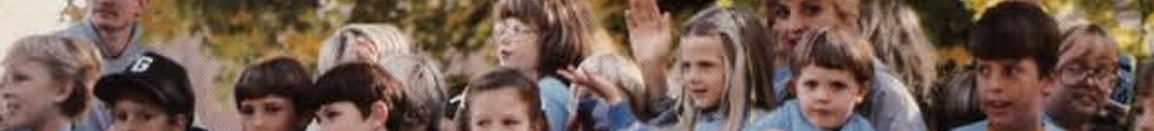

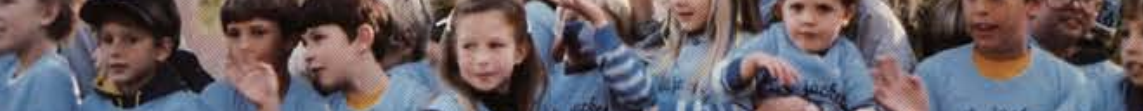

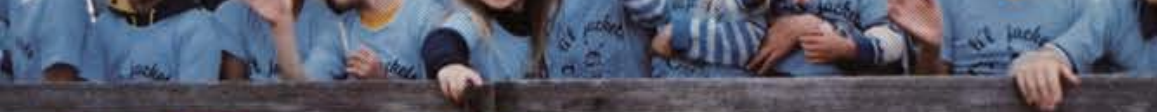

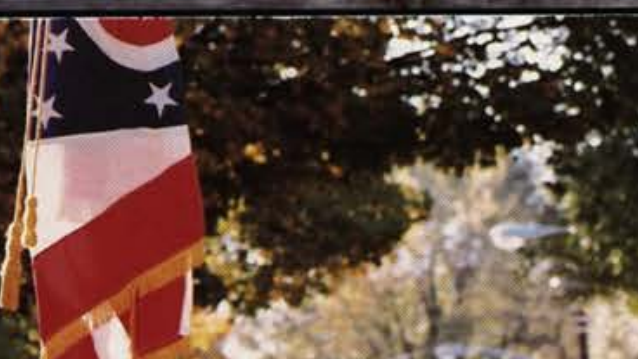

$1 x^{2}+y^{2} \mathrm{i}$.

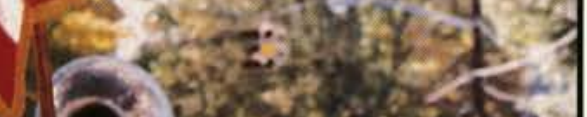
17,250

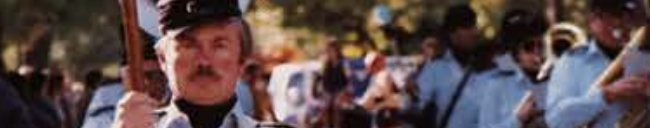

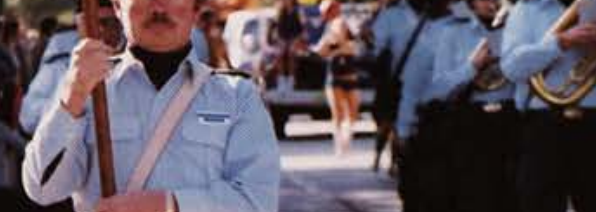$$
\text { , }
$$
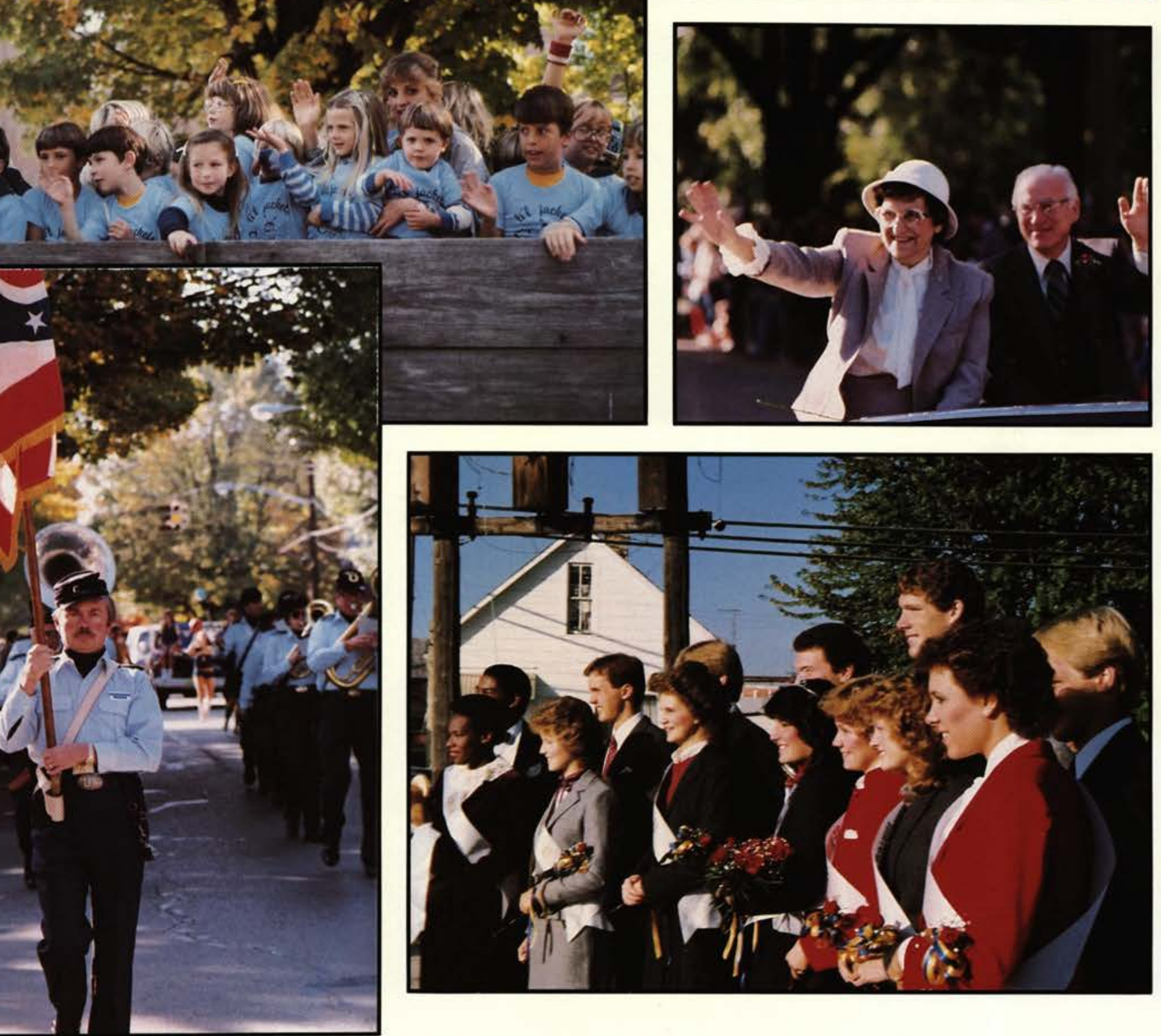
1 क s bulat as $\left(y^{2}, 11\right.$ if 51 ist 


\section{Senior Night}
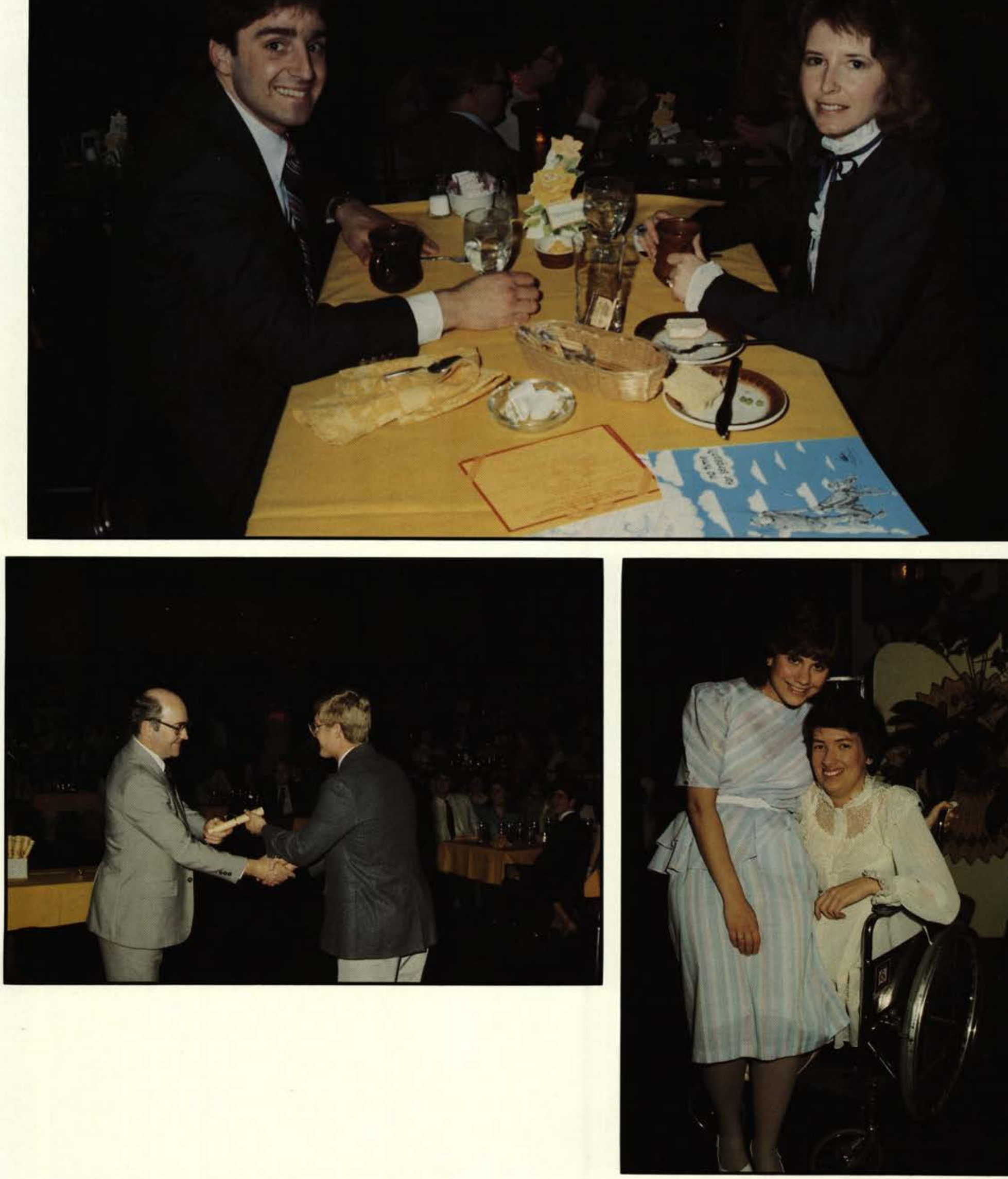

38 Senior Night 


\section{Expressing Appreciation}

or the second year in a row, the senior class elected a special evening at the dinner theater in lieu of the traditional senior trip to encourage a larger attendance of their number.

The entire audience at La Comedia Dinner Theatre on April 24 was composed of college people which contributed to a pleasant atmosphere and good fellowship. Having enjoyed a delicious buffet dinner served from the stage area of the theater, the group viewed the comedy, "No Time for Sargeants."

To 25 seniors selected by their class mates, Dr. Clifford Johnson, Academic Vice President, presented certificates stating the following:

The members of the Cedarville Col- lege Class of 1984 would like to express their appreciation for the godly example that you have demonstrated during the past four years. The manner in which you have manifested the Fruit of the Spirit has been a positive influence on the lives of your classmates. May the Lord bless you as you continue to magnify His name. "But the fruit of the Spirit is love, joy, peace, longsuffering, gentleness, goodness, faith, meekness, temperance: against such there is no law."

Galatians 5:22, 23

It was difficult to narrow the choice to 25. As in every class, some students surface during the fall quarter of their freshman year and remain very visible throughout their college careers. Others, not always visible, are always around when there are survival kits to prepare, chapels to plan, birthday cakes to deliver, floats to build, or a tree to plant. Many excel individually in their own areas of influence. Many work together on projects and, of course, the reduced price of the evening's dinner tickets was made possible by their contribution.

Many people in this senior class have shared the cloak of leadership and responsibility. As many have served, many will accomplish much for the Lord beyond Cedarville College.

by Martha Baldwin

Class of 84 's Advisor

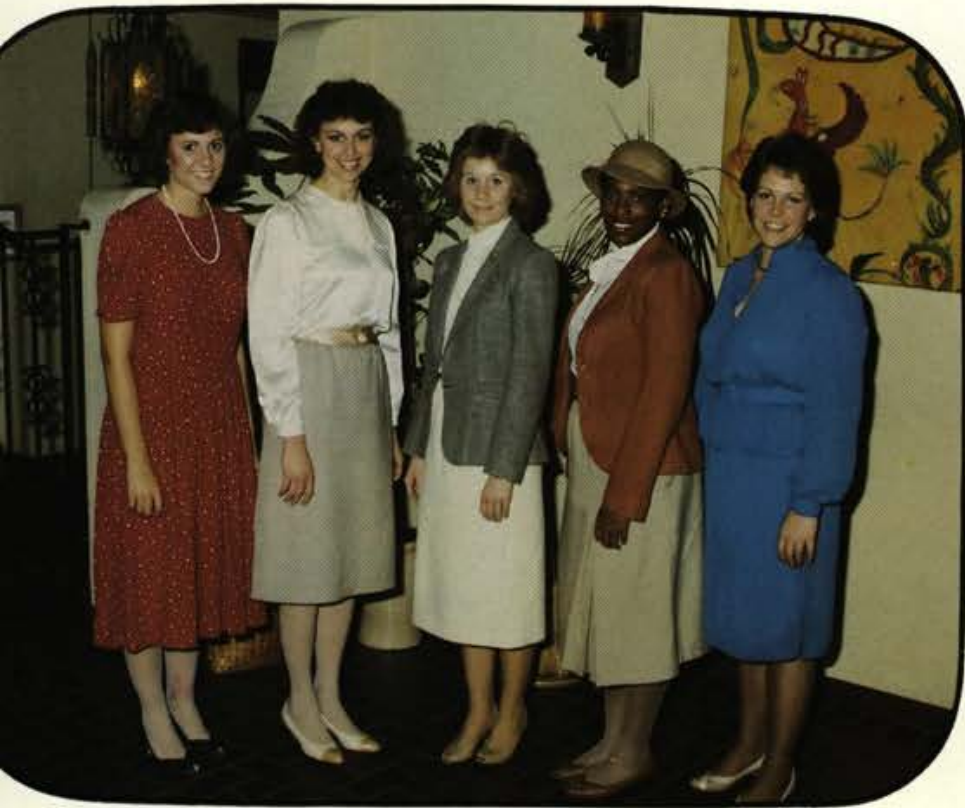

Left to right: Sara Beattie, Margaret Wolot, Laura Coffman, Angela Cooke, Jane Adams.

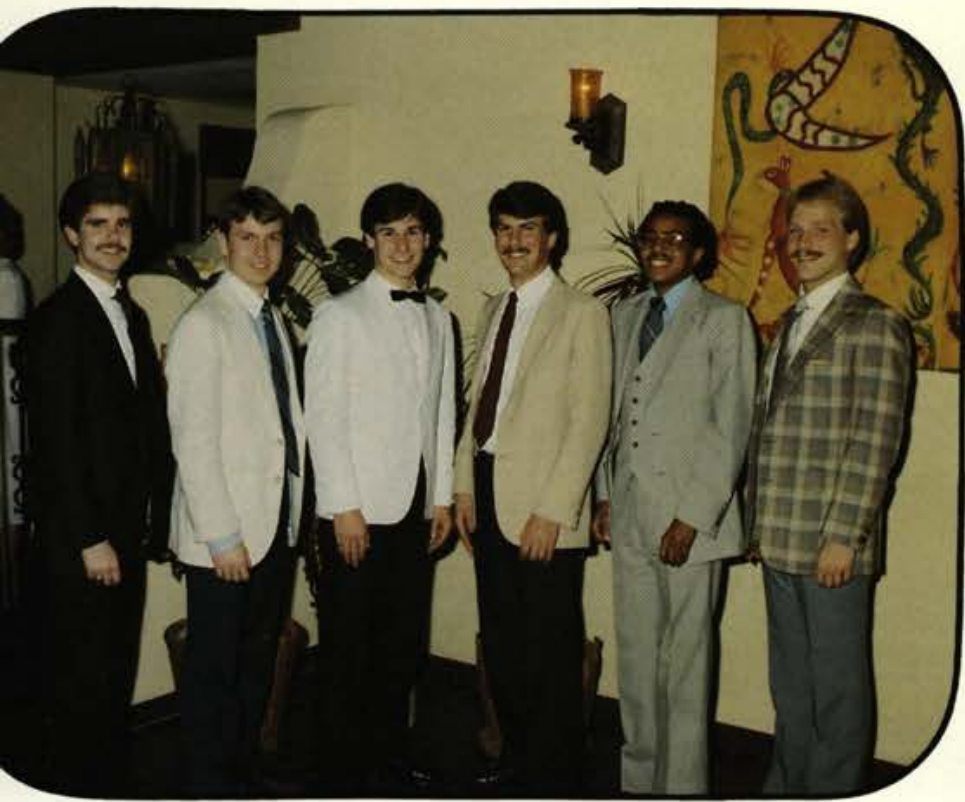

Left to right: Jon Anderson, Paul Hayes, John Jackson, Joe Walker, Arlan Palmer, Scott Dixon

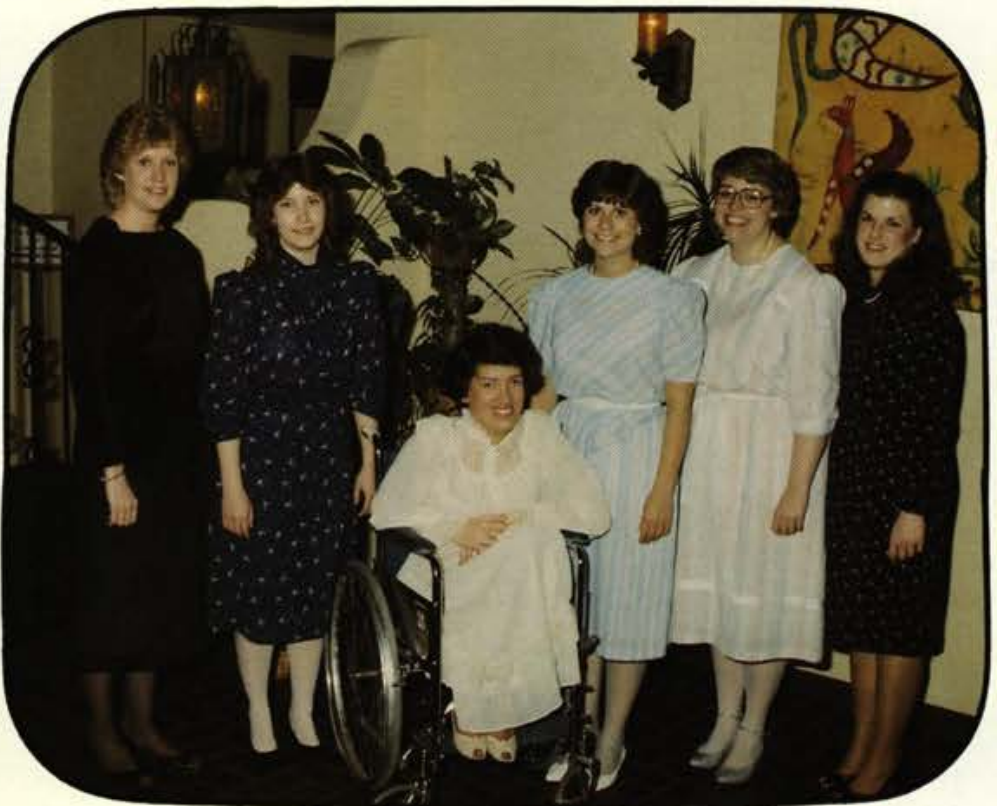

Left to right: Lisa Hudnall, Marcia Golike, Debbie Nash, Donna Einstein, Marcia Kingsbury, Irene Farley.

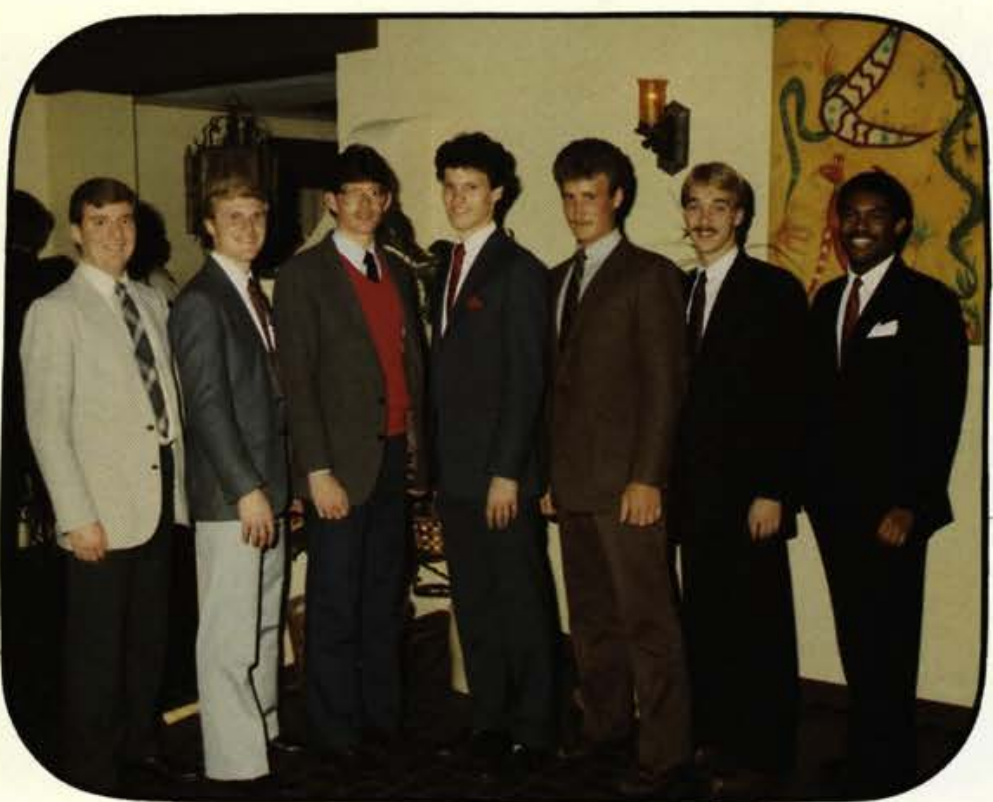

Left to right: Tom Wiggershaus, Eric Hellwig. Craig Slater, Tom Blackburn, Tim Woodard, Dave Jones, Gillis West. 


\section{"Glimpses Through The Looking Glass"}

"The banquet combined fabulous decor, excel. lent food and good entertainment to provide a night for seniors to relax and reflect ..."

A propriately named "Glimpses through the Looking A Glass," the 1984 Junior-Senior Banquet was held in the beautiful Hall of Mirrors at the Netherlands Plaza Hotel in downtown Cincinnati. The banquet combined fabulous decor, excellent food, and good entertainment to provide a night for seniors to relax and reflect upon their four years at Cedarville College. The evening began at 5:00 p.m. with a reception at which light snacks were served and pictures were taken. At 7:00 the doors opened, and 525 students, faculty, and staff entered the Hall of Mirrors for the meal. The menu for the evening consisted of Coupe de Fresh Fruit, Prime Rib au jus, Bouquetiere de Fresh Vegetables, and a dessert of Assorted French Pastries. After the meal, the entertainment was provided by the After Dinner Players, a talented Christian theatrical troupe from Houston, Texas. Following the entertainment, the banquet was climaxed by a slide presentation honoring the seniors and their contribution to Cedarville College. The 1984 J.S. Committee, who organized the banquet, consisted of co-chairpersons Linda Hess and John Sidle, Katrina Rowe, Becky Miller, Tricia Emerson, and Doug Miller. These six students, along with their committees, worked closely with the junior class officers to provide an evening which the class of 1984 will long remember.

by John Sidle
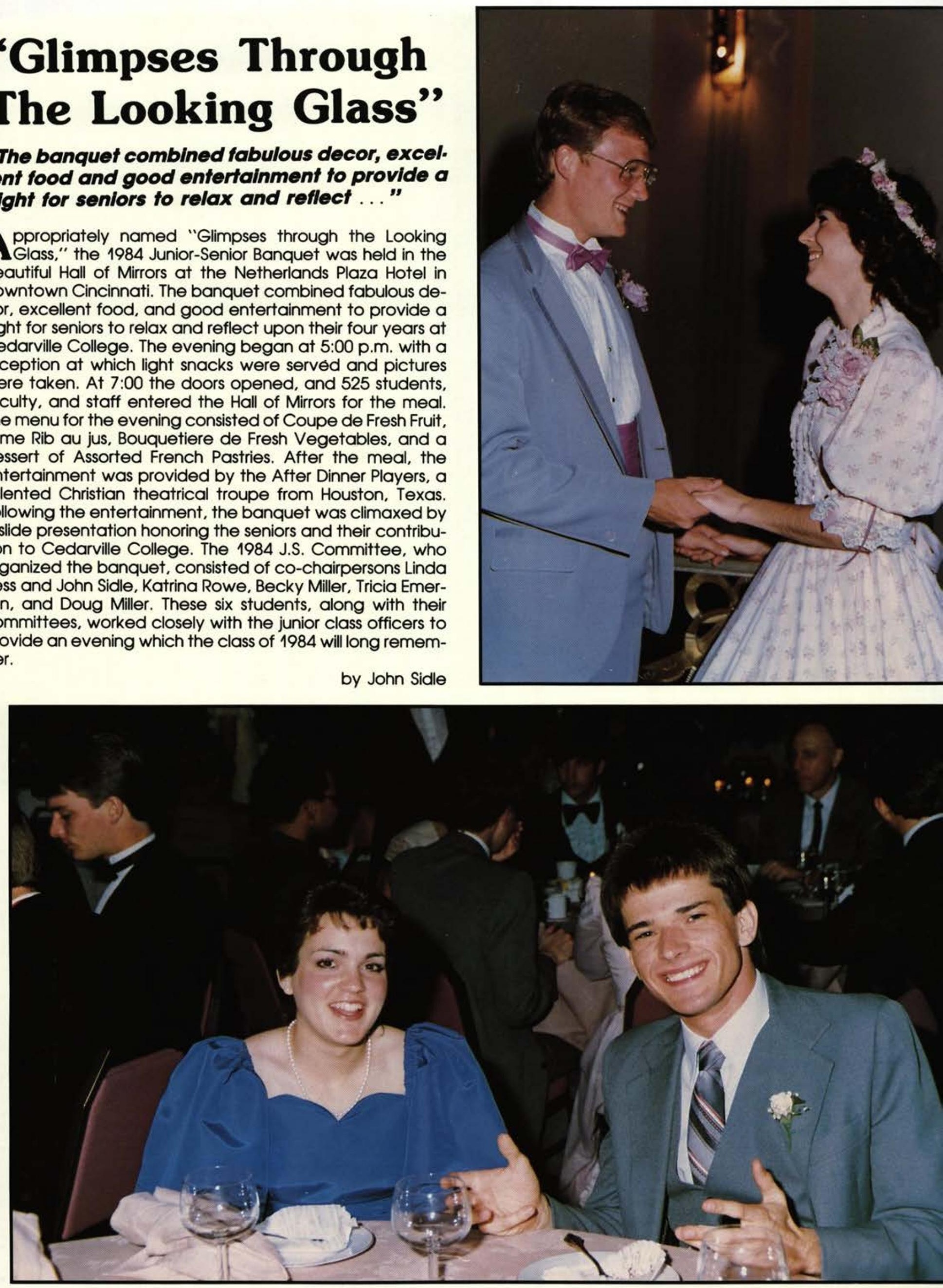

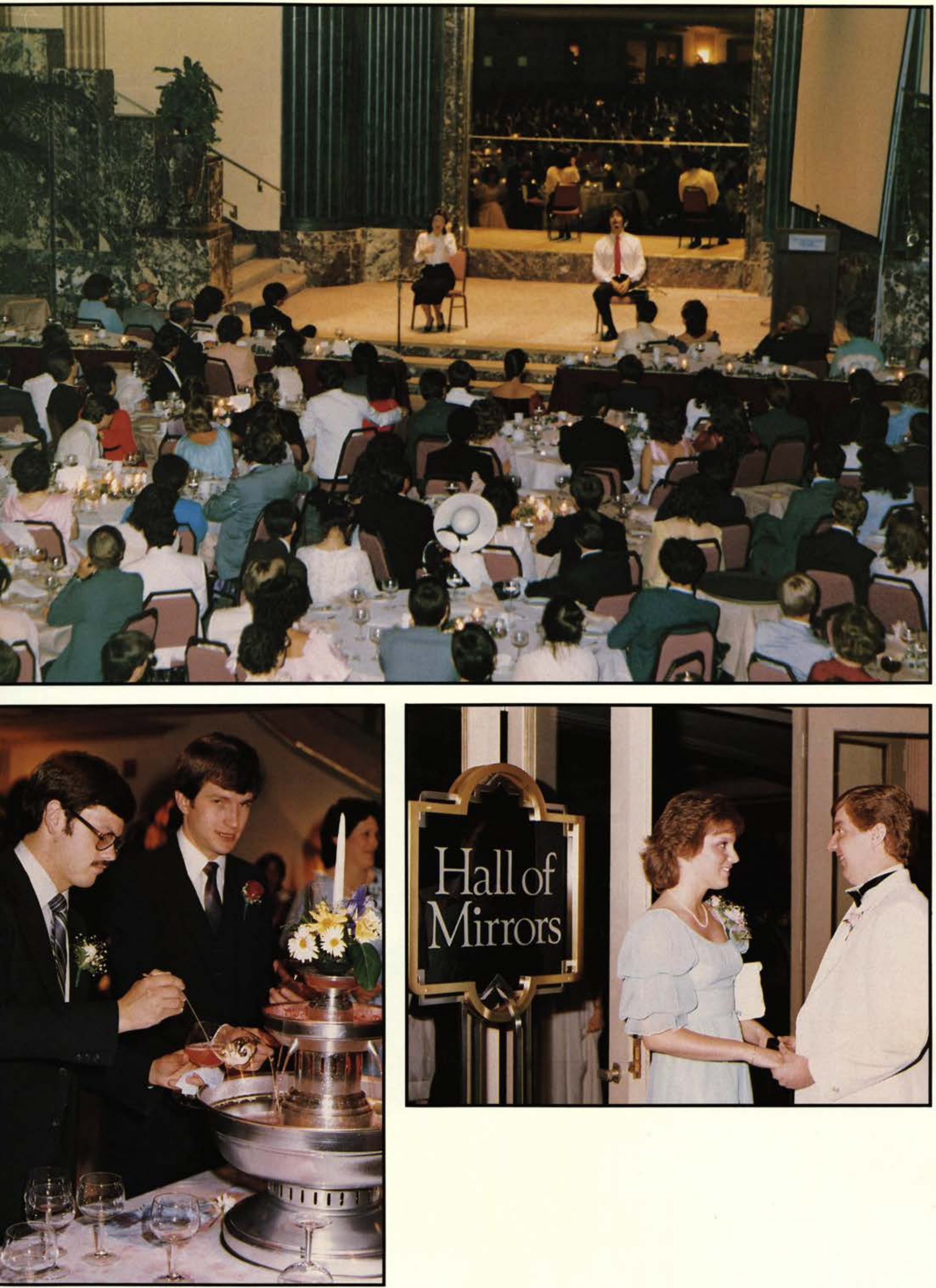
Honors Chapel:

\section{Awarding}

\section{Excellence}

$W^{\text {ith a }}$ a brilliant fanfare, the Brass Choir under the baton of Charles Pagnard opened the 20th Annual Academic Honors Program. This special chapel was established to recognize students for their contribution of excellence to the academic and Christian service of Cedarville College. Following the invocation by Dr. Sharon Biddle, Dr. Dixon was pleased to announce the naming of the new women's residence hall in honor of Earl Wil-

"This special chapel was es. tablished to recognize stu. dents for their contribution of excellence ..."

letts for his years of faithful service as a pastor and trustee. Recognition was then given to members of the Dean's
Honor List, Dean's List, and Hone Graduates followed by the presentc tion of awards by each academic de partment to outstanding studen within their discipline.

Finally, the Student Academic Adv sory Board on the behalf of the entir college family granted the "Outstane ing Faculty and Staff Members of th Year Awards." This year's deservin recipients were Dr. John Silvius, Assoc ate Professor of Biology, and Mr. Dav Purrington, Assistant Physical Plant rector.

by David Wrigl

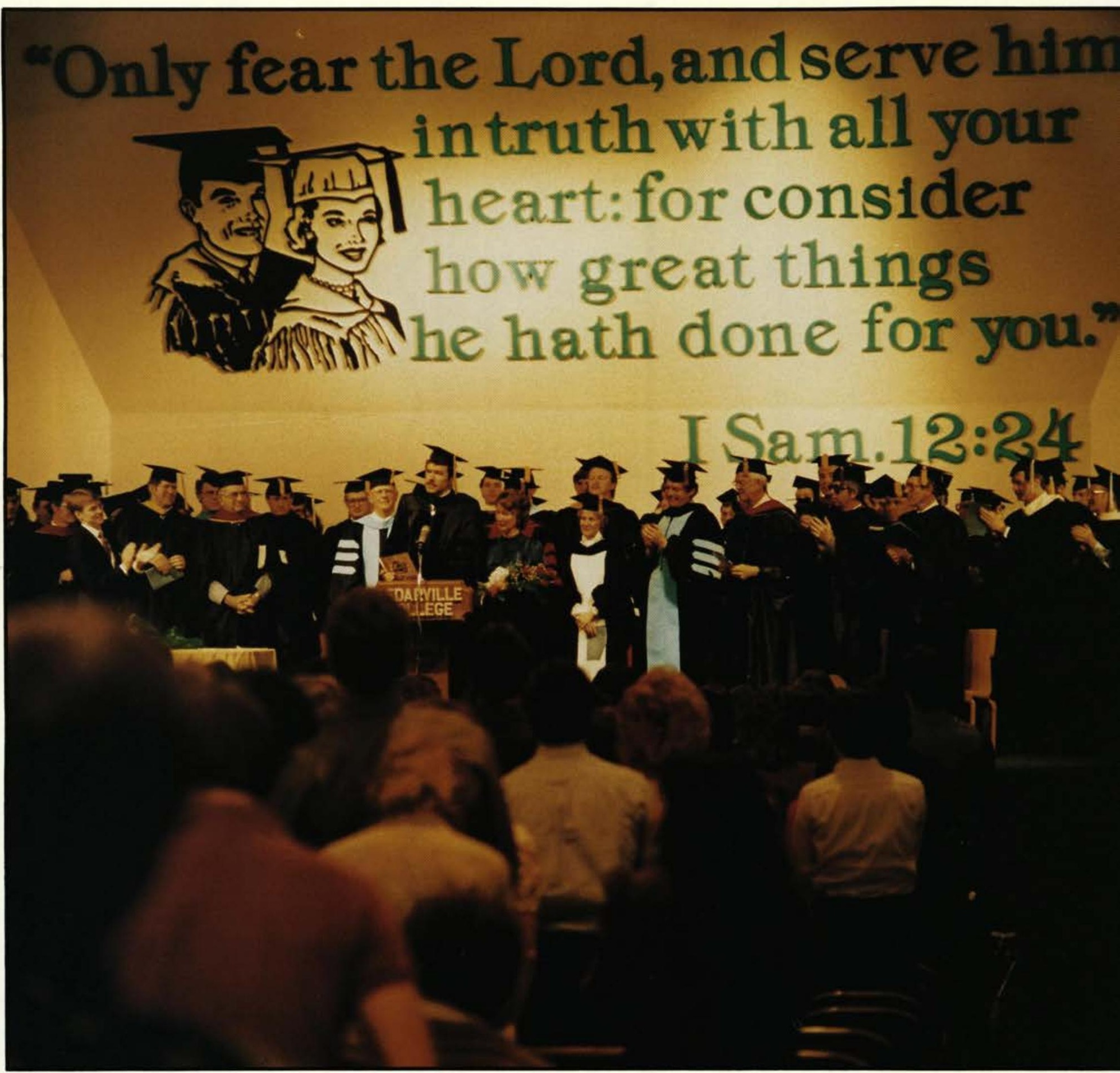



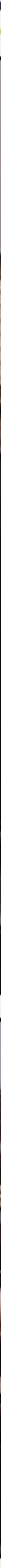

44 Graduation 
Honorary D.D.

Dr. Donn Ketcham
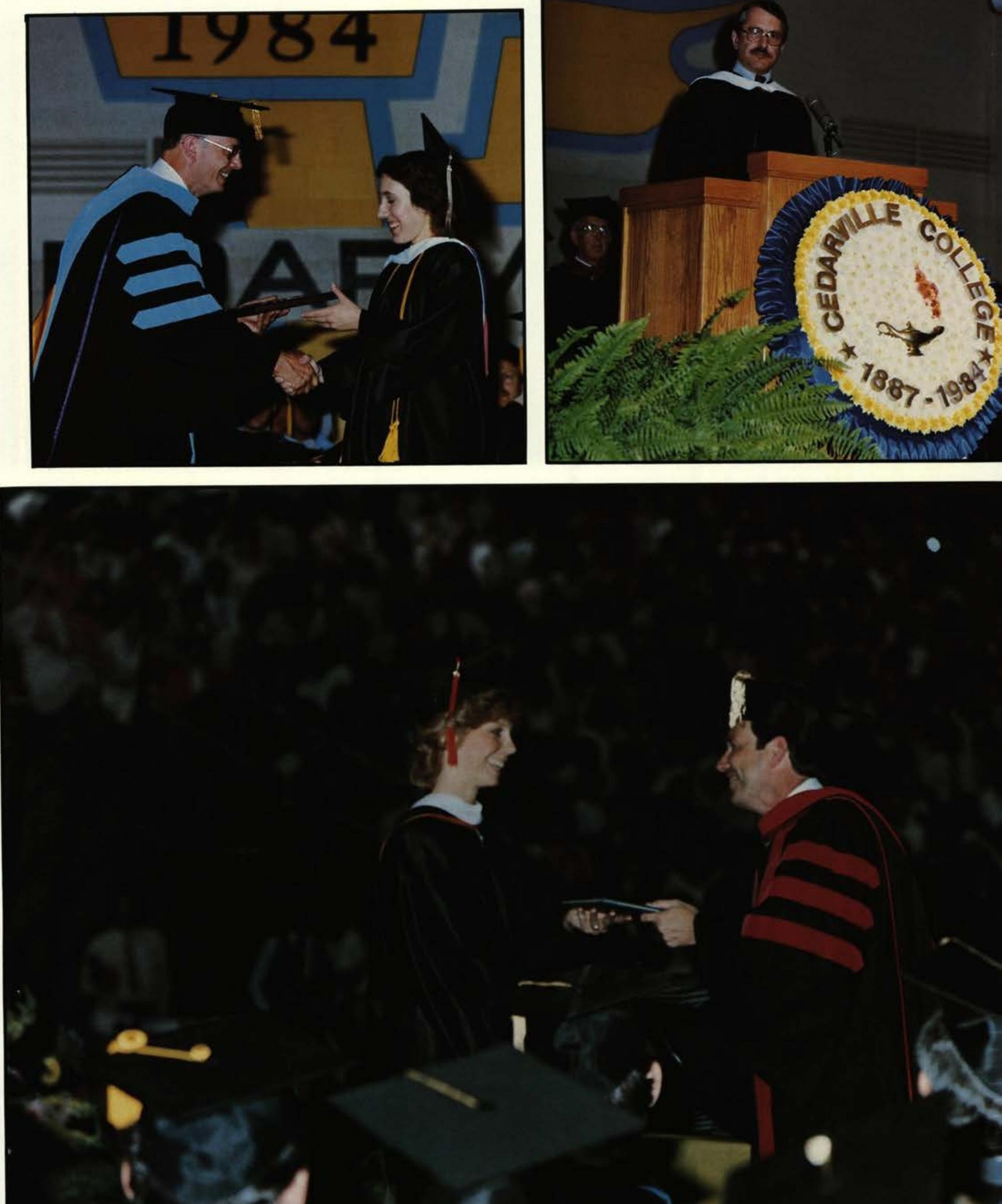

\section{Graduation}




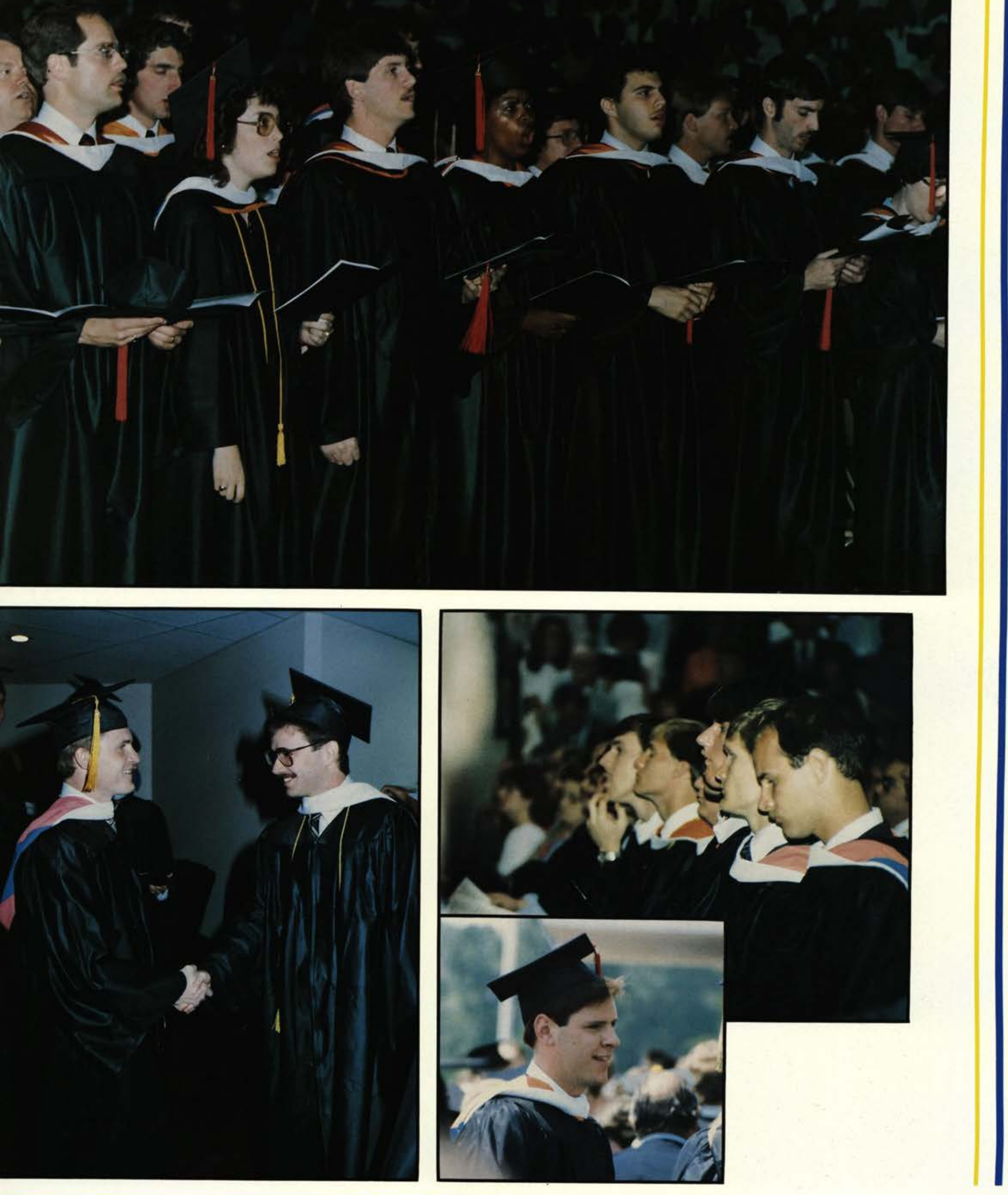




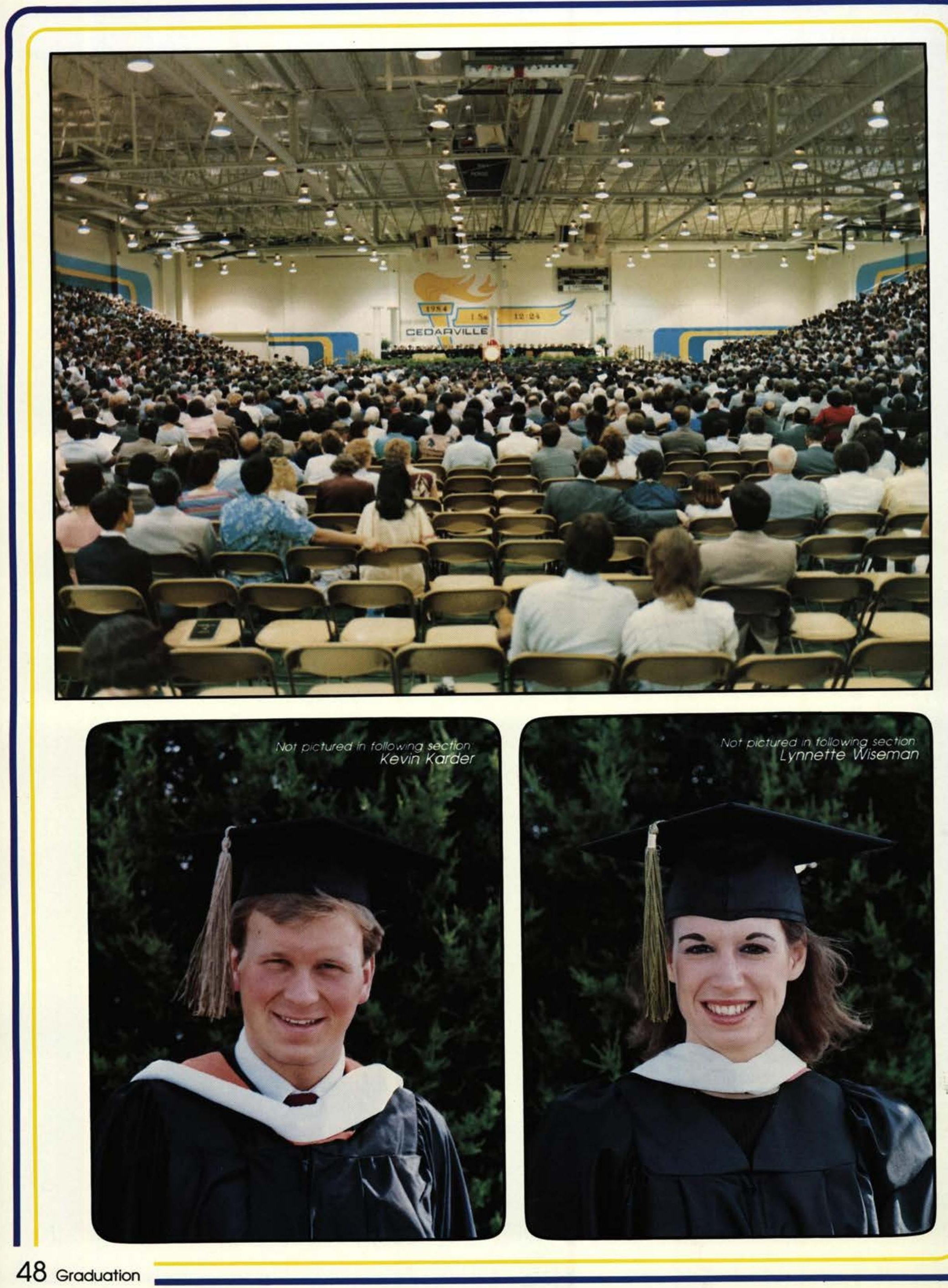



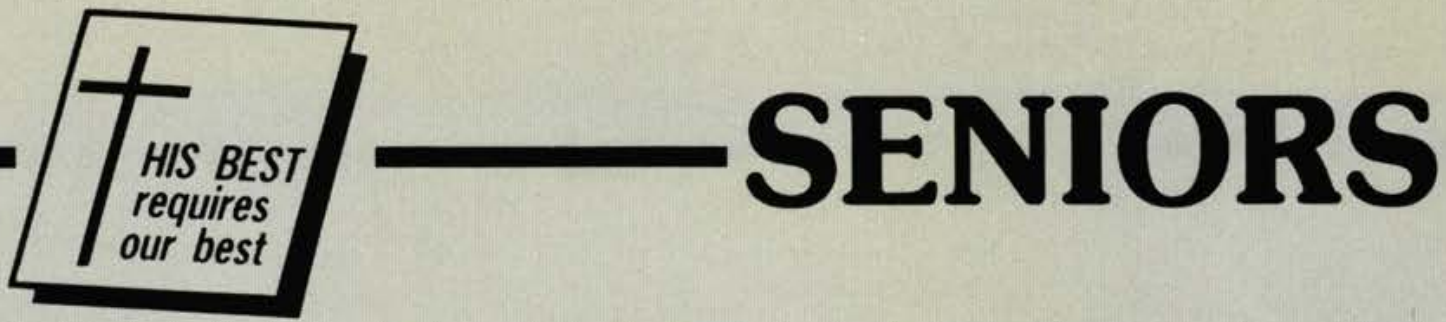

\section{"THE SENIOR CLASS"}

You are invited, exhorted, and beseeched to explore the following pages containing an expose of the students, the personalities, the leaders of tomorrow known as "The Seniors."

Listen to them as they bare their souls and reveal their true feelings about leaving Cedarville and stepping toward an unfamiliar, unexplored, and often very uncertain world.

Empathize with them as they leave behind a part of themselves which will remain here forever. The resulting void has been filled with poignant echoes of classes, professors, chapel services, friends, late nights, good times, hard times, and times of growth.

Look forward with them to their future preparation, career goals, and family plans; and strive to pray for them each time they cross your mind as you reminisce or peruse through this book.

Learn from them while you can, because one day you, too, will be ... "A Senior."

by Bill Thomas

\section{Contributors:}

Carla Mosher page 58

Brad Bishop page 66

Tracy Holtzman page 76

Ken Bandy

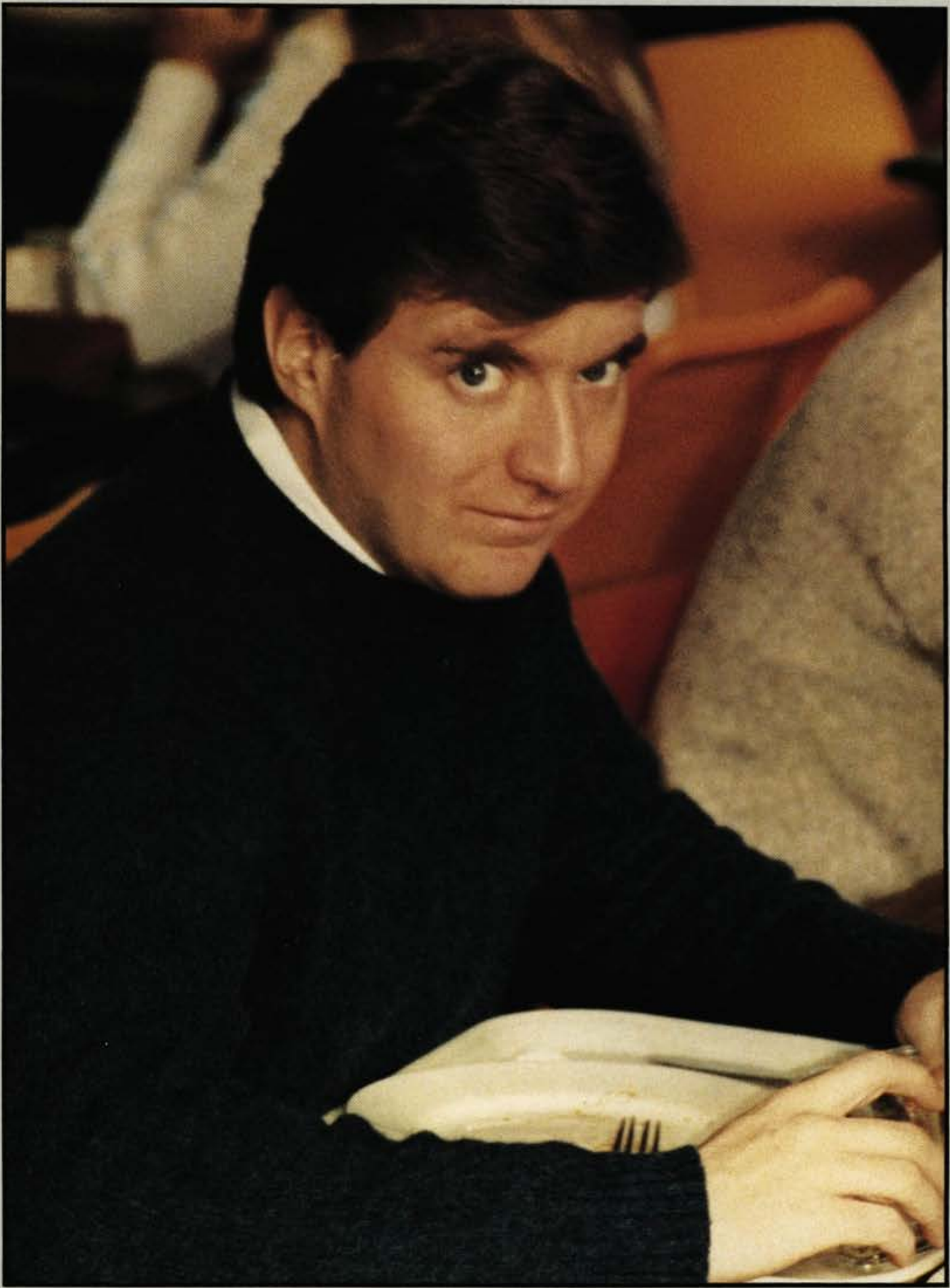

\section{Layout By:}




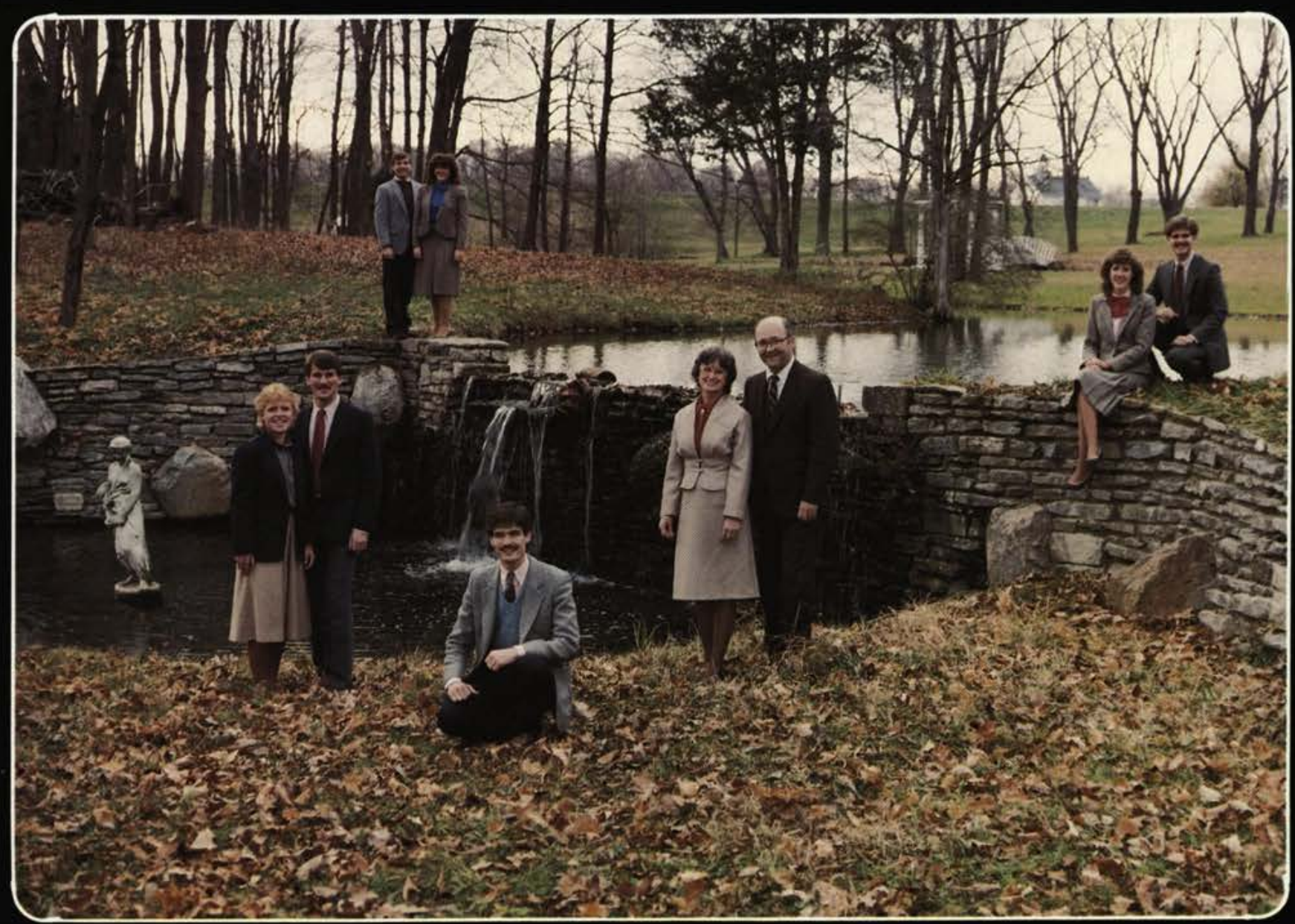

First row: Dave Dever, president; Second row: Ann Berger, Senate rep.; Joe Walker, Senate rep.: Mrs. and Mr. Baldwin, advisors; Third row: Tom Wiggershause, vice president: Suzanne Milevoi, secretary: Jane Owen, senate rep.; Jon Anderson, treasurer; Not pictured: Scott Dixon, chaplain.

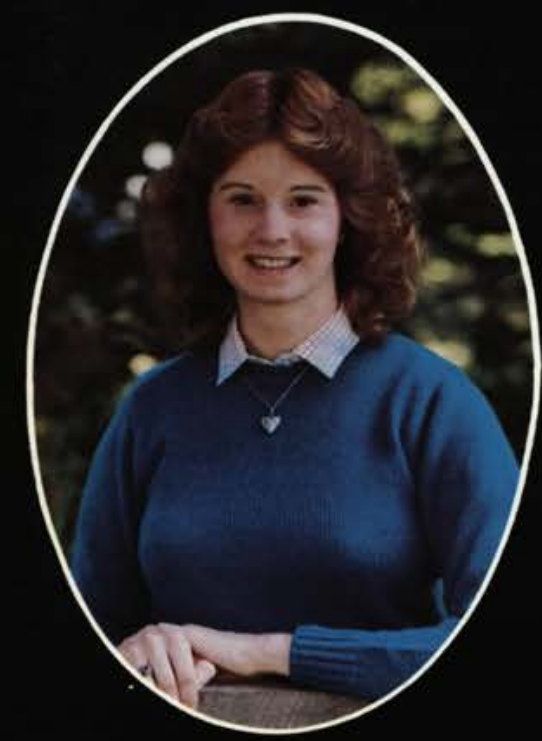

Nancy Lou Abel Behavioral Science

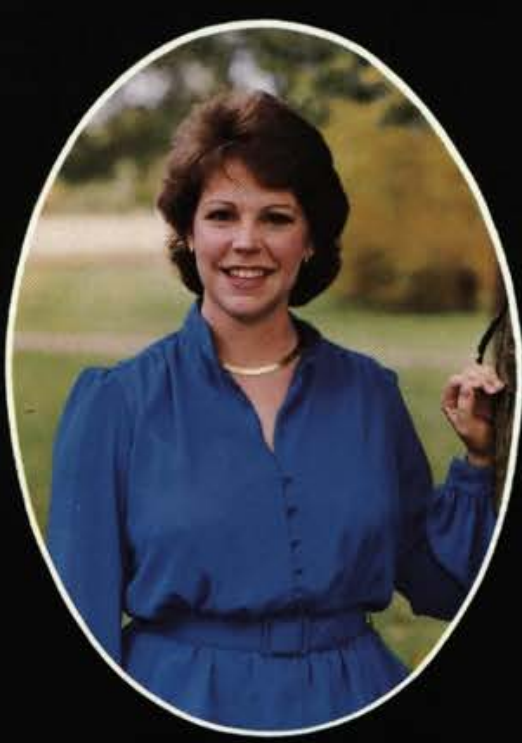

Jane Marie Adams

Psychology/Behavioral Science

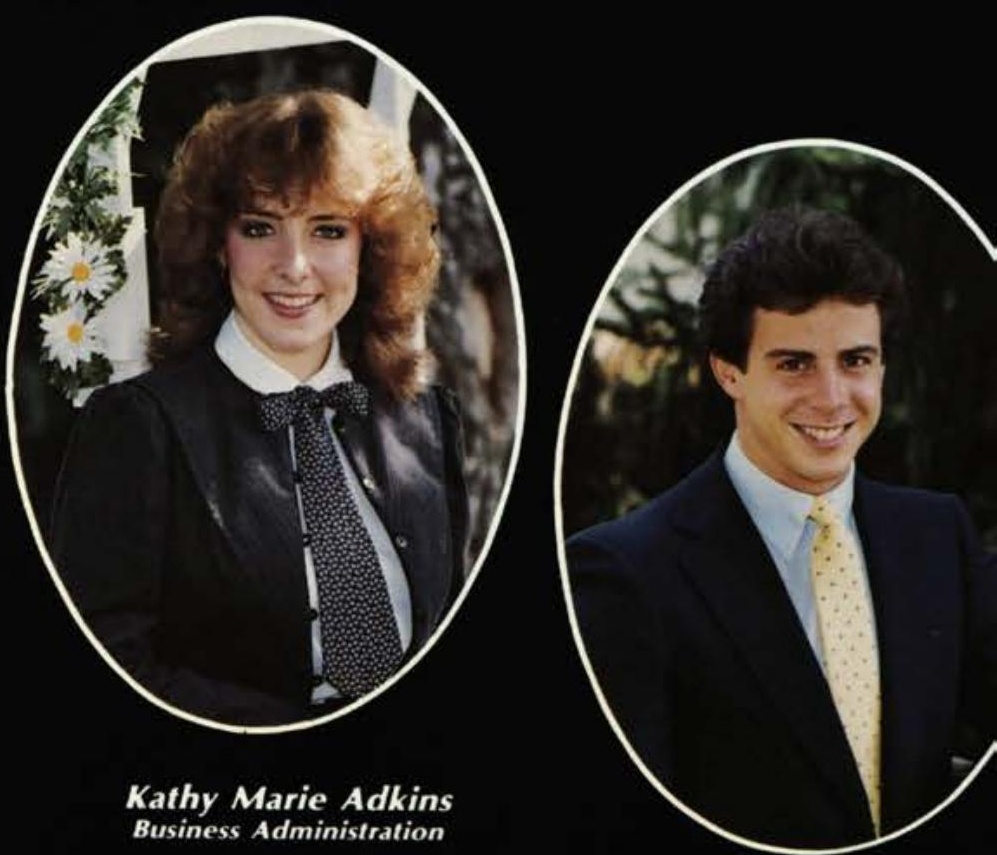

J. Mark Alcorn Political Science/History 


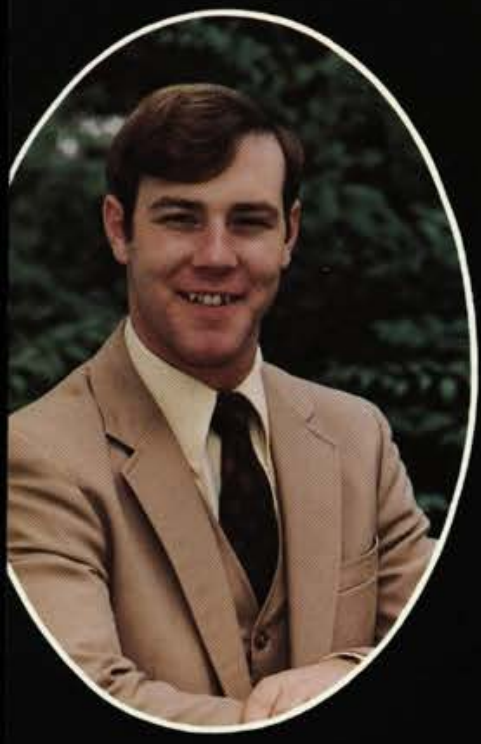

Kenneth Leon Alford Bible Comprehensive

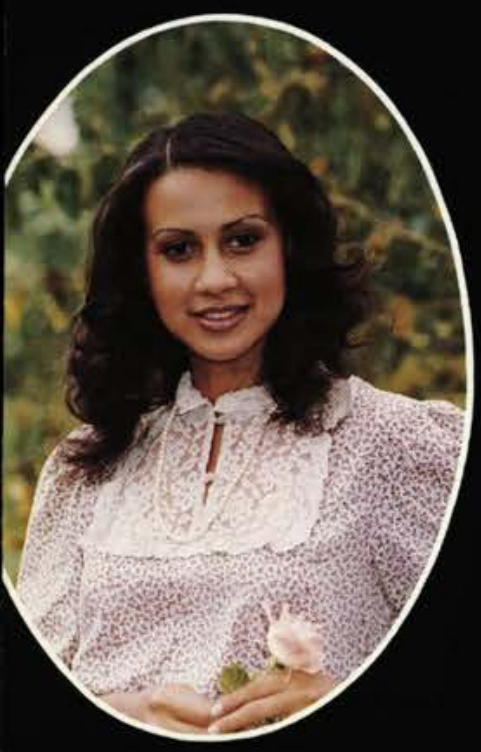

Regina Marie Anderson Spanish Education

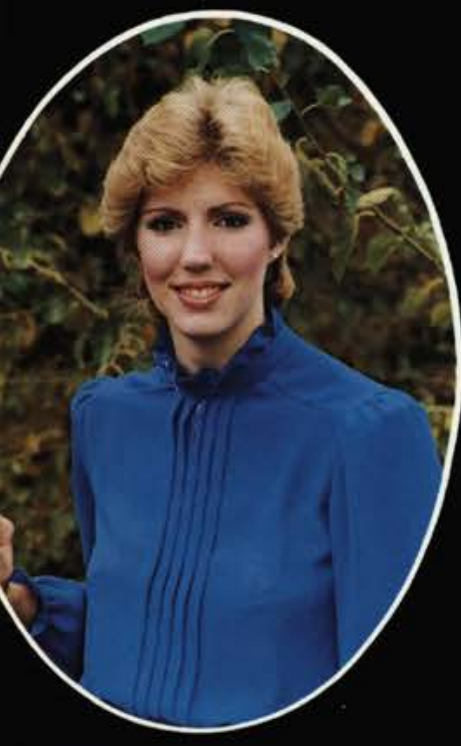

Cynthia Louise Armstrong Behavioral Science
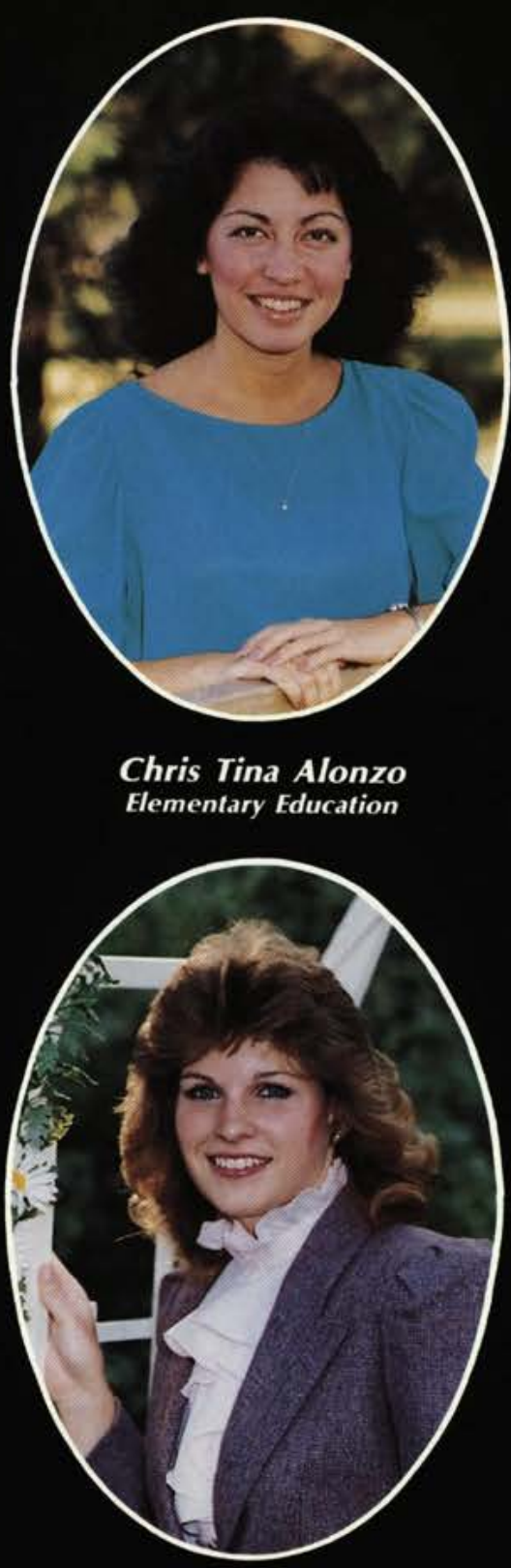

Robinette Anderson Behavioral Science

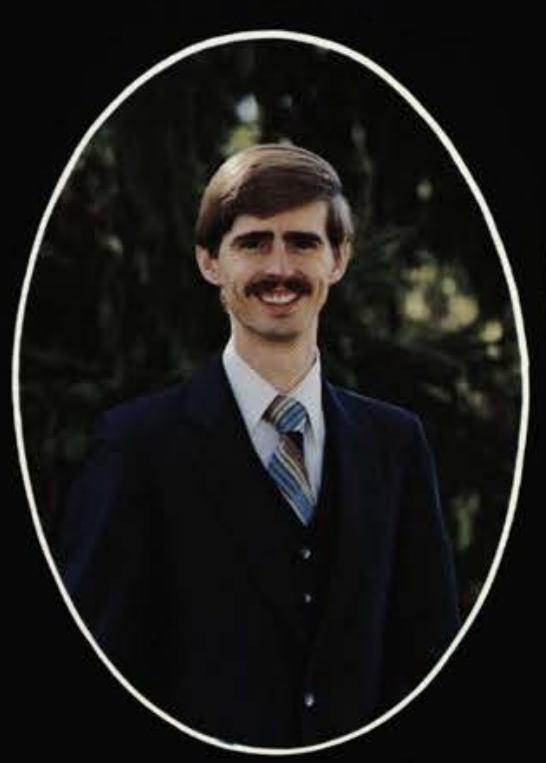

Darrell Keith Atchley Accounting
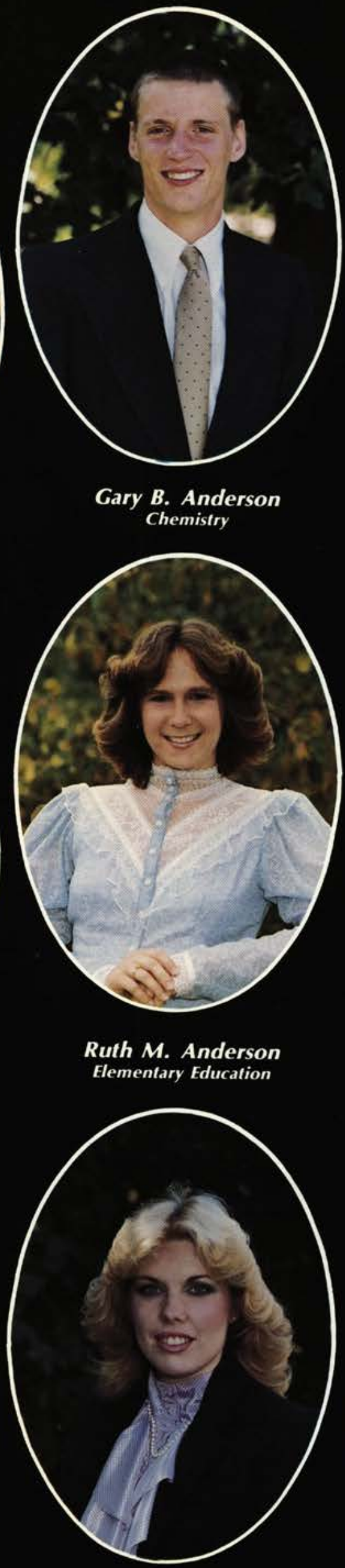

Diane M. Auckland Business Administration

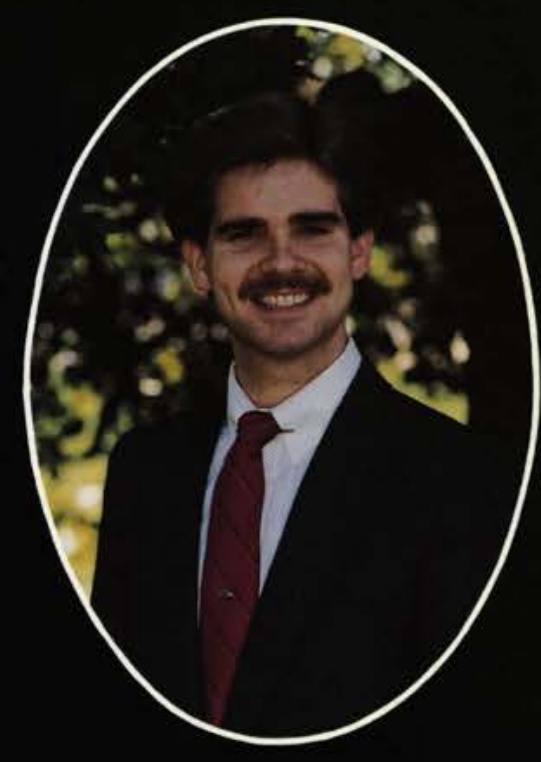

Jonathan Lee Anderson Accounting

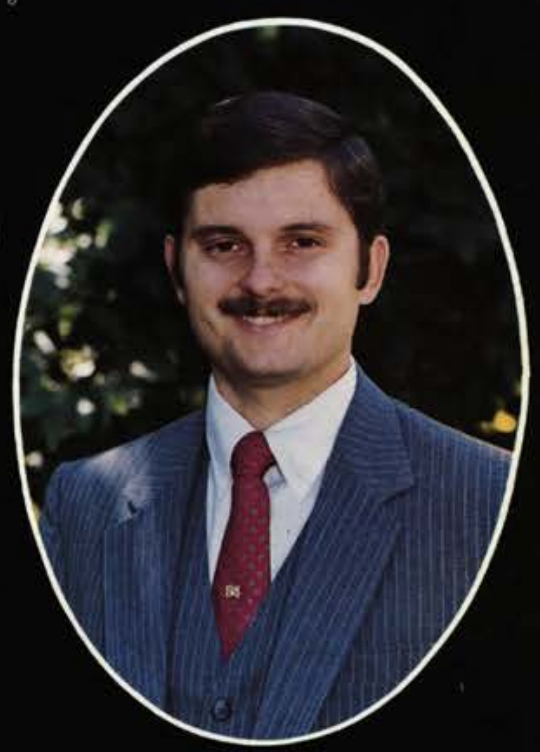

Dennis Clark Arbogast Bible/Pre-Seminary

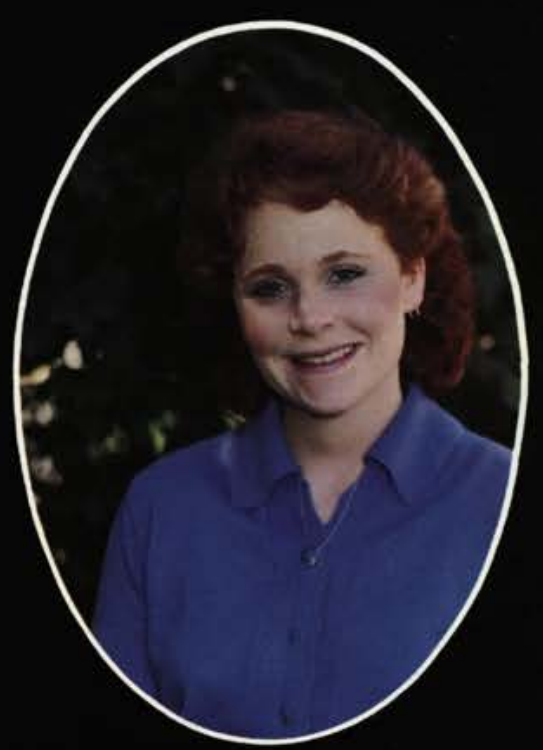

Kathy Lynn Bachelder

Communication Arts 


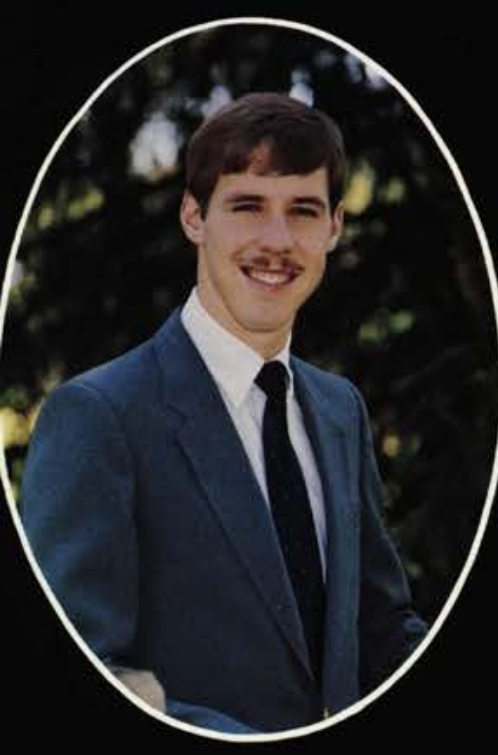

Jeffrey Robert Bailey Bible/Pre-Seminary

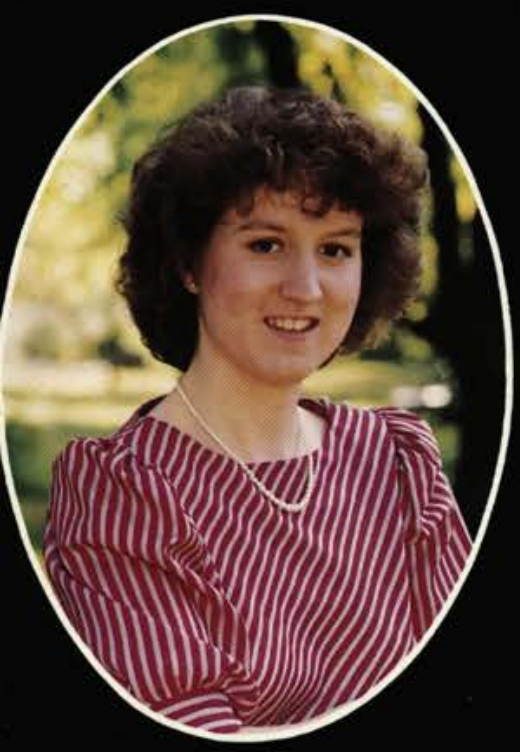

Kimberly Jean Bensink English/Secondary Education

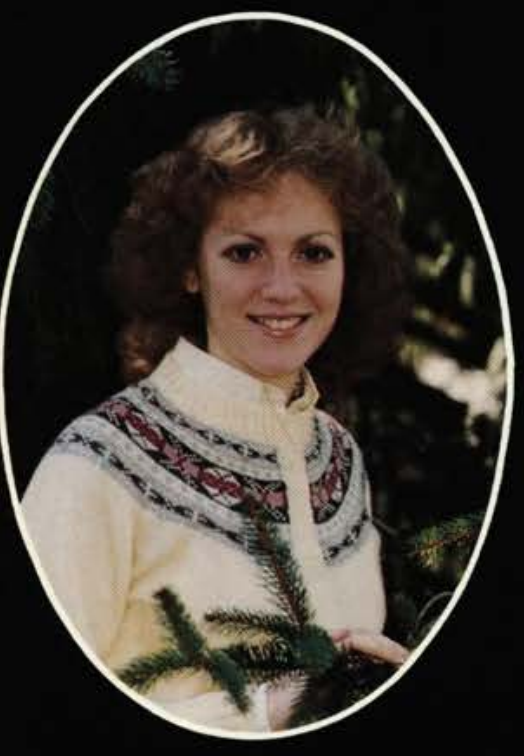

Donna S. Birch Accounting

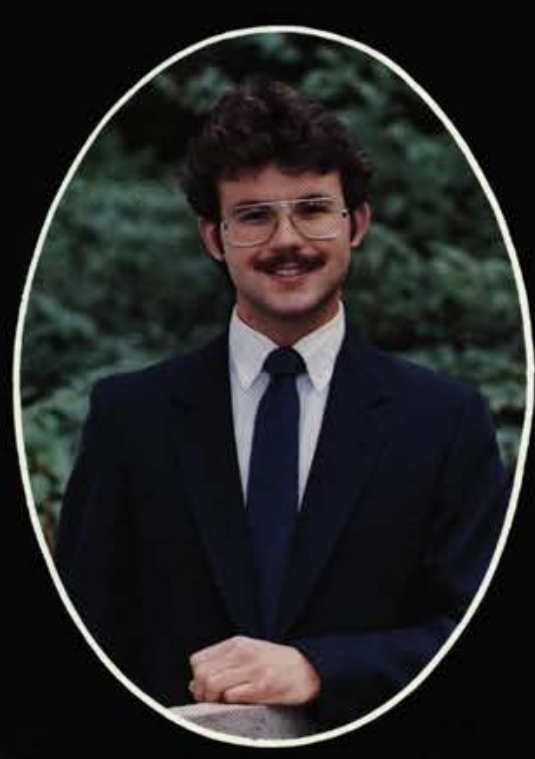

Kenneth E. Bandy Speech/Communications

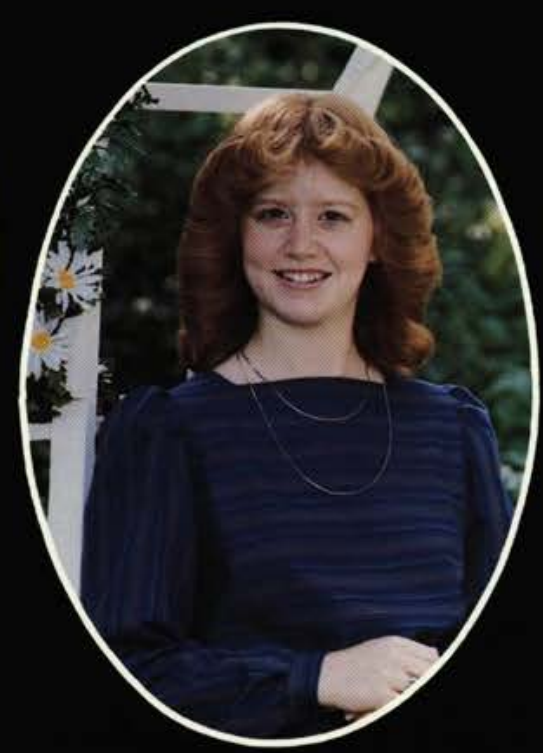

Bethany Kay Terpenning

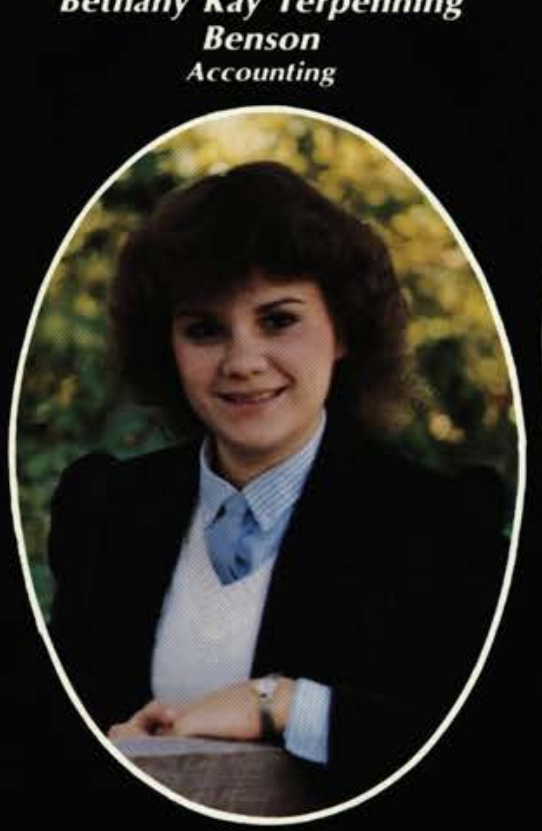

Lee Ann Bires

Behavioral Science/Psychology
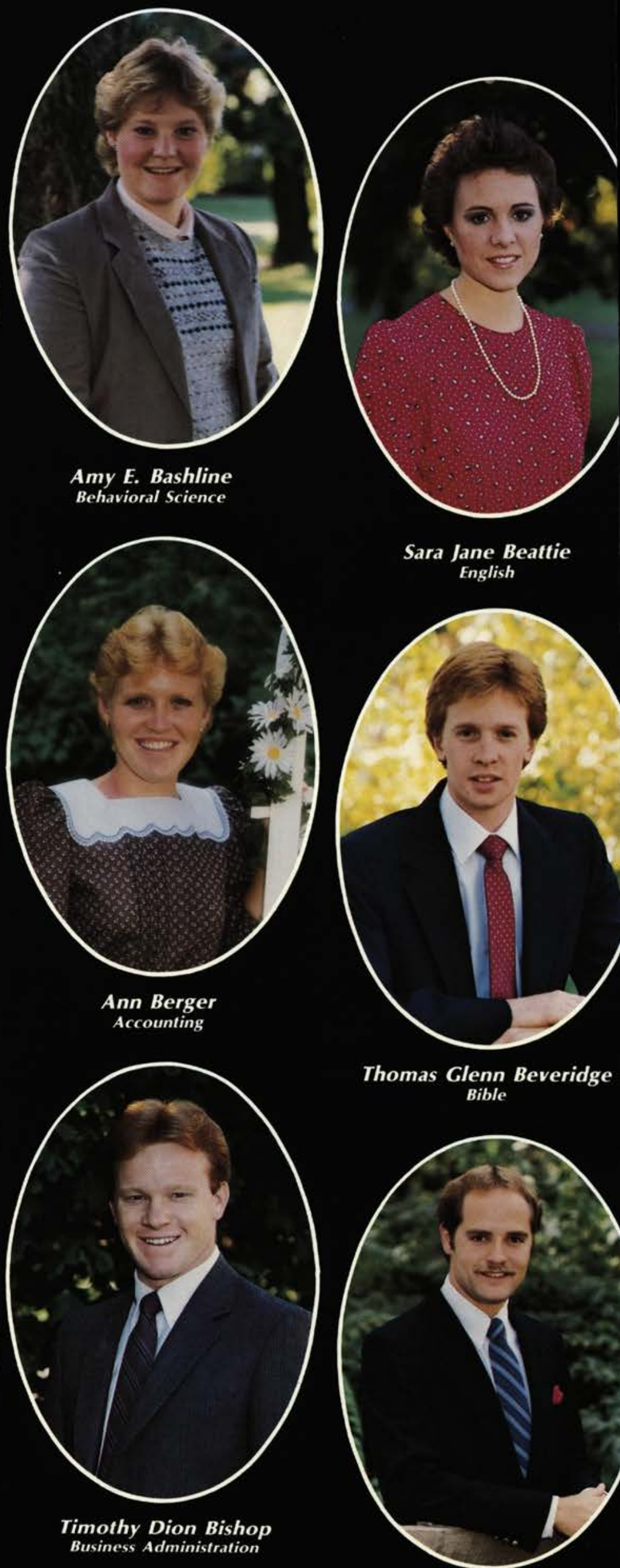

Thomas Glenn Beveridge Bible

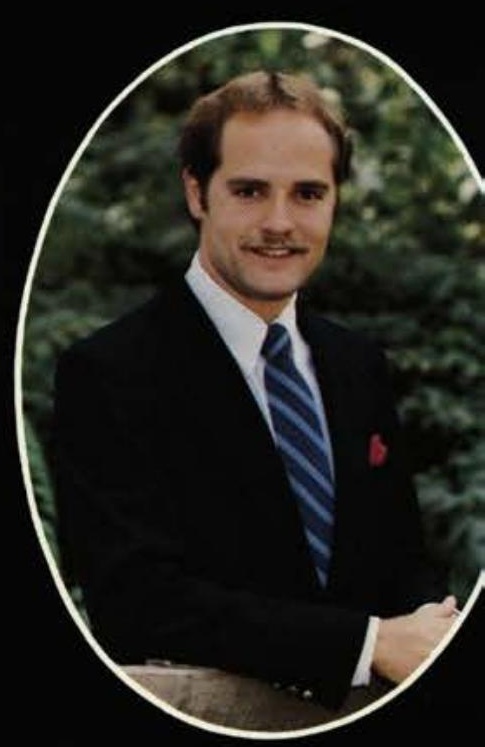

John C. Blackburn Bible Comprehensive 


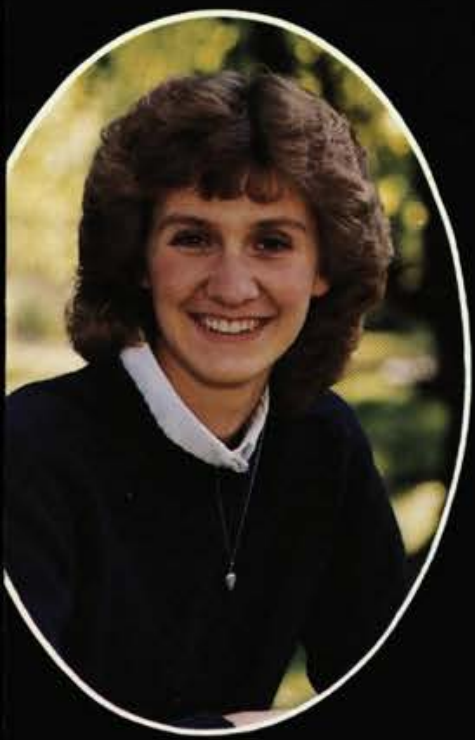

Kimberly Jean Blackburn Psychology

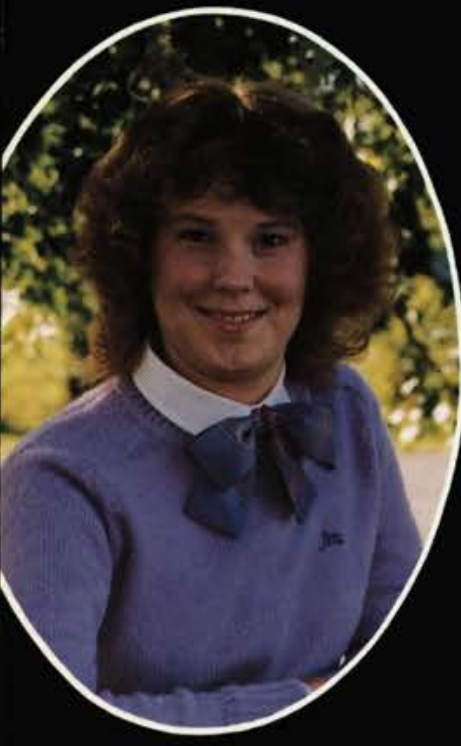

Joyce Ivy Bonenberger Biology

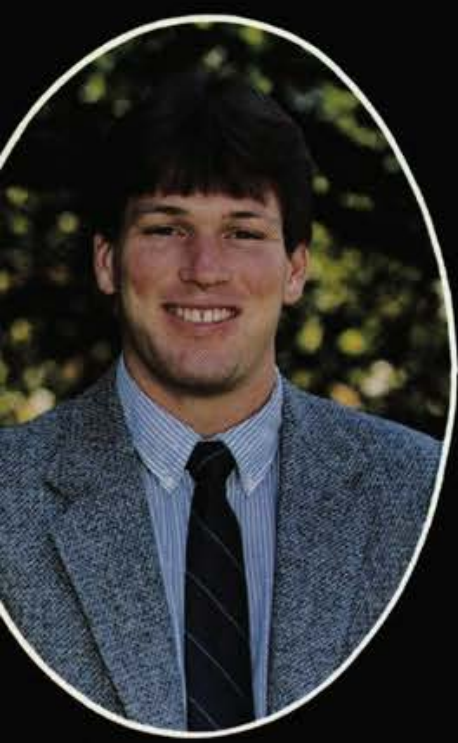

David Scott Bowser Biology

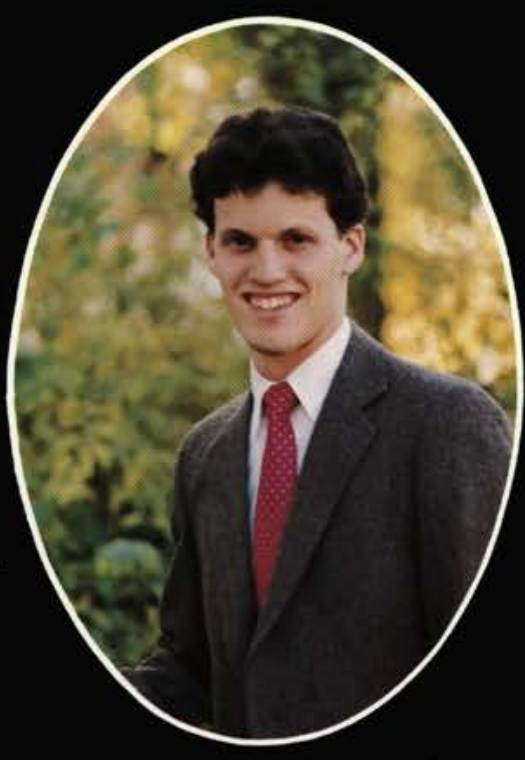

Thomas A. Blackburn

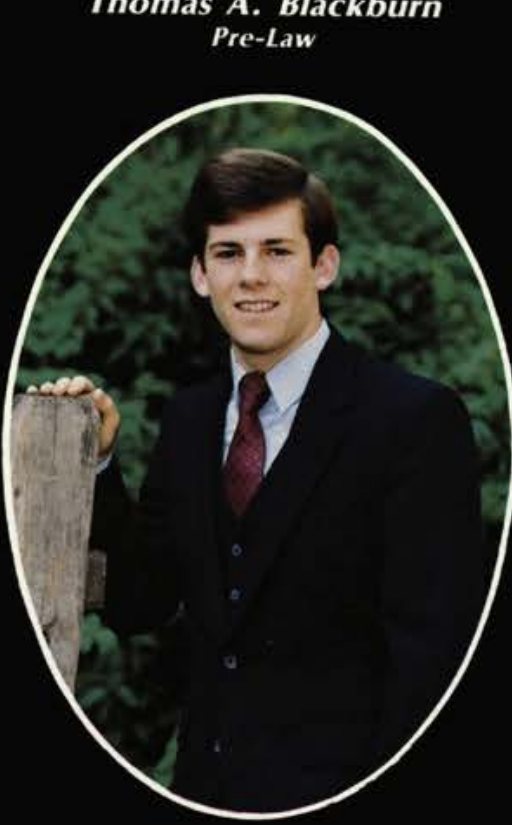

Don W. Booher Business/Computer Science

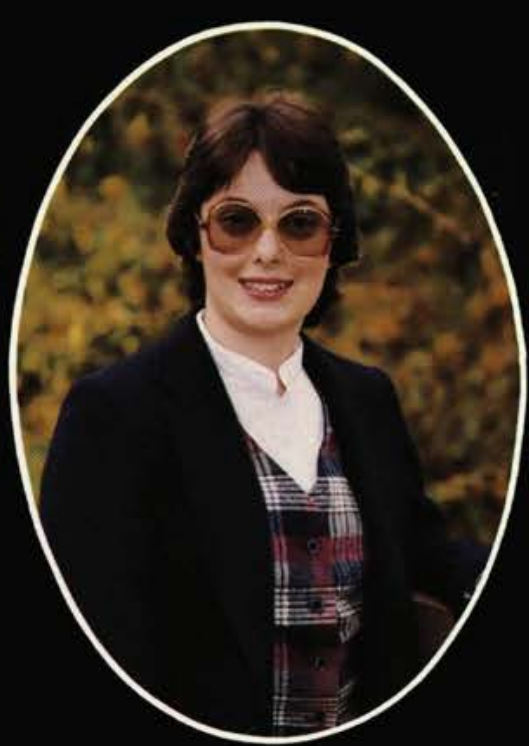

Alice Paulette Boyd Comprehensive Bible/Spanish

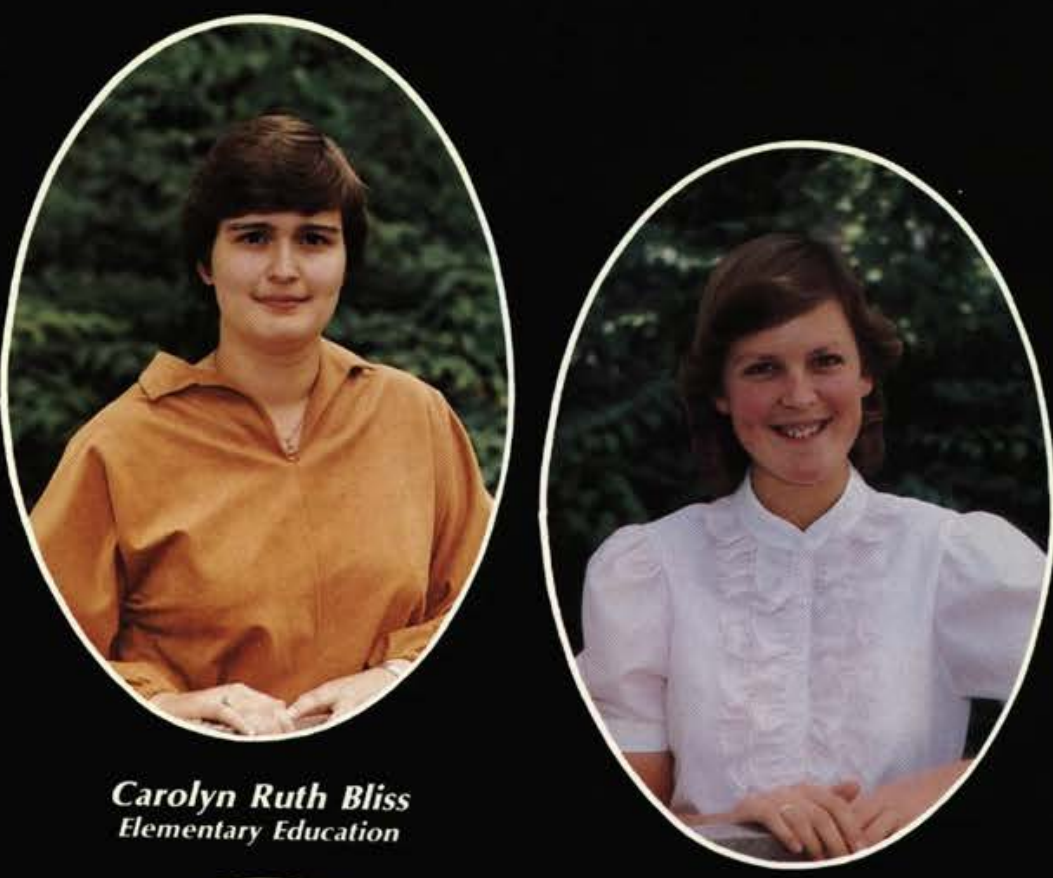

Jenny Anne Boer Elementary Education

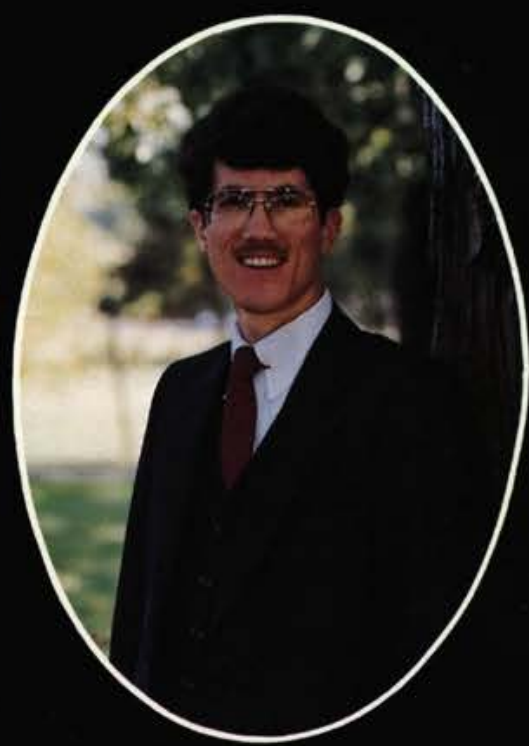

Jonathan Walter Bowersox History

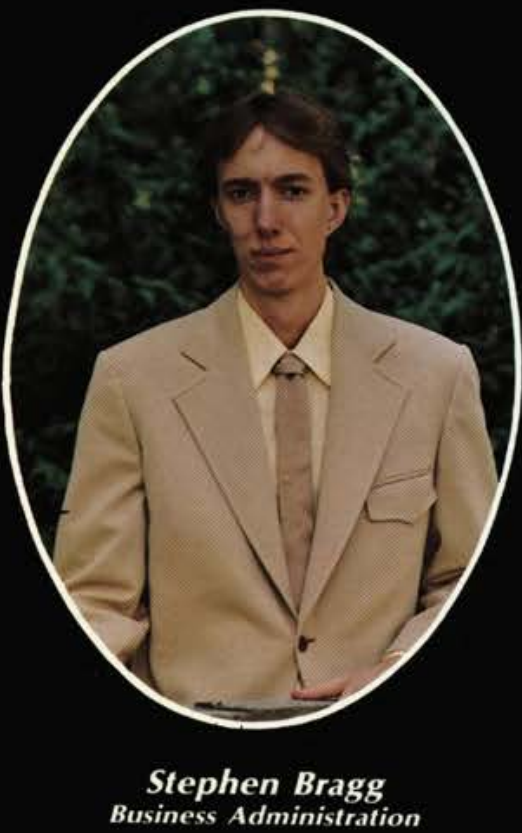

Business Administration

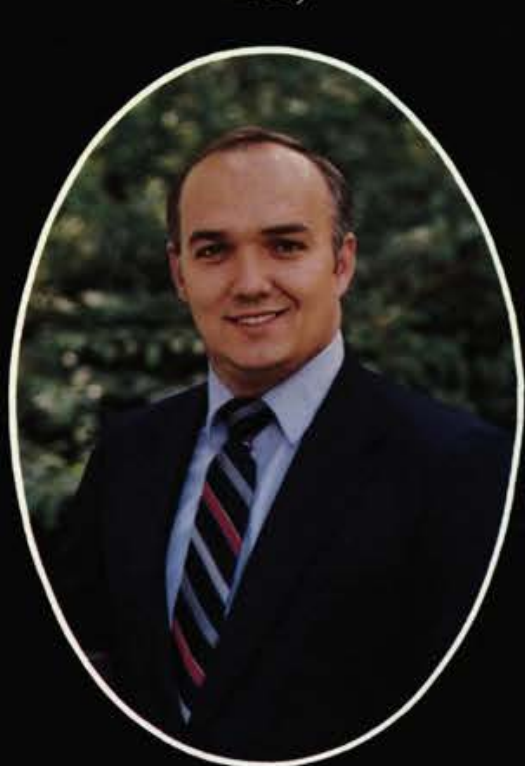

Gary Lee Brewer Business Administration 


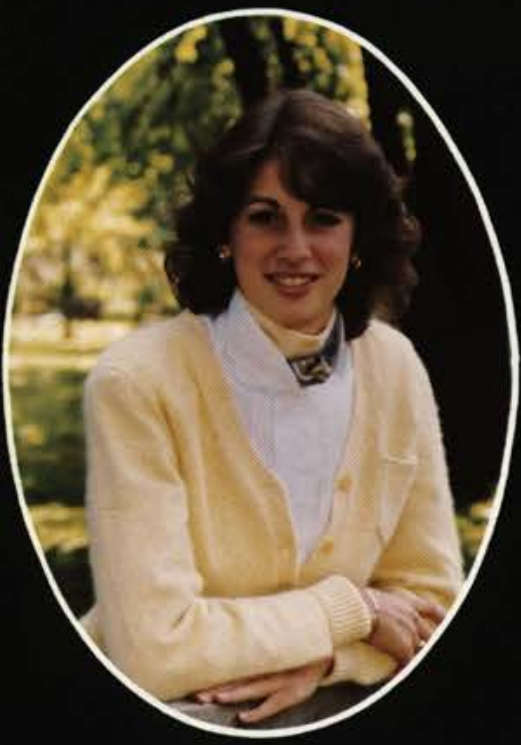

Karen Elaine Entingh Business Administration

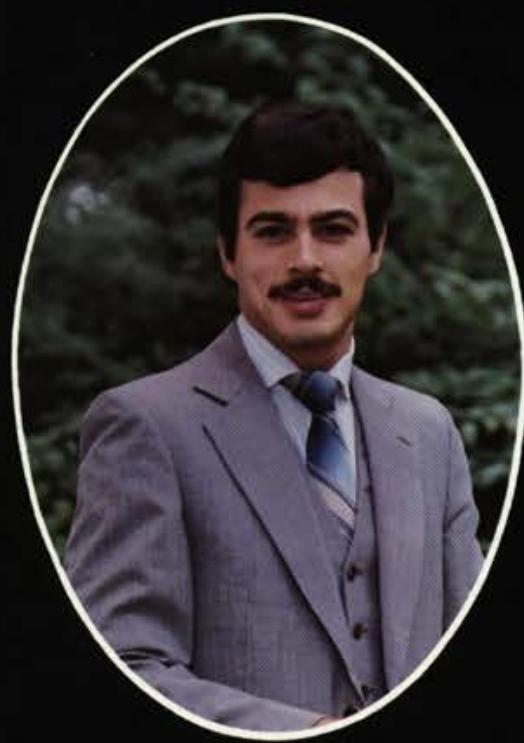

Robert Charles Entwistle Pre-Seminary

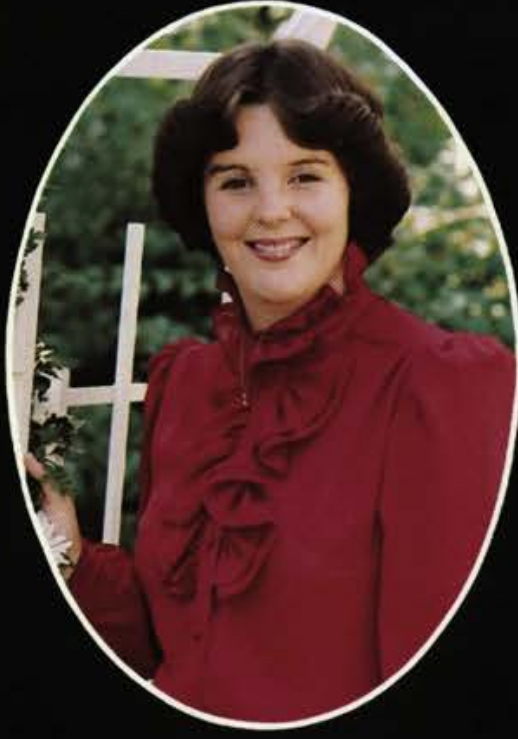

Carol L. Essler Business Administration English
Donna Marie Estes

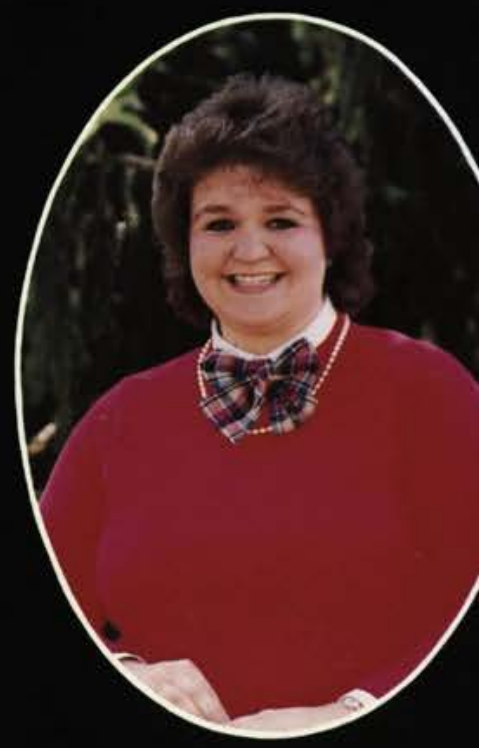

$\mathbf{R}$ eflecting on my four years at Cedarville causes me to I. remember all the fun times l've had, all the lessons l've learned, all the experiences l've been through, and all of the very special people l've met.

I think above any other time, my freshman year held the most surprises. I was 1,300 miles from home and homesick before l ever arrived here. Moving from the large city of Denver to the small village of Cedarville was quite a shock. It was a completely new way of life in a completely new environment and I couldn't imagine what God had in store for me!

Since that time, I have been led through many different events that have changed my life. One of which occurred in my junior year when I was a live-in nurse's aid for a blind, elderly woman in Clifton. Besides teaching me patience, it taught reliability, frugalness, and independence.

Personally, I have changed a great deal during my stay here. I started out as a shy, Bible-ignorant, chemistry major. I am no longer shy; and through the guidance of professors, chapel speakers, and friends, I have realized the tremendous importance of learning about God's Word. Also, I changed my major to English Education. Student teaching at the Ohio Veteran's Children's Home held more lessons than I could ever have imagined.

What do I appreciate most? This is the hardest question to answer because there is so very much. I appreciate the quality of Cedarville, academically, spiritually, and socially; I appreciate God's leading me here, and I appreciate my family. Being separated from them the full school year, except at Christmas, has shown me their value and love.

To fully reflect upon my four years here could take forever, but in summing it all up. I would have to say that these four years have laid my foundation; it will take the rest of my life to build upon this structure.

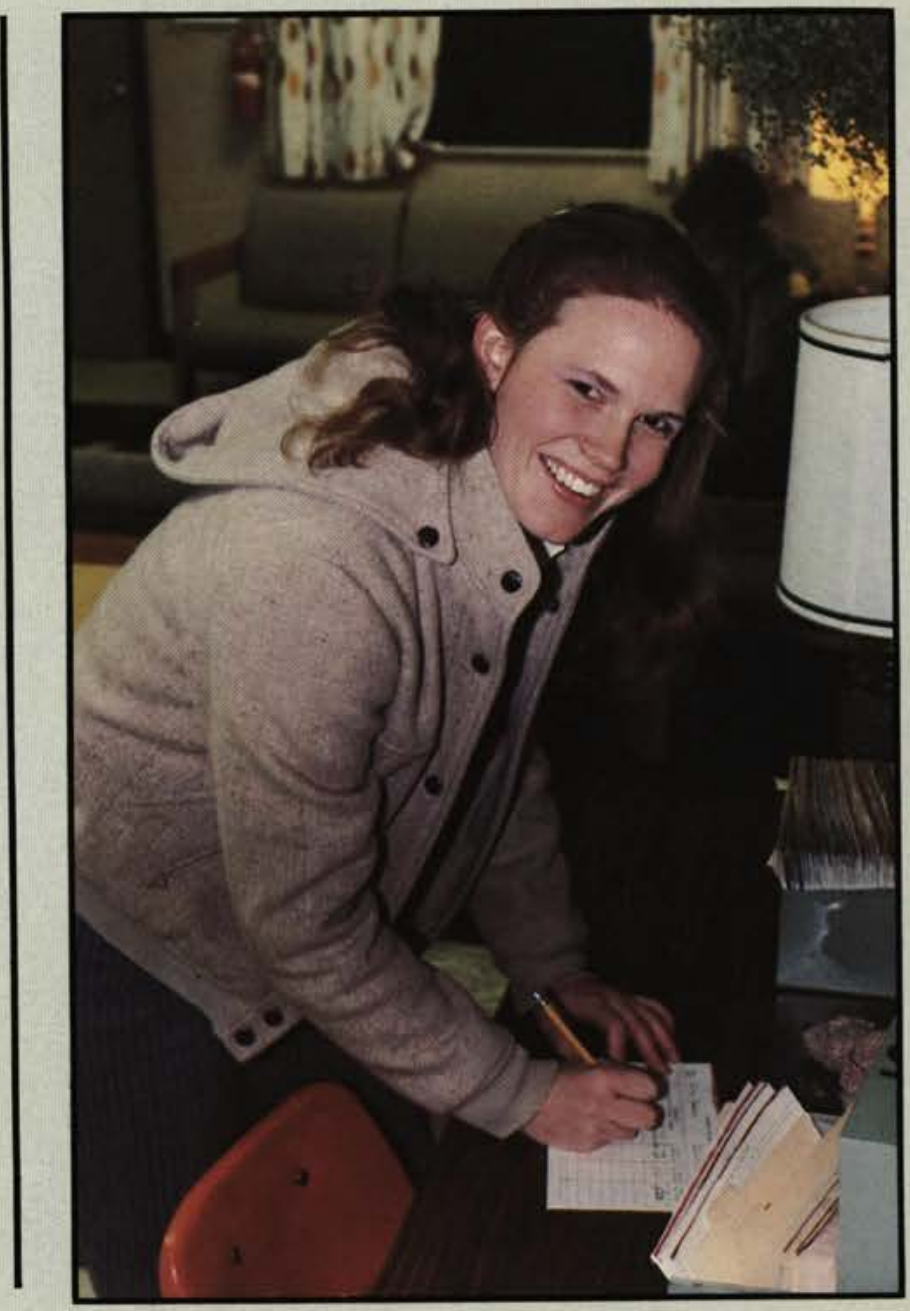

by CARLA MOSHER 



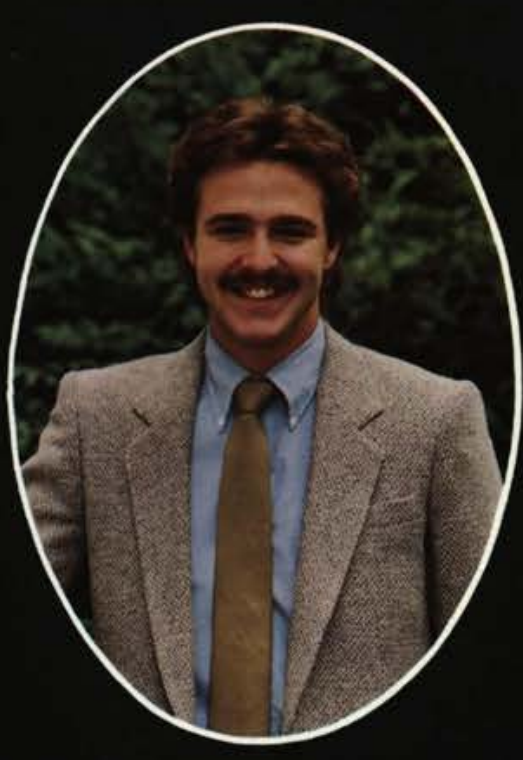

Brian M. Helwig Broadcasting

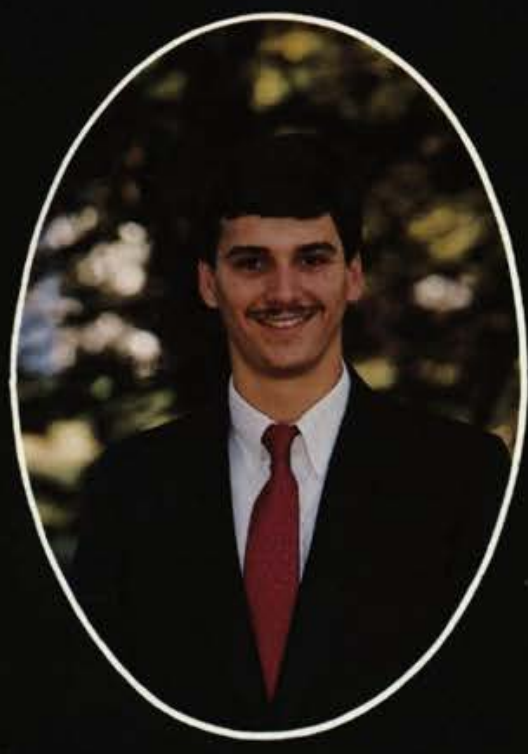

Jay C. Highman Business Administration

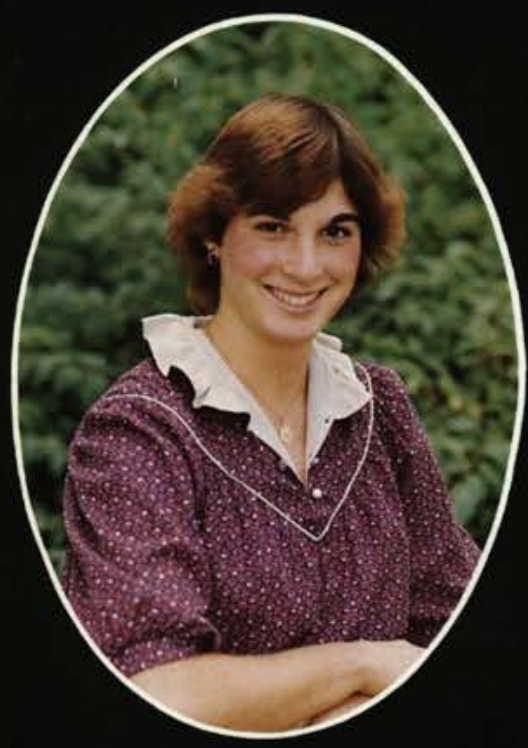

Karen A. Hobar Business Administration
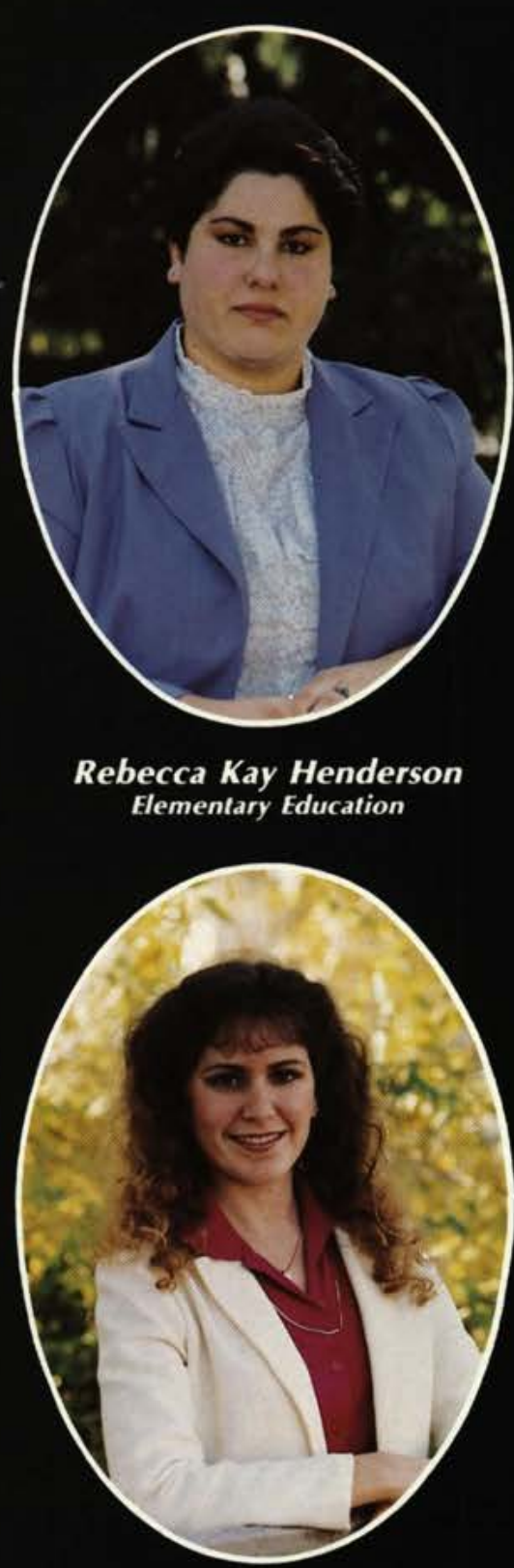

Grace Lorraine Hill English/Literature

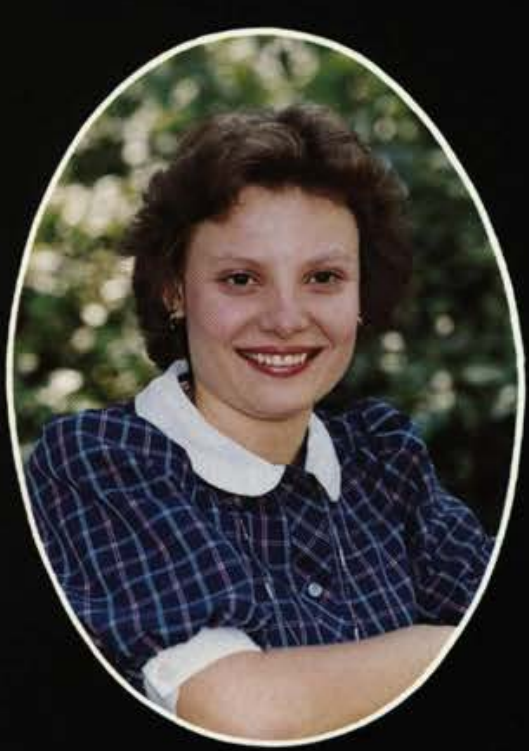

Lori Ann Hock Elementary Education

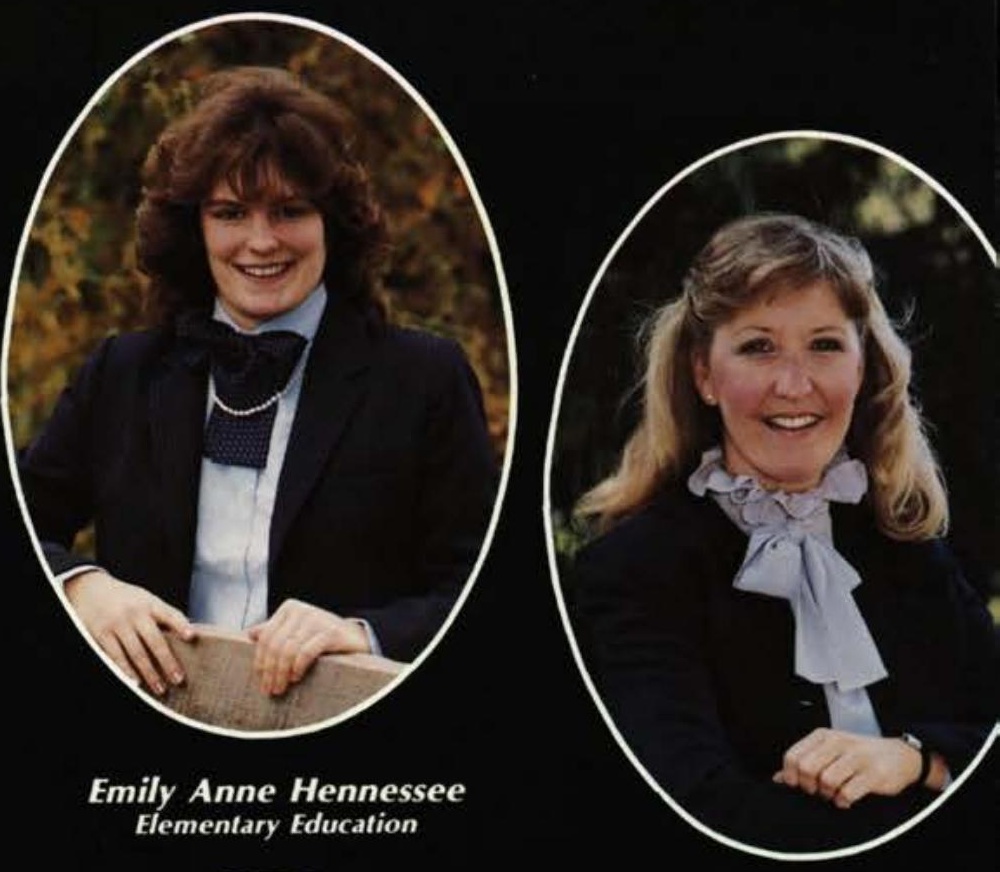

Ruth E. Hess

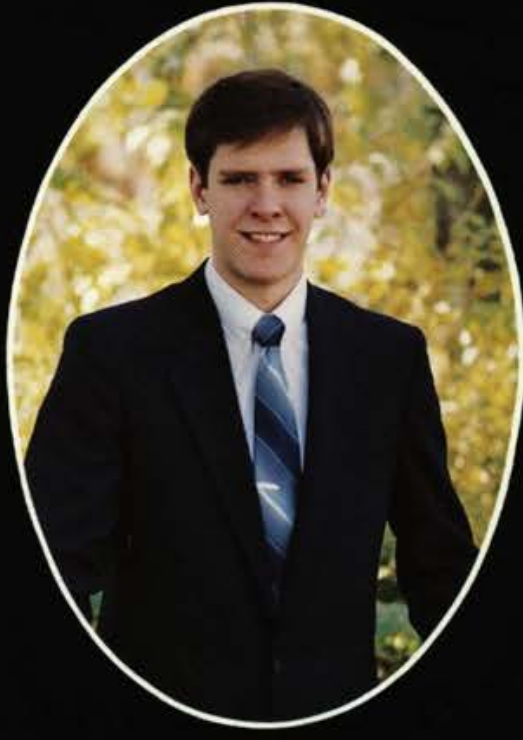

Richard R. Himes Bible

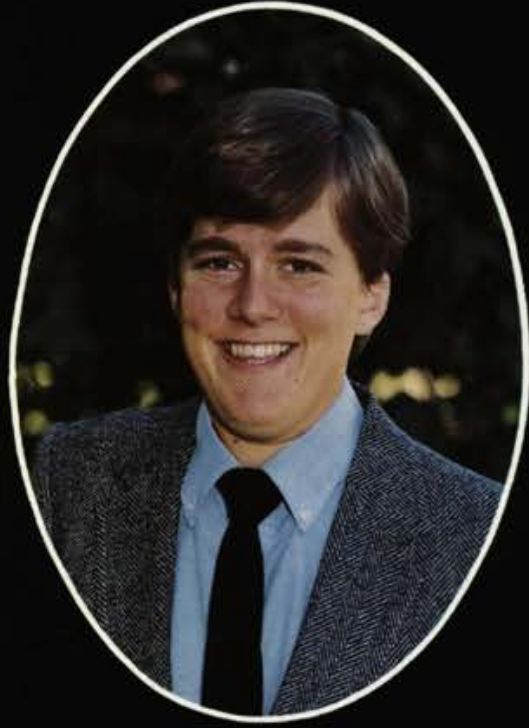

Mark Newton Holman Speech

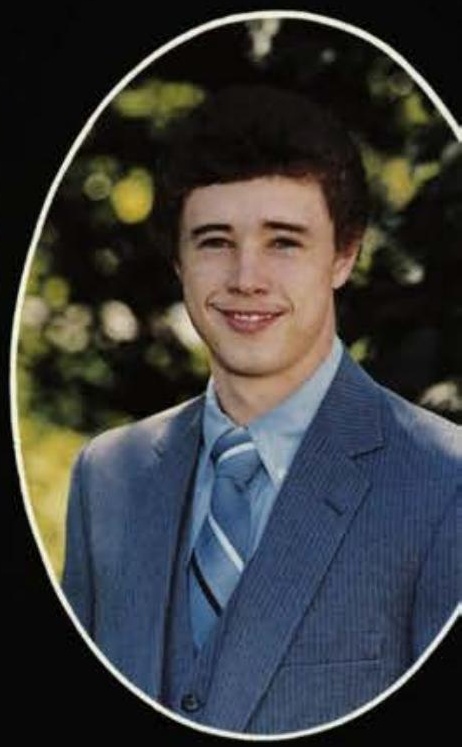

Andrew Allen Hitt Psychology/Behavioral Scien

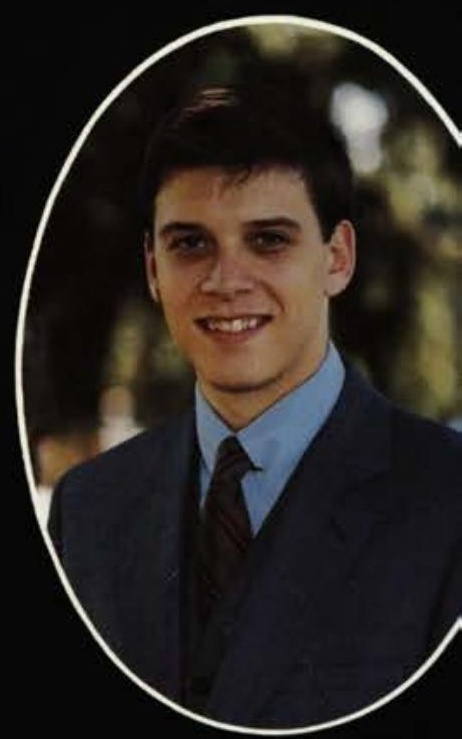

Jeffrey Thomas Holt Accounting 

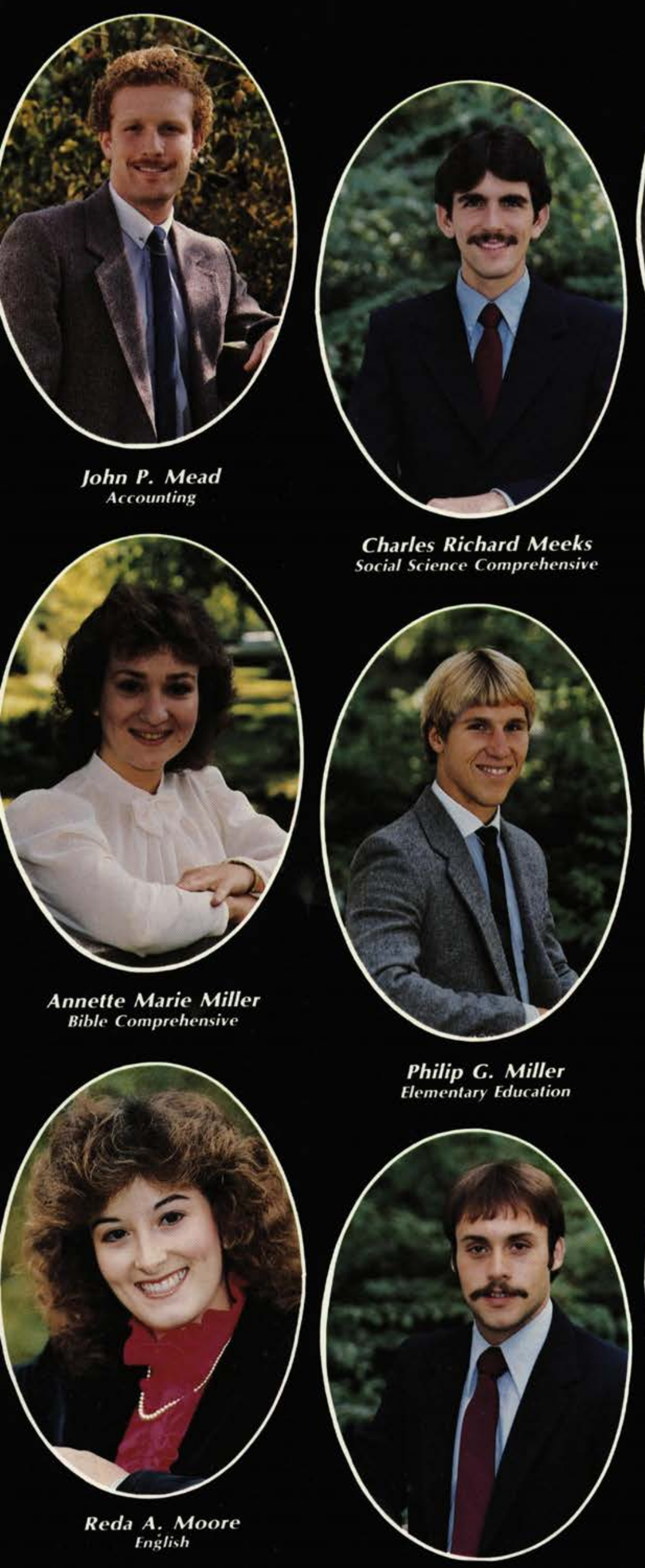

William S. Moore Behavioral Science
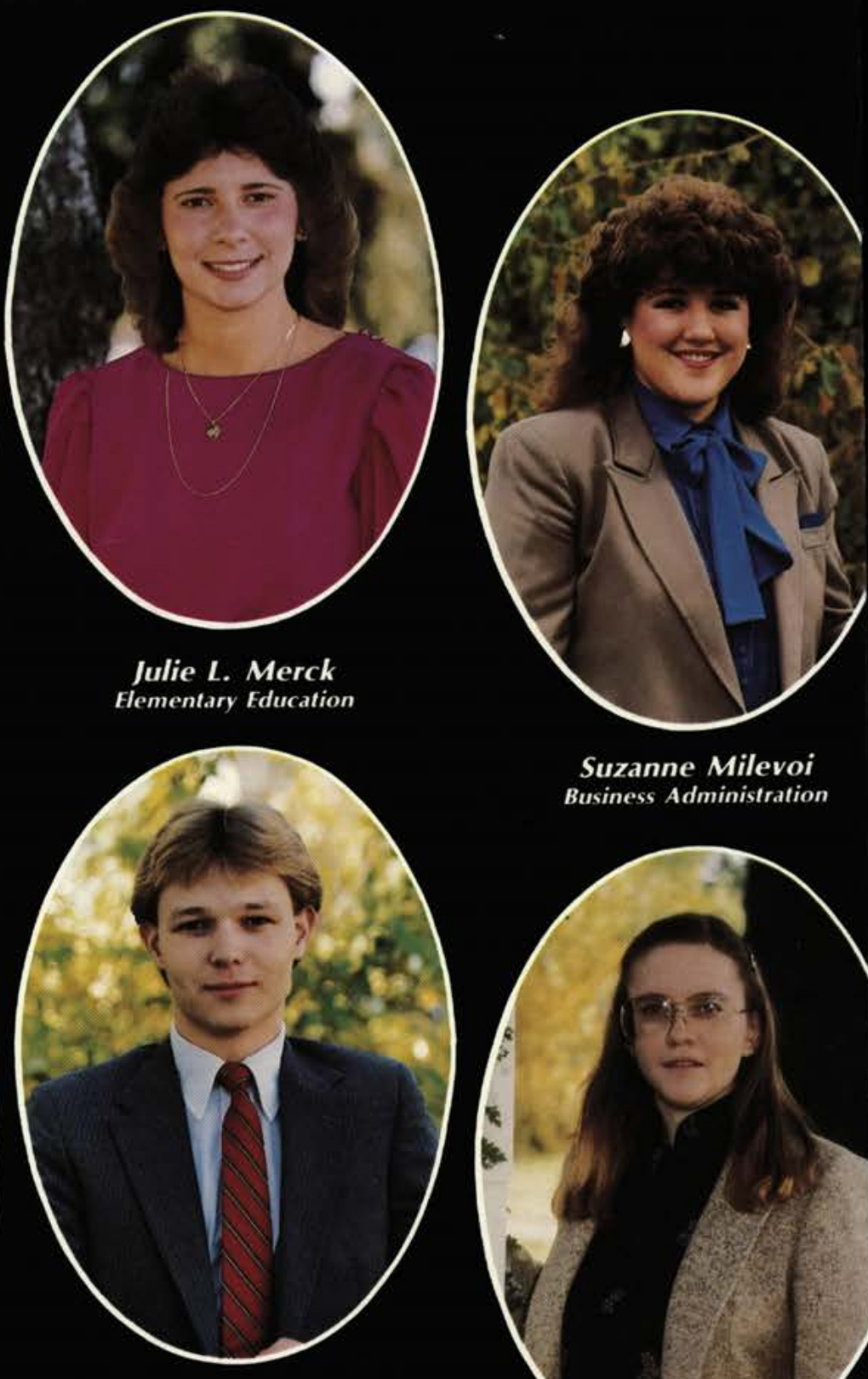

Greg A. Moffitt Business Administration

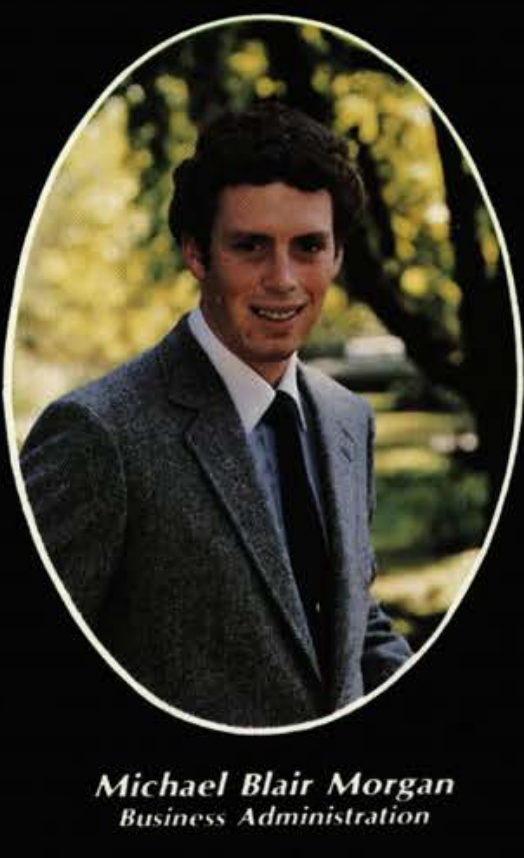

Michael Blair Morga

Victor Mitchell Morgan Accounting 


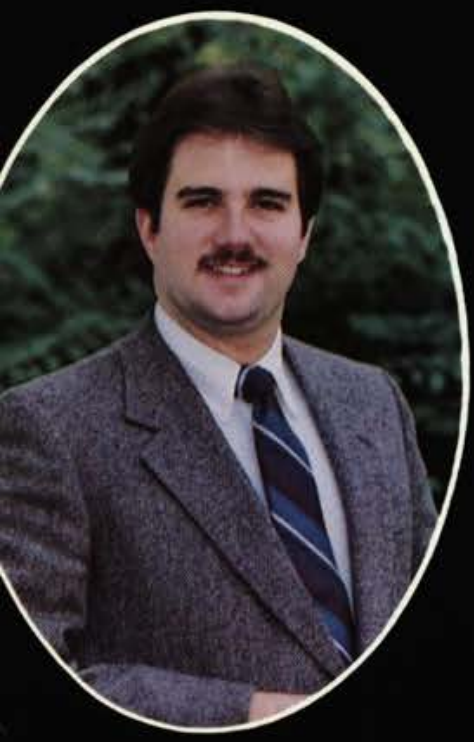

Gary W. Rouster Music Education

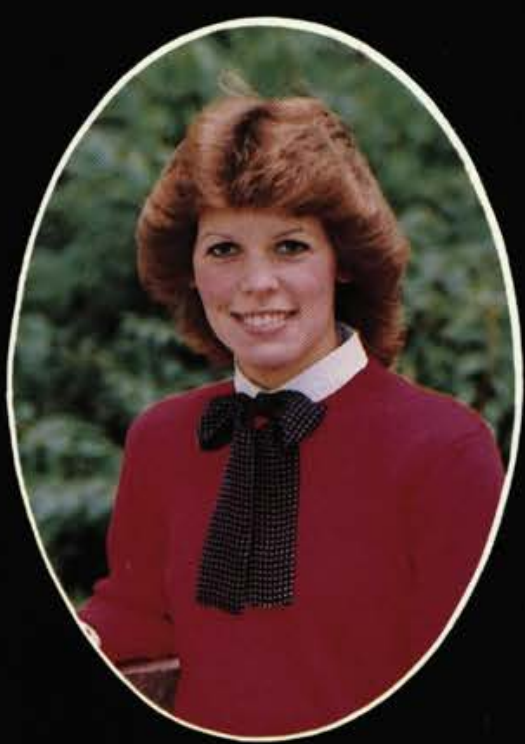

April J. Saathoff Business Administration

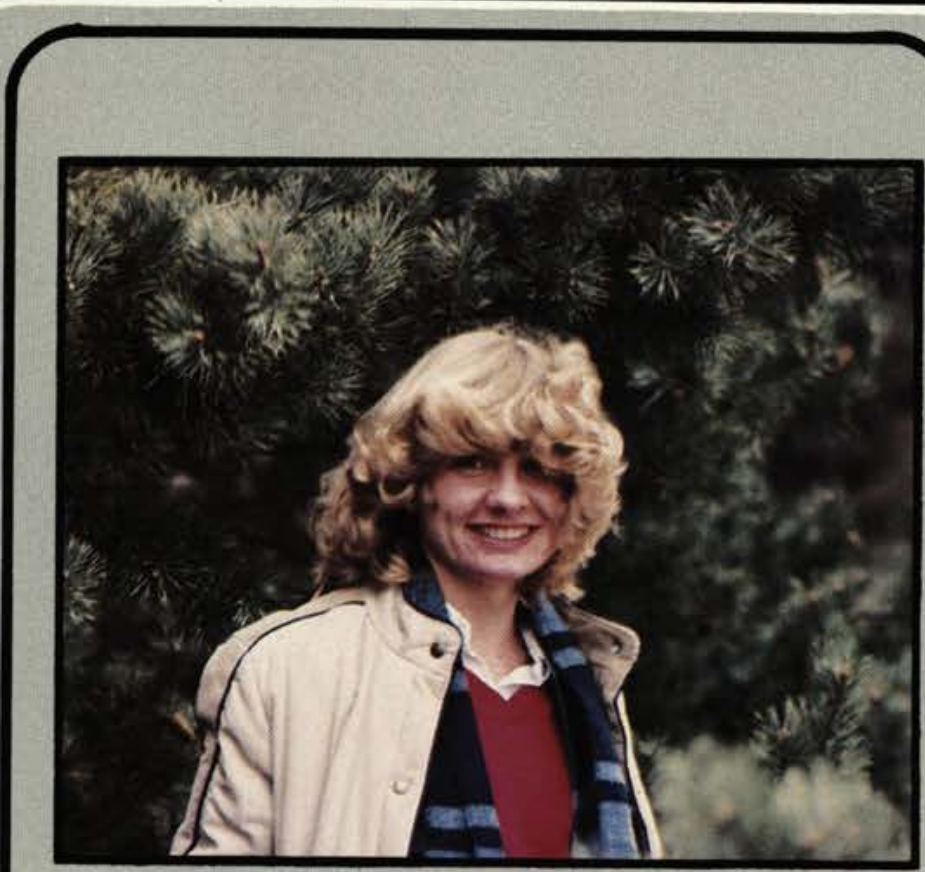

C trange incidentals always fasten themselves to my $\delta$ memories of college life. Dorm life, for instance, offered some queer delights. Crawling into bed at night was generally a rather comfortable event, except for when the process was hindered by my sheets growing mysteriously short. Not much better were the nights I felt the exotic sensation of popcorn kernels, nestled beneath the sheets, massaging my weary bones. Dorm life held other flavors of excitement, like struggling to keep two eyelids, ten fingers, and one fuzzy brain cognizant while typing a ten-page term paper at 3:00 A.M.

When I wasn't enjoying the luxuries of life in Maddox, I explored other exciting adventures. How often I recall crashing into the wall of a racquetball court, sending the
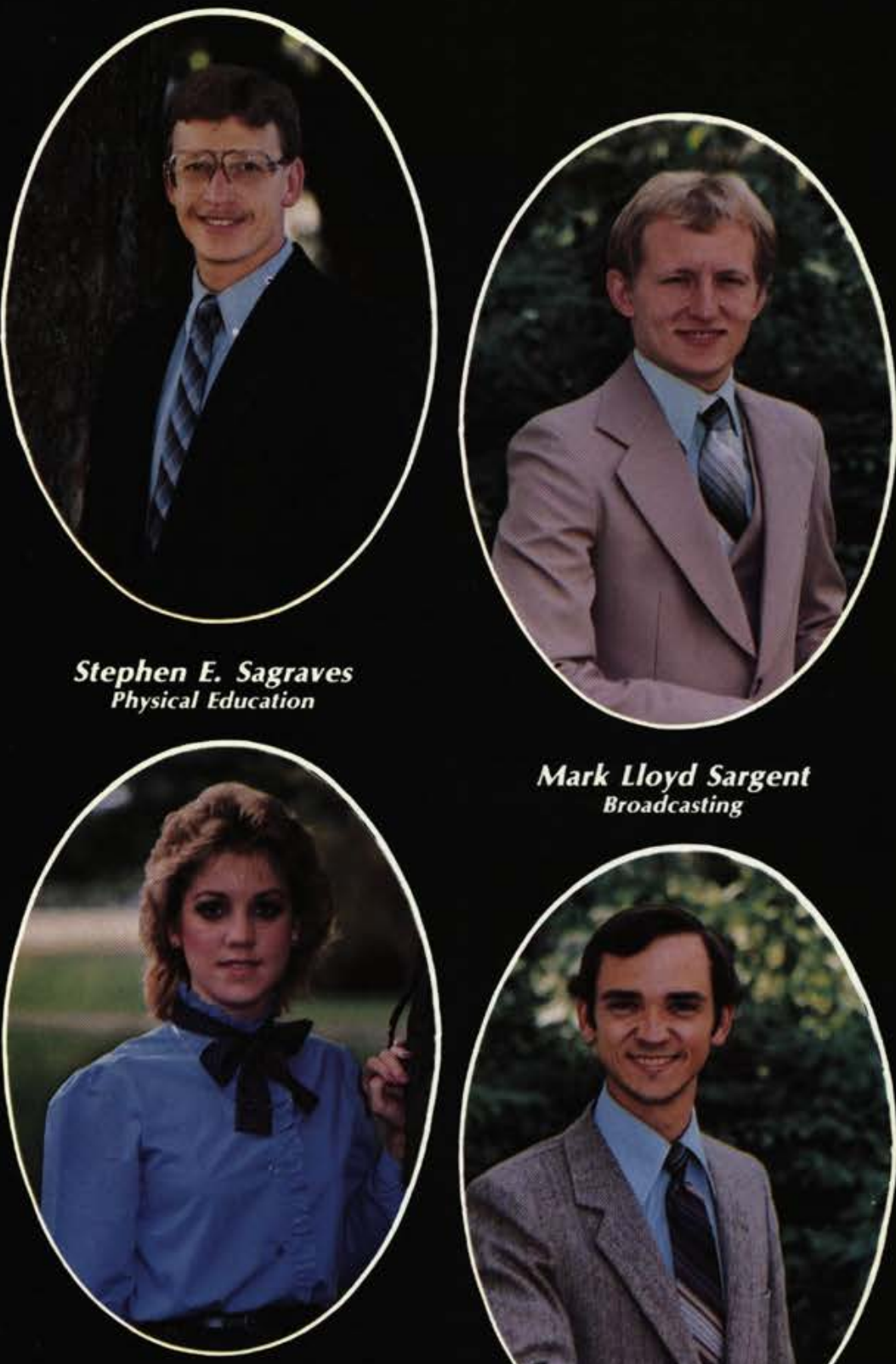

Jean Marie Saucier Speech
Mark Lloyd Sargent Broadcasting

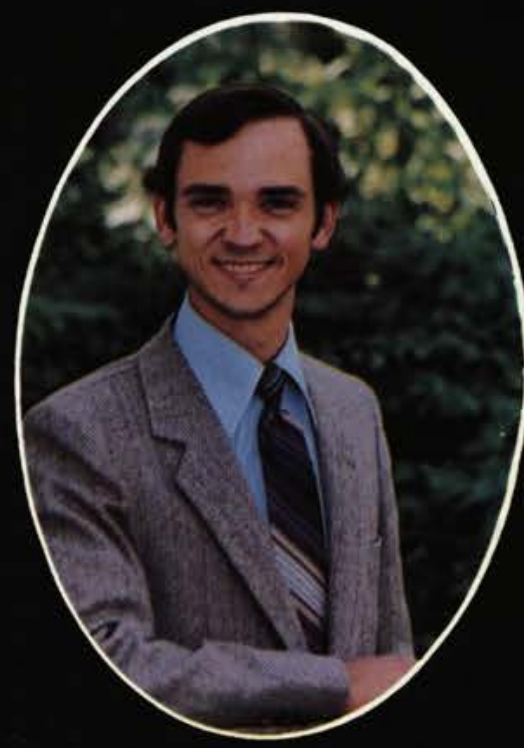

Arlin Oscar Schrock English ball surging toward the ceiling, and then noticing the grin of an amused spectator overhead. Obviously, athletics were not so very precious to me, but the freedom I enjoyed here was. Incredibly enough, I could disagree with my professor without being flunked, suspended, or exiled from campus. When the temperatures were unbearably cold, I could wear pants, and while playing tennis, I could wear shorts! (The only problem is that I can't play tennis.) I guess the biggest shock was the privilege of actually holding hands with a member of the opposite sex. (I never did that either, but just knowing that I could was thrilling in itself.)

Cedarville taught me much about people and much about life, and it taught me that learning is a lot of fun. 


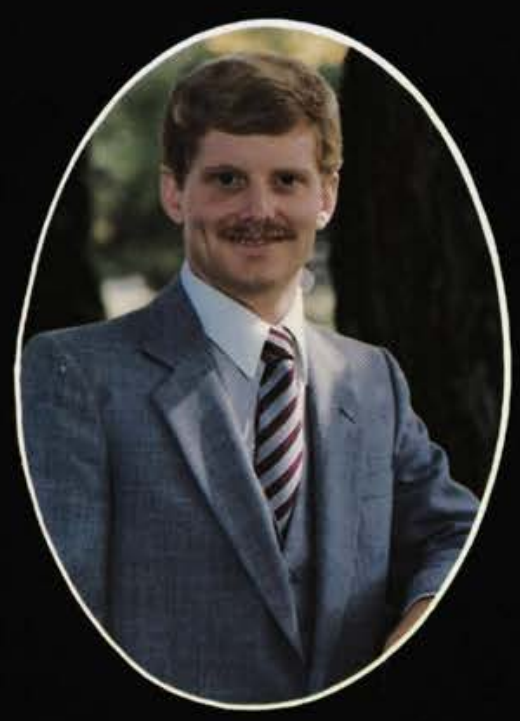

Timothy L. Stewart Bible/Pre-Seminary

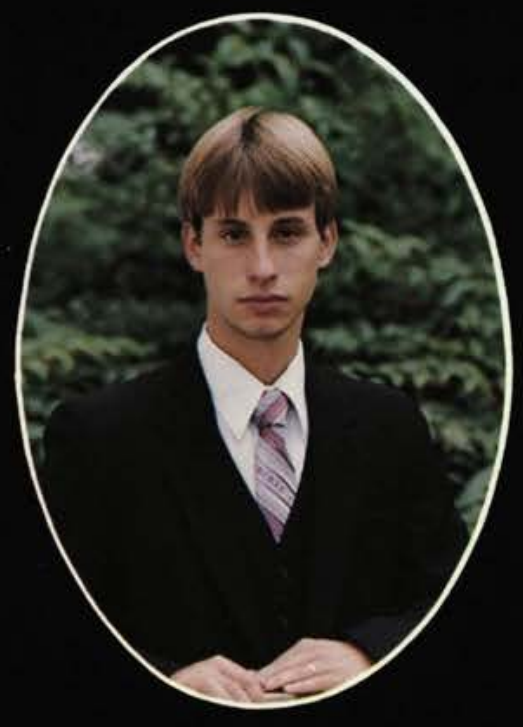

Allen Scott Swander Pre-Seminary

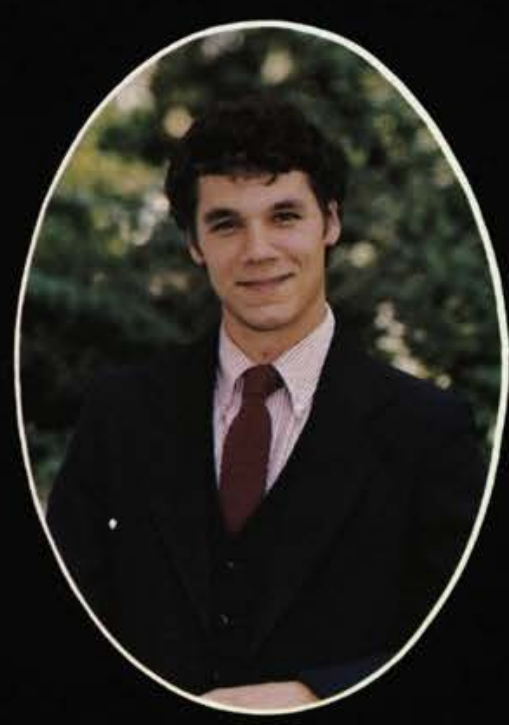

Thomas William Teall Social Science

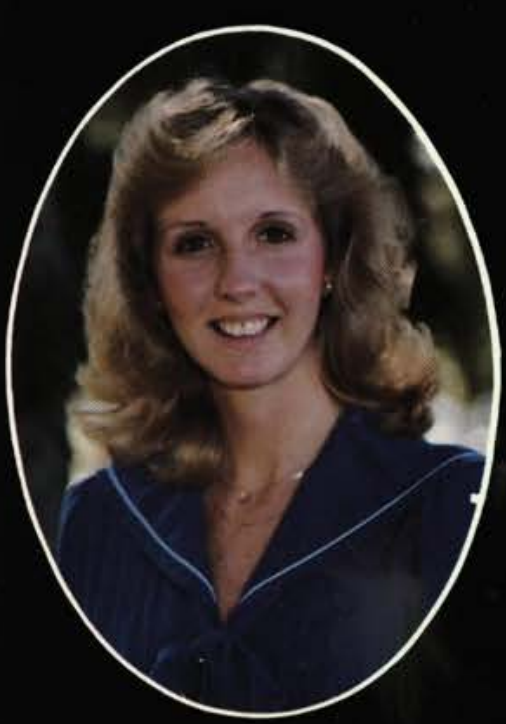

Jennifer L. Stork Behavioral Science/Psychology

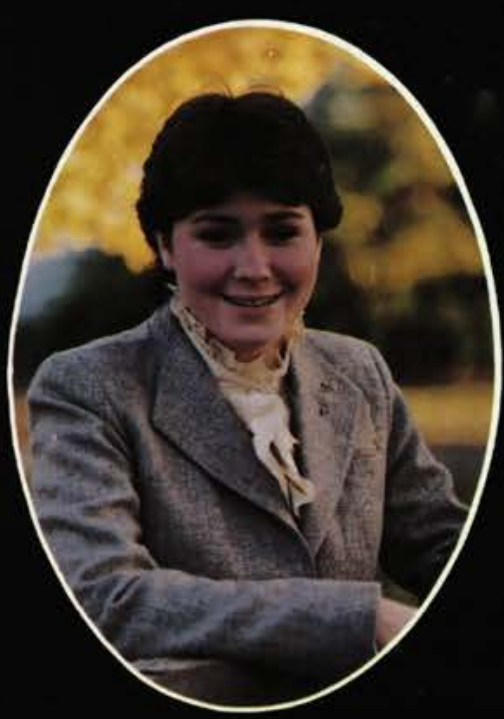

Lisa A. Swanson Accounting

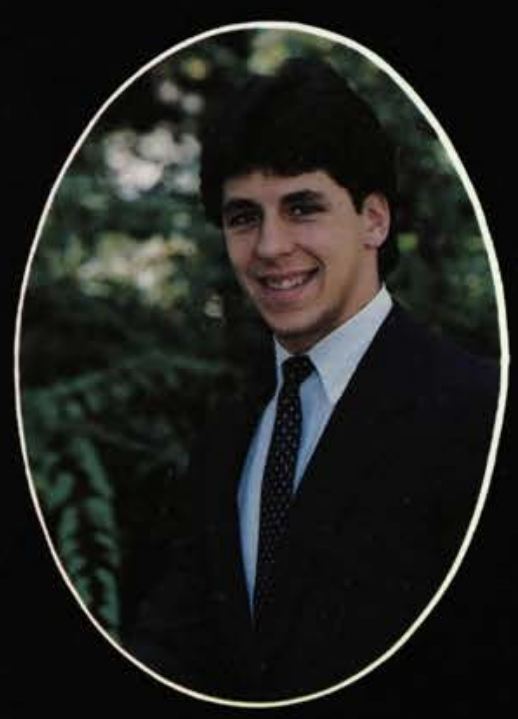

Mike Joseph Templin

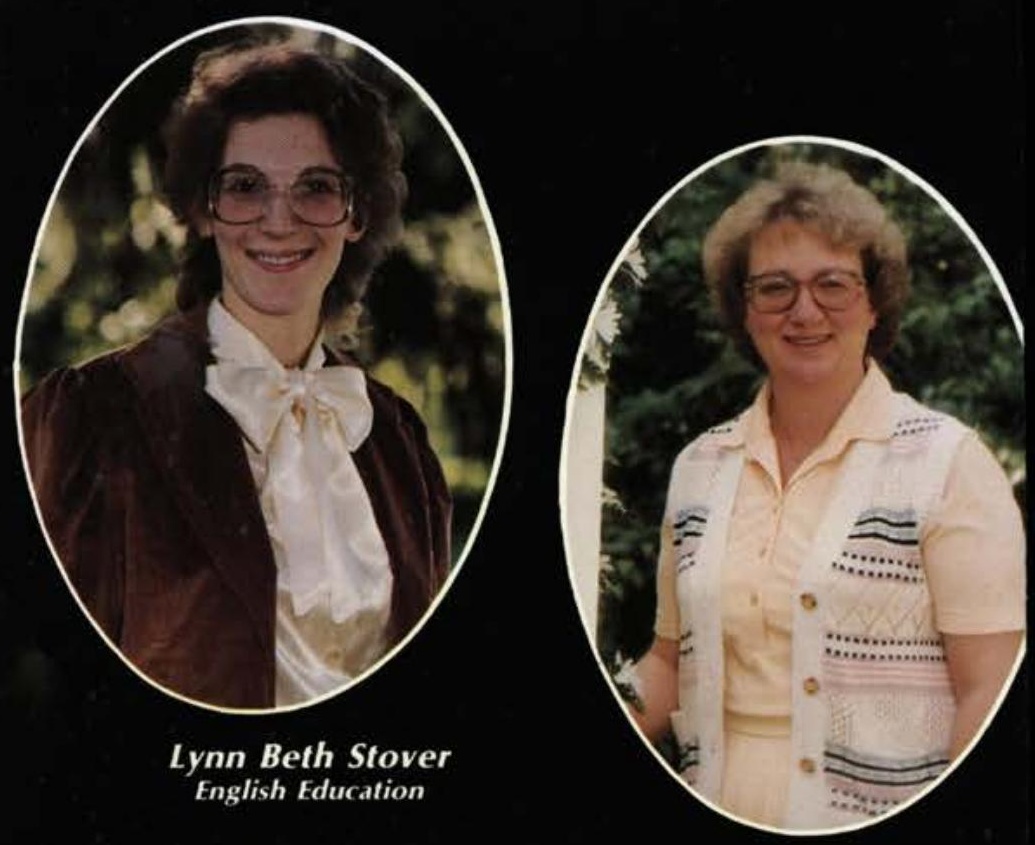

Loretta Marie Strock History

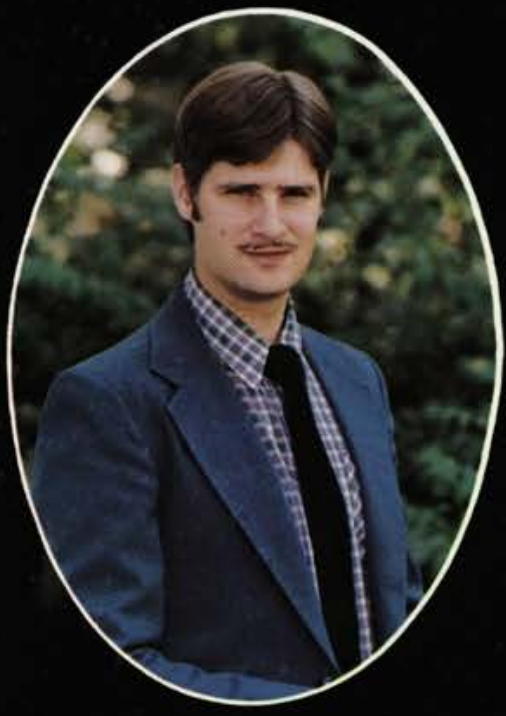

James C. Switzer II Church Music

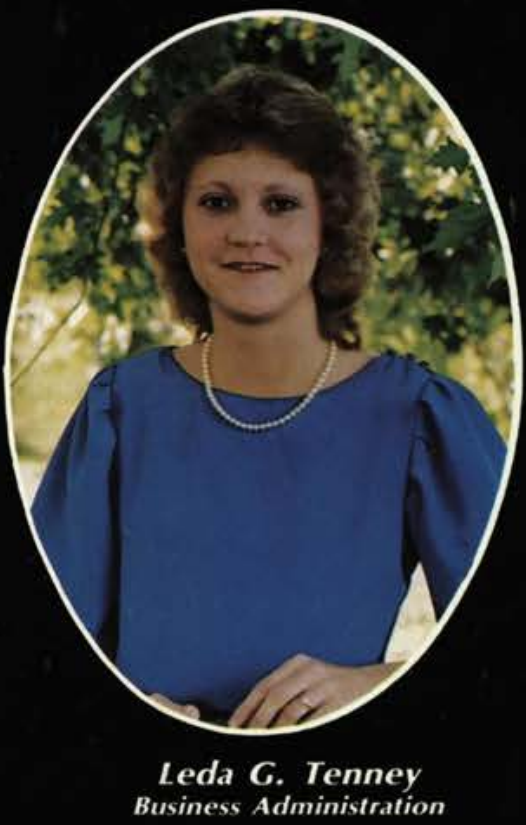

Business Administration

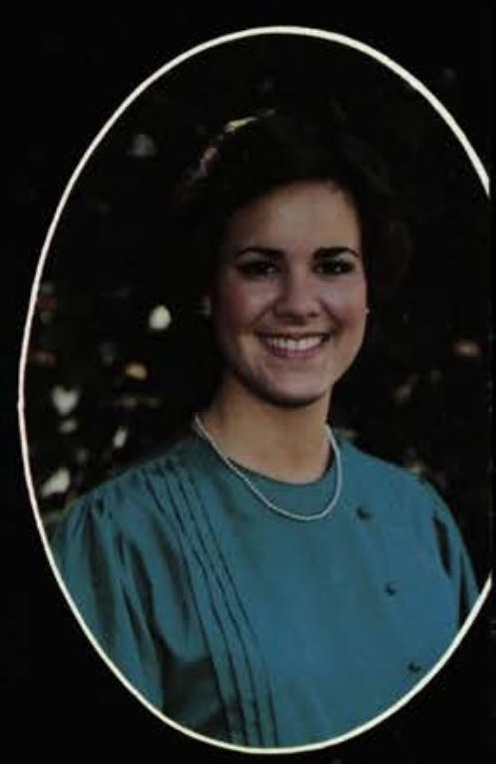

Janet E. Taylor Business Administration

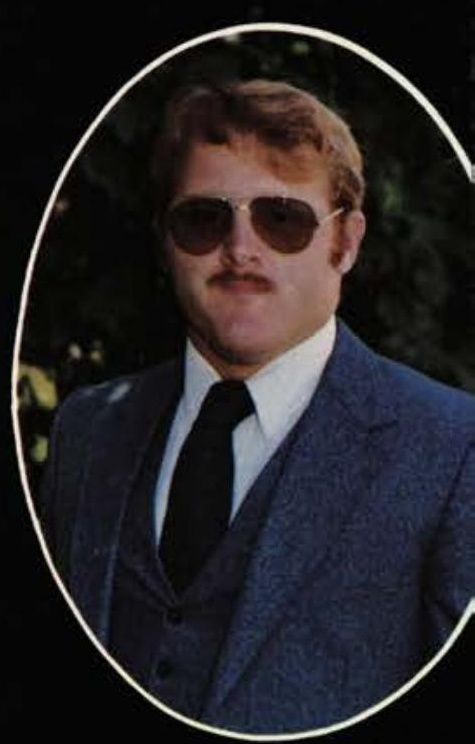

Michael Allen Thane Accounting 


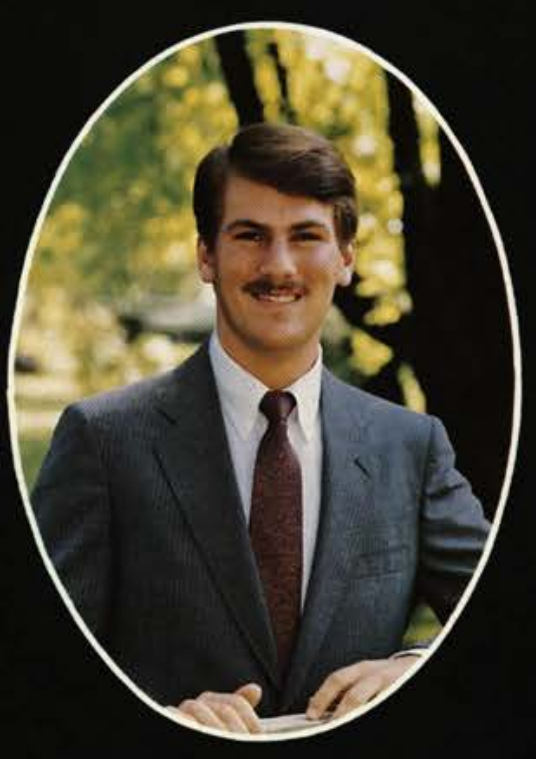

Joseph Arthur Walker Business

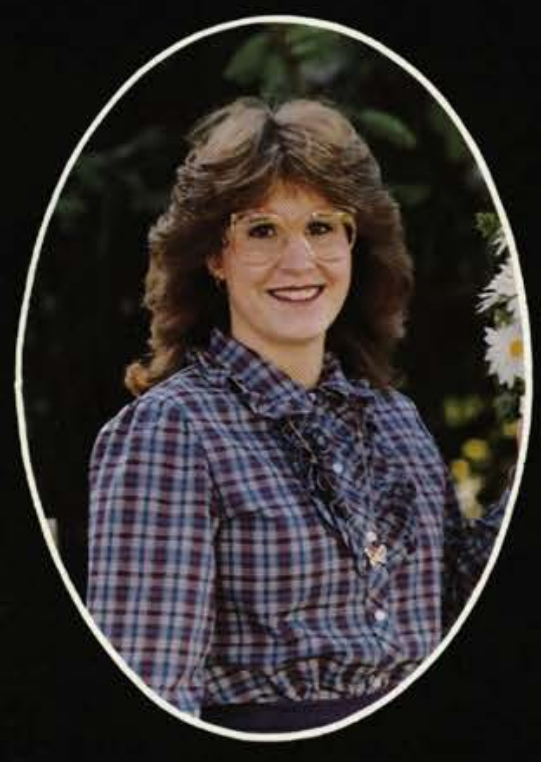

Kayla Ruth Webb

Behavioral Science

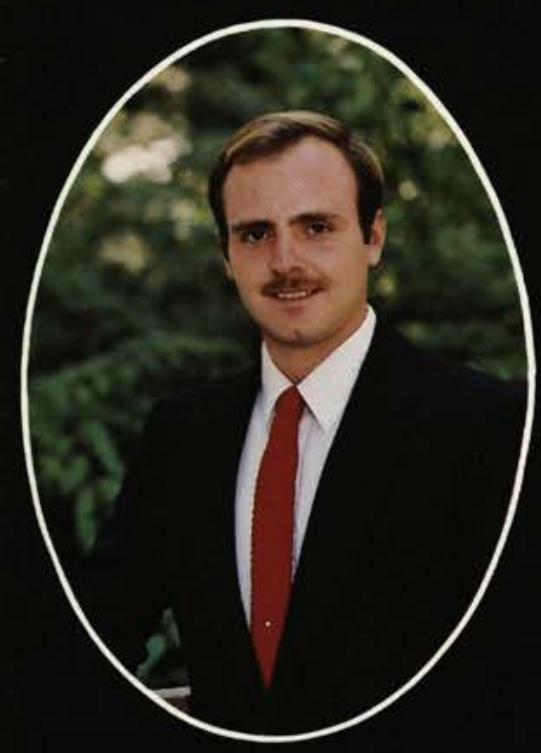

Jeffrey Scott Wenrick Business Administration

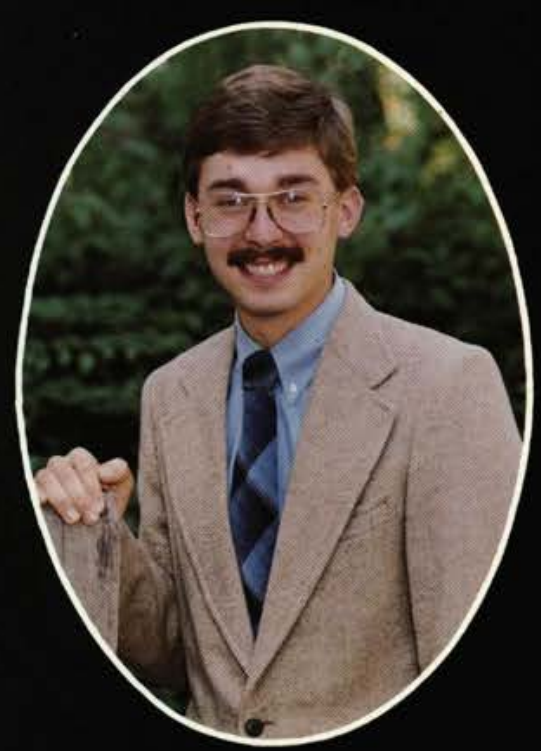

Mathematics/Psychology

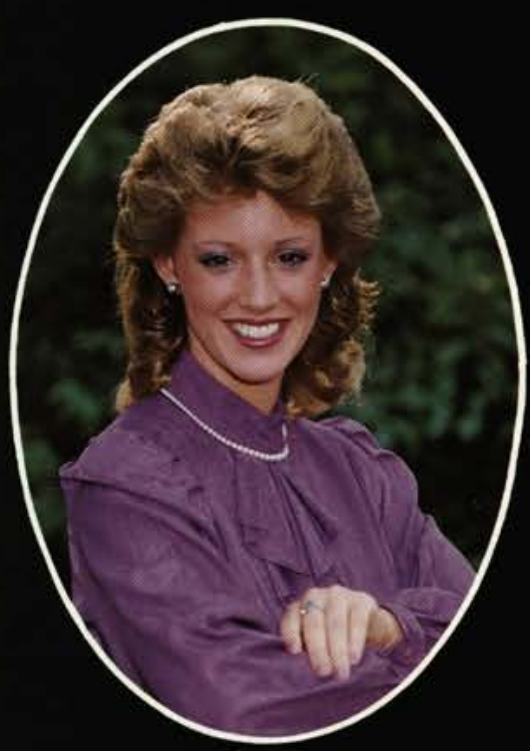

Cherie Renae Webber

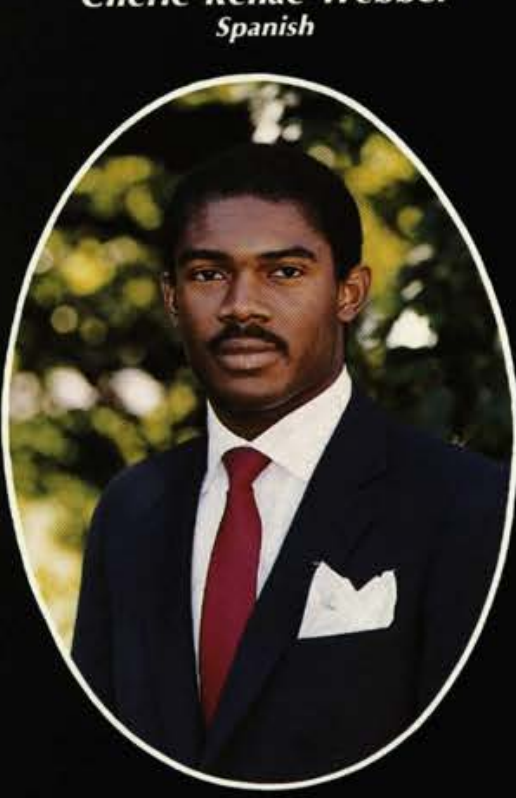

Gillis Cheetham West $_{\text {Accounting }}$
W

Gillis Cheetham West
Daniel F. Wallace

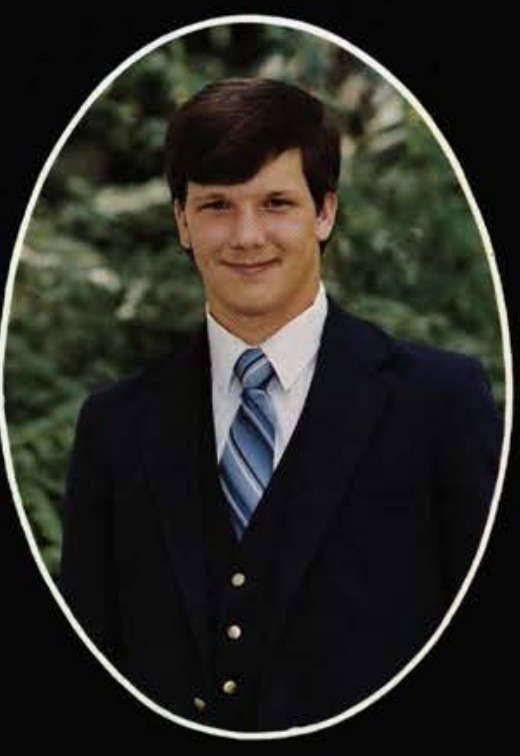

Gary Lee Wallace Physical Education

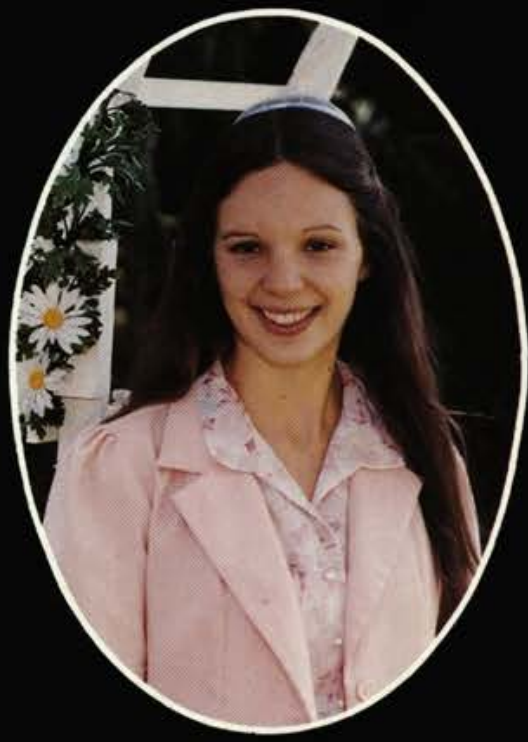

Twila Ann Weber Elementary Education

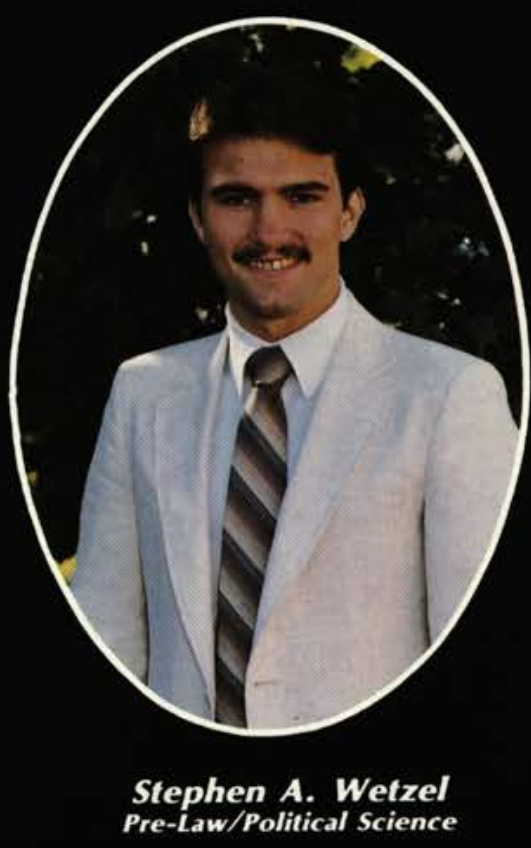

Stephen A. Wetzel
Pre-Law/Political Science

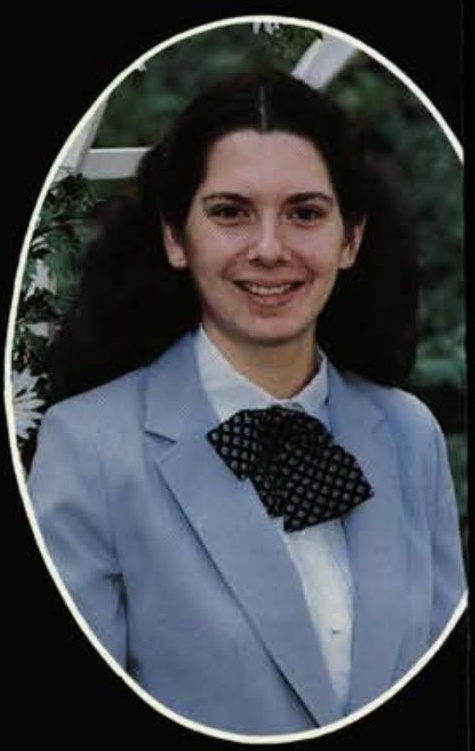

Karen S. Webb English/Elementary Education

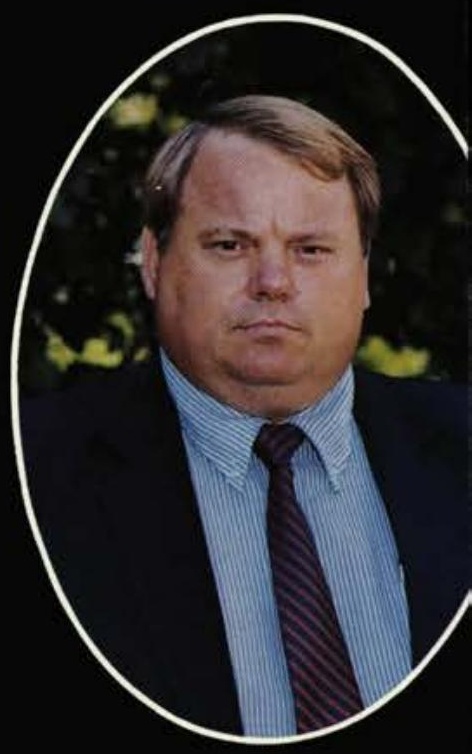

Thomas William Wedge Bible Comprehensive

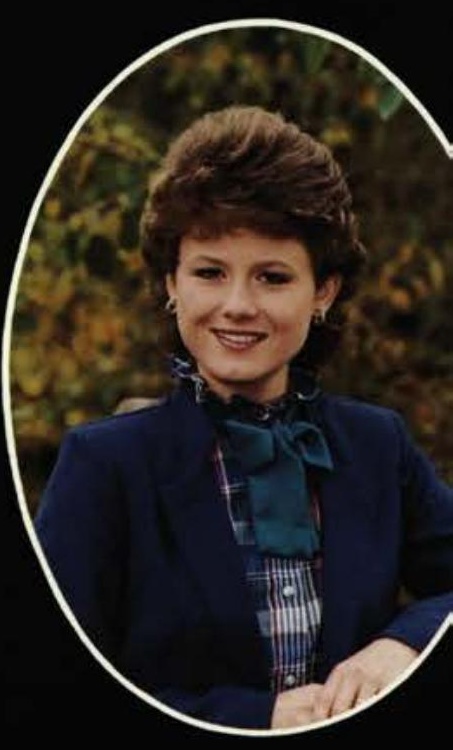

Karen Louise White Business Administration 


\section{by KEN BANDY}

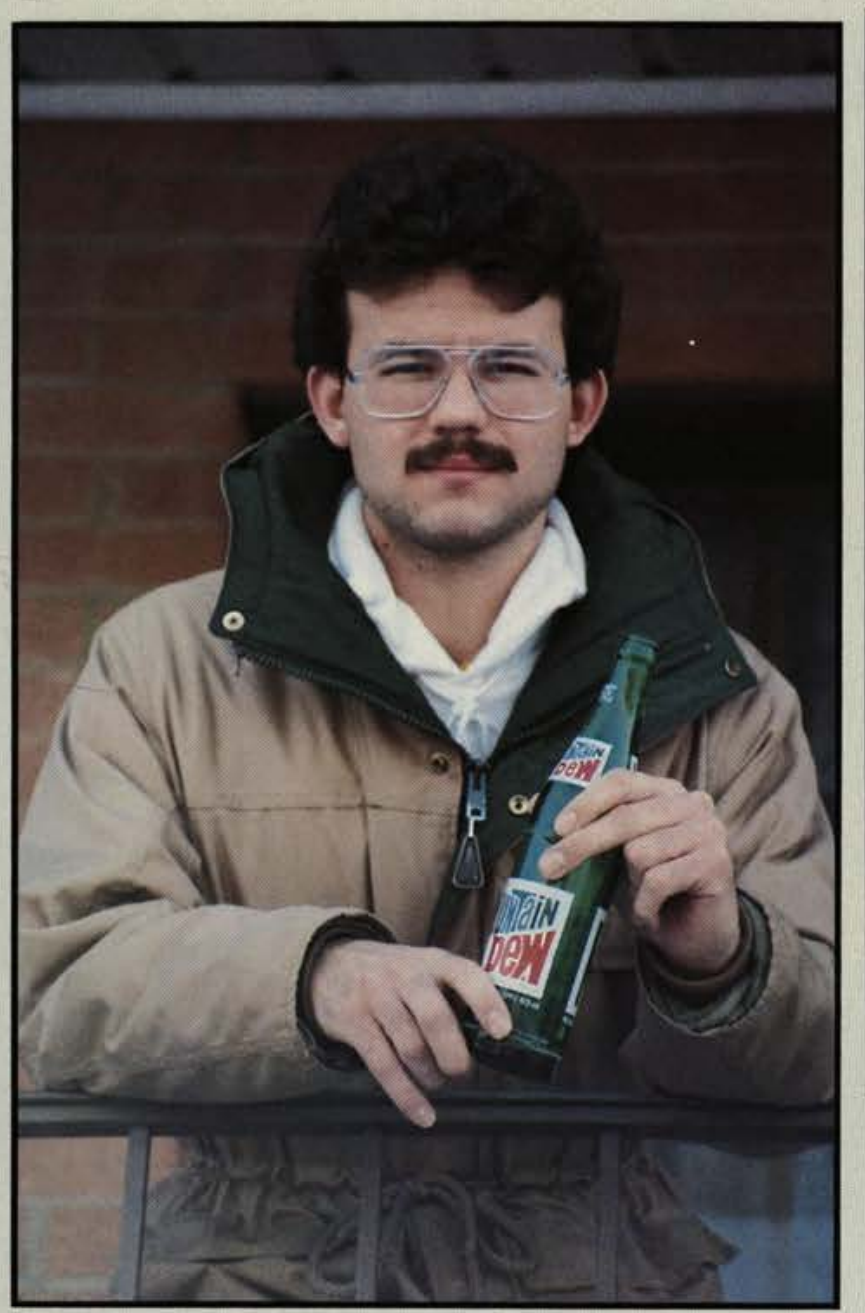

Een if I were to go back home, get a regular job, E make a good salary, live the rest of my life as though I had never gone to college - as though what I've learned and paid for didn't seem to do a thing for me - I still wouldn't trade my college experience for anything in the world.

A couple of paragraphs couldn't contain the meaning of the past four years. Ironically, when I arrived on campus as a sophomore, my friends were surprised that l'd even returned. But each quarter I grew more attached to this curiously flat cornfield, Cedarville.

I'm particularly appreciative of the influence that Dr. Dixon has had on my life. Though we've all heard the term "excellence" repeated almost daily, we've seen excellence in the person of Paul Dixon. Another important influence in my life in recent years has been the relationships with friends in the dormitory. I've enjoyed the challenge of thinking through some very key issues with these great friends. It will be interesting to see how these relationships continue to develop as we move apart from each other.

Naturally, the faculty members have greatly influenced my thinking, but space does not allow comment on each one. The most important influence, however, has been the close relationship that I have with my father. He's worked very hard to see that I could attend Cedarville. In fact, I can think of very little that he's done for the past 22 years that was not intended for my betterment. I hope and pray that in days to come if the Lord does not return that those who have worked so hard to influence my life will see the fruit of their labor and that it pleases God.

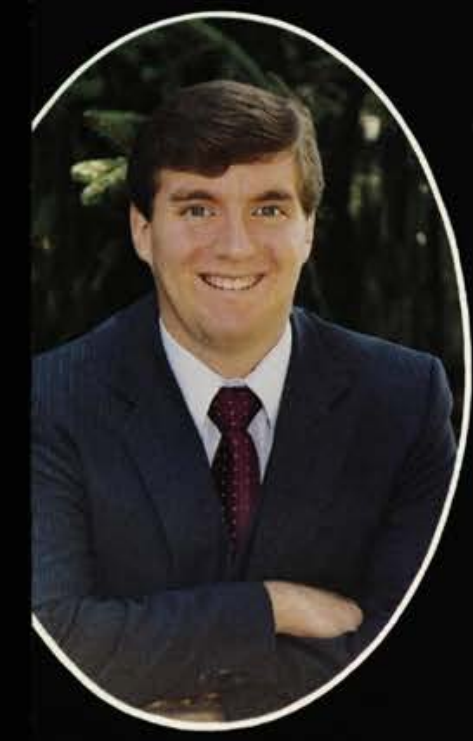

romas Carl Wiggershaus Broadcasting

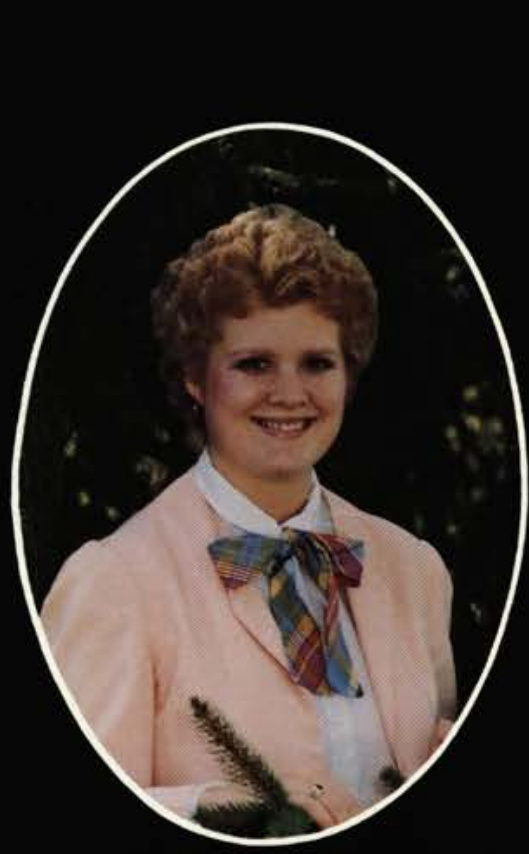

Marcia K. Witinamaki Psychology

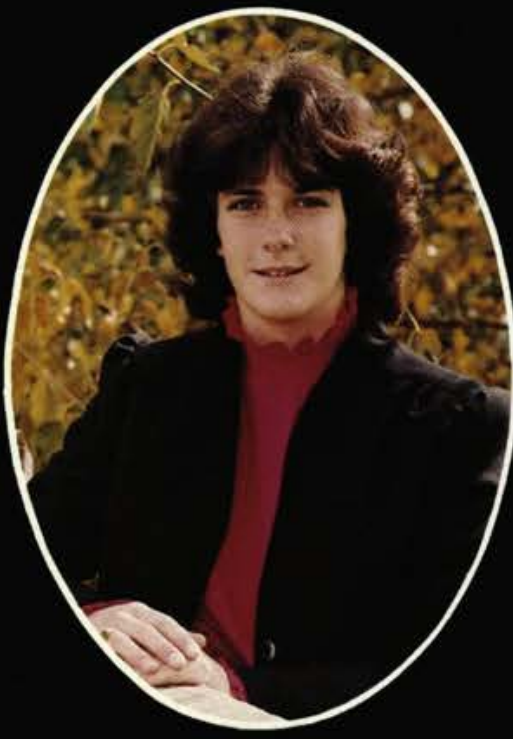

Corinne A. Wilcox Physical Education

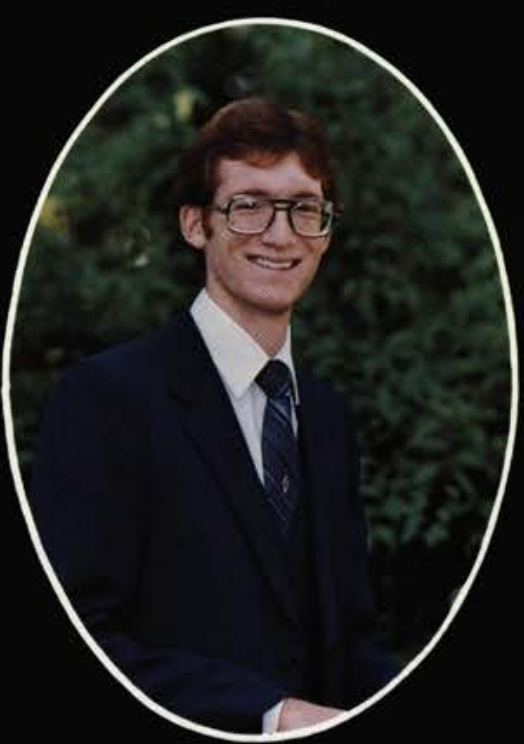

Kurt D. Wilcox Chemistry/Biology 


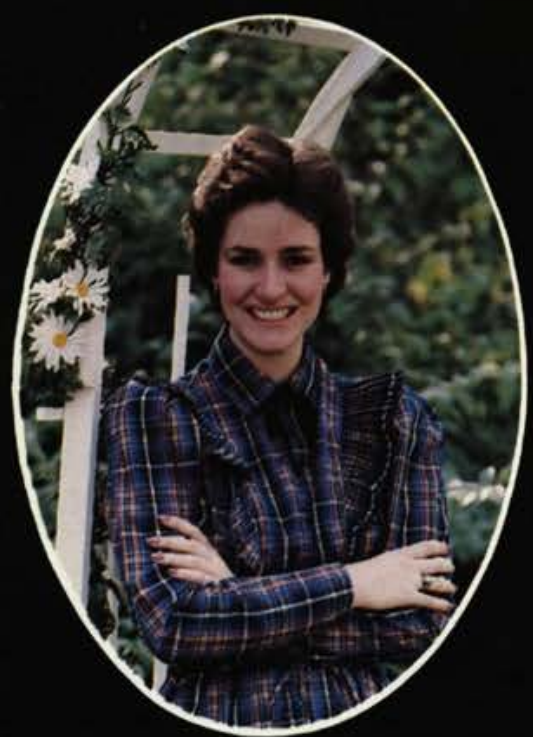

Linda S. Wilson Elementary Education

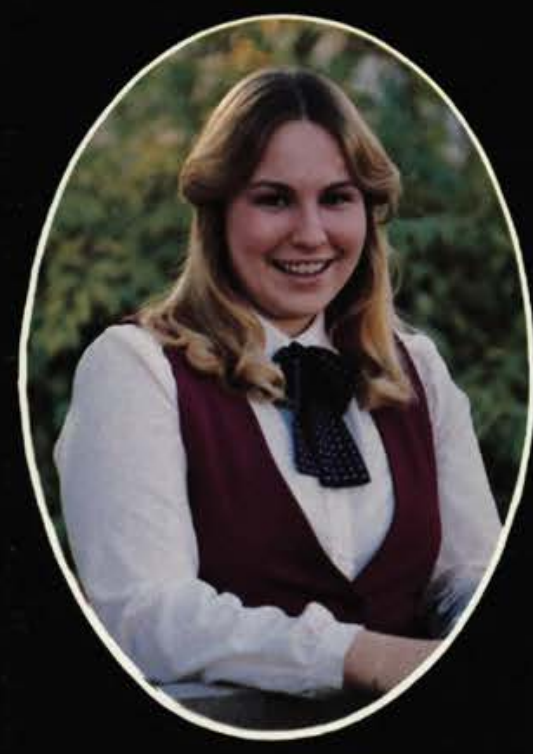

Karen Beth Witt Mathematics

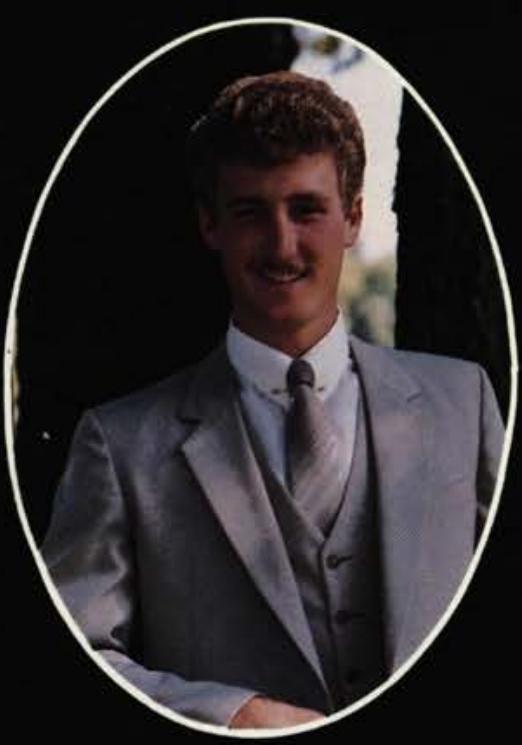

Tim C. Woodard Mathematics
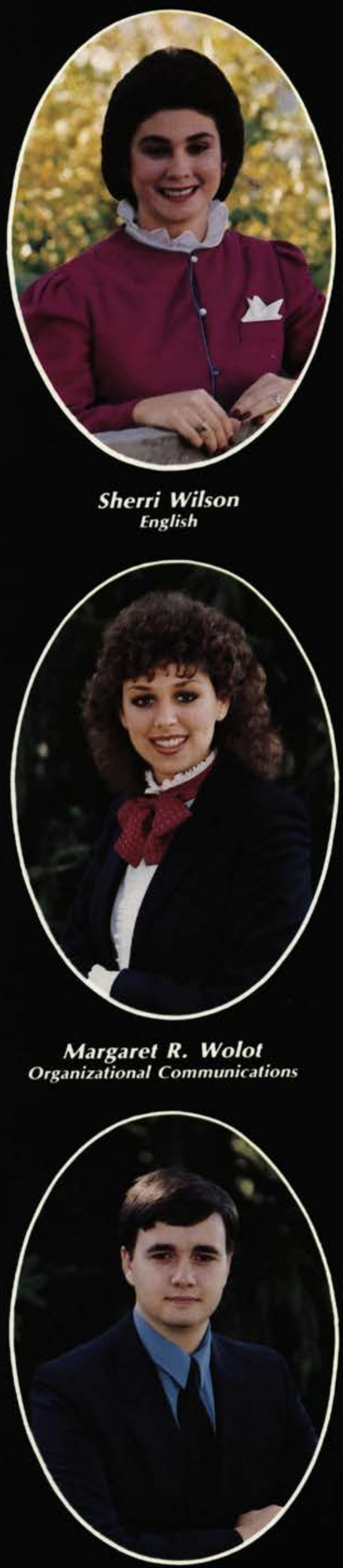

David Gene Wright

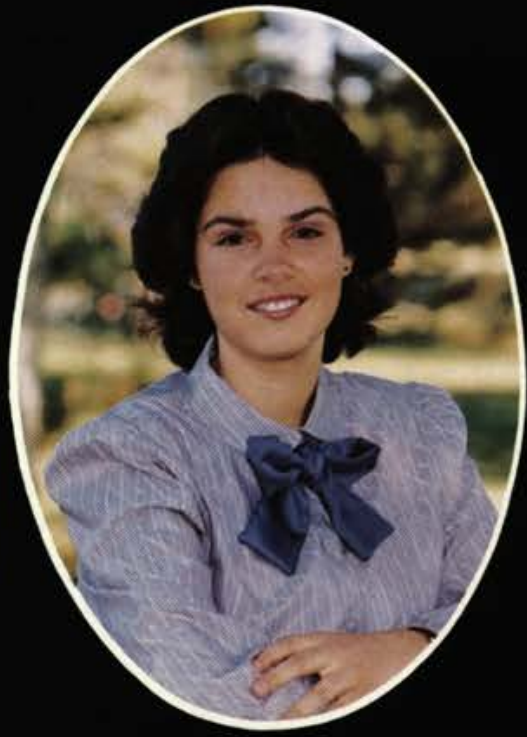

Carolyn Ruth Winsor Elementary Education

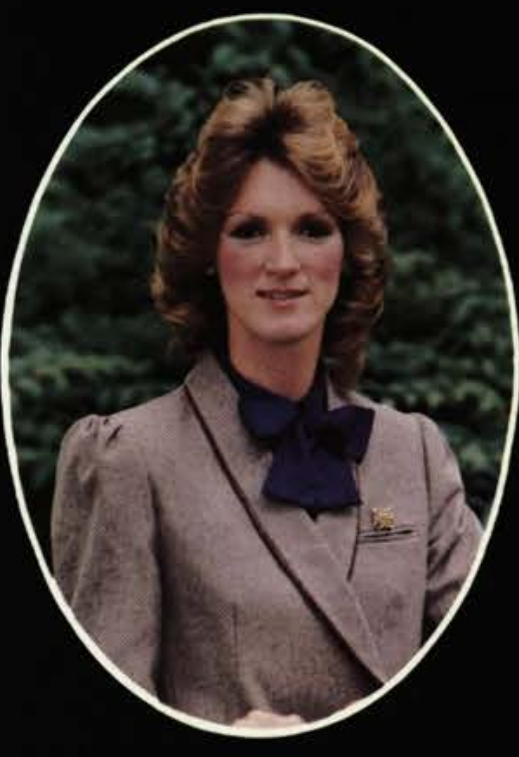

Carla Beth Womack Physical Education

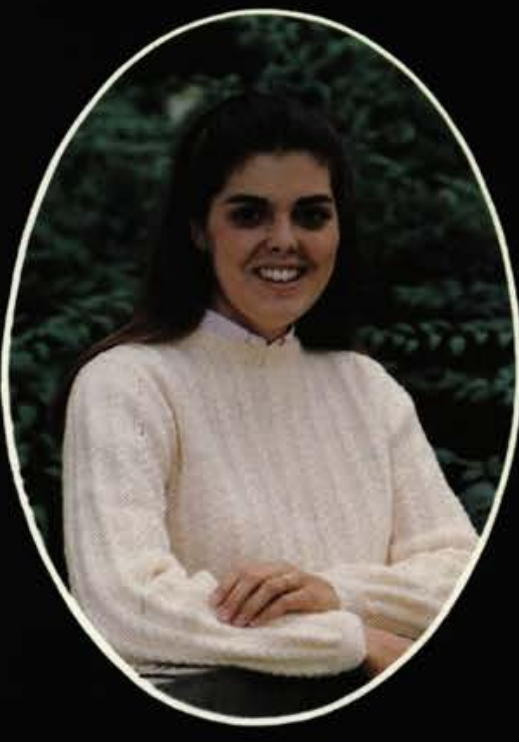

Kristine Ann Zaage English

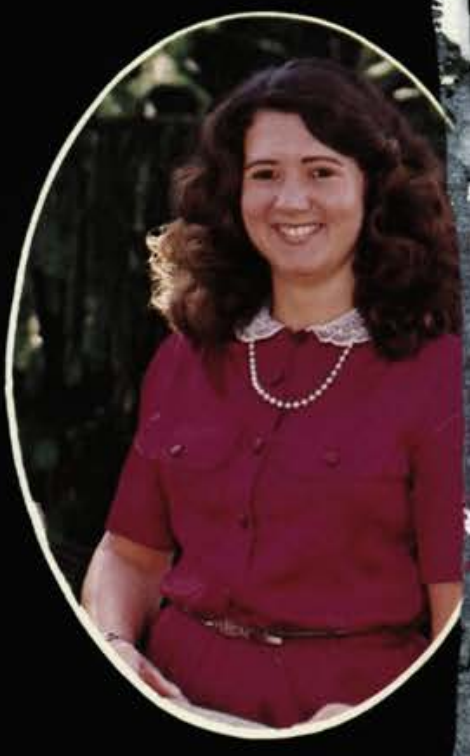

Deirdre L. Wiseman Physical Education

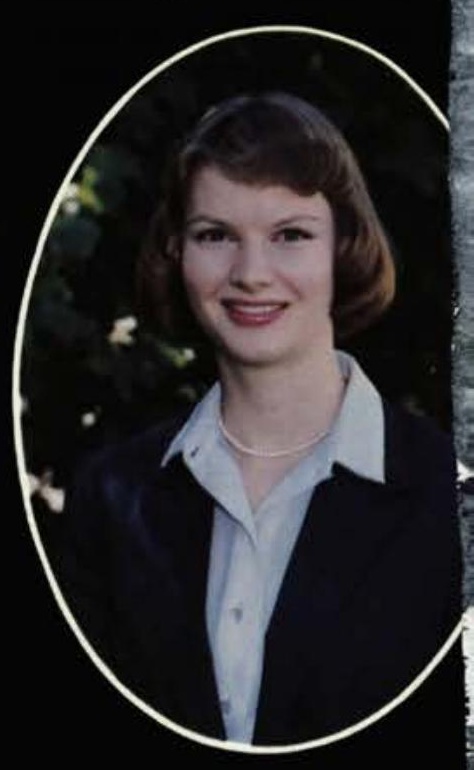

Joyce Irene Woodard Accounting

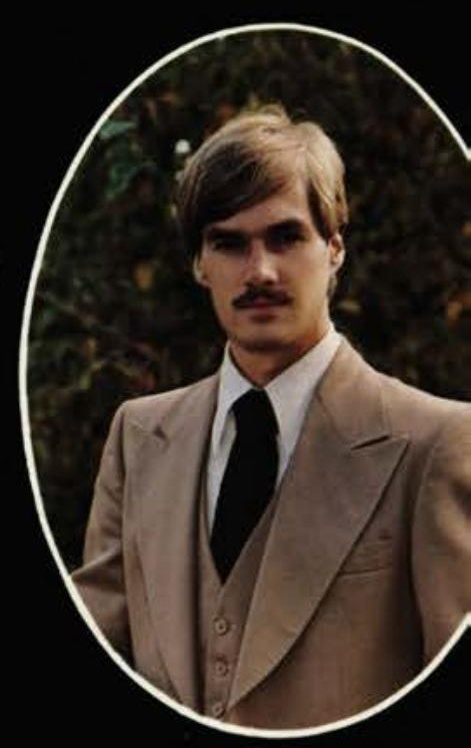

J. Max Zook

History/Secondary Fducation 

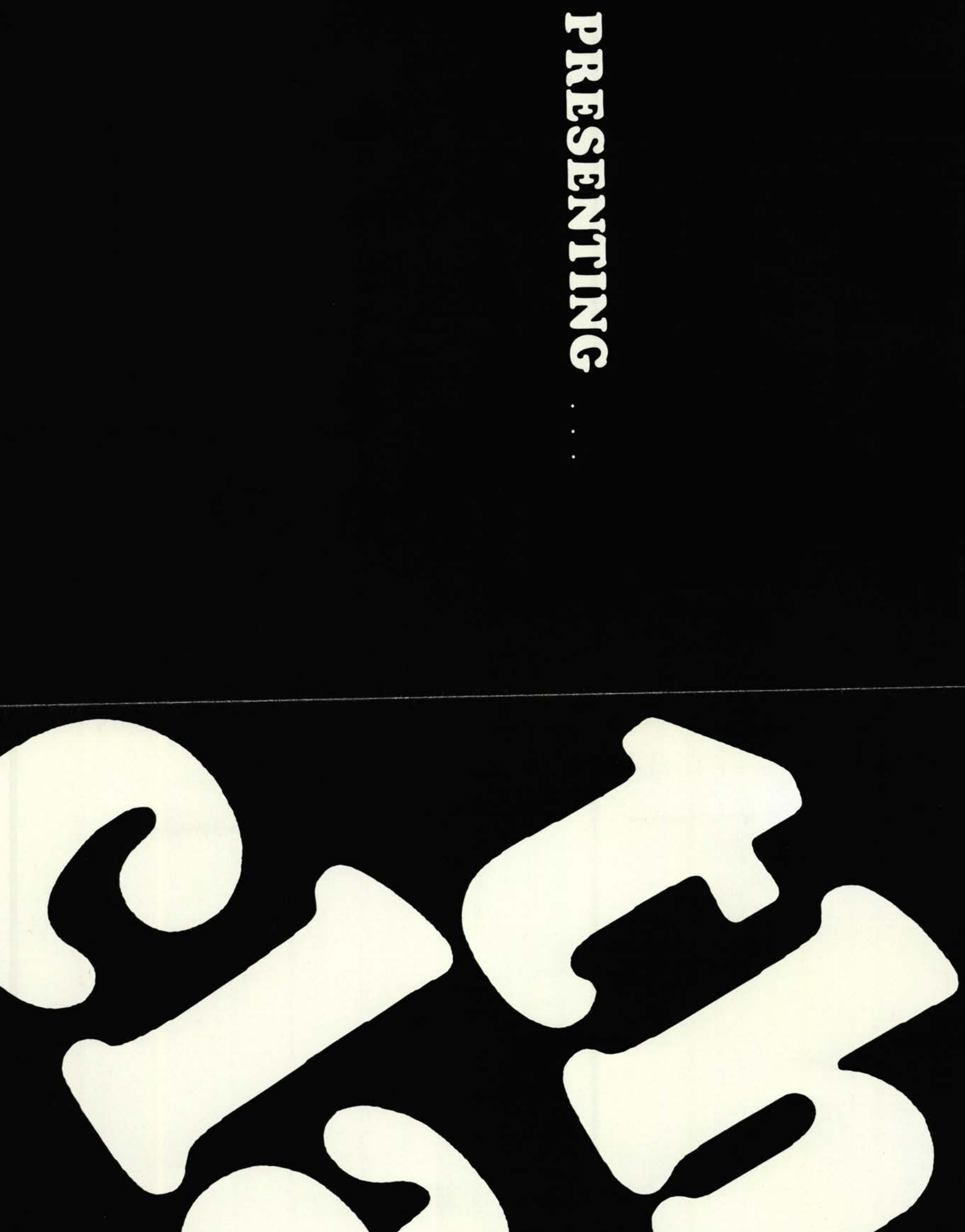
GREGORY AND CONNIE CRUM

1766 YALTA DRIVE

DAYTON, OH 45432

MR. AND MRS. RANDALL C. CRONIN 1720 GUYNEDD VIEW ROAD

NORTH WALER, PA 19454

MR. AND MRS. DAVID

DACHENBACH

RR \#2 BOX 30

CHARITON, IA 50049

MR. AND MRS. JAMES FL DAY

P.O. BOX 156

BELLE CENTER, OH 43310

DON AND BONNIE DENNEY

1982 CONWAY HILLS DRIVE

HEBRON, KY 41048

\section{JIM AND GINI DEVER}

$235 \mathrm{~N}$. VINE STREET

WESTERVILLE, OH 43081

MR. AND MRS. WILLIAM DIMACCHIA 1316 WEST 44th STREET

LORAINE, OH 44053

MR. AND MRS. KENNETH RL DOBBEL WORD OF LIFE

SCHROON LAKE, NY 12870

MR. AND MRS. WILLIAM DRUMMER

1035 WINDY HILL ROAD

FAIRVIEW VILLAGE, PA 19403

MR. AND MRS. W.H. DUBE

7430 ONYX DRIVE, SW

TACOMA, WA 98498

MR. AND MRS. R.M. DUKES

5162 CHURCHGROVE

FRANKENMUTH, MI 48734

MR. AND MRS. T.A. DZEDZY

MILL ROAD

PHOENIXVILLE, PA 19460

MRS. LETTER H. EDELIN

780 COLUMBIA ROAD NW

WASHINGTON, DC 20001

MR. AND MRS. JAMES P. ELLER

1412 WAYNE STREET

BARBERTON, OH 44203

M.L. ENSMINGER

4828 VALLEYVIEW ROAD

MINNEAPOLIS, MN 55424

MEL AND DORIS ENTINGH

6801 SWISSWAY DRIVE

DAYTON, OH 45459

DONALD E. EVANS

3641 WENWOOD DRIVE

COLUMBUS, OH 43220

MR. AND MRS. TERRY N. EVANS

2850 MC CALLIE AVENUE

CHATTENOOGA, TN 37404
MR. AND MRS. WALTER FELKER

4663 N. DELCO AVENUE

WAUWATOSA, WI 53225

MR. AND MRS. EDGAR L. FISHER

2679 ABINGTON ROAD

AKRON, OH 44313

KENNETH D. FLEETWOOD

420 WOODLAND WEST DRIVE

GREENFIELD, IN 46140

MR. AND MRS. ROBERT FRAZIER

1195 SYCAMORE LANE

AMELIA, OH 45102

MR. AND MRS. ROBERT FREAD

9372 GREENHEDGE LANE

LOVELAND, OH 45140

MR. AND MRS. KEN FREE

309 S. FOURTH STREET

COSHOCTON, OH 43812

MR. AND MRS. JOHN FREY

2376 BLARNEY DRIVE

DAVISON, MI 48423

JUDITH GALBREATH

435 S.W. 21ST STREET

RICHMOND, IN 47374

MR. AND MRS. JAMES W. GEIST

RD \#7

MEADVILLE, PA 16335

DR. AND MRS. DEAN GIFFORD

RR 1

URBANA, IN 46990

MR. AND MRS. CHARLES E.

GOODMAN

6008 CO RD R \#2

MT GILEAD, OH 43338

JACK AND JUDY GRADY

14707 W 90TH AVENUE

DYER, IN 46311

MR. AND MRS. DALE GREENAWALT

3472 ROSEMONT ROAD

NORTH JACKSON, OH 44451

MR. AND MRS. FRED GREETHAM 431 COURTLAND STREET

WELLINGTON, OH

PASTOR AND MRS. RALPH E. GRUENBERG

206 BEECHVIEW AVE.

JAMESTOWN, NY 14701

JEFFREY AND BARBARA GRUMBECK RT. 5 BOX 387

BURLINGTON, WI 53105

MR. AND MRS. BRUCE GRUNEISEN

R.D. 5

MANSFIELD, OH 44903
MR. AND MRS. NOEL F. HACK 40159 S.R. 303 E.

LA GRANGE, OH 44050

MR. AND MRS. D. HACKBARTH 50776 WOODBROOK DRIVE SOUTH BEND, IN 46628

CHARLIE L. HANCOCK

10803 PINE BLUFF ROAD NE

FRAZEYSBURG, OH 43822

MR. AND MRS. ROBERT D. HANNEY 4 HANNEY ROAD

WESTERLO, NY 12193

MR. AND MRS. GEORGE HAPPE

977 WILSON ROAD

MACEDON, NY 14502

ELVIN L. HARDEN

204 RIVERSIDE DRIVE

HART, MI 49420

MR. AND MRS. ROY HARDWICK

$136 \mathrm{~N}$. SCHOOL LANE

SOUDERTON, PA 18964

MR. AND MRS. DALLAS HART

1803 SOUTH 32ND STREET

TERRE HAUTE, IN 47803

RICHARD AND MARTHA

HASKOWICK

55 3RD STREET

PEQUANNOCK, NJ 07440

CHAPLAIN AND MRS. HAROLD E. HAYES

$\mathrm{HQ}$ AFSC/HC

ANDREWS AFB, MD 20334

WAYNE AND NORMA HEAL

R 2 BOX 98

BUNKER HILL, IL 62014

MR. AND MRS. FRANK HELLWIG 2592 SOUTH LIMA STREET

AURORA, CO 80014

MR. AND MRS. ESTY E. HELMICK 8385 EMERICK ROAD

WEST MILTON, OH 45383

DALE AND BARBARA HELMUTH

1251 STUDENT AVE

SPRINGFIELD, OH 45503

MR. AND MRS. ROBERT M. HENRY

2002 HAWK COURT

ROLLING MEADOWS, IL 60008

MR. AND MRS. LEO HERRICK

$2106 \mathrm{~S}$ 12TH STREET

MARSHALLTOWN, IA 50158

MR. AND MRS. MONTY HERRINGTON

501 11TH AVENUE

INTERNATIONAL FALLS, MN 56649 
JOHN HIPPARD

520 N. VINE STREET

SHELBYVILLE, IL 62565

MR. AND MRS. JOHN HOLMAN

527 TIMBER HILLS DRIVE

FREEPORT, IL 61032

MR. AND MRS. W.C. HOLTZMANN

RT. 13, BOX 601

LEXINGTON, NC 27292

ANNIE L. HOSKINS

5936 PALMETTO STREET

PHILADELPHIA, PA 19120

MR. AND MRS. FRANK A. HOWARD P.O. BOX 343

CEDARVILLE, OH 45314

DR. AND MRS. FREDRICK HOWARD

RD 2 HORTON ROAD

JAMESTOWN, NY 14701

REV. AND MRS. ROBERT HOWDER

329-2 YOSHINO CHO

KAGOSHIMA CITY, JAPAN 892

LAWRENCE J. HUCK

158 ROBSON ROAD

GRAFTON, OH 44044

MR. AND MRS. HERB HUDLET

RT 3 BOX 218

HAYDEN LAKE, ID 83835

LESTER AND DORIS HUDNALL

113 KANAWHA AVENUE

NITRO, WV 25143

MR. AND MRS. DAVID HEUBSCHER 14555 SCHREIBER ROAD

CLEVELAND, OH 44137

MR. AND MRS. PAUL HUNN

200 MARILEE DRIVE

NEW LEBANON, OH 45345

MR. AND MRS. WILLIAM T.

HUTCHINS

RD 2 BOX 447

CORNING, NY 14830

MR. AND MRS. JOSEPH HYSONG

36 FINCH AVE.

WHEELING, WV 26003

MR. AND MRS. SAMUEL J. JACOBS 4831 N. 87TH STREET

MILWAUKEE, WI 53225

MR. AND MRS. WILLIAM JENNEY 6426 ORCHARD ROAD

LINTHICUM, MD 21090

\section{JAMES P. JENSON}

2531 GAYNOR AVENUE

WIS, RAPIDS, WI 54494

MR.AND MRS. HAROLD R. JOHNSON

RR \#2 BPX 349

WINAMAC, IN 46996
S.G. AND NORMALEE JOHNSON

IN MEMORY OF RICHARD P. JOHNSON

REV. NORVIN T. AND BETTY JOE

JONES

4 BROKEN BOW

$\mathrm{BO} 983$

CHEROKEE VILLAGE, AK 72525

MR. AND MRS. ROBERT E. JONES

RR \# 1 BPX 170

WELLMAN, IA 52356

MR. AND MRS. LLOYD G. JUE

2830 ARCTIC AVENUE

ATLANTIC CITY, NJ 98401

GEUNTER AND INGRID KASS

8741 PARKHAVEN POINT

DAYTON, OH 45459

MR. AND MRS. EDWARD P. KEANE

42 SMOKY RIDGE ROAD

RINGWOOD, NJ 07456

REV. AND MRS. WAYNE KEISLING

BOX 275

PRATTSBURG, NY 14873

PAUL AND JOYCE KEMP

3102 BURGANDY ROAD

ALEXANDRIA, VA 22303

MR. AND MRS. KENNETH KIDD

7967 HUNTERSKNOLL

CINCINNATI, OH 45242

DAVE AND KAY KING

3721 E. BLANCHE DRIVE

PHOENIX, AR 85032

MR. AND MRS. OTTO A. KIRCHER

1616 DONOPAH DRIVE

CINCINNATI, OH 45230

MR. AND MRS. RALPH CL KRAWLES

15 JORDAN AVENUE

BRUNSWICK, MAINE 04011

MR. AND MRS. ROBERT J. KOERBER

BUCKLEY HILL ROAD

COLCHESTER, CN 06415

MR. AND MRS. JAMES KOHLMEYER 1114 IRVING AVENUE

WHEATON, IL 60187

MR. AND MRS. RAYRAYMOND L.

LABONTE

195 RYE ROAD

ROCHESTER, NY 14626

EARL AND RACHEL LACURE

13535 WEST FOREST KNOLL DRIVE

NEW BERLIN, WI 53151

C.W. LANE

118 ARBOGAST

GRIFFITH, IN 46319
MR. AND MRS. KENNETH LAUB

47 SHERWOOD DRIVE

HUNGTINGTON, NY 11743

DAVID AND VIRGINIA LAW

RD \#3 BOX 130

NORWICH, NY 13814

MR. AND MRS. DONALD D. LEACH

1029 WENBROOK DRIVE

KETTERING, OH 45429

MR. AND MRS. ROBERT E. LEACH

526 MAPLE RIDGE LANE

ODENTON, MD 21113

MR. AND MRS. RICHARD LINDBERG 16409 JOHN KIRKHAM DRIVE

LOCKPORT, IL 60441

MRS. ALICE LINDNER

821 E. ARNOLD ROAD

SANDWICH, IL 60548

ALAN AND EILEEN LIVINGSTON

1132 LA CASA AVENUE

YUBA CITY, CA 95991

RAUL E. LOPEZ

645 CREE CIRCLE

BOULDER, CO 80303

DAVID AND MAIZIE LORD

RT. 1 BOX 203

PERRY, IA 50220

BRUCE AND JUDY LYON

RD. 3

SHERMAN, NY 14781

GEORGE AND MARDEL MANION

403 SWEETBRIAR

PLANO, IL 60545

MR. AND MRS. JOHN MARSHALL

304 WOODLAND AVENUE

BLACKWOOD, NJ 08012

MR. AND MRS. RICHARD MASTERS 4616 EDWILLA DRIVE

CINCINNATI, OH 45245

\section{B.C. AND MACKIE MC CAIN \\ 11412 LIPPETT DRIVE \\ DALLAS, TX 75218}

MR. AND MRS. GARY MC COOL

515 N. 8TH STREET W.

MT. VERNON, IA 52314

MR. AND MRS. LESTER MC GRAW RT. 1 BOX 483

GALLIPOLIS FERRY, WV 25515

MR. AND MRS. PAUL MC MILLAN

705 COLLEGE WAY

CARMEL, IN 46032

MR. AND MRS. JOHN R. MEADOWS R.D. 3 BOX 73

BELLVILLE, OH 44813 
MR. AND MRS. CHARLES MEEKS 9016 GODFREY ROAD

GODFREY, IL 62035

FRANK AND BETTY MERCHANT

8604 MAPLECREST DRIVE

MC KEAN, PA 16426

MR. AND MRS. SALVATORE

MIGNOGNA

PARENTS OF LYNNE CALISTI

69 GLENVIEW AVENUE

GREENSBURG, PA 15601

MR. AND MRS. LARRY E. MILLER RT 1 BOX 284

GALLIPOLIS, OH 45631

HOWARD AND CAROLINE MILLS BOS 246

SANDY CREEK, NY 13145

MR. AND MRS. SANFORD NILLs 615 WOODSIDE AVENUE

VERMILION, OH

MR. AND MRS. LOUIE MOATS

65 HOUGHTON ROAD

NORTHFIELD, OH 44067

REV. AND MRS. L. EUGENE MOHR 303 COLORADO STREET

MUSCATINE, IA 52761

MR. AND MRS. CHARLES S. MONROE 144 BRENT DR. W. APT. E SPRINGFIELD, OH 45505

MR. AND MRS. THEODORE S. MONTROSS

CENTERMORELAND, PA 18657

PASTOR AND MRS. WILLIAM L. MOSER

967 THOMAS DRIVE

ASHLAND, OH 44805

MR. AND MRS. CHARLES F. MOSHER 7669 PECOS

DENVER, CO 80221

MR. AND MRS. ARTHUR E. MOTZER 223 BOND AVE.

HAMILTON, OH 45011

MR. AND MRS. DONALD MAYER

2728 COVE ROAD

PENNCAUKEN, NJ 08109

JOHN D. MULLIGAN

48 W982 RT. 30

BIG ROCK, IL 60511

MR. AND MRS. WES MURPHY

2505 DAVIS ROAD

INDIANAPOLIS, IN 46239

MR. AND MRS. JOHN W. MURRAY 1370 FRANK

GALESBURG, ॥ 61401
MR. AND MRS. RALPH W. MICKOSON

2718 PINEGROVE DRIVE

DAYTON, OH 45449

MRS. VERA OAKES

11 DE LAVAN AVENUE

BINGHAMTON, NY 13903

MR. AND MRS. ARNOLD OLSEN

RT. 6

DEFIANCE, OH 43512

BEULAH J. OLSON

RT. 1 BOX 29A

CANTON, MN 55922

MR. AND MRS. PHIL PARMAN

502 EDWARDS

EPWORTH, IA 52045

MR. AND MRS. DALLAS PARSELL

13622 TH 87

UPPER SANDUSKY, OH 43351

DR. AND MRS. CHARLES N. PATTON 2509 SUNRISE AVENUE

LAFAYETTE, IN 47904

\section{MARGUND PEARSON}

19 MECHANIC STREET

MILURN, NJ 07041

MR. AND MRS. JOHN B. PERRY

'HERONS FLIGHT'

BURNT HOUSE HILL

WARWICK, BERMUDA

REV. AND MRS. DOUGLAS PETERS

1375 FARNHAM ROAD

TROY, OH 45373

JAMES A. PETERS

RR. 5

SIMCOE, ONTARIO, CANADA

GORDON AND MARY PHILLIPS

101 WEDGEWOOD DRIVE

CINNAMINSON, NJ 08077

MR. AND MRS. JAMES K. PICKERING 507 WESTOVER PASS

GRAND BLANC, MI 48439

MR. AND MRS. SAMUEL L. PIERCE 7356 MAC BETH DRIVE

DUBLIN, OH 43017

\section{LAWRENCE AND BETTY PISTORE \\ P.O. BOX 157 \\ ELEANOR, WV 25070}

REV. AND MRS. J. EDWARD QUICK ECHOES OF JOY, INC. 224 HARVARD DRIVE

SIDNEY, OH 45365

MR. AND MRS. RALPH R. REED

RT. 1 BOX 216A

MT. SIDNEY, VI 24467
MR. AND MRS. GEORGE E. REEDE

175 GEIGERTOWN ROAD RD. 1

BIRDSBORO, PA 19508

MR. AND MRS. LEONARD R. REEVES

RD. 2

DERRY, PA 15627

MR. AND MRS. LOUIS RICHARDSON RR 2 BOX 132

COLUMBUS, NJ 08022

JIM AND JOAN RICKARD

2301 MICHAEL AVENUE

RICHLAND, WA 99352

DAVID ROARABAUGH

RD. 2 BOX 262

TYRONE, PA 16686

ROBERT C. ROCKEY

6105 THOMPSON ROAD

HOAGLAND, IN 46745

MR. AND MRS. THOMAS G. ROGERS

7339 DARROW ROAD

HUDSON, OH 44236

THOMAS W. ROSE, JR.

2634 PUTNAM AVENUE

HURRICAN, WV 25526

MR. AND MRS, JERRY L. ROWE

724 POINT SALEM ROAD

HAGERSTOWN, MD. 21740

MR. AND MRS. WAYNE T. ROUSTER

13811 LENMORE ROAD

BELLEVILLE, MI 48111

MR. AND MRS. MELVIN RUBY

500 N. HOLLY STREET

ELIZABETHTOWN, PA 17022

MR. AND MRS. MARSHALL RUNGE 67 STONECREST DRIVE

ROCHESTER, NY 14615

MR. AND MRS. H.L. SARGENT

330 FIRST AVENUE

GALION, OH 44833

MR. AND MRS. WILLIAM SAUNDERS

1621 LAKEVIEW LANE

HIGHLAND, MI 48031

MR. AND MRS. DALE V. SCHELLHASE

200 22ND STREET NW

WAVERLY, IA 50677

MR. AND MS. ERNEST M.

SCHUTTENBERG

6083 PARK RIDGE DRIVE

NORTH OLMSTED, OH 44070

MR. AND MRS. GEORGE R. SHAMIE,

JR.

22461 HEATHERSETT CR

PARMINGTON HILLS, MI 48024 
TINA SHEPARD

2395 JOHNSON ROAD

NORTH BRANCH, MI 48461

MR. AND MRS. DAVID SILVER 6880 MILLIKIN ROAD

MIDDLETOWN, OH 45042

MR. AND MRS. DAVID H. SIMPSON 1416 COUTANT

FLUSHING, MI 48433

MR. AND MRS. CLYDE W. SLATER 2412 HWY. 42

MAITOWOC, WI 54220

MR. AND MRS. ROBERT L. SMART 8400 E. TIPP-ELIZABETH ROAD NEW CARLISLE, OH 45344

MR. AND MRS. DEAN SMITH

561 HILLIARD ROAD

ELYRIA, OH 44035

\section{MAUREEN ESSLER SMITH}

379 KIM DRIVE

MADISON, OH 44057

PAUL L. SMITH

RT. 1 BOX 276A

WILLIAMSPORT, MD 21795

W. MERRILL AND HELEN K. SMITH

118 BARTRON ROAD

MARLTON, NJ 08053

MR. AND MRS. JOHN F. SMYTH

1086 CONCORD STREET

PLEASANTON, CA 94566

MR. AND MRS. LARRY SNYDER

310 HILLSIDE ROAD

ELIZABETHTOWN, PA 17022

MR. AND MRS. WILLIS SOMMERS

7800 AMISH PIKE

PLAIN CITY, OH 43064

PAUL AND JANICE SRNIS

725 TERRA LAND

AMHERST, OH 44001

MR. AND MRS. WILLIAM STEELE

2741 BRIERWOOD ROAD

BROOMALL, PA 19008

MR. AND MRS. DAVID STEERE

RR 3

PONTIAC, IL 61764

MR. AND MRS. KENT STOCKHOLM

1127 N. CARROLL STREET

CARROLL, IA 51401
MR. AND MRS. H.G. STONE

196 CATHY LANE

BIRMINGHAM, AL 35215

MR. AND MRS. JAMES STUTESMAN

712 COLUMBUS

GRAND HAVEN, MI 49417

MR. AND MRS. ROBERT L. SUPPLEE 6387 WEST 64TH STREET

FREMONT, MI 49412

MR. AND MRS. JAMES R. SWANSON

254 FILMORE AVENUE

CUYAHOGA FALLS, OH 44221

MAURICE AND NOEL TAVIERNE

11300 EASTON ROAD

RIVES JUNCTION, MI 49277

TRUMAN AND ANNA MAE

TERPENNING

$89 \mathrm{~N}$. VAN DYKE

MARLETTE, MI 48453

MR. AND MRS. DOUGLAS K.

THOMPSON

31 MEADOW DRIVE

BEREA, OH 44017

REV. AND MRS. JOHN E. TRAUTMAN

1631 JEFFERSON AVENUE

WEST ISLIP, NY 11795

MR. AND MRS. DONALD L. TUTTLE

RD 1, KEEN ROAD, BOX 59

SPRING CITY, PA 19475

MR. AND MRS. ELLIS VANNESS

$660 \mathrm{~W} .41$ ST STREET

STICKNEY, IL 60402

DAVID AND SANDRA VAN SCHOICK

8435 PEACHEY ROAD

BERGEN, NJ 14416

MR. AND MRS. CHUCK WILSON

RR 4 BOX $291 \mathrm{H}$

ROCKVILLE, IN 47872

DONALD C. WARD

204 ARDIS STREET

HUDSON, IA 50643

MR. AND MRS. VIRGIL R. WAGNER

$378 \mathrm{~S}$. TERRACE AVENUE

COLUMBUS, OH 43204

\section{J.H. WAINWRIGHT}

$465 \mathrm{E}$. DELAWARE AVENUE

ROEBLING, NJ 08554

FRANK AND DORIS WALKER

MOUNTAIN ROAD

CORNWALL ON HUDSON, NY 12520
MYRON E. WALKER

101 BETA ROAD

COLUMBUS, OH 43207

GeRALD C. WALLACE

234 S. ROBINSON DRIVE

OAK HARBOR, OH 43449

JIM AND LORETTA WALLACE

864 GATEHOUSE LANE

WORTHINGTON, OH 43085

MR. AND MRS. JACK WASSENAAR

2751 MEADOWBROOK

GRAND RAPIDS, MI 49506

MR. AND MRS. JOHN WEBER

888 MC CAFFERY ROAD

BIGFORK, MO 59911

\section{BOB WHITAKER}

8139 WOODWARD DRIVE

WEST CHESTER, OH 45069

MR. AND MRS. CARL

WIGGERSHAWS

5417 IDLEWOOD ROAD

DAYTON, OH 45432

MR. AND MRS. GORDON WILCOX

7305 RED HILL LANE

UPPER LAKE, CA 95485

JERRY WILLIAMS

2718 ST. JOSEPH

COLUMBUS, OH 43204

THE DWIGHT WINKLEMANS

RT. $1 \mathrm{BOX} 133$

BUFFALO CENTER, IA 50424

MR. AND MRS. RALPH WINSOR

RD. 2

HARPUISVILLE, NY 13787

MR. AND MRS. FRED WITT, JR.

100 THORNHILL ROAD

CHERRY HILL, NJ 08003

WILLIAM WOLST

$5215 \mathrm{~N}$. MOODY AVENUE

CHICAGO, IL 60646

MR. AND MRS. GALEN $W$.

WOODARD

10005 KENWOOD ROAD

CINCINNATI, OH 45242

MR. AND MRS. RALPH W. WYAND

827 OAK HILL AVENUE

HAGERSTOWN, MD 21740

DR. AND MRS. ROD WYSE BOX 241

CEDARVILLE, OH 45314 


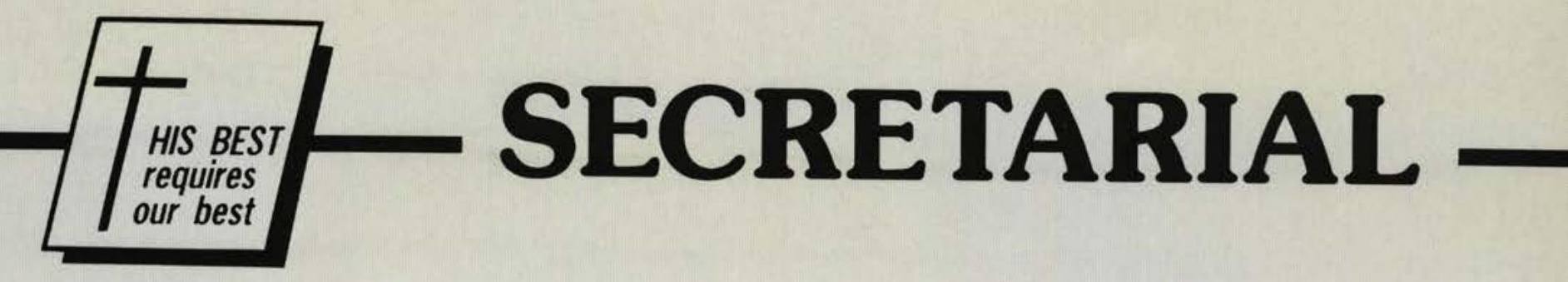

\section{"HONORING THE BEST"}

B eing only a two year program, Secretarial Science graduates are often overooked. But for the past couple of years these students have worked hard preparing to let the job market fight over their rediously trained typing skills, and their dexterously deft dictaion taking. Come with us to the hext page as we honor the Secetarial Science graduates for their hard-work, dedication, and aithfulness in striving to be the jest in their field.

\section{Contributor:}

- Diane Moats

\section{Layout By:}

- Karen Beattie

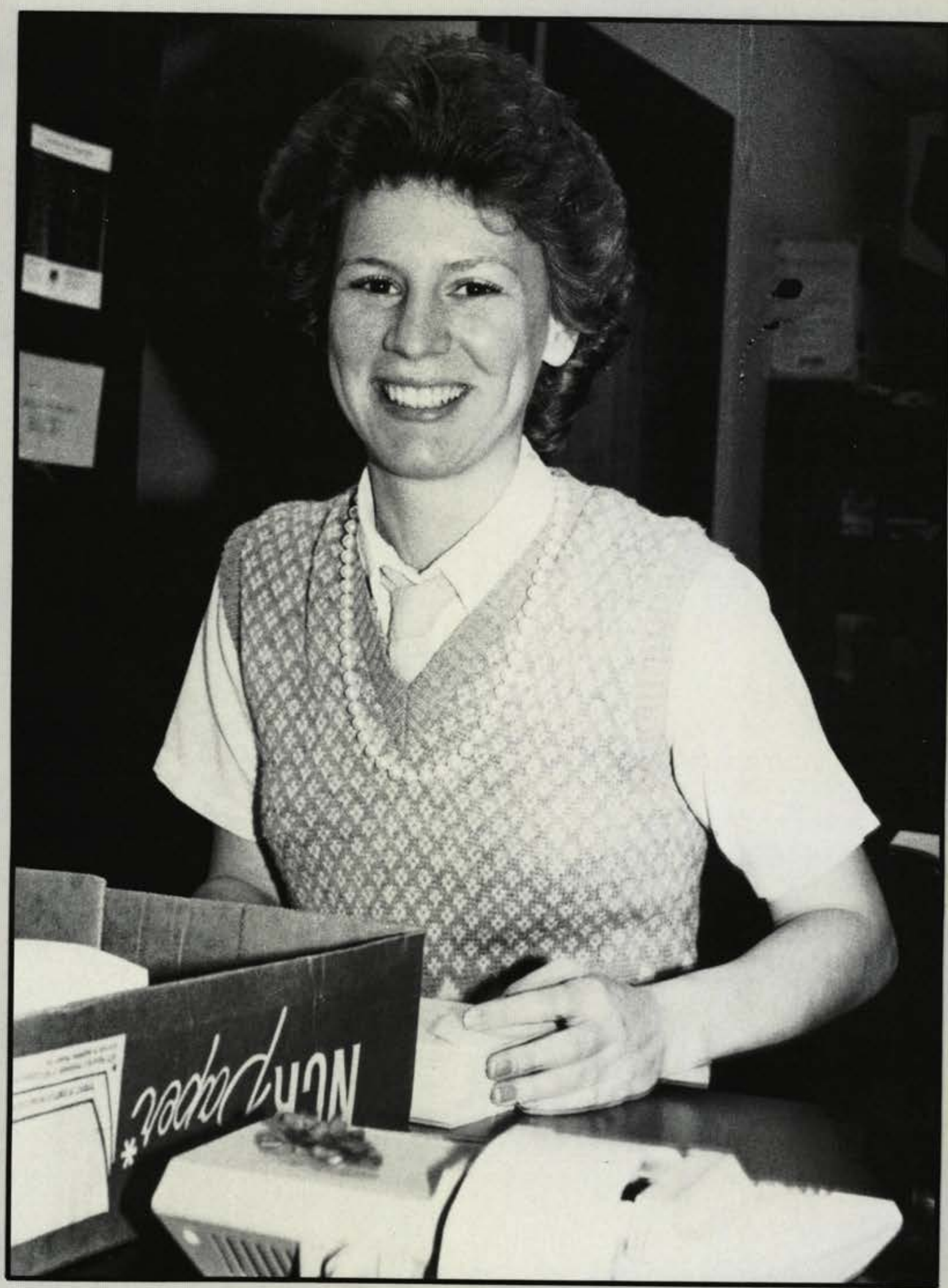


Jennifer Bernard

Cynthia Butler Beth Dunn

Betty Lou Ehret

Dawn E. Erlandson Patricia E. Henry Julie Kay Mears Jill Anne Milliken

Diane M. Moats Judith Lynne Mohr Daneen Joy O'Wade Lisa Beverly Rarick

Jacqui C. Ward Janet Marie Wilson Brenda K. Yoder
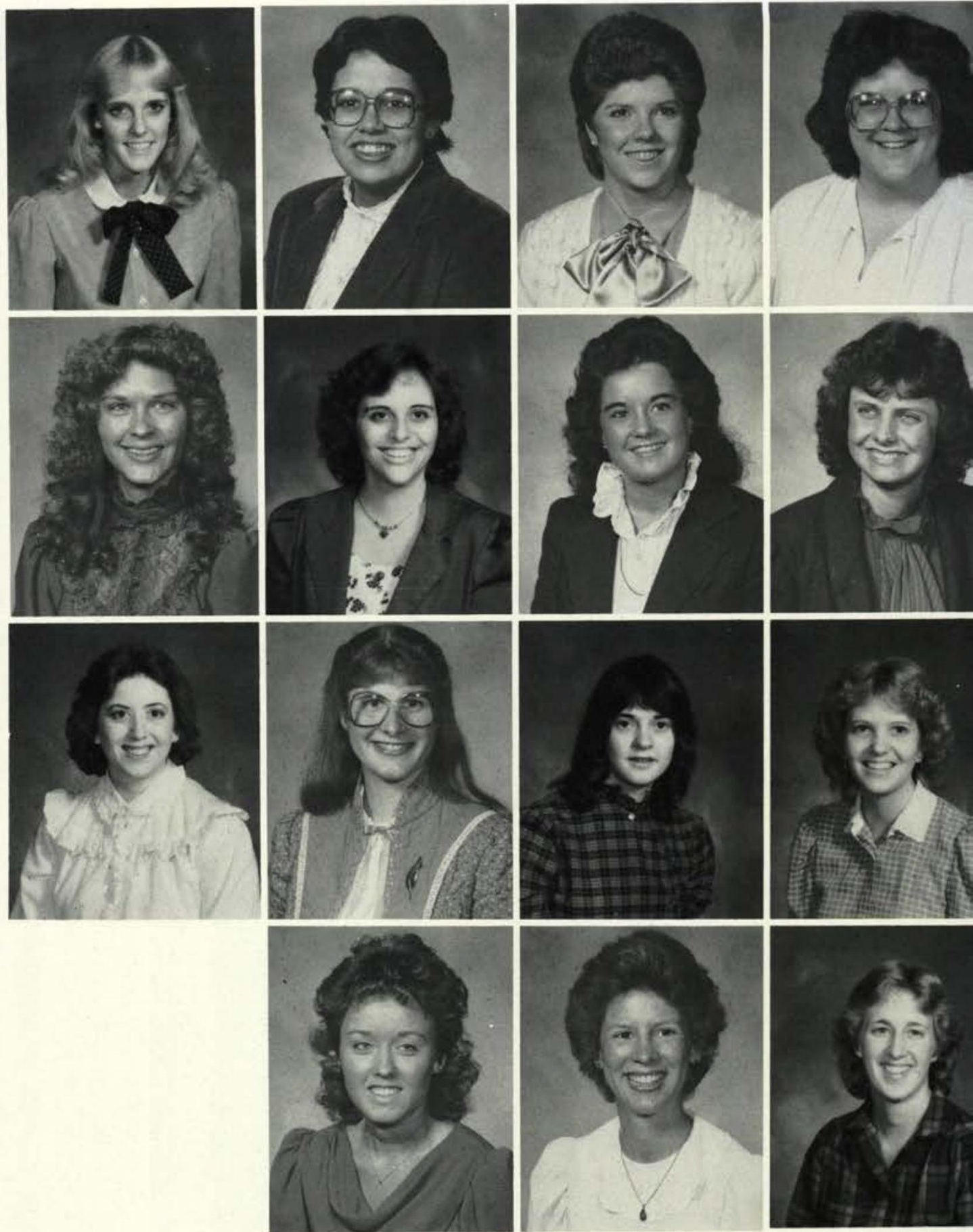

$W^{\text {hen the Lord brought me to }}$

Cedarville, His purpose was for me to grow. My years here, however, have been more than just an opportunity for increased knowledge and an excellent business education. I will always treasure the relationships I have established and especially the manner in which the Lord allowed individuals to help me to grow to a greater understanding and love for Him.

I know my years at Cedarville have been a stepping stone into another stage of my life. When I leave, I take with me innumerable precious memories to cherish and the sincere desire to serve the Lord throughout the rest of my life.

Diane Marie Moats

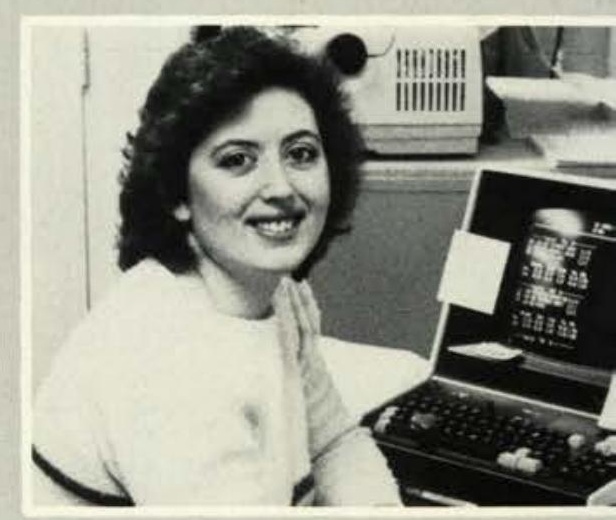




\section{tEx}

\section{JUNIORS}

\section{"TRULY}

\section{UPPERCLASSMEN”}

C or many, the junior year is a - year of challenges, challenges which demand to be met head-on and conquered. The largest challenge a junior faces is that challenge of adjusting to the role of truly being an upperclassman. As the year begins, there are more than one thousand individuals watching us, following our example, be it good or bad. Almost all of the people we admired as leaders and role models during our first year at college have graduated and moved on to some new phase in life. And suddenly, we find outselves thrust into the same positions that these people held only two short years ago. Quite a responsibility, wouldn't you say? Indeed, knowing that lives are being patterned by the example that we are setting forth on a daily basis is a challenge not easy to overcome.

Keith W. Holt

Junior Class President

\section{Contributors:}

Elaine Stone

Rick Horsfall

Kathy Clayton

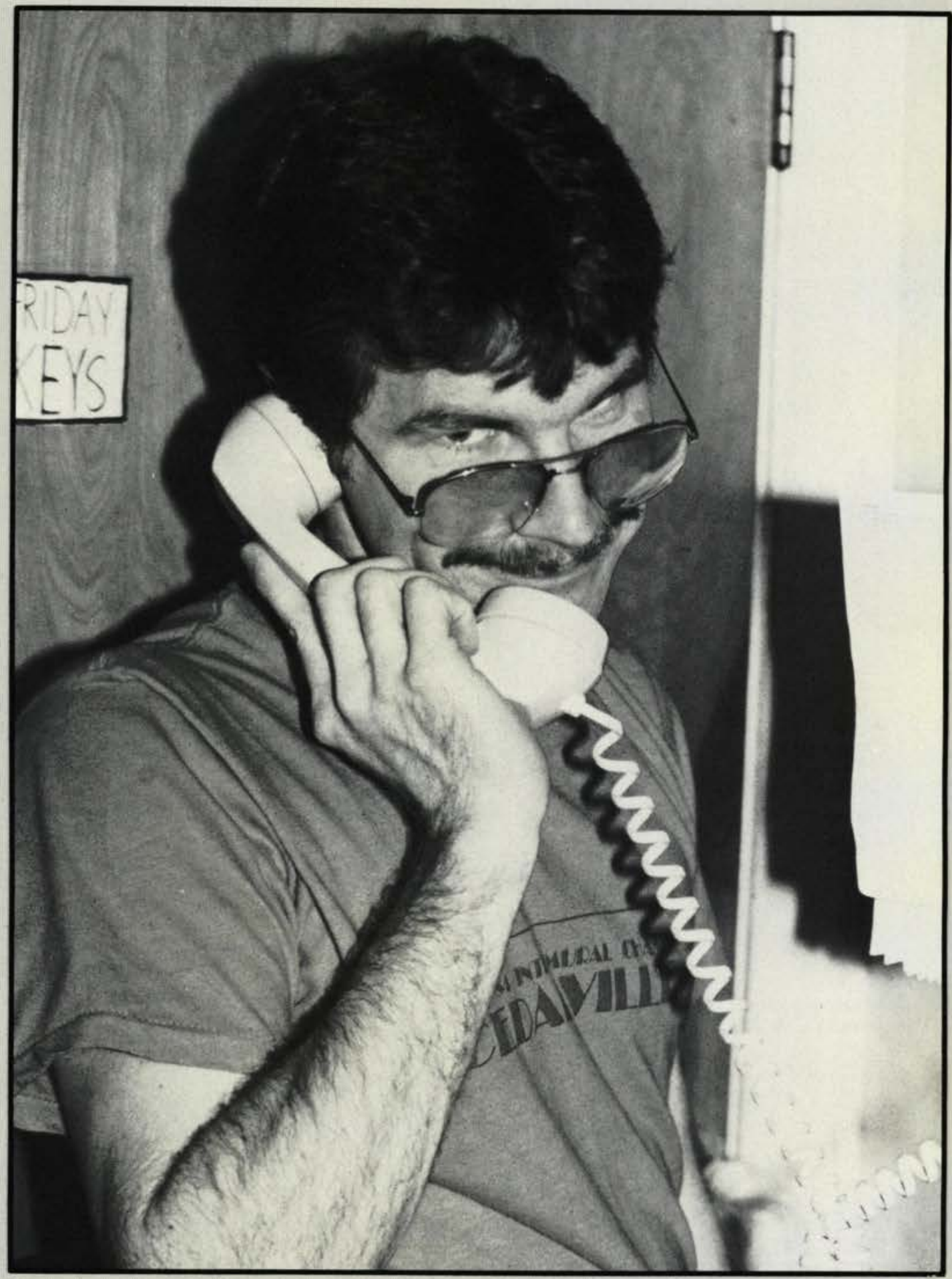

\section{Layout By:}

Karen Beattie 


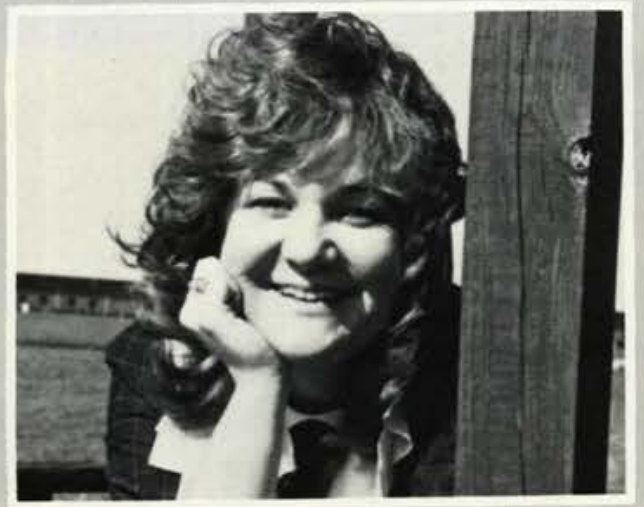

$W_{\text {It is difficult to comprehend that }}^{\text {Oosh! Another year overtakes us! }}$ three-fourths of our college life is already history! How can we measure our accomplishments as we progress toward graduation? Is it possible to survey three college years by a pile of items containing well-used popcorn poppers, innumerable Young's sacks, weary blow dryers, old Student Data Sheets, "Call for package" slips, grade reports, heeless, tattered shoes, sign out cards, broken umbrellas, overworked coffee pots, and many other objects. The above list poses a serious problem. Not one item indicates spiritual growth - the accurate measure of true achievement.

Matthew 6:19-21 compares earthly treasures, "where moth and rust destory." with treasures in heaven " where moth and rust do not destroy:' Yes, we are here for our education however, when we overlook a friend's

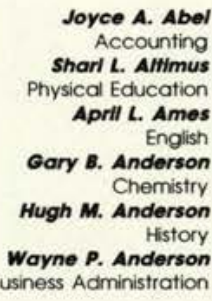

$$
\begin{array}{r}
\text { Dawn M. Angell } \\
\text { Psychology } \\
\text { Debble Armor } \\
\text { Elementary Education } \\
\text { Tina L. Astley } \\
\text { Elementary Education } \\
\text { Kimra L. Ayres } \\
\text { Accounting } \\
\text { Katherine L. Baker } \\
\text { Bble Comprehensive } \\
\text { Kenneth D. Bane } \\
\text { Communication }
\end{array}
$$

Stephen A. Banning Broacasting Sharon L. Banzhof Business Administration James R. Barber Behavioral Science Lorene F. Barram Elementary Education Lori A. Barrand Elementary Education John E. Bartu: Social Science

Debble A. Battaglla Accounting Robert A. Baver Marketing Brad W. Baugh Shellie L. Beaman English
Judy L. Bears Jon D. Beight Bible

Robert C. Belkert Pre Seminary Elementary Education IIm A. Bell Business Administration Jodl L. Beltz Elementary Education James R. Benedict James R. Benedict
Elementary/Secondary Education Laurie A. Benediet Elementary Education

$$
\begin{array}{r}
\text { James A. Bennett } \\
\text { Bible, Preseminary } \\
\text { Jay P. Benson } \\
\text { Broadcasting } \\
\text { Julle M. Bergman } \\
\text { Elementary Education } \\
\text { Lorl E. Bishop } \\
\text { Accounting } \\
\text { Sara J. Blackburn } \\
\text { Nursing } \\
\text { David J. Blackstone }
\end{array}
$$
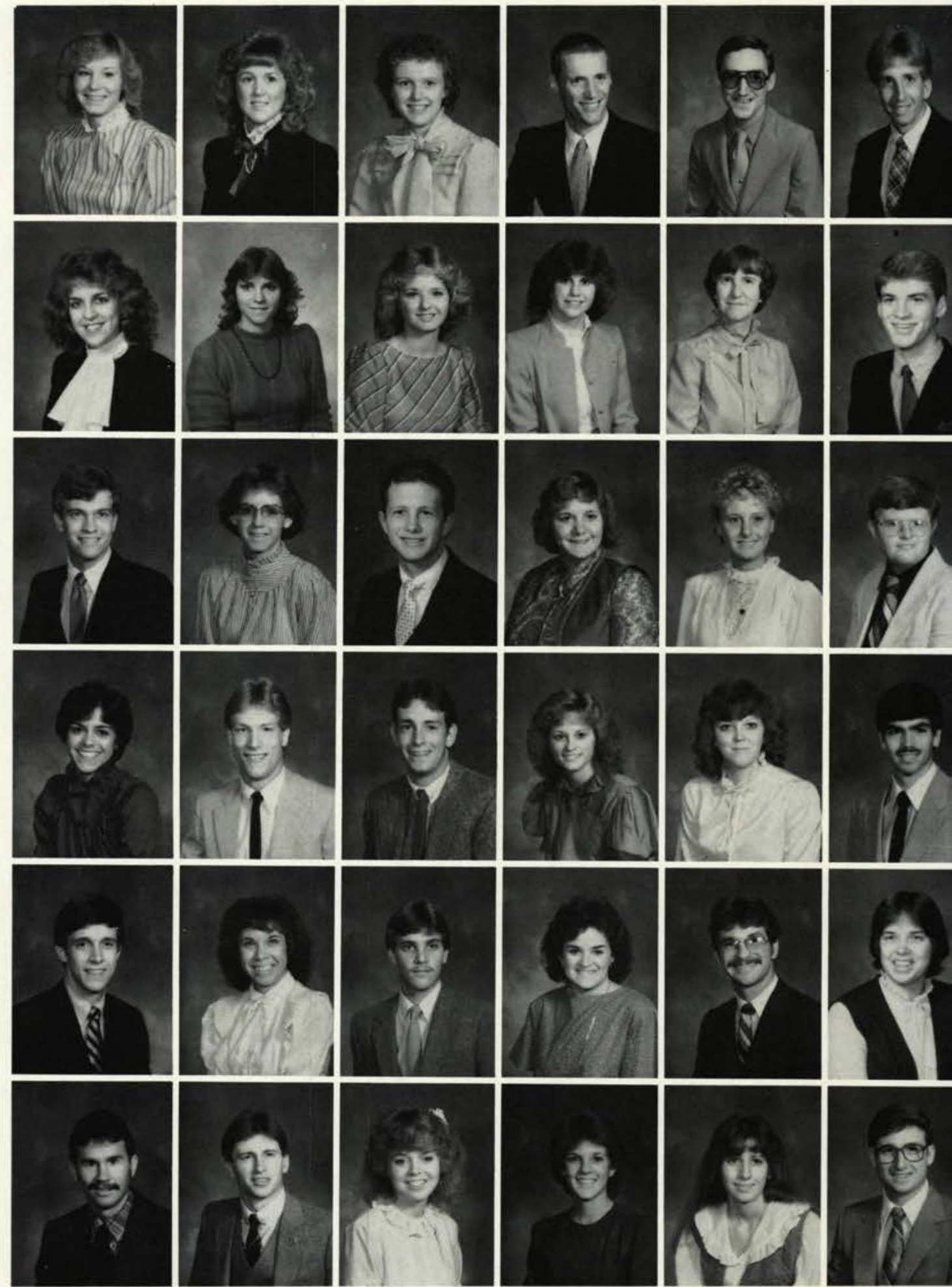
need - an open ear, a prayer, a hug - by focusing on trivial matters of personal worries, we store up treasures that will eventually dissolve.

God has spaced us in an ideal environment for growth through fellowship: just consider the opportunities we have to minister! Let's compare our present spiritual standing to our position as freshmen. I trust that we observe growth, even if only a little. Now consider the additional growth we could have experienced had we replaced our vain, earthly treasures with eternal, indestructible treasures. Our actual growth is not so dynamic in comparison. Growth involves pain. Have we really suffered? Or have we taken the easy way out to avoid growth's blood, sweat, and tears?

My challenge to the class of 1985 is that we practice the love, discipline, and investment required to grow through ministering to others. Let's ac- cept our last year together as a challenge to take advantage of growth through fellowship in order to bring honor and glory to the name of our Heavenly Father - the richest treasure we can possible store in heaven!
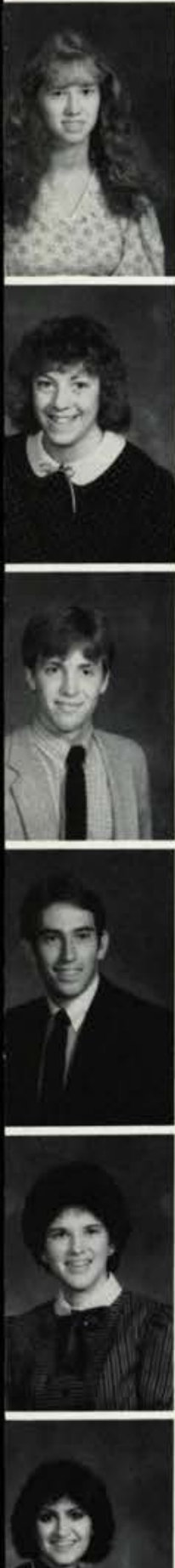
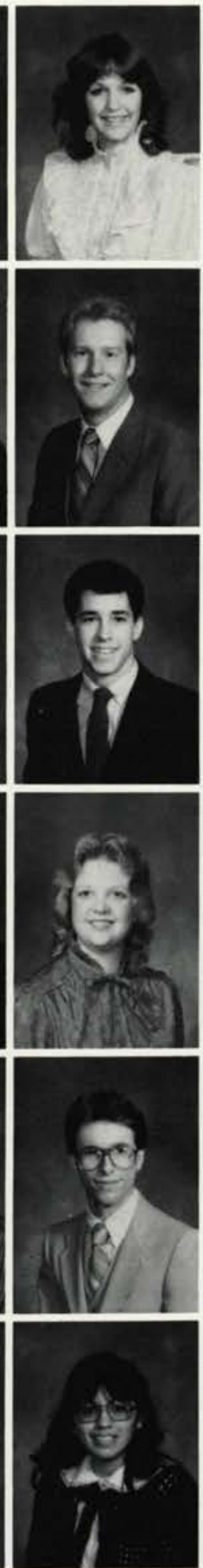
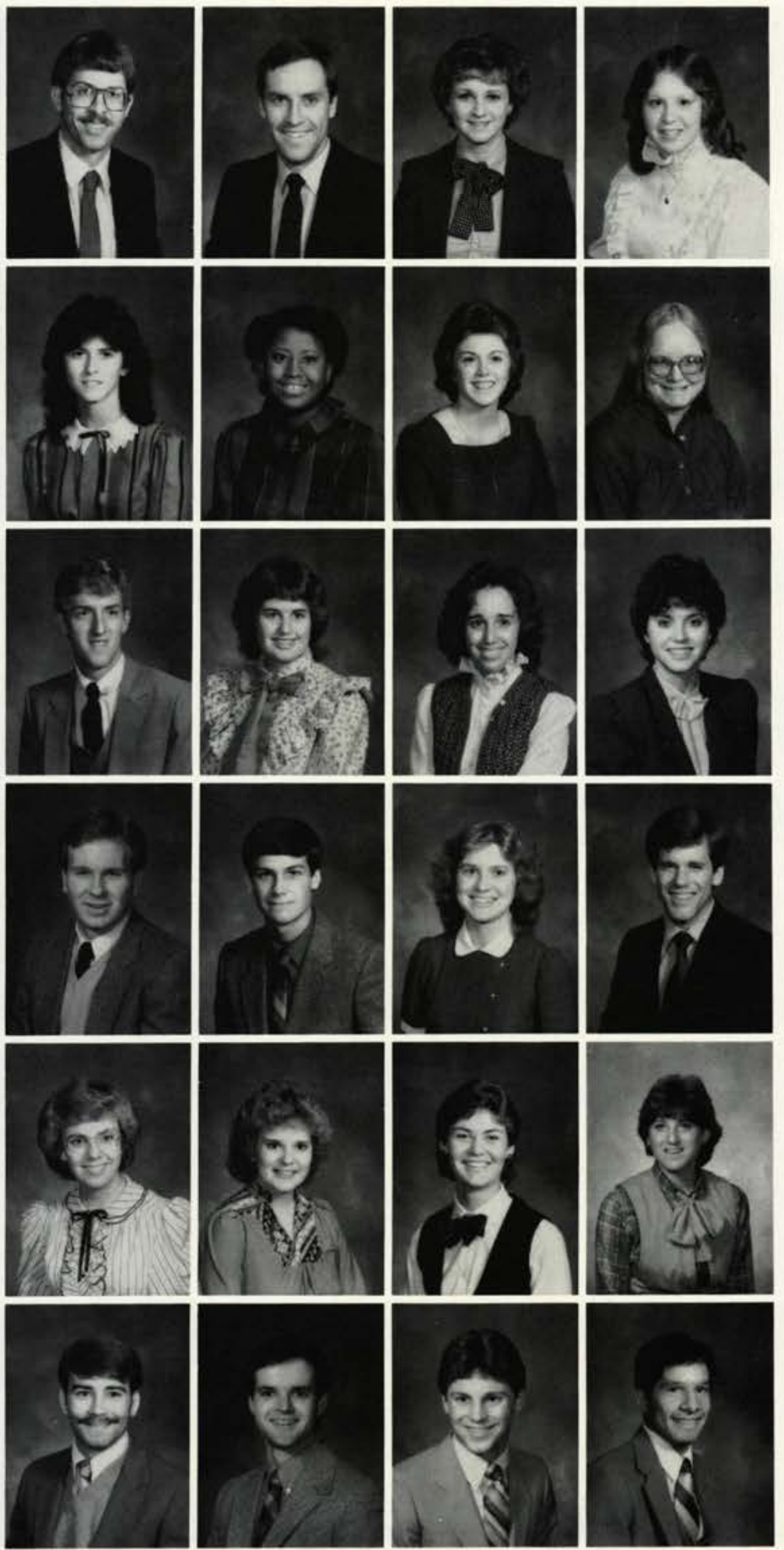

Dlane L. Blasde!

English

Bronda L. Blass

Nursing

Jeftrey S. Bolyard

English/Psychology

Aaron T. Bow

Robln $\boldsymbol{R}$. Bowling

Speech

Colleen R. Boyer

Nursing

Elisabett A. Britton

Biology/Secondary Education

Gien C. Brown

Business Administration

Tracy L. Brown

Communications

Nursing

Esther $\boldsymbol{K}$. Bucklew

Nursing

Cynthla E. Bursick

Bible Comprehensive

Dale J. Burdlick

Business Administration/History

David C. Burghen

Business Administration

Scott M. Burtis

Bible Comprehensive

D. Lynn Butcke

Broadcasting

Stacey L. Butler

Business Administration

Heather L. Byrnes

Nursing

Jon D. Callan

Elementary Education

JiII M. Campbell

Music Education

Kovin Carder

Business Administration

Daniel w. Carey

Psychology

Llsa M. Casteel

Nursing

Stove T. Caswell

Physical Education

Lynette M. Chezilk

Nursing

Kovin L. Clark

Accounting

Cheryl L. Clayton

Nursing

Kathleen M. Clayton

Elementary Education

Shelley L. Clements

English/Secondary Education

Sally J. Cochran

Elementary Education

Laurle D. Colas

International Business

Rebeca J. Colthorp

Behavioral Science

Ronald D. Comfor

Physical Education/Secondary Education

James B. Conley

Speech

Oary s. Cooke

Broadcasting

Luls A. Corchado

Pre-Low 


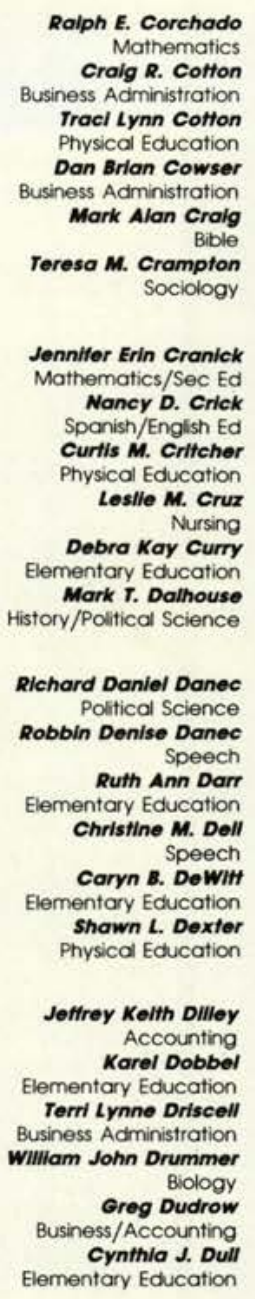

David C. Dustin Pre-Law/Pol. Sci. Jennilter Susan Dye Behavioral Science Timothy J. Dysert Mathematics/Ed. Kelly Ann Ebersole Cathy Carol Eckam Physical Education David Paul Eckert

Mathematics

Daniel Earl Edwards R. Michael Edwards Accounting Mitchell Dain Ely Bble, Preseminary Tricla Maurine Emerson Brian Scot Ensmincer Business Julie Diane Erdmann
Physical Education
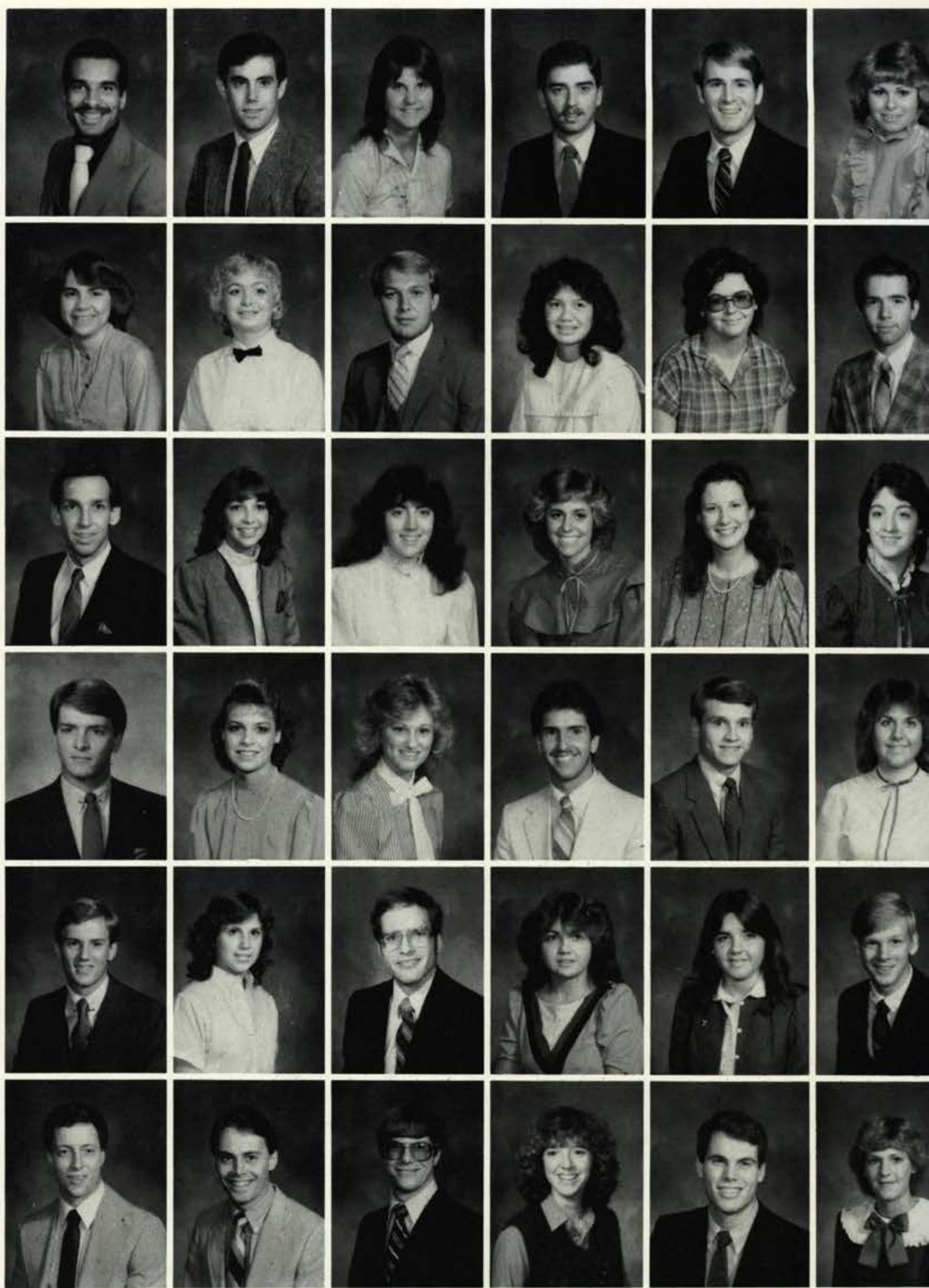

to "think" properly. Before college I just accepted things as they were and believed whatever anyone told me. Here the teachers challenge you to consider everything in light of God's Word. They teach us to critically analyze the books we read, what we hear in chapel, and even what they tell us in class. The best part is that they are available to talk when we have questions about .... oh, just about anything. It's not like some of the other schools and universities I went to before com- ing here. At the 'Ville, the faculty care about the students. They show us by their actions and by giving their time

Guess what? Mondays have gotter good! Almost every Monday mornins Dr. Dixon speaks in chapel. Through the years l've come to appreciate these messages more and more. This pas year he has challenged us regarding our thinking, integrity, and values. Hi messages have been a real help in m spiritual battle with sin. I look forward to this messages each week. 


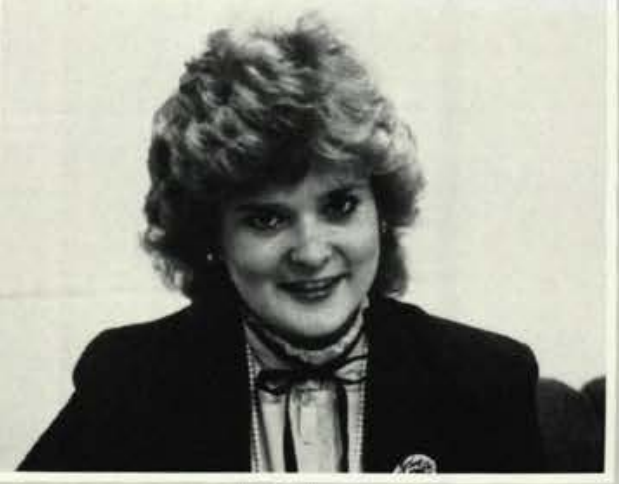

Tust as two powerful teams struggle in a tug-of-war, so I battled to make the proper choice between various colleges and institutions. Cedarville College was highly recommended. and after much thought and prayer, made the decision to come here. Like many young people who want to make right decisions, I had doubts as to whether God wanted me here. But after getting into the swing of college life, declaring my major, and meeting new people, I knew I would not be

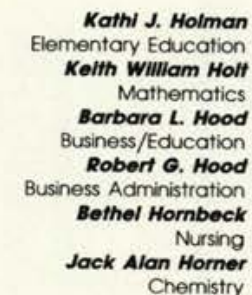

Lorl Ann Horner

Richard Q. Horsfall

Carolyn Adriano Hunter

Nursing

Leah Rae Jayne

Todd Kevin Jetson

Business Administration

Timothy Andrew Jennings

Music

Katherine J. Jllison Mathematics/Comp. Sci. Debra K. Johnson Elementary Education Douglas Andrew Johnson Physical Education Joni L. Johnson Paul E, Jones Business Administration Business Administration

David A. Kammeyer Business Administration Paul Stephen Kasabian Accounting/Business Birgit E. Kass

Wayne W. Keislling Jr. Business Administration Robln Kaye Kessler Marketing/Business Mary Lou Kincald Elementary Education

Phillip Alan KInney English/Sec. Ed. Elleen Faye Kirby English/Sec, Ed. Kathleen Renee Kirby Business Ruth Ellzabeth Kirtland Mathematics Robert James Kolko English
James John Kolar Bible

Julle Kay Kolkman Music Education Carol Lynn Koppe Jili Carver Kramer Elementary Education Sharl Lynn Kratche Elementary Education Lewis R. Lyle Cart w. Lane Business Administration
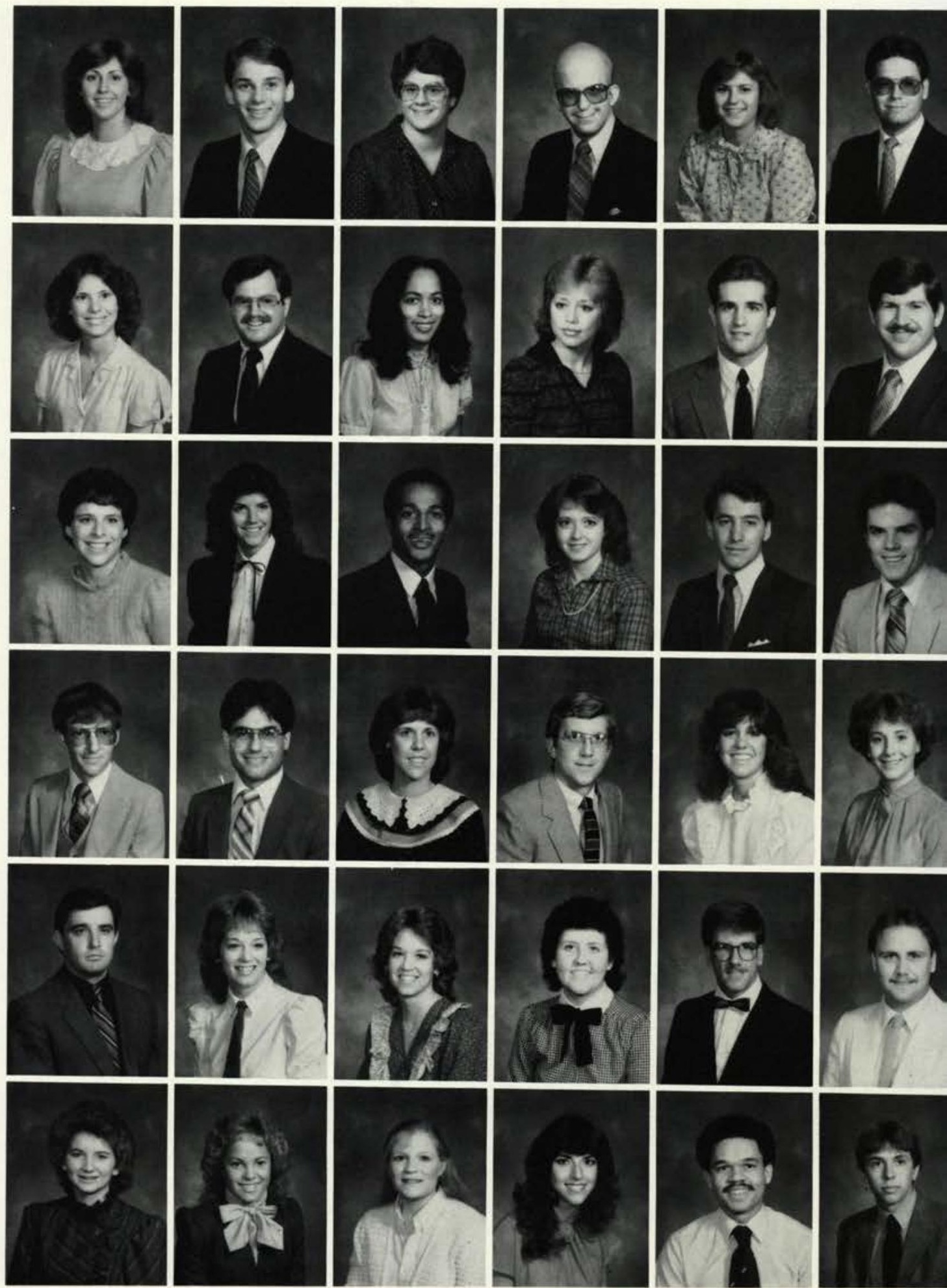
Douglas J. Miller Rebecca Sue Miller Behovioral Science

Bible

Chemistry Randall C. Monroe Behavioral Science David Moody Business

Danny L. Moore
Preseminary

David A. Mowry Business Administration

Clcero Mukes

Preseminary

Byron Mullet

Steve Mulligan

Mathematics Education

KImbra K. Murphy

Music Education

Rex Alan Mussolman

Business Administration
KIm A. Myers

Business/Psychology

Dwight David Mytelt

English/History

Molonie Jane Neudeci.

English/Elementary Ed

John Alan Nicholas

Kenneth Allen Nickell Mathematics

Lorene Norton

Political Science

Linda Sue Noyes

Social Science

Randy Scott Nuss

Patrick Andrew O'Donnell

Biology

KIm E. Oljace

Elementary Education

Preseminary

Martyn Rhea Park Psychology

JiII M. Parks

Joan Elaine Parsons

Biology
Joan Elaine Parsons

Dennis Patterson

Helen M. Pearson

Marianne Pearson

Elementary Education

Ellen Maria Pedersen

III Perks

Lynn B. Porn

Lynn B. Porry
Bible

Steven Alan Poters

Business

Held Sue Peterson

Joan E. Paterson

Elementary Education

Teri Lynne Peterson

Social Science

James M. Ptuelt

Cheryl A. Phillips

Political Science

Tod L. Phillips

Davld Poul Plper

Preseminary

Lorl JoAnne Pltonyak

Business Administration

Kelth Alan Plunket

Preseminary

Frank H. Porter

Kathryne D. Power

Business Administration

Rick Allan Powers

Stefanle Lelgh Pratt

Stefanie Lelgh Pratt

Cheryl Lyn Provost

Business Administration

Mark A. Price

Preseminary

Unda Kay Prichard

English Education

Joyce D. Pyerat

Nursing
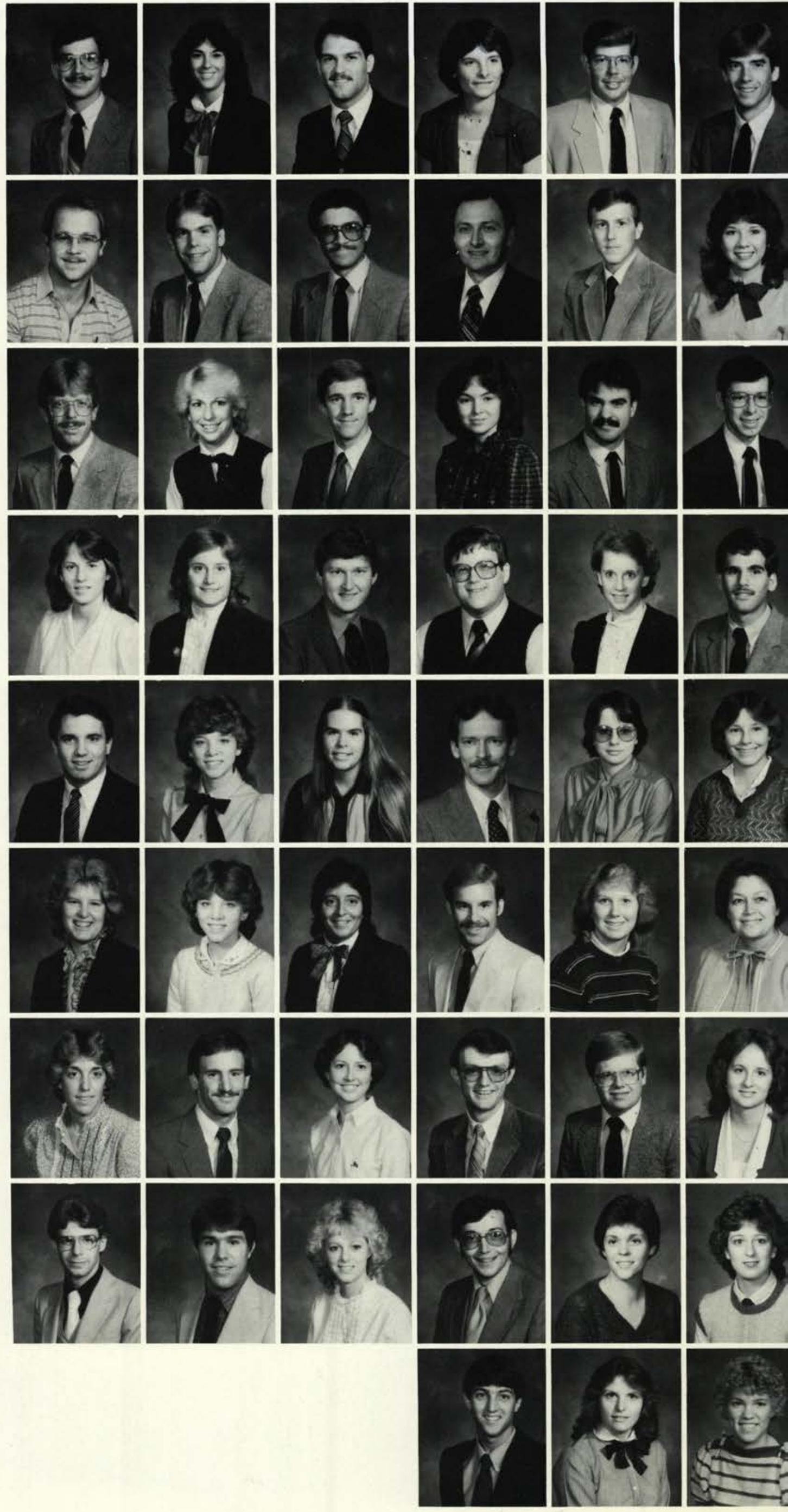

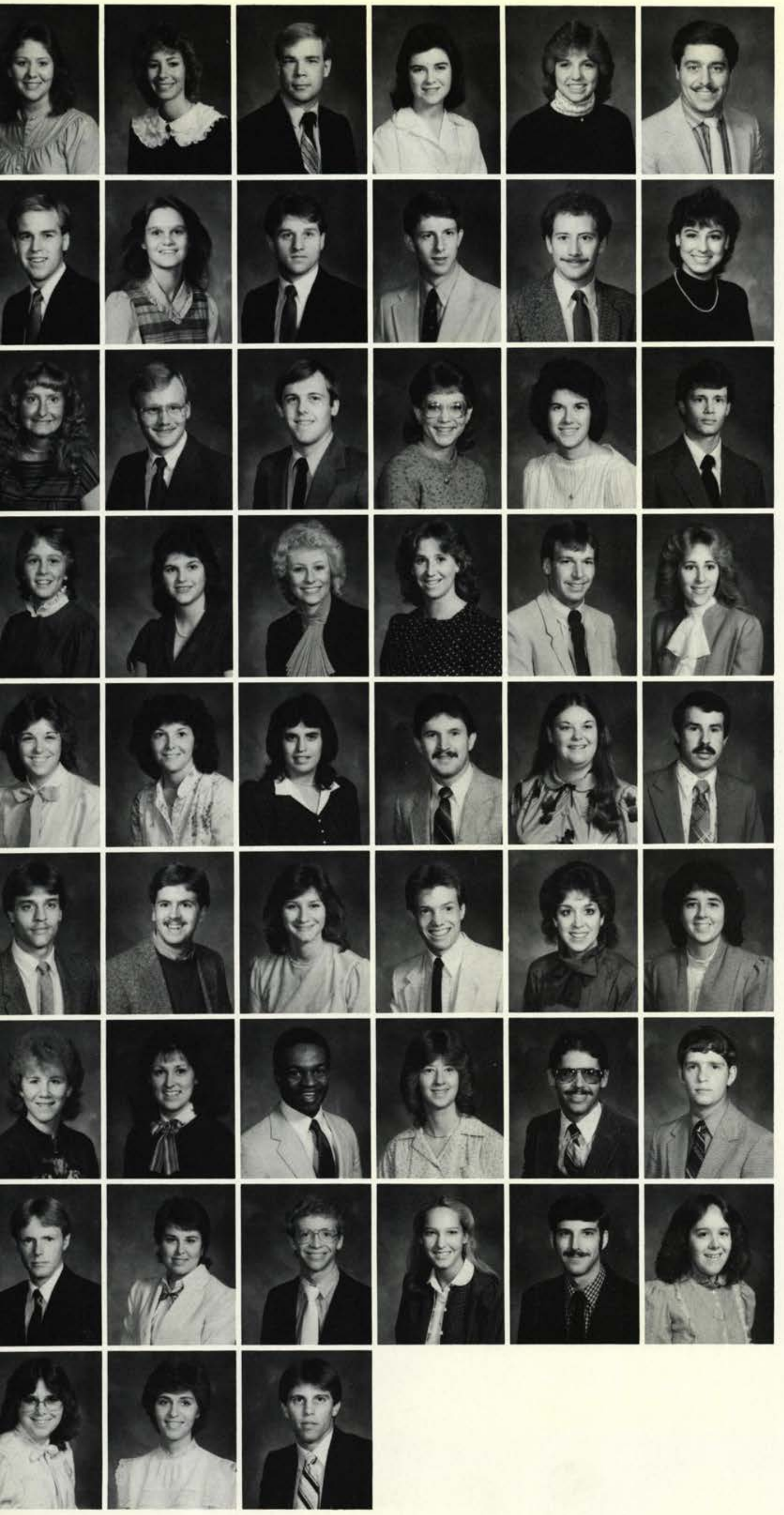


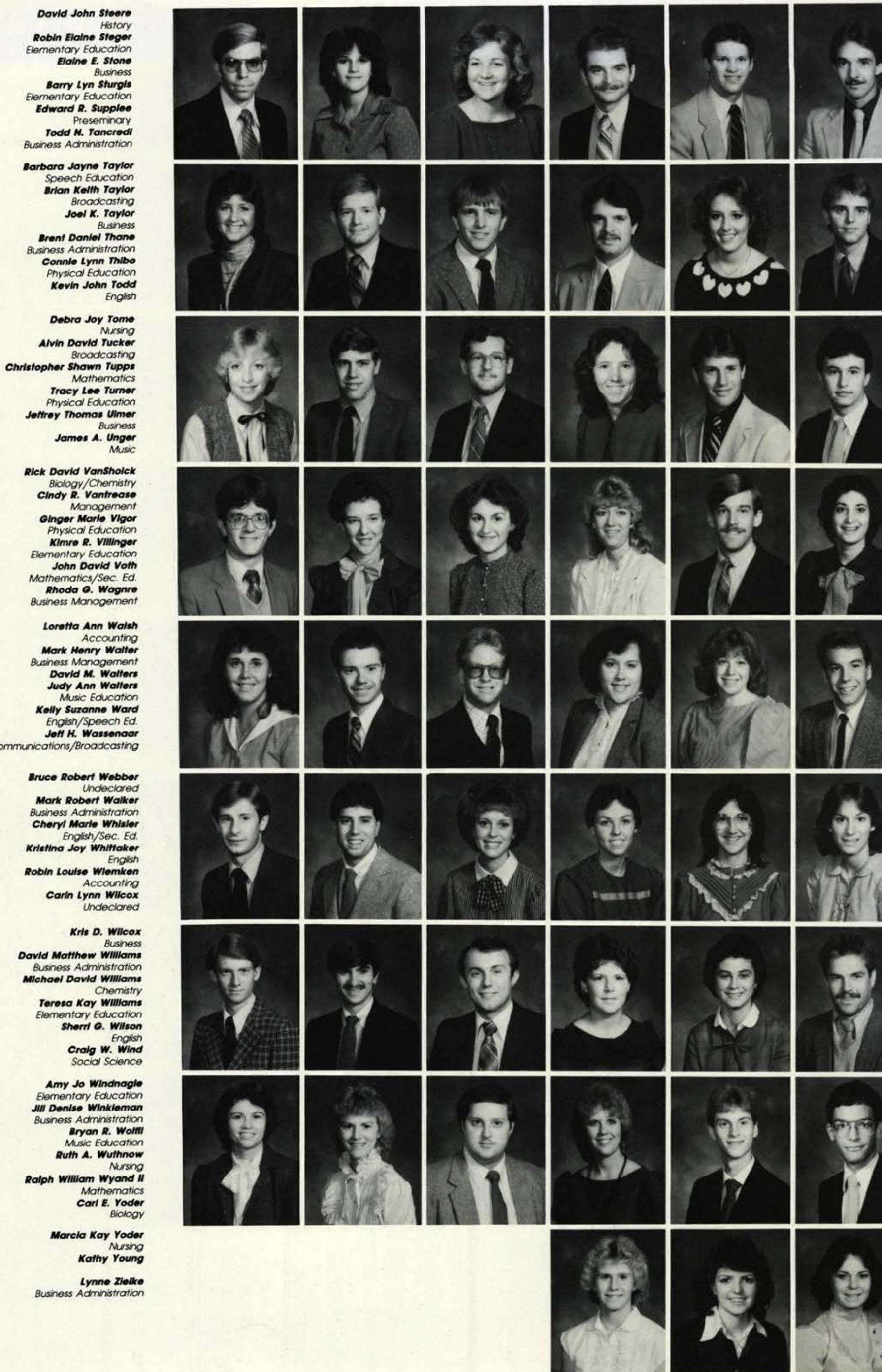




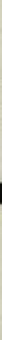

\section{“GROWING AND LEARNING"}

The end of our sophomore I year brings us to the midsoint of our college years at Cedarville. To any of us, the two years have slipped by quickly, and with only two years remainng, graduation day will soon be reaking on the horizon. But wait, just stop for a moment and contemplate these last two years of our lives. Think about the many close friendships we have made, the unforgetable experiences, the thought provoking and mind expanding classes, the challenging chapel services and Christian service spportunities, and our deeper elationships with the Lord. Relecting on these many facets of our lives, we can see how the wo years already past have peen very rewarding. To consider these thoughts can make us ealize that the past two years lave not been as short as they nay have seemed. Class, I chalenge us to continue this growng and learning process in our emaining two years here at Cedarville College.

James M. Reiter

Sophomore Class

President

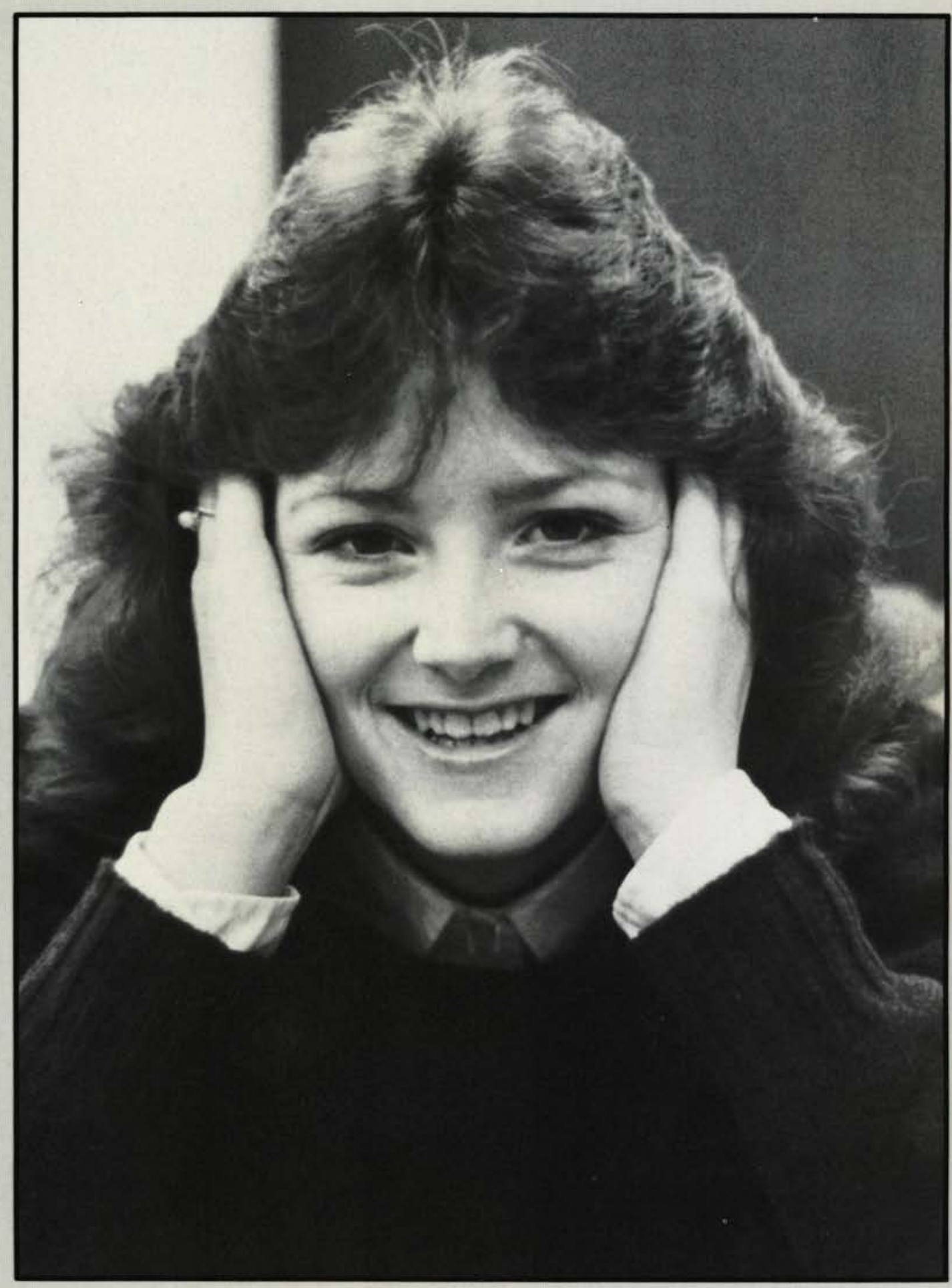

\section{Contributors:}

Gary Barker . . . . . . . . . . . .98 98

Brenda Fisher ........... 100

Jon Weber .............. 102

Kathy Klose ............. 104

\section{Layout by:}




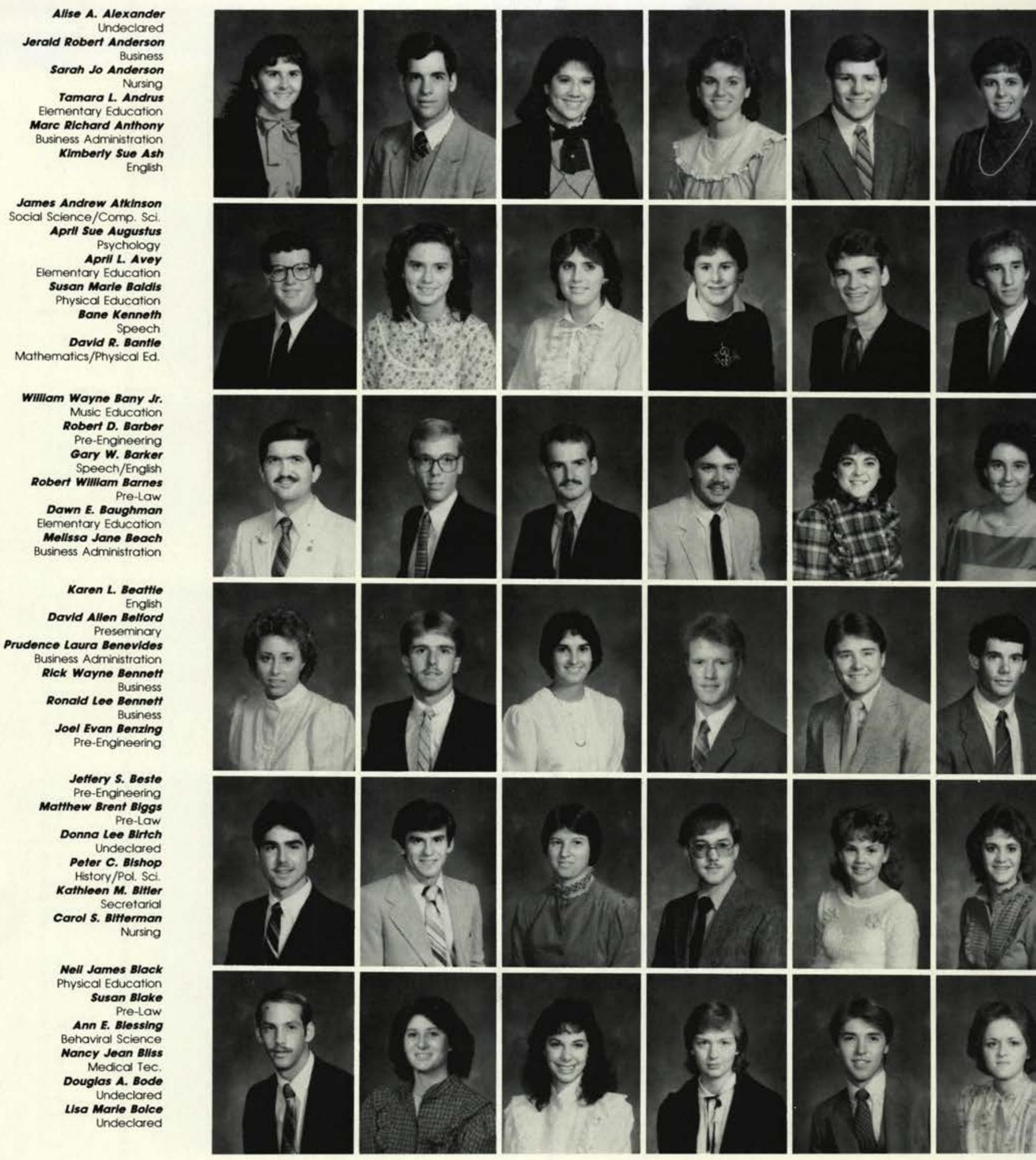

$\mathbf{W}$

hen the class of 1986 came in as freshmen, the first major college activity we were to experience was Homecoming. The theme of that Homecoming was "Reflections." Reflections? It was a little difficult for us to reflect on our memories of college life when we had only been here for two weeks! But now, two years have gone by - so reminiscing becomes a little easier

As a sophomore, I would have to classify the past two years as years of discovery - but discovery in two completely different areas. As freshmen, we were overwhelmed to discover new facilities, new friends, new courses, new challenges - new everything. We spent a year of excitement, adventure, fun and learning. We discovered things about other people and a "new world."

Then came our sophomore year. It. too, was a year of discovery - bu not as much about college life. Som might say that we became "seasone veterans." The programs were not a dazzling and overwhelming as that firs year; we had seen friends come an go: our college life became settle into a more knowing and stable rou tine. Rather, this time the discoverie were about self. We discovered mor about our attitudes and values, an we began to crystallize future plan and goals. We no longer were discov 


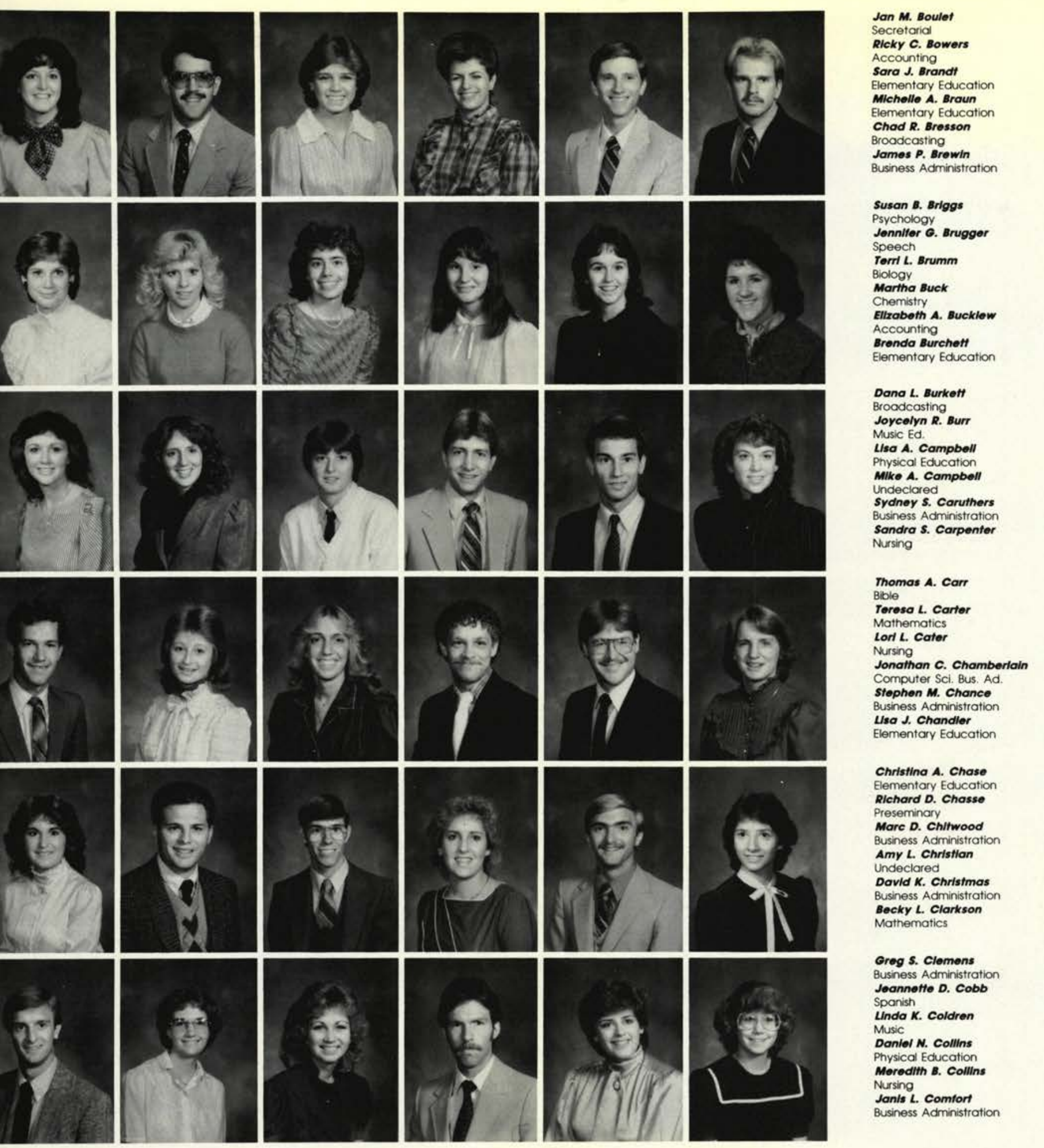

ering what college wanted out of us, out what we wanted out of college. It has been a positive two years wo years that have raced by. As we are now able to "reflect" on the past years, we are also impressed with how quickly the next two years will pass. As we have made memories in the past. we will continue to do so. I am certain that next year holds even more discoveries for the class of 1986 .

By Gary Barker

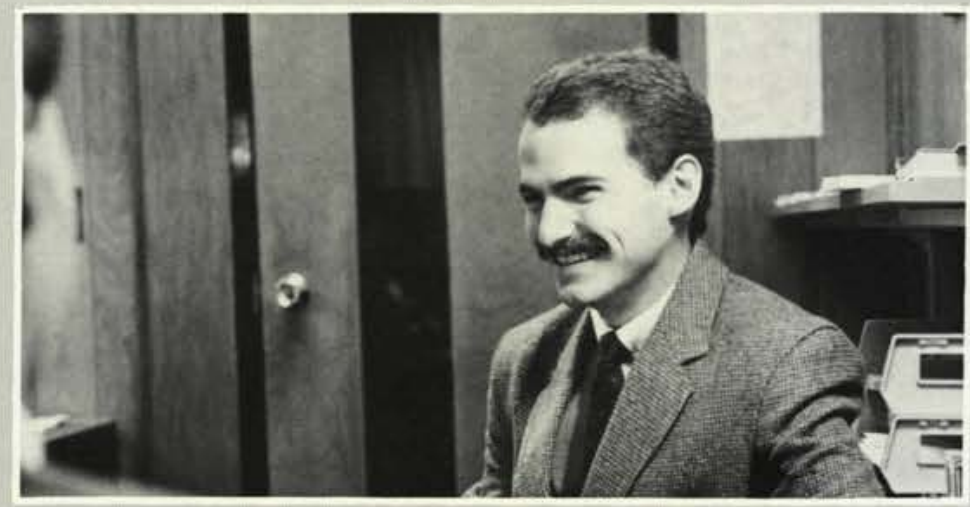




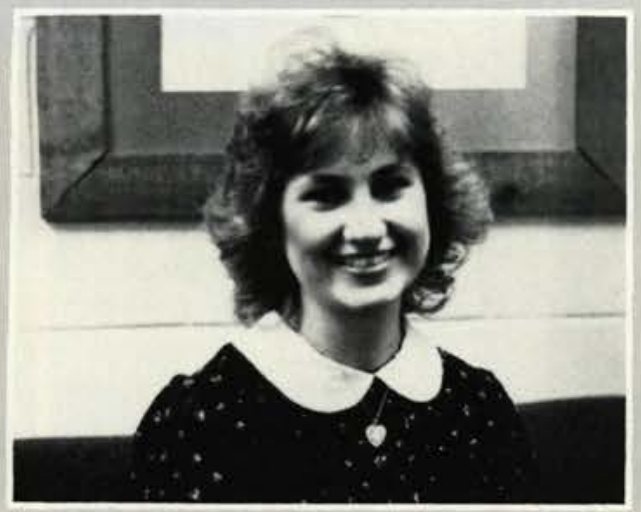

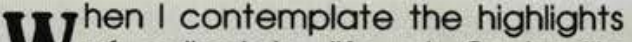
of collegiate life at Cedarville College, the traditional events that bring with them a host of colors and personalities usually come to my mine: Homecoming, concerts, plays, guest speakers, banquets, basketball games, softball intramurals, the dorm "experience" (whatever your particular dorm), open-house, Christmas parties ... and ultimately, the grand finale of graduation (even if it is still but a hopeful dream)! Yet tucked in be-

tween the holiday hoopla and pomp of special occasions are those ordinary experienced that pass by without $c$ parade, those peculiar pleasures o Cedarville College that are so ofter over-looked, yet they add specia touches and spice to our lives.

These are a few of one sophomore's favorite things - passing by Cedal Lake on the daily trek to and from Printy when the lake is as still as a mirror painted with the reflections of russet trees and blue sky or shimmerinc

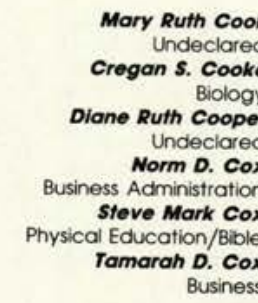

Stephen J. Cremean Mathematics Lisa A. Cross Business Administration

Bryan L. Crump

Mathematics

Unda C. Curtis

Business

obert Leo Custdio

Lisa K. Cyrus
Lical Education

Elementary Education

Karen Dachenbach
Behavioral Science

Behavioral Science
Sherie P. Davis

Sherie P. Davis
Business Administration

Brian Edward Davison

Business
Deborah Sue Deeter

Nursing

Steven Rew DeHoney

Guy A. Demetrl

Comp. Science/Sec. Ed.

Jamie Richard Devney Accounting

Susan Lynne DeWitt

Elementary Education

Gary A. Dillsworth

Business Administration

Laura A. Dimacehia

English

Eleme

Jana L Dowsett

Music

Mark Anthony Duquette
Preseminary

Amy J. Dykes

Chemistry

English/History

English/History

Bonlta J. Eberhardi

Clarence David Eddy

David P. Edwards

Political Science

Donalda L. Edwards

Accounting

English

Steve Robert Eisentrager

Accounting
David S. Eller

Steven J. Emmons

Physical Education

David Andrew Engdah

Undeclared
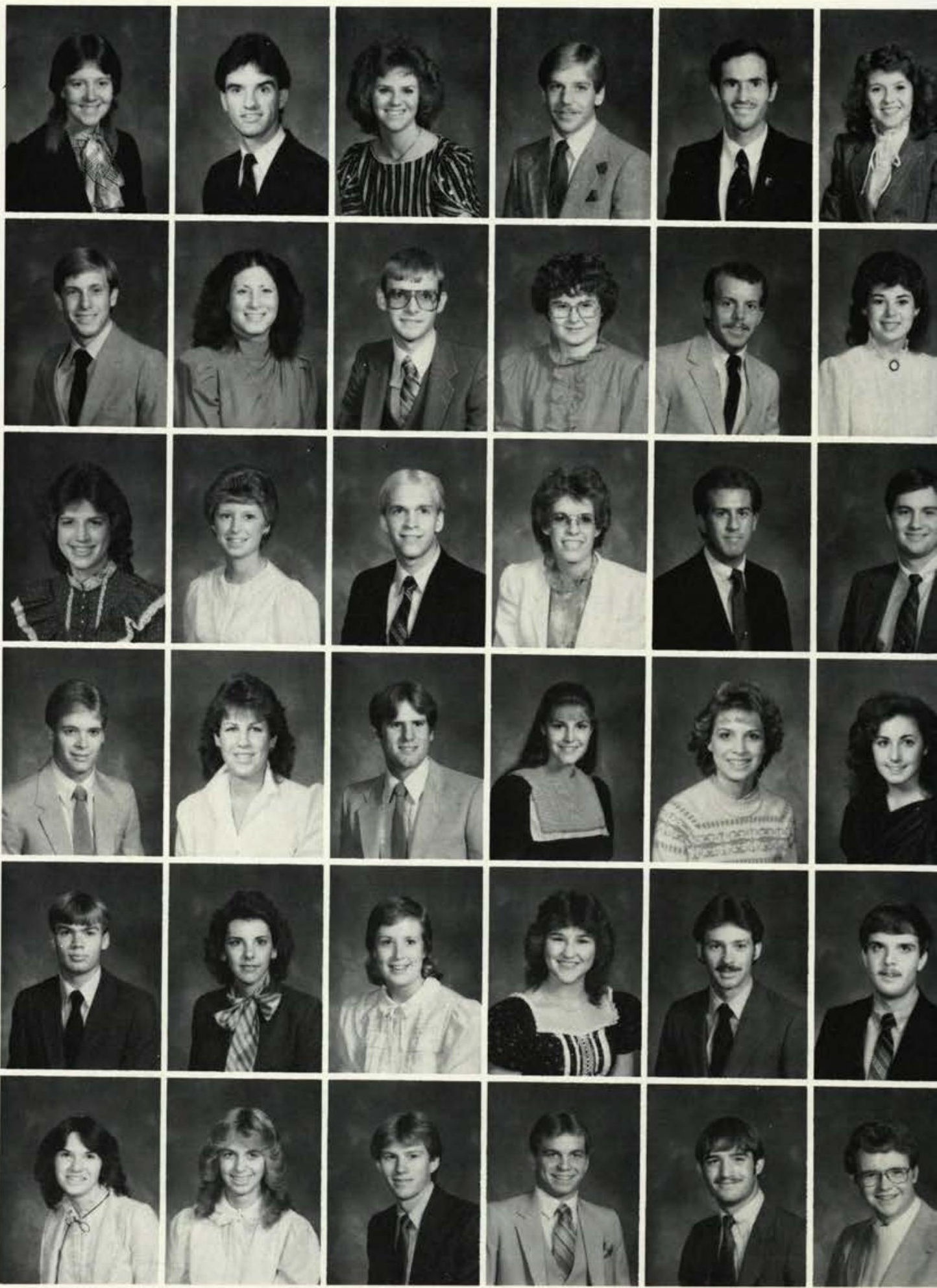


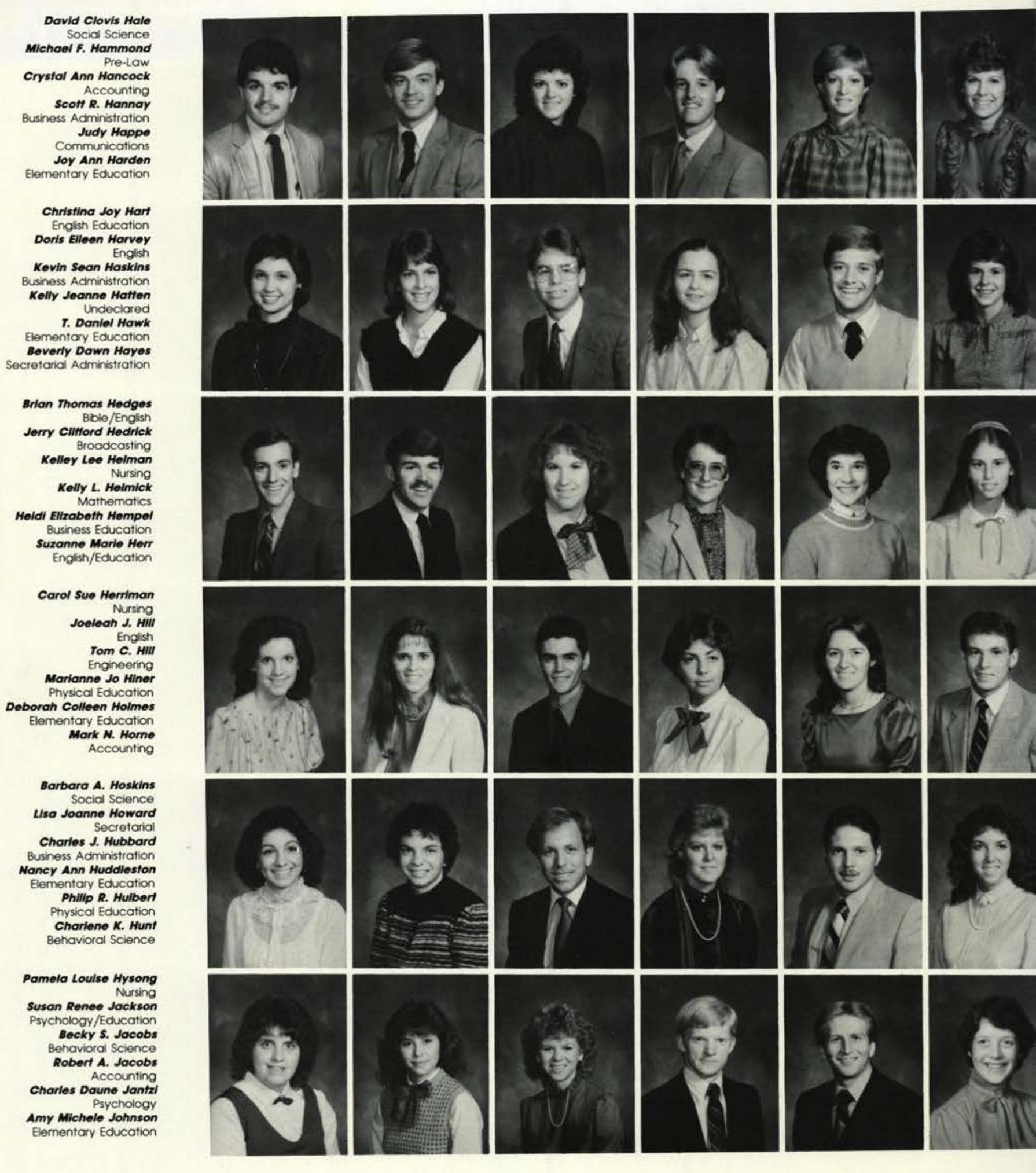

$\mathbf{W}$ hen I first came to Cedarville last year, I really did not know what to expect. I told myself that life at a Christian college would be somewhat like camp. The first couple weeks were like that, indeed. It finally took a "Dr. Monroe Foundations" quiz to make me realize that I was in college. From that point on, it seemed that the reality of college started to affect me in a negative manner. I was sick of washing my clothes: I missed my friends back home; I hated the work that the pro- fessors were giving me; and I was just plain homesick. I thought I had made a mistake and was thinking of transferring.

The summer after my freshmen year, I discovered that the root of my problem was that I had no desire to be in the center of God's will. I then decided that my sophomore year would be committed to God's will and not my own.

The following fall quarter an opportunity knocked that really turned me around. I was asked to be on the Mas ter's Puppets team. At first, I though that only elementary education mc jors tried out for the team, so I didn" know what to do. I prayed about it and the Lord seemed to tell me that should try puppets. Now, I just prais. God for giving me a ministry that he blessed me so much. The members the team have been an extreme er couragement and have shown me th meaning of servanthood. The puppe ministry has given me a positive ou 


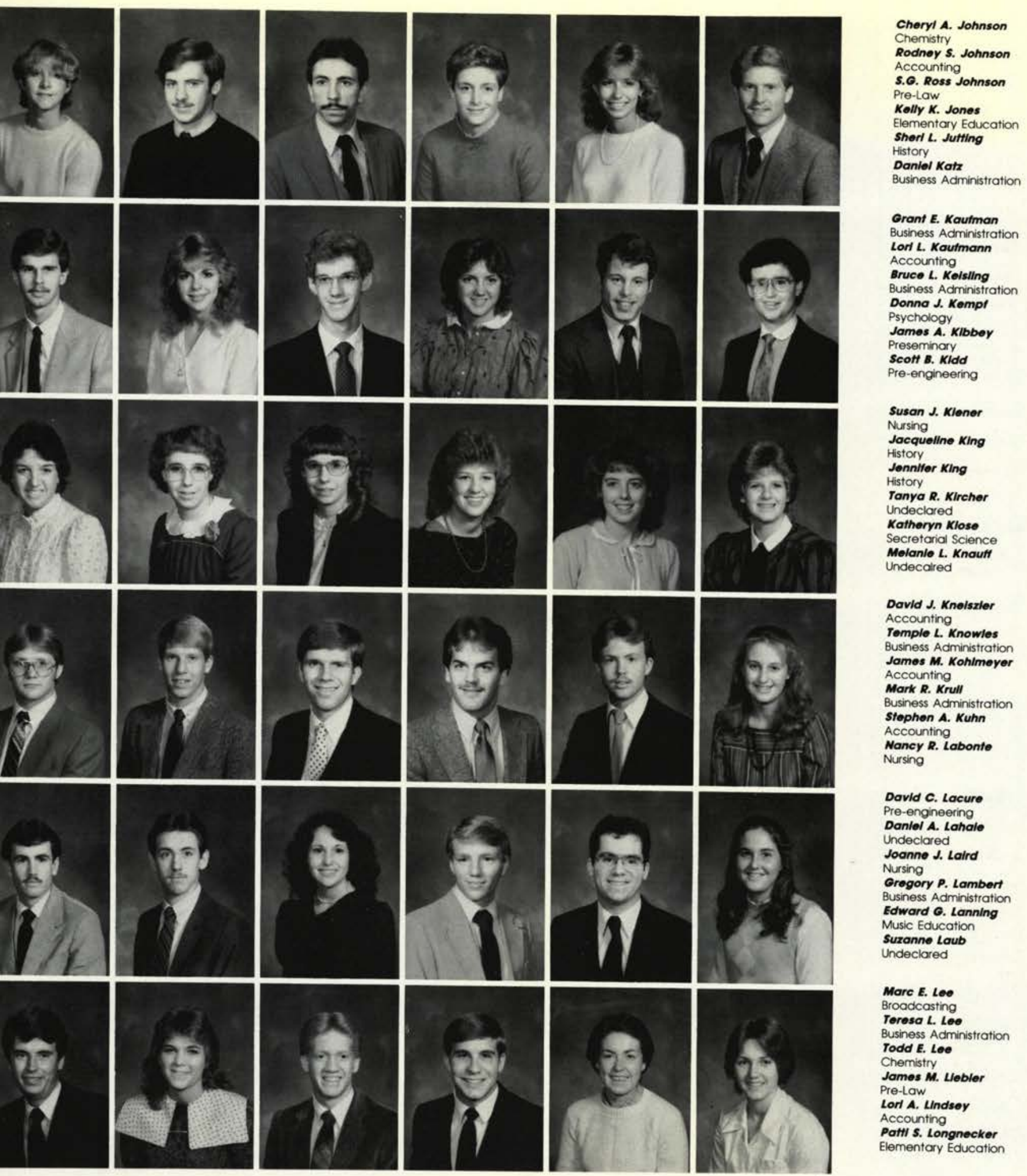

ok on all the other aspects of college nd has shown me the importance of eing in the center of God's will.

I still have a long way to go, but how now that I am striving to be in the enter of His will, and all the good and ad experiences were given to me to ake me a stronger servant for $\mathrm{Him}$ nd that I should praise God for everhing that He has provided for me.

by Jon Weber Matthew 9:37-38

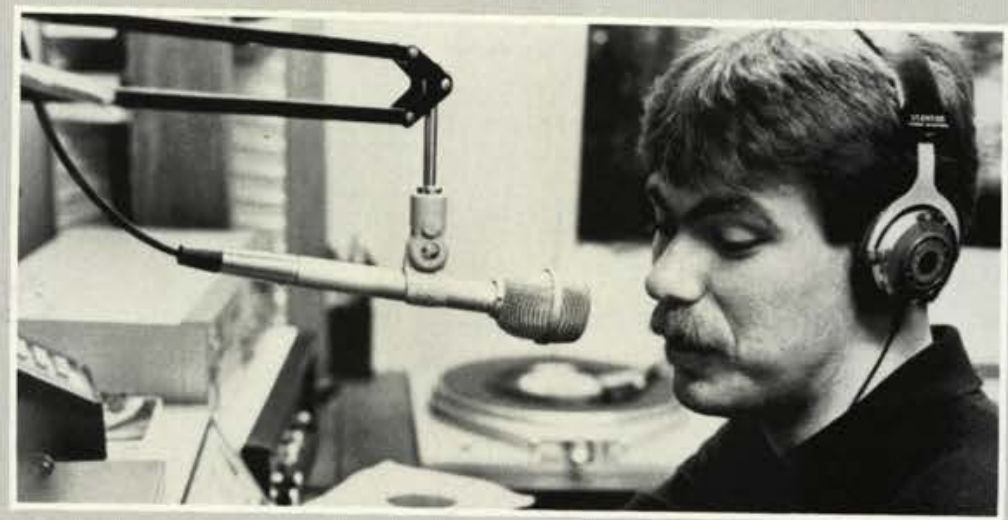




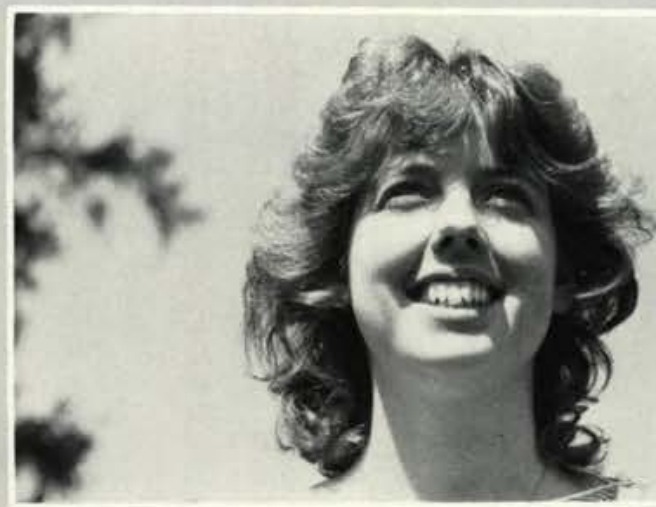

can't believe it! Another one of my 1 umbrellas has just been totally destroyed by a typical Cedarville rair storm. That makes a total of four umbrellas this year (not bad compared to last year's total of six!)

Besides umbrellas, I've ruined the heels on two pairs of shoes and pu runners in approximately 30 pairs of ny. lons. Not only that, but my "used-to be" faithful watch stopped running and my roomate's hair dryer blew up (just a small disaster).

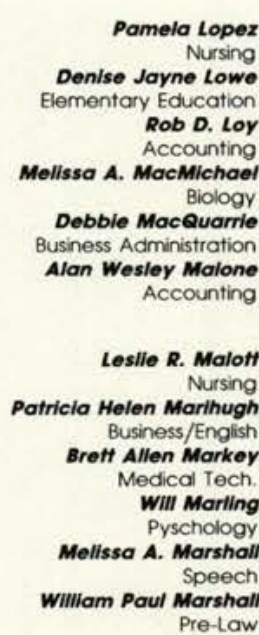

Jay Wesley Martin Rodney Mark Mason Rodney Mark Mason Puth Marlo Mason Rum Mario Mason Kristi Elaine Massie Kristi Elaine Massie
Elementary Education cilford L. Mast Undeciared Lois Kay Masters Undeciared

Mark Edward Mathews Business Steven J. Matson Business Administration Jennifer Lynne Matthews Political Science/Broadcasting Michael Stoven McAllister William Alan McCain Business Administration Lisa K. McDonald Elementary Education

Foith A. MeGhee Music Education Richard Daniel McGIII Camille Ann McGraw Elementary Education Sara Lea McGuire Nursing Eoth Ann Mcki.ben Bruce Raymond McNabb Undeclared

Marilyn Jean McNelsh Undeclared
David J. McVoy Elena M. Michael English/Speech Larry Edward Miller Mark Judson Mitchell Undeclared
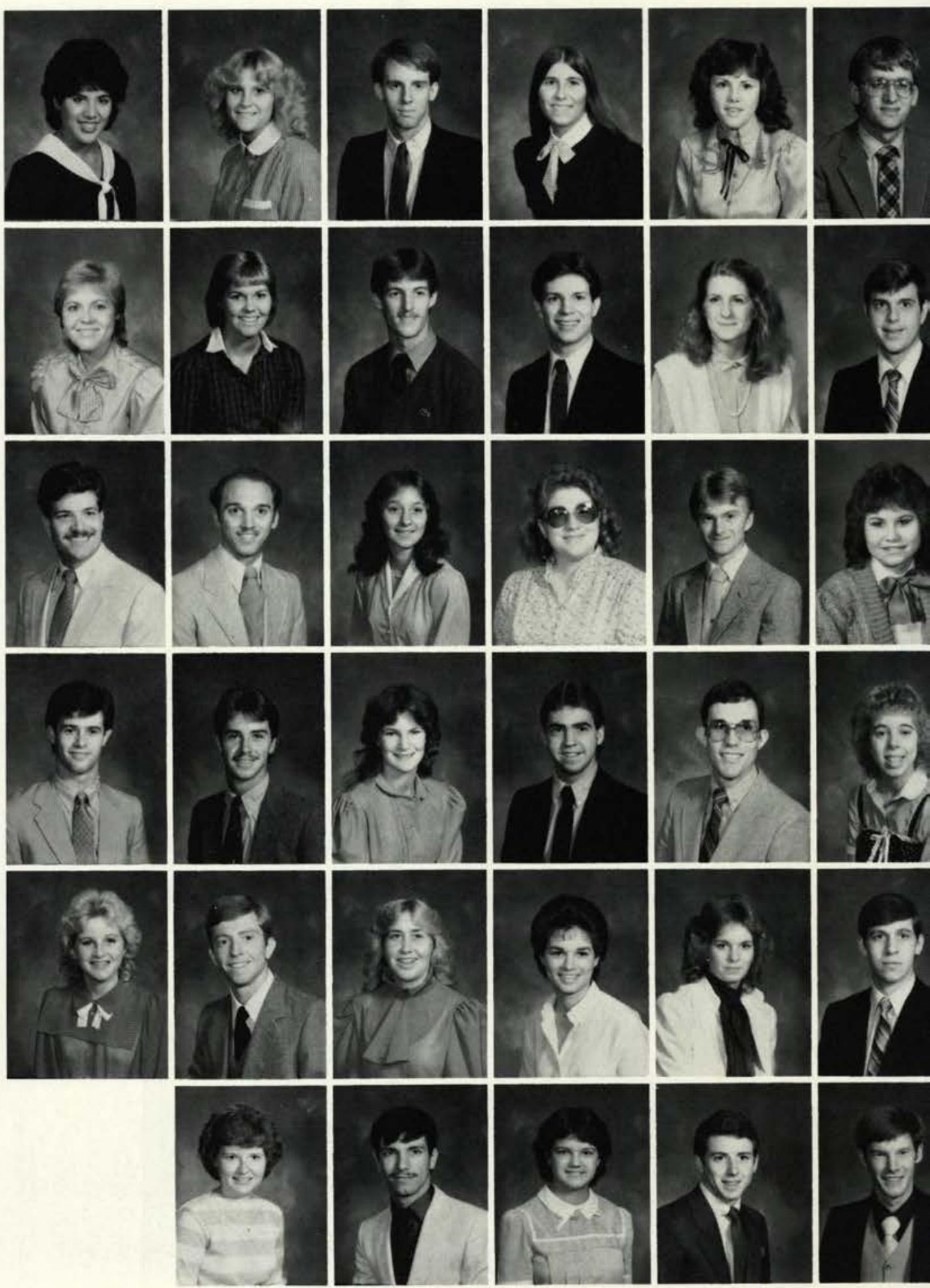


\section{Doesn't anything last?}

Yes, friendships are something which ast. This is one of the most important hings I've learned during my sophonore year at Cedarville College.

The Lord has brought some very special friends into my life. These friends lave been with me through times of orrow and despair as well as times of oy and happiness. They have taken he time to encourage me and show ne their love. Most importantly. hey've continually focused my atten- tion toward God and His Word in many areas of my life.

At the same time, my friends had their own needs which were just as important as mine. I had to learn to give of myself in order to encourage them during their hard times. I also had to depend on the Lord to give me the strength and wisdom necessary to meet their needs.

When friends have Christ as a bond between them, their friendships are secure because of His love. Although friends may come and go, the friendships themselves will always last.

By Kathy Klose
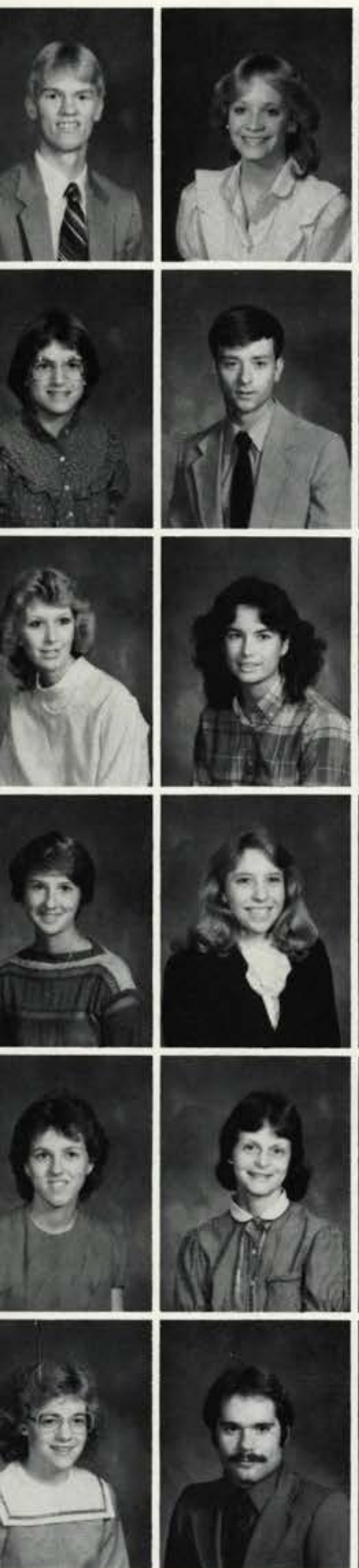
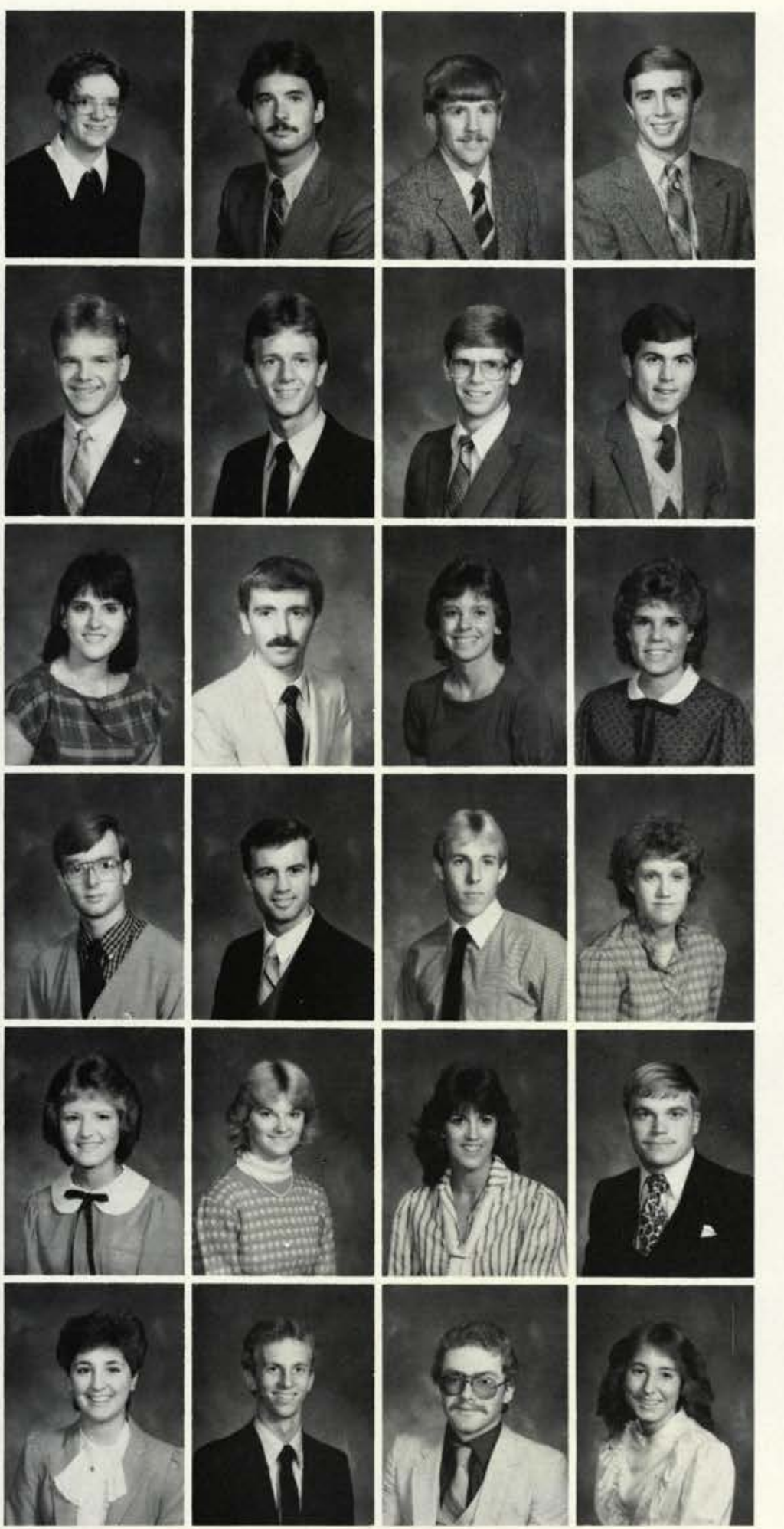

Public Administration

Bonnie Modesty

Nursing

Jean M. Moeser

Biology

Jim B. Moll

Business Administration

Dale Dean Moore

Biology

James W. Morton

James W. Morton
Business Administration

Susan J. Moser

Elementary Education

Mark A. Moses

Accountin

Charles H. Mosher

Pre-Medicine

w. Scott Moyer

Business Administration
Dan E. Mulholland

Dan E. Mulhollan

Greg A. Murray

Business Administration

Allela M. Murrin

Psychology

Roseann Nemeck

Nursing

JiII M. Nespor

Biology

Edward w. Neudeck

Undeclared

Mary B. Newsome

English

Sonya R. Nichols

Speech Therapy

Sue Ellen Nicke

Undeclared

Krista L. Nickoson

Psychology

Gary S. Nonnemache

Mathematics

William B. Norvell

Biology

John C. Novak

Business Administration

Judith E. Oakes

Business Administration

Rebecca E. O'Connor

Accounting

Barbara J. Olson

Nursing

Susan L. Olson

Behav. Sci./Psychology

Diane S. Ottaway

Accounting

Patricla C. Pagnotfi

Undeclared

Jerry A. Parker

Bible

Kristine K. Parman

Undeciared

Donald L. Pensworth

Business Administration

Jo.Ellyn M. Peters

Mathematics

Timothy S. Phillips

Broadcasting

Stanley K. Plett

Undeclared

Shelley M. Polsdorler

Elementary Education 


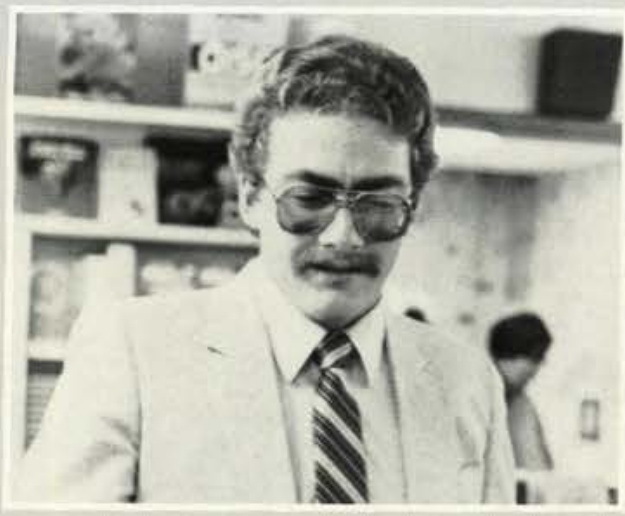

B eing Mexican born and Canadian raised must make me about as atypical of Cedarville College as three consecutive days of sunshine. However, it is this diversity of students converging at a common place with a common goal that has made Cedarville the special place it is.

The challenge of the classes. the inspiration of the chapel services, the theological "discussions" with friends, and the many social activities have all contributed to shape and prepare me for the future. Weak areas of my life have been strengthened and stabi- lized, while inconsistent areas have had to be re-evaluated and revamped. Hectic, stressful days have not been uncommon, but energies expended in struggling through assignments have always been reimbursec with new insight or a new appreciatior for truth.

I am very grateful for this privilege o: attending Cedarville College. The dedication of the college to maintair its high academic and spiritual standards makes me proud to be a part o it as it continues to become a part o? me.

by Stan Plet

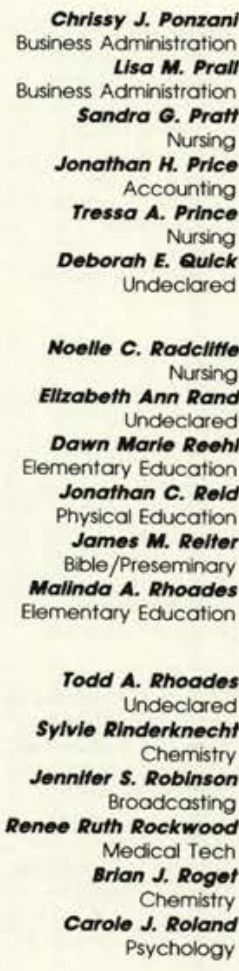

Catherine A. Romano English Business Administration Denise C. Ross Psychology/English Tracy A. Roy Political Science Judy L. Runge Accounting Glen W. Salloe

Robert M. Sand Business Administration Shirley J. Schneppe

Pre-Optometry

Paul N. Schultz

Physical Education

Kelth A. Seager Elementary Education

E. Yvonne Selpelt

Yvonne Selpeit

Todd E. Shonnan

Accounting

Rlchard P. Sharpe Pre-Med./Biology

David $M$. Shepherd

Pol. Sci./History

Marlene $\boldsymbol{K}$. Slefert

Elementary Education

Holly L. Silver

Tammy w. Sloan

Undeclared

Dave M. Slyby

Communications
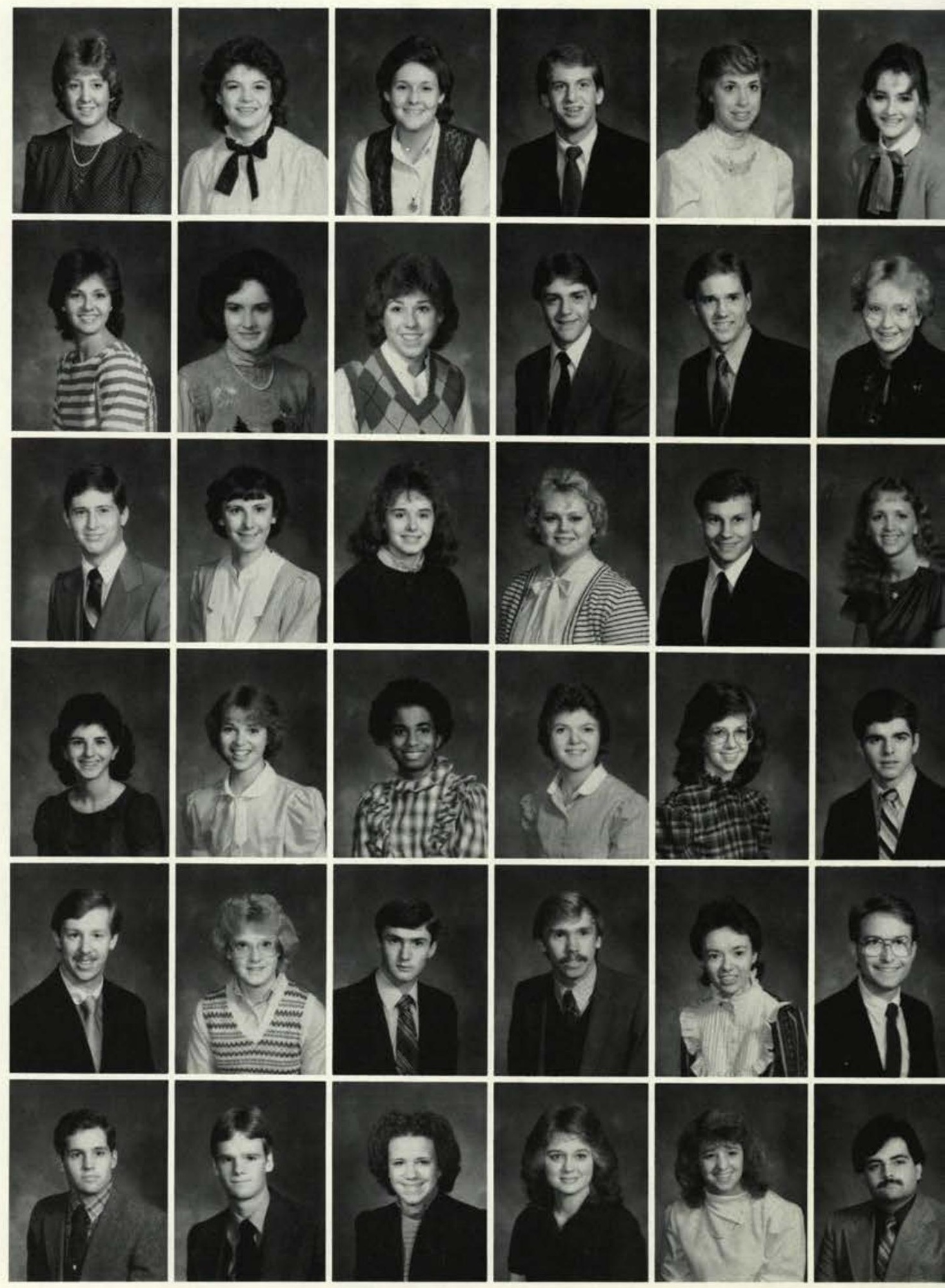
Jonathan David Tuttle Jettrey C. Vander Helde

Barbara Kay Vanness

Accounting

susan Claire Vaughan Physical Education KImberlee S. Venman Bridgot $\boldsymbol{K}$. Vissman English/Secondary EO

Joy Marle Wagner Laura Eva Walker Undeclared Michael A. Walker Chris Michael Walter Accounting Ronald Eugene Walter Bible/Preseminary Mike Leroy Walton Business Administration

$$
\begin{array}{r}
\text { Robert K. Ward } \\
\text { Preseminary } \\
\text { Brian J. Wartle } \\
\text { Elementary Education } \\
\text { Debra Ellen Wasson } \\
\text { Nursing } \\
\text { Sherrl L. Watson } \\
\text { English } \\
\text { Diane Lynette Weaver } \\
\text { Nursing } \\
\text { Jon Karl Weber } \\
\text { Communications }
\end{array}
$$

Chrlstine Rae Weldman Elementary Education Jason James Weindort

Kurt $v$ Accounting v. Welsenfluh Business Administration Psychology/Behov. SC

Mary Lynn Wells Broadcasting

James $\boldsymbol{w}$. Wemett Undeclared

Steve Mark Wemett Judith Joy Wiology Judith Joy Weston Anita Kay Whipplo Tammio sue whitaker rammic Sue Whitaker Business Administration Sherl Lynn Whitcomb Pyschology

Jerry Andrew White
Pre-engineering

Rebecca J. White Davena Michelle Whitham Judith Koren whist Elementen Whitraker Elementary Education Psycholnda Lea Wick Chology/Benav. SC. Torry L. Wilder Bible/Preseminary Business Administration

Kenneth Jerry Williams Business Administration Kay Michele Wilson Business Administration Joy $s$. Windham Elementary Education Kendra Sue Witfenbach Elementary Education Linda Ruth Woodgate Pamela Joan Woods

Peter R. Wright Broadcasting Laura Elizabeth Wuestner Business Administration Jacquelyn Jean Wyse

Jacqueiyn Jean Wyse

Angela Kathleen Yost

David Loo Zursing

Preseminary
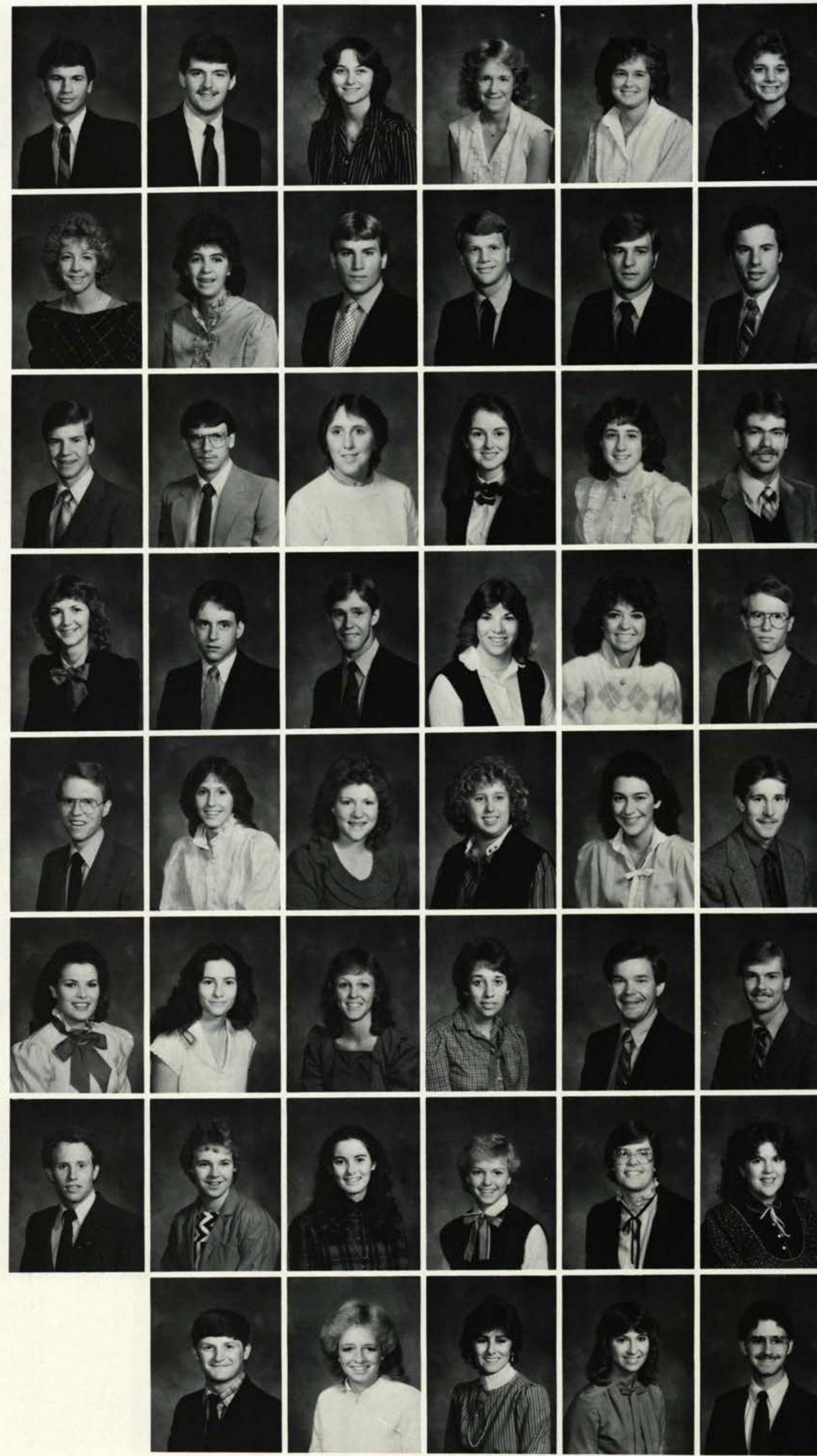


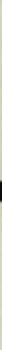

\section{"TH

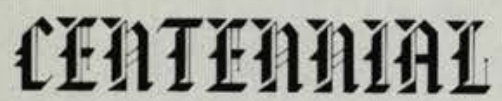 (XIASG"}

1 he class of 1987, the Centennial Class. We, the Freshmen, represent the 100 year aniversary of Cedarville College. Ne arrived on campus on that warm autumn day to experence long lines, long meetings, and hundreds of new faces. But oon we developed into a class with a strong bond of unity. great enthusiasm, and most importantly, a heart for the Lord. In the next few years, we will exserience good times, and mayse even hardships that will help us to develop into men and women so much different than those who stood in long lines on that warm autumn day. We will mature into men and women who will glorify God and hopefully be an excellent representation of the 100 year anniversary of this great institution.

\section{Contributors:}

Stacy Gunther .......... 110

T.J. Rivetti .............. 112

Amy Thomas ............ 114

John Williams .......... 116

Julie Stackhouse . . . . . . . 118

Lamar Eifert . . . . . . . . . . . 120

Laura Fish

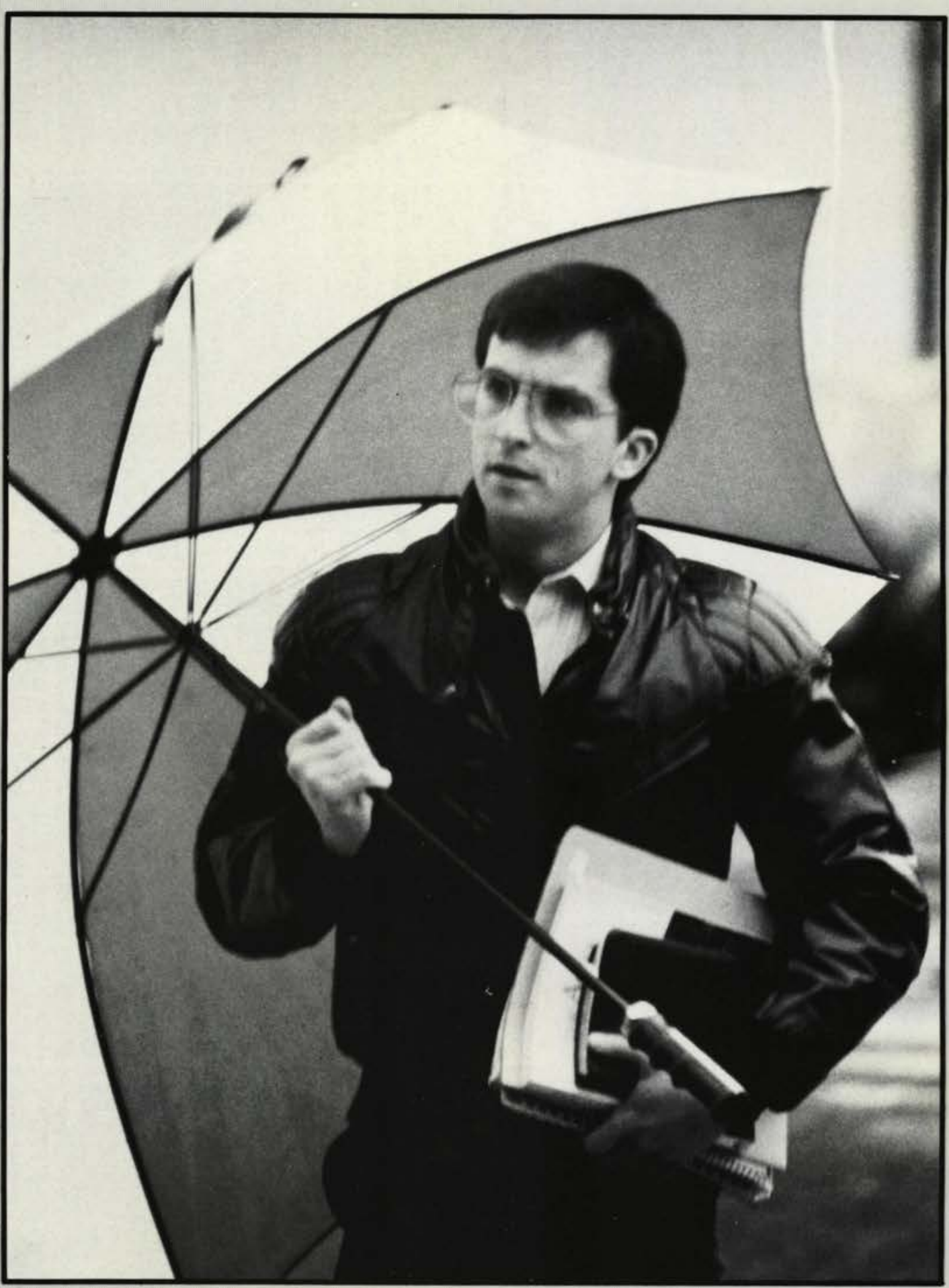

ayout By:

(aren Beattie 

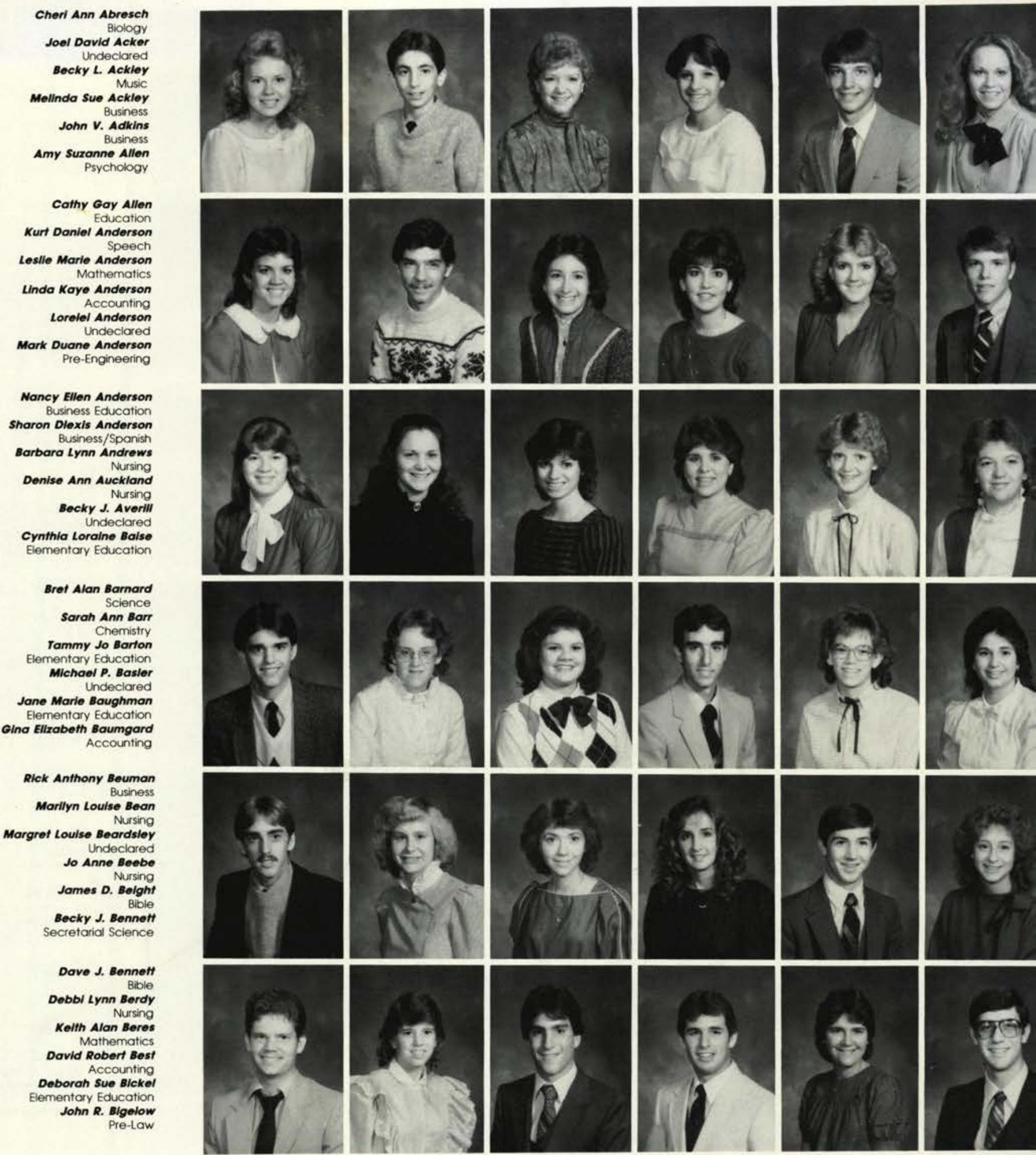

$W^{\text {ith the car packed full to over- }}$ parents and I headed down the road. Our destination on that sunny September day was Cedarville College. As we travelled, some questions filled my mind. What will college be like? Will I have fun? Will l like my roommate? Will I fit in?
Upon arrival, my first challenge wa - registration. After being pushed anc shoved and standing in line, I emergec with a stack of papers, a key, and c funny looking rock in my hands. Then, was off to my home away from home the dorm. I searched for my room anc was greeted by four bare walls and ai empty looking room. This too would be a challenge.

Before long, Cedarville took on c more positive appearance. With a fev posters here and there and some spe 


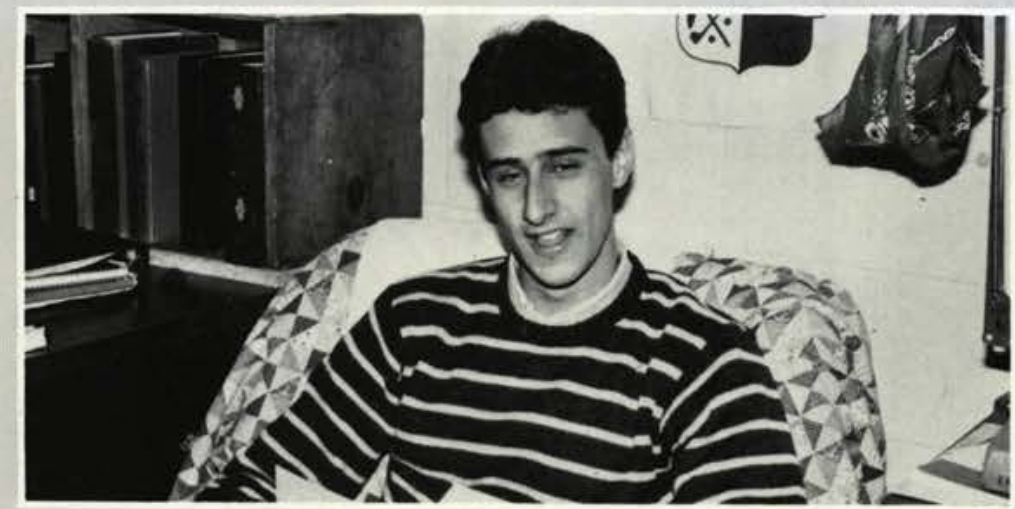

As the Class of 1987 contemplate A the upcoming Centennial Cele bration, we see the importance of re flecting on where we have come fron and anticipating where we are goin as a Christian, liberal arts institution. A a freshman class, we need to have
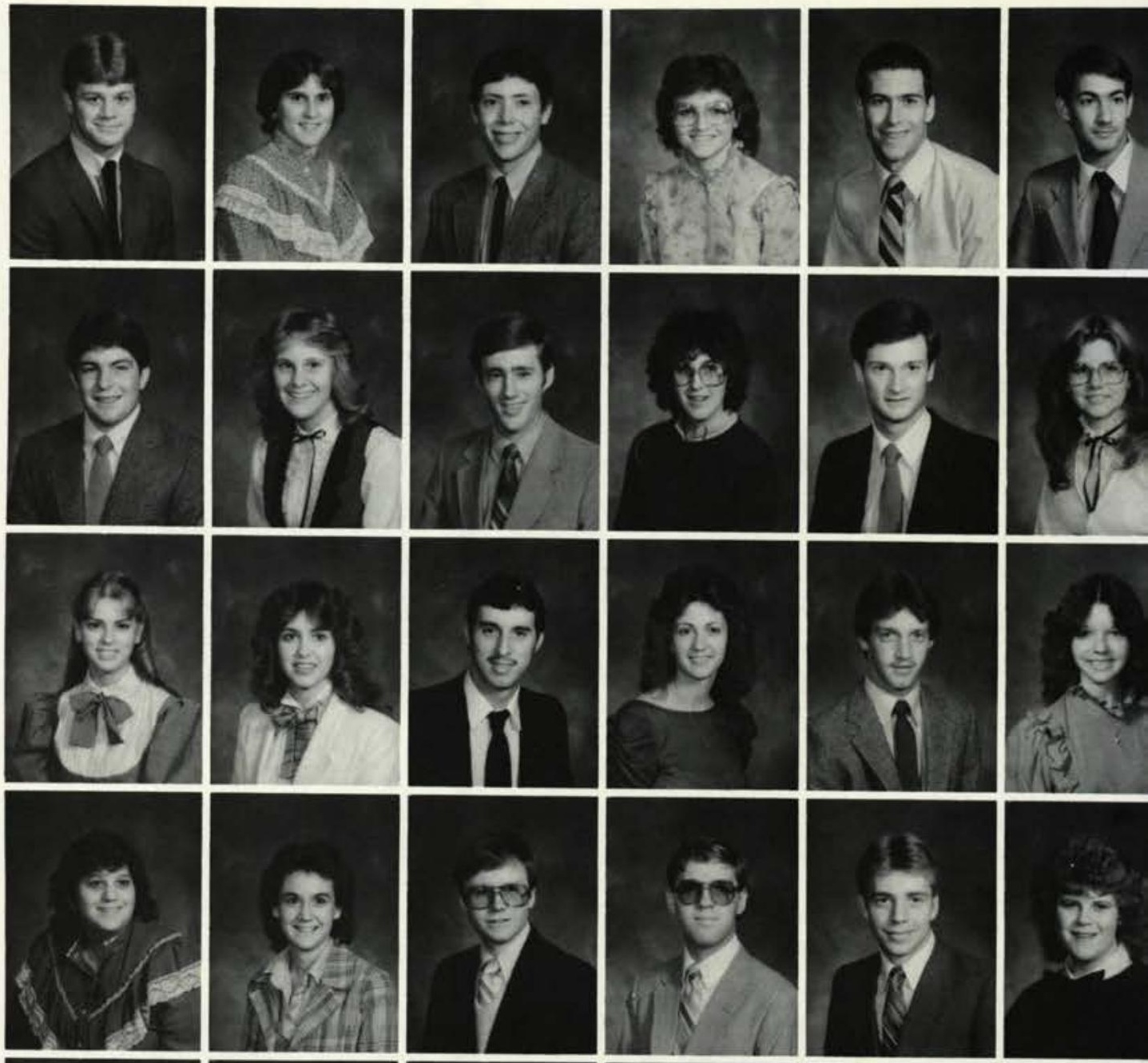

Jodie Dane Credity

Angela $K$. Cremean Undeclared

Chrisfopher Scot Cripe

cynthia 4 sychology

lementary Ed/Missions

Clancy Calvin Crulse Bible/Physical Education

Carolline welch Curtis

Elemenatry Education

$$
\begin{array}{r}
\text { Troy Dale Custodlo } \\
\text { Biology } \\
\text { Christine Fern Dall } \\
\text { Elementary Education } \\
\text { Dianne Allce Davis } \\
\text { Business Education } \\
\text { Kimberly Anne Davis } \\
\text { Undeclared } \\
\text { Timothy Paul Davis } \\
\text { Physical Education } \\
\text { Timothy M. Day } \\
\text { Pre-Law }
\end{array}
$$
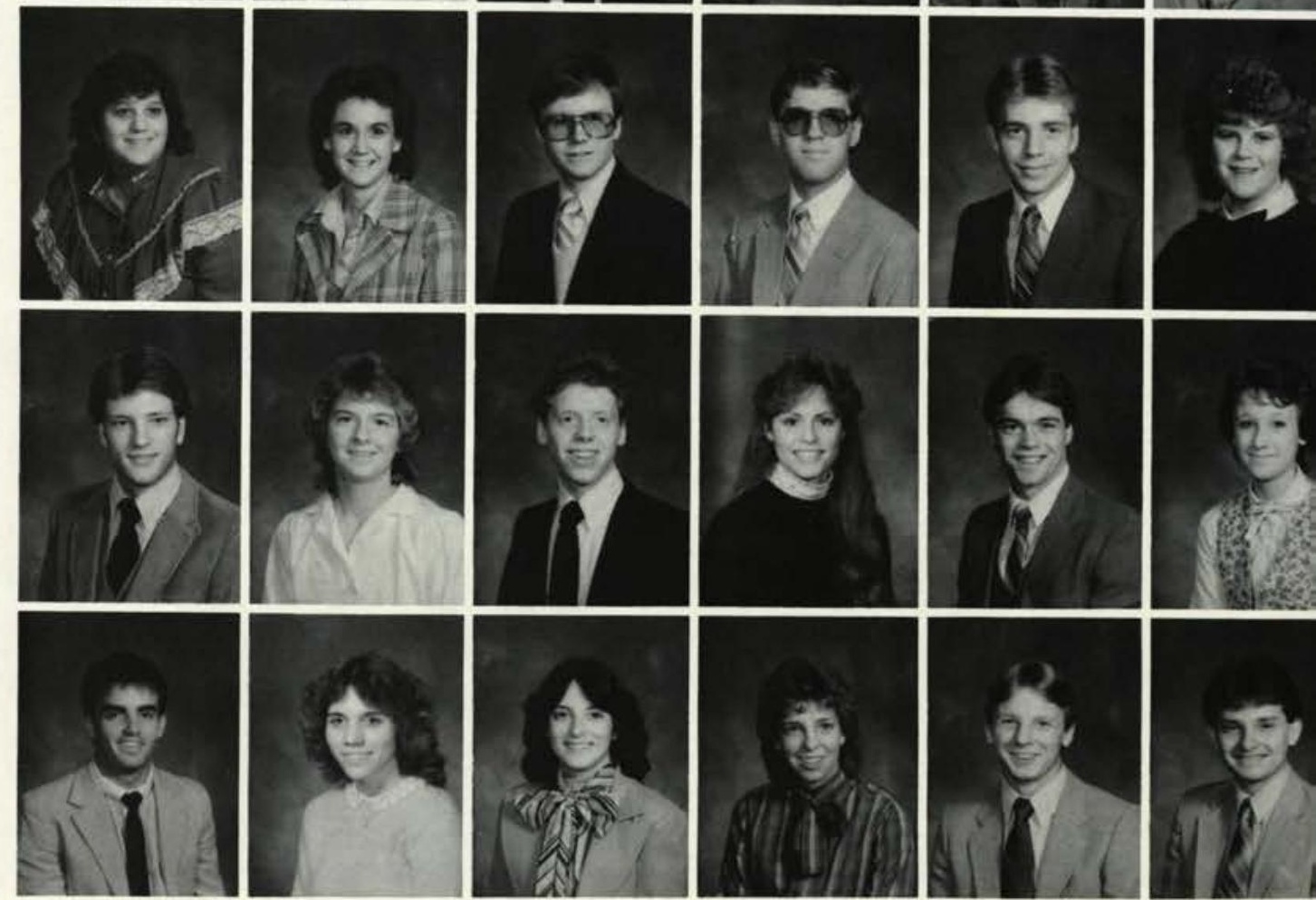
greater understanding of the princioles, values, and purposes upon which our school was founded. In doing so, we can responsibly take on the task of exemplifying how the recipients of a Christian, liberal arts education should 'ace and handle life's difficulties. Havng the privilege to attend Cedarville after one hundred years of hard work and determination, our freshman class heeds to seriously remember our obligation to succeed, for success is what ve all must strive to attain.
Looking forward into the future, our future in our society, we must become leaders to meet the demands of our forever moderninzing society. Striving for excellence in all that we do must be our foremost goal and that also includes the preparation of the Centennial Celebration. The freshman centennial class is an example and hopefully will stand as a model for future classes of our great school.

\section{By T.J. Riretti}
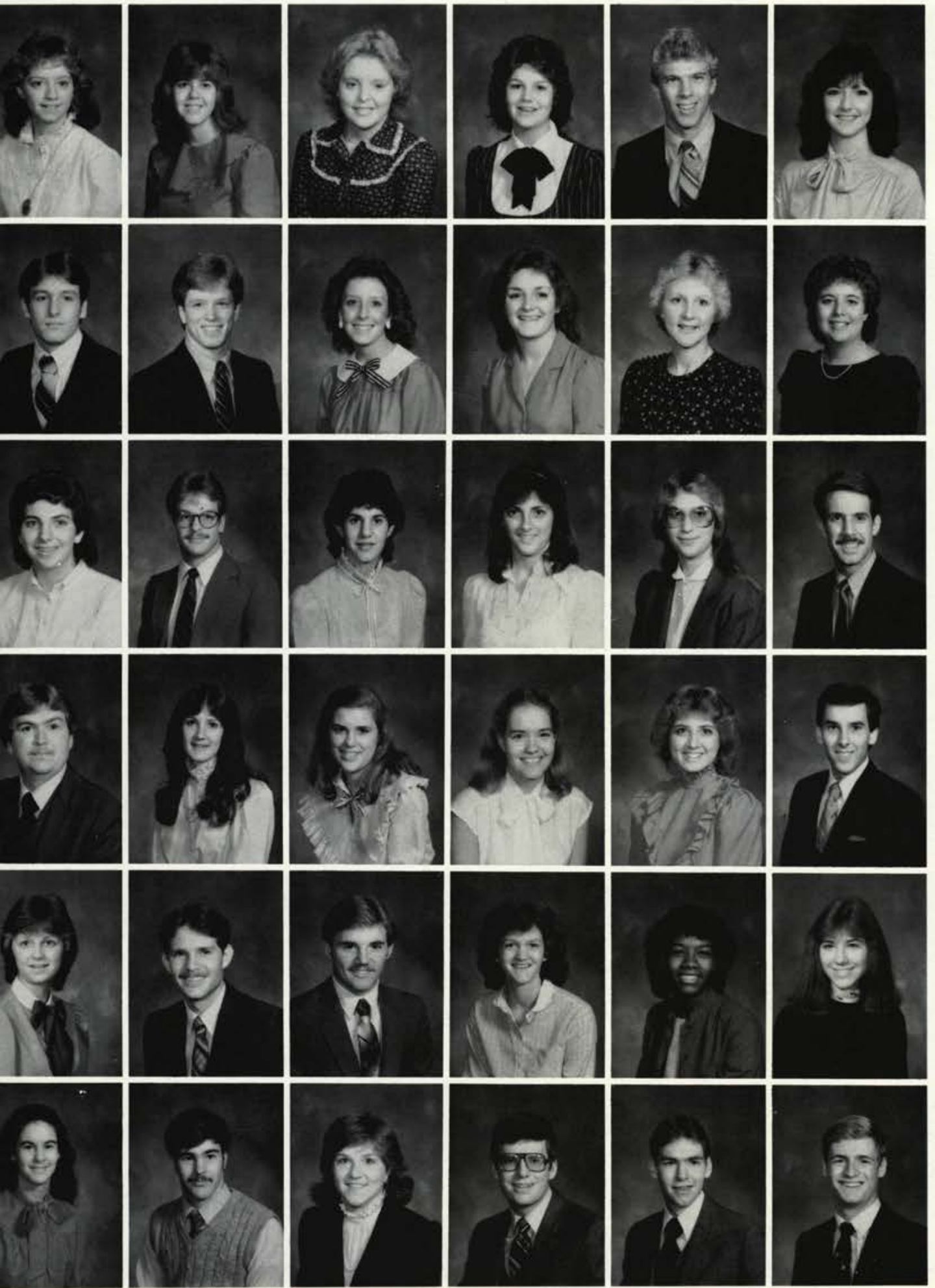
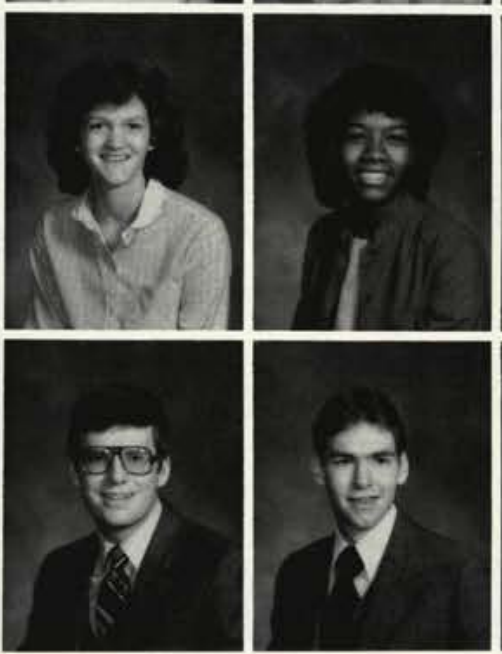

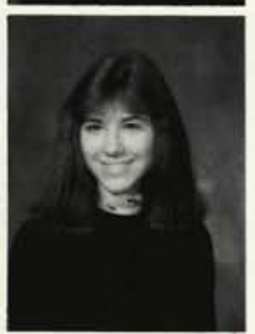

Jenny S. Dean

Business Administration

Susan M. Dean

English

Sandra Jeanette DeBolt

Nursing

Kelly Jo Docker

Nursing

Steven John DeCook

Pre-engineering

Susan Patricla Deegan

Undeclared

Perry Clayton Defellee

Pre-pharmacy

Brian Patrick Deffet

Business Administration

Shawha Marle Denney

Showha Mario Denney

Judy Kay Denning

Political Science

Katherine Denty

Janet F. Derstine

Secretarial

Theresa Ann Deshetsky Business Administration Matthew J. Dickinson Accounting

Annette L. Dimacehica Business Administration Robln Kay Doan

Elementary Education

Kendra Jean Doctor

Elementary Education

David Frank Dooley

Undeclared

Kevin James Doseck

Broadcasting

Joy E. Douglass

Undeclared

Rebecca Jane Dye

Nursing

Debble Ann Dysert

Music Education

Judy Elaine Eagleston

Undeciared

Luke S. Eoton

Mathernatics

Anne Ellzabeth Edwards

Psychology

David J. Edwards

Psychology

Lamar C. Elfort

Psychology

Christina Elotzinger

Lita Marla Elmore

Nursing

Sally Jo Englo

English/Second. Ed.

Judith Ann Enman

Bible

Michael James Enman

Mathematics

Tammy A. Evans

Psychology

Dan Davld Everett

Pre-veterinary

Jonathan L. Exley

Pre-Medicine

Clifford Willam fawcett it

Bible 


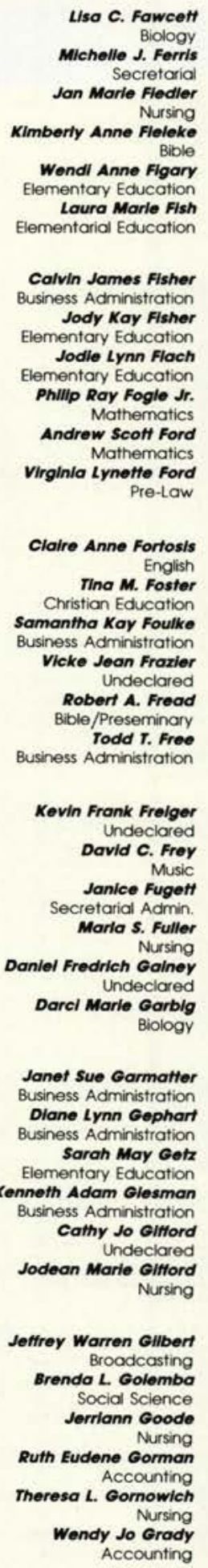
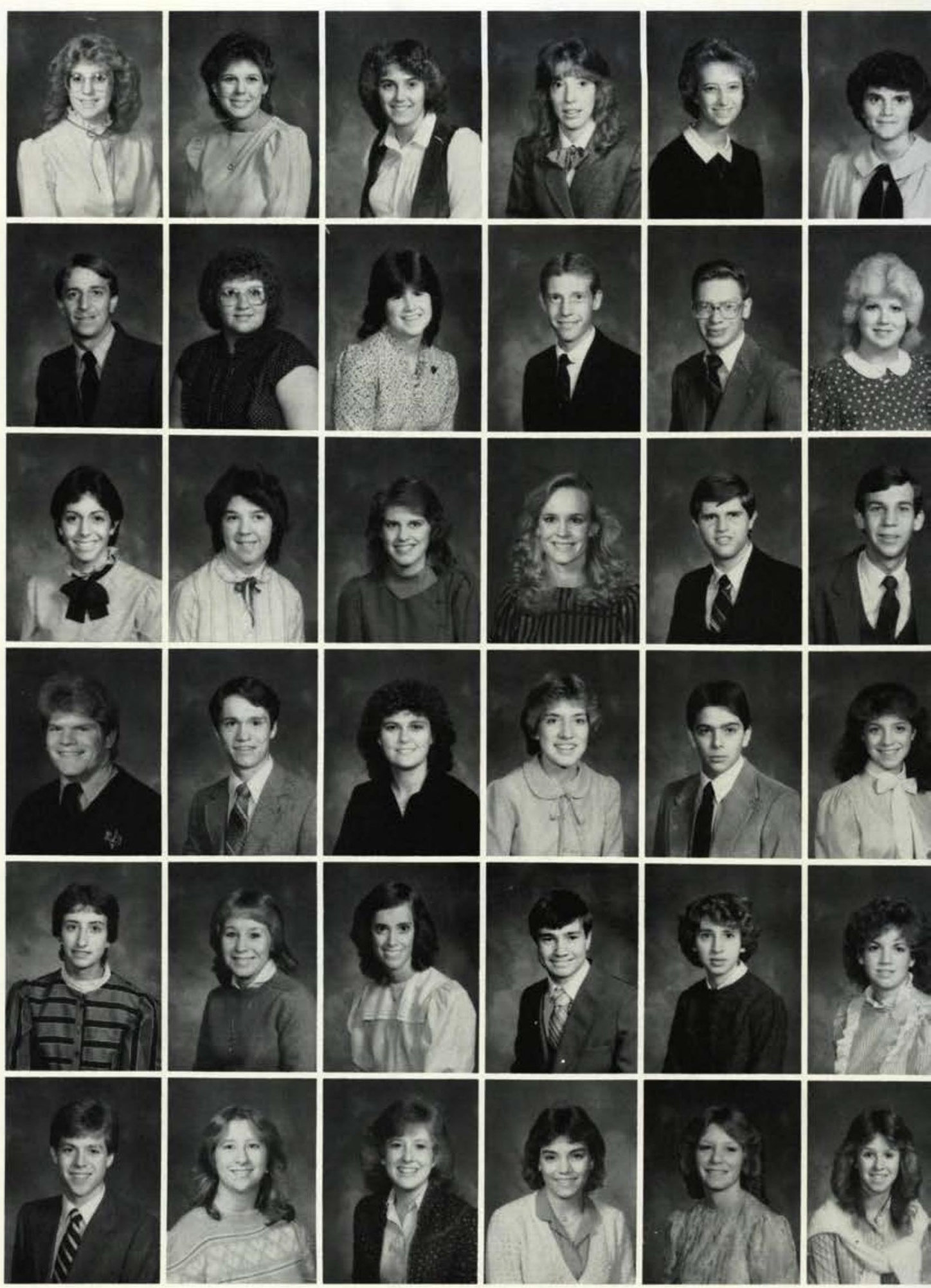

1

can remember standing in the chapel, scared stiff and looking very "freshmanish," not believing that the day so long anticipated had finally arrived. I had never seen so many lines. Being the efficient person that I am, I decided to get the longest line over with first, only to be told (when I got to the front, of coursel) that skipping lines was not allowed.

After registration, we made our way to the new dorm. There were boxes, clothes, suitcases, a guitar, sewing machine, typewriter, books, a rocker, two bean bags, and all of our health food for the refrigerator. WE did find a place for everything!

After we stashed all of our belongings just in the nick of time, we needed to beautify ourselves for our big debut at dinner time. When the hour finally arrived, we were ready with the perfect outfits; every hair was in place. and our make-up was applied with the 


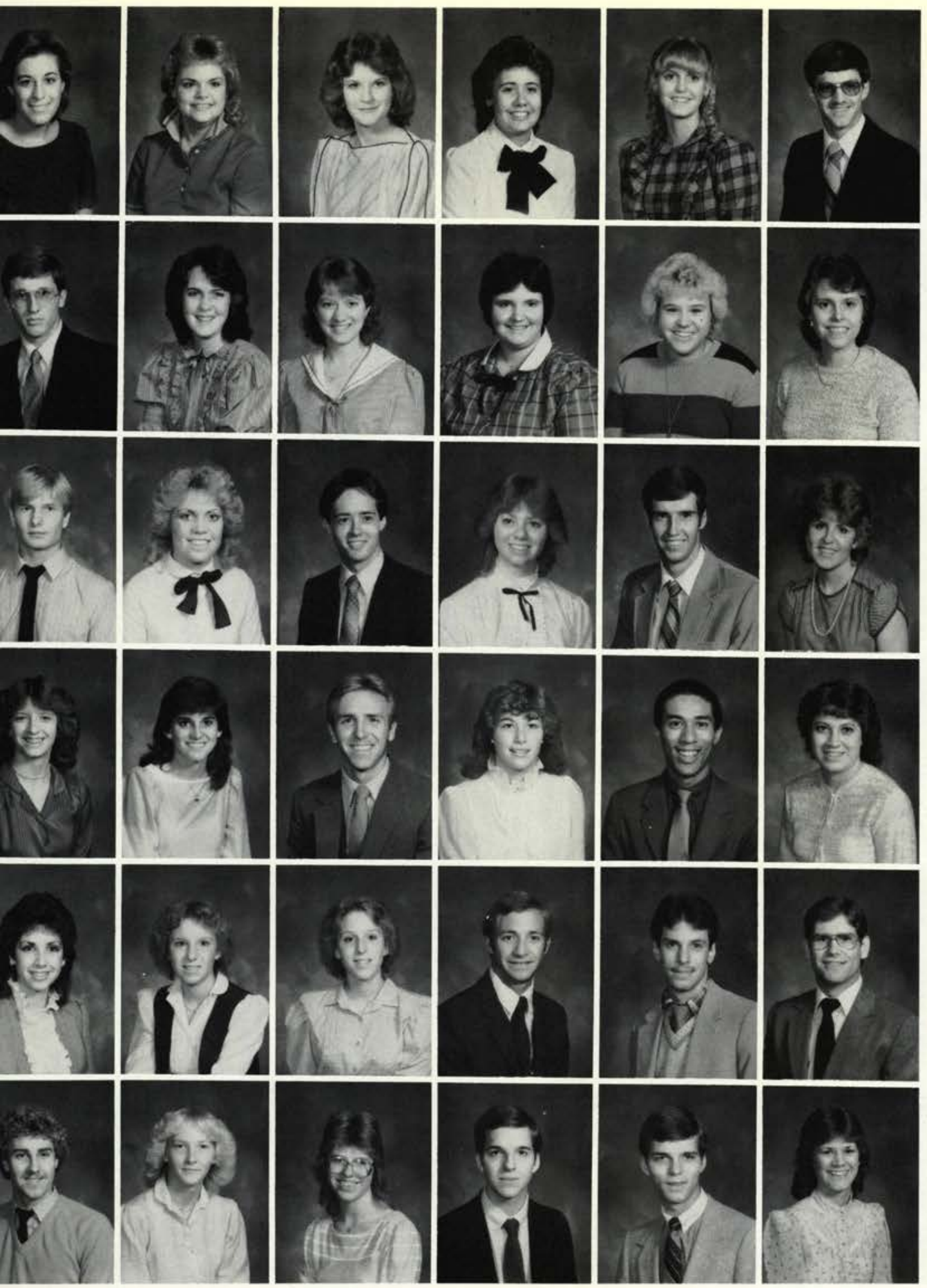

Mitzl Irene Graybeal

Undeclared

Sarah Michele Greenley

Computer Science

Christine Ruth Oriffith

Nursing

Tracy E. Orimes

Mlchael Davld Grinnell

Medical Tech.

WIIIIam G. Grosk

Business Administration

Amy Jo Quest

Uusiness Administration

Virginio Ann Orunelsen

Stacy Lolgh Gunther

Elementary Education

Brenda Jo Gusi

Nursing

Lorl R. Haberll

Nursing

John R. Hackbarth

Bible

Lyn Marle Hackenberry

Elementary Education

Gregory Allen Hale

sychology

Karen Dlanne Halnes

Elementary Education

Dean Robert Hammond

Pre-Engineering

Laure S. Hancock

Pre-Law

Jonda Sue Hankins

Secretarial Administration

Dlann M. Hardesty

Mathematics

Bradloy Roy Hardwick

Mathematics

Kathl Jennifer Harris

Undeclared

Larry LoRoy Harrls

Broadcasting

Shelly Lynne Harris

Psychology

Laura A. Hartsough

Nursing

Anna Kathleen Haskowich

Nursing

Frances J. Haskowich

Business

Rlehard O. Haywood

Pre-Law

Larry Leon Heacoy "I

Pre-Engineering

Jettrey Lee Hetfelfinger

Psychology

Jefferson Lee Helland

Dlana L. Heltzma

Business

Cynthia Joan Helmick

Undeclared

Eric D. Helmuth

Undeclared

Matthew Loe Henderson

Pre-Law

Nadeen Kay Henderson

Elementary Education

reatest of care. Now please tell me, Shuck McKinney, how in the world is a irl supposed to make a favorable imression when she's sitting on the round, trying to balance a paper late, and eating corn on the cob and arbecue chicken?

But it was only the beginning. A beinning that led to a great year at a reat school with great people, and I hank the Lord for it.

by Amy Thomas

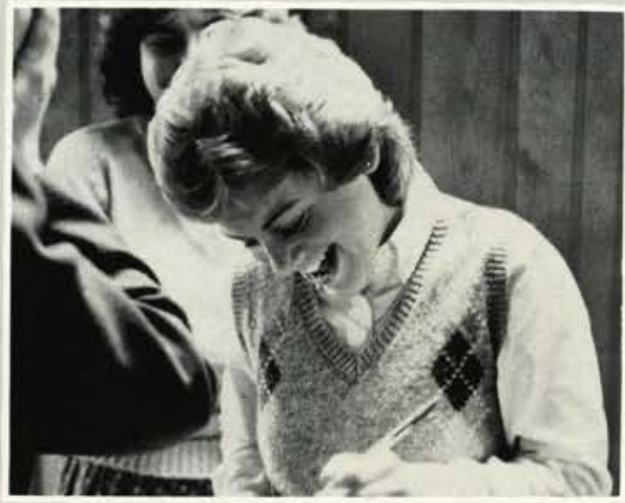




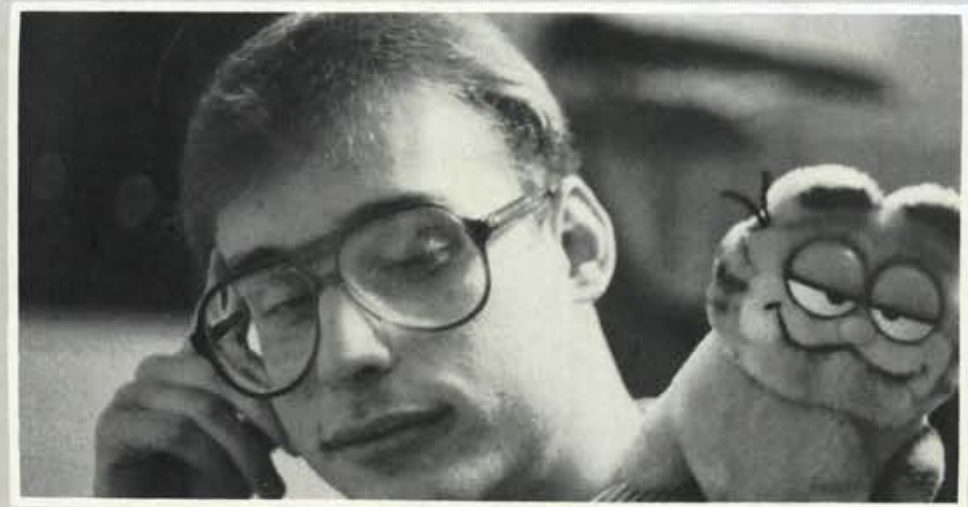

C ome psychologists have stated $\checkmark$ that we tend to remember the good times we have had and blot out the bad. When I was asked to write this article, my mind drew an almost complete blank. After further consideration, though, I realized that the year hasn't been that bad.

The "culture shock" of coming to college was somewhat lessened for me because I knew a few people from home, namely those that had graduated with me. Still, the transition was a

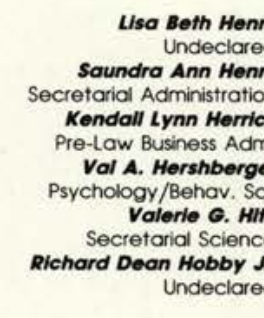

Virginia Marle Hochstettler Nursing Candace S. Hodge Biology Beth Jeanne Hoecke Nursing Angla Leah Holma Phillip Dean Hopper Phillp David Horn Accounting

IIII Lynnette Horvath Accounting Joel Mark Hoskinson Accounting One Year Bible scott Jonathan Howder Undeclared

Dorothy Elaine Howdyshe Elementary Education Steven D. Hudlet Pre-Engineering

Robert George Hugan Pre-Engineering Paul R. Hughes

Business Business Marle Hu

Paul Mae Hun

aul Mae Hunn Undeclared Nursing Ann Hunter
English Education

Kristine Kay Hyatt Kristine Kay Hyait John Thomas Irving Ji.

Robyn Annette Irwin Accounting Douglas Scott Iverson Undeclared Christine Lea Jackson Undeclared Lloyd Charles Jackson Pre-Medical

Rlchard Don James Business Administration Undeclared

Susan Laverne Jessop Elementary Education

Connie Sue Jessup David Garland Johnson Broadcasting Diane Johnson Nursing
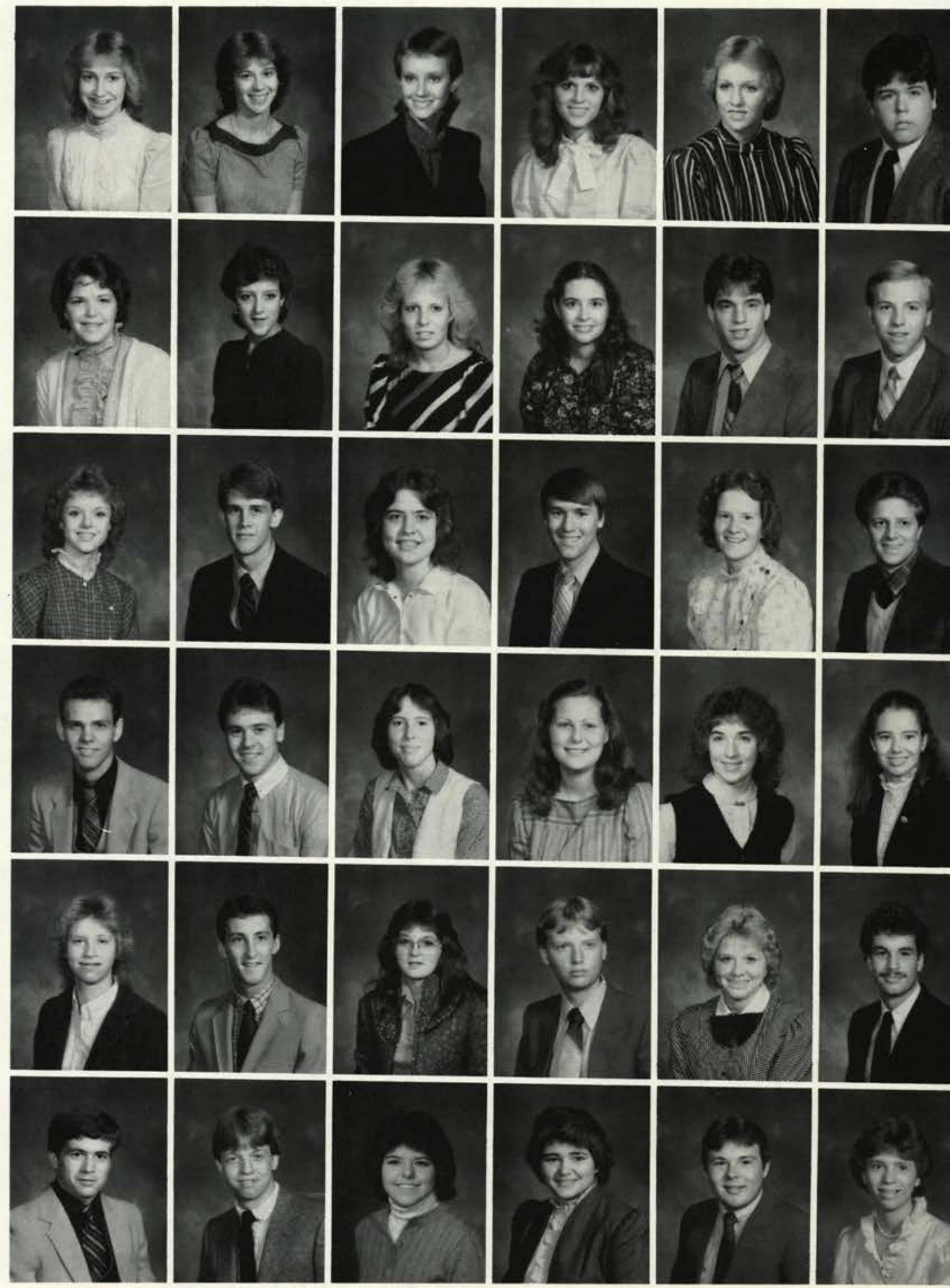
little difficult at first. The lines were unbelievably long; the food was not home cooked, and I have never seen so much money change hands so fast! We've spent the past school year making memories of our newly encountered experiences: college basketball games, "all nighters," Dr. Dixon's chapel messages, and the first phone bills. It would take another year to remember them all and share them with our parents and friends.

For me, at least, the social and aca- demic scene could probably be summed up by the famous sports commercial: "The thrill of victory ..." No, I mean it! I actually have a date, "... and the agony of defeat ...." and "I get the feeling that I'm going to see that prof again next quarter.'

Our experiences learned will be used again and again; the friends won will last forever, and those memories will linger on long after 1984 is over. All in all, it's been the kind of year that makes me want to come back for more.

by John Williams
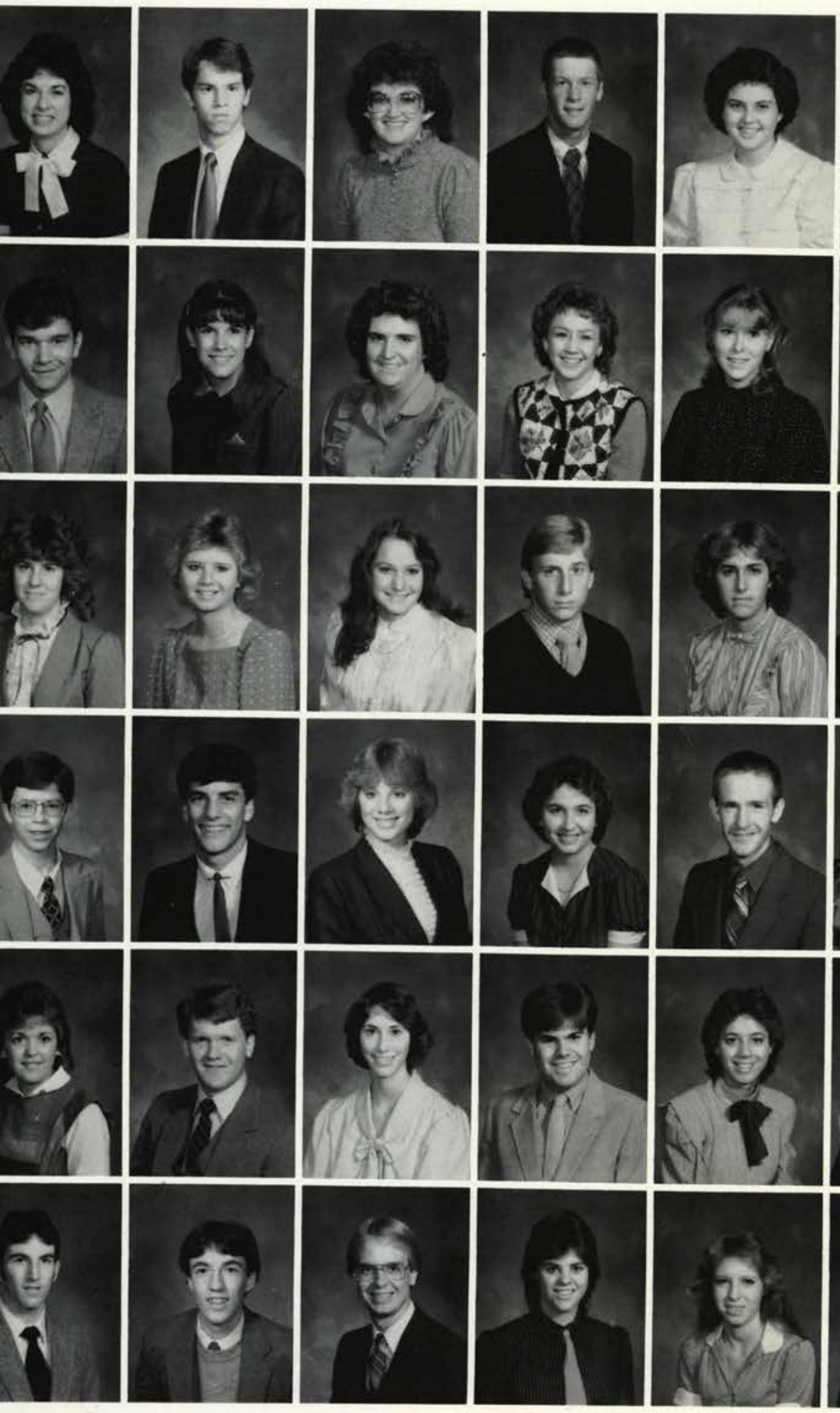
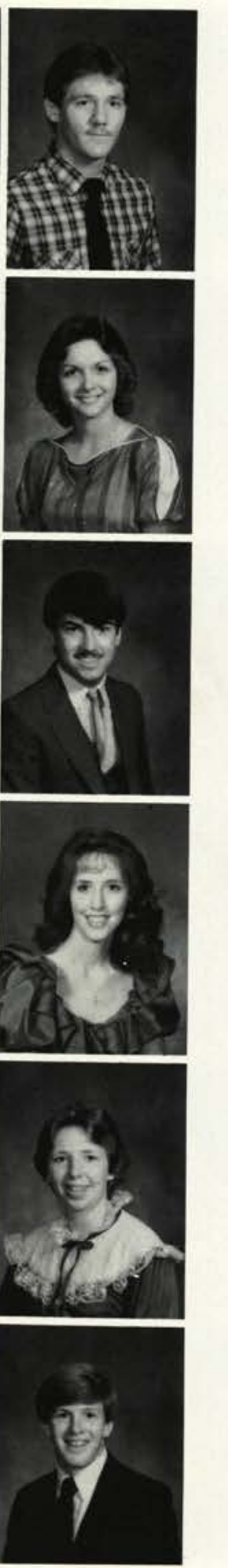

Kelly Lynn Johnson

Nursing

Stephen John Johnson

Psychology

Virginia Irene Johnson

Business Administration

Robert C. Johnston

Biology

Robin Lynn Johnston

Special Education

Charles Jones

Physical Education

Erlc Don Jones

Accounting

Jonnilfer Ruth Jones

Secondary Education

Marsha J. Jones

Accounting

Mary C. Jones

surgy

Suzanne Eve Jones

Elementary Education

Tammy Lynn Jones

Elementary Education

Valerie C. Jones

Pre-medicine

Lynn M. Kadamus

Business Administration

Jennilfer Lynn Kellogg

Mathematics

Rlck Qlenn Kensinger

Broadcasting

Catherine Ellzabeth Kesinger

Nursing

IImothy B. Kesselring

Business Administration

Richard Thomas Kester

Undeclared

Davld w. Ketcham

Business Administration

Pamela J. KImble

Elementary Education

Both Ann KIng

Nursing

Russell Allan KIng

Connie A. Klrby

Elementary Education

KImberly $\boldsymbol{K}$. KIrby

Business Administration

James LIddon KIrfland

Undeclared

Danlelle Kay Klzer

Elementary Education

Jeftrey W. Klline

Undeclared

Rebecca Ann Klopp

Elementary Education

Mary B. Knicely

Mathematics

\section{James R. Koerber}

Undeclared

Desmond Wayne Koval

Pre-Law

Lorln Kenneth Kritte

Pre-engineering

Cheryi Jean Kuhbander

Elementary Education

Susan Jane Lafferty

Business Administration

Michael Cole Lane 
Sandra $M$. Lauterbach Business Administration Michael David Lav Music Education

Kathy sue Lay Elementary Education Jeffrey Alan Leach Spanish
BuII D. Lee BiII D. Lee

R. Frank Lindaberr

Doris Ann Lindley Undeclared Michael w. Little Undeciared

Michelle Barbara L/vingston Nursing Catherine M. Lombard Annette Mario Long Prelaw Linda A. Lon Accounting

Alberto Lopez Pre-medica KImberly Annette Loy Undeclared Amy Lynn Lyolle Secretarial Andrew P. Lyon Business Administration Brian Edward Maas Mathematics Terrl Lynn Mackenzle Music

Brian David Maddox Chemistry Lisa Q. Manion Undeciared JoAnne Loulse Mantz Accounting Holly S. Marshall English/Pre-Law Aprll D. Martin Wes C. Martin Business Administration

William Scott Martin Business Administration Lynda L. Masters

Bryan Kelth Mathews Pre-engineering Kelly Ray Mathis Lauren Dean Maxson Biology Secretarial Science

Terry Gone MeBrayer Diane Rae McClure Dlana Lynne McConnell Tracy L. McCoy Psychology Margaret Ellzabeth McGllivivay

Kelly Maureen McGinnis Bible
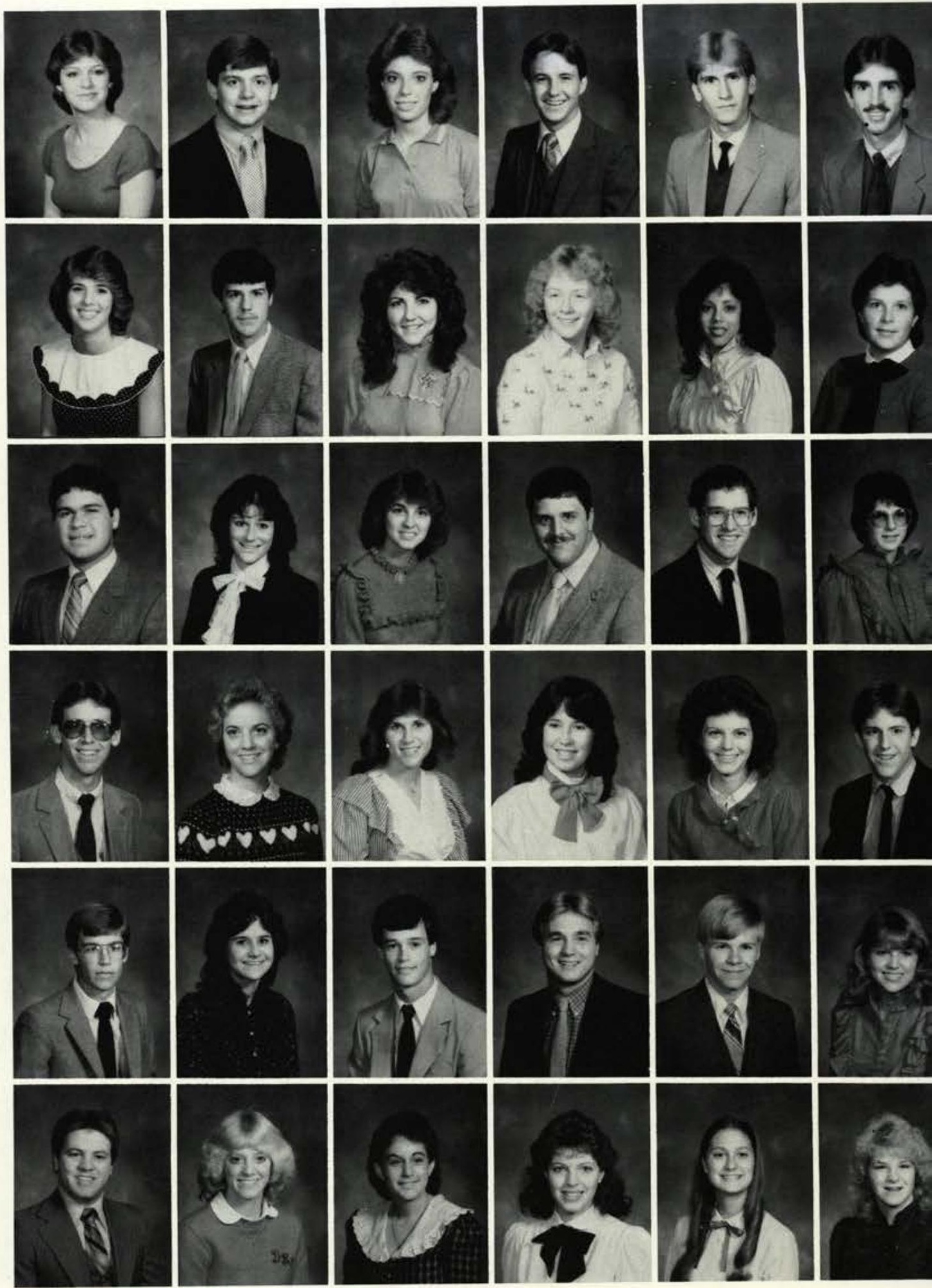

kay, Cedarville College, here I am. Love me. Accept me. Drool over me.

I am now on campus. "Yes, this is the normal freshmen attitude shared by most freshmen. Excited with high expectations, I arrived on the scene of the 'Ville. And what have I learned since that day? One should never eat the barbecue chicken the first meal here: never leave home without an umbrella; and never expect hot showers in the morning.
Oh, the memories ... shouting c the basketball games at the top of $m$ lungs for a team named after painf pests. And how about those cool wir ter days? Jack Frost ripping off you nose. I must be fair. The snow and slee beating against my fragile ea could've been prevented; I could'v worn brain suckers (alias: ear muffs) would've rather died!

Seriously, however, I have enjoye the very best aspects of Cedarvillo The chapel services have been a cor 


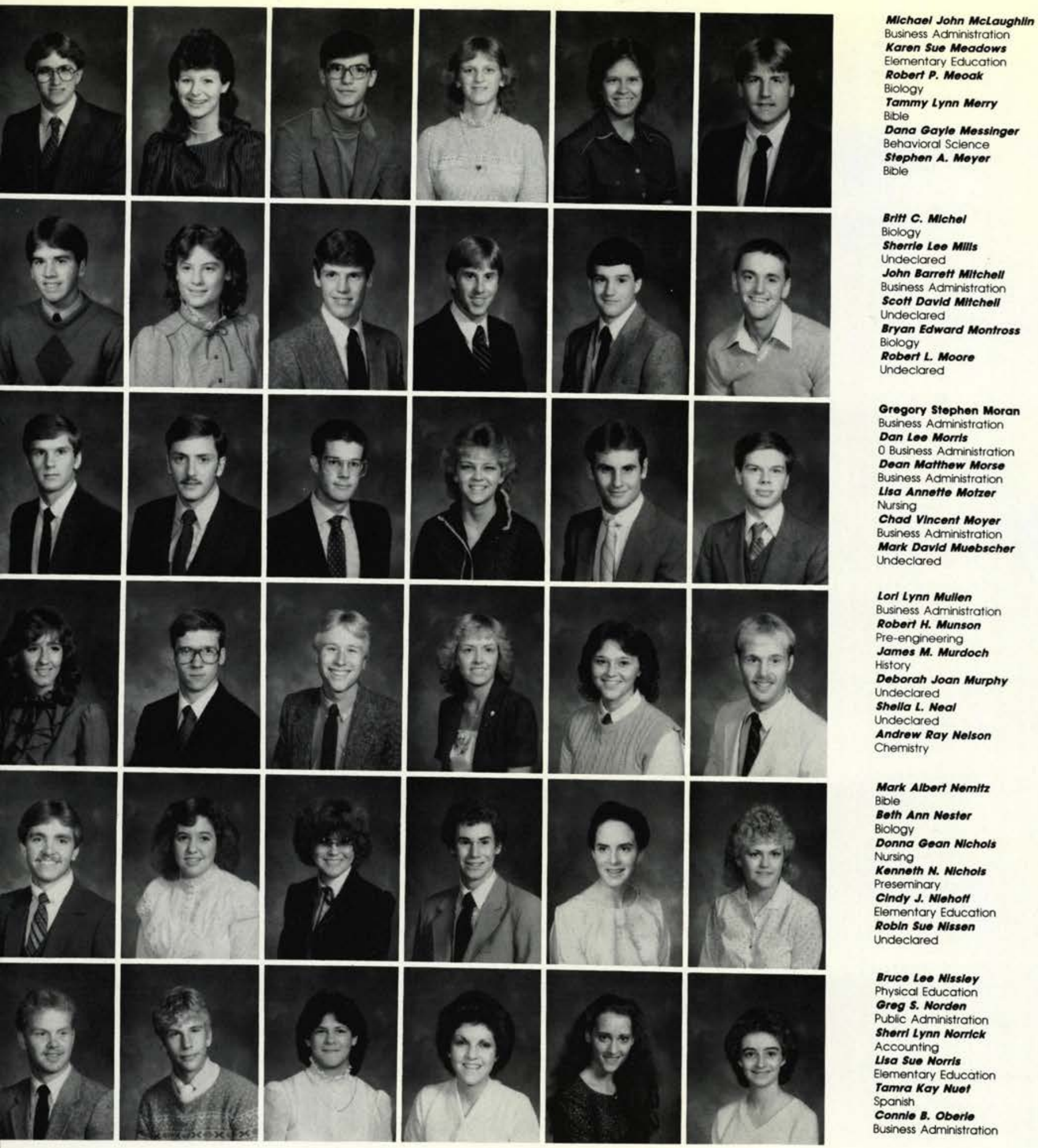

tinual blessing and have challenged me to grow in the Lord. In my classes, I have acquired massive amounts of knowledge. Finally, the friendships formed have enriched my life. There is hothing better in this world than to have a friend with whom I can be embarrassed, with whom I can laugh, and with whom I can cry tears of pain and joy. Truly, this is what college life is realy about.

by Julie Stackhouse

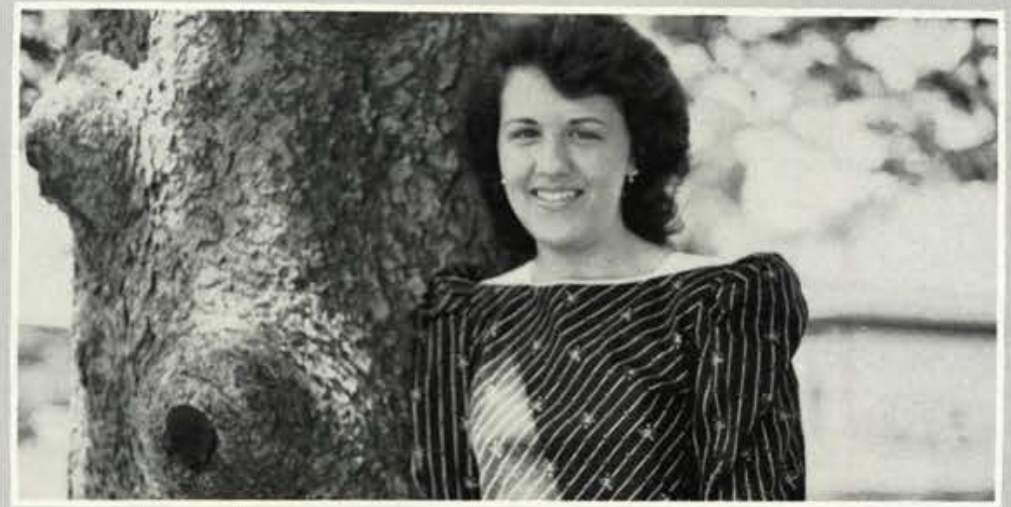




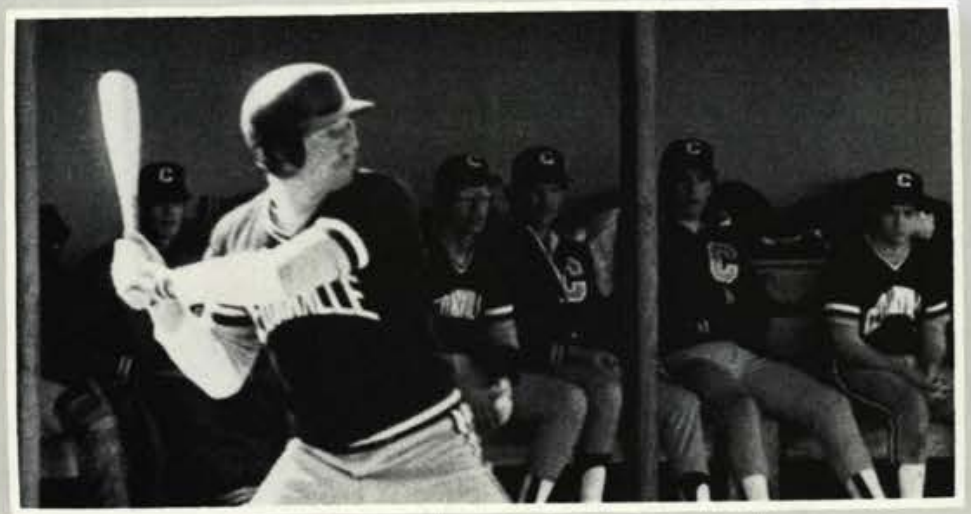

y name is Lamar Eifert and I'm a I freshman at Cedarville College. Before coming to Cedarville, I experienced the typical fear and anxiety that most students feel before they begin their first year at college away from home. The thoughts of leaving my family and taking on a whole new lifestyle and many new responsibilities caused me to be a little hesitant. At this time I had to learn to put my faith into action and trust the Lord for his will to be accomplished in my life.
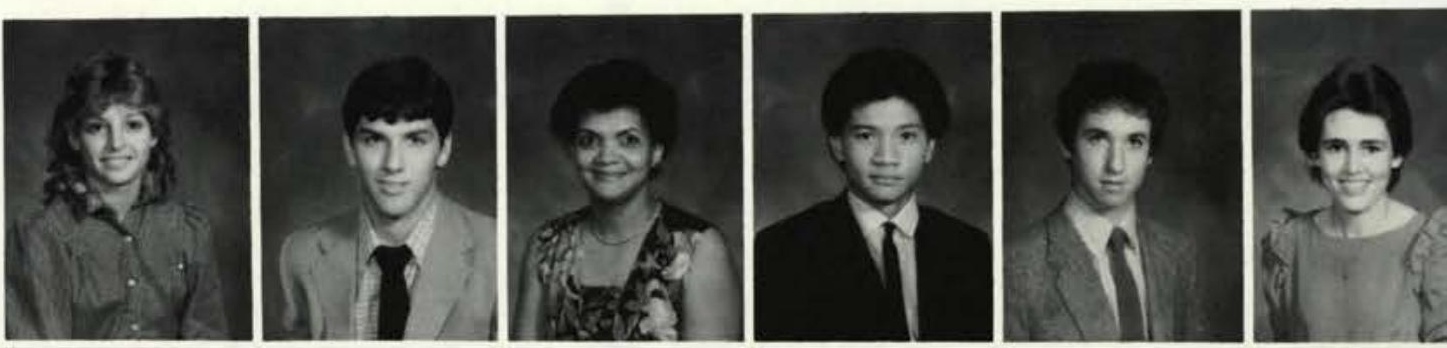

John Joseph Papp Business Administration Broadcasting

Deborah C. Pate

Physical Education

Max O.F. Pauley

Thurman Robert Payton

History

History

Nursing

Rhonda Michelle Perkins Mathematics Danlel C. Potek

Business Administration

Steve R. Peterson

Preseminary

Thomas Lynn Peterson

Amy Loulse Phillips

Behavioral Science

Phyllls M. Phillips

Undeclared

Stephen M. Plerce Undeclared

Llane M. Plercy

Jean Esther Pinkerton

Nursing

Jeftrey Scott Plper
Undeclared

mmy Marie Pistore

Gladys Caneda Plaga

Biology

John Mark Polson Business Administration Deborah L. Posey Iementary Education KIm Elaine Potts Undeclared

Rae Ann Powell

Secretarial Science

Dean Andrew Prlce

Business Administration Scott Price
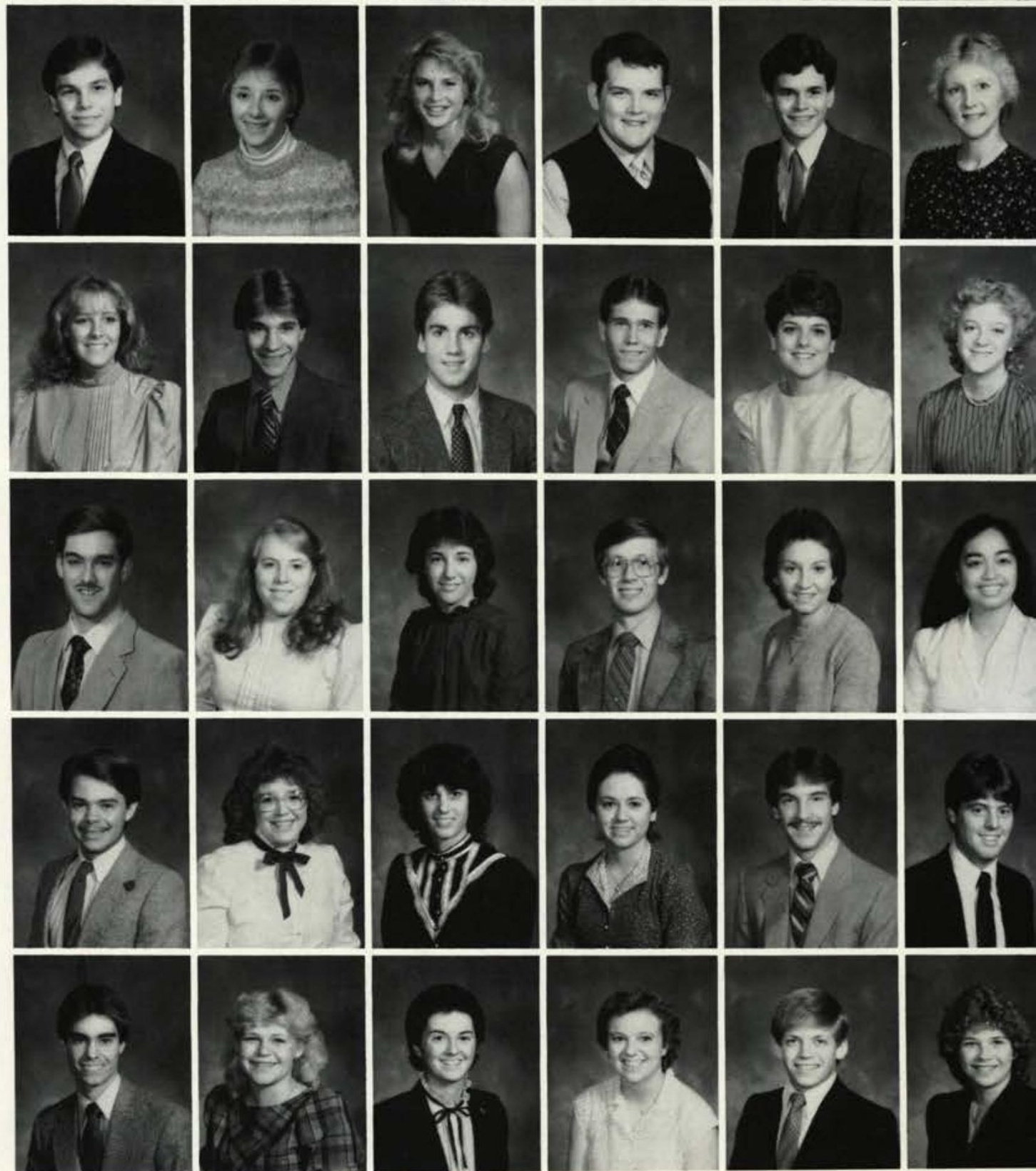

Douglas Edward Pugh Business Administration
Melvina Dawn Pugh

Undeciared
Kimberty Jean Ramsier

Sue Irene Rasmusson

Greg Richard Rawsong usiness Administration Business Administration
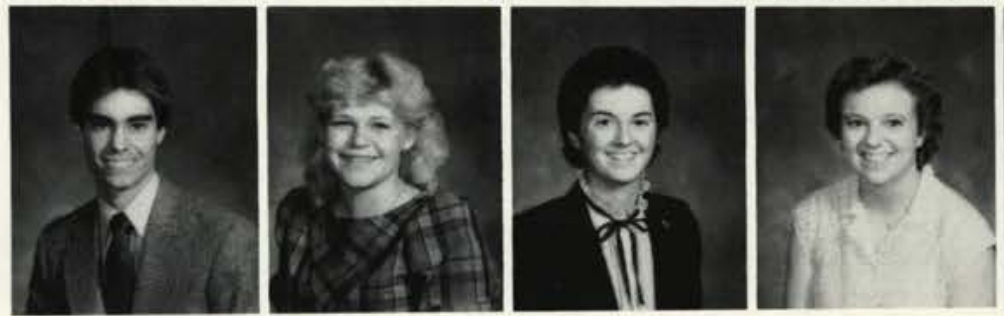


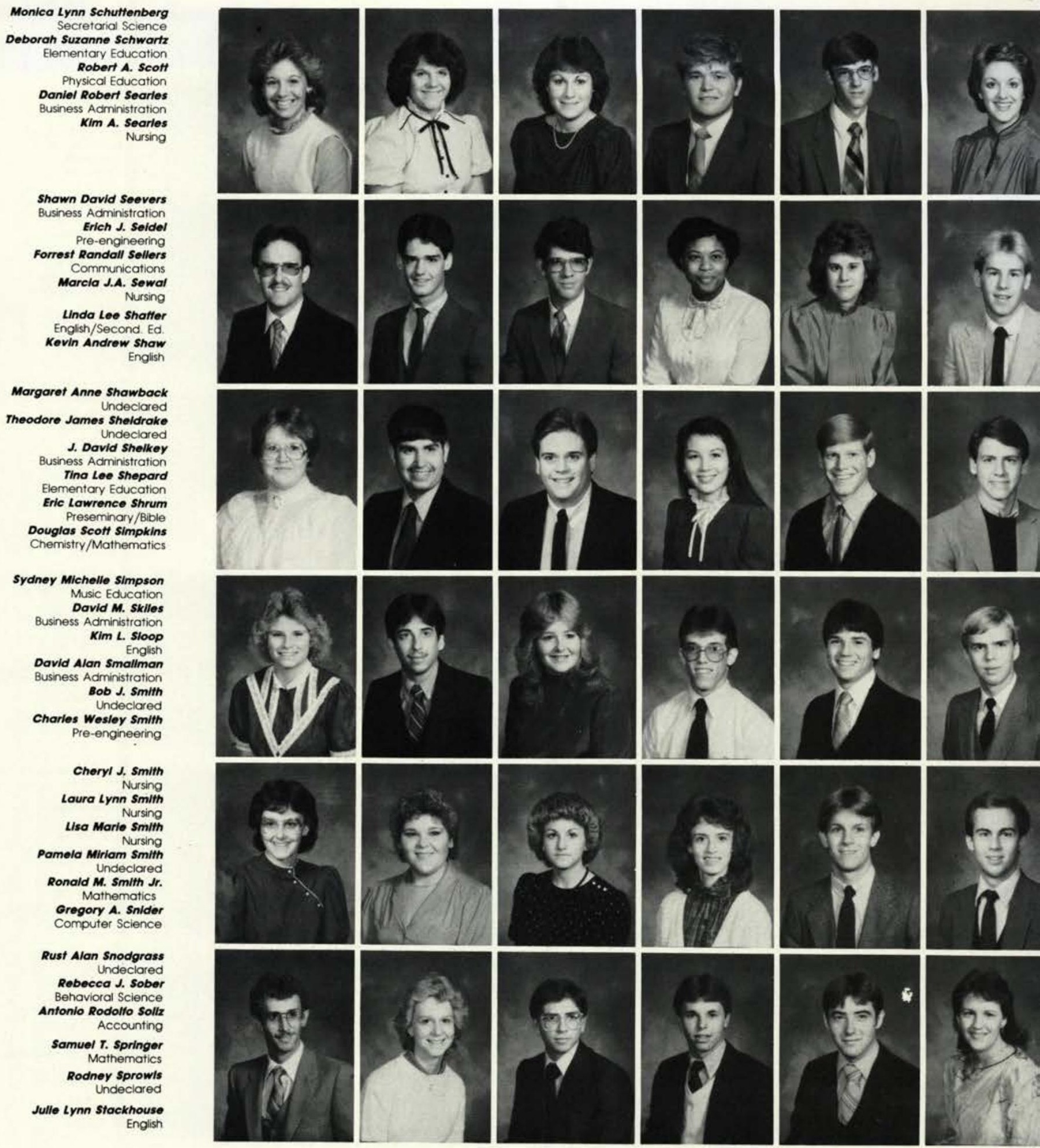

(3)

hawn David Seevers

Shawback

Wesley Smith

Cheryl J. Smith

Undeclared

ckhouse

English

$\mathbf{M}$

y first year here at Cedarville College has been a tremendous time of adjustment for me. Coming from Indonesia where my parents are missionaries, I arrived in America on June 5 , and ever since that time I have been reorienting myself to the American culture. When I arrived on campus, the difference hit me the hardest. Never had I seen so many people of my own race and language all in one place. I wanted to shout "hello" to ev- eryone to make sure that they coulc understand me!

Another big adjustment was the way that women are treated here America. In Indonesia, all the men sit ol one side of the church, and all the women sit on the other. I was just c little disoriented when I first walked intc chapel and everyone was all mixec together! I am still adjusting, but little by little I am learning to "be American" as my roomate would say. 


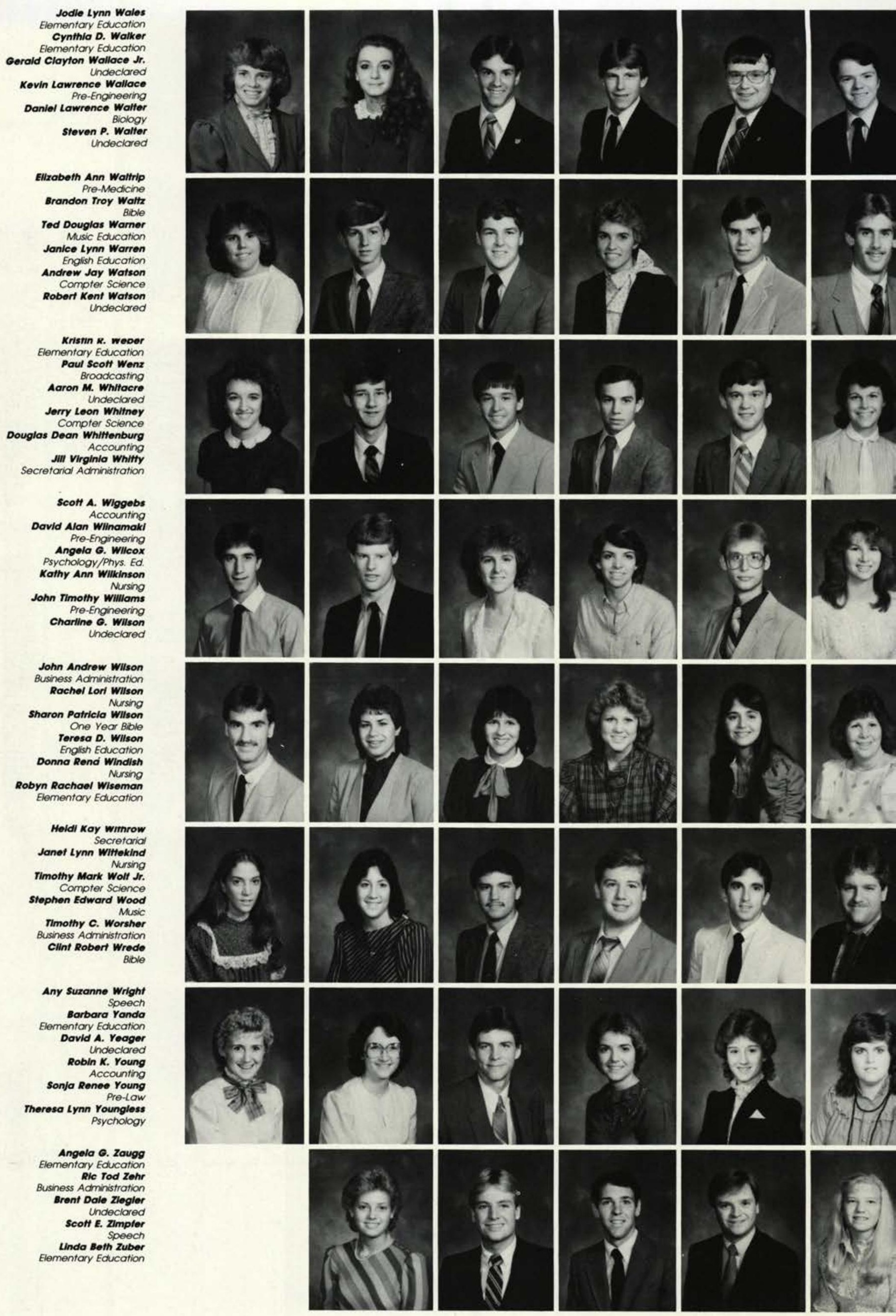




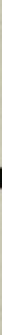

\section{"MORE THAN YOU \\ REALIZED"}

IThat's it like? I mean, what's it really like? To be a Cedarville College student, that is. What goes on in a day in the life ff one of those 1,800 fun-loving. izza eating, cold shower takh, all-nightering, hard(ly) rudying (take your pick) colge kids? This next section atempts to depict some of those veryday trials of life that somemes seem so trite and trivial. et, some of these experiences ccur so often that, when we op to think about them and xamine how much time we rioritize for them, they take on whole new meaning and sigficance. For example, three pit ops at the cafeteria every ay is hardly the excitement we ill-seeking young people thrive n. So what's the big deal? The eal is, some of us spend 45,60 metimes 90 minutes or more t mealtime socializing with our ends. I mean, really, do you ink anyone would be in there lat long just to eat!? As you rutinize the upcoming pages, e if you might, peradventure, cognize the fact that student $e$ at C.C. offers more than you alized.

by Bill Thomas

pntributors

Mrs. Joan Street

pat Farrow

Curt Berger

Matt Kunkel

Brandi Fisher

Charles Pagnaro

Pr. Ellington

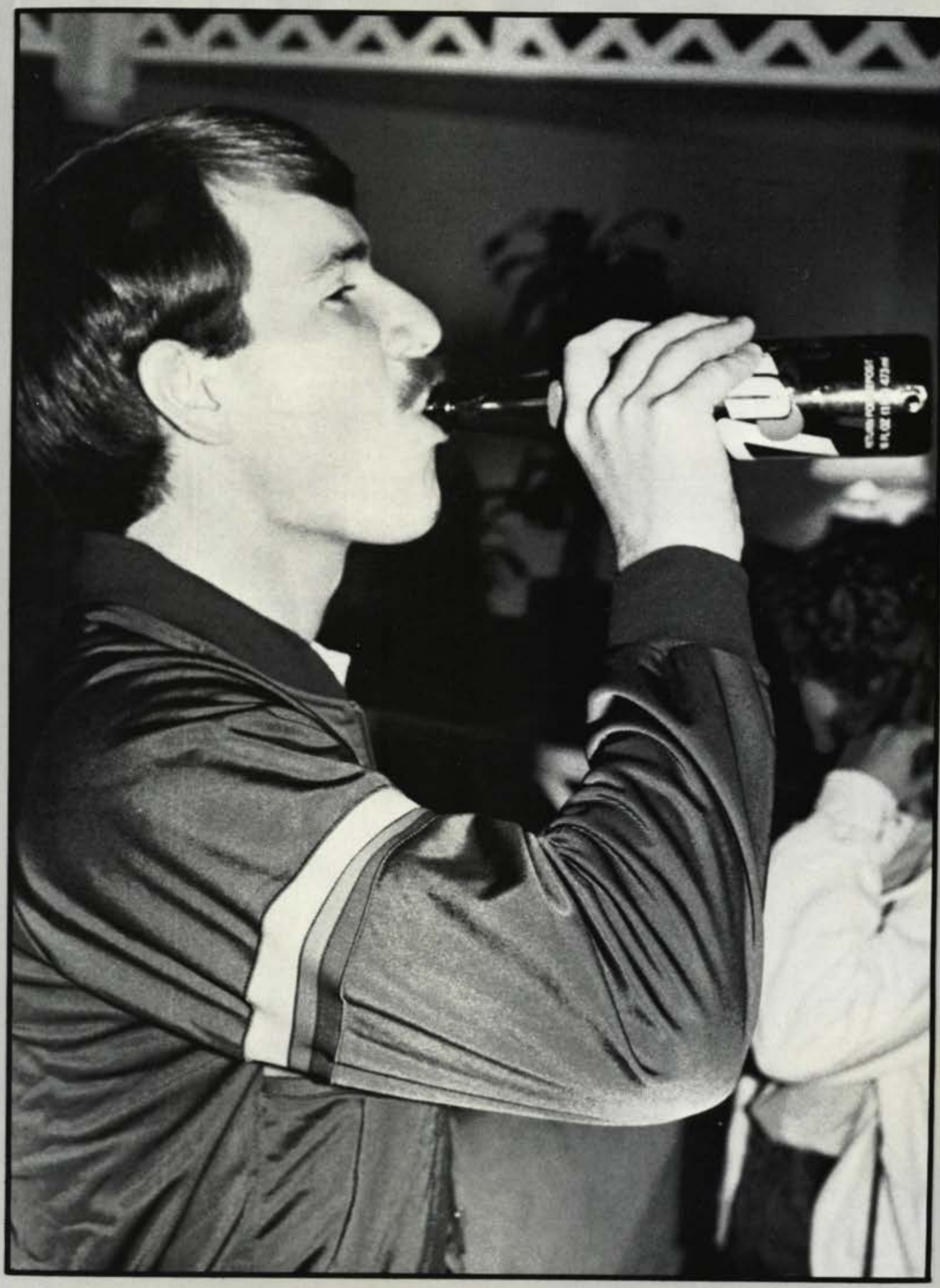

Layout By:

- Donna J. Thomas 
TJ hen I became a Head Resident at Cedarville College, I had behind me 27 years of experience in working with young people in my husband's pastorates. However, being a Head Resident has its unique and contrasting experience in personal relationships that it makes it a relatively new experience compared to a pastoral ministry.

Living with students on a 24 hour basis and working with them on a one to one personal encounter is to

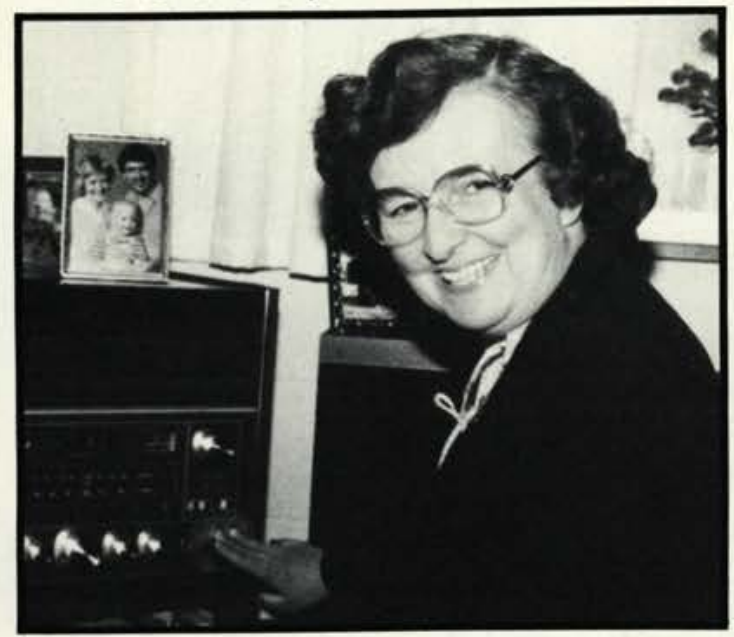

Mrs. Joan Street Head Resident-Maddox

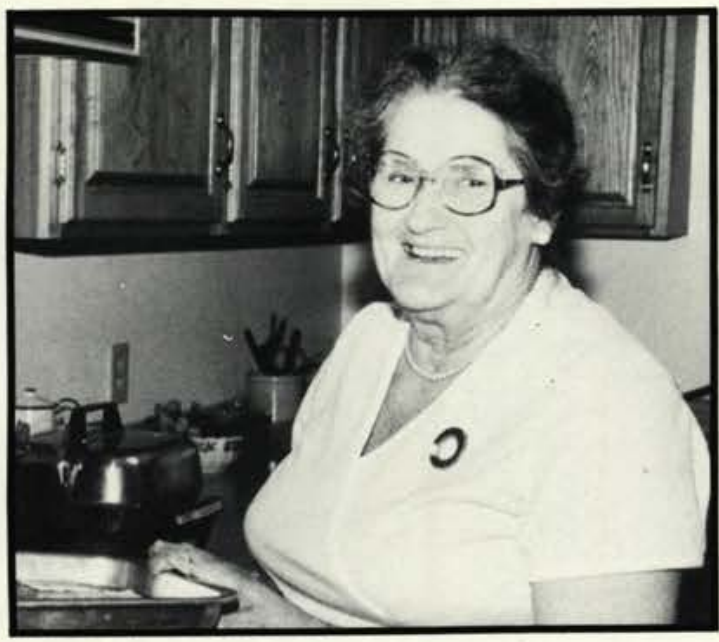

Mrs. Beatrice Printy Head Resident-Willetts

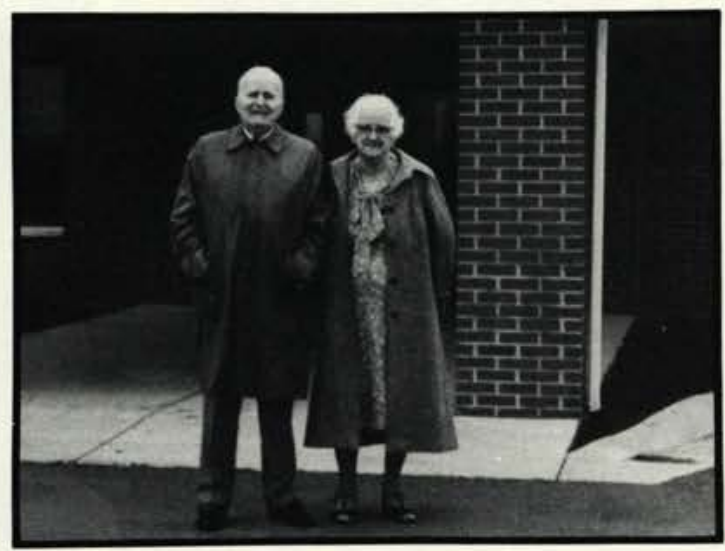

Mr. and Mrs. Earl V. Willetts me the most important part of my work. I wish I could share with the Miracle readers some of the letters and notes that I have received from graduates and students that I have worked with in my six years as a Head Resident at Cedarville.

Recently I was conversing with a graduate of Bowling Green State University and was surprised to hear how enthusiastic he was about the responsibilities of being a Head Resident. He thought it was exciting to have so many personal contacts with people from all parts of our country, the world, and from every town.

Someone has said that nuts and bolts are small, but without them our big jets could not fly. So it is with being the Head Resident of a college dormitory - we are a small. but very important part of the machinery that keeps Cedarville College flying.

by Mrs. Joan Stree

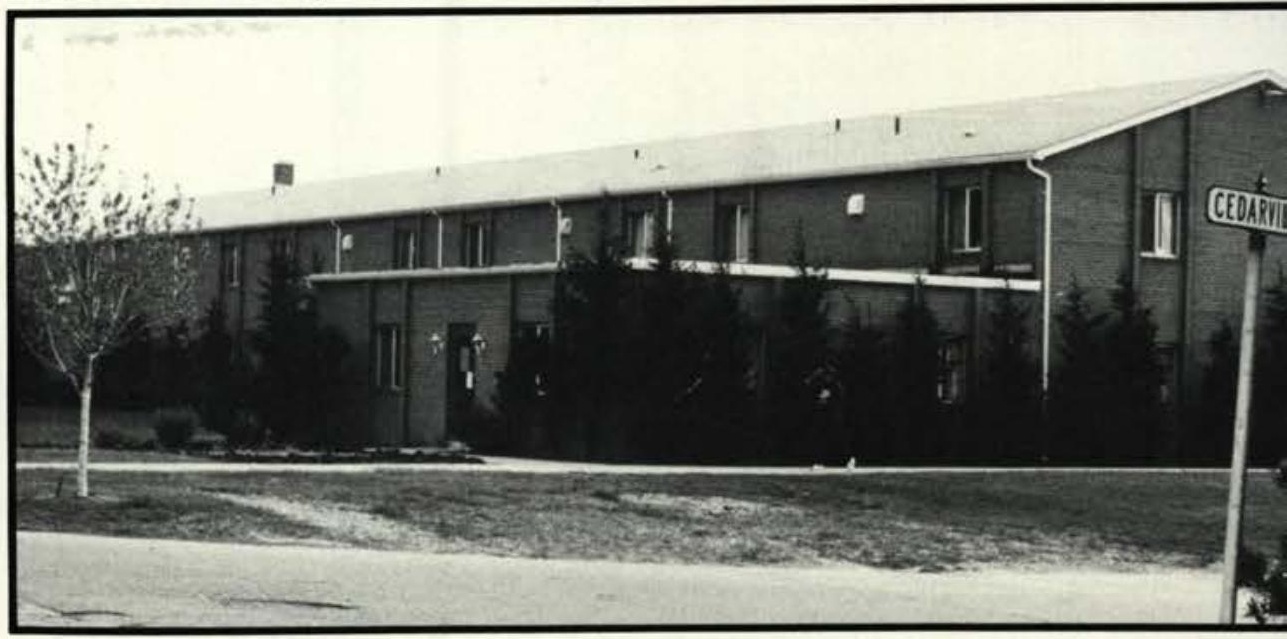

\section{Maddox Hall}

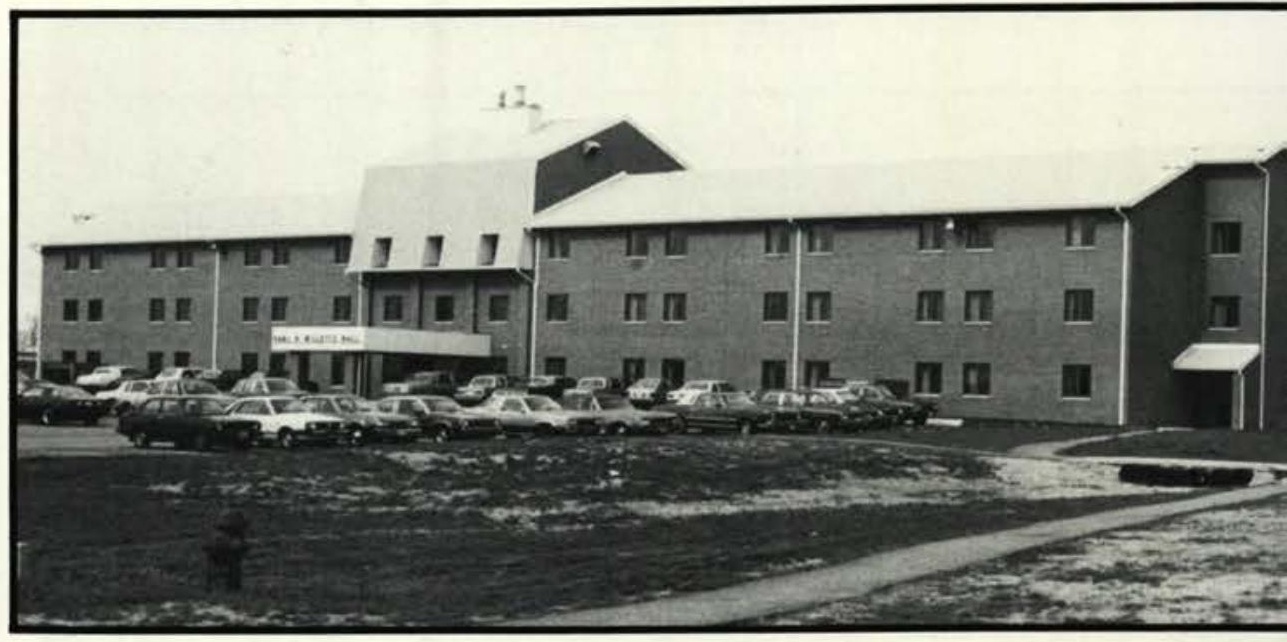

\section{Willetts Hall}

\section{EARL V. WILLETTS HALL}

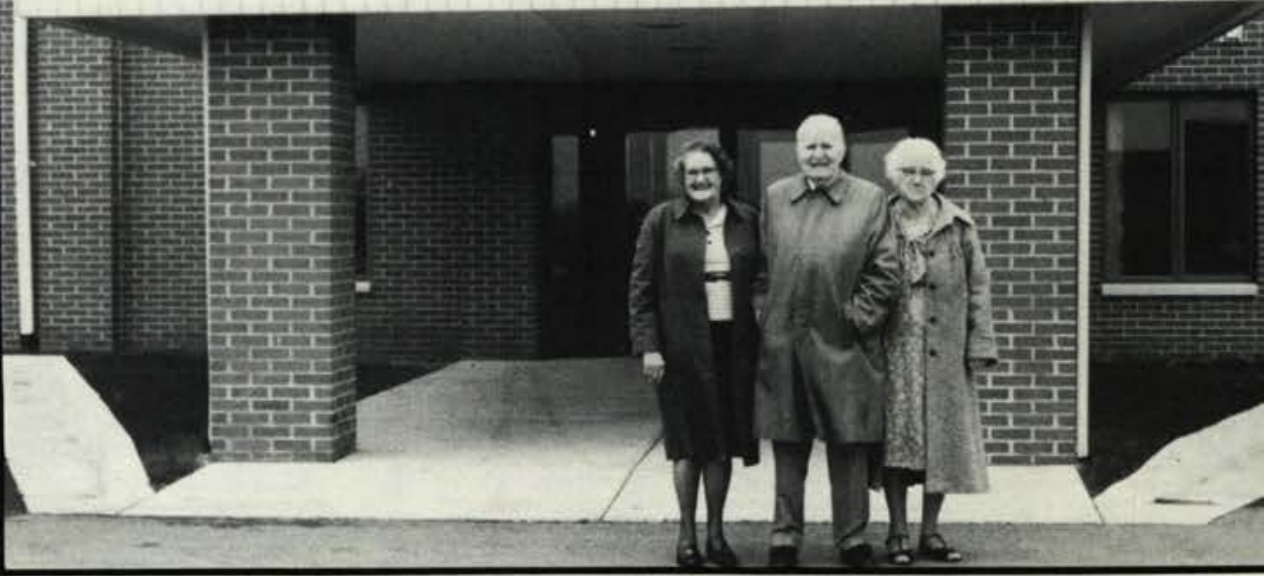


y first year as a Head Resident has 1 been a challenging, rewarding nd learning experience. I apoached the job with some appreension, but I was confident that the ord had provided this opportunity for $e$ and I willingly accepted the posin. The young ladies in Faith Hall have ecome very speical to me. We have ared the highs and lows, the sucesses and failures, the joys and sorws. Through it all, God has greatly blessed. My life has been enriched by the relationships formed with the women in the dorm.

A life changing lesson for me has been how to handle authority in a biblical way. The basis for authority is relational. God has shown me that my relationship with the women as Head Resident is one thing, but the greater relationship with them is theirs in Christ. God has given me this position with its responsibilities and authority to serve my sisters, not to lord over them.

Looking forward to next year, I desire that God will use me as an instrument of encouragement, edification and comfort in the lives of the women in Faith. I also seek to enter the new term with a learner's attitude, looking to be more conformed to the image of my Lord Jesus Christ.

by Pat Farrow

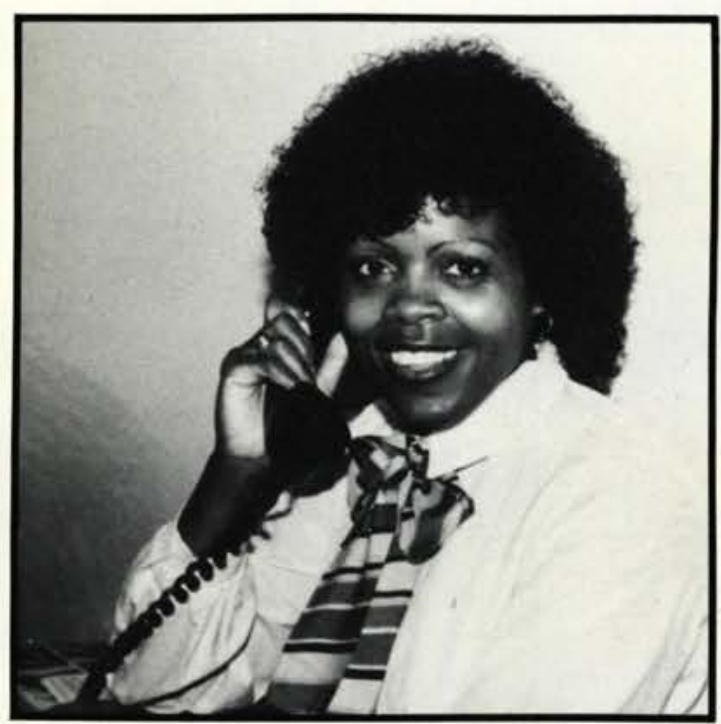

Pat Farrow

Head Resident — Faith

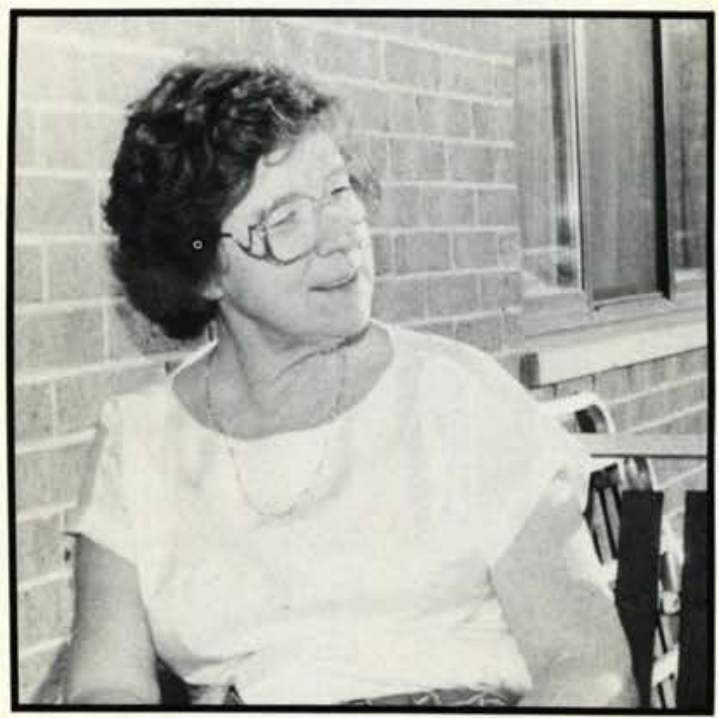

Mrs. Agnes Howell Head Resident - Printy

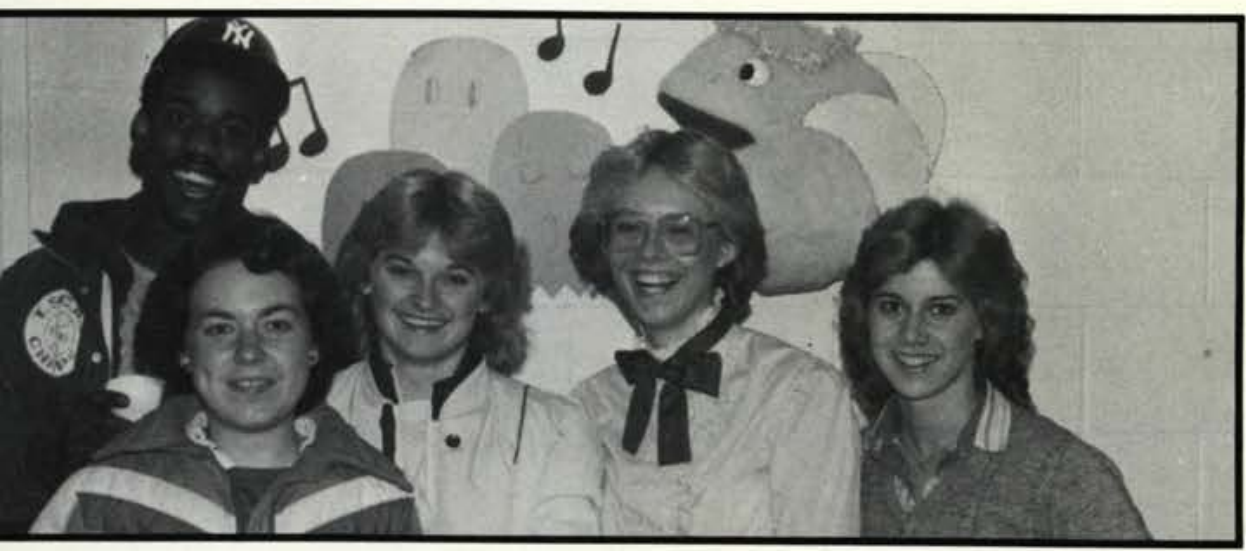


his past school year was a growing time for me and many of my men in the dorms. There are many "special events" that will surely be remembered, but what will stick in the guys' minds the most is the informal time of sharing and talking about everyday occurrences. It was through these times that I got to know more guys on

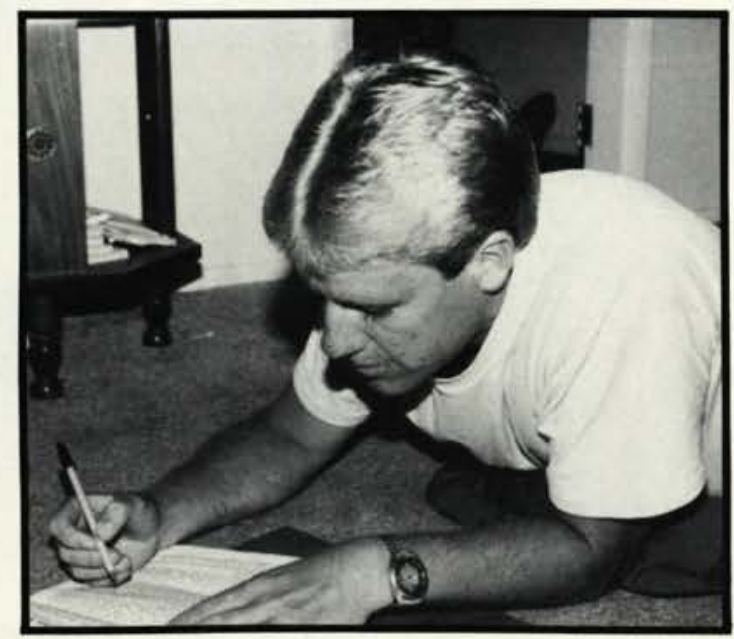

Curt Berger - Head Resident of Bethel, South and Harriman

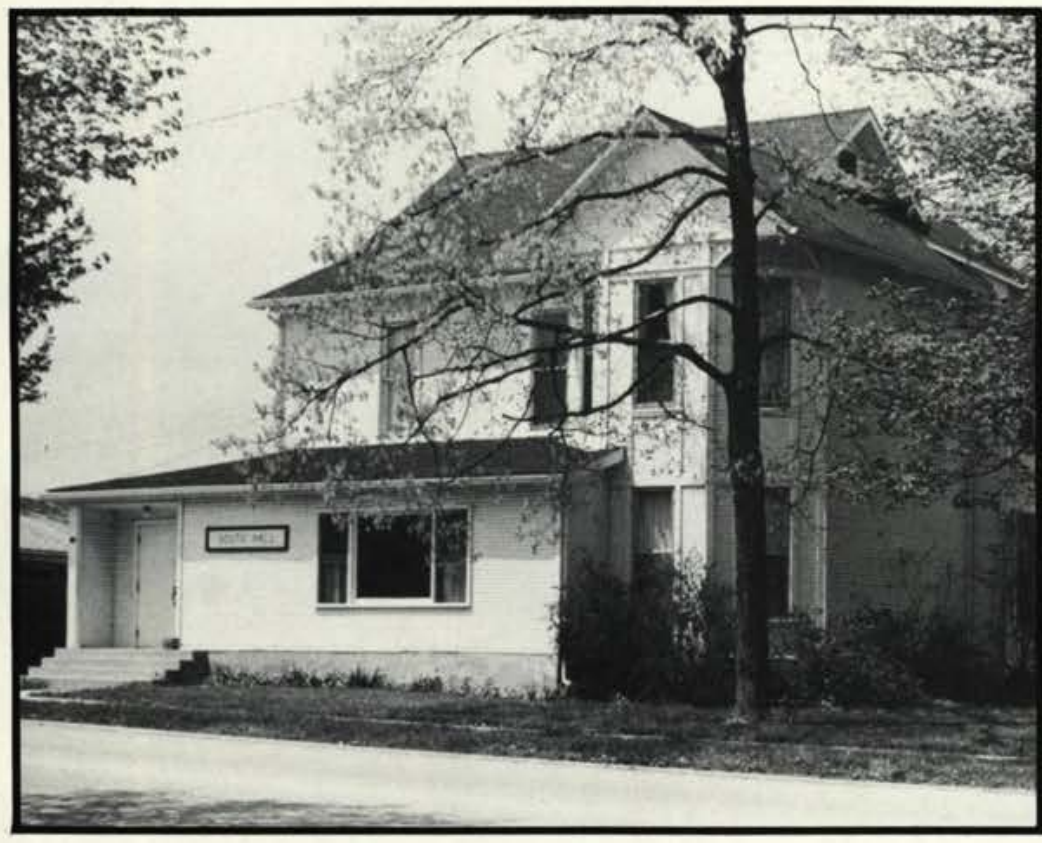

South Hall a personal basis and I'm sure they got to know one another better also. When each guy reflects on the year, I wish him to be able to say that someone along the way encouraged him in his walk with the Lord. After all, the reason we are here is to serve and glorify Christ.

Some of the special events that the dorms shared were late night gyn nights which were always well attend ed and liked by all. Each dorm hac prayer meetings with various women' dorms to encourage friendship in more relaxed atmosphere. The big gest event was a cookout and putt putt outing held the last week c school.

by Curt Berge

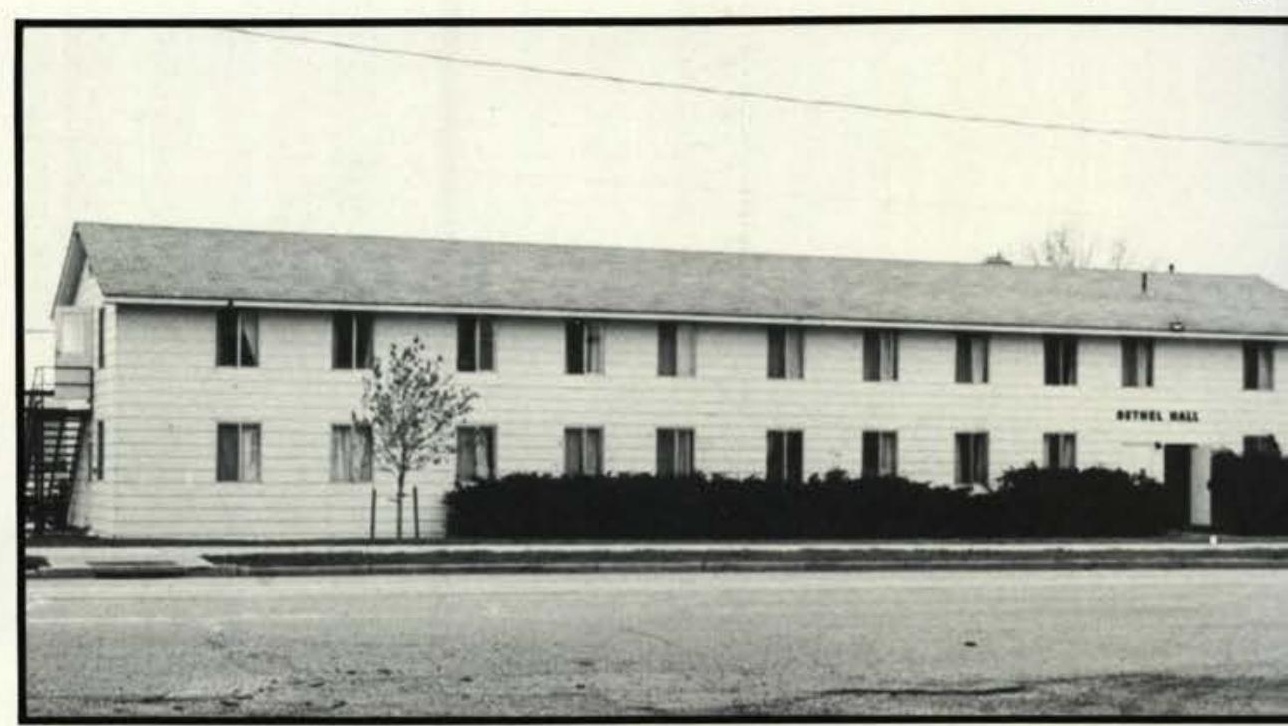

\section{Bethel Hall}

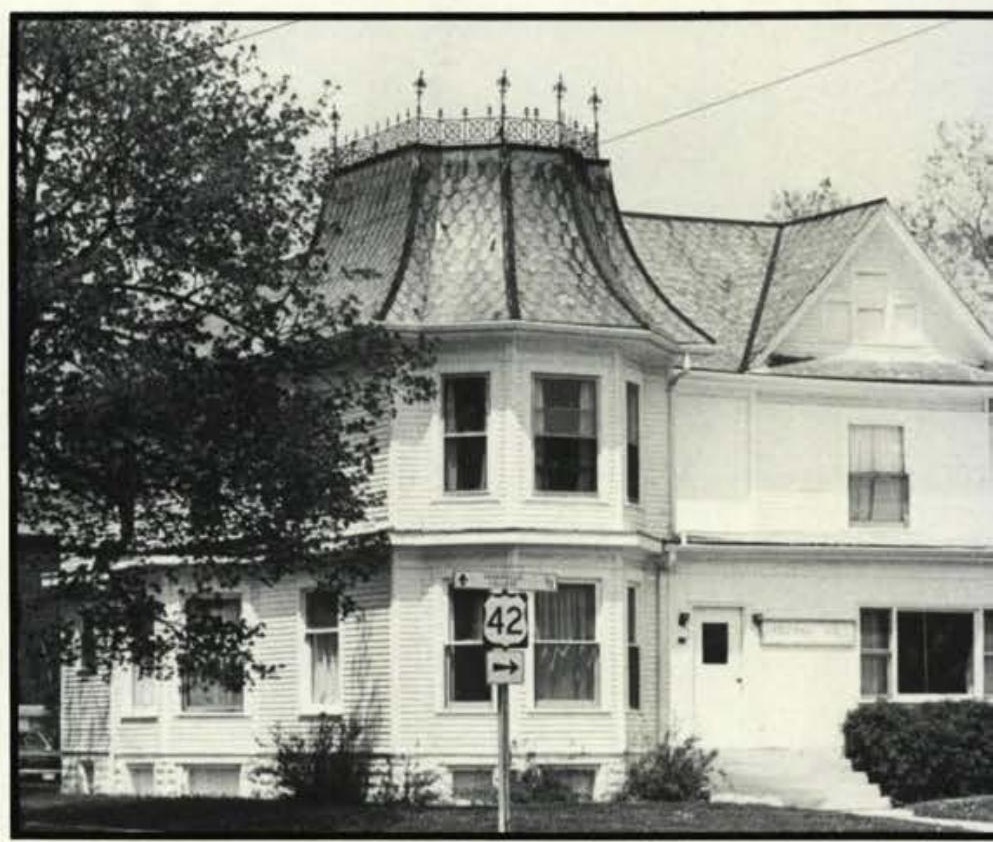

Harriman Hall

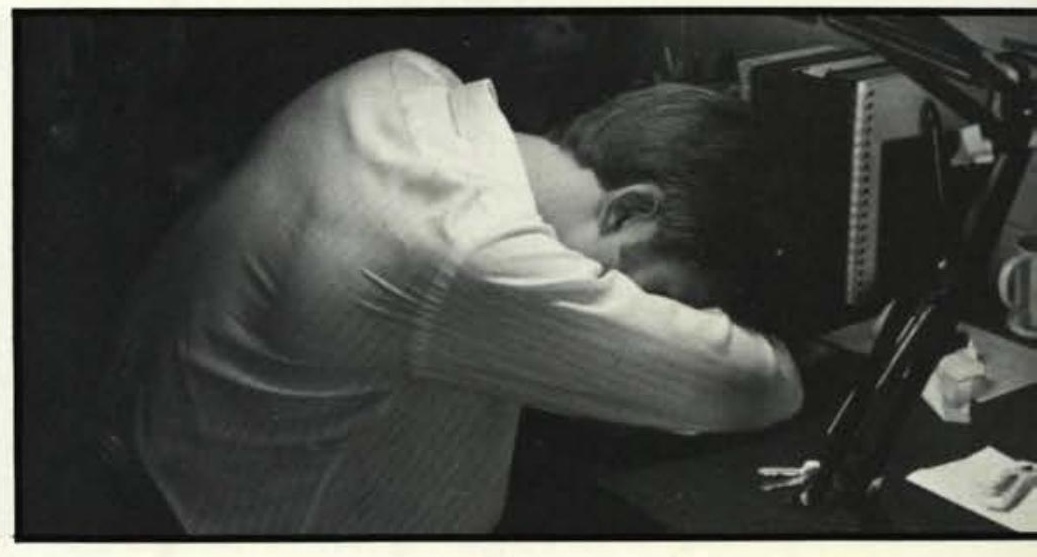




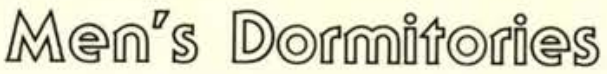
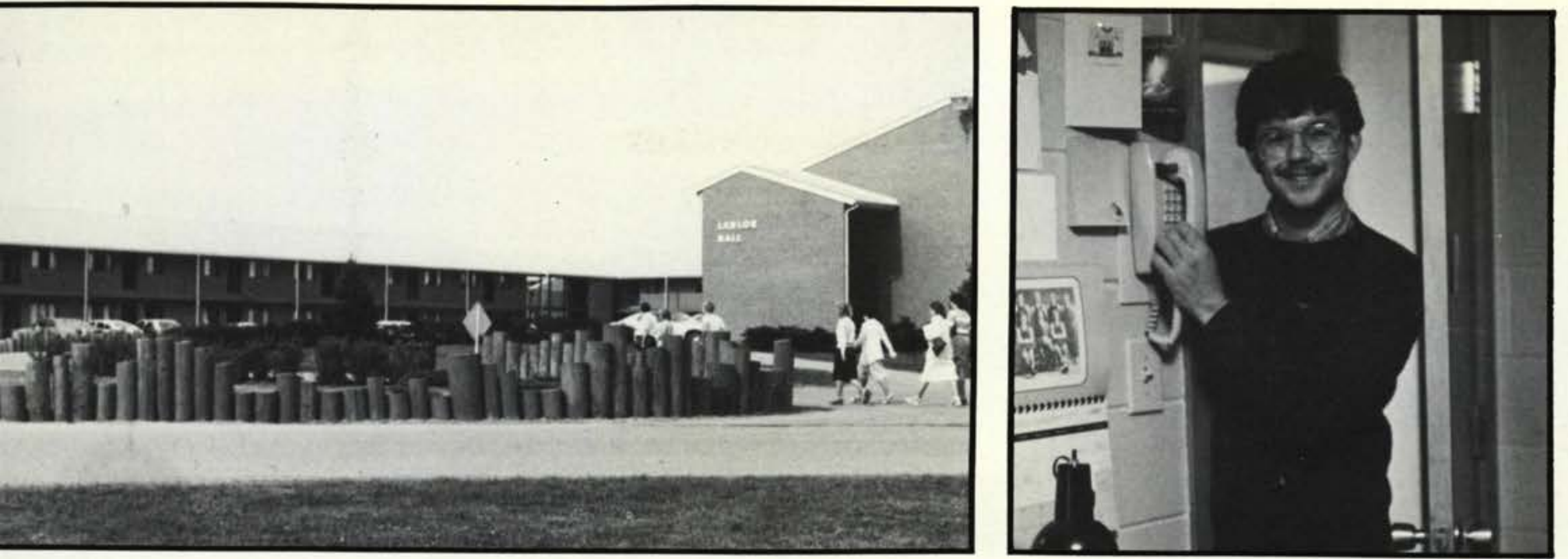

\section{Lawlor Hall}
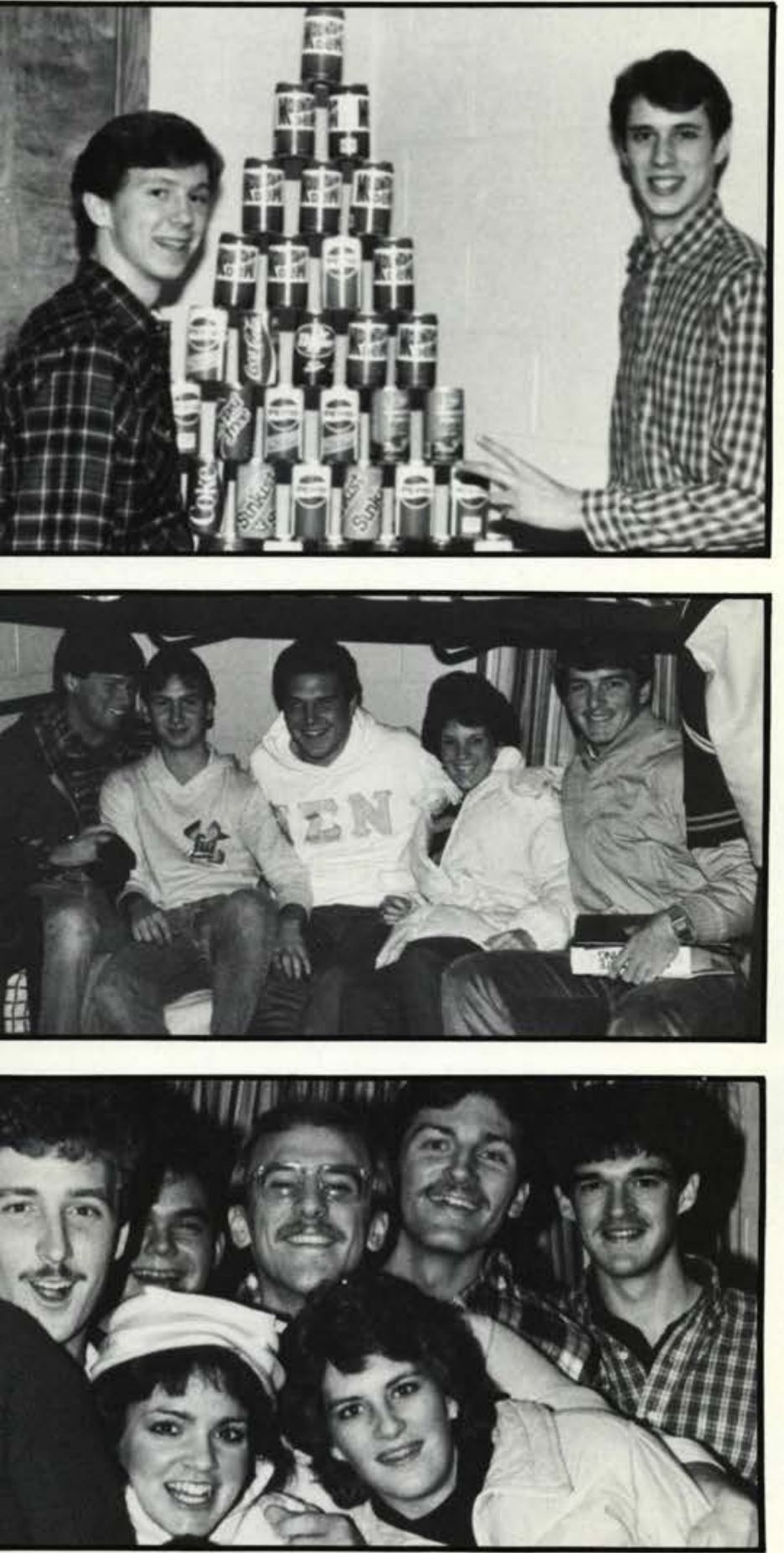

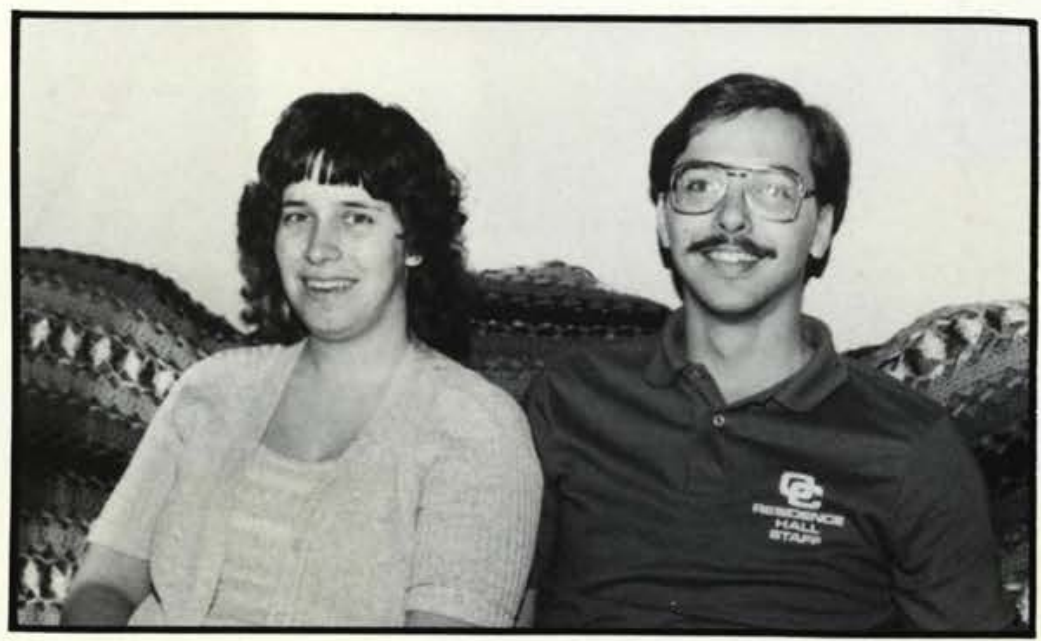

Mr. and Mrs. John DeMeester Head Resident of Lawlor

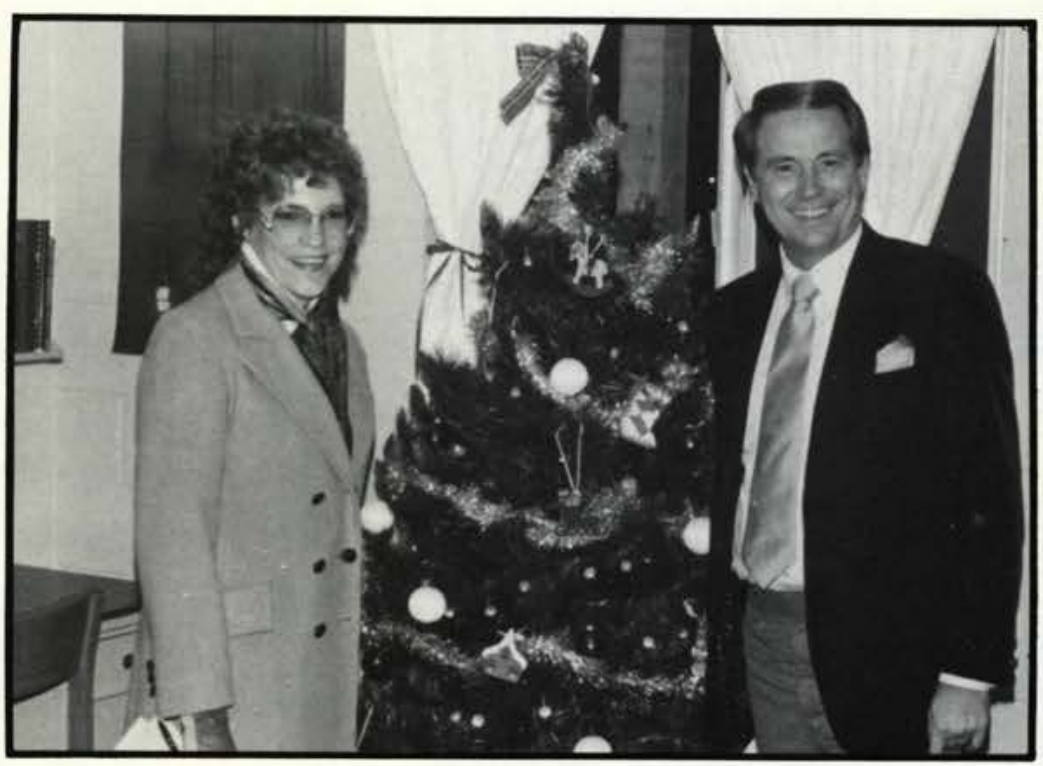


The head resident position here at 1 Cedarville presents unique opportunities not found at secular colleges. There are many situations where I can integrate Biblical principals into a student's life. Young men go through many changes while at school. Some mature faster than others and demonstrate an interest in spiritual things.

The most effective impact I can have in their lives comes from living a consistent lifestyle before them. The guys do not set their standards according to the handbook because most of them never bother to read it. They watch the R.A.'s and see where they will set their boundaries as pertaining to the rules.

If a Head Resident can be balanced in his position, he will gain the respect of his students. I must get to know the student and assure him of the open channel to always come and speak with me.

The most important aspects of this job are getting to know the young men, being balanced in discipline, and living a consistent life before them. This job has taught me a lot, and I am thankful for the many good times that it has given to my family.

by Matt Kunke

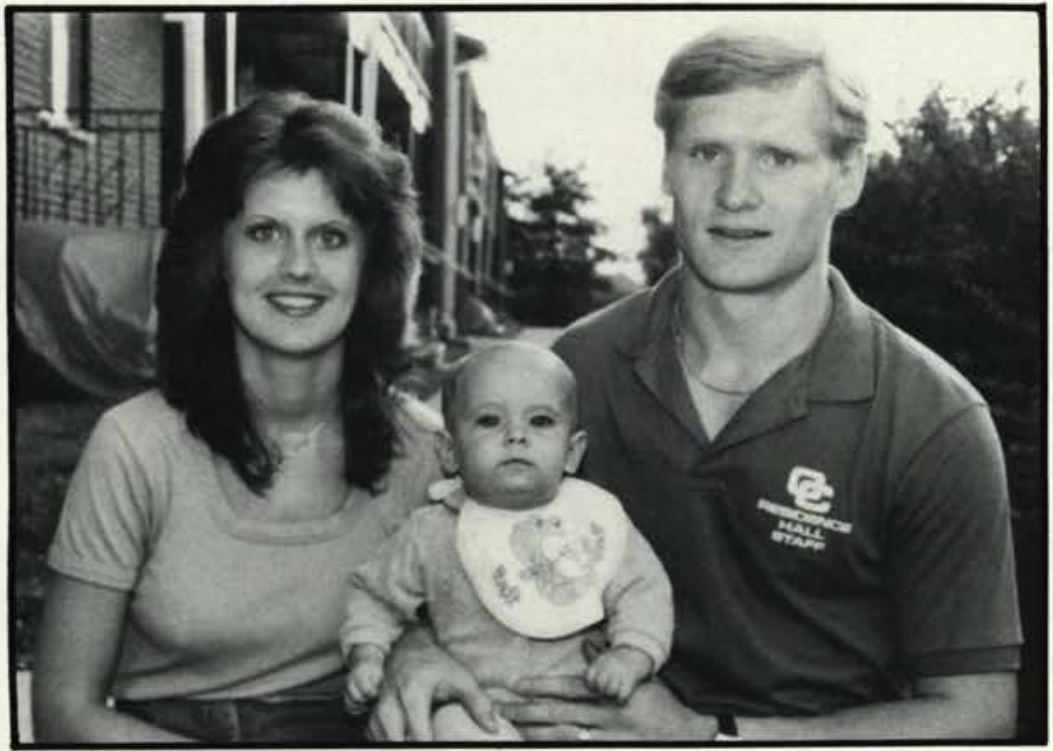

Mr. and Mrs. Matt Kunkel

Head Resident of "The Hill"

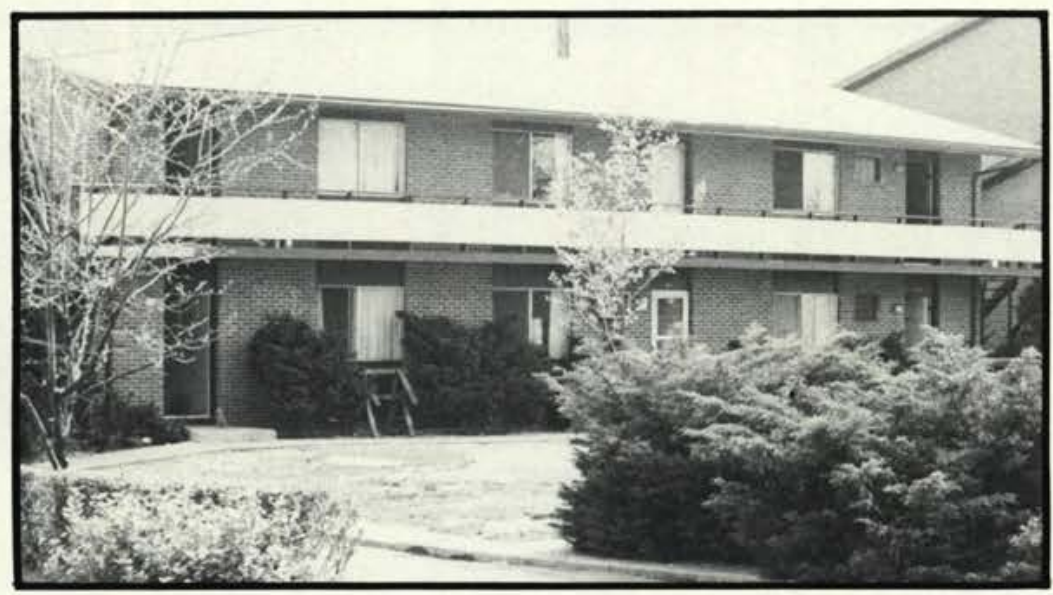

Rogers Hall

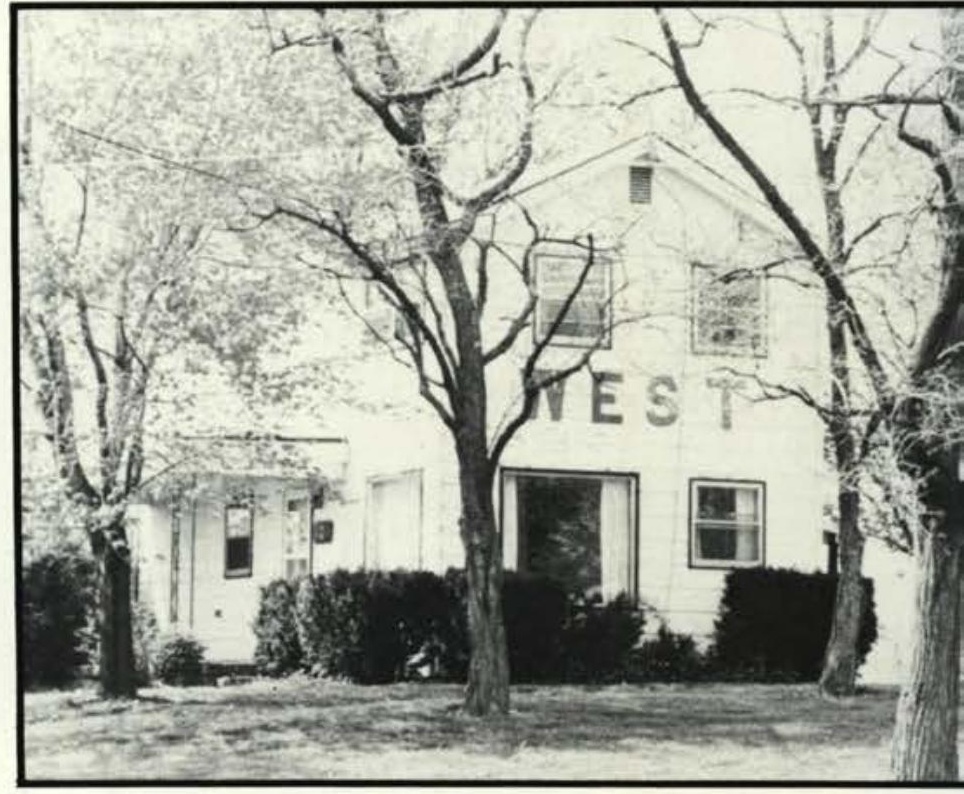

West Hall

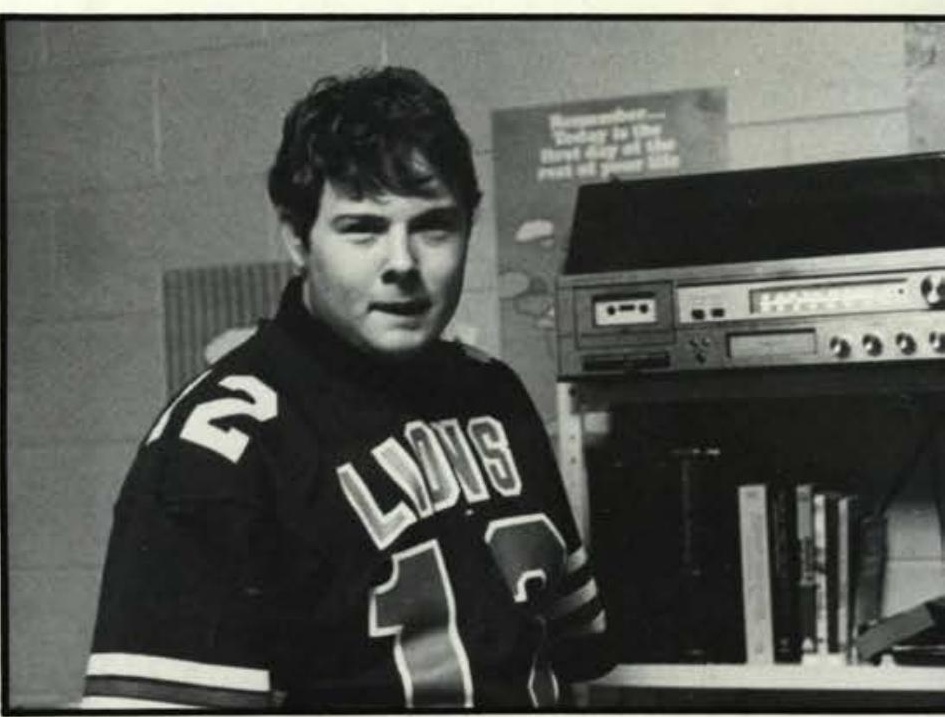

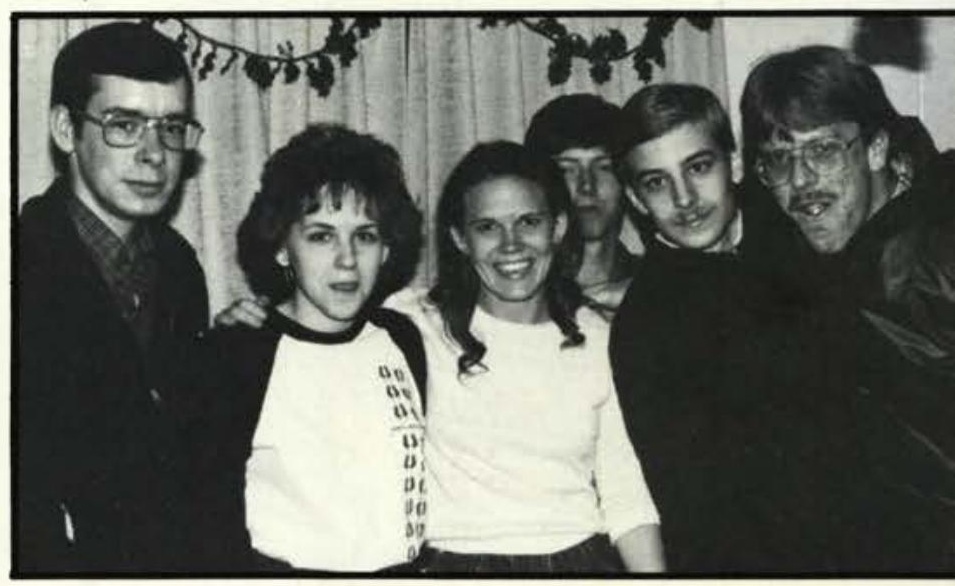




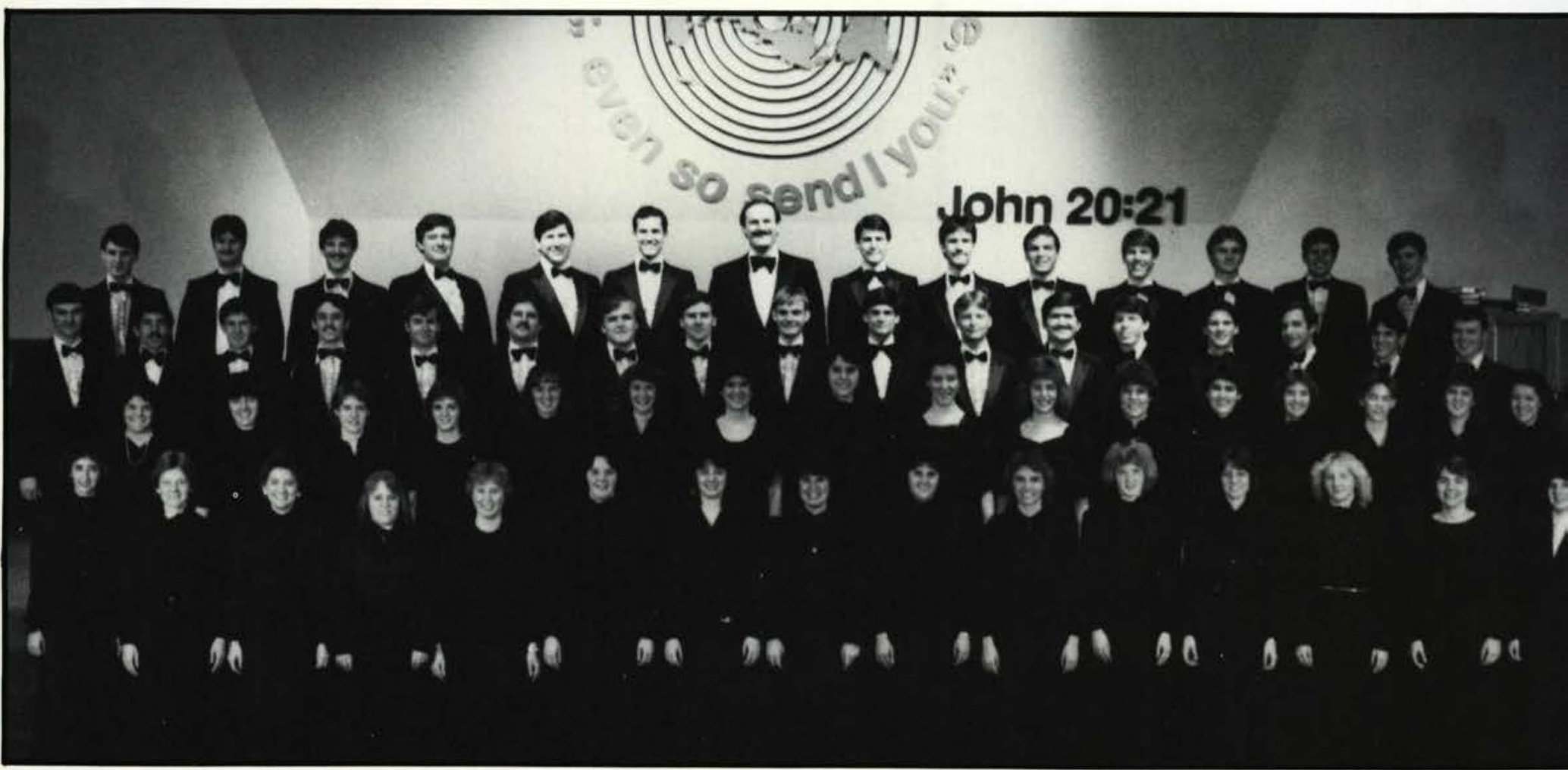

Row one: J. Garmatter, B. Fisher, J. Kolkman, L. Piercy, J. Warren, S. Schneppe, B. Vaghn, D. Heitzman, J. Cranick, T. Mackenzie. Row two: M. Schuttenberg, R. Darr, J. Oakes, P. Trivett, J. Burr, C. Weidiman, D. Fisher, L. Haberli, C. Vantrease, K. Vantrease, S. Nichols, T. Palmer, J. Cobb, J. Baughman, J. Sandy, S. Scott. Row three: S. Harper, R. Kuntz, R. King. A. Jensen, G. Nonnemacher, G. Rouster, R. Carey, B. Munson, B. Crump, D. Carey, D. Iverson, W. Baney, C. Lord, E. Supplee, R. Haywood, G. Wallace, D. Walter. Row Four: B. McBrayer, J. Switzer, D. Price, S. Wood, T. Jennings, T. Carr, Mr. M. Dicuirci (Conductor). D. Simpkins, T. Smith, D. Eller, T. Knowles, C. Mast, C. Carothers, D. Mckool. Not Pictured: J. Benedict, D. Dysert, K. Herrick, V. Martin, Mrs. A. McClure, L. Norton, A. Ranew, R. Van Schoik, D. Wagner.

n the Fall of 1983, some eighty Cedarville College students assembled themselves in the band room of the Fine Arts building. Their mission was that of organizing, rehearsing, and ultimately performing as a cohesive group of musicians. They began by presenting their first concert, as a part of Prism IV, only three weeks into the Fall quarter. Other activities included the first and last edition of the BAND$A I D$, which was their attempt at humorously informing the band members of the upcoming events through the medium of the printed page. The finishing touch to this quarter, was the Thanksgiving concert.

Winter quarter however, was anything but uneventful. Many hours were spent diligently practicing, both as a group and independently. Occasionally, shrieks could be heard from the basement of the Fine Arts building as the phantom trombonist would frighten the unsuspecting person feverishly rehearsing for the upcoming concert. This concert was performed during the Christian Band Conference, in which Cedarville College hosted eight high school bands from various schools in the Midwest. A highlight of the winter

\section{"It was exhilerating to see the crowd stand to their feet."}

concert was the guest conductor, Mr. James Curnow.

Spring quarter culminated our efforts over the past year. At this time, we were privileged to represent Cedarville College in various churches from Ohio to Washington, D.C. where the band participated in Baptist Fundamentalism '84. It was exhilerating to see the crowd stand to their feet on the final note of "The Battle Hymn of the Republic" as performed by The Cedarville College Symphonic Band in Washington, D.C.

Throughout the year, the band strove for unity in more than just a musical sense. During this Spring Tour, that goal was achieved and demonstrated by the fact that each person gave of themselves as unto the Lord. Truly the Lord did bless their efforts when they were careful to give Him the praise.

by Brandi Fisher

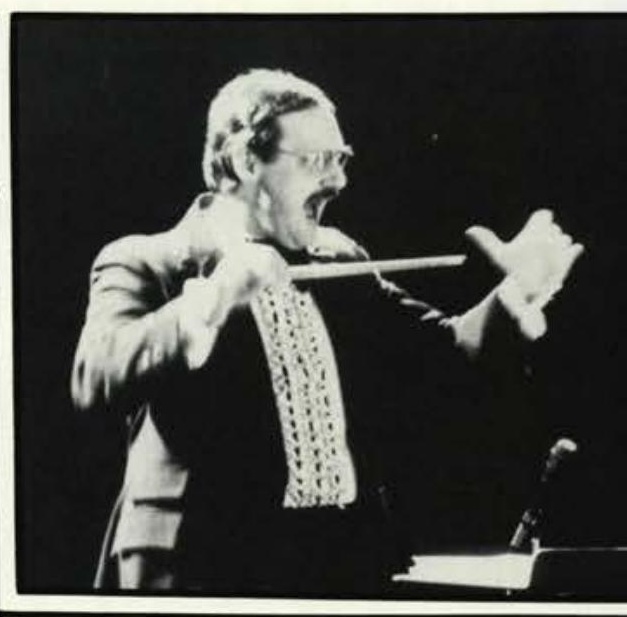




\section{Blessed Year For Brass Choir}
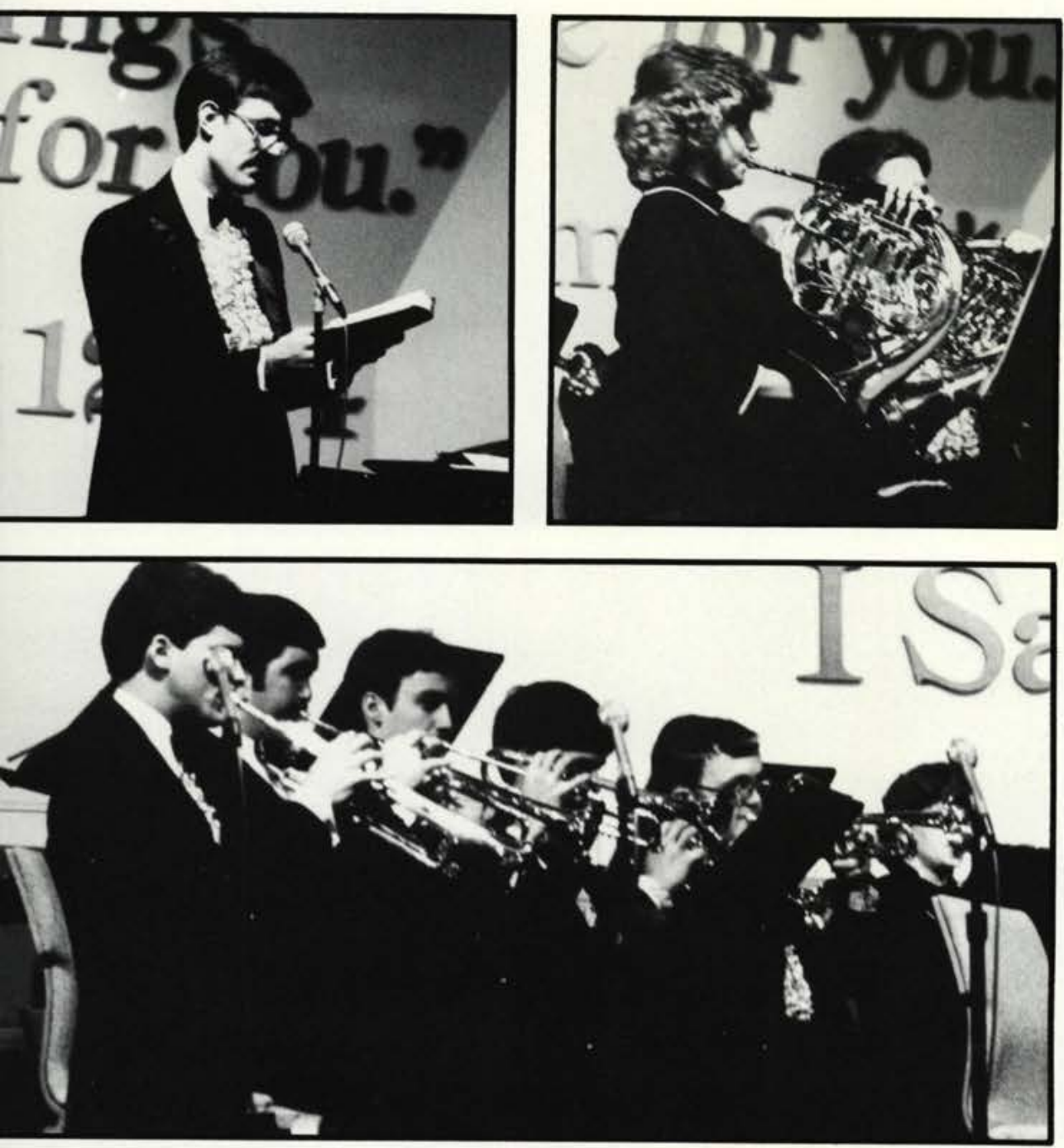

$M$ usic is a gift, a great gift from our M great and glorious God. Each year the Cedarville College Brass Choir attempts to praise the matchless name of our Saviour through the medium of instrumental music.

Fall quarter, 1983 brought a flurry of activities to the Brass Choir. October 18 and 19 found the group performing for Prism IV followed by the Fall Band and Brass Choir Concert in November. Both these concerts featured a wide variety of classical brass music.

Winter quarter was a time to prepare for the annual Spring Tour. Hymn arrangements, gospel tunes, and sacred literature were put together into a God honoring program to be taken into churches and Christian schools. The tour was a highlight of the year. The Lord provided the opportunity to do 10 concerts in 9 days in the state of Florida where many beautiful lessons were learned and blessings experienced as the group ministered to and stayed with many Christian families.

Spring quarter brought final activities of the year, including the Brass Choir sacred Home Concert on April 6, and the annual performance for the Honor's Day Chapel on May 4. The group's finale concert came as it performed in the Gabrieli Festival along with the Wittenberg University and Wright State University Brass Choirs on May 13.

So ended a long but blessed year of musical service and performance for the Cedarville College Brass Choir.

by Mr. Pagnard

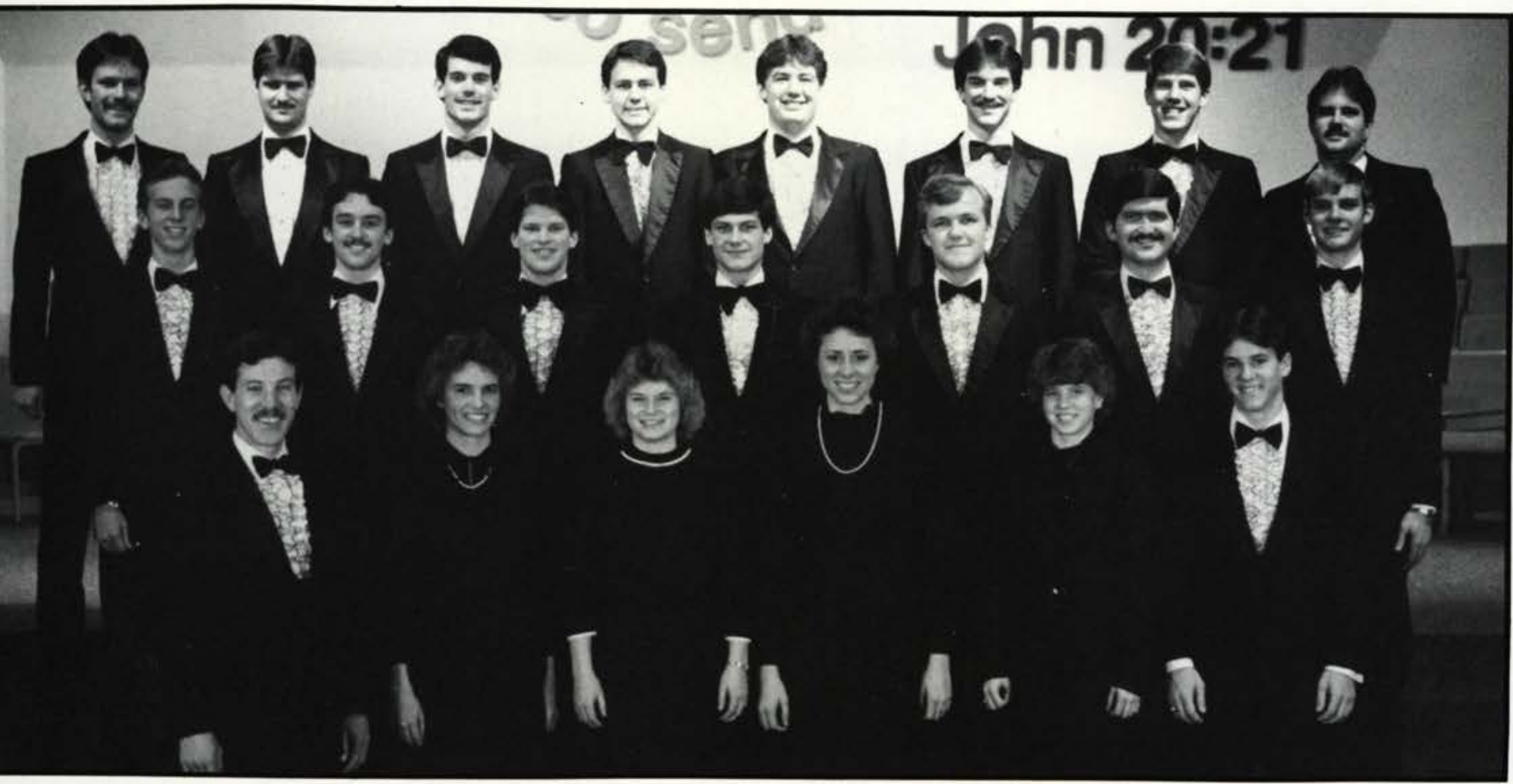

First row: Mr. Pagnard (conductor), J. Warren, S. Simpson, K. Beattie, D. Berdy, G. Wallace. Second row: T. Phillips, A. Jensen, E. Supplee, D. Carey. R. Carey, W. Bany, B. Crump. Third row: T. Smith, J. Switzer, J. Benzing, D. Simpkins, S. Wood, D. Price, T. Knowles, G. Rouster. Not pictured: S. Clark. 


\section{Oratorio}

\section{Oratorio choirs have gained acceptance in both community and colle. giate life.}

The popularity of the oratorio choir I move came about as a result of the English-speaking peoples' great fondness for choral music. It has remained a moving force in the music world for some 250 years. Oratorio has gained the attention of a goodly number of the world's most noted composers who have given works of great

\section{"participation is open to any student regardless of major or prior music train. Ing."}

majesty and beauty. The subject matter is usually Biblical and presents a narrative of an element of God's people or one of His saints. The works involve not only chorus but also soloists and instrumental accompaniment.

Because of its employment of such substantial forces and the excellence of the many works that exist in the genre, oratorio choirs have gained acceptance in both community and collegiate life. The existence of such a group in the liberal arts and university setting is almost assumed. It gives the

\section{Presents The Creation}

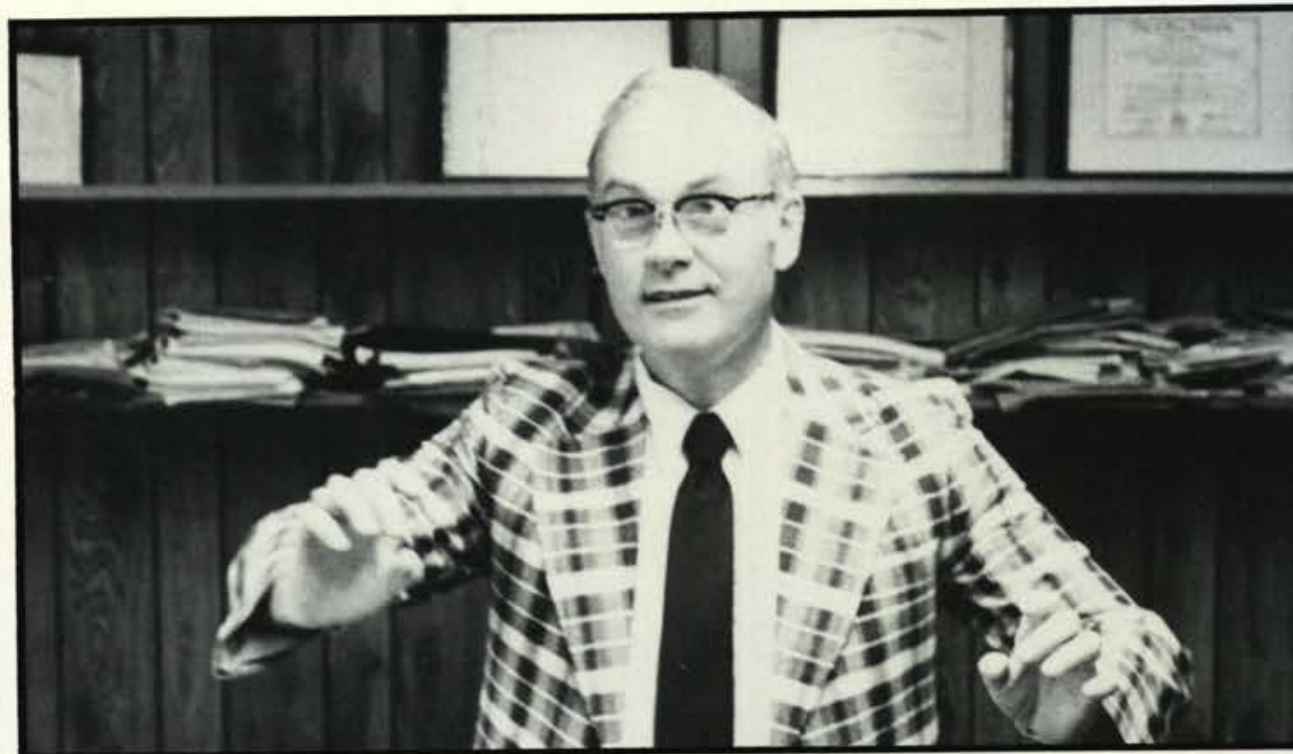

\section{Dr. Charles Ellington - Conductor Of Oratorio}

\section{"It gives the general stu. dent an opportunity to participate in the re.cre. ation of a genuine work."}

general student an opporutnity to participate in the re-creation of a genuine art work, something which perhaps he could not do alone.
Oratorio Choir numbering from 75 to 150 members in varying years. Partici pation is open to any student regard less of major orprior music training.

The 1983-84 Oratorio Choir present ed Haydn's THE CREATION and the 1984-85 season will feature MESSIAHb G.F. Handel.

by Dr. Ellingtor

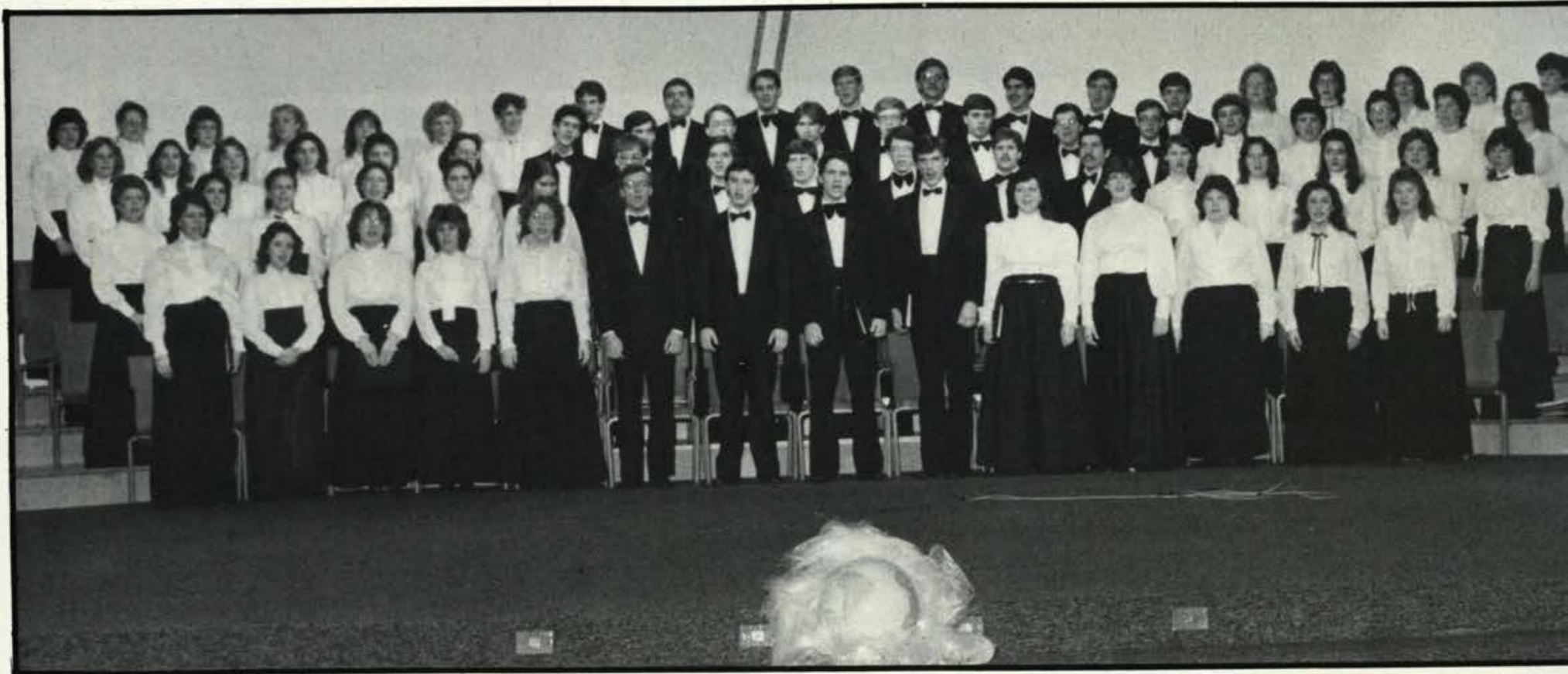

Row one: J. Adams, J. Johnson, B. Riggs, L. Shaffer, B. Riggs, G. Nonnemacher, J. Unger. D. Frey, D. Price. J. English, M. Collins, R. Dempsey, J. Dowsett, L. Libby. Row two: S. Davis, L. Tyson, D. Messinger, M. Knicely, R. Dye, M. MacMichael, P. Bishop, E. Helmuth, T. Rhoades, C. Lord, D. Shulse, R. Kuntz, J. Woodard, C. Long, D. Quick, P. Rickard, K. Murphy, Row three: L. Coffman. A. Holman, V. Gruneisen, A. Lydic, B. King. J. Walters, T. Rivetti. D. Miller, T. Shannan, B. Herr, D. McCool, D. Wright, E. Lanning, W. Brown, K. Dobbel C. Jessup. C. Smith, J. Price, F. Irvin. Row four: C. Hancock, L. Stover, J. Sandy, D. McClure, D. Freeburger, J. Winkleman, P. Smith, D. Price, A. Strait, J. Lyle, E. Shrum, A. Malone, J. Beste, T. Wiggerhaus, M. Law. J. Campbell, J. Runge, R. Bowen, R. Ackley, J. Thompson. Not Pictured: Dean Wagner, organist. 


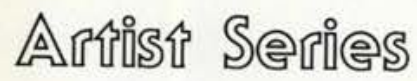

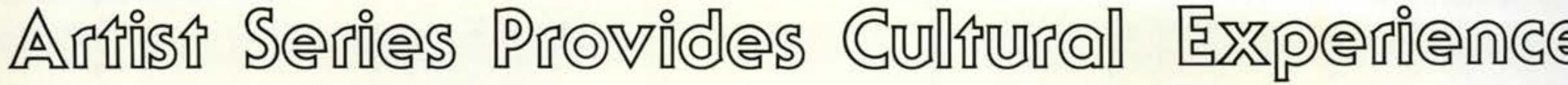

The Artist Series, put together by

I the Campus Activities Office, seeks to provide a variety of cultural experiences in order to encourage a well-balanced education. This year began with Ron and Gary Matthews who treated us to a concert of regal trumpet music. Llord's International stunned the audience with its intense attention to the most minute detail.

\section{"She made us all realize that God can use us no matter what our infirmity may be."}

The marionettes seemed almost alive as they walked, ran, or danced their way across the elaborate and ornamental stage. Another very special evening blessed our hearts as Kim Wickes, a blind vocalist, sang praises to our Lord. She made us all realize that God can use us no matter what our

\section{'This year's series blend. ed the talents of a variety of individuals."}

infirmity may be, as long as we are available. Those who enjoy classical music found the Bowling Green University Philharmonia or David Baker and Sonja Foster Gillian to be a wonderful opportunity to enjoy well performed favorites. Truly, this year's series blended the talents of a variety of individuals to entertain the entire college family.

by Bill Thomas
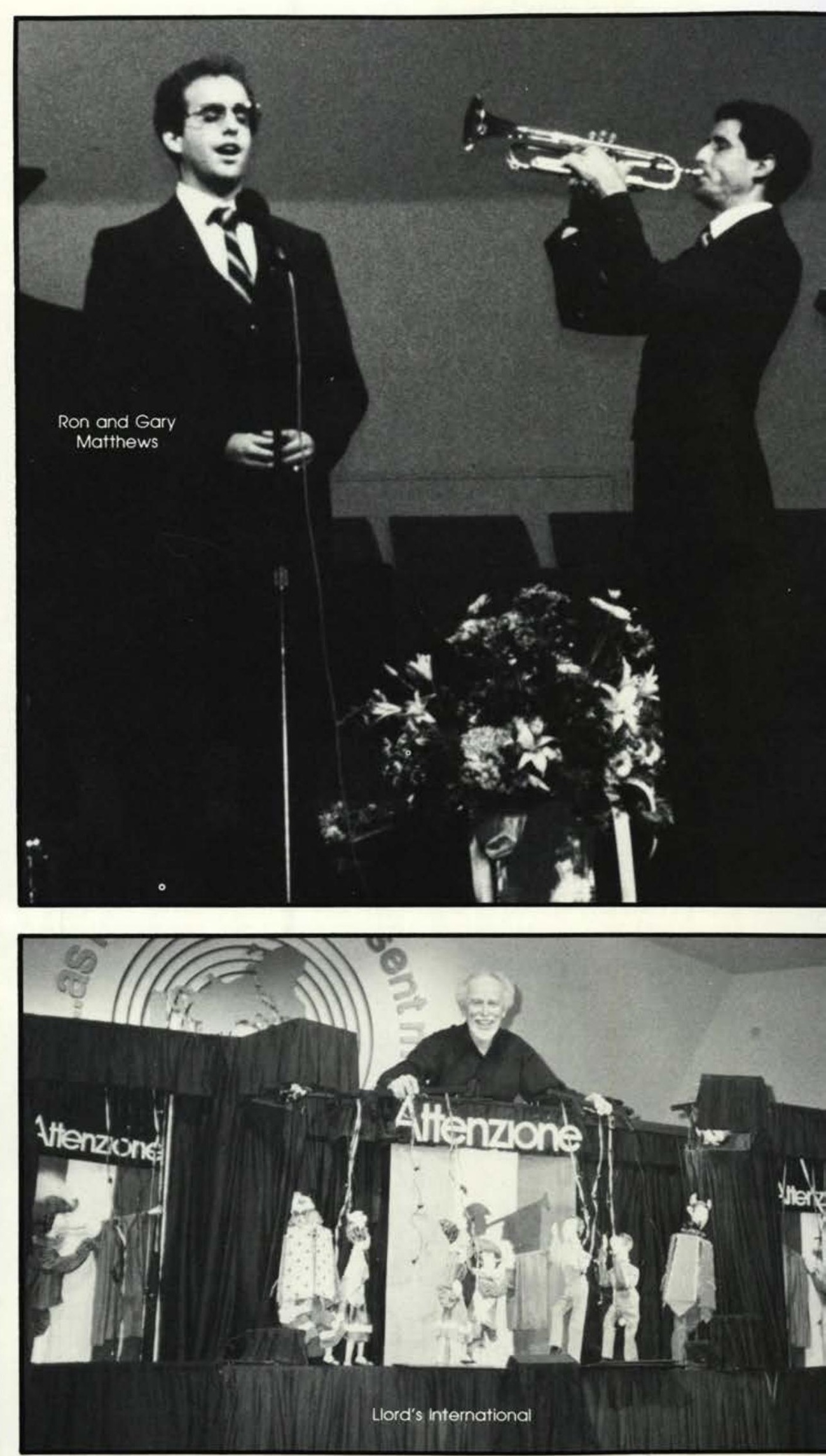
Anuînsฬ Series
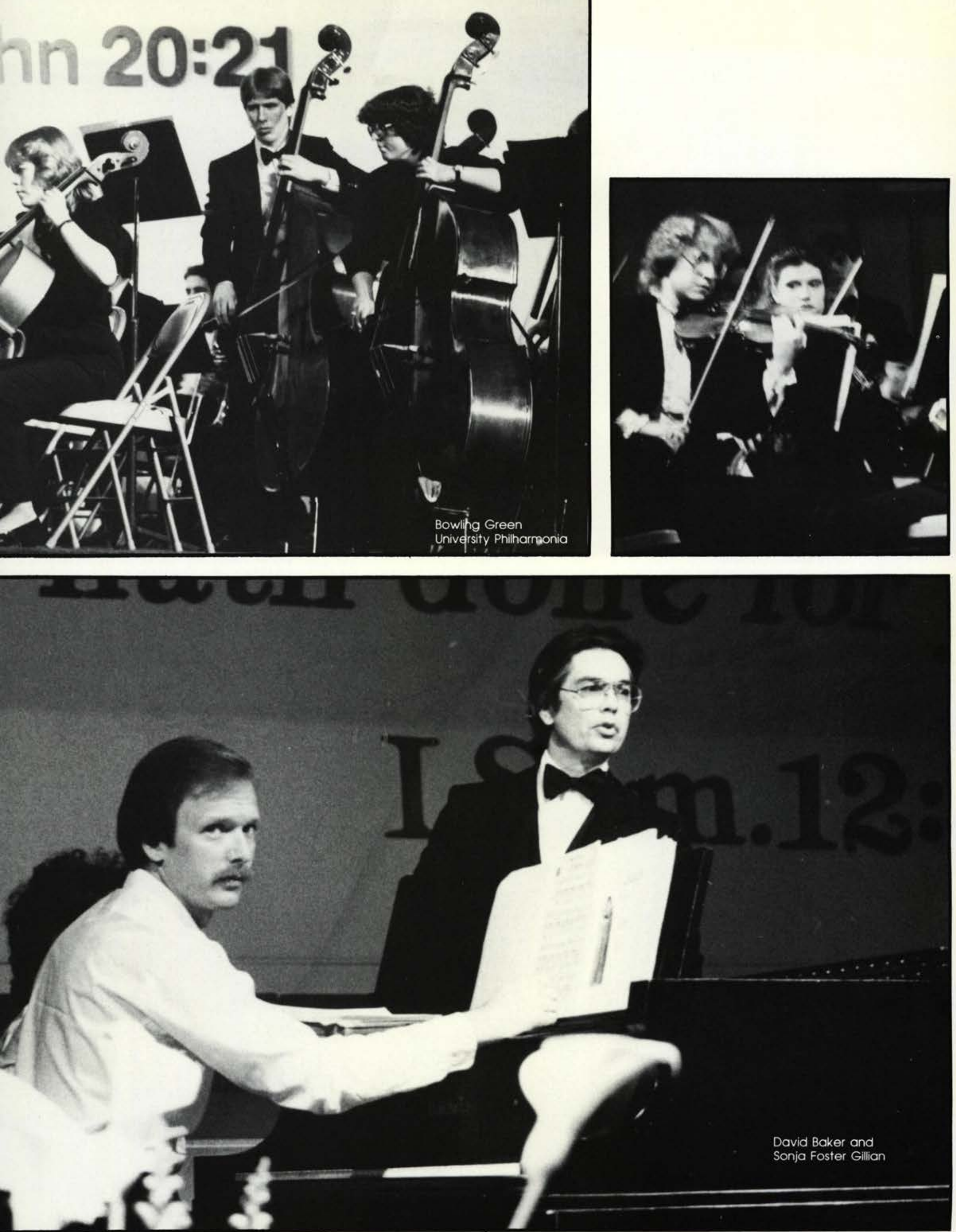


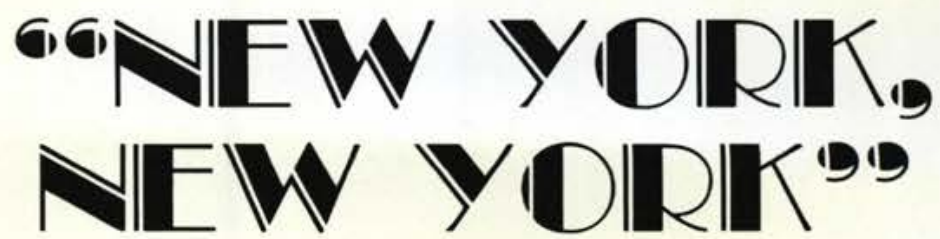
acter, leadership, attitude of service, a Christ-centered social life, and a testimony to others. One way Alpha Chi accomplishes this task is to put together the annual Alpha Chi Banquet. This year's banquet was held on February 3 with the theme "New York, New York." The cafeteria was transformed into a lovely restaurant with chandelier-like decorations and candle lit tables. As soon as everyone was seated, waiters and waitresses served a delicious menu of Prime Rib, Chicken Cordon Bleu, Baked Potato, Peas and Pearl Onions, Hard Rolls, and a variety of cheesecakes for dessert. During the dinner, Chris Tupps strolled from table to table playing his violin.

After dinner, the audience took a trip through New York City stopping at different places such as the Majestic Theatre and Radio City Music Hall, where they were entertained musically. Debbie Henry welcomed everyone with the song "New York, New York". Next, Bob Munson played "Ice Castles" on the saxaphone followed by Dana Mosley singing "Tomorrow" from the broadway hit Annie. "Maria", from West Side Story, was sung by Dan Price, and Kathi Holman closed the evening of New York entertainment with the song "Memory" from the broadway musical Cats.

Each year the men of Alpha Chi crown a Sweetheart at the banquet to represent them in the coming year. The women are chosen on the basis of character, service, and Christian testimony. The new 1984 Alphi Chi Sweetheart was Debbie Henry; her court included Esther Bucklew, Christine Dell, and Jenny Dye.

by Paul E. Jones President
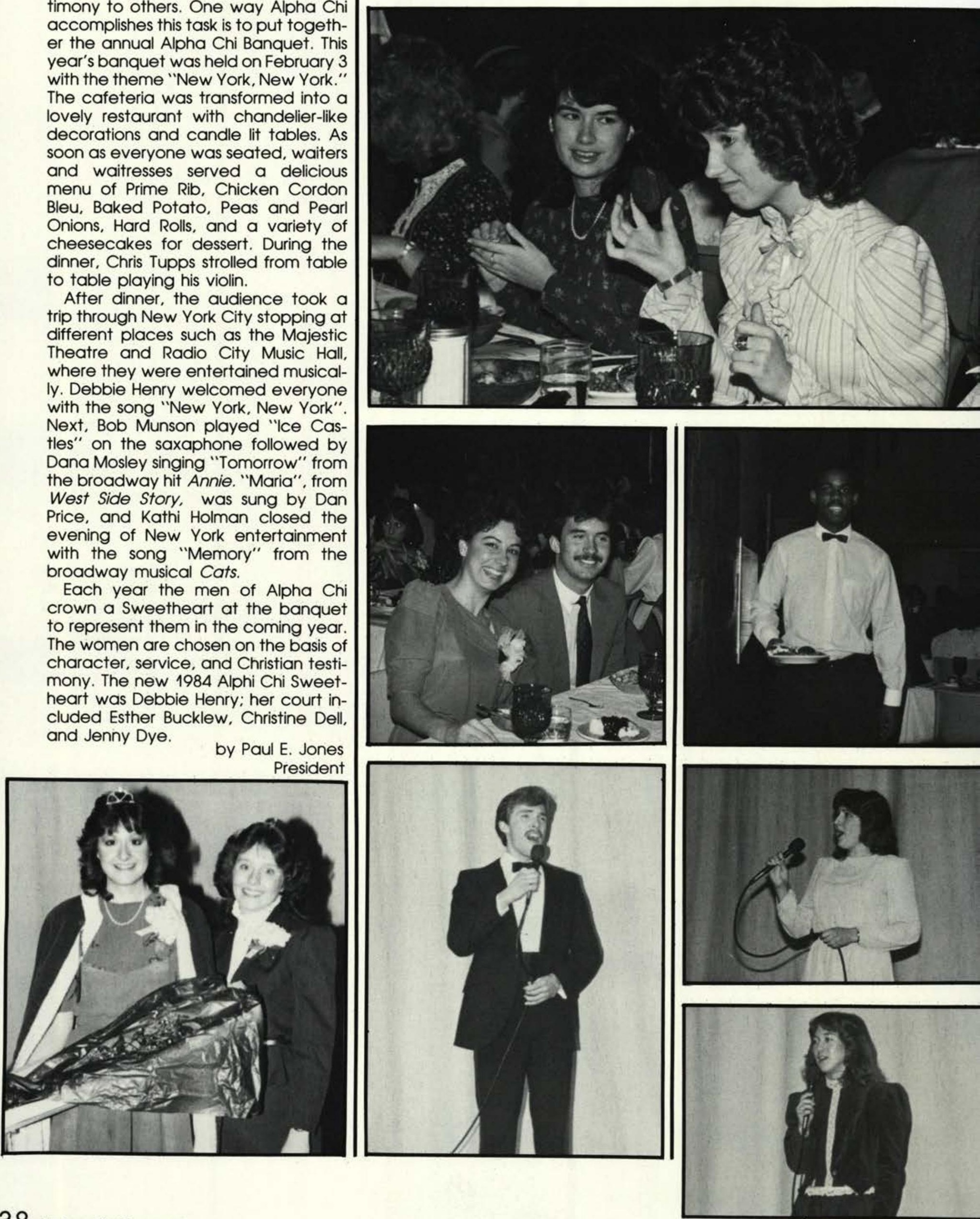


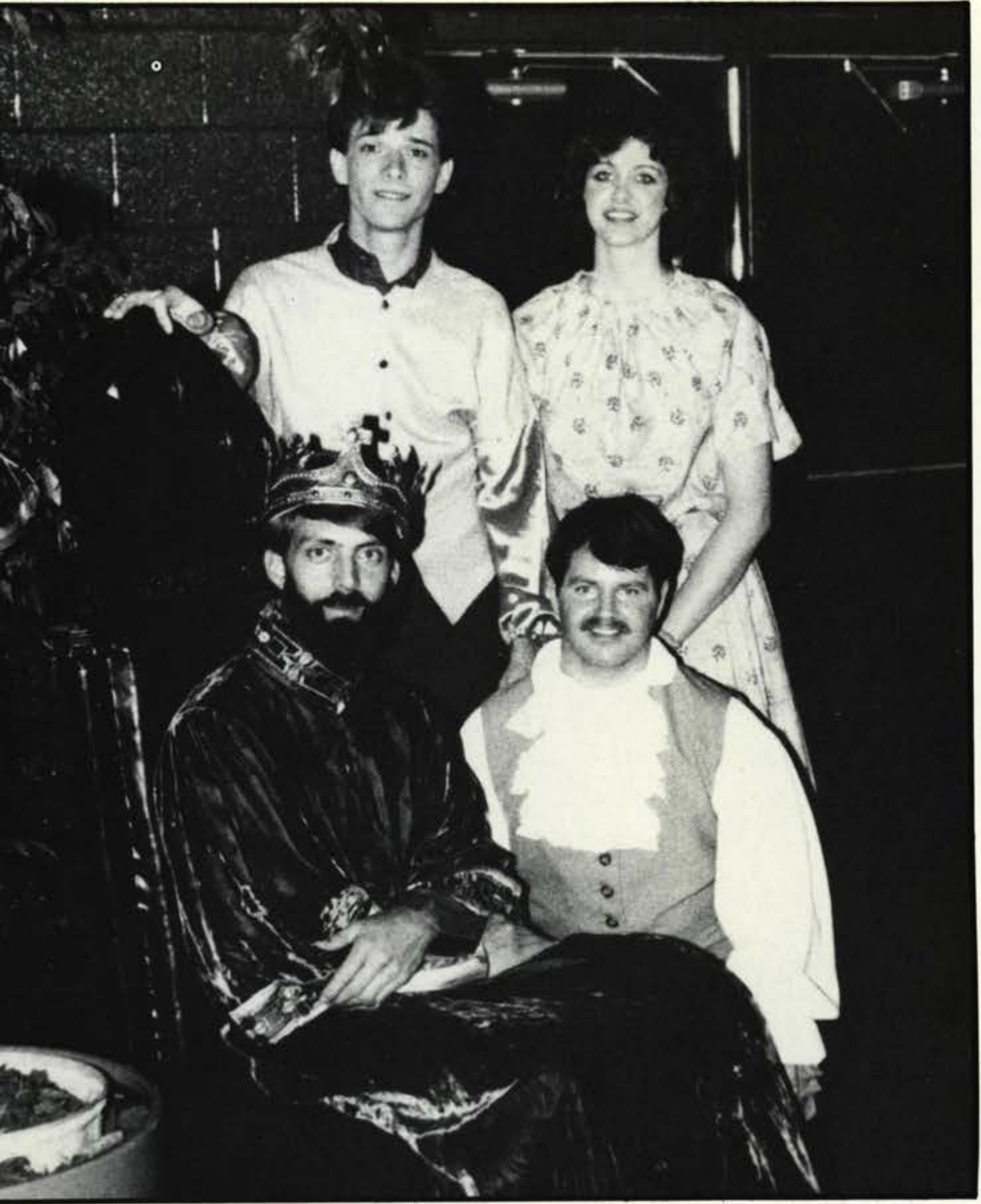

\section{"Beauty And The Beast"}

he evening of April 14, 1984, had I finally arrived. I must admit; however, that I questioned at times whether we would be ready. Endless phone calls, long meetings, various committees, food, decorations, sound, lighting, pictures, and entertainment required our very best planning. The most tedious job came the evening before the banquet when we transformed the cafeteria into a medieval castle. Fun, food, and fellowship kept us perservering through the night. In the back of our minds, we were asking, "What have we forgotten?"

\section{At the king's request ev. eryone enjoyed a dellight. ful evening of "theater.in. the.round."}

As I sat enjoying my meal, I reflected on the hard work and numerous hours invested to produce a successful Gamma Chi banquet. I smiled because I realized that, in preparing for the banquet, the frustrations and problems were just as important as the progress.

Along with the spectacular entrance of the king, "Beauty and the Beast" highlighted the evening. At the king's request everyone enjoyed a delightful evening of "theater-in-theround" in Gamma Chi's enchanted Castle of Dreams. What a pleasure and blessing from the Lord to have been part of that experience.

by Christine J. Hart 
ON 饥医 A吸
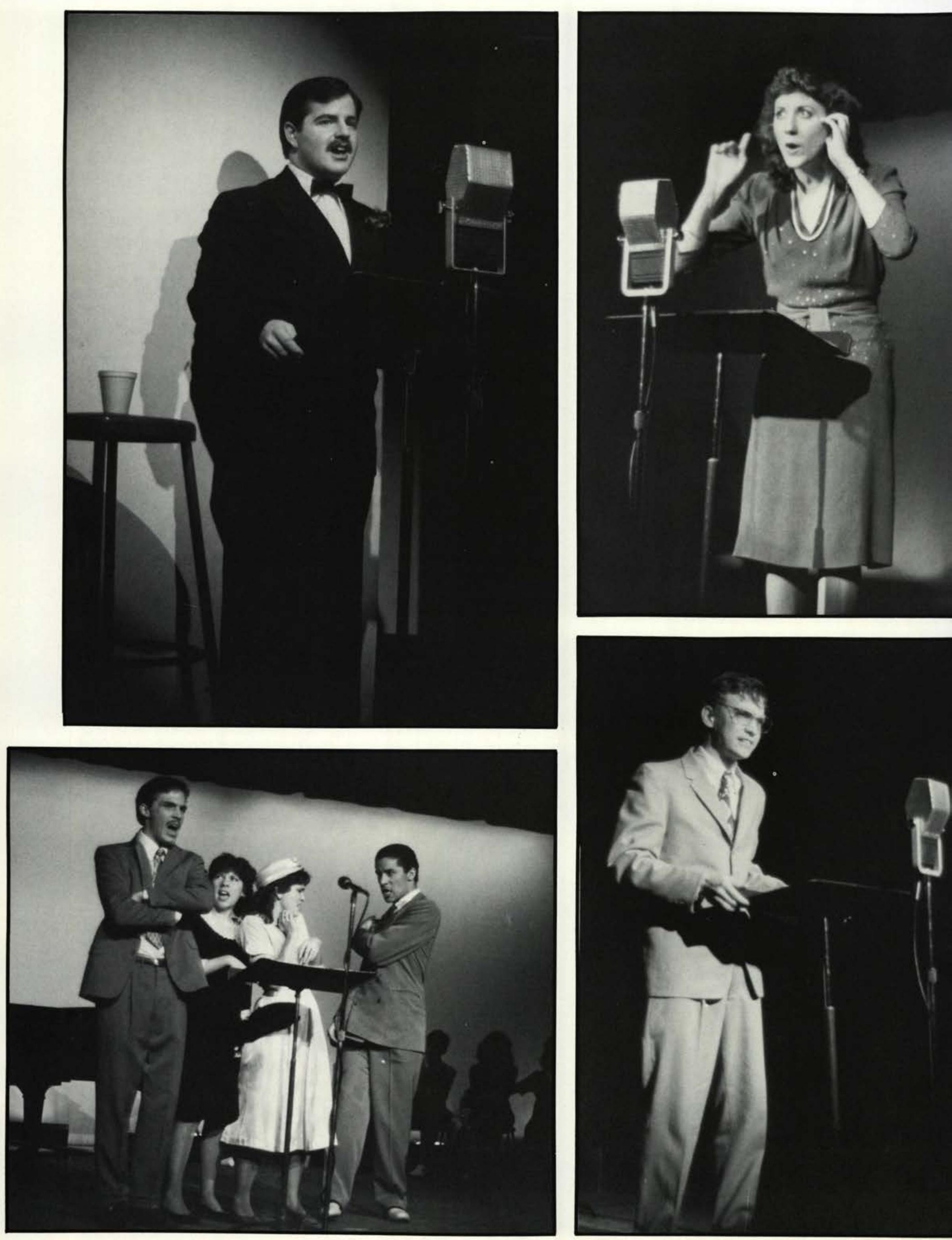


\section{으 The Ân}

C ood evening, ladies and gentle3 men! We're on the air!"

A mid-winter break from the snow and sub-zero temperatures ... a time ight back into the 1940's with "On the ir," a re-enactment of a World War ॥ adio show.

Sponsored by the Communications lub and directed by broadcasting intructor Jim Leightenheimer, "On the ir" took a tongue-in-cheek look at oth the overdone melodrama and the slapstick humor of radio in its peak.

Performed in Alford Auditorium Feb. 17-18, the program included a taste of most things common to radio, whether it be Kate Smith urging the sale of war bonds and bullets to shoot Nazis, or singing commercials with a four-member chorus extolling the virtues of Wheaties and "new Oxydol with Albinolite."

Mystery and adventure series were glimpsed, as were the heart-rending

romance tales, where, battered and bruised by life's hardships (and probably by tomatoes from the audience) the leading lady bravely and pluckily pulled herself from despair to see that "life can begin at 35."

The six-member cast, student-directed by Lynn Butckey, assumed various roles interchangeably, from the tragic to the sepulchral to the comic to the adventure roles, adjusting their voices, dialects and posture to convey each different character.

Taking a few liberties with the radio tradition, the cast panfomined sound effects which were flexibly supplied by senior Marty Berrien, who did everything from beating an oatmeal box to make a drumbeat, to breaking branches over his head for jungle noises.

Junior Rick Horsfall emceed the show, acting as announcer and transition artist from series to series.

Horsfall and Berrien also did a midshow rendition of Abbott and Costello's "Who's On First?"

The rest of the cast included sophomore Steve Banning, freshman Melanie Coleman, and senior Jane Owen.

The chorus, who not only sung commercials but also soloed on "Your Hit Parade," were directed by Jeff Lyle and accompanied by Judy Walter. They included freshmen Larry Harris and Lisa Tyson, as well as junior Kim Murphy and senior Dan Price.

by Jane Owen

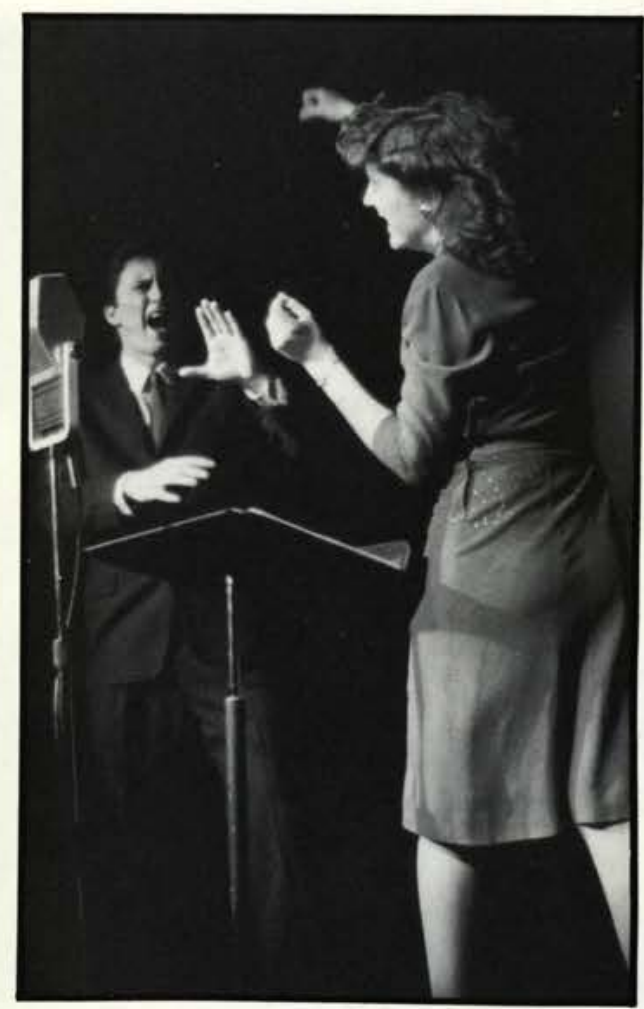




\section{CEDARVILLE STUDENT}

Smille. Sure, I'll go out with you - how about December 17, 1993?"

Diary. "Isn't that Seven-star diary!?!"

Umbrella. A necessity at Cedarville, where it rains 360 days of the year - the other 5 days it snows! (polka - dots for the extra zip of prep).

Wool socks. A necessity for those January days when one lousy degree determines that it won't be a pant day.

Bass loafers. For those icy days when high heels are a sure way to find yourself fallen on the sidewalk in front of the College Center and 50 Cedarville College men.

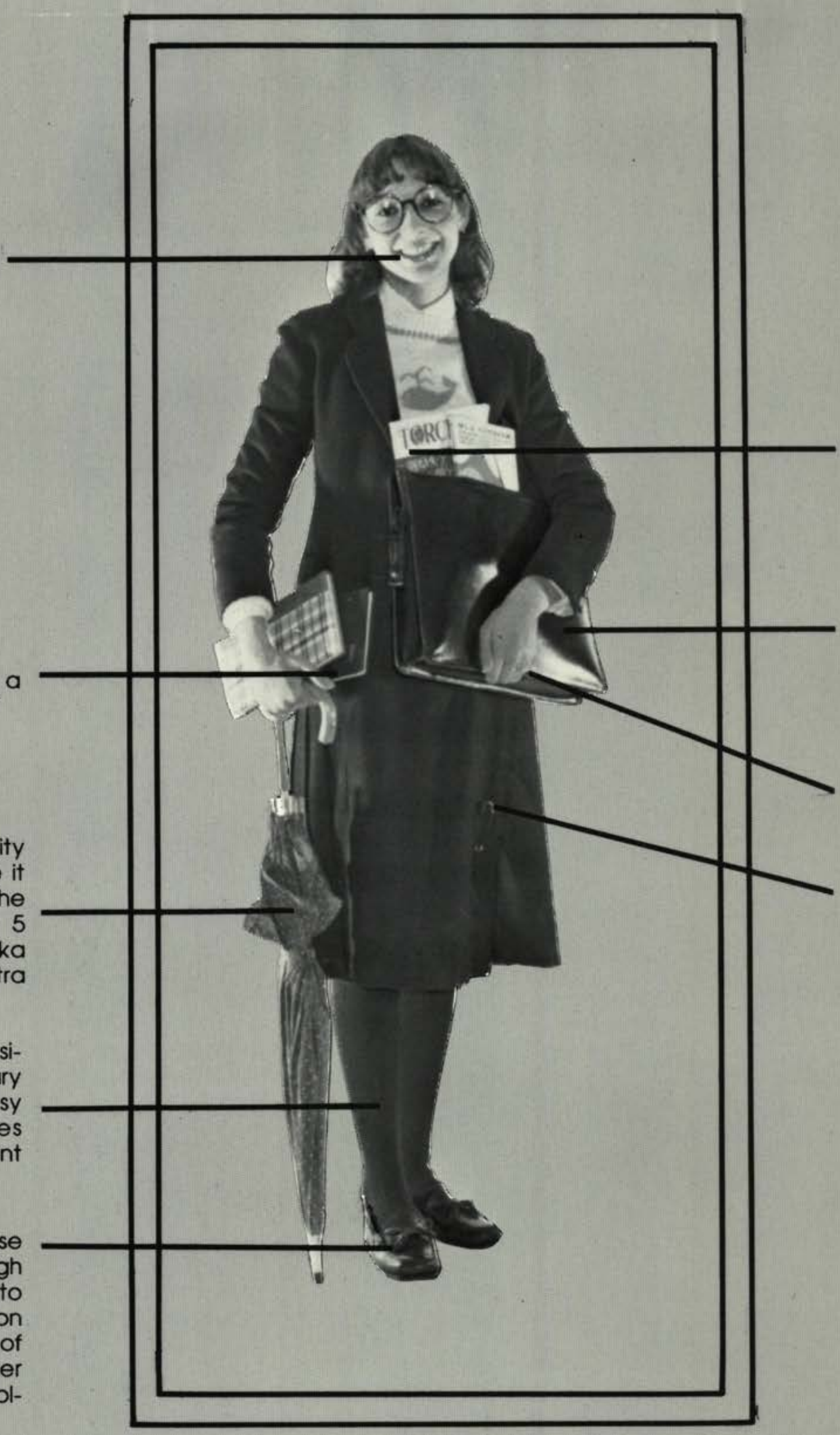

Torch. "The truth, the whole truth, and noth. ing but ..."

Briefcase. Carried by those who want tc look professional, ye can never find wha they want in it wher they need to.

Engagement Ring. The pride, joy, and goal o Cedarville females.

PInned Skirt. For those blustery Cedarville days when it pays tc "be prepared."

\section{CEDARVILLE FEMALE: (seeder-vil) (fee-mäl) noun:}

1: person of the feminine persuasion attending Cedarville College. 2: Activities include trips to Young's as a reward for successful dieting, spending Spring days getting some sun in Maddox courtyard, and attending aerobics class every Tuesday and Thursday. 3: Also characterized by adding a touch of class to Cedarville College. 


\section{CEDARVILLE STUDENT}

1e. Cedarville male ө. Can't be too big he might give her wrong impression!

Ivity calendar. 101 is to have a date. E!!

Handbook. "BapApocrypha"

ts. ys

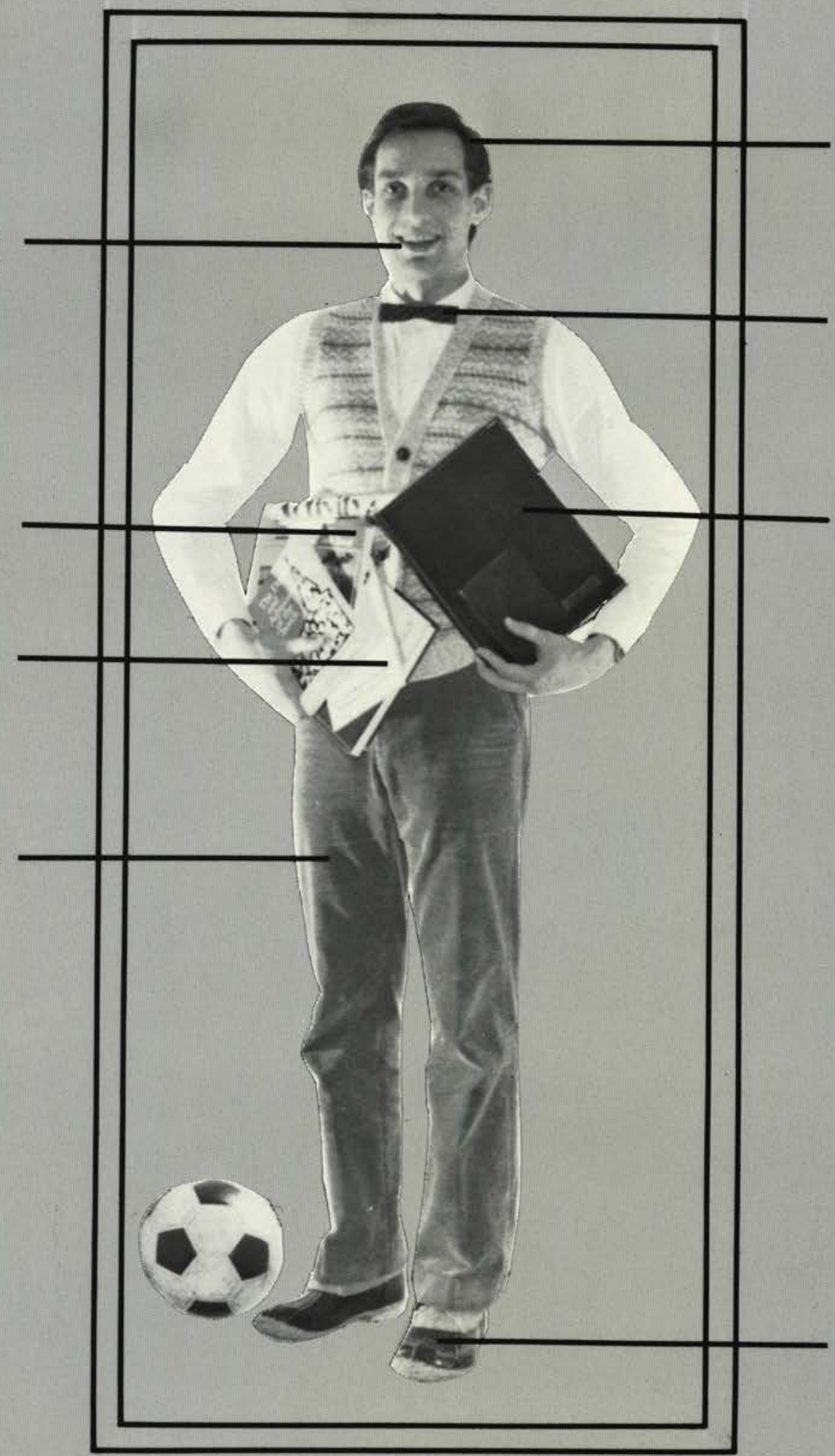

Hair. Cleanly cut and above the ears (unless of course it is the end of the quarter, then it is behind the ears).

Bowtle. Found on those classy rare individuals who are the preppiest of all!

Leather folder. Equipped with gold plate with name engraved on the front right corner, designed to impress!

Duck boots. All weather footwear.

\section{CEDARVILLE MALE: (seeder-vil) (mäl) noun:}

1: person of the masculine persuasion attending Cedarville College. 2: Activities include hanging out in the Athletic Center in gym shorts and a torn Tee-shirt, tucking over-grown hair behind the ears (and avoiding Dean Walker), and eating four helpings of the main dish at supper. 3 : Also characterized by the "I have a big test tomorrow - let's go play basketball" syndrome and by adding a touch of excitement and craziness to Cedarville College. 


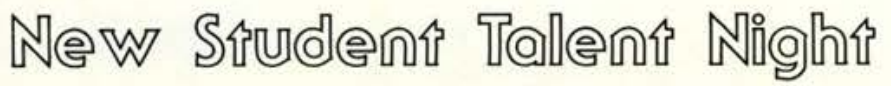
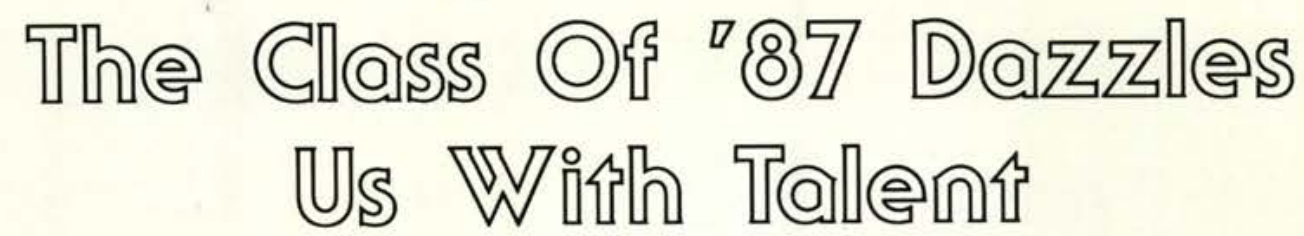

$\mathbf{W}$

hen the curtain opened and the announcement was made that Ma Printy and Mrs. Howell would not be able to emcee the New Student Talent Night, many disappointed sighs made themselves known. However, we were not to be dejected.for long. The first act presented two very ravishing, mature ladies singing "Little Girls." AHA! They couldn't fool us! We soon saw through their little masquerade and as they sang we responded with enthusiasm and acceptance. After setting an appropriate atmosphere for an evening of laughter and entertainment, these two campus sweethearts proceeded through the program providing the transitions between acts for the many students who wanted to use this opportunity not only to entertain but also more importantly to glorify the God who gave them their talent.

Eric Helmuth won first prize in this year's competition for both originality and talent. This year's New Student Talent Night only gave us a taste of the potential of the class of ' 87 . Let's pray that they continue to use their talents for God's glory.

by Bill Thomas
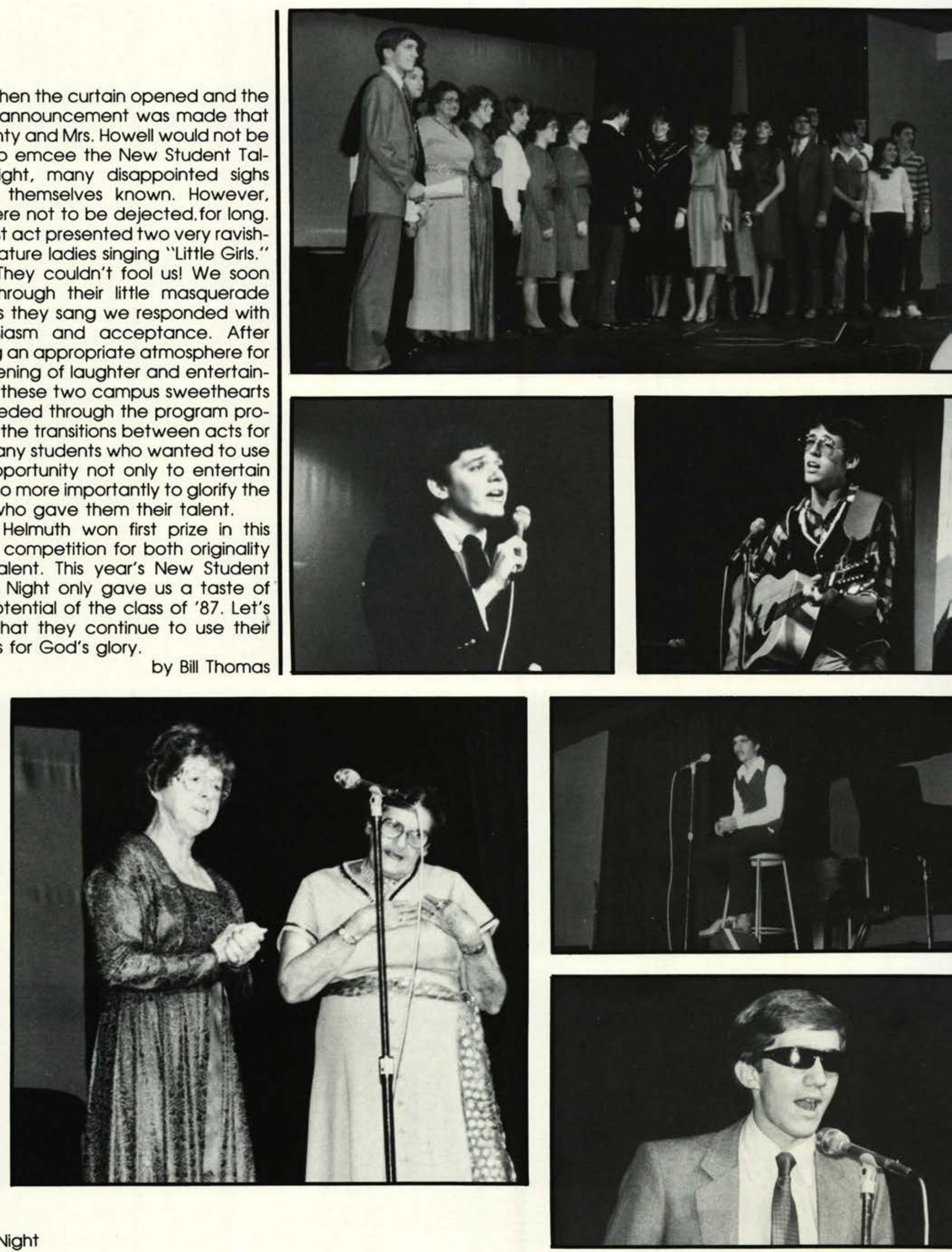


\section{AX Talent Night Proves To Be Unique}

This year's Alpha Chi Talent Night once again proved to be a unique

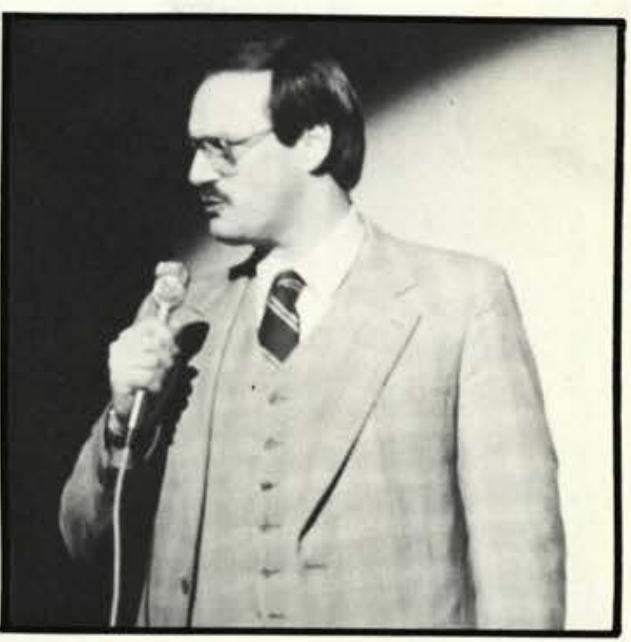
affair. The covert "humor" and the ease of ad lib of emcee, Mr. Mike DiCuirci, provided a pleasureable break between each act.

Once again a mixture of solemn, heart warming classical and sacred music along with knee slapping, rib tickling, laugh-a-minute sketches characterized this year's talent show. The acts ranged from Eric Helmuth's rendition of Rachmainoff's "Polichinelle" and Janice Warren's and Rusty King's piano duet, "Heaven Came Down and Glory Filled My Soul," to a spoof of The Sound of Music and a monastic quartet number in honor of our beloved President Dixon entitled, "Passin' the Faith Along." Not to mention the satirical "The Day After Tomorrow" show or the song every girl sings at least once in her life, "I'm Gonna Wash That Man Right Outta My Hair," as performed by Debbie Henry and Lisa Tyson. Angela Cooke favored us with a song from The Wiz and Alice Boyd enacted a humorous oral interpretation entitled "The Waltz."

Eric Helmuth took first prize for the evening's performance followed by the Cedarville singers' "The Sounds of Cedarville" and those marvelously mirthful monks at second and third respectively. Thanks AX for another job well done.

by Bill Thomas
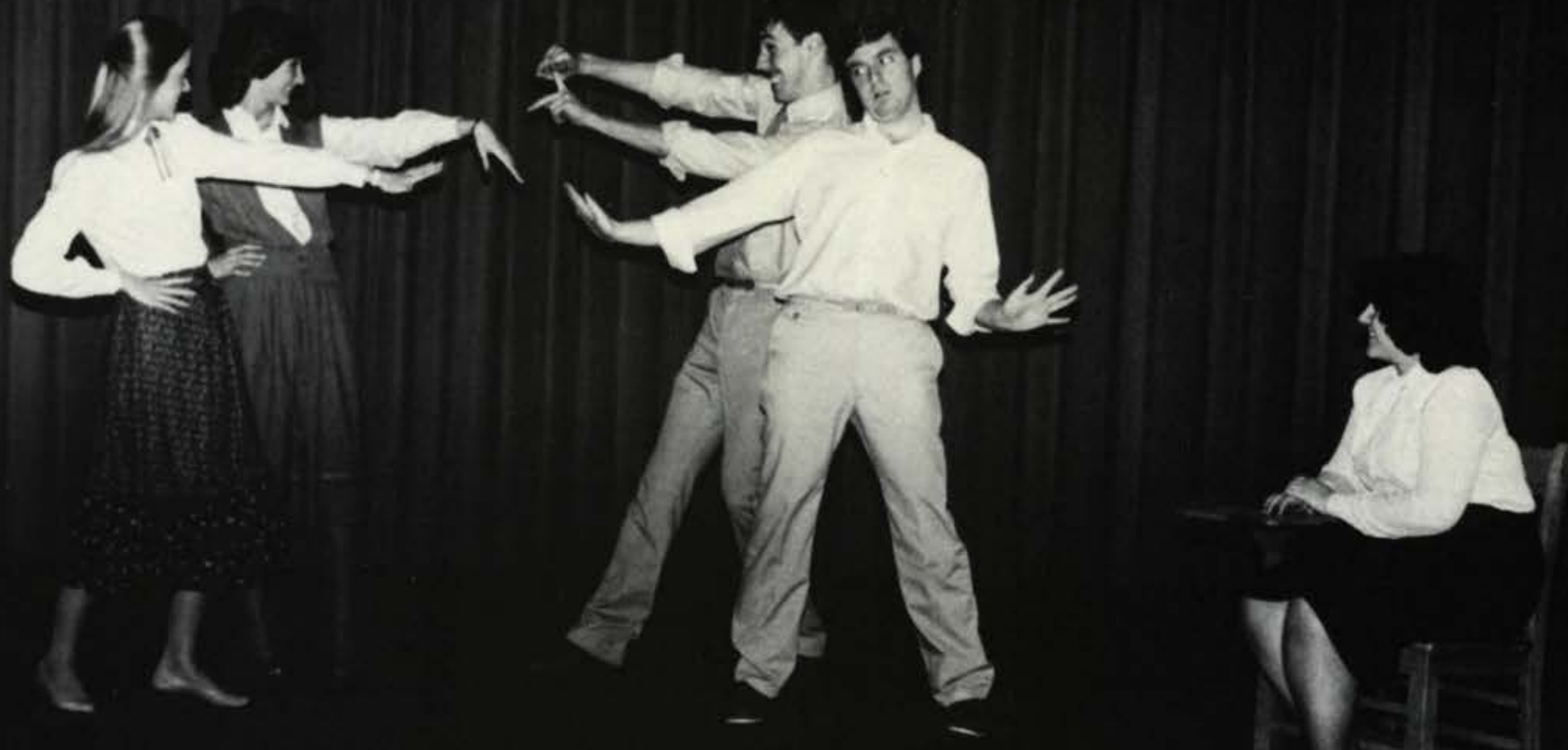


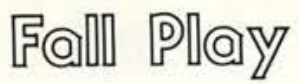

\section{Behind The Scenes}
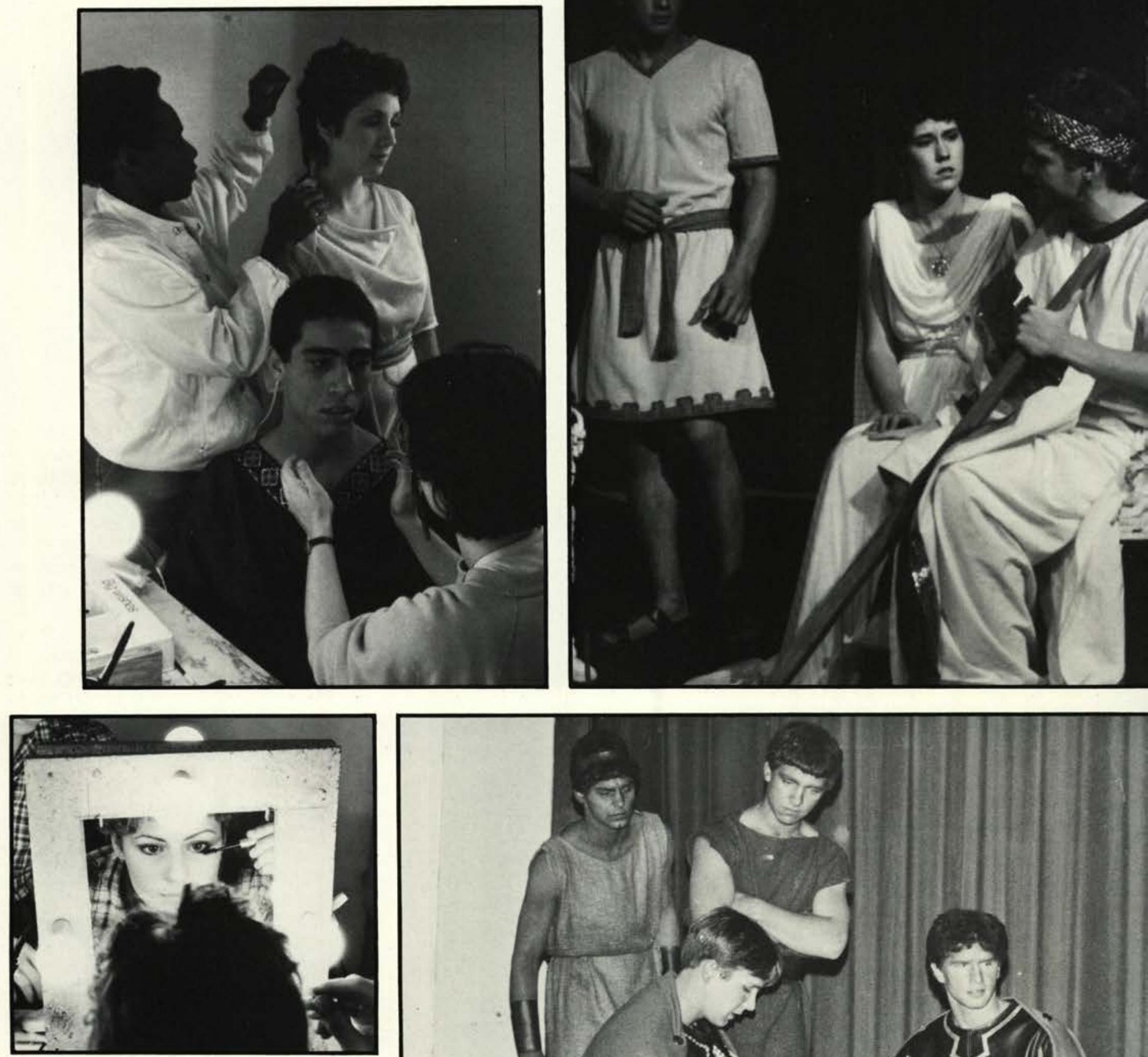

THE CAST:

\section{Dale Burdick}

Mark E. Matthews

David Hale.

Mark A. Nemitz
Gary S. Cooke

Benjamin Herr

Jim Liebler

Stephen A. Banning

Joanna Tyler

Robin Randolph

Melissa A. Marsho

Julia L. English

Irene Farley

Elena Michael ...

David Johnson

David Olsen

Gary Barker

Larry Harris

Rebecca J. White

Kenne

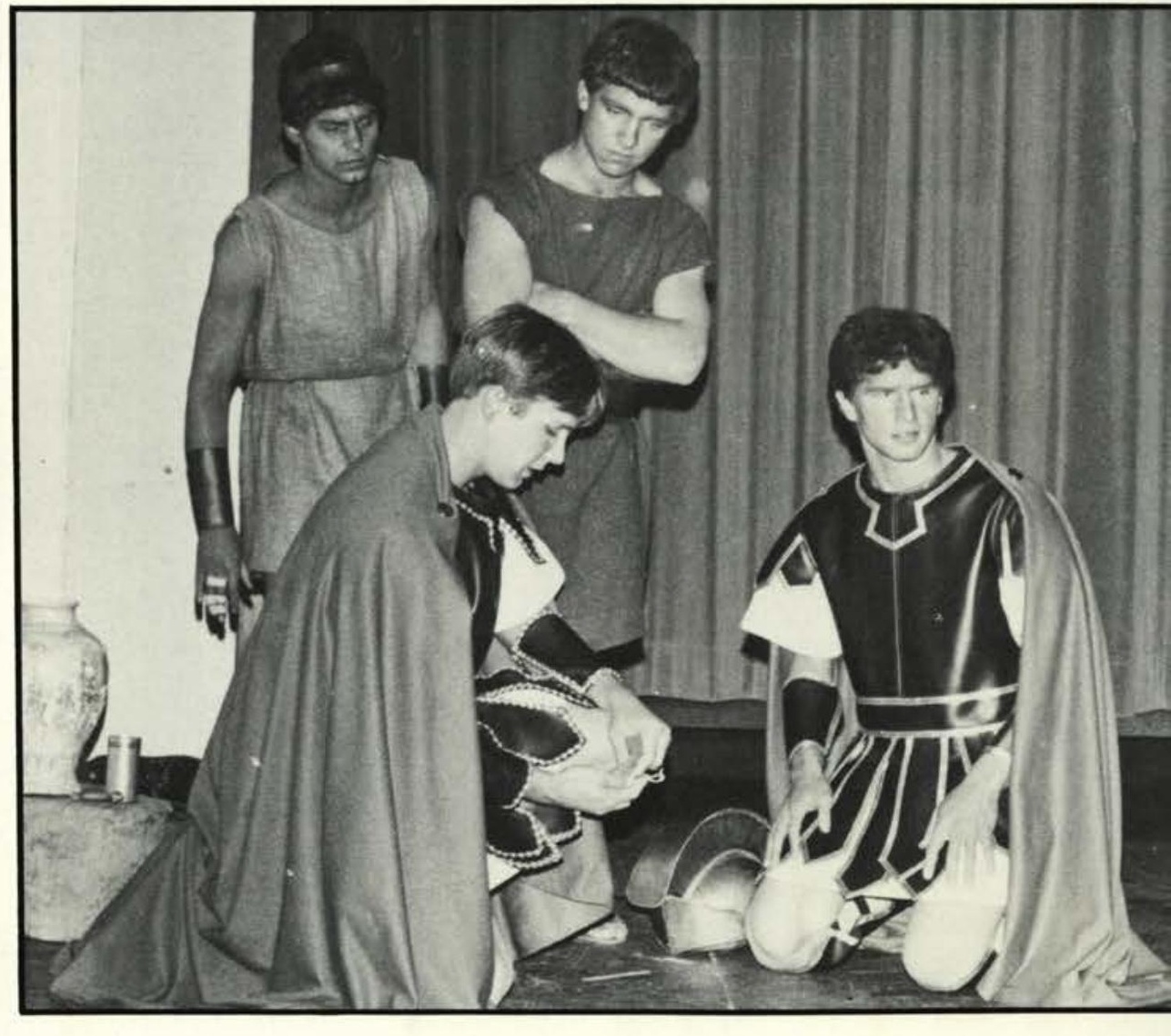

Extras: Lori Barrand. 


\section{The Pages Of Anne's Mind}

Tas stunned. The houselights flashed back on and found me staring ahead, shocked back into the reality of my auditorium surroundings. For the preceding ninety minutes, the explorations of my mind were transposed to a dim apartment above a warehouse in Germany. There, I had witnessed the powerful struggles of human nature: the struggle for freedom, for satisfaction, for mere sanity in a world gone crazy with darkened thinking.

Eight Jewish people swept me into their world of frustration and bitterness, of boredom and loneliness, of hope and laughter. The characters graphically unfolded themselves, magnificently interacting with one another and with their captivated audience. Kathy Bachelder, once a senior speech major with curly red locks, suddenly became a dark-haired Jewish girl of twelve named Anne. The play followed the events of her life from age twelve to fifteen, as written in her diary.
Anne recorded everything: the classes with her mother (Tricia Emerson), the deep affection for her father (Dave Jones), her feelings about being locked up inside a tiny apartment for endless days, her witty remarks about their food, the favoritism everyone held for her quiet sister Margot (Laura Hartsough), her running commentary on the strange antics of Mr. and Mrs. Van Daan (David Johnson and Stephanie Pratt), the disagreements with her "temporary" roommate, Mr. Dussel (Dave Shulse), her simple longing for an afternoon bike ride or a game of pingpong, and finally, her initial distaste for Peter Van Daan (Gary Cooke), which eventually transformed itself into love. She also wrote about the eagerly awaited visits of Mr. Kraler (Chuck Christ) and Miep (Carol Silver), the two who sustained them with food and supplies throughout their hiding.

After more than two years of secretive existence, police stormed into the apartment. Everyone was taken to (Cont. on 149)
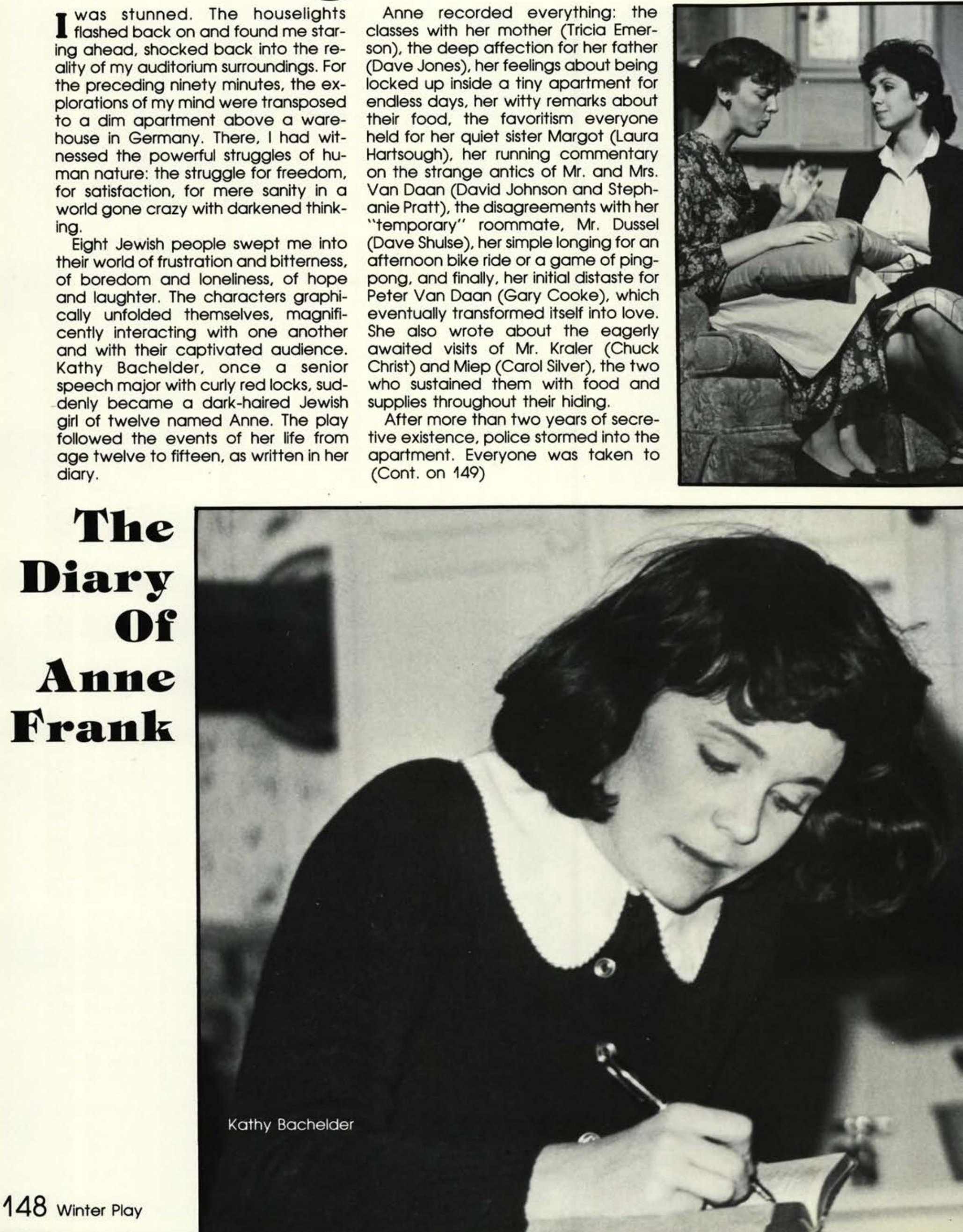


\section{She Stoops To Conquer by Oliver Goldsmith}

S ome of you may remember the S "Soup and Sandwich" jingle sung in Campbell's commercials a few years ago. Actually, the tune goes back even further, originally sung as "love and marriage, love and marriage can't have one without the other ... love and marriage go together."

Though love and marriage don't always "go together," the concept remains legitimate. Apparently Goldsmith thought so, too. Parental ar- rangement of marriages for finaicial or social reasons was still being practiced in England. This combined with other factors contributed to an unusually high social acceptance of love outside of marriage.

Though certainly not the play's predominant focus, this situation is addressed. The couple embodying the subplot - Hastings and Constance are willing to marry without the family jewels. Likewise, main characters Kate
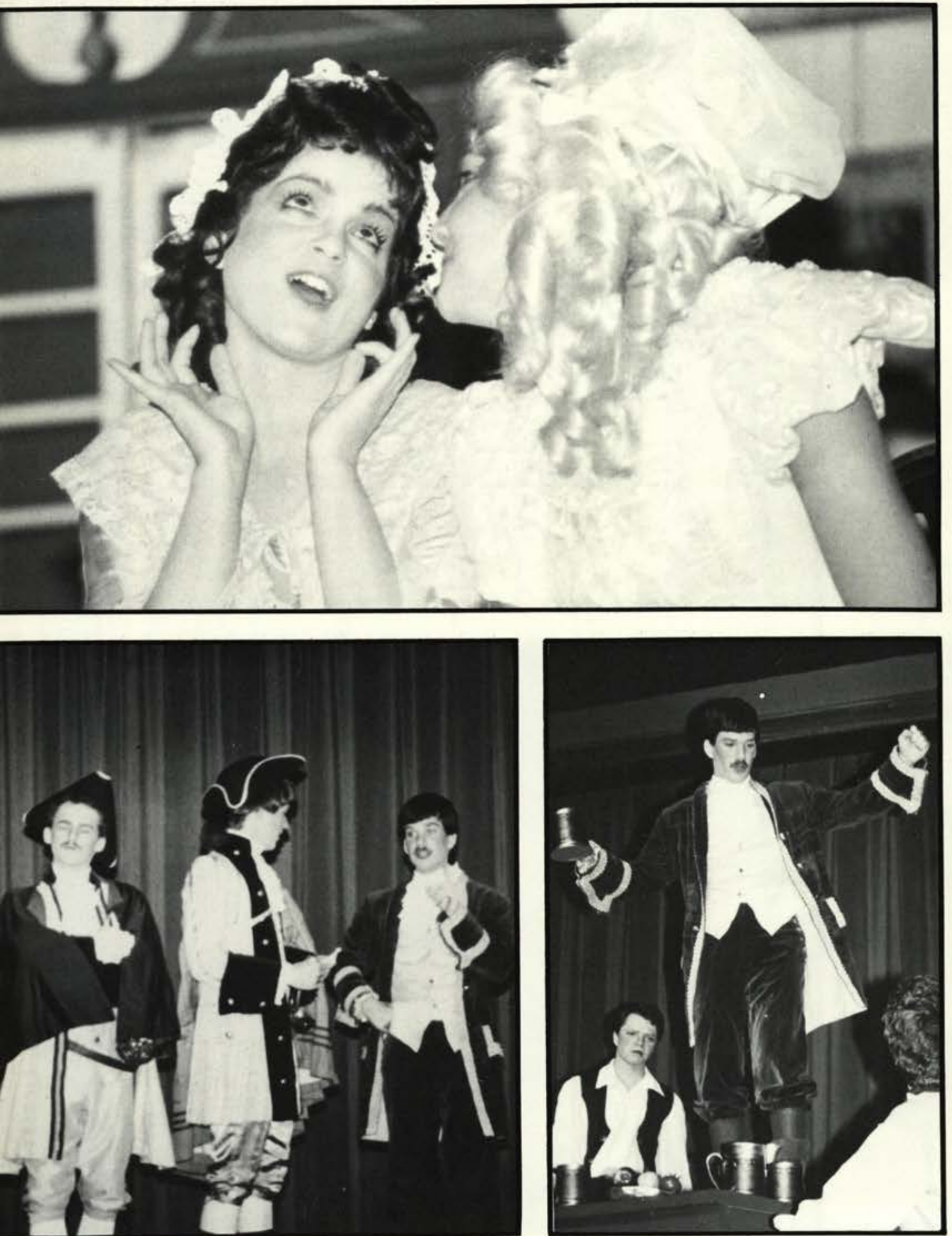

and Marlowe ultimately decide to "ti the knot" because of what they hav discovered in each other rather tha for name or rank. Marlowe rises to her status when he declares he would giv up the high-class arranged marriage i order to marry "the maid." You ca almost hear Goldsmith whistling "can have one without the other ... lov and marriage go together."

by Rebecca Bake

\section{The Cast}

Kate Hardcastle .... Robbin D. Dane Young Marlow ........ David S. Olse Tony Lumpkin ........ Douglas J. Mille Squire Hardcastle ....Gary S. Cook Mrs. Hardcastle .... Tammy A. Evar George Hastings ..... Gary W. Barke Constance Neville ...... Lisa L. Tysc Sir Charles Marlowe, Sr. . . . . . Mark Holmc

Diggory ............. Jeffery R. Baile Dick ..... . . . . . . . . David L. Zehrun Roger .............. James M. Lieble Thomas .... . . . . . . Richard D. Hobk Stingo ............. Steven P. Walte Muggins ............. Robert K. War Slang ............... George Ree Aminidab ...........Matt Hendersc Jeremy ................ Barry P. Kar Dolly ............... Cynthia L. Ree Bridget ............... Brenda Jo Gu

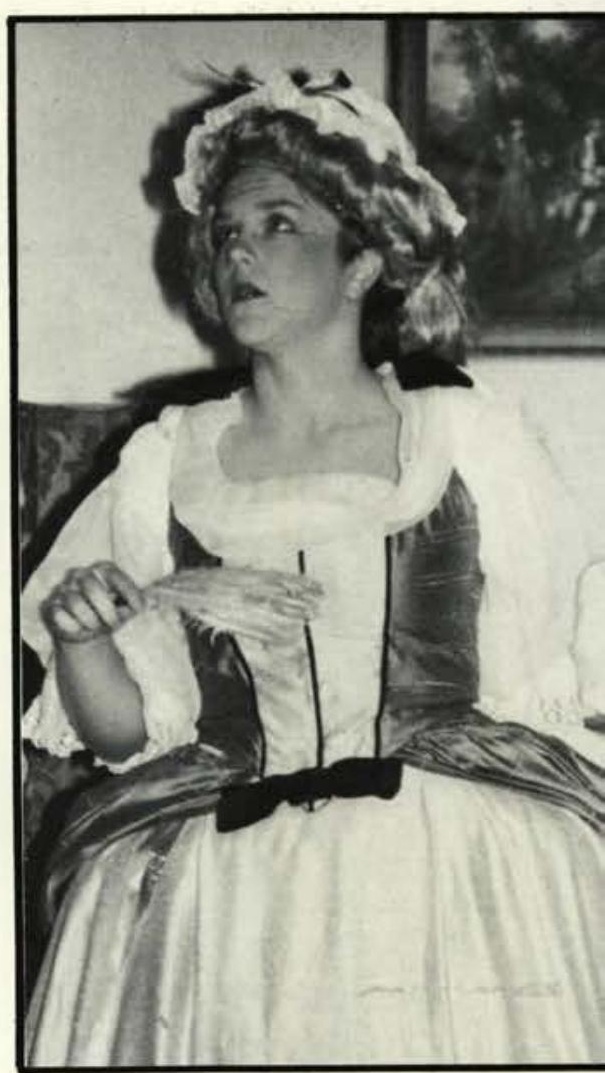



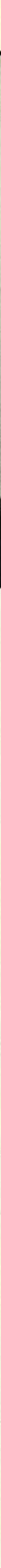
W

$\theta$ read in the scriptures of the manifold grace of God. Peter uses the term in relation to the gifts given to his servants as they minister to the body of Christ. It has been a real joy experiencing this through the chapel program during the 1983-84 school year.

The varied colors of the spectrum were clearly presented during the major Bible conference of the year. Starting with the Fall Bible Conference and Dr. David Burnham's emphasis on commitment. The variety of this missionary conference emphasied the different types of servants God uses: Dr. Vigo Olsen a talented surgeon, Dr. Raymond Buck a veteran missionary, Brother Norm Nicklas a young effervescent church planter and the qualified French missionary, Jan Gazdik. Dr. Don Jennings brought a vibrant challenge through the Spring Enrichment Conference that will long be remembered.

Many special speakers were used to bring a special insight into the ministry

\section{"Many special speakers were used to bring a spe. cial insight into the minis. try and the Word of God."}

and the Word of God. Several that were extremely helpful in showing the many colors of God's grace were: Professor David Warren on "True Spirituality", Dr. Joe Stowell III speaking on "Jesus Loves Me", and those special inforum days with the young Pastor Don Jennings and his battle with M.S.; Mrs. Debbie Haffey and her struggle with grief, and finally the reflection on tradgedy with last years graduate Curtis Hoke. I don't think I'll ever forget how faithful God is to his servants.

I believe the Staley Lecturship was one of the best with Dr. Gary Friesen and Decision Makin and the Will of God. Let us not forget the special servants who shared during the inforum: Dr. Jerry Falwell, Mr. Samuel Ericsson, Dr. Paul Feinberg, and Dr. Richard Mouw on the Christians' Responsibility to Politics.

Last, but not least, the timely messages by our president especailly the message on honesty. How timely and challenging.

God has many colors in His manifold grace and we have been richly blessed through the gifts of His servants in our chapel services during the 198384 school year.

by Pastor Harold Green
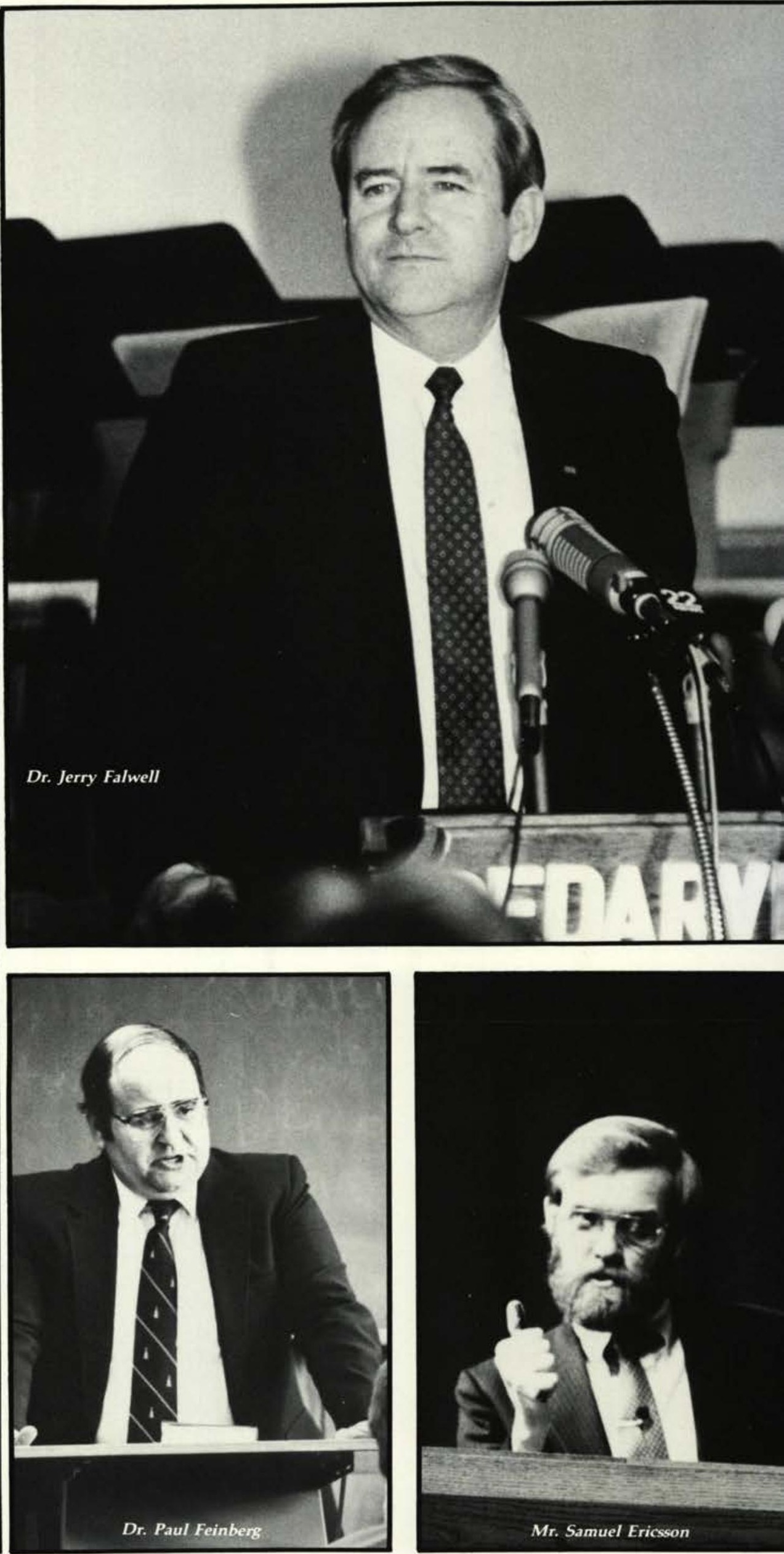
Ch@pel

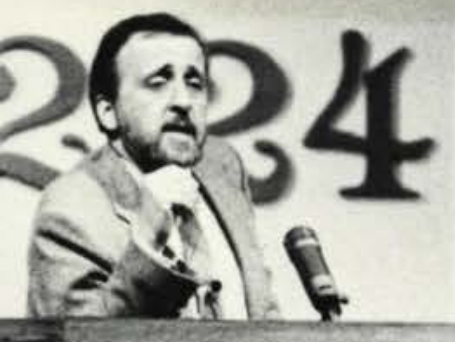

r. Richard Mouw

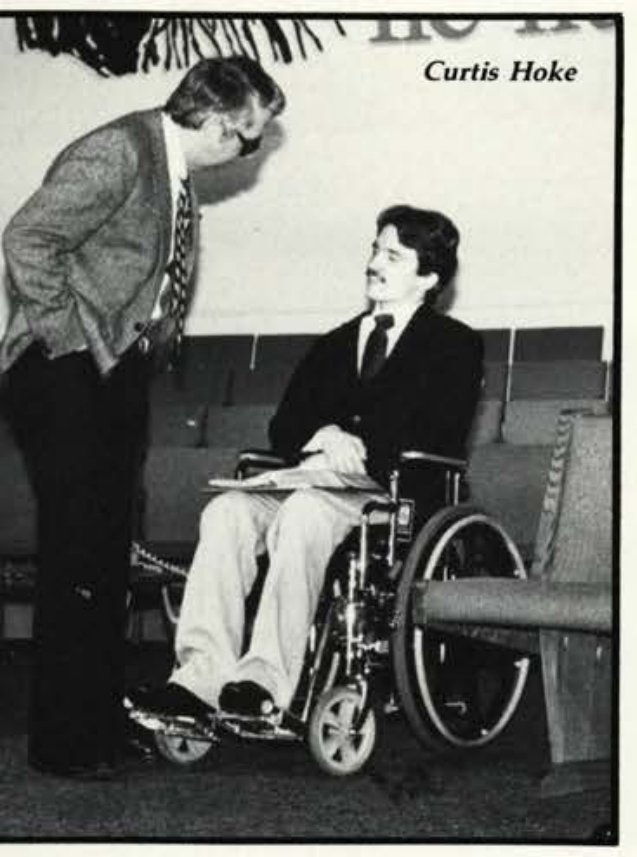

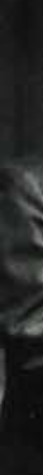

Dr. James $T$. Jeremiah

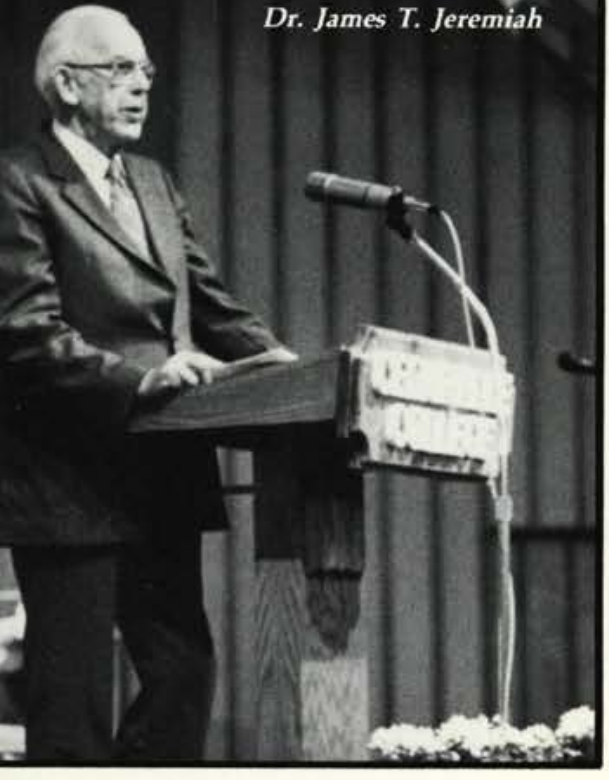

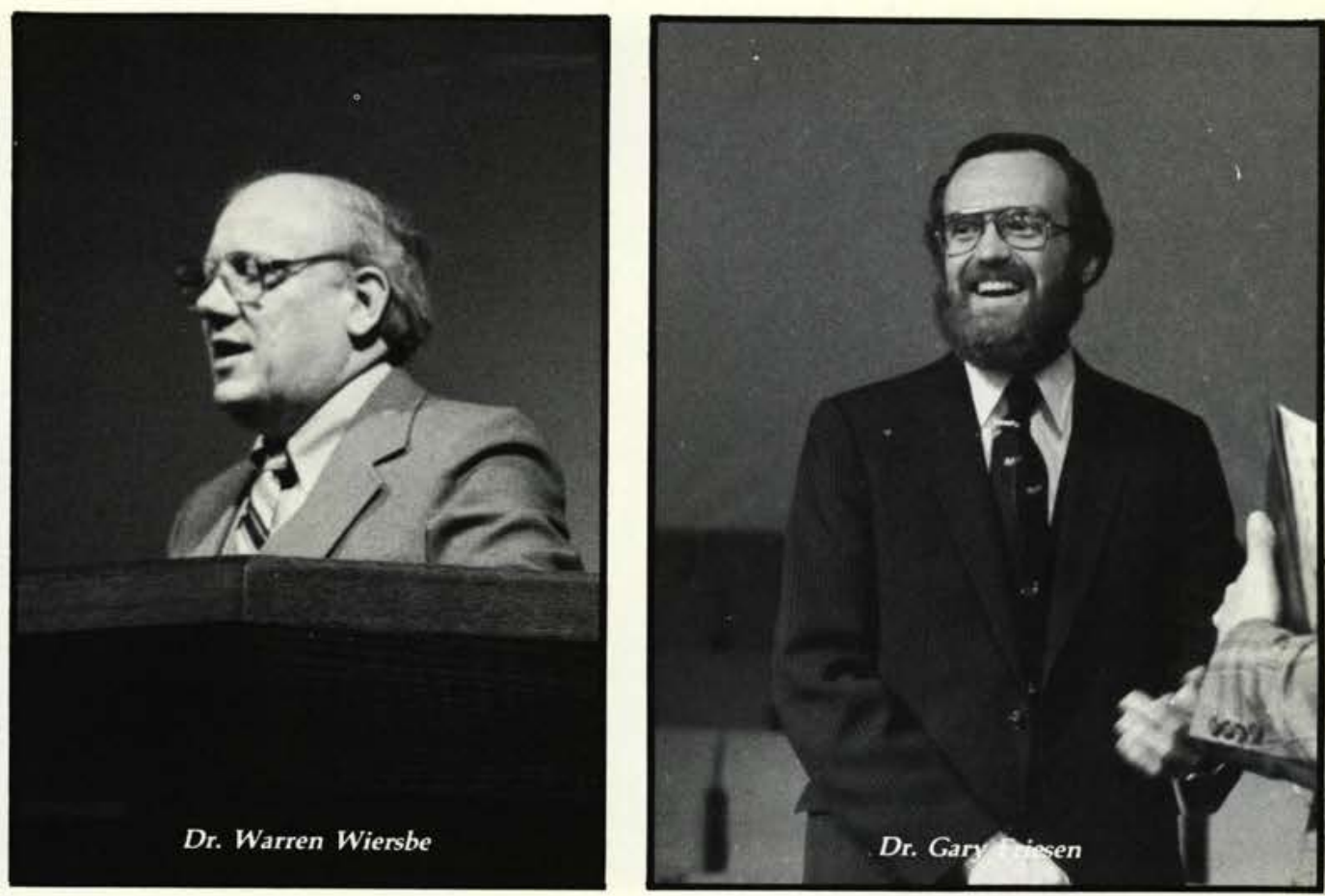

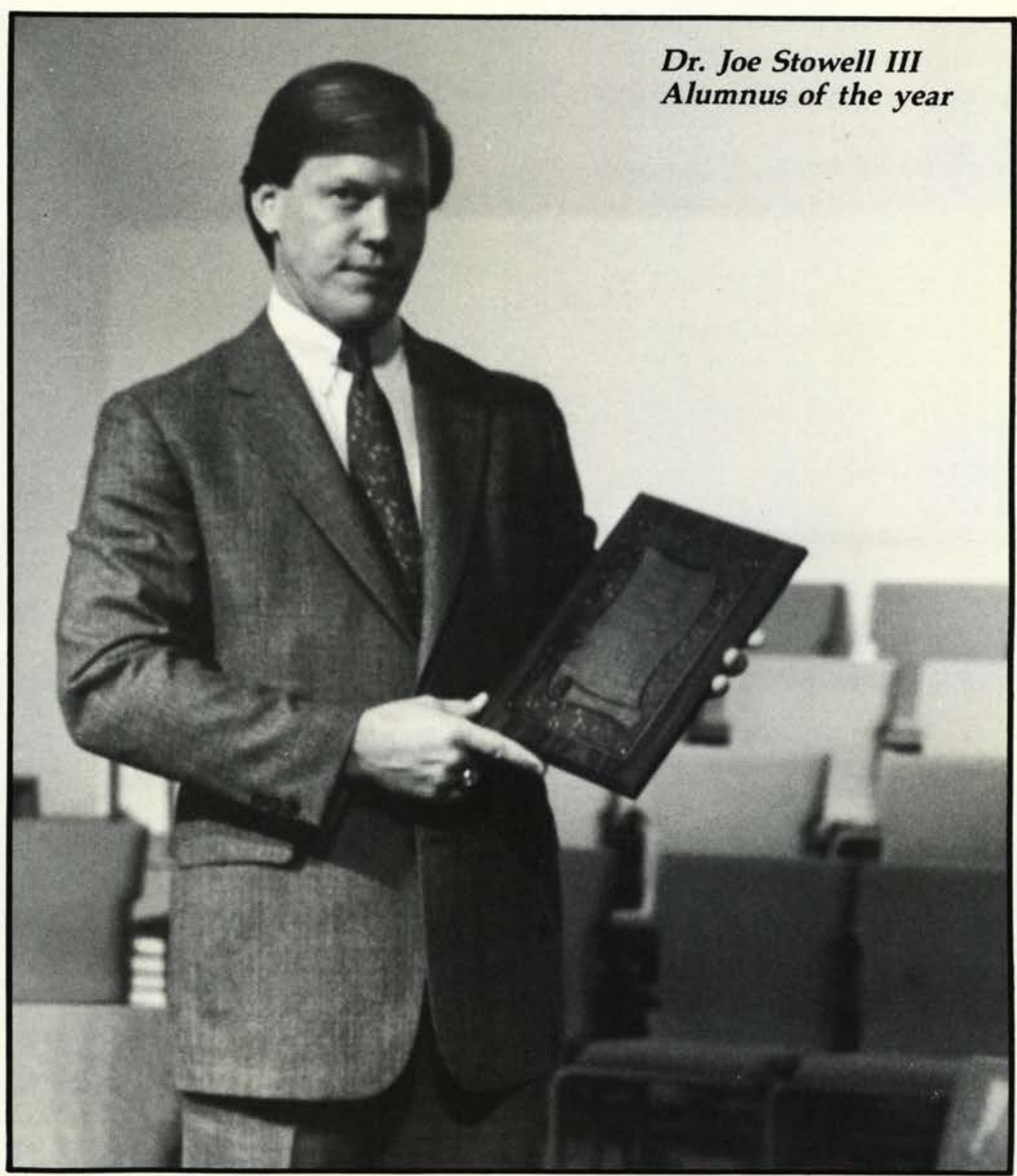




\section{"Who can forget his chal. lenge to wholeness and godli. ness?"}

O ur President Dr. Dixon had told us, "You are really going to enjoy Dave Burnham." And enjoy him we did! We discovered that he had the ability to capture our attention early on and to hold it to his final syllable. His blending of humor and pathos, rhetoric and logic, wisdom and wit both tantalized and challenged us. By the time the week was complete, we felt as though we had a brush with reality and with God. We shall not soon forget Dave Burnham. In fact, let's check out our memory of him just now. Ready? Let's go!

\section{"We ran with him from a blood.soaked bedroom to the emergency room."}

Who can forget the account of his wedding day? Pants too short, cumberbun too tight and too low, voice too squeaky! We will never see another cumberbun without inwardly smiling and reflecting on what happened to him. And how about when he first met the girl who was to become his wife - how this football star impressed her with his fumbles and missed passes during a sandlot football game at church camp? Yes, we will remember Dave Burnham as a man with a terrific sense of humor.

Who can forget his breadth of knowledge? Did we know that our fairy tales and nursery rhymes had historical antecedents; that English history was as interesting as he portrayed it: that the term love had so many shades of meaning? And how about his emphasis and insight regarding critical thinking and integration at the college level? We found him to be very well read in the liberal arts, a very perceptive thinker, didn't we!

Who can forget his humanness? We agonized with him in his decision to marry the woman he loved even though she did not seem to fit the supposed model for a pastor's wife. We ran with him from a blood-soaked bedroom to the emergency room of an Akron hospital. We supplicated with him for his wife's life in the small chapel. We rejoiced with him in the birth of a son and in the sparing of his lover. She even looked beautiful to us through her matted hair and in spite of her puffy lips. We learned from him what true beauty and true love were all about!

Do you remember when he felt

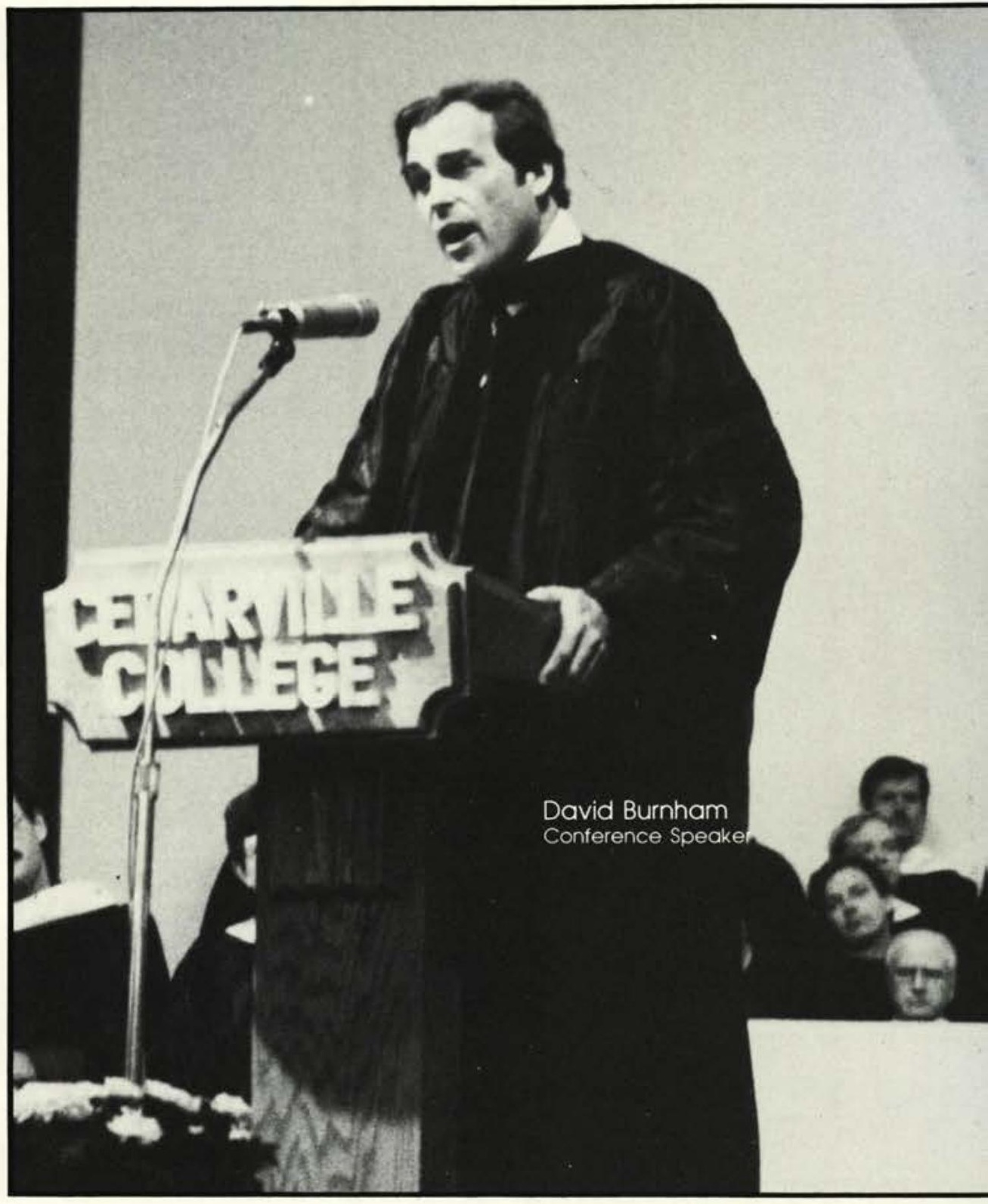

threatened by his son's affections toward a youth pastor, preferring his to his dad's preaching? Will we not feel threatened by younger people coming to replace us? What would we have said to that marvelous athlete now lying in the hospital with two amputated legs? Would we, too, not have wondered about moving from the well-established Chapel in University Park in Akron to the newer Community Bible Church in Boca Raton? Yes, he showed us his humanity with its foibles and frailities. And we identified with him!

Who can forget his challenge to wholeness and to godliness? From this point on we are committed to know. to love, to be, to do as never before. We must strive for academic excellence in every facet of life. We must make decisions in the will of God and commit ourselves to the results of those decisions.

Yes, we will remember Dave Burnham - and be the better for it!

By Mr. Warren

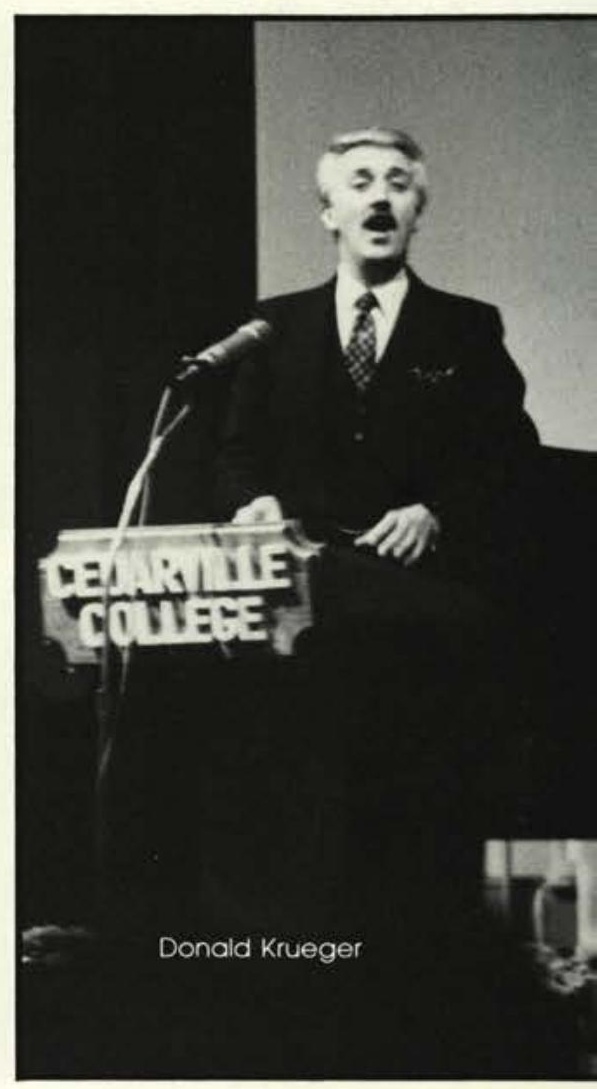




\section{A CHALLENGE FOR COMMITMENT}

J

ohn 20:21 sparked the theme for the 25th annual missionary conference: ". . . as my Father hath sent me, even so send I you." The conference, which was held January 8-13, brought to the platform of the chapel four men whom God greatly used to stir and challenge hearts for missions. Norman Nicklas, executive director of home
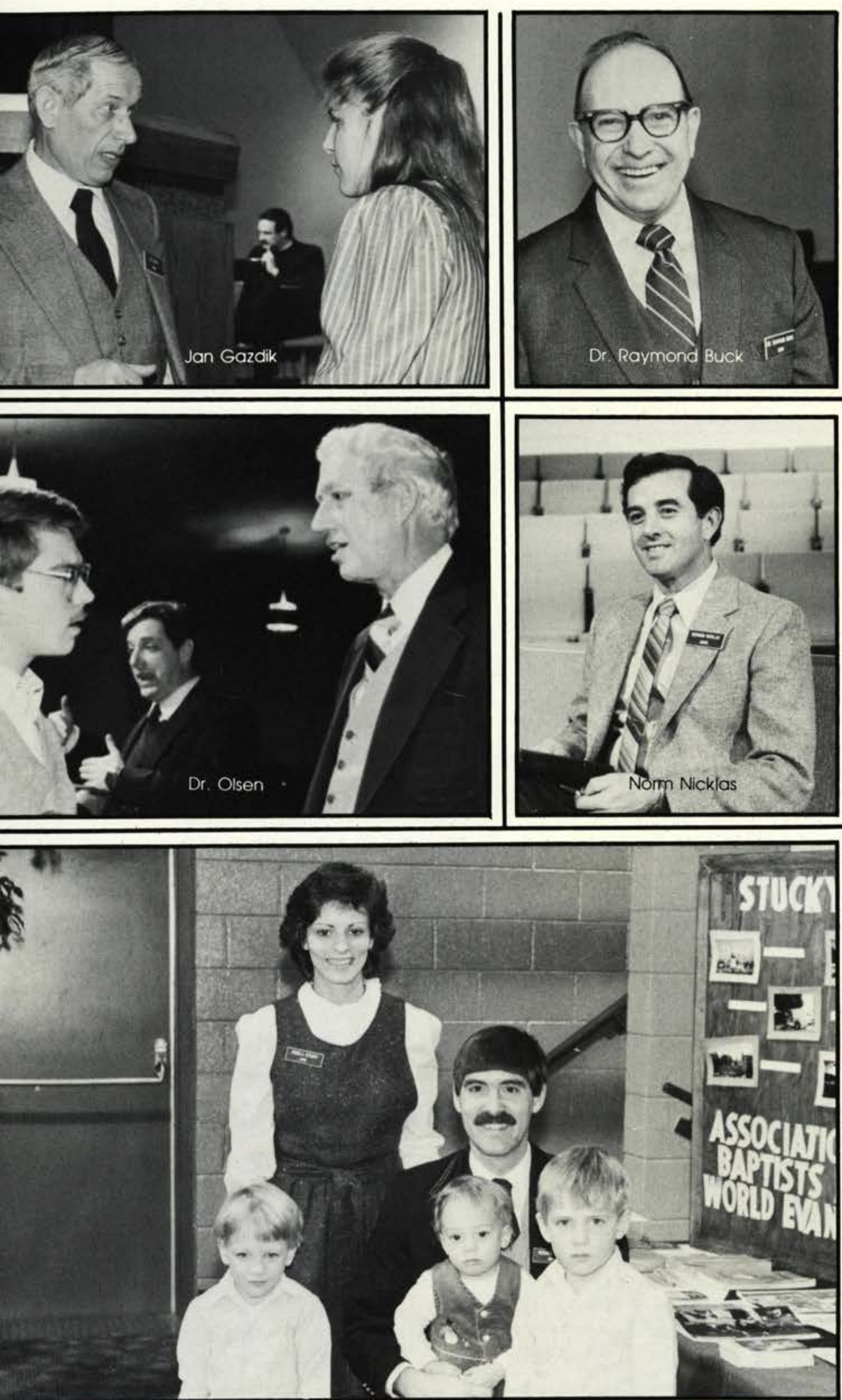

down-to-earth illustrations enhanced his burden to challenge us to be involved in God's great program of redemption.

The newly elected president of Baptist Mid-Missions, Dr. Raymond Buck, brought many years of missionary experience to the conference. He served 15 years in the Central African Republic before taking an administrative position in the mission. He emphasized obedience to the great commission from the life of Caleb and Joshua as well as from the theme verse of the conference.

Jan Gazdik, church planter with Baptist Mid-Missions serving in Quebec, Canada, spoke four times and stirred our hearts as he shared how God is working in Quebec to call out a people for His name in an area that had formerly resisted missionary endeavors. $\mathrm{He}$ brought with him a "living illustration" of the power of the gospel and prayer, Mr. Gilles Marcoullier, who shared with us his testimony. Mr. Gazdik challenged us to send an MIS team to Quebec.

Dr. Viggo Olsen, veteran missionary with the Association of Baptists for World Evangelism in Bangladesh represented medical missions. Dr. Olsen related not only the ministry of outreach he has had through medical missions, but also the importance of translating the Word of God into the heart language of the people. He stressed the vital roles of salvation, commitment, and service.

Approximately 60 missionaries attended the five-day conference, representing missions both at home and abroad. Colorful displays in the chapel and cafeteria provided students with the opportunity to visit with these missionaries on a one-to-one basis. Six seminars were held, presenting such mission challenges as MK Education, Great Britain, medical missions, church planting in the USA, the single woman missionary, and the process involved in becoming a missionary. A number of missionaries visited the dorms in the evenings and answered students' questions.

The Spirit of God worked in our hearts and students made many decisions during the conference. After the last session on Friday morning, nearly 100 students stood in the front of the chapel to indicate their commitment to serve the Lord in some phase of missionary work. Truly, this conference was a time of challenge and commitment to the Lord for service, and we praise Him for working in our midst. 

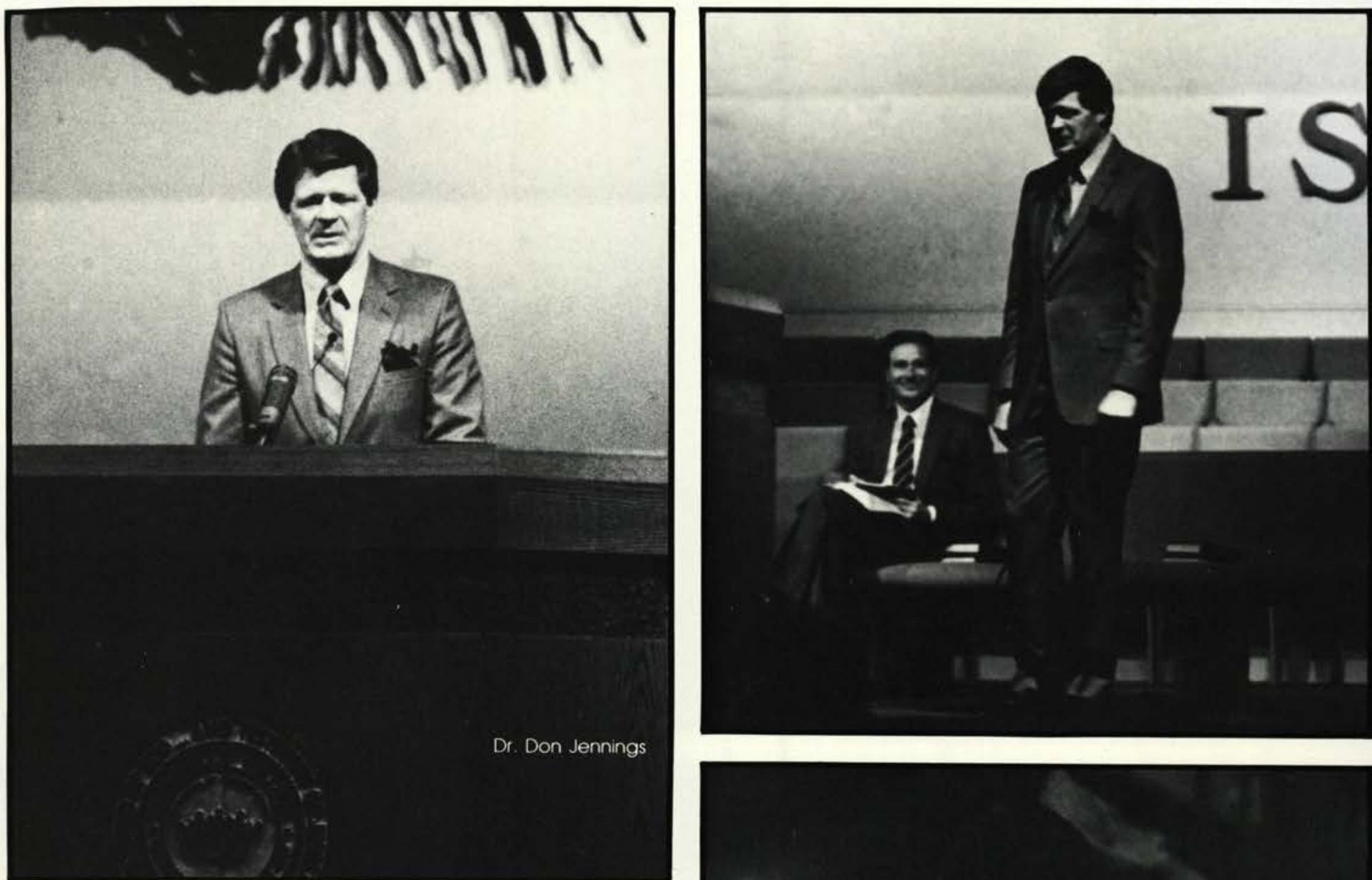

\section{"Heavenly Horticulture"}

D r. Don Jennings' ministry to the college during Spring Enrichment Week held special meaning for the members of our family. We have had the privilege of knowing $\mathrm{Dr}$. Jennings as pastor and friend and have been influenced by the consistency of his walk with the Lord, his burden for the unsaved, and his commitment to serve others.

His evening series on John 15:1-8 en-

\section{"Now is the time for believ. ers to involve themselves in God's vineyard."}

titled "Heavenly Horticulture" reminded us that God's vineyard is the world. that $\mathrm{He}$ is the proprietor and that His purpose is to glorify Himself and to reveal the gospel to man.

Building on the exhortation found in the parable of the two sons in Matthew 21:28 to "go work today in my vineyard." Dr. Jennings presented an evening series entitled "Heavenly Horticulture." He reminded us of the "Branch-Vineyard" relationship be-

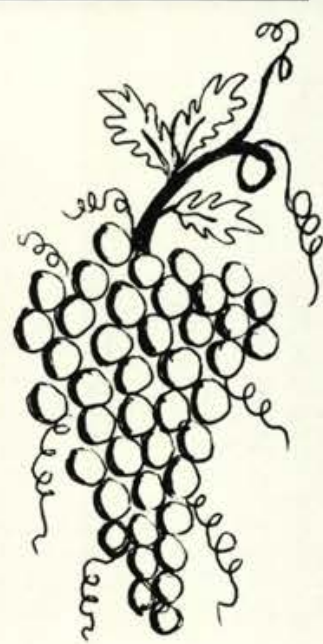

$\infty$

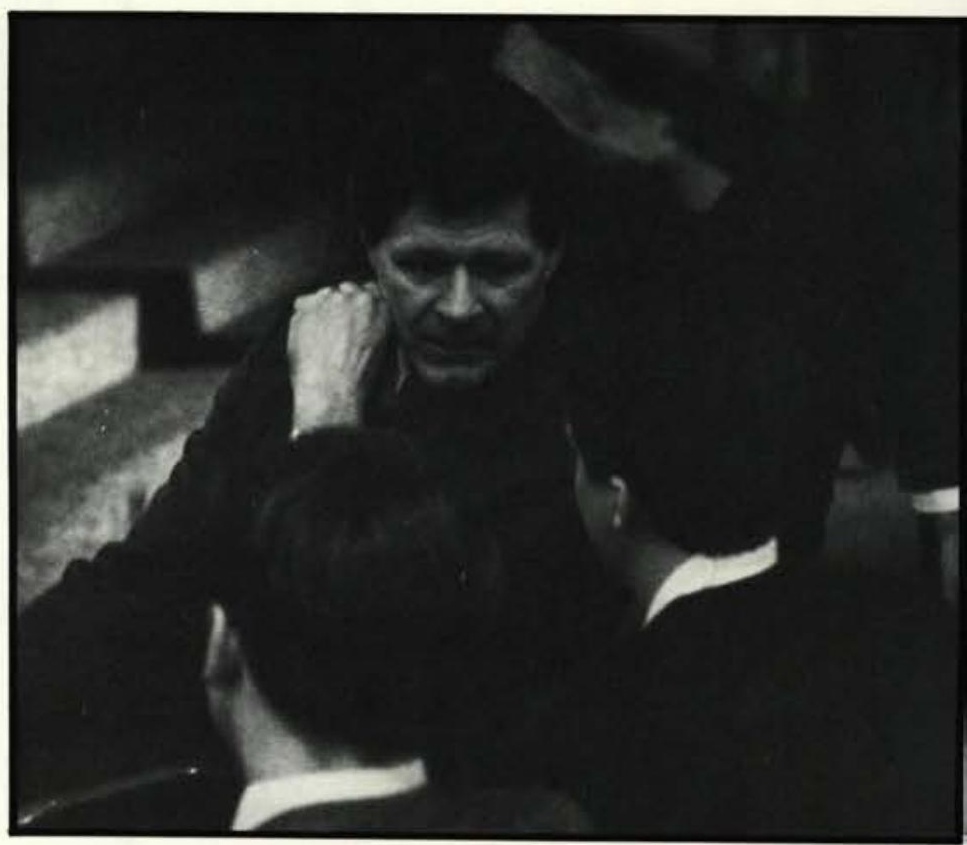

tween Christ and believers; and while $\mathrm{He}$ is the proprietor of the "business," we have been placed in His vineyard to work for His glory.

We were also reminded of our dependency upon God in the "BranchVine" relationship in producing the fruit of the Spirit, fruit of our lips, fruit of stewardship, the fruit of righteousness and the fruit of souls. In speaking of "plant management," he stated that the plant or vine must be managed by the Holy Spirit if the fruit produced is to be appropriate. Next, he challenged us with the truth that the Owner of the vineyard was coming and that we should "shape up and ship out": now is the time for believers to involve them selves in God's vineyard and to exercise faithful stewardship as we work for Him.

Dr. Jennings also brought a Morning Chapel series on salvation using I Peter 1:6-7. He emphasized the trust that God knows if we need to experience heaviness; or in his words, "winter in order to experience spring."

This man, pastor, now seminary president ever continues to be a consistent doer of the godly principles which he expounds. That makes his ministry even more powerful to my life.

by Dean Rickard 


\section{t:}

\section{GLIMPSES OF \\ SERVANTS}

$\mathbf{W}$

e now turn to the Christian Service ministries to give you a glimpse of where the teams go and what they do. Cedarville College stresses spiritual development: one way it meets that objective is through outreach. Too often, Christians "sit, soak, and sour" because of a lack of outreach, so this service provides the student body with numerous and diversified opportunities to serve the Lord in surrounding communities, in the U.S., and overseas. Service is a vital part of a rich and rewarding Christian education. Anyone who fails to take advantage of the opportunities afforded to him has missed a blessing indeed.

by Bill Thomas

\section{Contributors:}

- Christian Ministries' team members

\section{Layout By:}

- Tracy Holtzmann

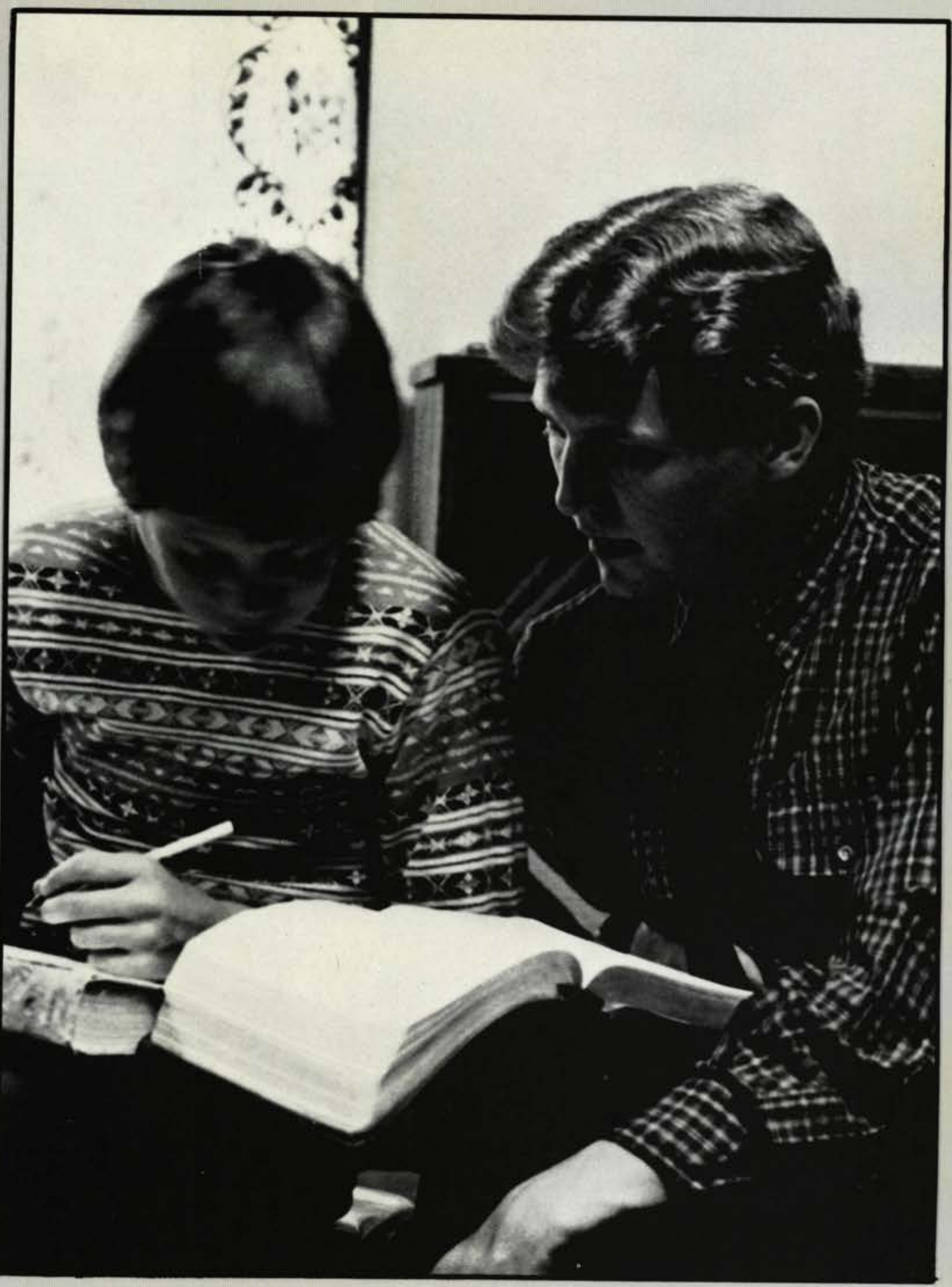




\section{Chreistian Ministries}

\section{Jvory Coast Soccer Team}

"Our ministry is to help unlock the doors of villages that have been closed to missionaries. By playing the village soccer teams we can enter the village and plant the seed of the Gospel for the full-time missionaries to cultivate."

- Rodney J. Smith

First row: Noel Hack, Rodney J. Smith, Dan Hawk, John Nicholas, David Frey, Gary Cooke, Second row: Coach John Mc Gillivray, Cregan Cooke, Brent Zieglar, Mike Morgan, Dave Moody, Ric Zehr, Rick Seidel

\section{Knights of Pythias}

"Investment of time, energy, love yourself - are the only things which can open the door to presenting the gospel to the elderly."

\section{- Wayne Keisling}

Diane Blasdell, Lynn Cramer, Chris Cripe, Wayne Keisling, Glen Jones, Paul Jones, Judy Oaks. Alesia Replse, Ted Sheldrake, Carol Smith, Cynthia Walker
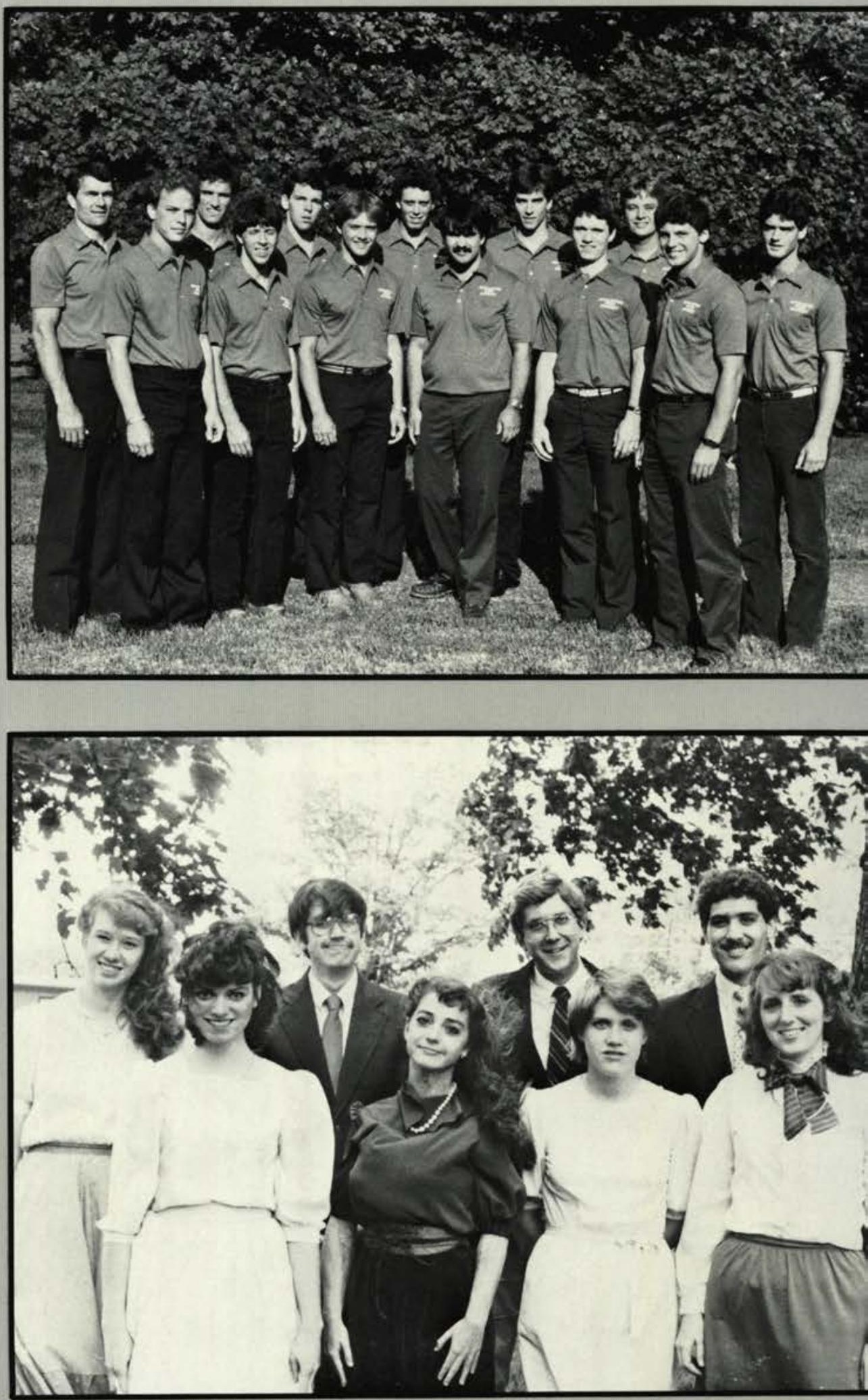


\section{"Therefore, since we are receiving a kingdom that cannot be}

shaken, let us be thankful, and so worship God acceptably with reverence and awe, for our God is a consuming fire." (Hebrews 12:28)

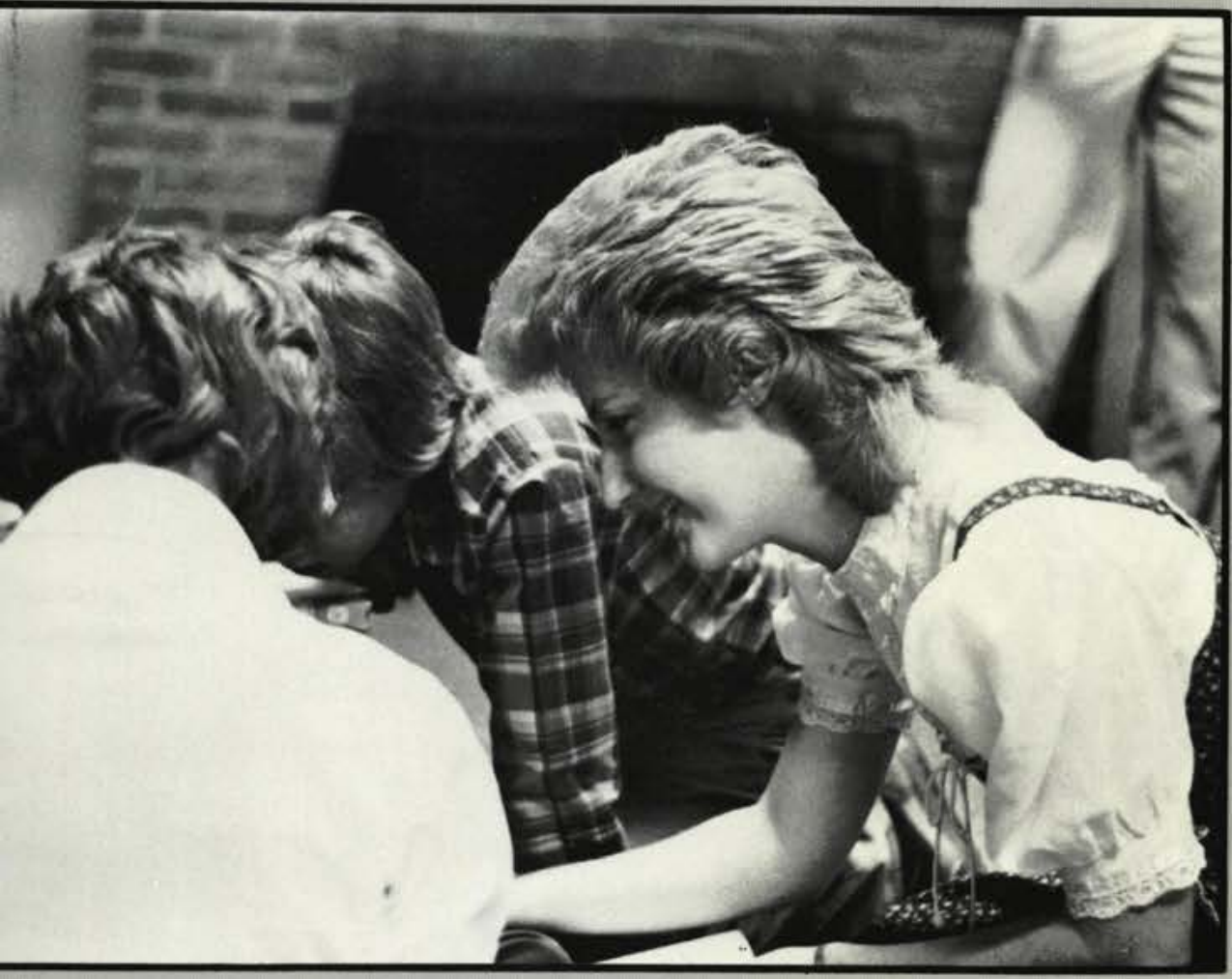

Ohio Veteran Children's Home (A.M.)

"My friends at Cedarville really care about me; I wish my parents were like that."

\section{- an OVCH resident}

Jane Adams. Marc Anthony, Julie Bergman. Jonathan Chamberlain, Mark Duquette, Joyce Felker, Kelly Herbert. Debbie Holmes, Dan Katz. Desmond Koval, Suzanne Laub. Sharon Longnecker, Denise Lowe, Don Arlis McCall, Edwin McGraw, Ken Nichols, Sherry Rotramel, Dave Sallee. Melody Shultz, Carol Silver, Holly Silver, Craig Slater (Asst. leader), Jayne Snyder, Crystal Starr. Susan Vaughan, Bridgot Vissman. Brandon Waltz. Bob Ward (Leader)

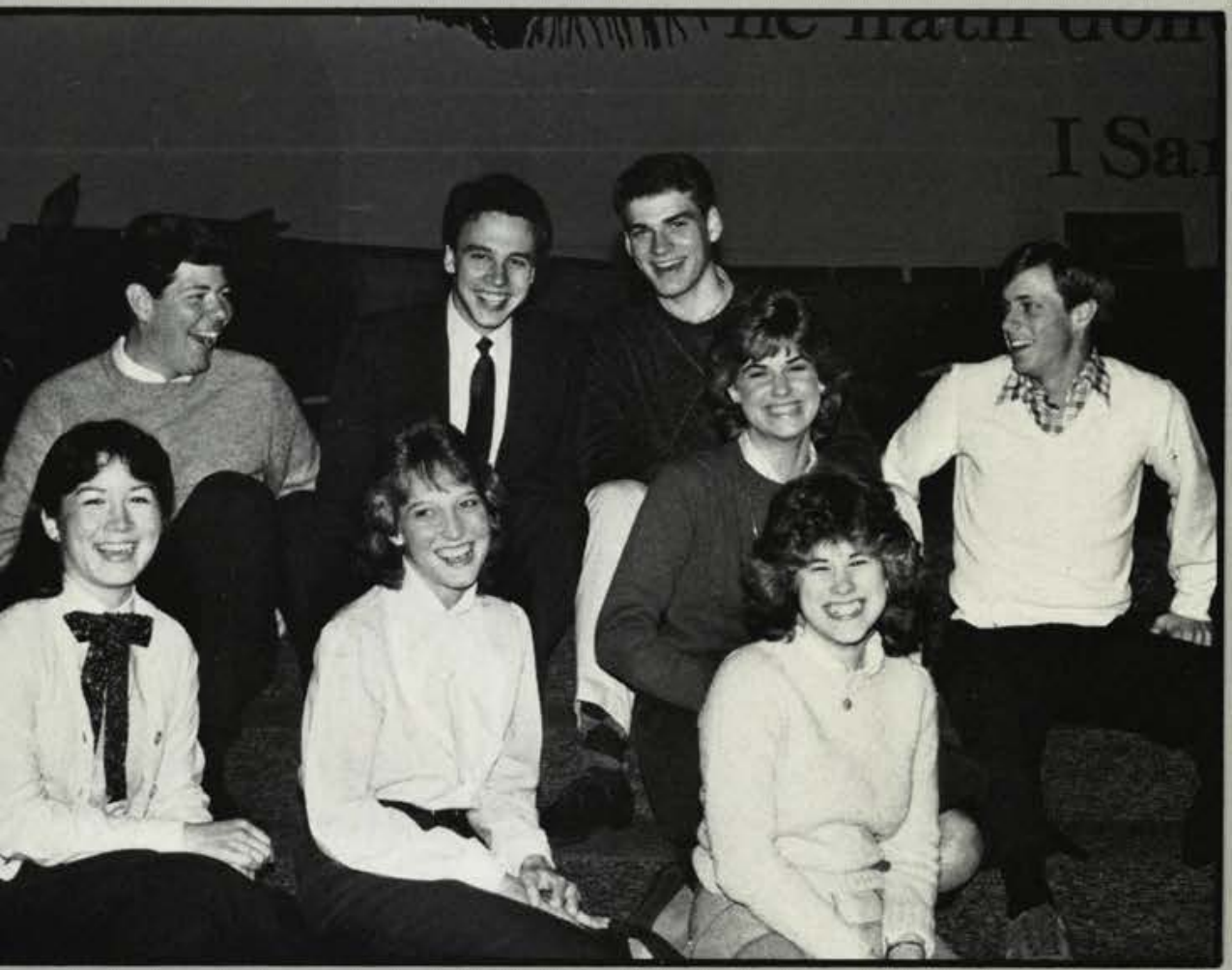

Odd Fellows Rest Home

"It's been a blessing to see friendships develop between the team members and the residents, and among the team members themselves."

- Rod Fillinger

Gina Baumgarder, Laurie Briggs. Steve Cremean. Laura Dimacchia, Rod Fillinger (Group Leader), Mike Hammond, Saundra Henry, Randy Monroe. Cami McGraw, Cindi Robinette, Max Pauly, Cheryl Provost, Glen Sallee, Linda Shaffer, Tina Shepard, Aaron Whitaker. Barbara Yanda, Lynne Zielke 
Bible Clubs "... Changing lives with the Word of - Mrs. Agnes Howell

First row: Kris Parman. Becky Reid, Second row: Mary Jo Savage. April Augustus, Wendi Figary. Sharon Banzhof, Marla Fuller. Third row: Sylvie Rinderknecht, Jacqueline King. Jennifer King, Linda Ladygo. Dave Dooley. Andy Wilson

Master's Puppets $J J$

"... we really enjoy the opportunity to share Christ with others... However, we ourselves learn to trust in God totally and to change and strengthen our own lives."

Jack Horner

Brian Taylor, Sue Moser, Lori Pitonyak, Susan OIsen, Jon Weber, Jack Horner
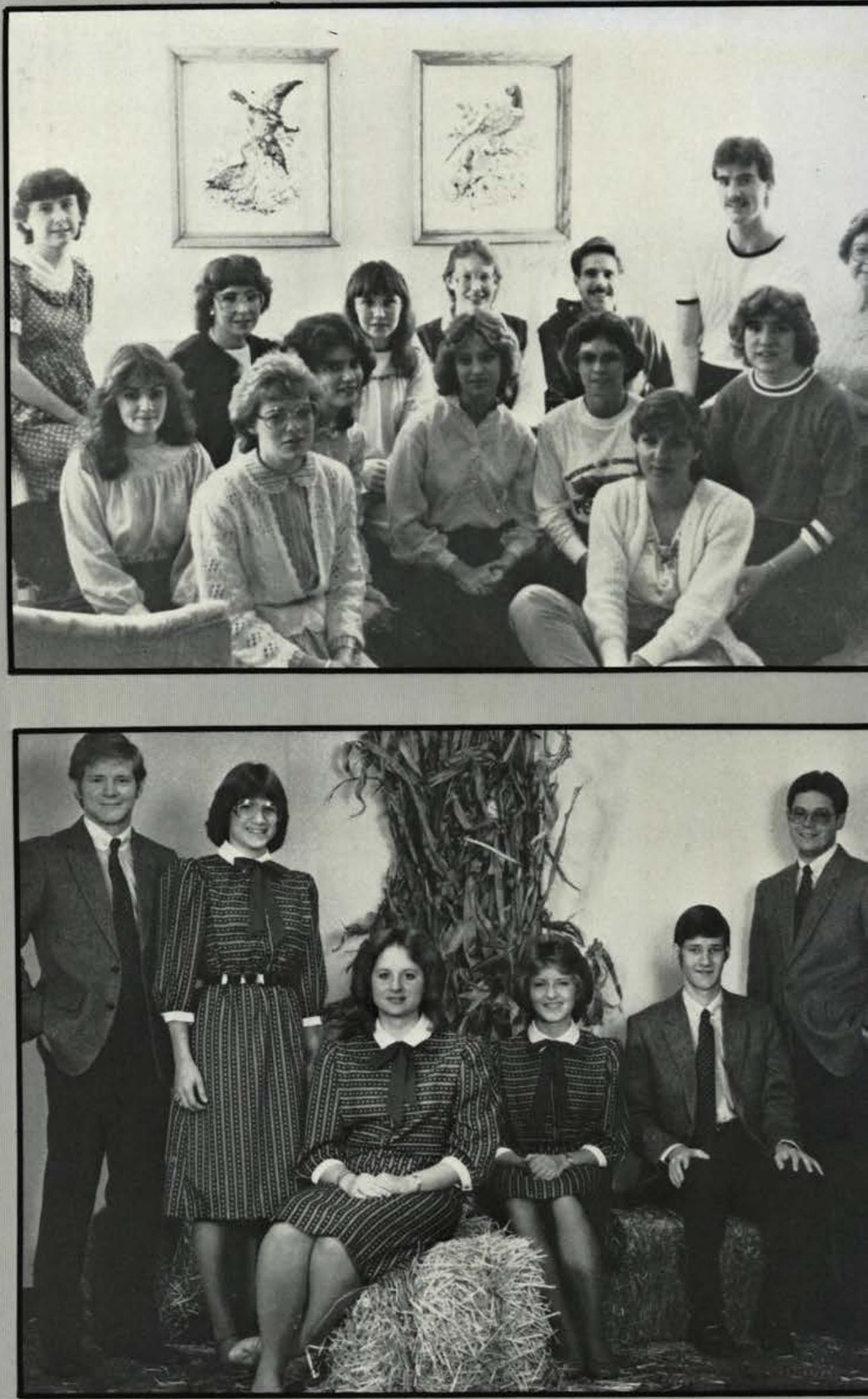

\section{"Dear children, let us not love with words or tongue but with actions and in truth."}




\section{Chroistian

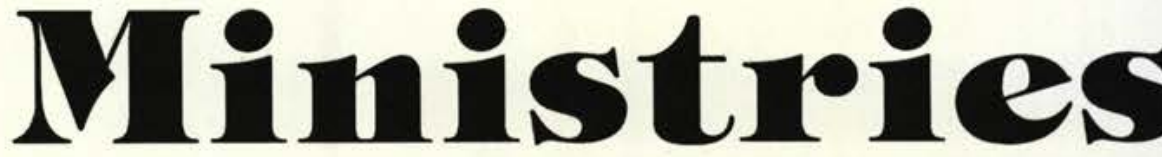

\section{Quebec $\tau$ eam}

"This is the first year for the Quebec team. The whole idea began when Jan Gazdik came for our missionary conference. It's exciting. This is not a typical musical team. We're a group of soloists and instrumentalists who will be working in churches, doing open-air meetings, and probably some other things we're not aware of yet."

\section{- Julie English}

Kneeling: Colin Lord, Standing: Jo Anne Michael, Paul and Mike Dicuirci, Julie English, Judy Walters, Linda Coldren

\section{Children's Medical Center}

"It is not uncommon to see wheelchair races or children riding in wagons ... or to hear the sounds of I.V.'s beeping, and children laughing and playing coupled with occasional crying or screams from the rooms."

Julie Murray

First row: David Wright, Lisa Henry, Julie Murray (group leader), Jeff Heffelfinger, Second row: Joe Cox, Chuck Jantzi, Kay Wilson, Tammy Barton. Third row: Gay Stebbins, Cathy Allen, Doris Lindley, Grant Kaufman Not pictured: Pam Kimble. Amy Wright, Teena Fleetwood, Amy Allen. Melissa Bixler, Debbie Nash, Jean Pinkerton, Richard Hobby
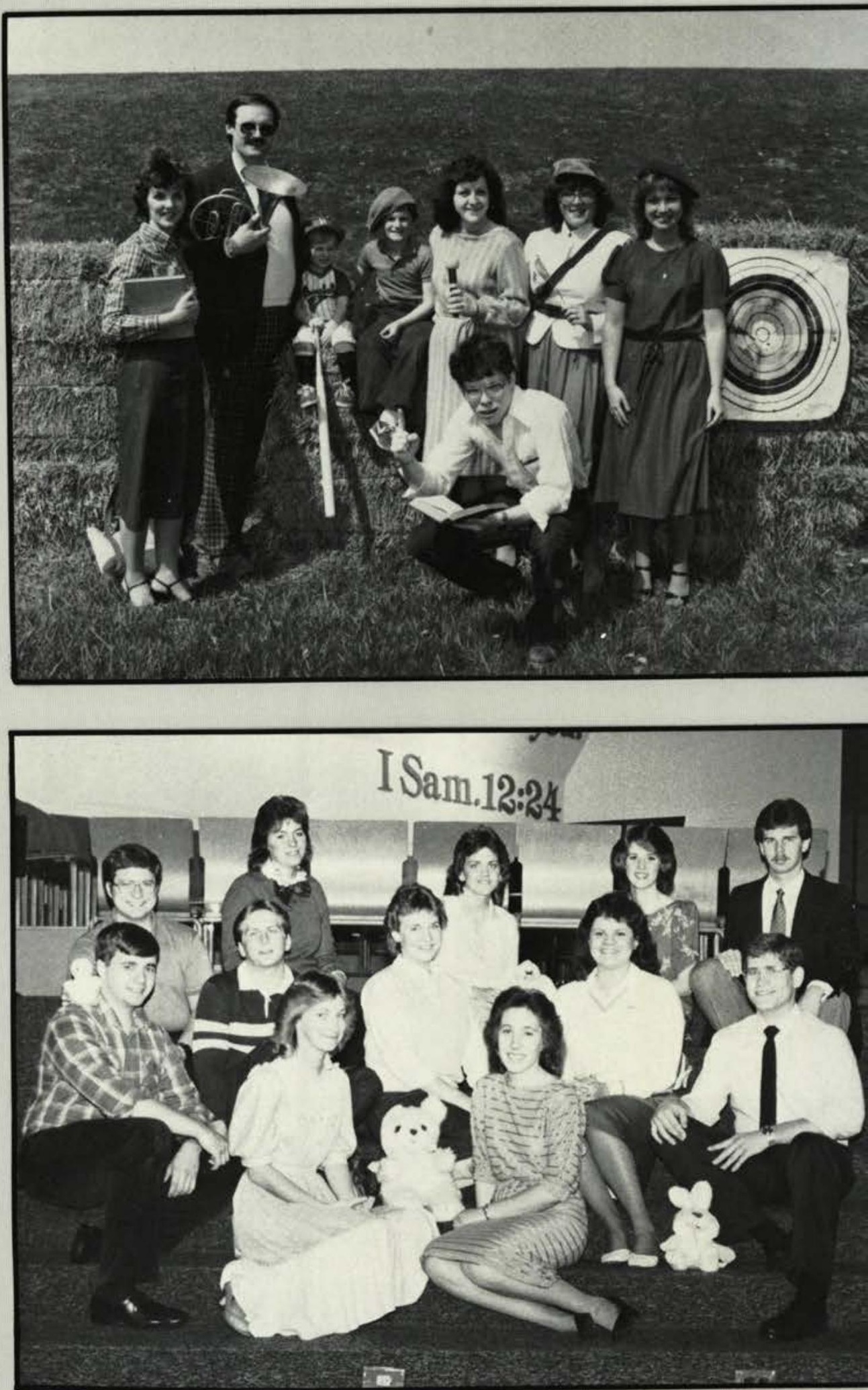


\section{"They are darkened in their understanding and separated}

from the life of God because of the ignorance that is in them due to the hardening of their hearts."

\section{(Ephesians 4:18)}

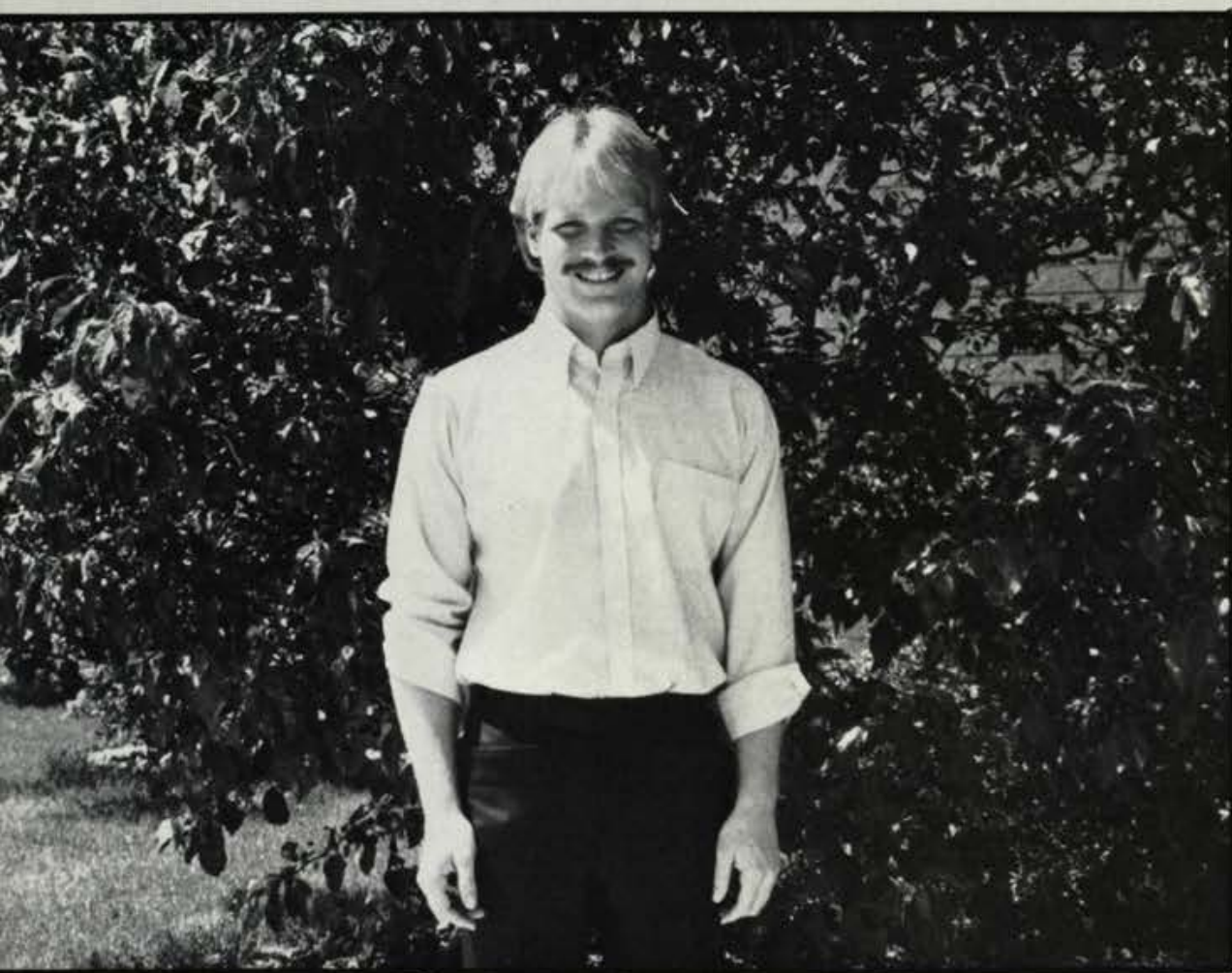

Cincinnati Rescue Mission

"Although these men have an outward appearance of depravity, one also realizes that their inward depravity is just as bad."

- Scott Dixon

Tom Blackburn, Scott Dixon (Group leader), John Mead

Australia Team

"Seeing the excitement of the team to learn the music and minister to the people is refreshing ... In public schools, the kids swarm around with a bombardment of questions about America. Such opportunities allow us to share the gospel."

- Tom Wiggershaus

First row: Pam Rickard, Rick Van Schoick. Tom Wiggershaus, Esther Bucklew, Second row: Cheryl Spradling, Mark Price, Alvin Tucker, Randy Johnson, Renee Bowen, Inset: Lori Greenwalt, Debbie Nash 


\section{Schulze Nursing Home}

"There is nothing as joyful, blessed and rewarding as seeing an ederly person accept the Lord as his Saviour. It is a tremendous feeling witnessing the last-minute rescue by God, through you, of a soul that is teetering on the edge of eternal separation from God."

- Rich McGill

Lyle Campbell, Jim Kirtland, Rich McGill (group leader), Scott Santee, Karen Troyer

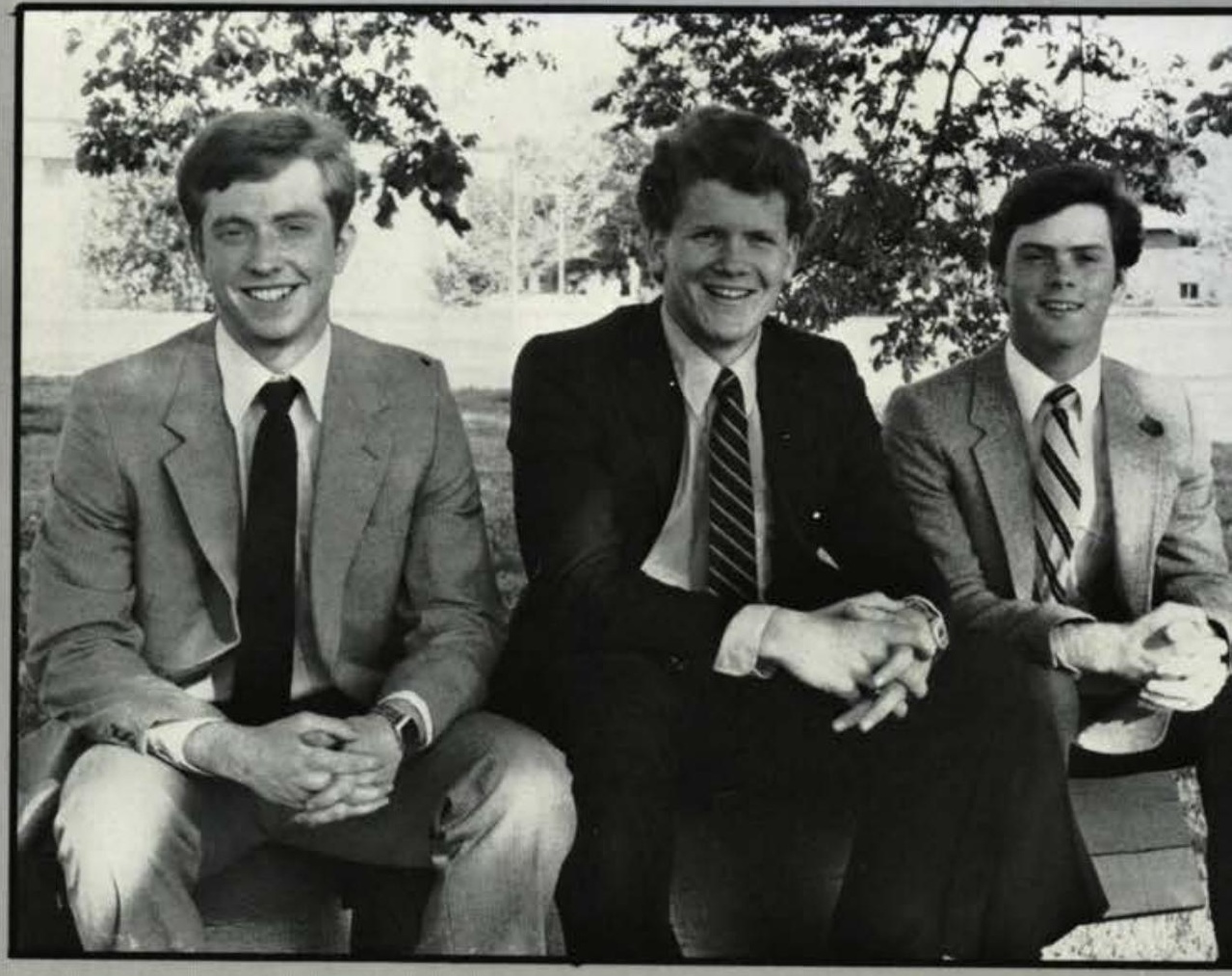

\section{China Team}

"We have the privilege of ministering to those who have not heard the gospel and meeting with Christians who have little fellowship with other saints. It requires a lot of strength, a lot of faith, and a lot of prayer. It's a great avenue of learning to trust God."

- Jane Sparling

Seated: Dwayne Frank, Tracy McCoy, Robin Young, Michelle Livingston, Standing: Greg Dudrow. Brian Orget, Karl Fetzer, Jane Sparling, Jim Benedict, Bob Ward, Mike Pitts

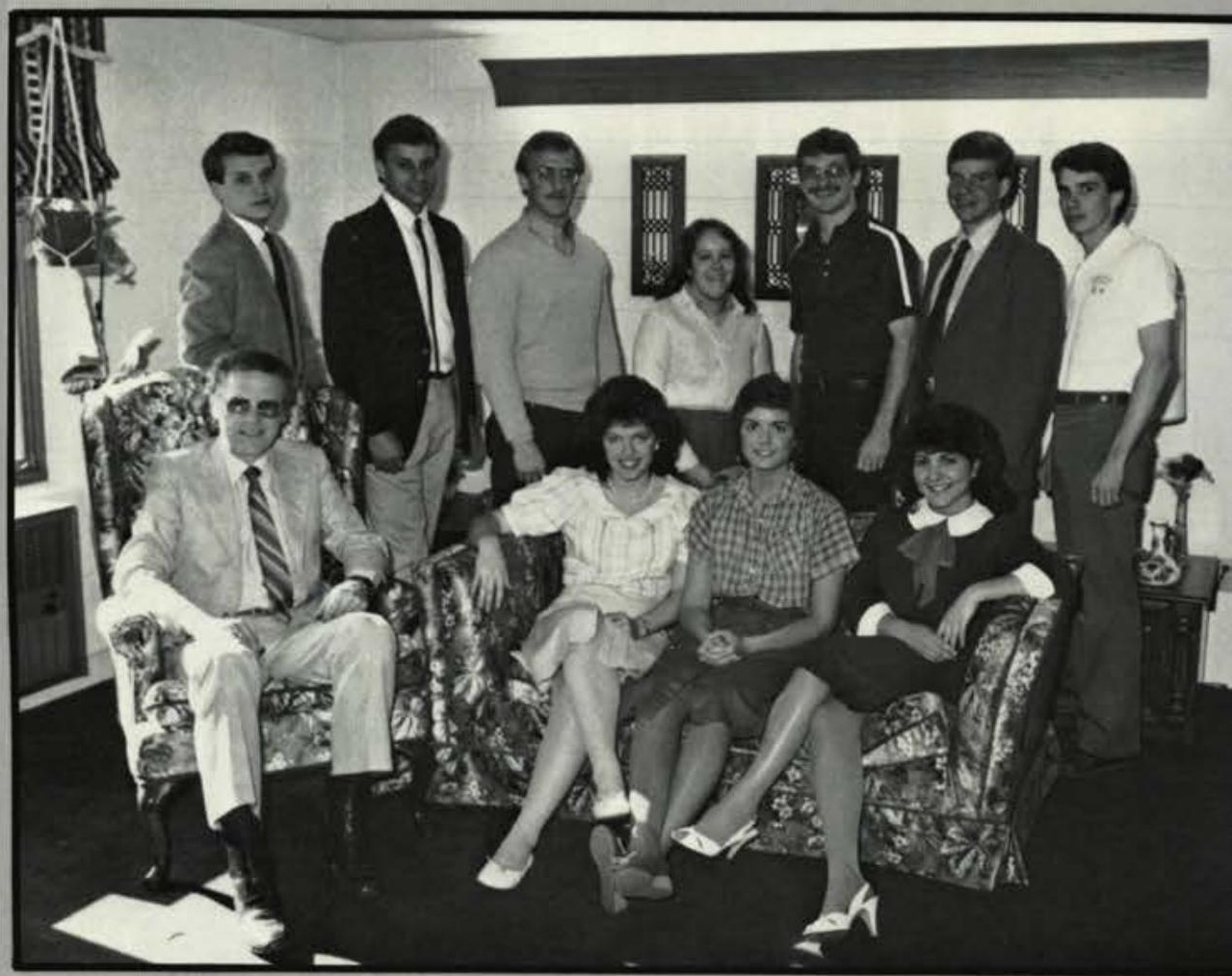

\section{Love is patient, love is kind.}

It does not envy, it does not boast, it is not proud. (J Corinthians 13:4) 


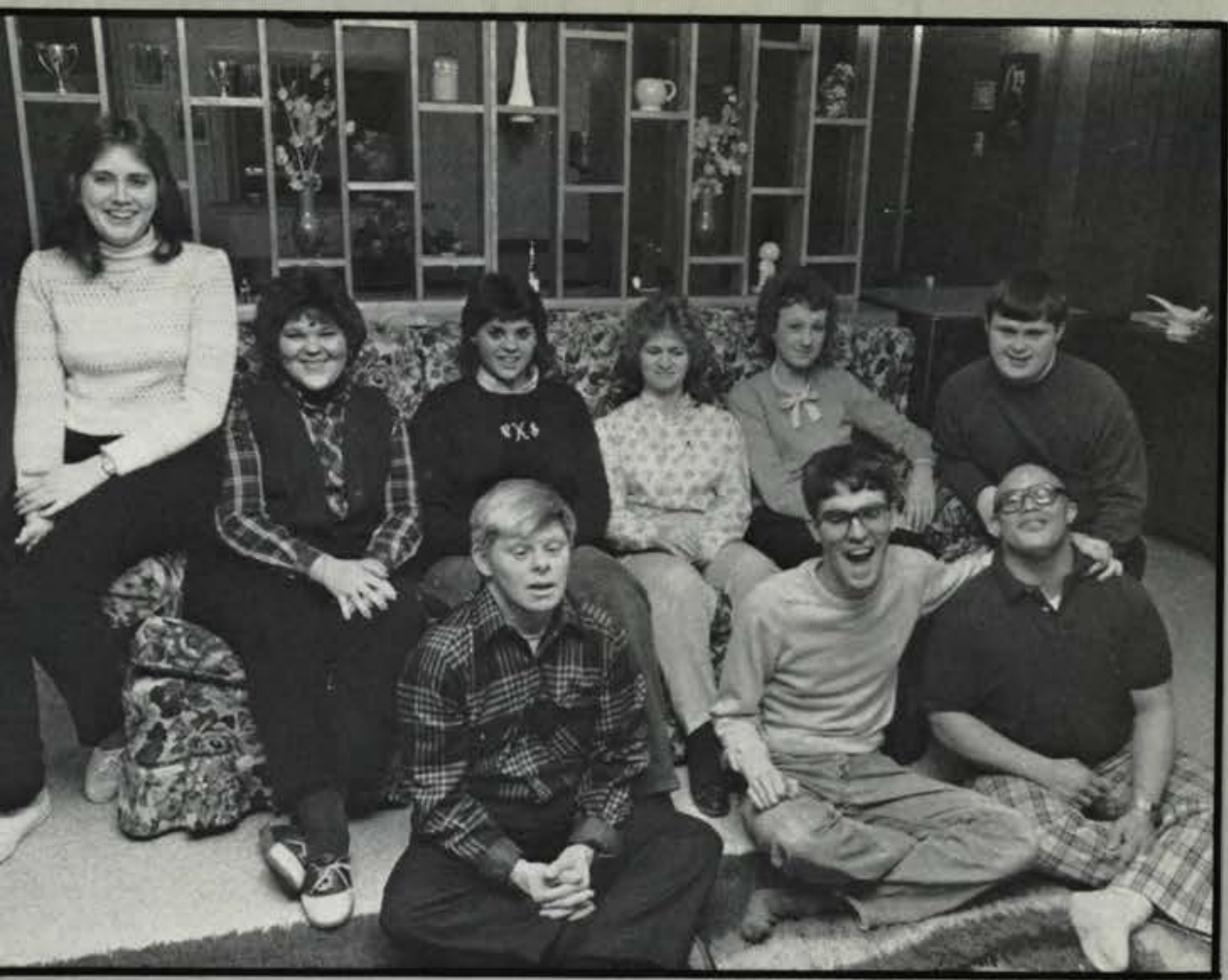

\section{Mueller Residential Center}

"We try to teach them social, athletic, and other skills. The mentally handicapped are some of the easiest people to work with, and I've learned a great deal from them as well as they from me."

\section{- Daniel Wallace}

Tim Day, Mitch Ely, Beth Dunn, Debi Firman, Sarah Getz. Marsha Jones, Robin Johnston. Cheryl Kuhbander, Loretta Walsh. Dave Salles, Scott Wig gers, Tressa Prince, Liz Stutesman. Ralph Sprague, Connie Siegle, Dan Wallace (Group leader), Karen Witt

\section{portugal $\mathcal{M} \mathcal{S S}$}

"My ministry is working with the missionaries as a computer programmer. The people are Roman Catholic and do not welcome new religious doctrines, so I will try to teach them by a life-style evangelism. As the church begins to loosen up, however, the people may open their minds to new ideas."

\section{- Rodney N. Smith}

Rodney N. Smith

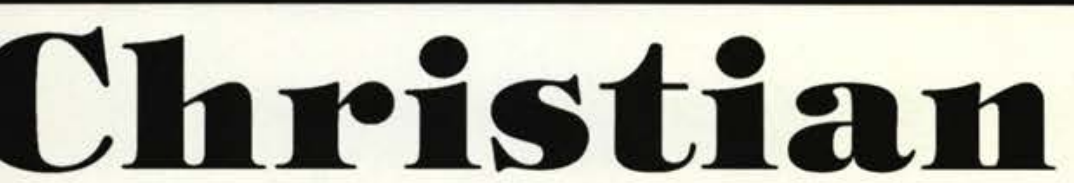




\section{Christian Ministroies}

\section{Scotland Team}

"Willingness is so important, but backing our attitudes with actions is the key to serving the Lord. I'm looking forward to really being a servant to the people of Scotland."

- Teena Shupert

Shellie Beaman. Teena Shupert, Karen Snare. Barbara Taylor

\section{Greene County gail}

"These people are looking for real answers; not "pie in the sky" religion. It is a great challenge to be able to relate to these people, but such a rich reward to see them saved and live for God."

\section{- Luis Corchado}

Lee Ann Bires, Luis Corchado (group leader), Perry Defelice, Laura Dimacchia, Rick Kensinger, Jill Kramer. Steve Myer, Krista Nickoson, Greg Norden. Darren Ruby, Jane Sparling. Dave Spradling, Don Thacker, Kathy Young
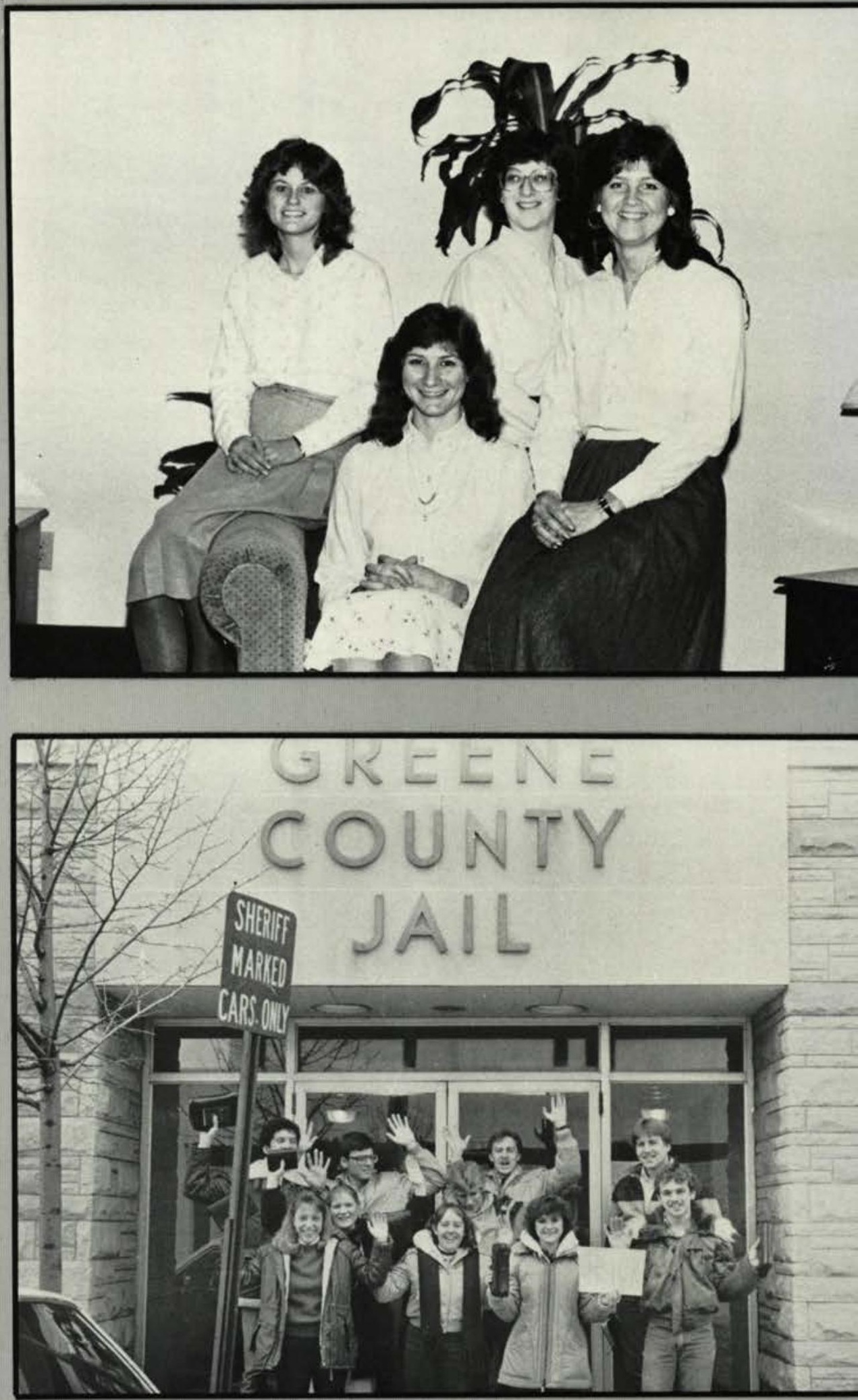


\section{Brazil Team}

"By assisting the missionaries, we can see what mission work is really like. Due to the language barrier, our songs are limited to those we can memorize in Portugese. We want our songs to communicate truth to the Brazilian people who stand in need of the gospel."

\section{- Karen Beattie}

Kneeling: Gerry Wallace, Mr. Rickard. Gary Rouster, Ed Supplee, Standing: Mrs. Rickard, Karen Beattie, Jill Campbell, Janice Warren

\section{College Partuers}

"College Partners is similar to a big brother/big sister program. It began last year when some Cedarville students met with young people from the community for Bible studies. We meet weekly with our "partners" to grow together as Christians. I've been able to establish a new friendship, learn more about communication and encouragement, and have the joy of sharing some things I've learned with someone who is encountering the same struggles."

- Deb Richardson

Jerry Parker, Deb Richardson. Sandy O'Boyle. Mark Nemitz
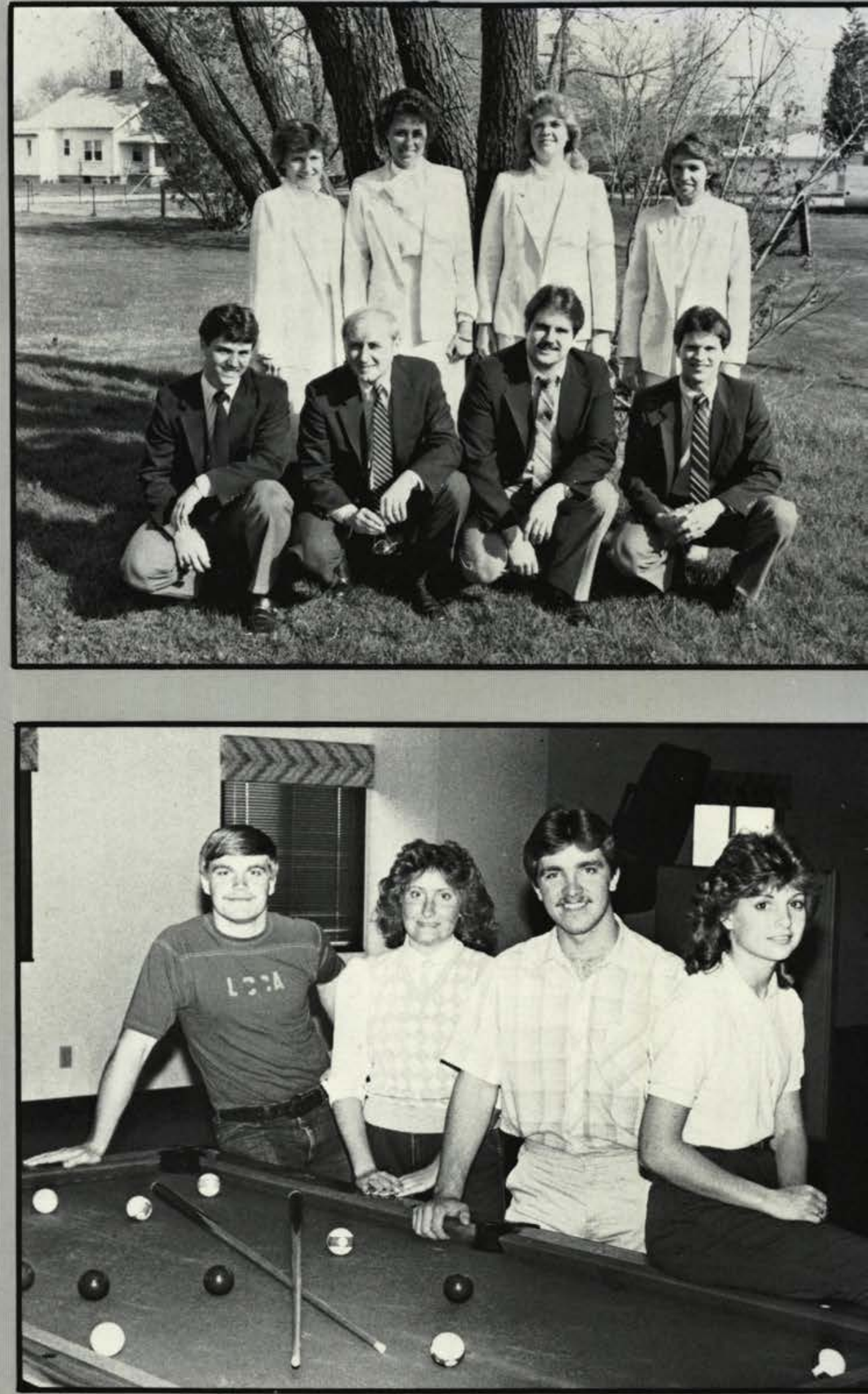

"Be very careful, then, how you live - not as unwise but as wise, making the most of every opportunity, because the days are evil." 


\section{Chroistian Ministroies}

\section{Florida Spring Break Team}

"Sometimes at school relationships can be superficial. Once we're on the beach, we may look terrible, but we still like each other for what we are. We get to know one another as real people, not mere acquaintances."

- Laurie Colas

First row: Julie Kolkman, Alesia Repke, Jim Reiter, Rick Seidel, David Blackstone, Second row: Donna Ford, Marsha McNeish, Julie Bergman, Susan Dube, Melissa Marshall, Laurie Colas, Sara Beattie, Phil Fogle, Third row: Teena Shubert, Tom Carr. Ginny and John Potter, John Buckholz

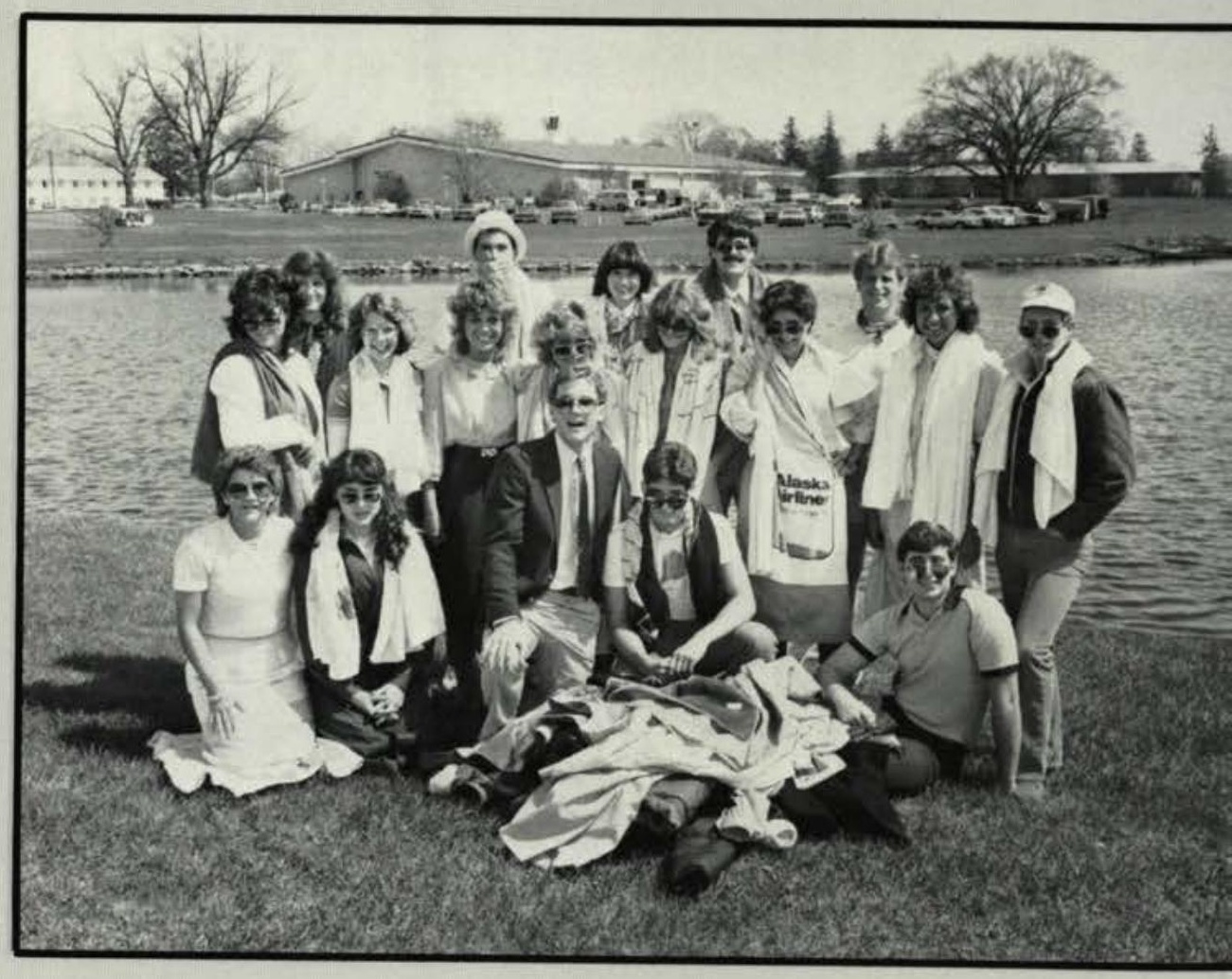

\section{Hospitality Home East}

"A counsellor, a friend in a time of need, planting the much needed spiritual seed."

Rick Van Schoick

Reda Moore, Larry Miller, Tim Peters, Jim Peterson, Kathy Potbury. Brian Roget, Sandi Ross, Jewell Schroder, Diane Taylor, Rick Van Schoick (Group leader), Cherie Webber, Judy Weston. Sheri Whitcomb, Linda Wilson, Rachel Wilson. Terry Youngless

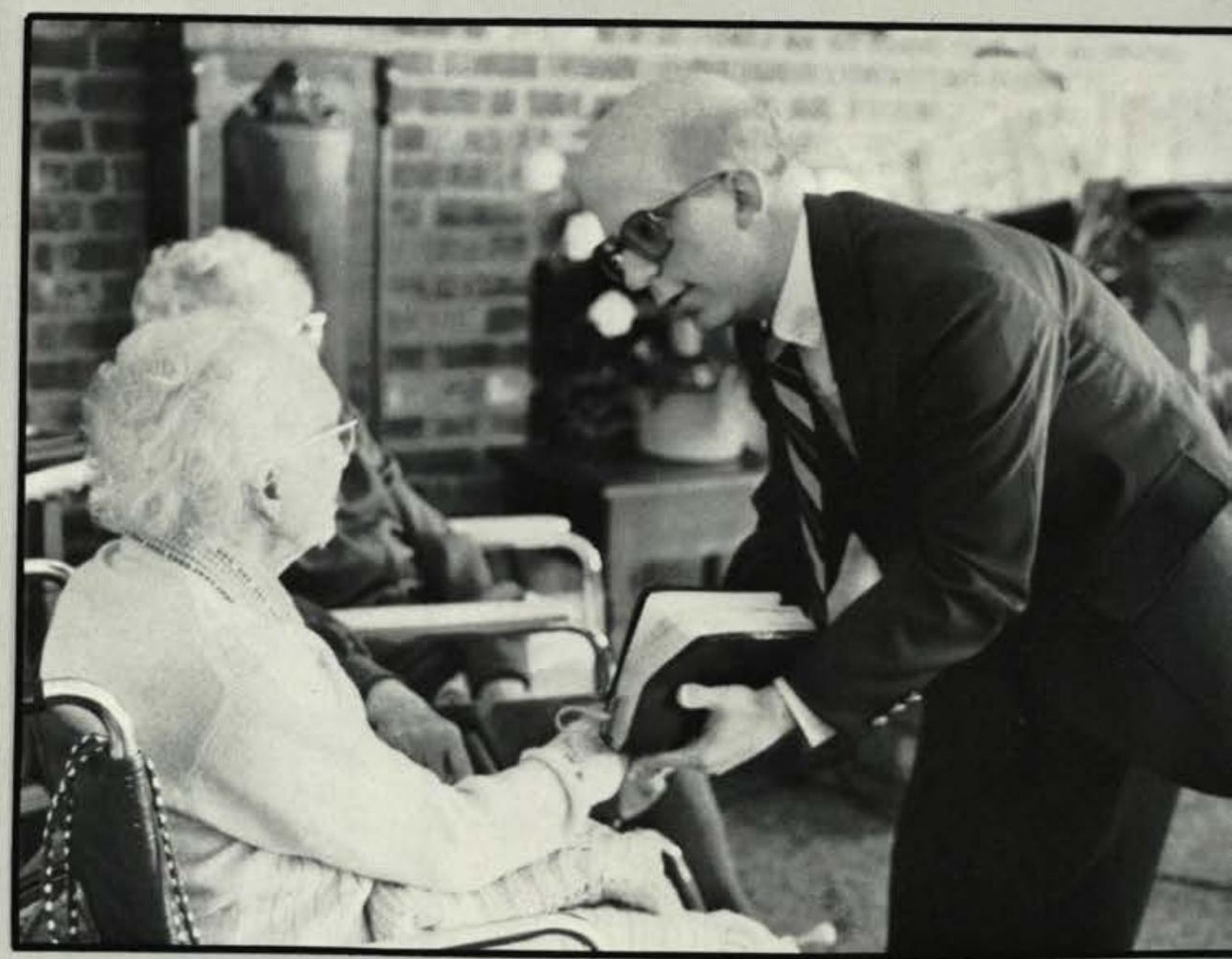




\section{"Share with God's people who are in need. practice hospitality."}

\section{(Romans 12:13)}

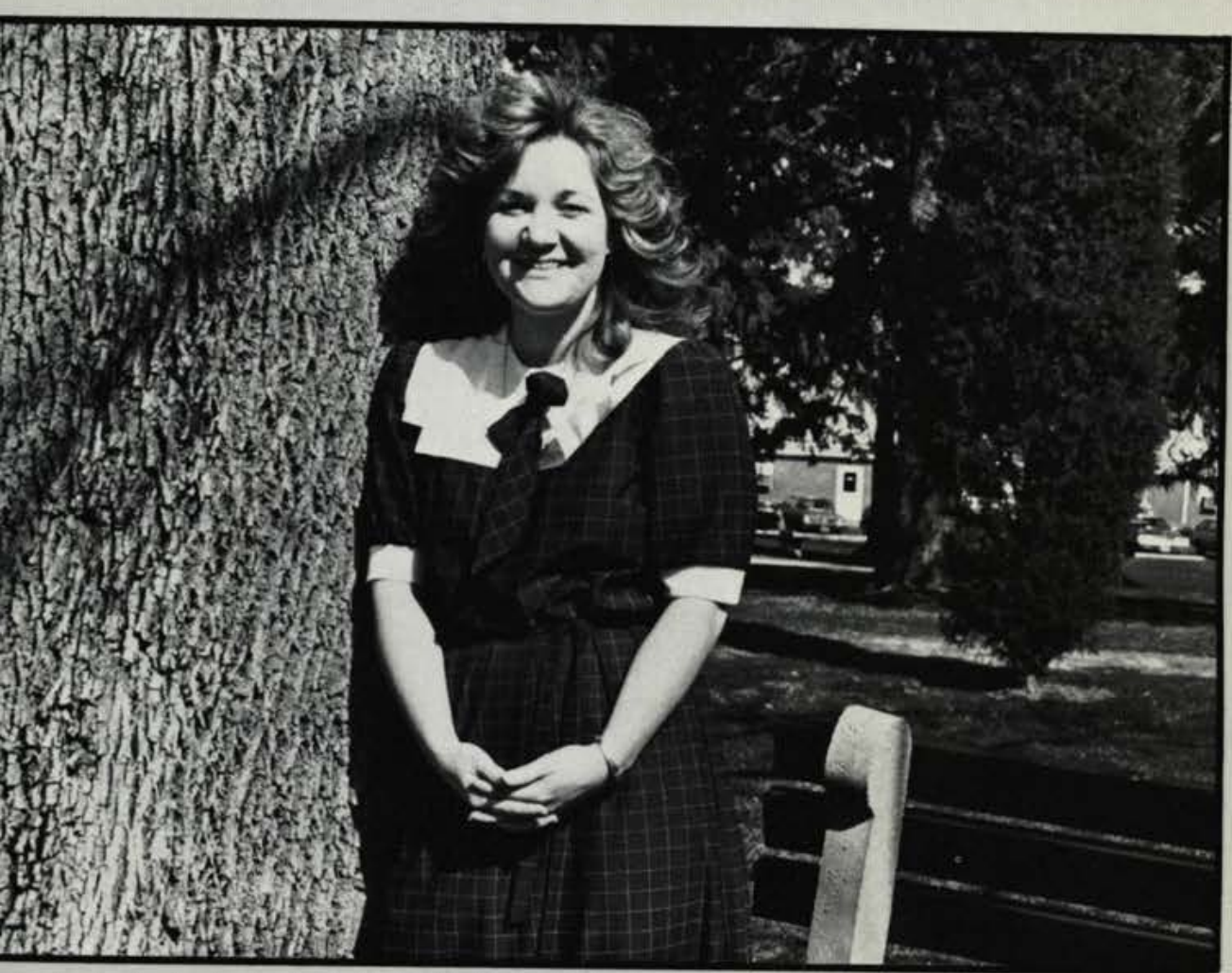

$J_{\text {stael }} \mathcal{M} J \mathcal{S}$

"The land captivates me. There's something special about being able to picture the places in my mind of which the Bible speaks. The land is beautiful ... and I have an opportunity to become better acquainted with the Jewish people by working with them." - Elaine Stone Elaine Stone

\section{Operation Rebirth}

"... frustrating, but a growing and stretching experience. They often teach us more about ourselves than we feel we're teaching them."

- Mark Walter

John Hackbarth, David Hale, Wayne Troutman. Mark Walter (Group leader), Steve Walter, Mary Welch 
Ohio Veteran Children's Home

"You have to learn to really love the very kinds of kids that most of us couldn't or wouldn't love when we were in high school."

Eric V. Hellwig

Eric Hellwig (Group leader). Mark Mitchell, Jim Moll, Bob Munson. Charon Nagy, Kim Oljace, Daneen O'Wade. Chuck Pyatt. Beth Reeder Jenny Rodriguez, Carole Roland. Sherry Rotrenial, Kurt Rumille, John Sidle. DeMaurice Smith. Rodney Smith

Bethesda Rehabilitation Center

"This ministry has made each one of us more appreciative of our Christian homes."

- Julie Kolkman

First row: Rick Seidel, Ron Walter, Don Wagner. Second row: Brian Maddox, Kevin Shaw, Julie Kolkman, Cliff Fawcett III, Not Pictured: Linda Curtis, Jana Dowsett, Shawn Kinkson. Tonya Kircher, Sandy Pratt. Deb Quick. Connie Thibo. Diane McClure
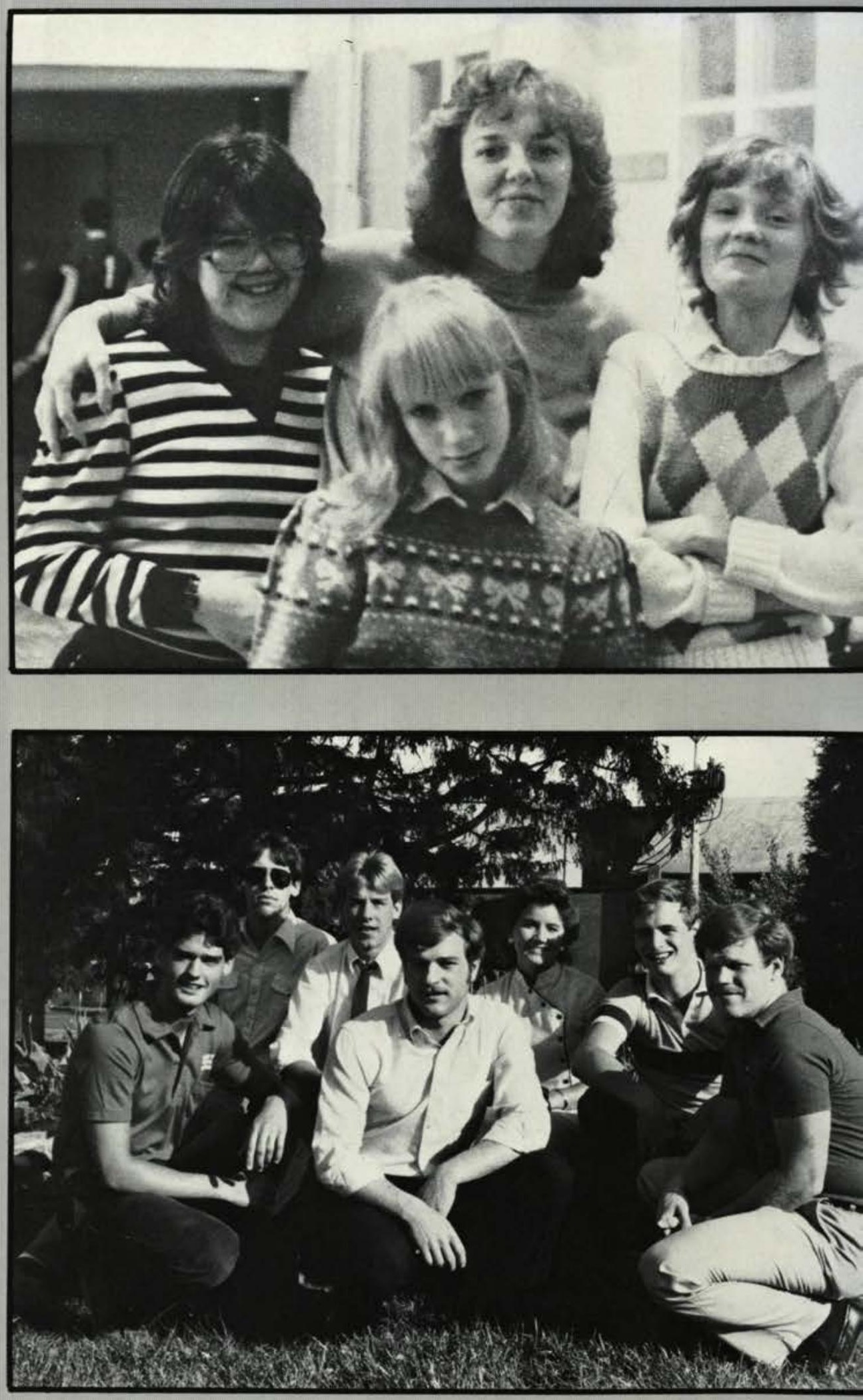

"Therefore, as God's chosen people, holy and dearly loved, clothe yourselves with compassion, kindness, humility, gentleness and patience."

(Colossians 3:12) 

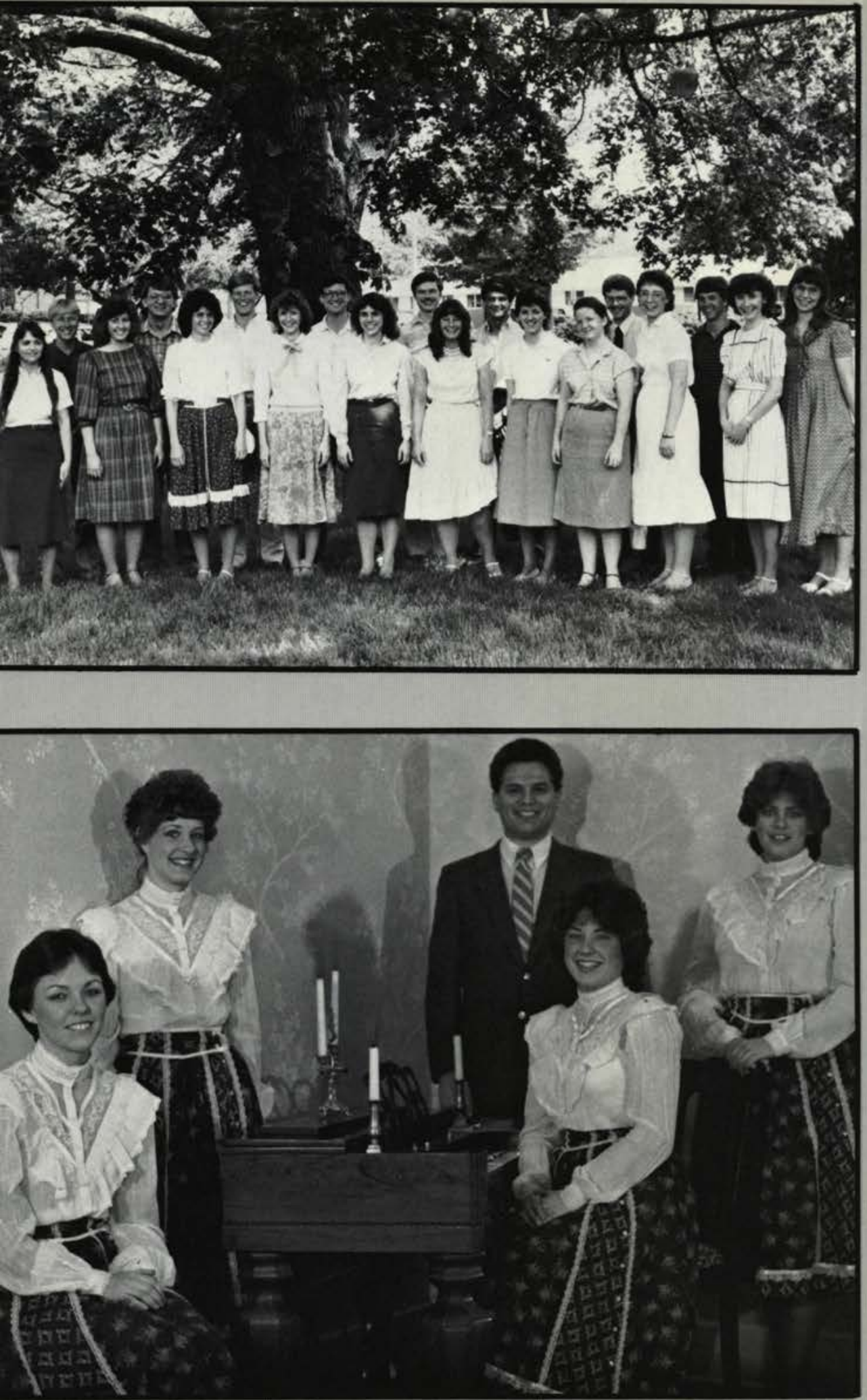

Wright State Campus Evangelism

"This ministry helps us to develop a compassion for people and turn our eyes away from judging people on outward appearances.

\section{- David Blackstone}

Debbie Battaglia, David Blackstone (Group leader), Chris Dail, Jody Fisher, Joy Hart, Kathi Holman, Jacqueline King. Cyndia Long. Chris McCauley, Mark Nemitz, Becky O'Conner, Keith Plunket. Sylvia Rinderkricht. Eric Shrum, Gerald Wallace, Chris Weidman, Donna Windish, Linda Woodgate

\section{Sounds of goy}

"Having only five members - four of them being female - has been different ... We have a unique ministry with the women of the church. I'm looking forward to giving our seminar on older ladies teaching the younger ladies in the church.... It's an experience I'm glad I didn't pass up."

\section{- Donna Ford}

Kristina Whittaker, Mendy Jackson, Richard Chasse, Donna Ford, Meredith Collins

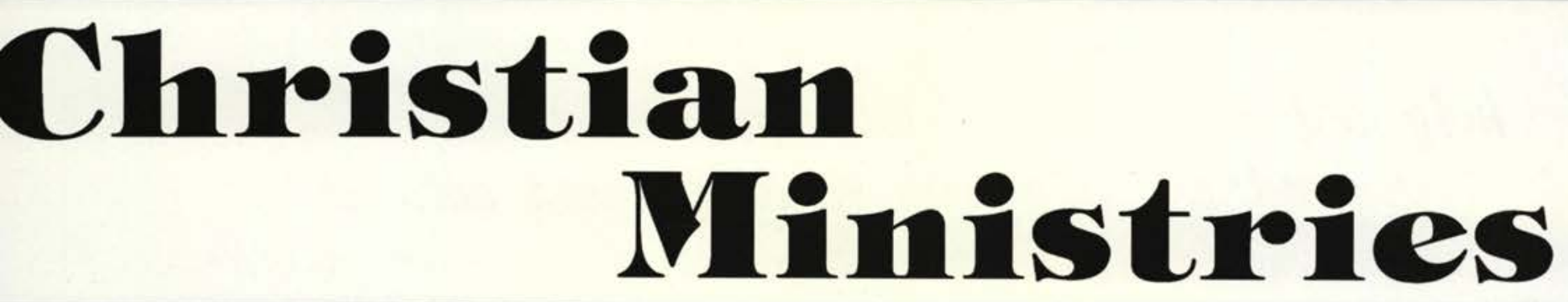




\section{Chroistian \\ Ministroies}

\section{Girl Scouts}

"It takes someone half crazy to work with six excited, energetic, rambuctious, wild grade school girls. However, we are helping the girls develop their characters."

- Kim and Kayla

Kim Ramsier, Kayla Webb

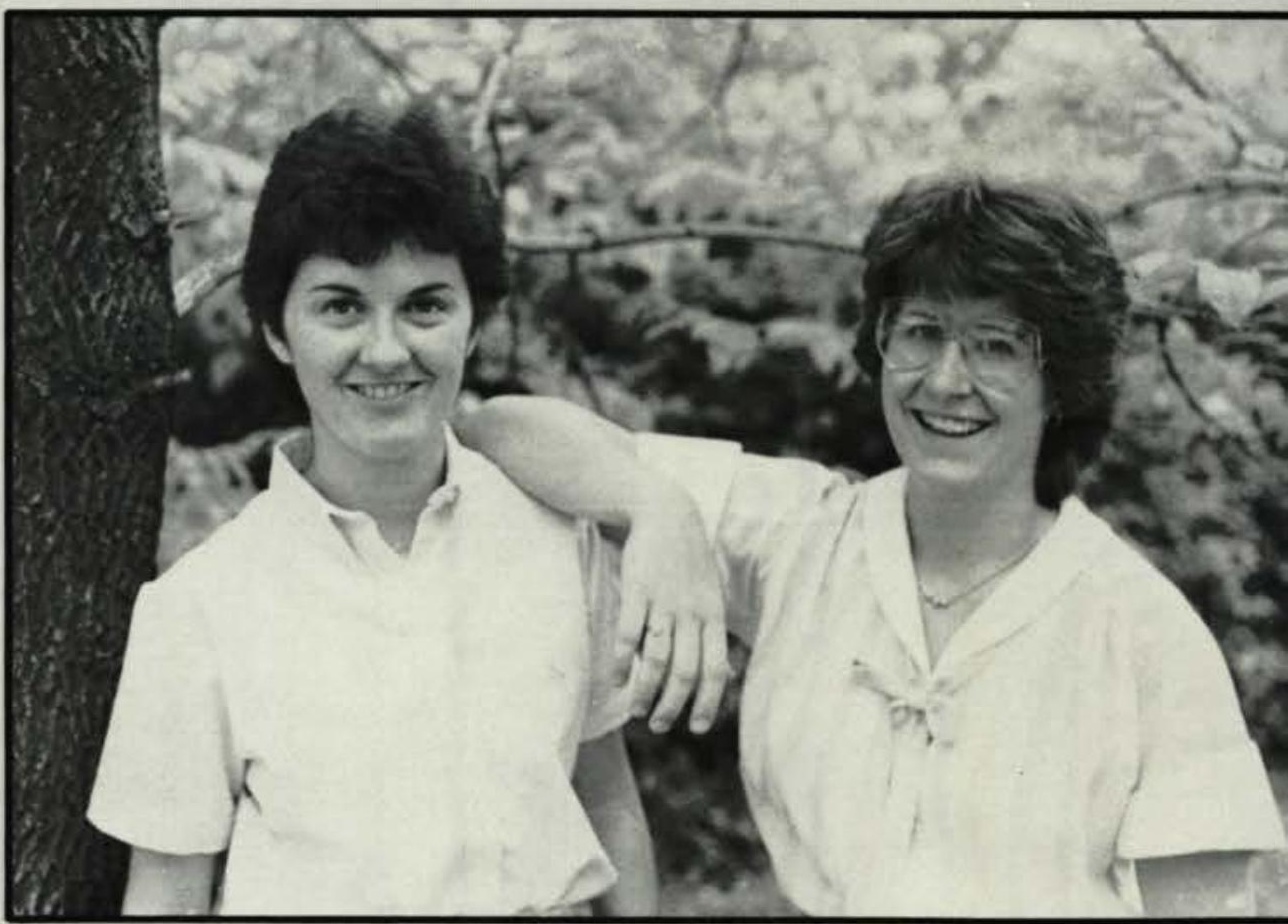

\section{Swordbearers $J j$}

"Learning to adjust to the time schedule - the pressure of classes coupled with responsibilities of ministering was a challenge, but I enjoyed broadening my musical abilities, learning to get along with twelve other people in a twelve passenger van, and watching personalities mesh as we worked together as a team."

- Sarah Anderson

First row: Ken Heiland, Glen Gordon, Second row: Sarah Anderson. Amy Thomas. Cathy Farley, Mindy Ritter, Diane Moates, Third row: Bruce Keisling, Dan Barfell (Leader), Pat Henry, Alvin Tucker. Alan McCain

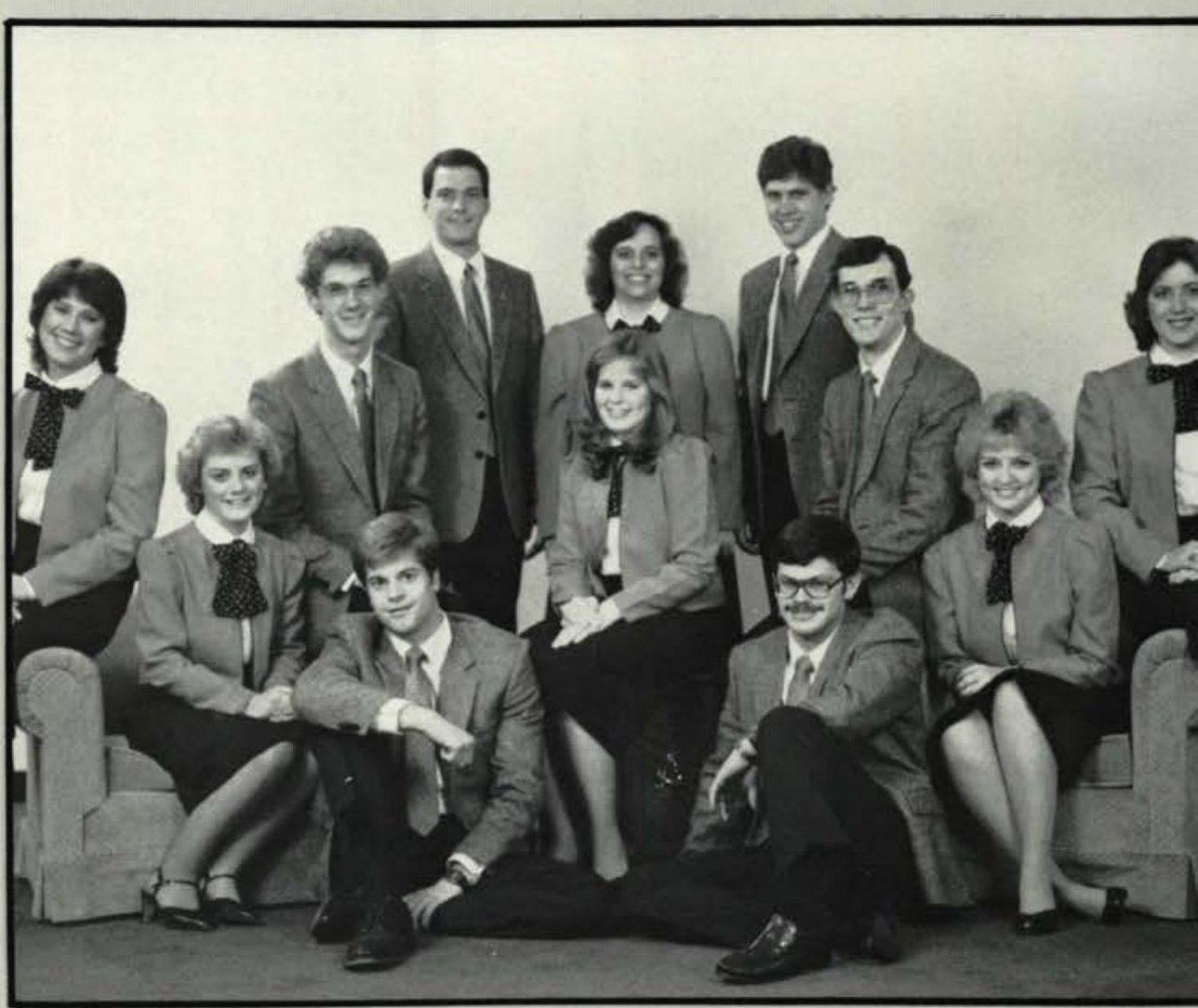




\section{Philippines Basketball Team}

"I wanted first-hand experience to see what it's like to serve on a foreign mission field. We Americans are somewhat spoiled; I anticipate some difficulties with the heat and the inconveniences, but these experiences will aid in becoming more like Jesus Christ. That's the whole purpose for our being saved."

- Chuck Pyatte

Kneeling: Chad Breeson. Todd Geist. Chuck Pyatte, Brad Breeson, Standing: Don Callan (Advisor. Jon Breeson. Tod Reinhart, Dave Yeager. Charles Jackson, Dave Gaffner

New York Spring Break Team

"The idea of getting up in front of 40 to 50 strangers in a subway is frightening. Before you do it, your stomach is full of butterflies, but when you're finished you feel satisfied and are glad to have been a part of spreading the gospel."

- Steve Meyer

Steve Meyer, Amy Dykes, Mark Horne
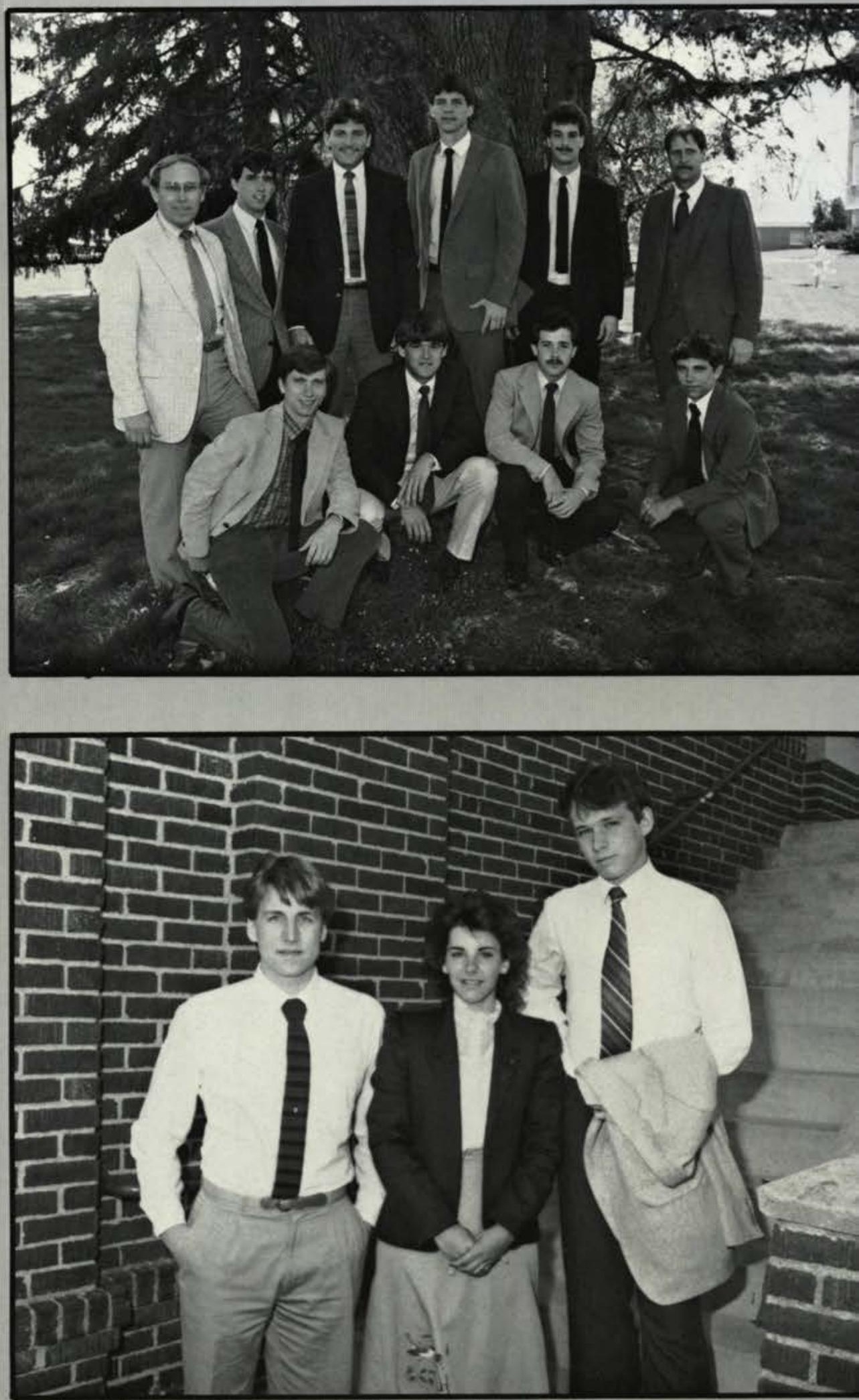

\section{"Live in harmony with one another. Do not be proud, but be willing to associate with people of low position. (Romans 12:16)}



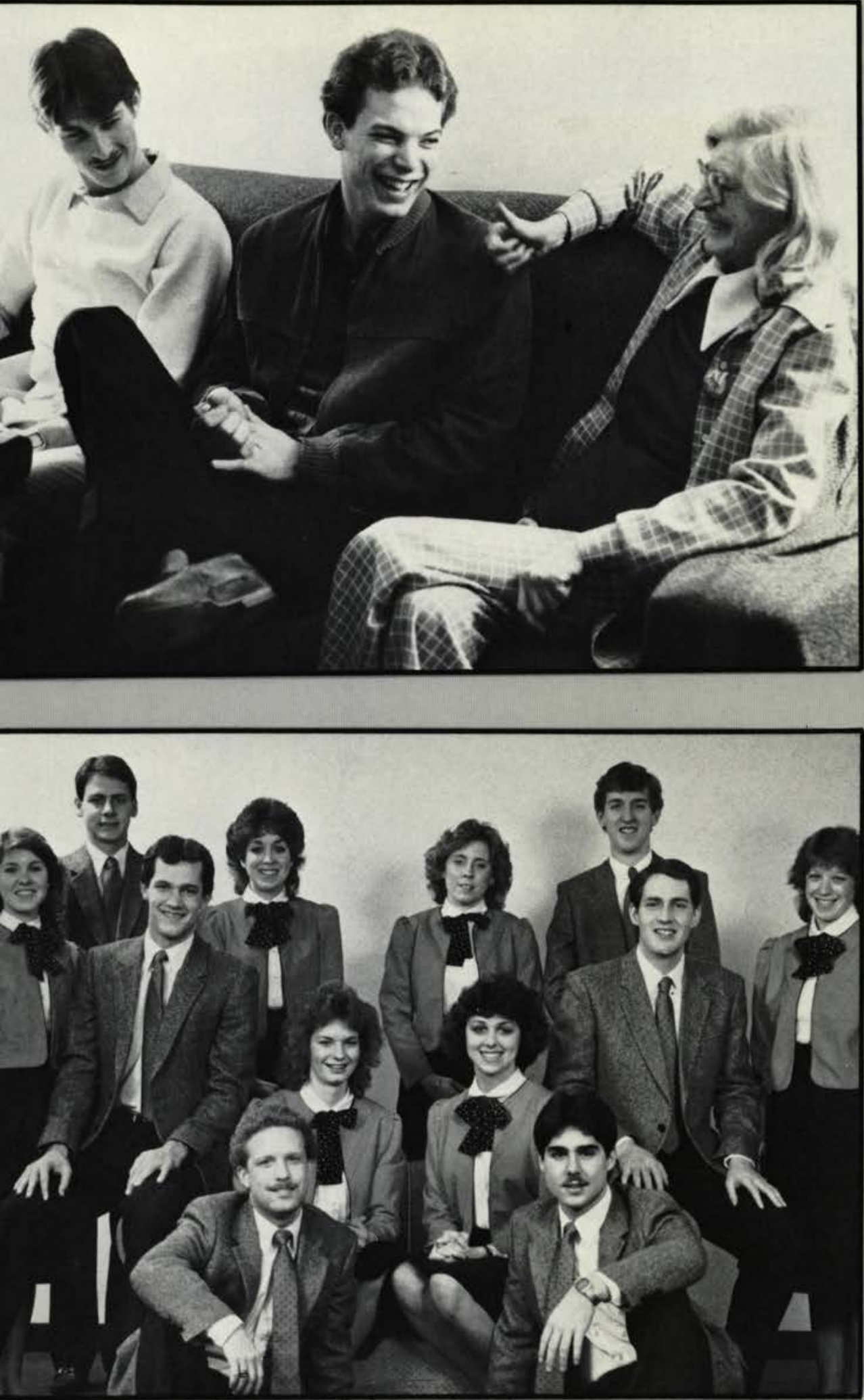

\section{Cedarcliff Elderly Housing}

"Our ministry is one of giving, caring. and sharing as we follow the example of Jesus Christ who loved us and gave Himself for us."

- Noel Hack

Joy Able, Tina Ashley, Marc Chitwood, Annette Dimacchia, Gene Evans, Noel Hack (Group Leader), Lori Leach, Dave Snyder, Todd Tancredi, Gayle Taylor

\section{Summer Swordbearers}

"Singing, sharing our testimonies, talking to people who have needs and loving every minute of it. At times the workload got heavy with homework and the many lines that needed to be memorized, but it was all worth it. We see the purpose for our ministry and are proud at the effort and time we devoted to such a program."

$$
\text { - Jeff Lyle }
$$

First row: John Mead, Jeff Beste, Second row: Tammy Cox, Tom Carr, Beth McKibben, Margi Wolot, Jeff Lyle (Leader), Kelly Ward, Third row: Doug Simpkins, Karen Simpson, Julie Kamphaus. Scott Burtis

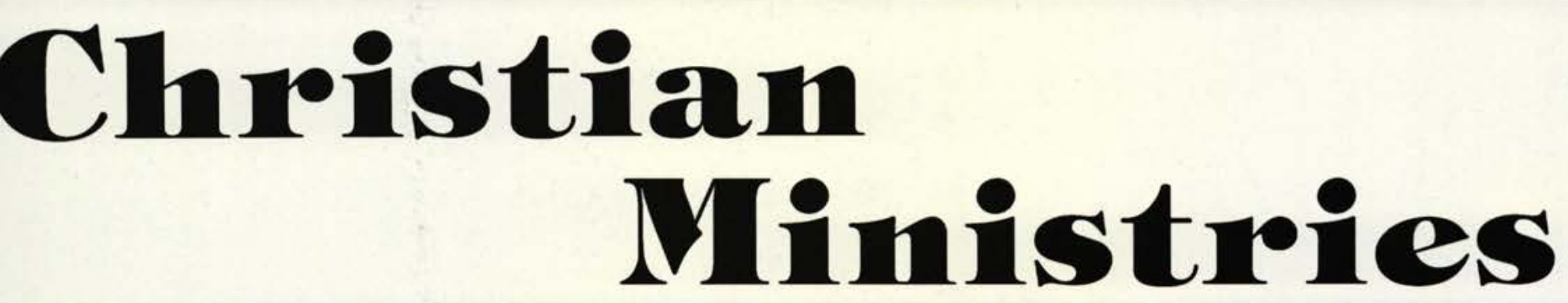




\section{Christiam

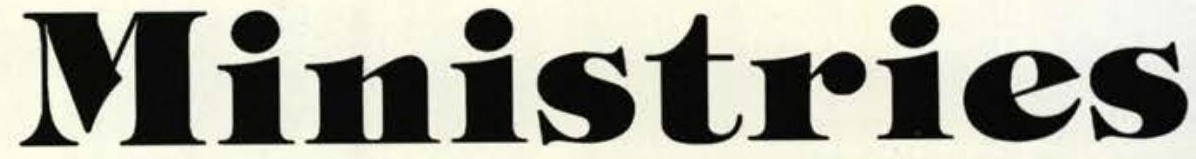

\section{Summer Master's Puppets}

"... cramped van rides, daily programs, pooled ignorance ('Theological Discussions'), and kids, and more kids! But we grew as a team, a unit of oneness for the Glory of Jesus Christ which was the primary goal which we set out to accomplish. All praise to the Master!"

- Dennis Papp

Dennis Papp, Tamra Hershberger, Rich McGulli. Cynthia Cronrath, James Beight

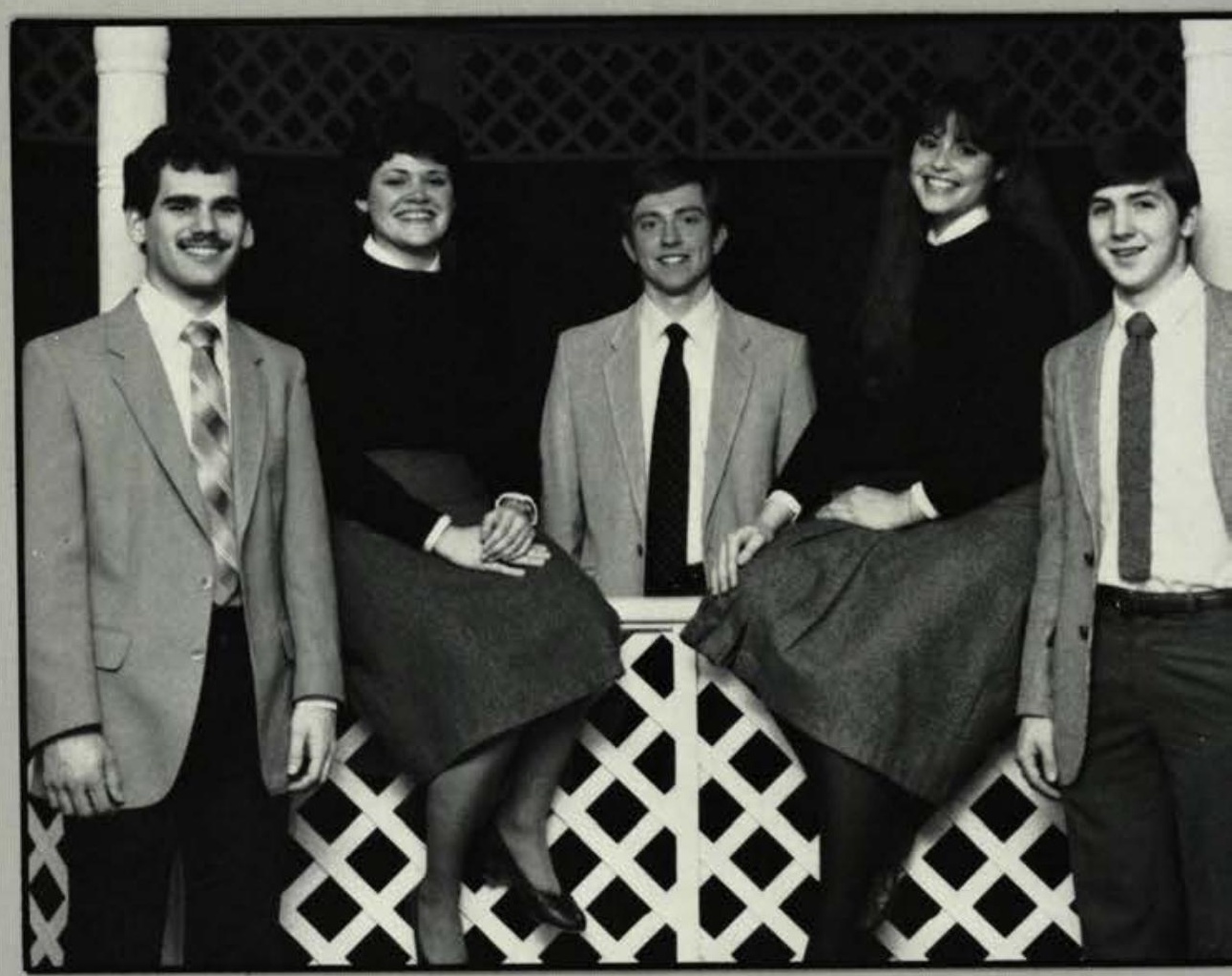

\section{Living Springs}

"The purposes of the publication are to encourage, entertain, and witness to our readers. Living springs is a great way for students to use their talent of writing in the ministry to the elderly."

- Joan Parsons

First row: Ben Smith, Lamar Eifert. Forest Sellers. Second row: Terri Lynn Mackenzie. Joan Parsons. Lynn Dee Cramer, Leah Jayne, Jerri Goode. Brenda Fisher

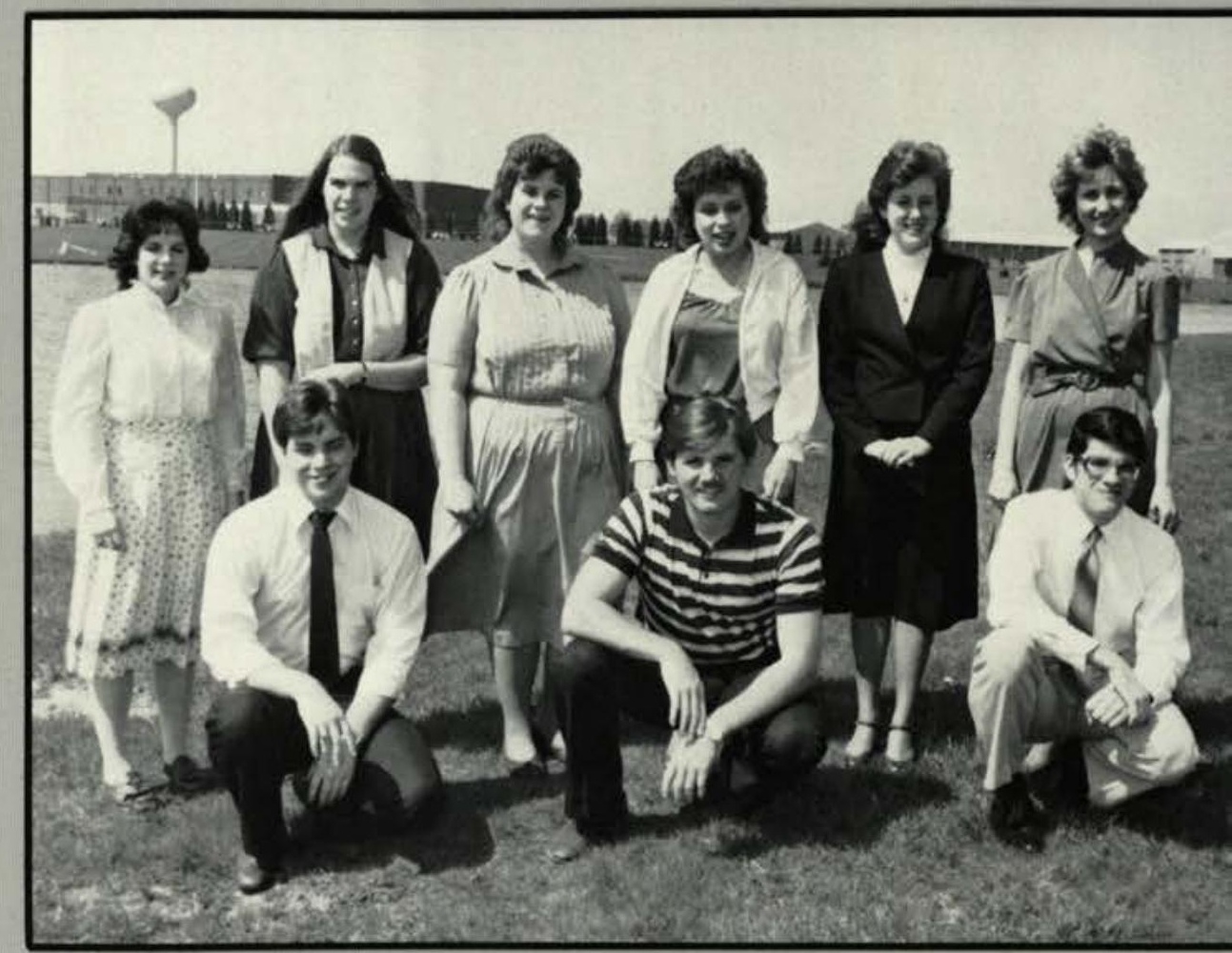




\section{Abundant Life}

"' 'Refreshing the Saints' with laughter, loving concern, and a listening ear, we strive to emulate a Christian fellowship that brings glory to God not only through carefully prepared worship in song. but also through that intimacy in Christ which all believers share. 'Hallowed be the name of Jesus.'

- Doug Miller

Seated: Mike Law, Sue Scott, Dan George. Standing: Jeff Vander Heide, Jennifer Dye, Christina Chase. Annette Miller, Doug Miller (Leader). Debi Henry, Dave Eller

Central State Campus Evangelism

"In a semi-cultural environment (compared to Cedarville), we establish friendships, share Jesus, and disciple college students."

- Bob Ward

Rob Barber, Lynne Calish, Ed Colon, Christine Griffith, Carolyn Hunter, Joanne Laird, Darryl Little. Scott Mitchell, Rose Ann Nemecek, Ken Nickols, Barbara Olson, Robin Randolph. Alesio Repke, Jane Sparling. Curtis Summerville, Bob Ward (Group Leader)
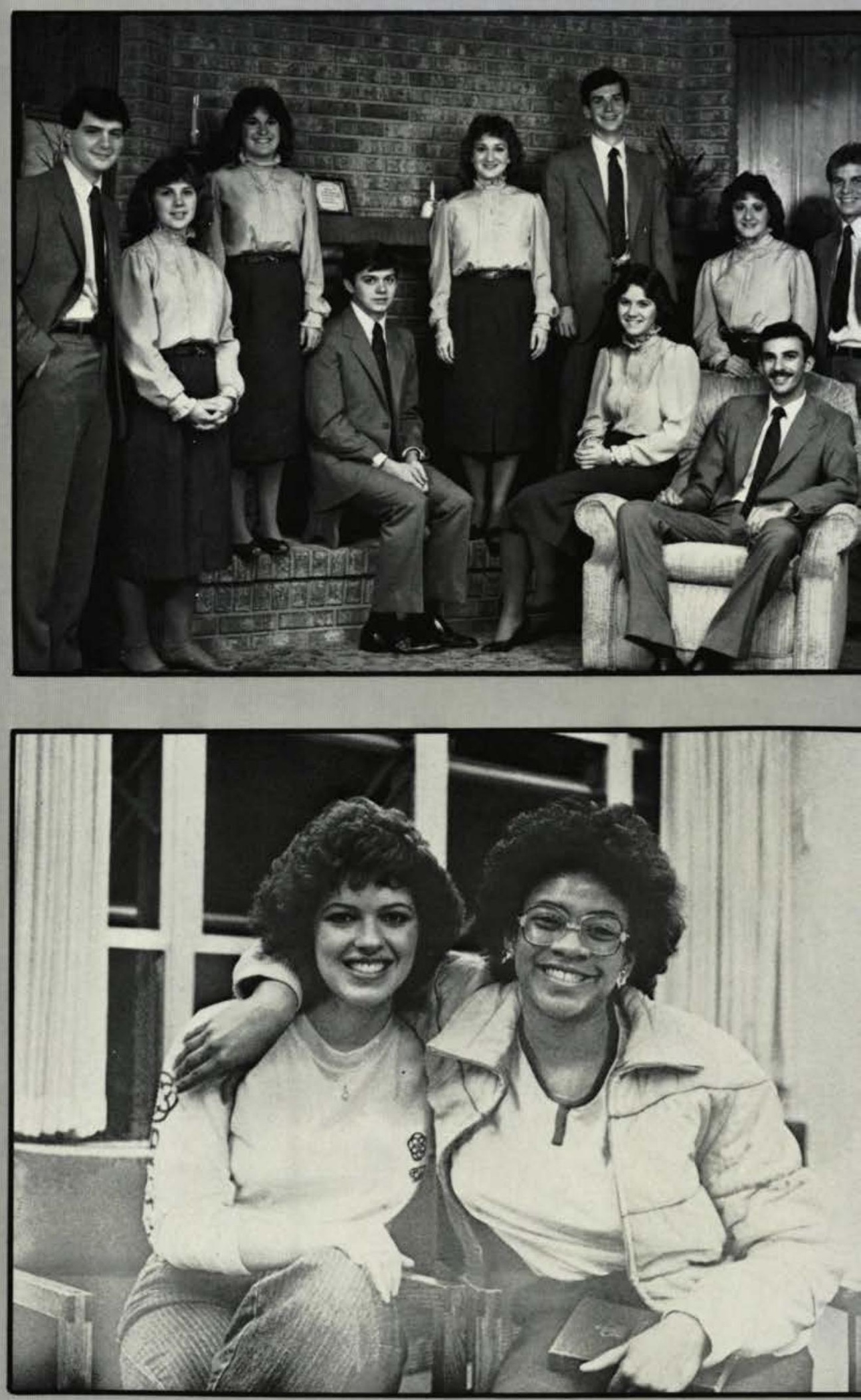

"Sing to God, sing praise to His name, extol Him who rides on the clouds His name is the $\mathcal{L O R D}$ - and rejoice before Him." (Psalm 68:4) 

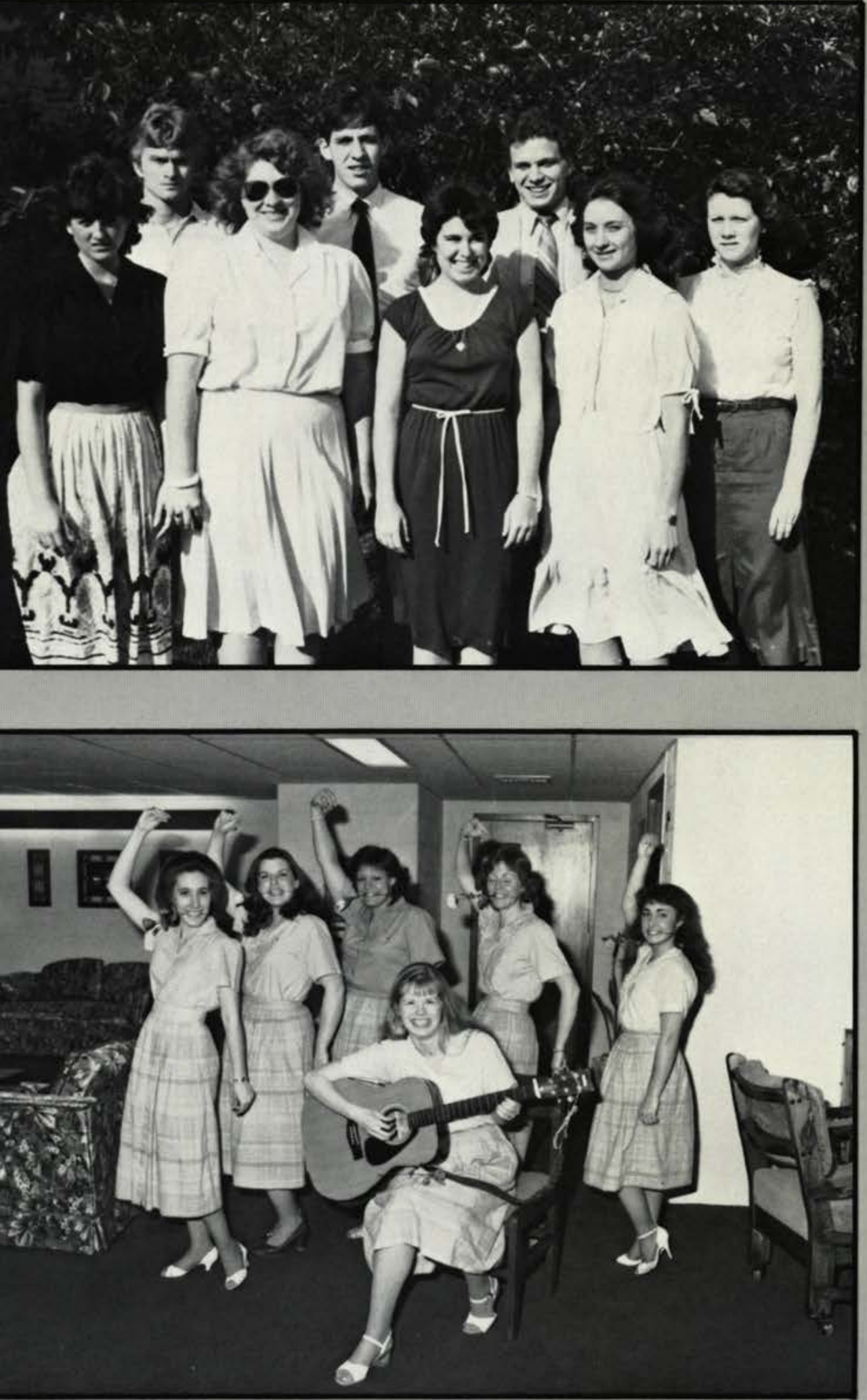

Greenwood Manor Nursing Home

"The liberal soul shall be made fat: and he that watereth shall be watered also himself."

(Proverbs 11:25)

Ann Berger, Amy Christian, Sally Cochran, Janis Comfort, Laura Dykstra, David Eller (Group Leader), Linda Hess, Bruce McNabb. Jeff Reynolds. Sue Scott, Sharon Wilson

\section{Spain Team}

"Although I feel well-prepared, this will be a new experience. I've never before been forced to speak only Spanish. (And so rapidly!) This will tie me to the people more, though: living in the people's homes and speaking their language."

- Irene Farley

Seated: Delana Powers, Standing: Julie Murray, Irene Farley, Sandy Green, Donna Birch, Jana Dowsett

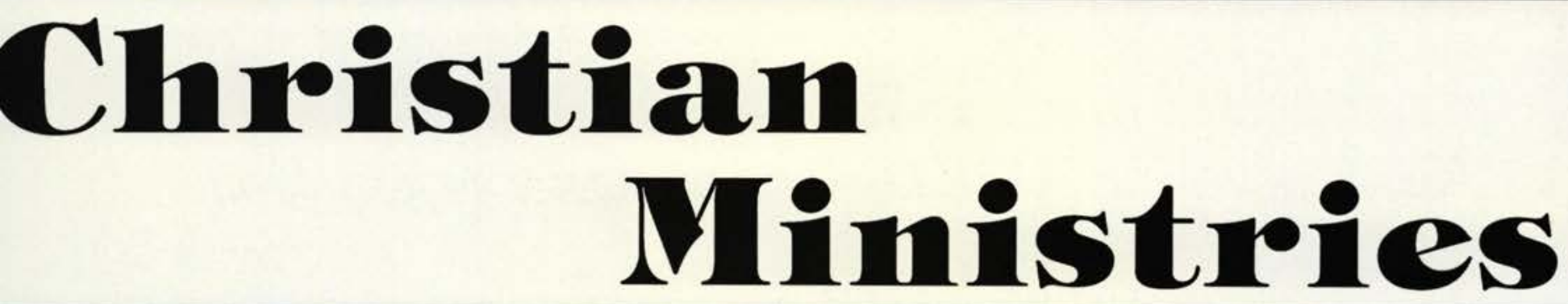




\section{Chroistiam Ministries}

\section{Green Oaks Health Center}

"Sure, these people need our love and affection, but it is often that we receive the greater blessing."

\section{- Mike Edwards}

Beth Bucklew, Esther Bucklew, Lynette Chezick, Cathy Echam, Mike Edwards (Group leader) Dawn Fisher, Dave Hartsough. Crystal Hancock. Kathi Holman, Rick Kester. Mike Lindberg. Melanie Matthewson. Barb Sanford, Robin Stockham

\section{Springfield Detention Center}

'They feel an emptiness of purpose. of desire, of direction, of love ... Yet, the Lord has enabled us to fill this emptiness by sharing the love and life that can only be found in Jesus Christ."

$$
\text { - Jim Liebler }
$$

Karen Beattie, Tracy Cotton, Clancy Cruise, Deborah Deeter. Anne Edwards, Tammy Evans, Kirk Fairhurse, Barb Hoskins, Sheri Jutting Todd Jeffson, Jim Liebler. Pam Lopez. Tracy McCoy, Melissa Marshall, Bill Moore, Steve Mulligan, Kim Murphy. Vince Peak, Trish Pragnotti, Jim Reiter, Bruce Richards, Chris Stone. Andy Strait (Group leader), Rich Tavierne, John Voth. Curt Weisenfluh, John Williams
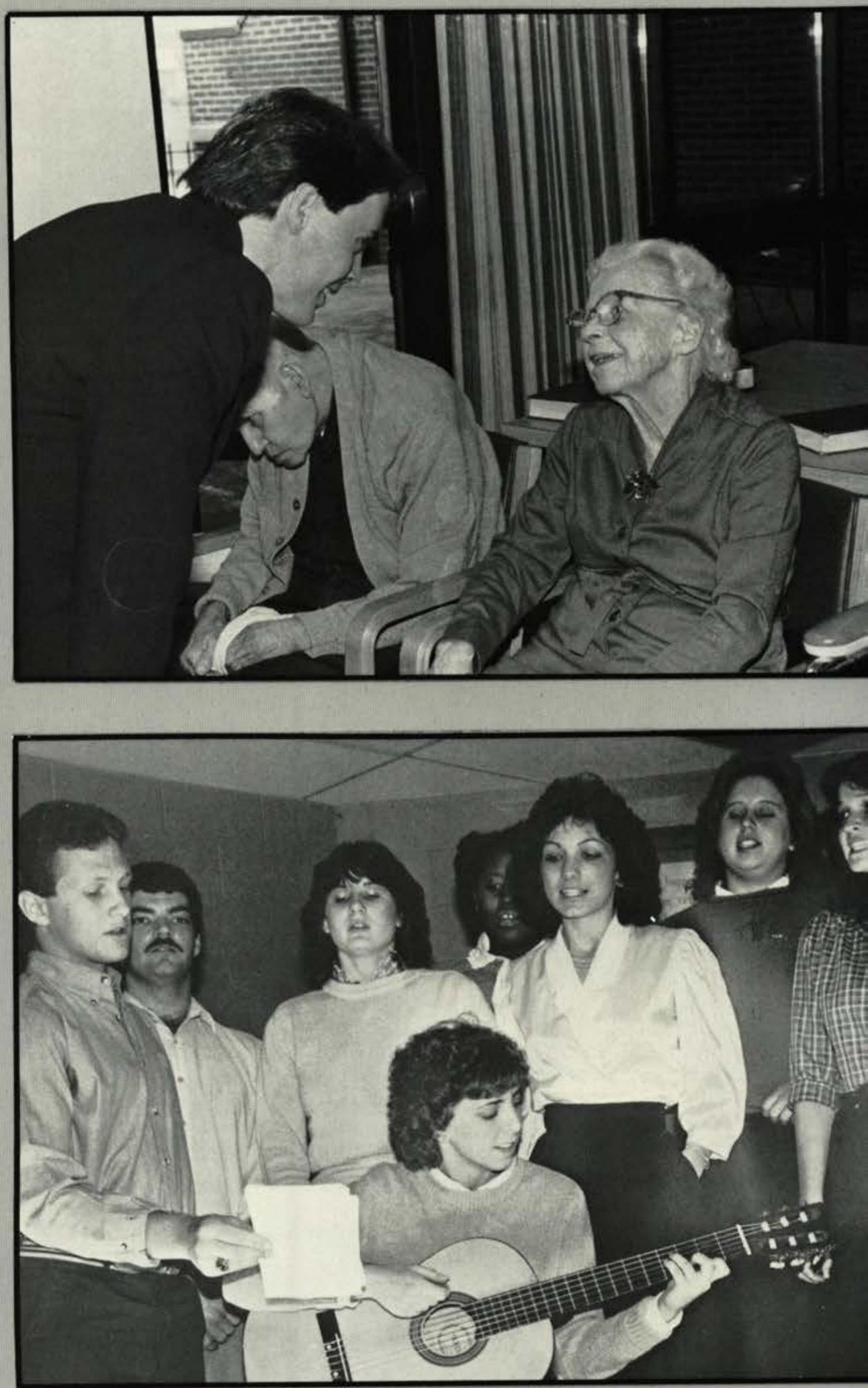


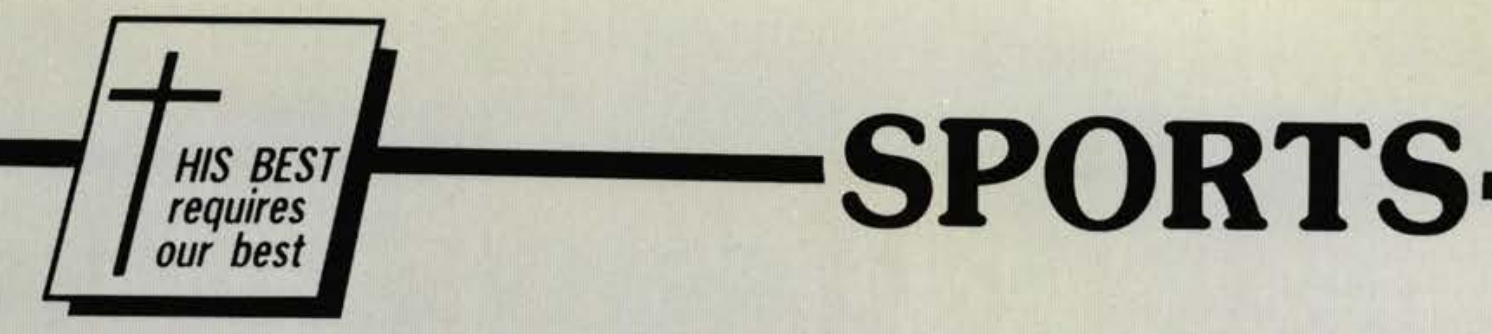

\section{YELLOW JACKET MANIA}

D ractice after practice, serve after serve, mile after mile, the Cedarville College Yellow Jackets ended the 1983-84 season very successfully.

Fans, coaches, and athletes alike recognize the importance of physical strength and stamina in order to achieve such success. Because of this recognition, students of Cedarville College are also encouraged to become physically active either through intercollegiate sports, intramurals, aerobics, or one of several other activities.

The Athletic Center offers a potpourri of sports from which to choose ranging from badmitton to racquetball. An effective exercise program will provide a healthy balance to the rigors of academic life.

by Bill Thomas

\section{Contributers:}

- Shelly Harris

- Dave Jones 186

- Gary Anderson .......... 194

- Beth Britton ............. 196

- Dana Burkett . . ........... 198

- Brent Ziegler ...........202

- Laurie Benedict ........206

- Steve Cremcans .......208 208

- Karen Harrington . .......210

- Craig Slater ...........212

- Ann Berger ............214

- Shawn C. Huck ..........216

\section{Layout By:}

- Keith Beres

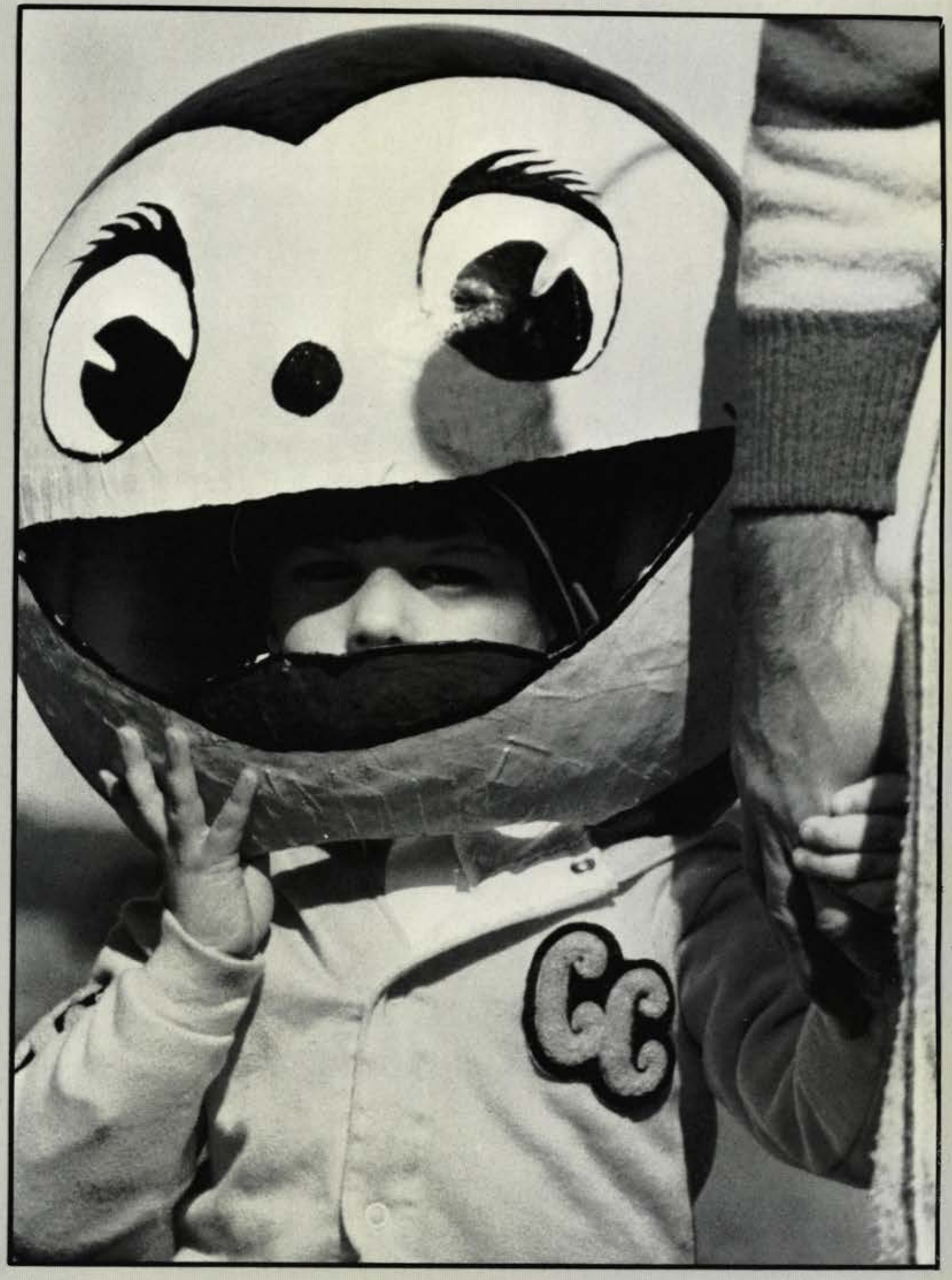

\footnotetext{
(n)
}




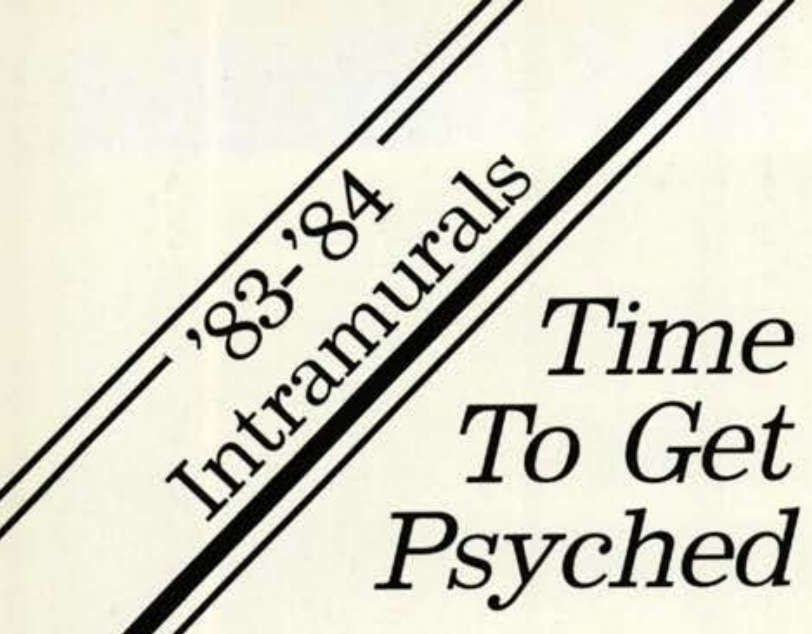

t's only 6:45 pm and I'm already sick 1 of homework. And even if my eyes weren't blurring the pages of Dr. Monroe's "Collateral Reader," I couldn't study because the guys in the hall are being so loud. here?"

"Guys, What are you doing in

Hey, That's right! Tonight is Tuesday, the big night for basketball at the gym. Now I won't be thumbing through "Christian Economics" for sure. I gotta get psyched! This is just the release needed. Who says Cedarville is all work and no play? ... How could this

\section{"Humility and fitness rather than pride and power are the hidden elements of success in approaching intramurals."}

game have slipped my mind? Where are my stinkin' Converses? I'm probably late for warmups ... Why didn't I do my laundry? Where are my cleanest dirty socks? I just hope that little red haired girl will be there watching again. I better take my comb just in case.

Intramurals teaches humility as well as competition. It teaches you to be a member rather than an individual. Humility and fitness rather than pride and power are the hidden elements of success in approaching intramurals. Sports discipline enhances Cedarville life by providing a non-academic education. Besides that, it's good clean (but smelly) fun.
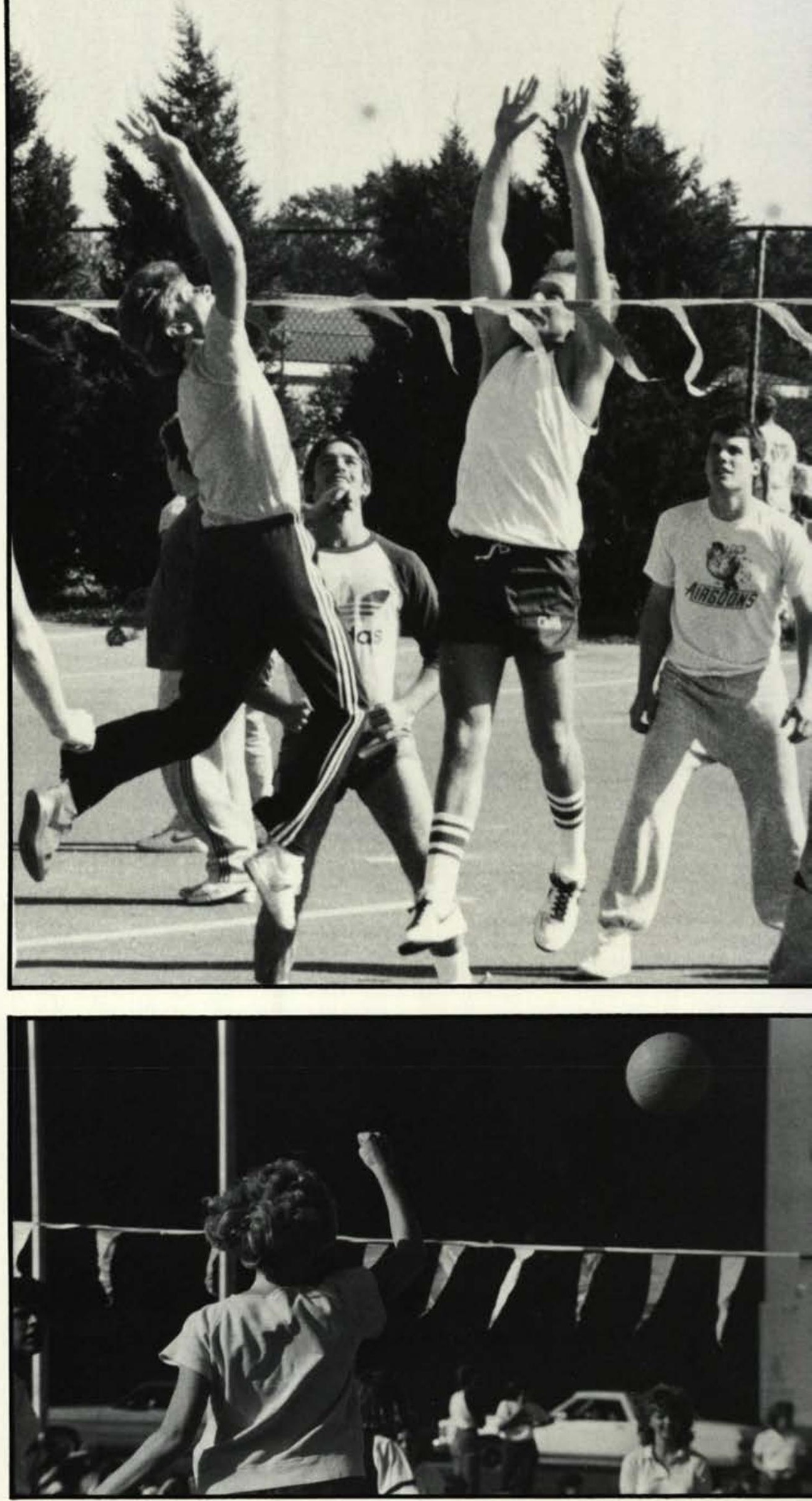


(5)

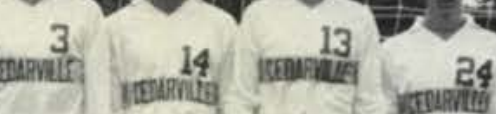
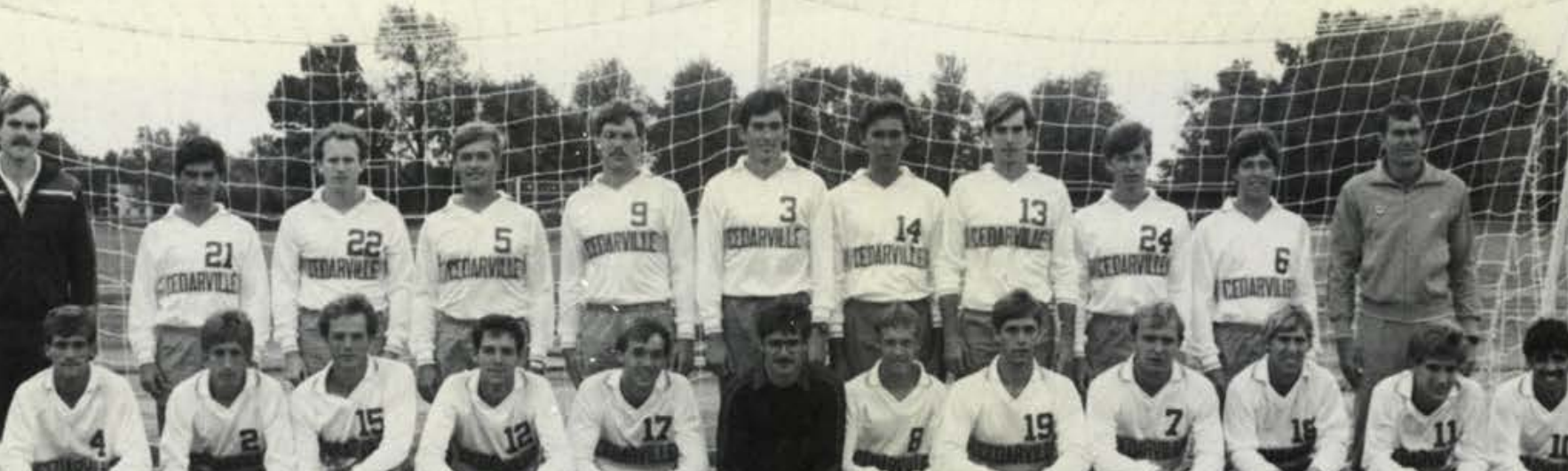

in 2 .

First row: Greg Norden, Chuck Abel, Wayne Anderson, Noel Hack, Brent Ziegler, Dave Jones, Bill Jaquis, Phil Fogle, Kurt Weisenfluh, Curt Critcher, Phill Miller, Tom Fite, Bobby Shomo; Second row: Assistant Coach; Joe O'Neal, Kurt Anderson, Ken Williams, Dan Hawk, Mark Fleetwood, J.D. Callan, John Stone, Dave Moody, Bill Martin, Rod J. Smith, Coach; John McGillivray.
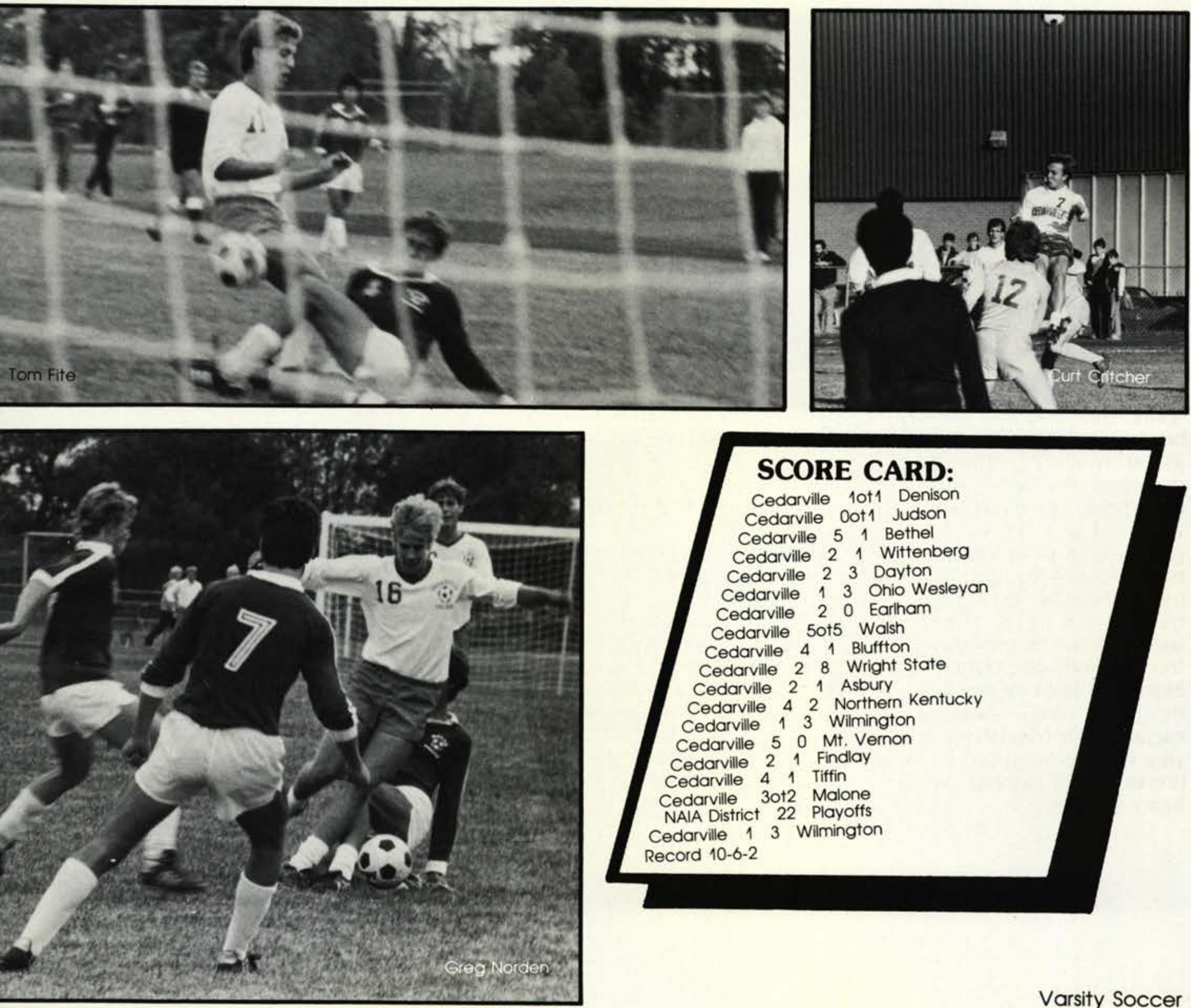

SCORE CARD:

Cedarville 1ot1 Denison Cedarville 0ot1 Judson

Cedarville 51 Bethel

Cedarville $2 \quad 1$ Wittenberg

Cedarville 23 Dayton

Cedarville 13 Ohio Wesleyan

Cedarville 2 o Earlham

Cedarville $50+5$ Walsh

Cedarville 41 Bluffton

Cedarville 28 Wright State

Cedarville $2 \quad 1$ Asbury

Cedarville 42 Northern Kentucky

Cedarville 13 Wilmington

Cedarville 50 Mt. Vernon

Cedarville 21 Findlay

Cedarville $4 \quad 1$ Tiffin

Cedarville $30+2$ Malone

NAIA District 22 Playoffs

Cedarville 13 Wilmington

Record 10-6-2 

The 1983-84 Lady Jackets came a I long way this year to pull a 10-13 season. The record doesn't come close to showing all the hard work that went into the season.

As the season began in November, many new adjustments had to be made. The arrival of a new Coach, Dr. Karol Hunt, was the major change. She brought with her high expectations and goals, which the team strived to accomplish.

This year was a building year with only two seniors leaving the squad at the completion of season. There is much anticipation that the team will continue its upward progression to become one of the best women's basketball teams that Cedarville has developed.
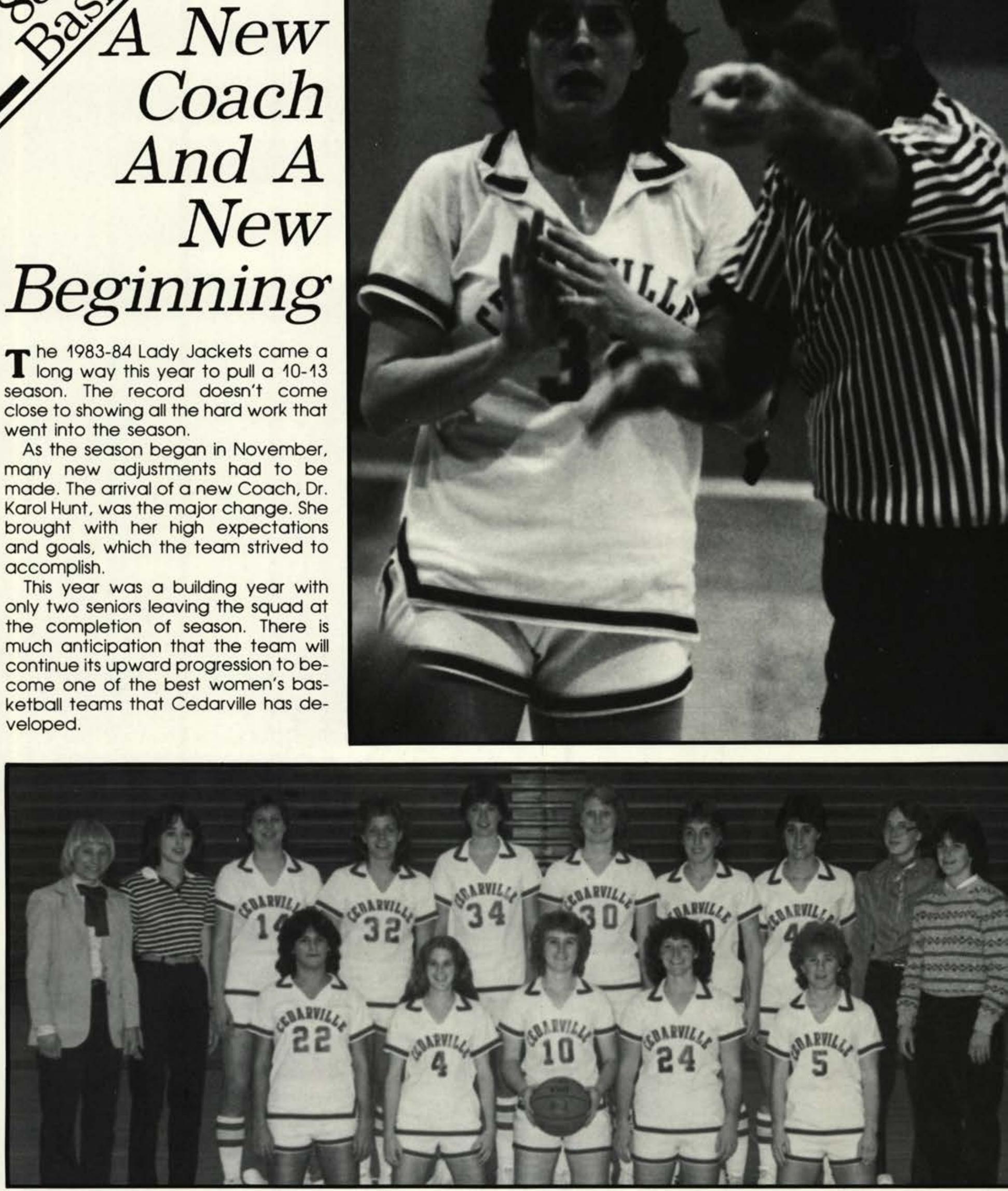

First Row: Sherri Norrick, Vickie Stuiber, Angie Wilcox, Jewel Shroder, Linda Smart: Second Row: Coach Dr. Karol Hunt, manager, Kristi Burton, Karen Headdings, Peg Quigley, Lisa Campbell, Heidi Peterson, Teri Peterson, Beth Goldsmith, statistician, Julie Butler, statistician, Corrine Wilcox. 


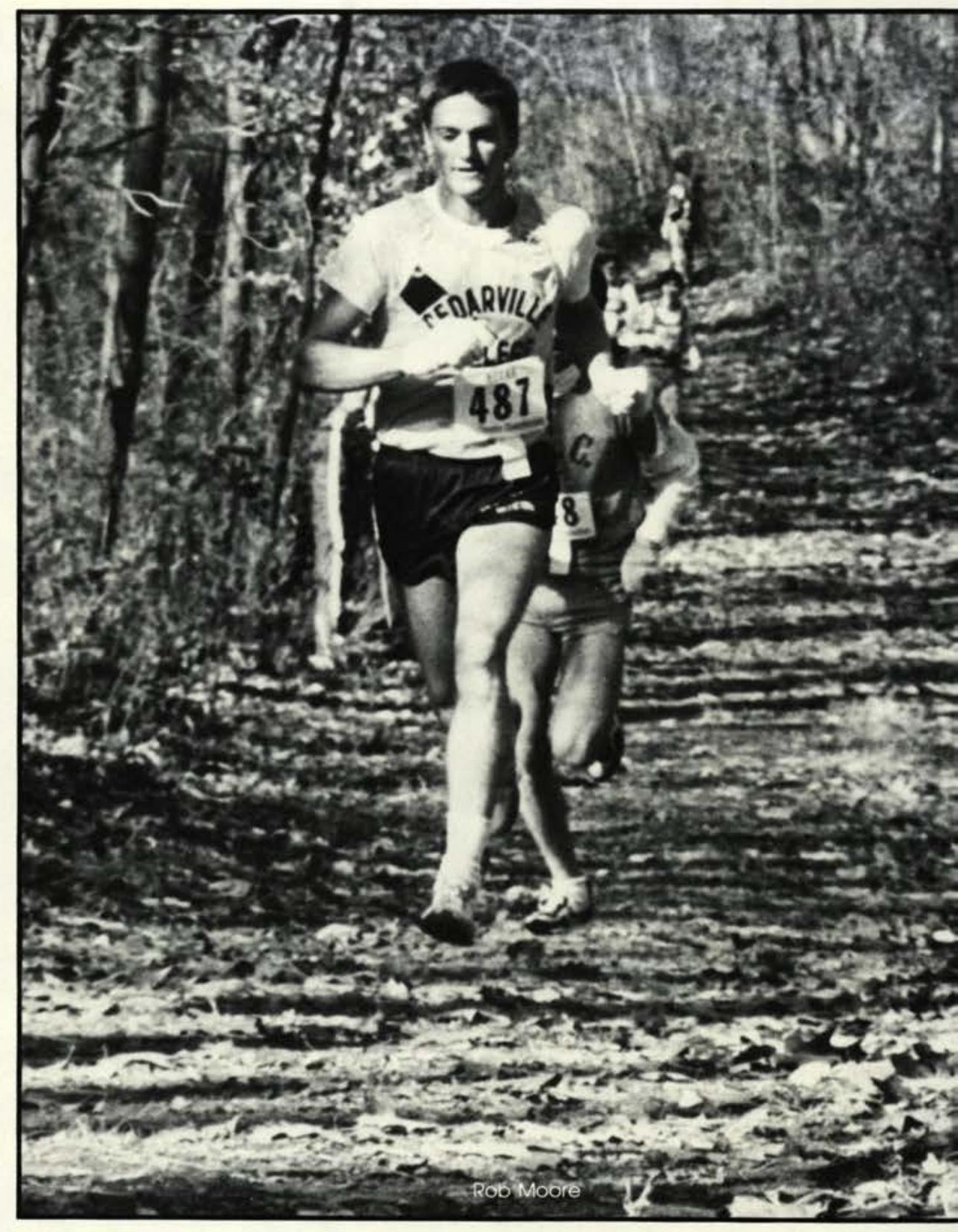

C rom the first four meets of the I year, Coach King knew that he had the best men's cross country team ever at Cedarville College. By winning at Muskingum College and Ohio Northern University, taking second at Grace College and third at Marion College. the "Hairless Harriers" compiled a 44-3

\section{"He lost both of his shoes half way thru the race and ran without them in true West Vir. ginian style."}

record. The two goals, obviously at this point, were to beat Walsh College and to earn a trip to the NAIA national Tournament.

The first objective became reality on October 22nd as Cedarville beat Walsh by 15 points. Everyone ran well, but something special sparked the team when Tom Hill ran the last $2 \frac{1}{2}$ miles shoeless, ( $1 \frac{11 / 2}{2}$ miles on gravel.) $\mathrm{He}$ lost both of his shoes half way thru the race and ran without them in true West Virginian style.

Cedarville struggled to beat Anderson College but had to settle for a second place finish to its fired-up squad. However, Cedarville did earn a trip to the NAIA nationals. Unfortunately, the Jackets seemed to get lost in the multitude of 450 runners and placed 29th out of 37 teams.

Overall, the season went very well and we were very pleased with the success the Lord allowed us to have. We look forward to future seasons and the opportunities to give our best for His glory.

by Gary Anderson.

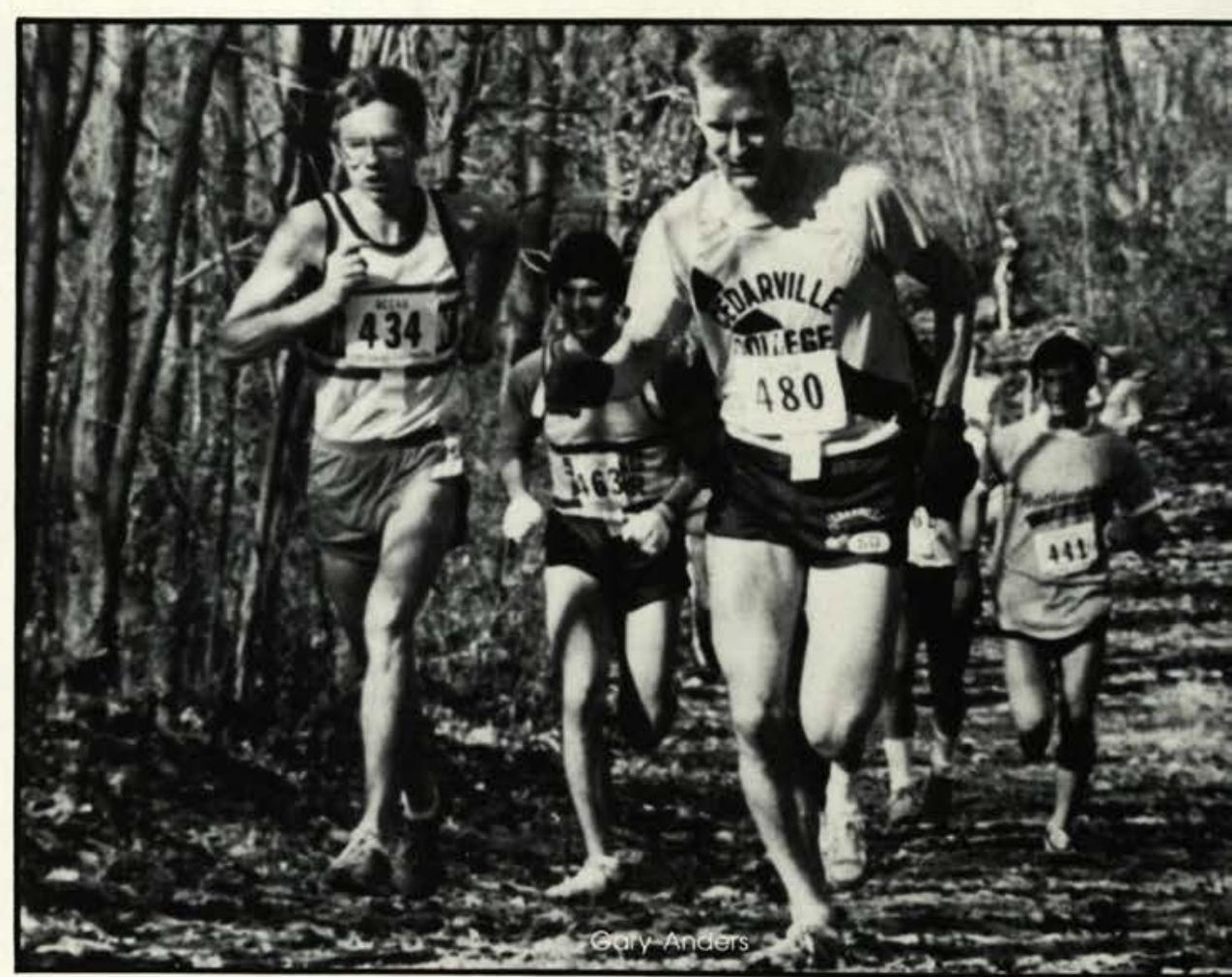




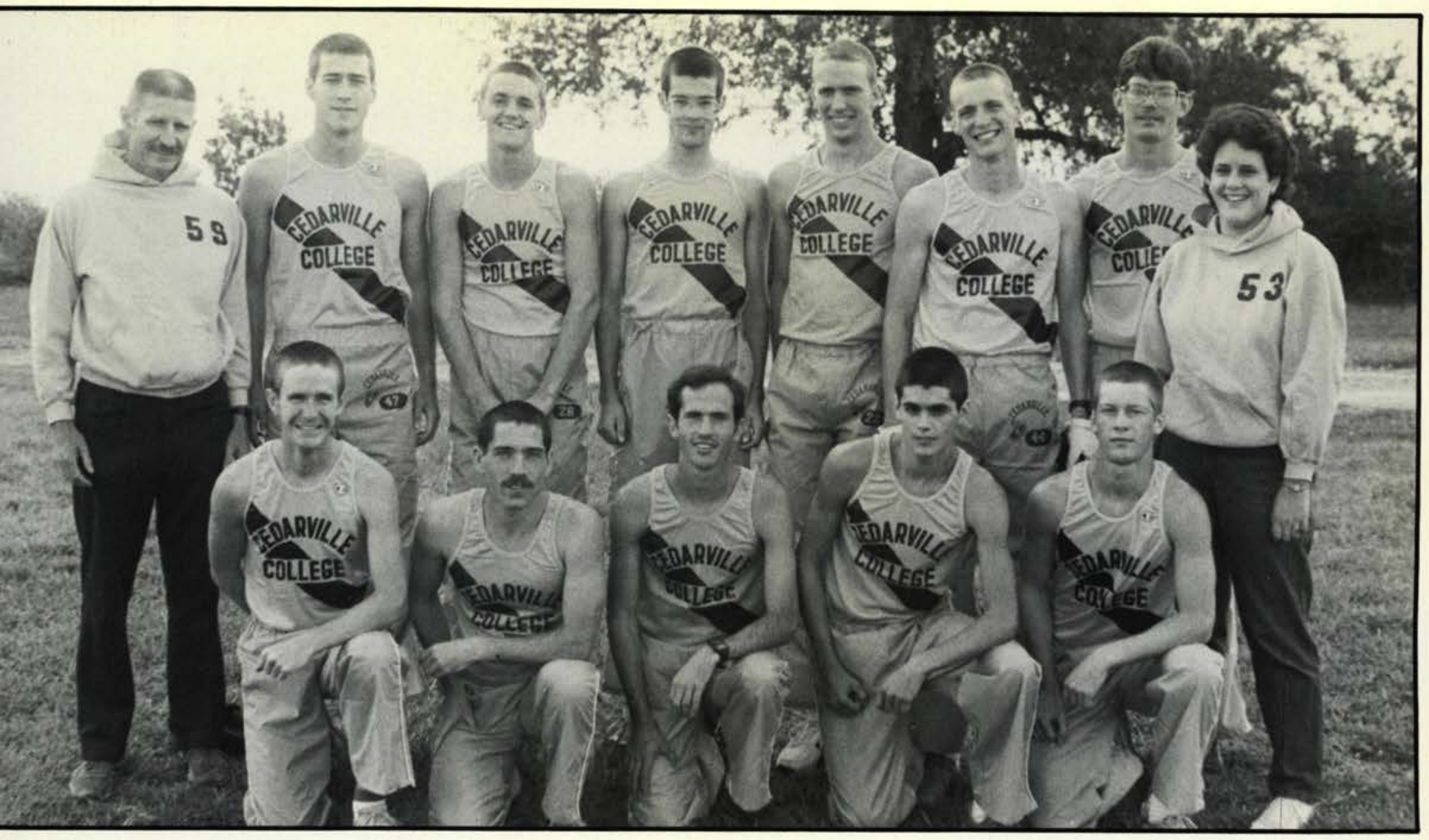

First Row: Rusty King, Ron Kuntz, Steve Cox, Tom Hill, Rob Johnston; Second row: Coach Elvin King, Doug Cherry, Rob Moore, Dean Morse, Scott Brooker, Gary Anderson, Craig Slater, manager Becky Payton.
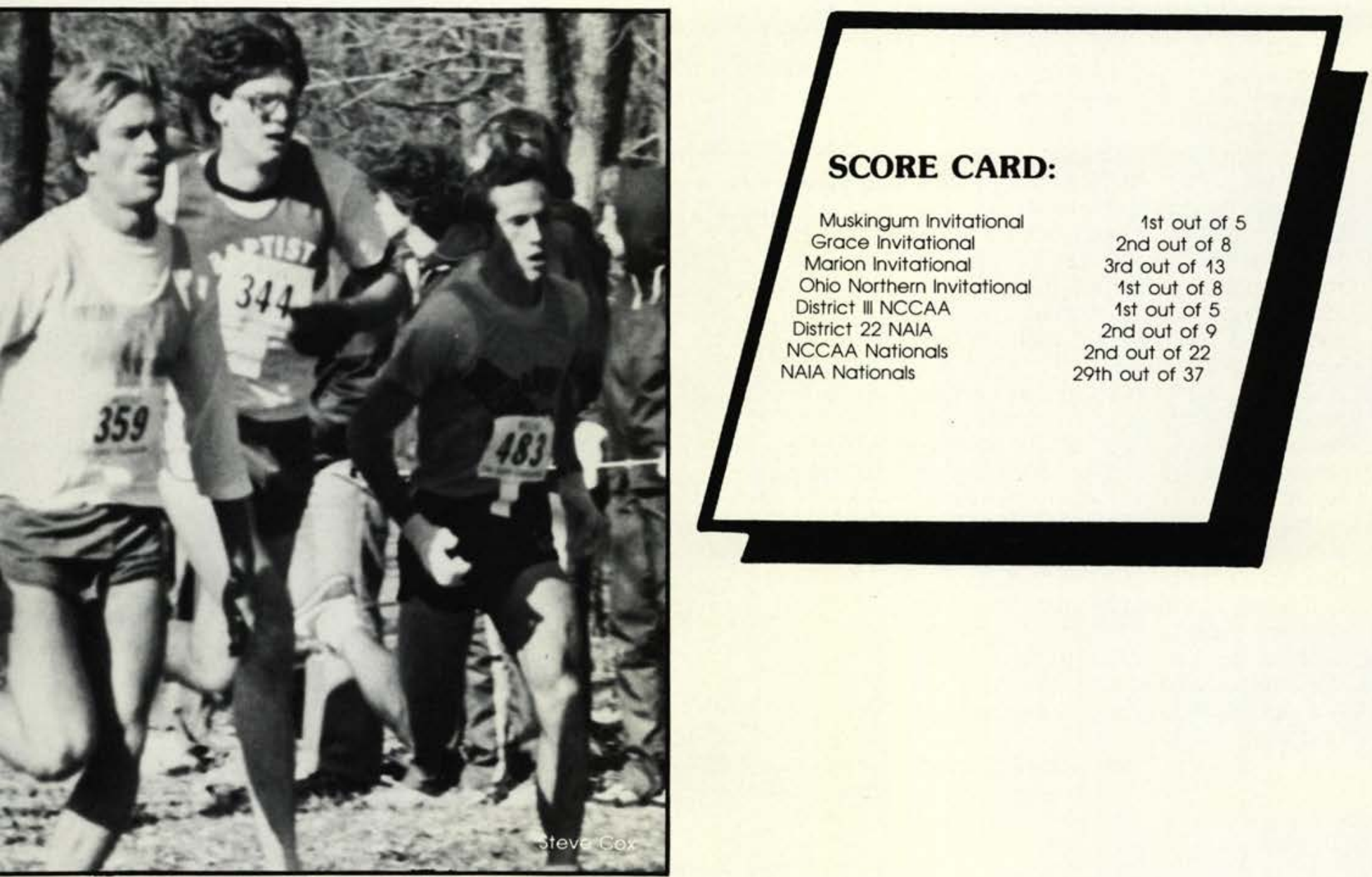


\section{New Team Brings Success}

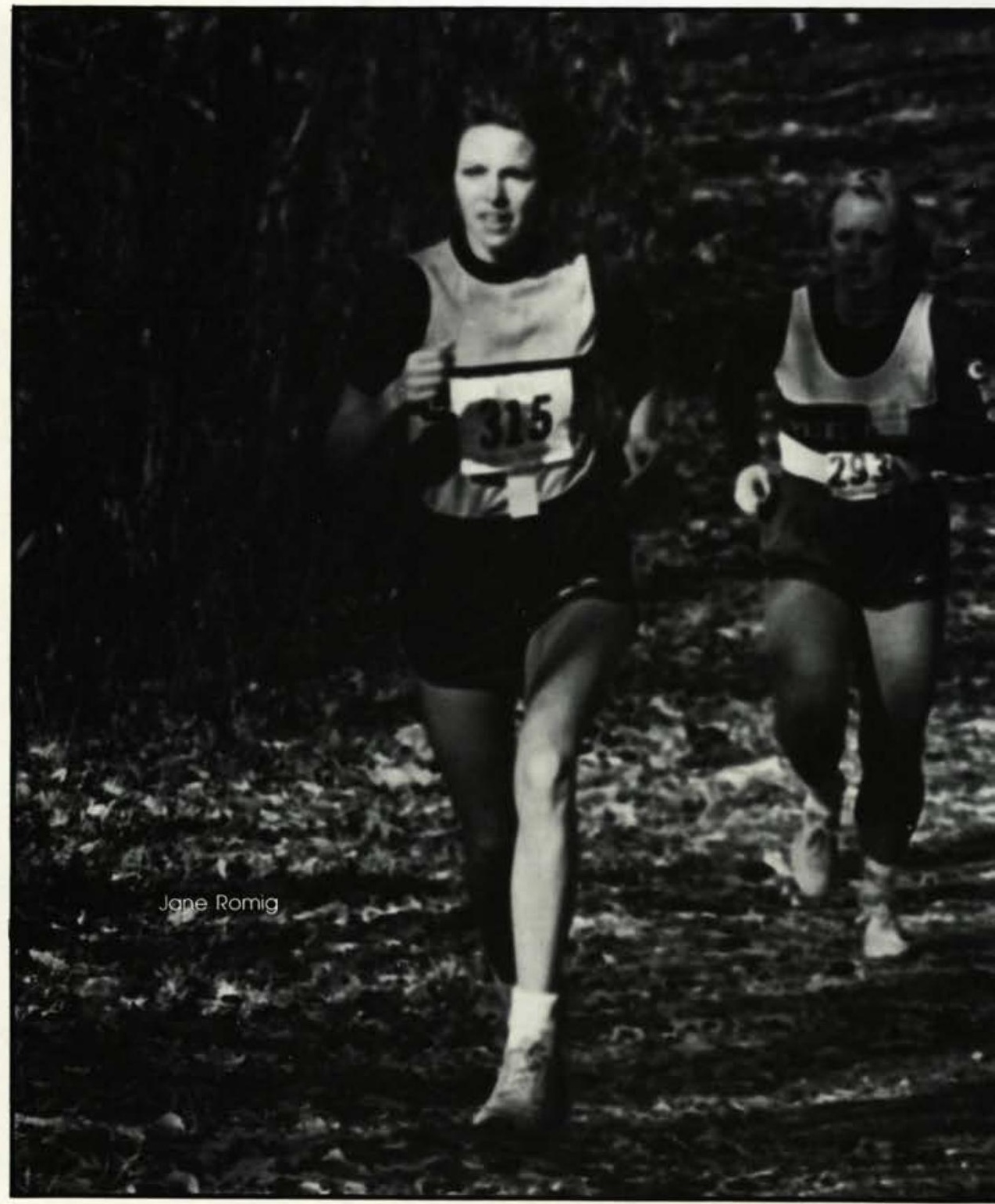

Spring Arbor, the 1982 N.C.C.A.A. champs, placing second at the Ohio Weslyan invitational. They also successfully defended their N.C.C.A.A. district title, with sophomore Jane Romig winning the meet. The team then participated in the N.A.I.A. district meet, where they surprisingly beat Walsh College and finished second to Malone College. The team ran their best race of the year at the N.C.C.A.A. national meet where they placed second out of the eleven schools represented. The team's top two runners, Jane Romig and Sue Vaughan, obtained All-American honors that day, which was a first for $\mathrm{Ce}$ darville's women cross country team. The female harriers ended their first winning season with an 18-14 record.

by Beth Britton

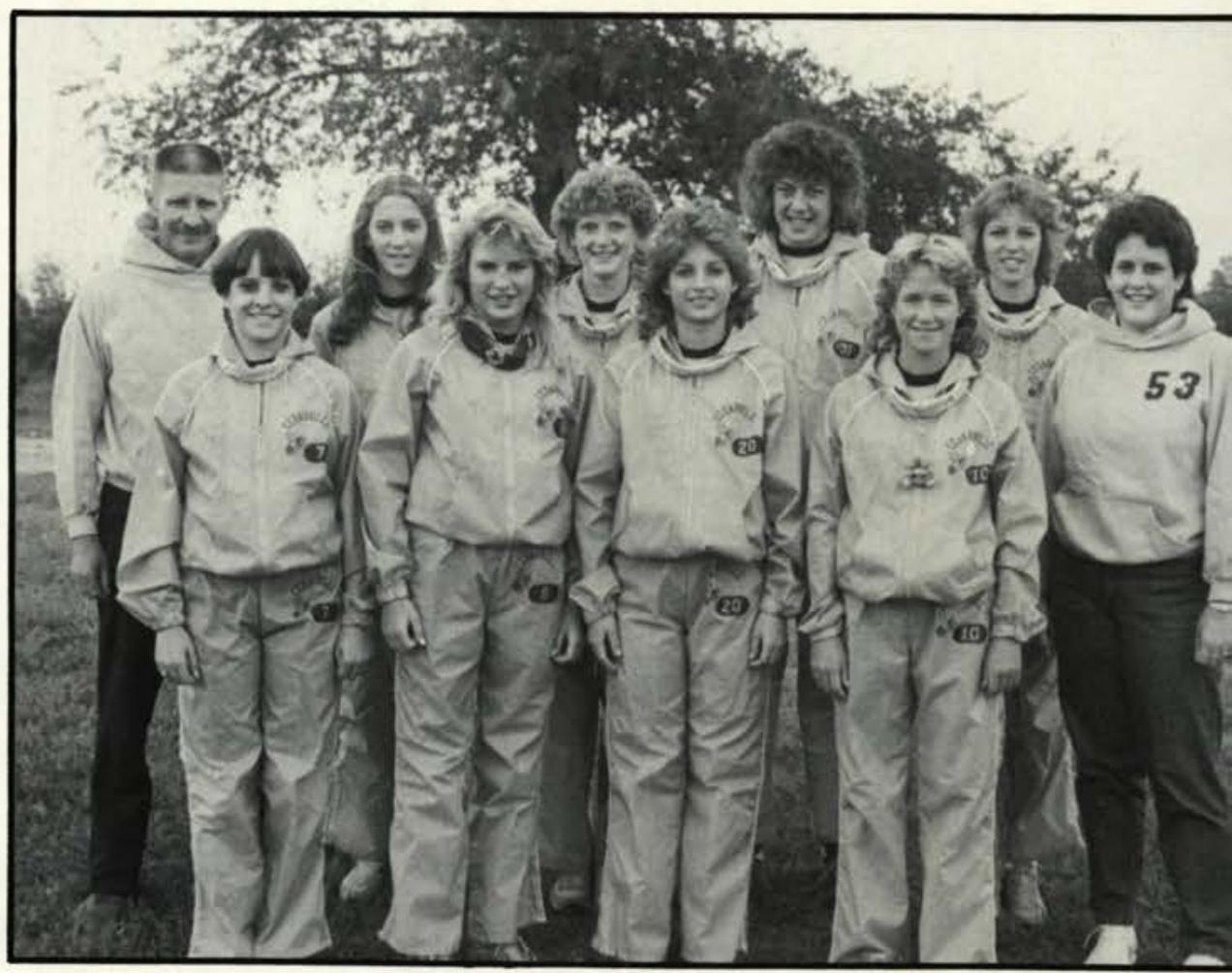

First row: Mindy Ackley, Debbie Pate, Sandy O'boyle, Sue Vaughan: Second Row: Coach Elvin King. Heidi Withrow, Becky Averill, Beth Britton, Nane Romig, Manager Becky Payton. 
3

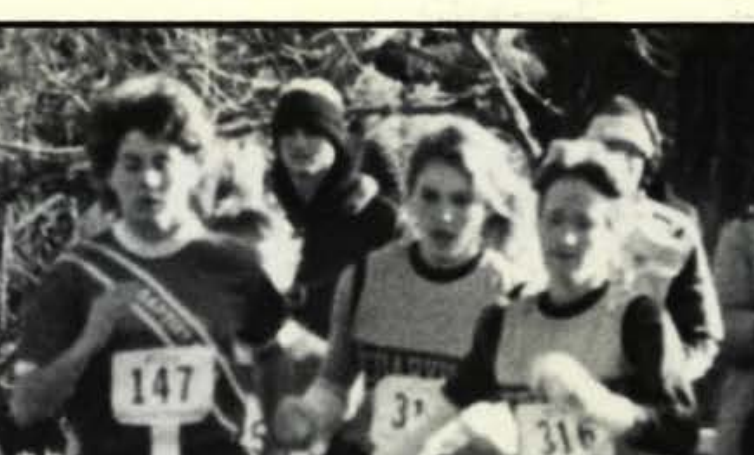

(146) 140
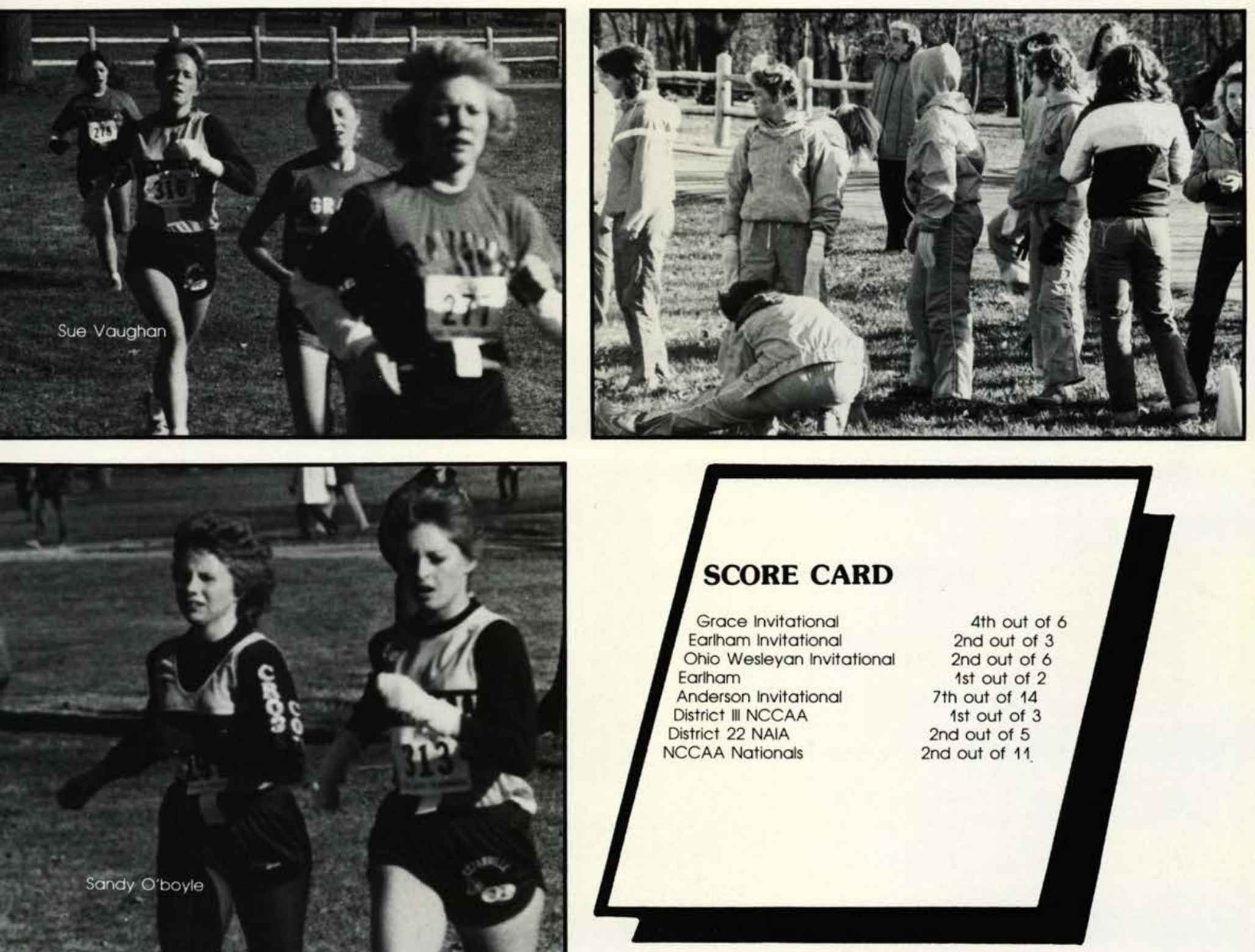

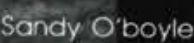

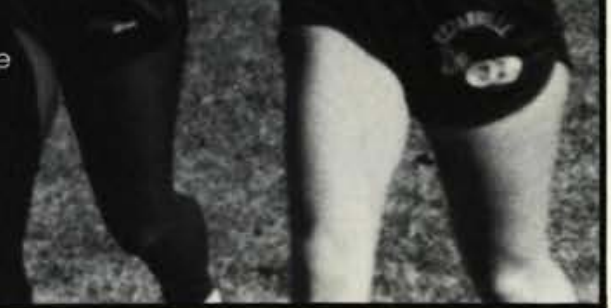



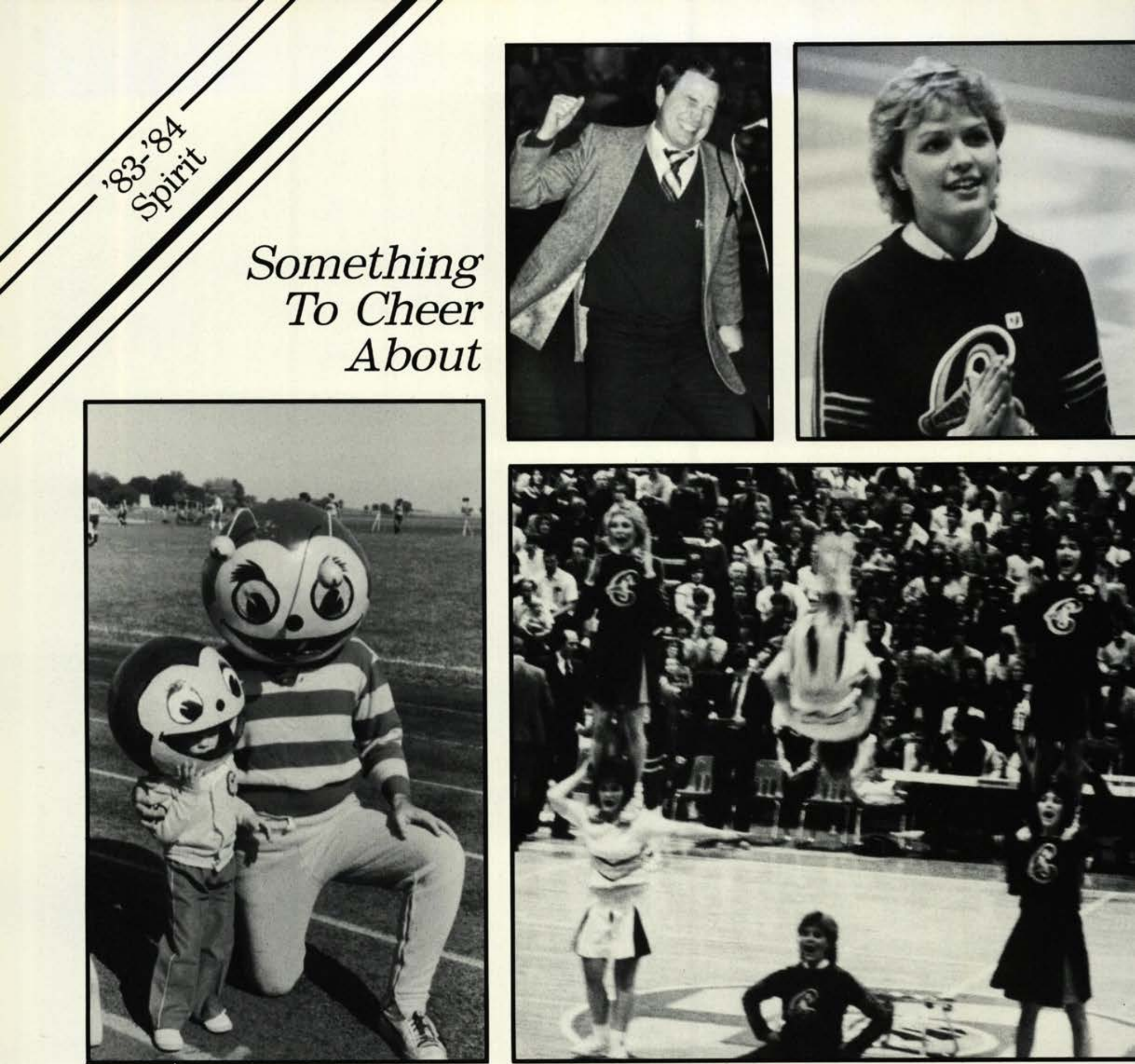

\section{J ackets are going to the top!"}

Sometimes yes, sometimes no. But the cheerleader always had to believe in her team and convince the crowd that the Jackets were worth believing in. Win or lose, the six women on the Varsity and J.V. squads had to be ever-enthusiastic, cheerful, and supportive. During breaks in the game, they had to keep up the fan's spirits with floor cheers and routines accompanied by the pep band.

But cheerleading isn't just "show-ntell." It is a sport in itself, and requires absolute dedication and top-priority. Hours of back-breaking practice each week, working together as a squad, facing defeat with a smile, striving for Christ-like attitudes ... all of these are part of being a cheerleader. Doing behind-the-scenes jobs all year long that take a lot of time with little credit. Being there when the team needs you. Cheerleading is a sacrifice, but to those of us who cheered this year, we wouldn't trade it for the world. Terrific benefits came out of this opportunity: close, life-long friendships; meeting and witnessing to other cheerleaders: conducting rigorous cheerleading camps, and the agony of staying physically fit, to name a few.

One of the best things about cheerleading, though, was our advisor, Amy Womack. Amy encouraged us when things got tough, kept our spirits up and our eyes on the Lord, and was always there when we needed a friend to talk to. Our co-captains, Susan Jackson and Kendra Wittenbach, made cheerleading this past year even better! They were both kind, compassionate, crazy, and exhibited strong Christian leadership. They never pushed us, nor asked us to do some thing that they wouldn't do them selves.

Combine that with the fantastic per band this year led by Mr. Dicuirci, ane you have a totally enjoyable season Mr. DiCuirci always seemed to know just what the fans needed, and when It was a real joy to work with him! Hi pep band put their hearts into the music and turned the gym inside-ou many times with their infectious enthu siasm.

To top it all off, the Bee and Buzz Bee (Mike Troutman and Chad Fires sparked spirit wherever they went. Thi being Mike's last year as school mas cot, he deserves a special thank-yo for his dedication and great job all sea son long. 



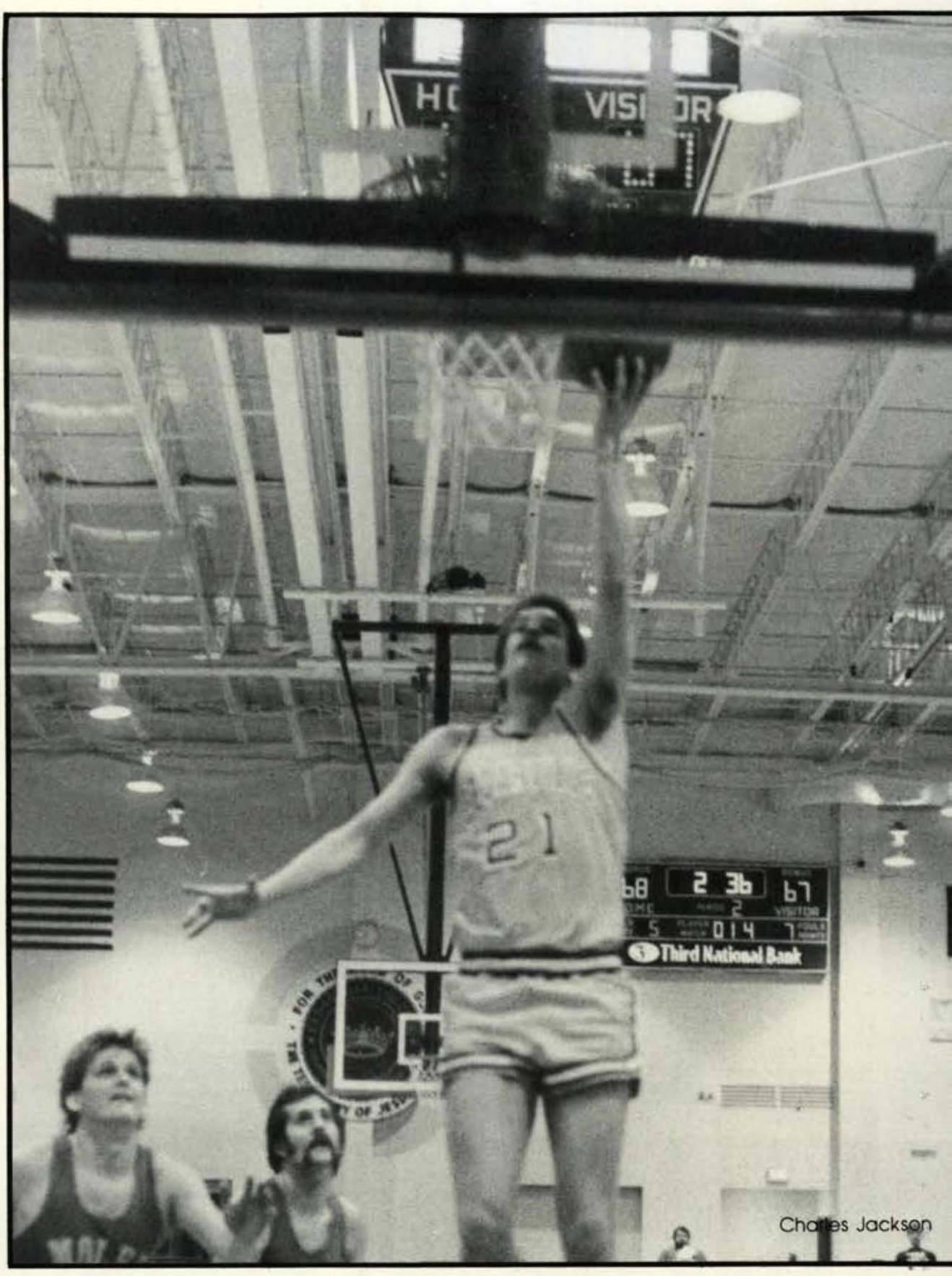

\section{Building For The Future}

F inishing the season with a $10-10$ reF cord, the men's Junior Varsity Basketball team laid the foundation for the future of Cedarville basketball. The year was a roller coaster ride for the team as it fought to stay above the .500 mark. Winning one game and losing the next became a common occurrence this year, but the team continued throughout the season with de-

\section{"... but the team continued throughout the season with de. termination to finish with a win. ning season."}

termination to finish with a winning record. The bright spot in this year's season was the play of the team's big men. Freshman Dave Yeager (17.7 pt. average, 10.3 reb. average) and sophomore Steve Terpstra (13.1 pt. average, $6.6 \mathrm{reb}$. average) led the team with their tough play inside. Although the team lacked experience and sometimes ability, it was characterized by continual determination and desire to improve their game.

by Brent Ziegler

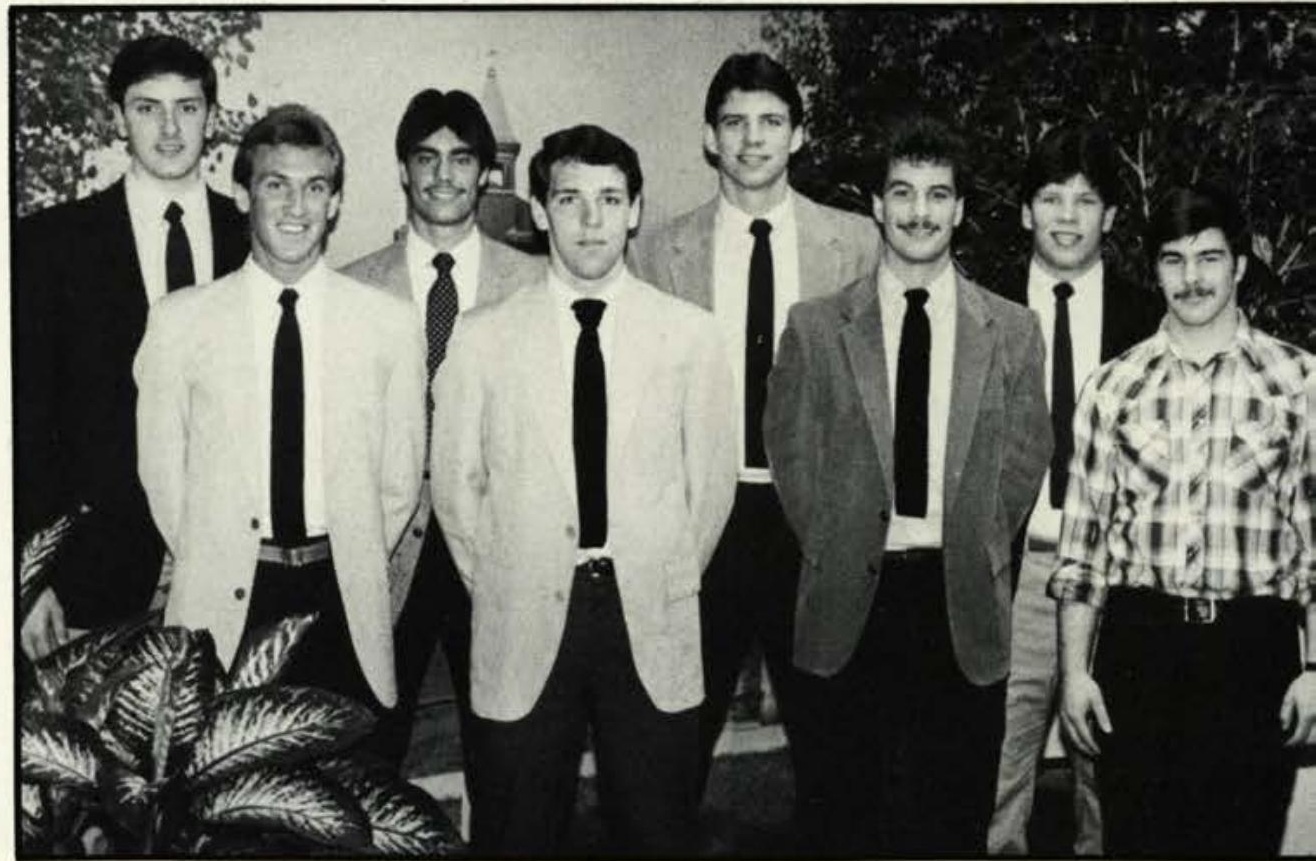

First Row: Mike Donahoe, Brent Ziegler, Charles Jackson, manager Mike Enman; Second Row: Dan Morris, Doug Pugh. Dave Yeager, John Sykes. Not pictured Steve Terpstra. 


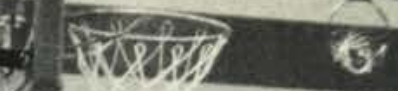
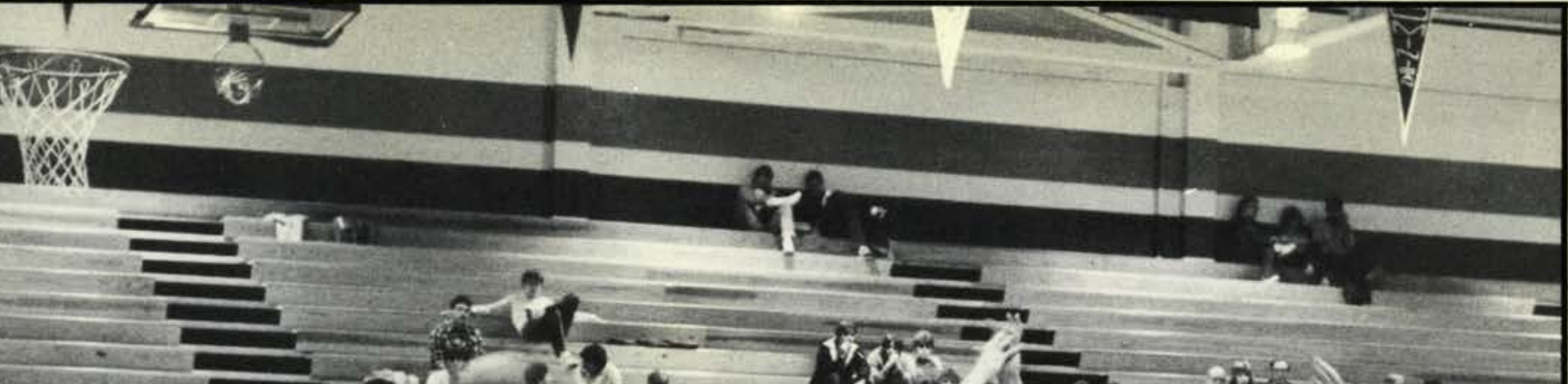

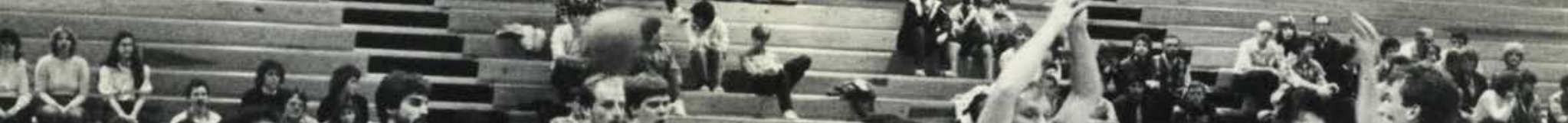

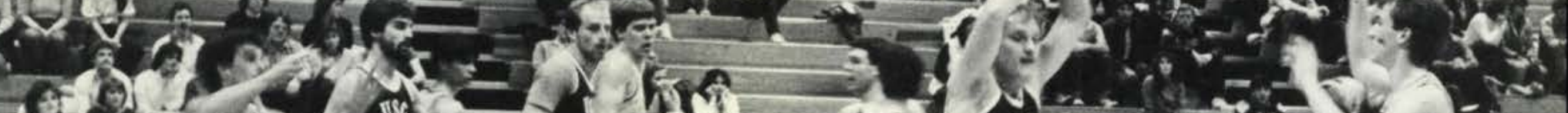

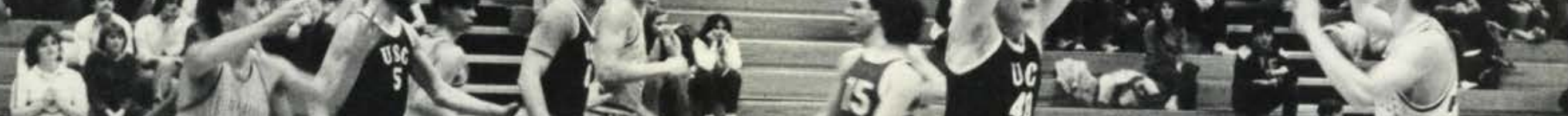
(1)
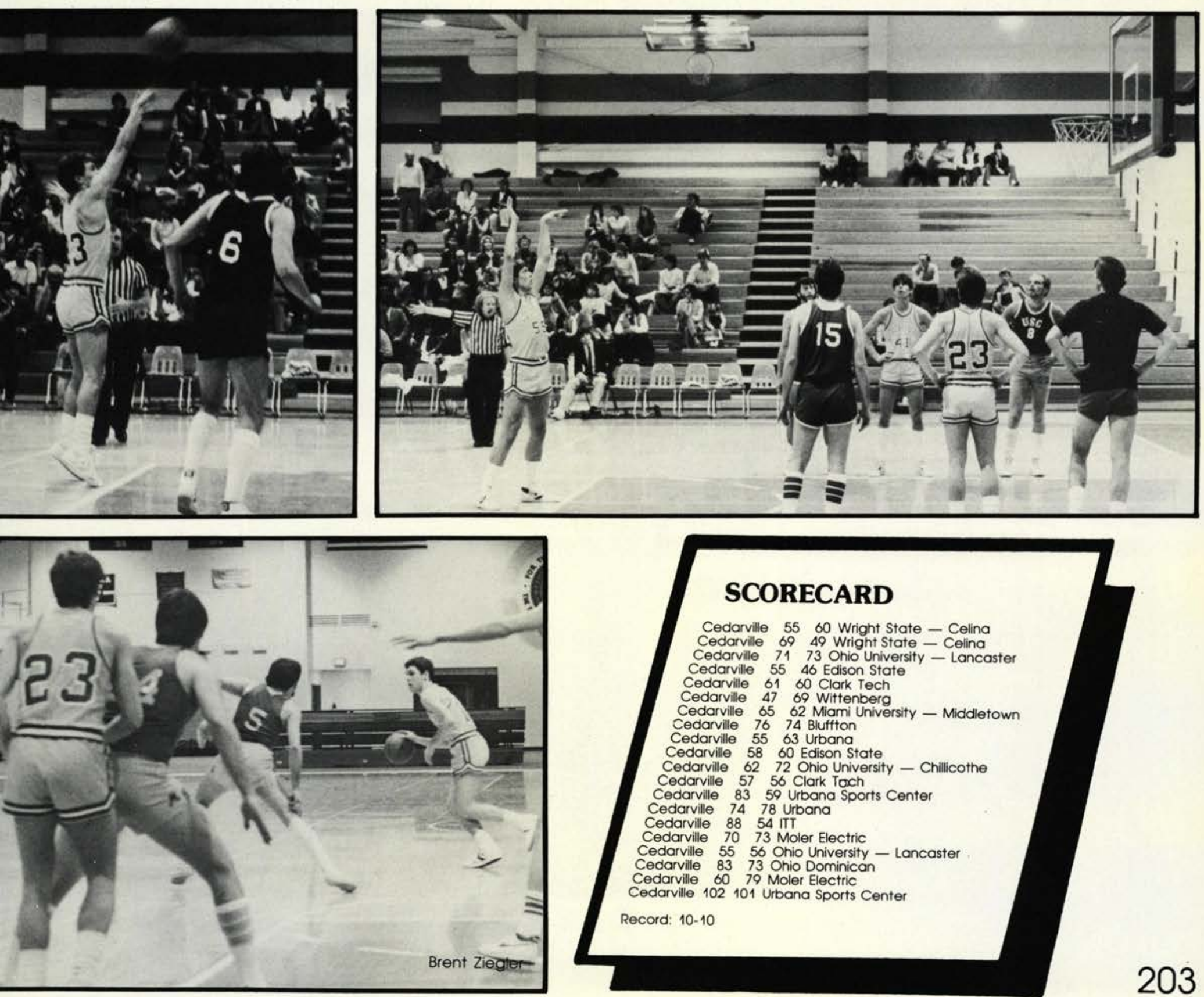

\section{SCORECARD}

Cedarville 5560 Wright State - Celina Cedarville 6949 Wright State - Celina Cedarville 7173 Ohio University - Lancaster Cedarville 5546 Edison State

$\begin{array}{lll}\text { Cedarville } & 61 & 60 \text { Clark Tech } \\ \text { Cedarville } & 47 & 69 \\ \text { Wittenberg }\end{array}$

Cedarville 6562 Miami University

Cedarville 7674 Bluffton

Cedarville 5563 Urbana

Cedarville 6272 Ohio University - Chillicothe

Cedarville 5756 Clark Toch

Cedarville 8359 Urbana Sports Center

Cedarville 7478 Urbana

Cedarville $88 \quad 54$ ITT

Cedarville 7073 Moler Electric

Cedarville 5556 Ohio University - Lancaster

Cedarville 8373 Ohio Dominican

Cedarville 6079 Moler Electric

Cedarville 102101 Urbana Sports Center

Record: $10-10$ 



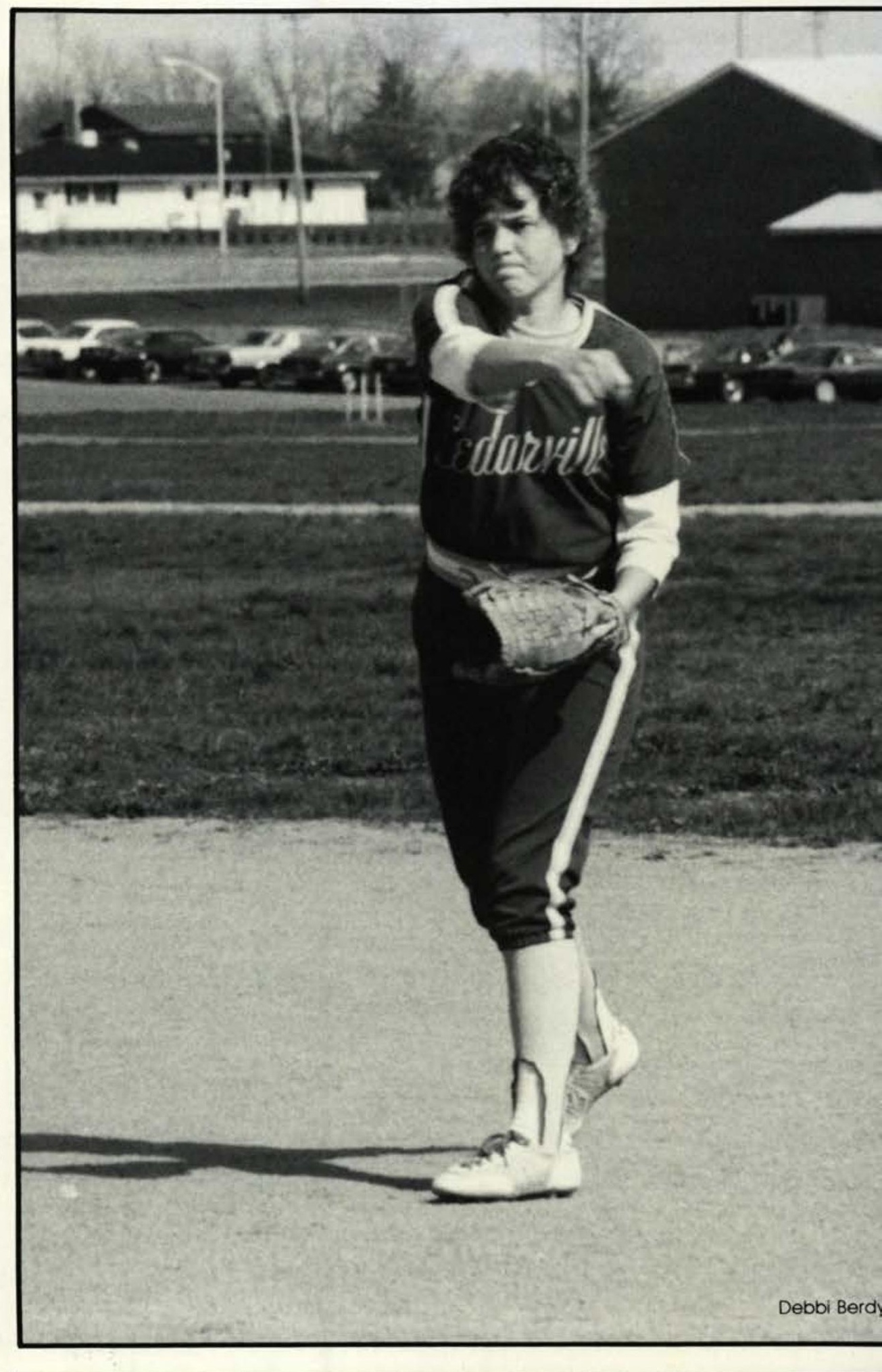

A s March, 1984 weather came roarA ling in, the softball season arrived and fourteen girls came together to form the final slow pitch team for $\mathrm{Ce}$ darville. This was the first miracle as God took a variety of different personalities to form a unit. Inspite of the

"... the Lady Jackets were able to come through the sea. son with the best softball re. cord ever at Cedarville with a 25.11 record.

Lord's working in nature, with the rescheduling and postponing of severa games plus a tournament, patience was taught and servanthood practiced as seven games were won by one point and eight games were lost by one point. However, miracles did not cease there: the Lady Jackets were able to come through the season with the best softball record ever at Cedarville with a 25-11 record. With only three starters missing for next years team, the 1985 team should be able to better their record as they encounter a new, difficult, and challenging season of fast-pitch play.

by Laurie Benedict.

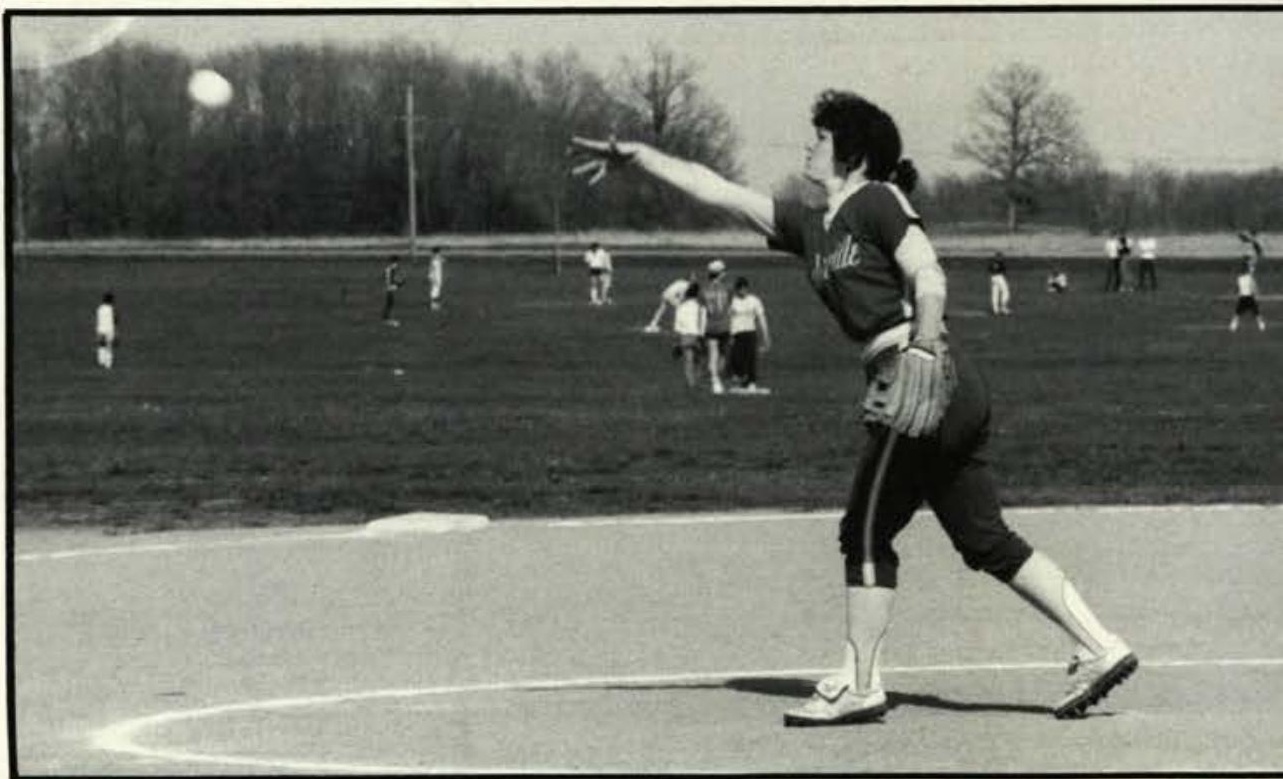




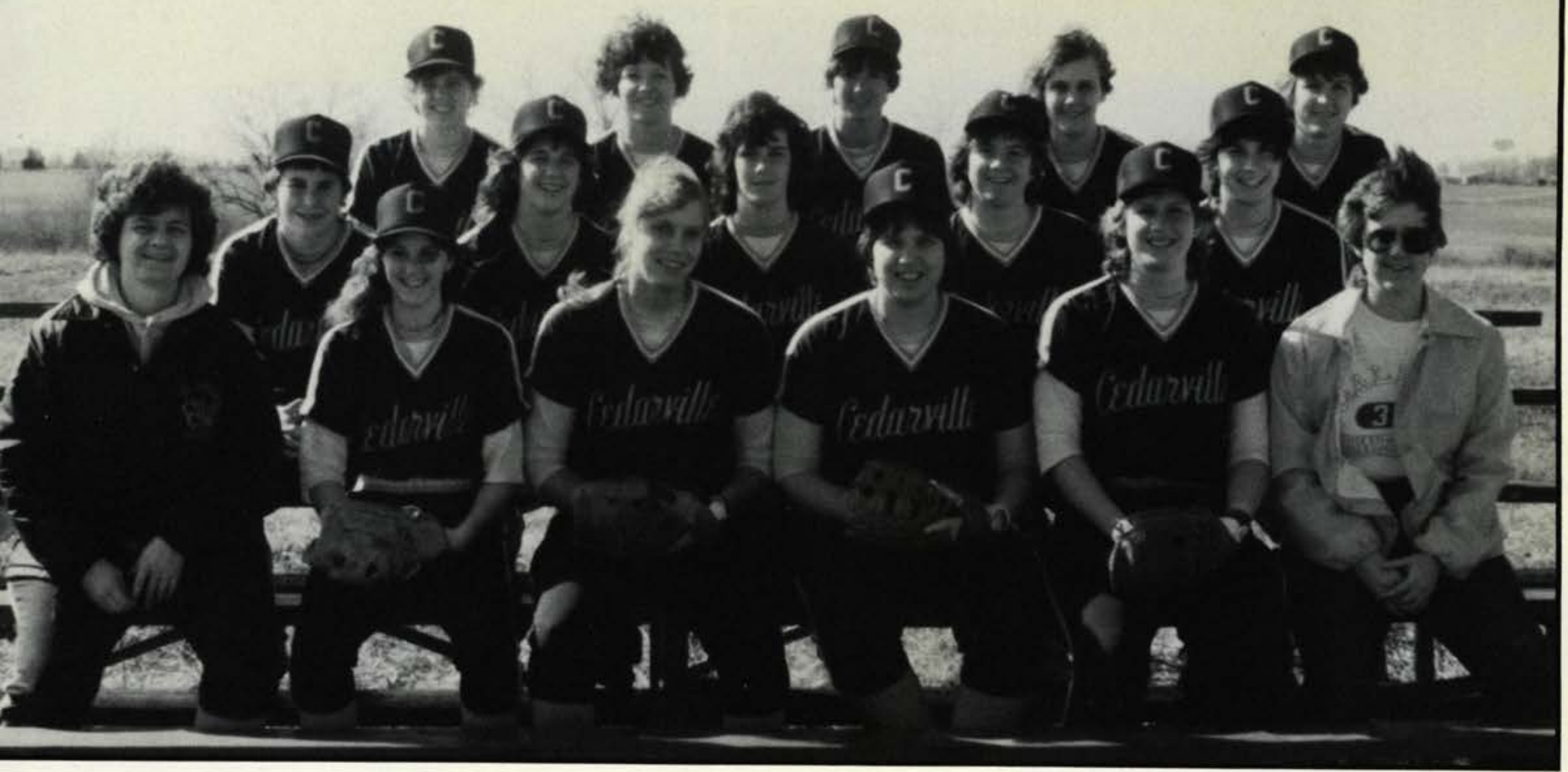

First Row: Coach Elaine Brown, Vicki Stuiber, Renee Gaston, Laurie Benedict, Gayle Taylor, Kelly Helmick: Second Row: Sue Baldis, Sherri Tice, Corrine Wilcox, Angela Cremeans, Karen Hobar: Third Row: Debbi Berdy, Jewel Schroder, Lisa Campbell, Karen Clark. Angie Wilcox
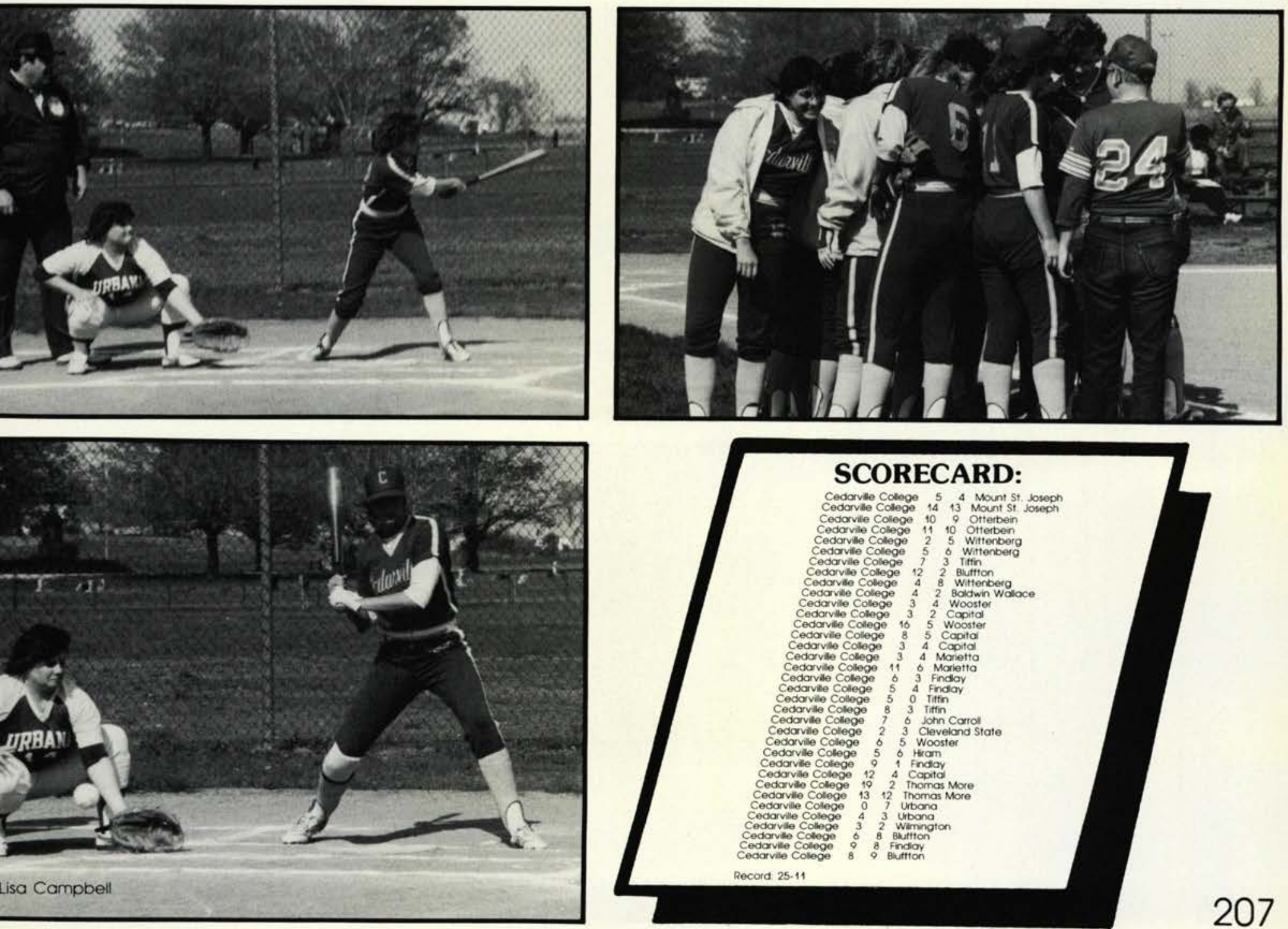


\section{Building Friends With Competitors}

Tnder the leadership of Coach John McGillivary our women's track program began its third season since its existence in 1982. Assisting Coach McGillivary were co-captains Beth Britton and Karen Harrington.

From the outset of the first meeting, our team goals were established. Our first goal as a team was to win the MidOhio Conference, which we did by defeating the defending champions, Defiance College 192 to 180 . The second goal was to finish in the top 4 at the NCCAA National Track and Field meet at Marion, Indiana, which was accom-

"... we also wanted to build friendships with those kids we compete against both now and in the future."

plished by placing third.

After hearing Dr. Dixon's series on friendship, we also set a goal to establish closer friendships with our fellow teammates. Taking this one step further, we also wanted to build friendships with those kids we compete against both now and in the future. Friends truly are of the Lord, and this season is a building block for those future track and field athletes.

by Karen Harrington
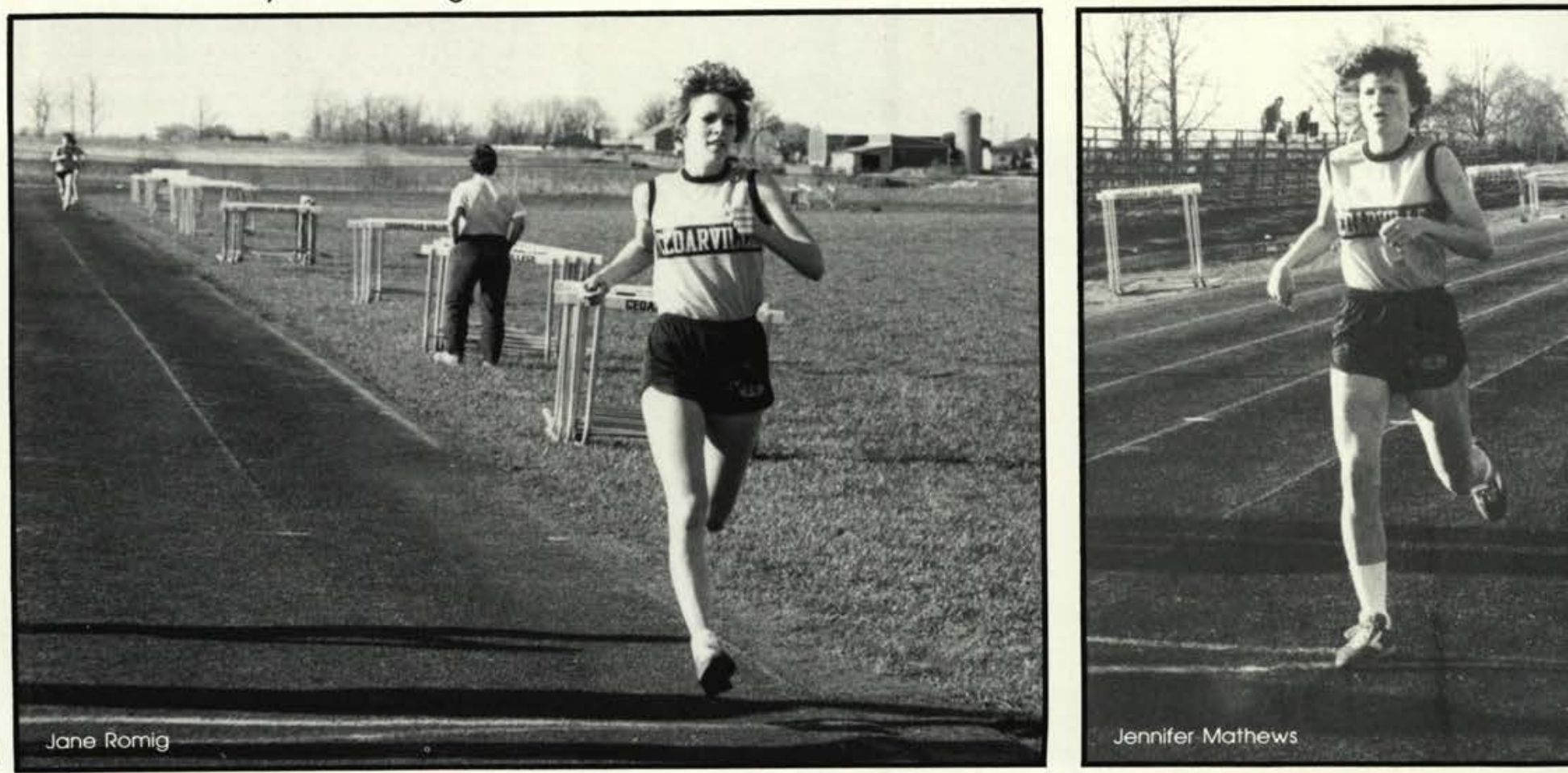


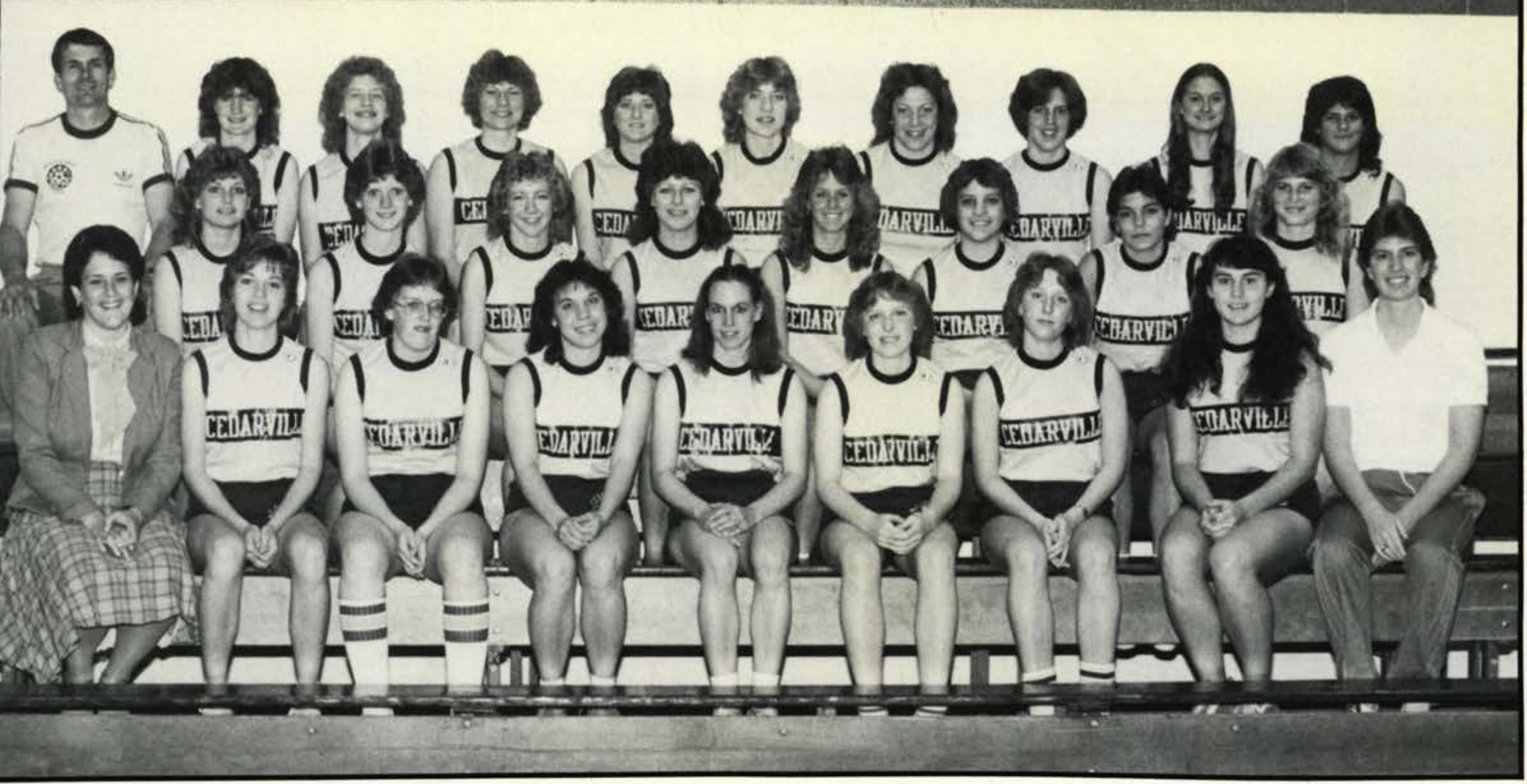

First Row: Becky Payton, Jane Romig, Sarah Barr, Debby Bell, Lynette Wiseman, Anna Haskowich, Fran Haskowich, Rose Ann Repke, Barb Taylor; Second Row: Sandy O'Boyle, Becky Averill, Joy Wagner, Karen Meadows, Wendy Grady, Mindy Ackley, Ruth Gorman, Debbie Pate; Third Row: Coach McGillivary, Jenny Mathews, Kris Hyatt, Karen Harrington, Sally Cochran, Marla Fuller, Beth Britton, Cheryl Rendle, Beth McGillivary, Sherri Norrick.
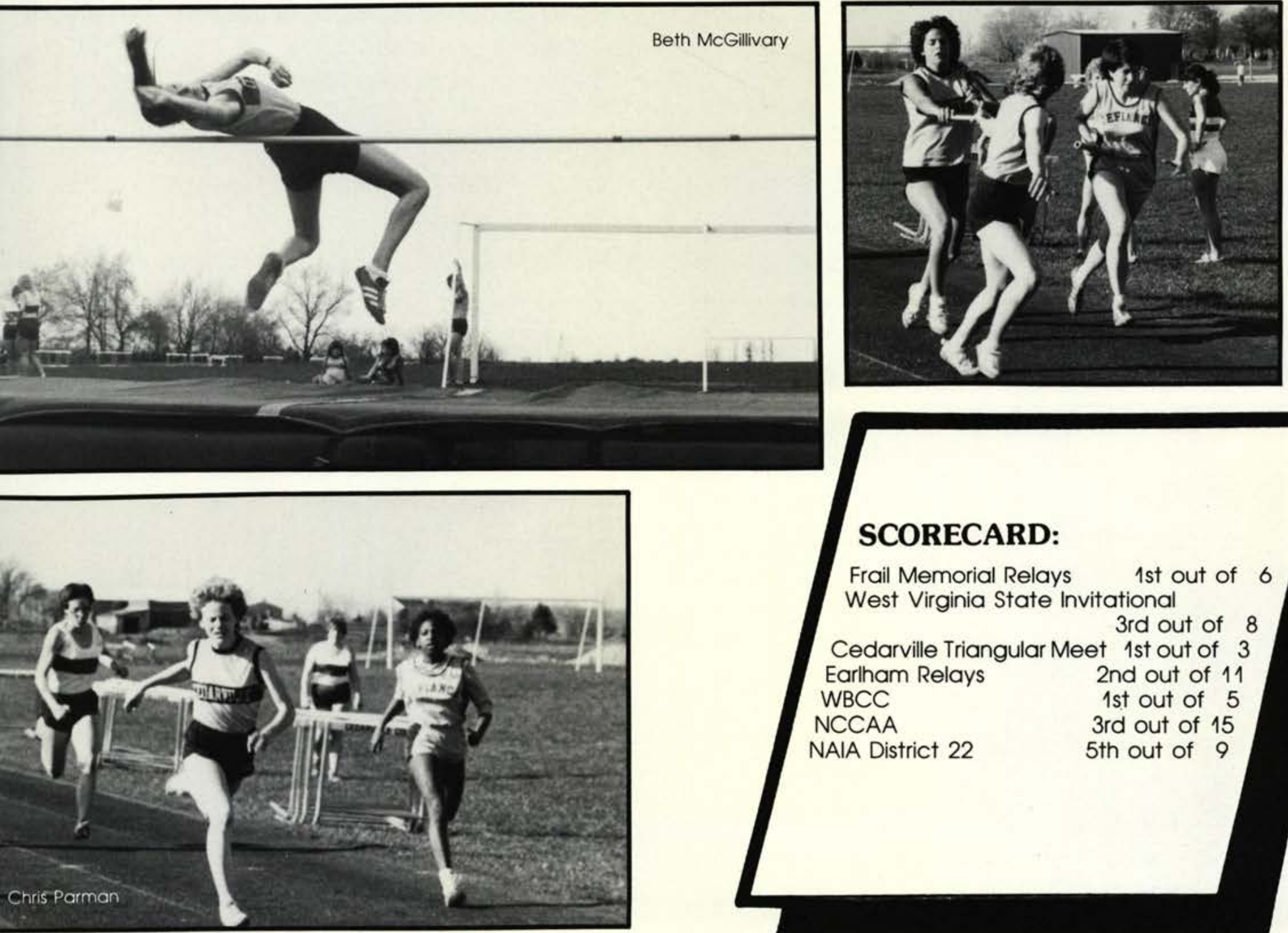

SCORECARD:

Frail Memorial Relays

West Virginia State Invitational

3rd out of 8

Cedarville Triangular Meet 1 st out of 3

Earlham Relays

WBCC

NCCAA

NAIA District 22

1st out of 5

3rd out of 15

5 th out of 9 


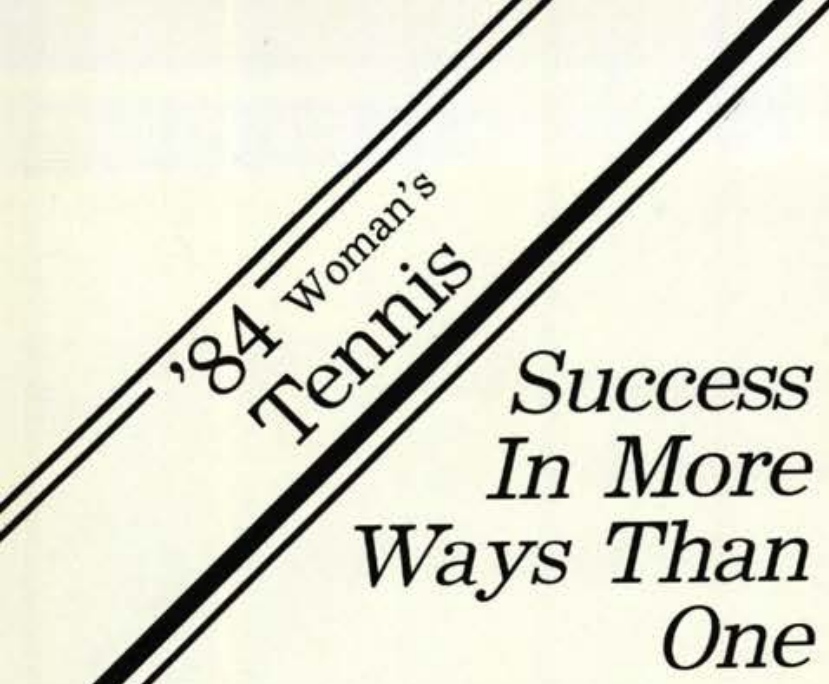

The women's team completed anI other successful season under the direction of Dr. Pamela Diehl. In dual matches they finished with a record of $6-3$. They ended the season by finishing first in the district 22 tournament and representing the district at nationals in Kansas City. A goal for the team was to qualify for nationals and it was a total team effort which accomplished this. There were several accomplishments by being named to the All Conference Team and All District Team.

The Lord worked so much in the lives

"... finishing first in the district 22 tournament and represent. ing the district af nationals in Kansas City."

of the team members and taught them so much through the experiences of winning and losing throughout the season. One of those experiences was when they were expected to win the conference tournament, and then lost it by 1 point to Bluffton. It is certain that this year's team will look at the season as a successful one, not only on the court but also off as well.

by Ann Berger
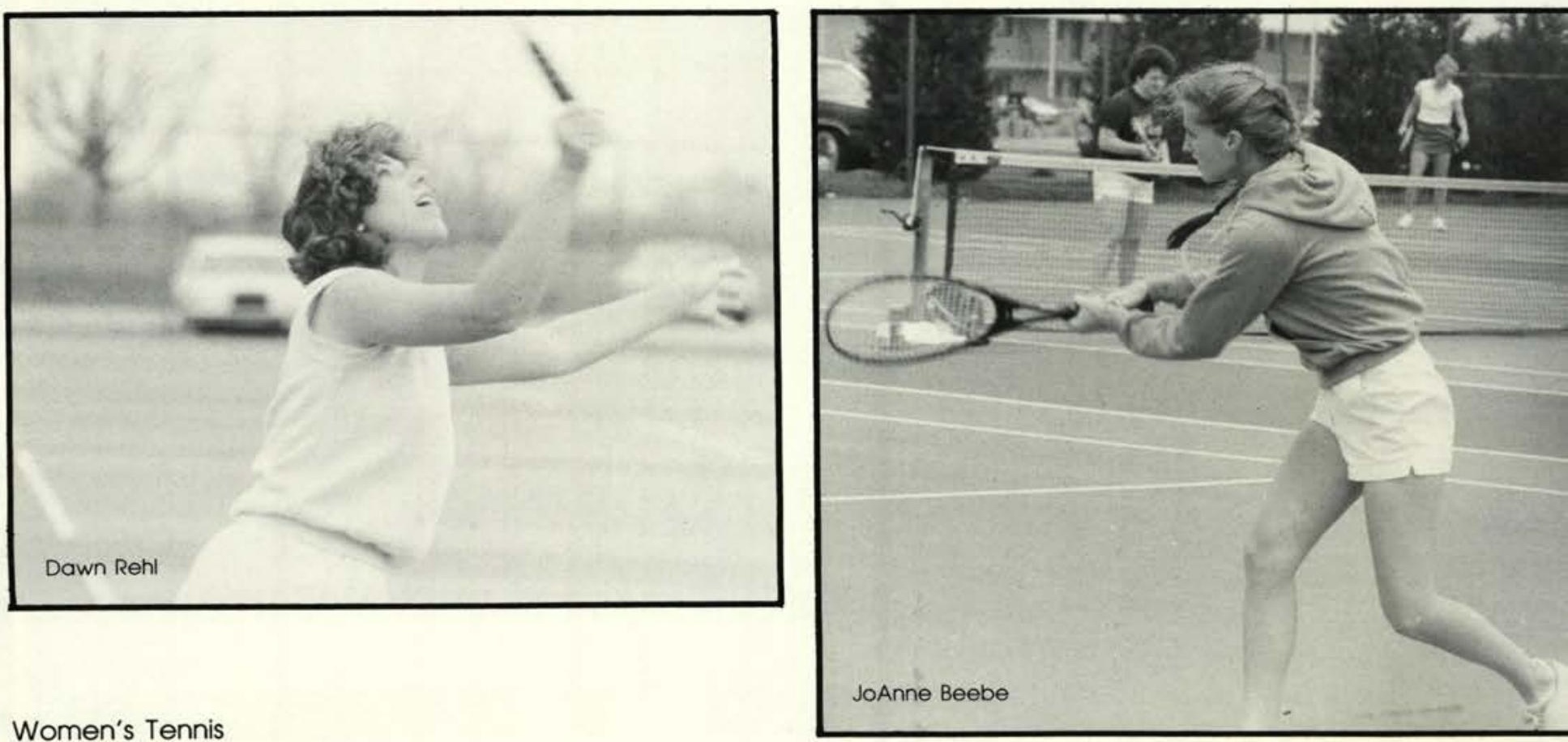


\section{Back To \\ Kansas City}

T has been very exciting for me to 1 devote much of my time and energy with the Cedarville men's tennis team. Our team has worked very hard regaining strength after losing four seniors from last year's team. Through great coaching, hard work, and God's enablement, we have been very suc-

"... We have been very suc. cessful capturing the Mid Ohio Conference title and the Dis. trict 22 title."

cessful capturing the Mid Ohio Conference title and the District 22 title. In capturing the district title, we will not only represent district 22, but also Jesus Christ at The NAIA National Tennis Championships in Kansas City.

by Shawn C. Huck
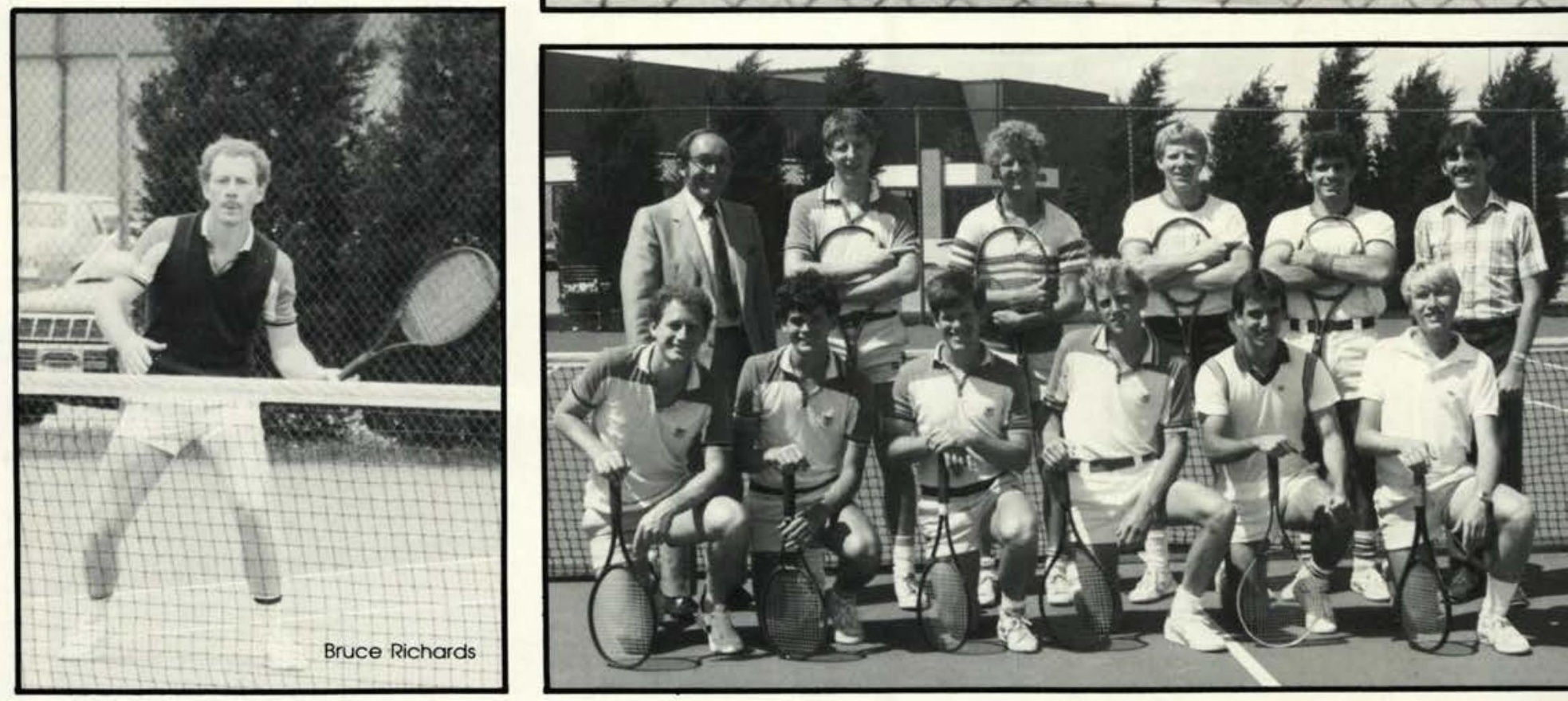

First Row: Bruce Richards. Thurman Payton, Steve Caswell, Frank Terkelsen, Mike Basler, Jim Murdoch: Second Row: Coach Murray Murdoch, Jeff Reynolds, Ray Johnson, Shawn Huck, Gary Corio, Rick Meeks. 


\section{Golfers Attain Goals}

G olf season 1984 transpired into 3 another successful year with a record of 12 wins and 3 losses. Personal goals were achieved by each team memer, and the overall attitude of the

\section{"The success of the team can be recognized by the output of the golfers themselves ..."}

\section{season was victory.}

The team was credited with being Co-Champions of the Mid-Ohio Conference with Malone and furthered their success with the NAIA District 22 championship. The success of the team can be recognized by the output of the golfers themselves, but mainly through the miraculous way that the Lord worked through the golfers as a team.

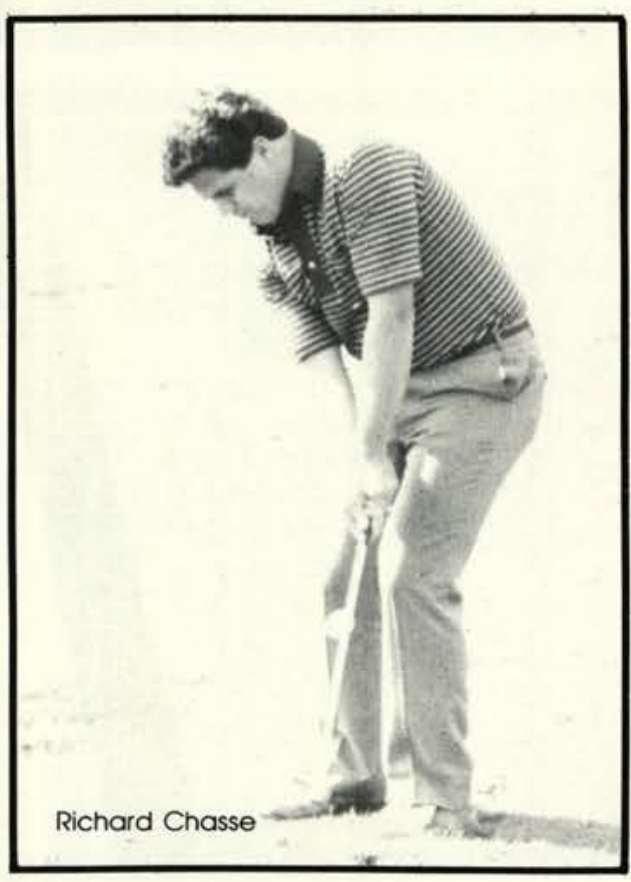

John Greenwood

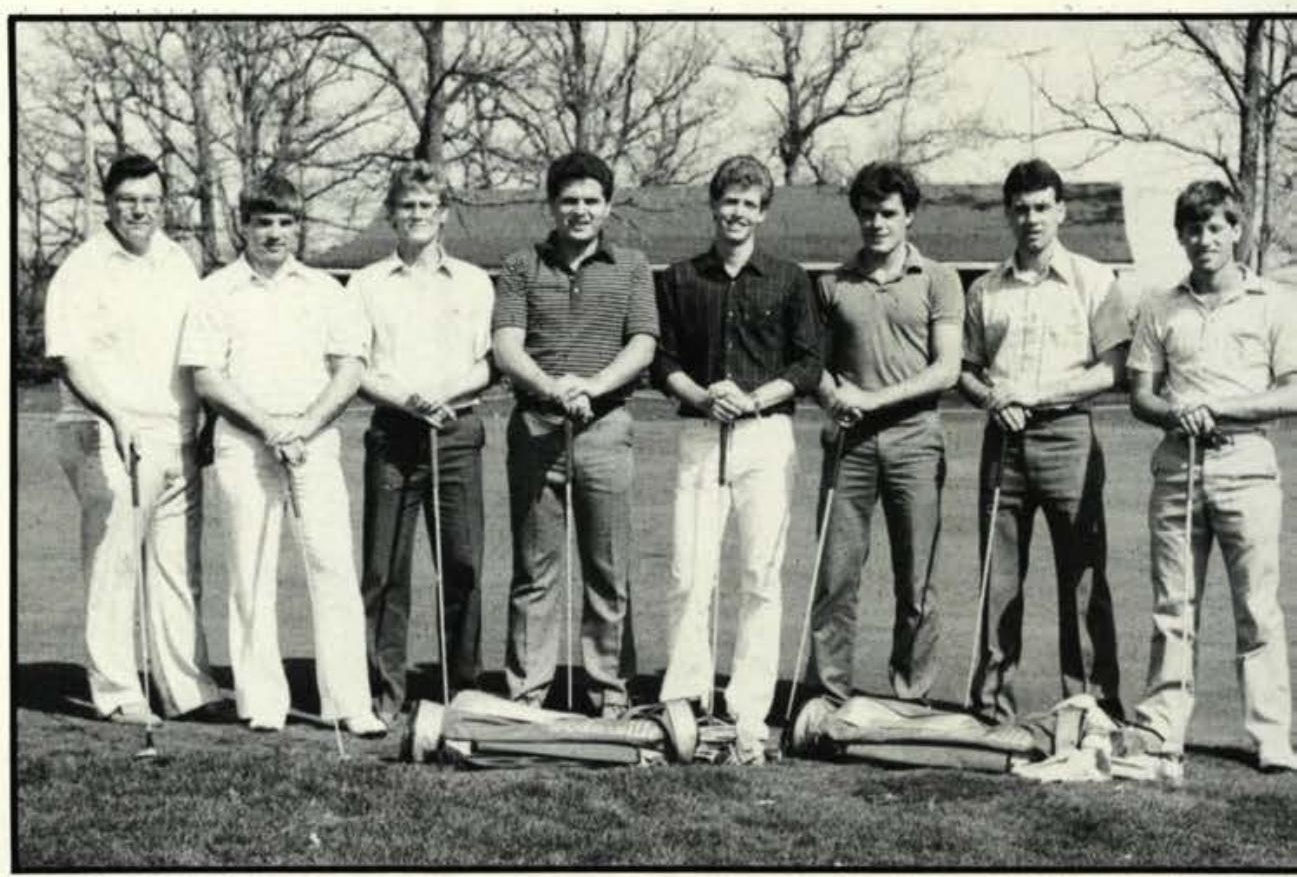

Coach Dr. Allen Monroe, Bob Fires, John Greenwood, Richard Chasse, Tom Ewing, Dave Kalin, Tom Greve, Mike Reed. 

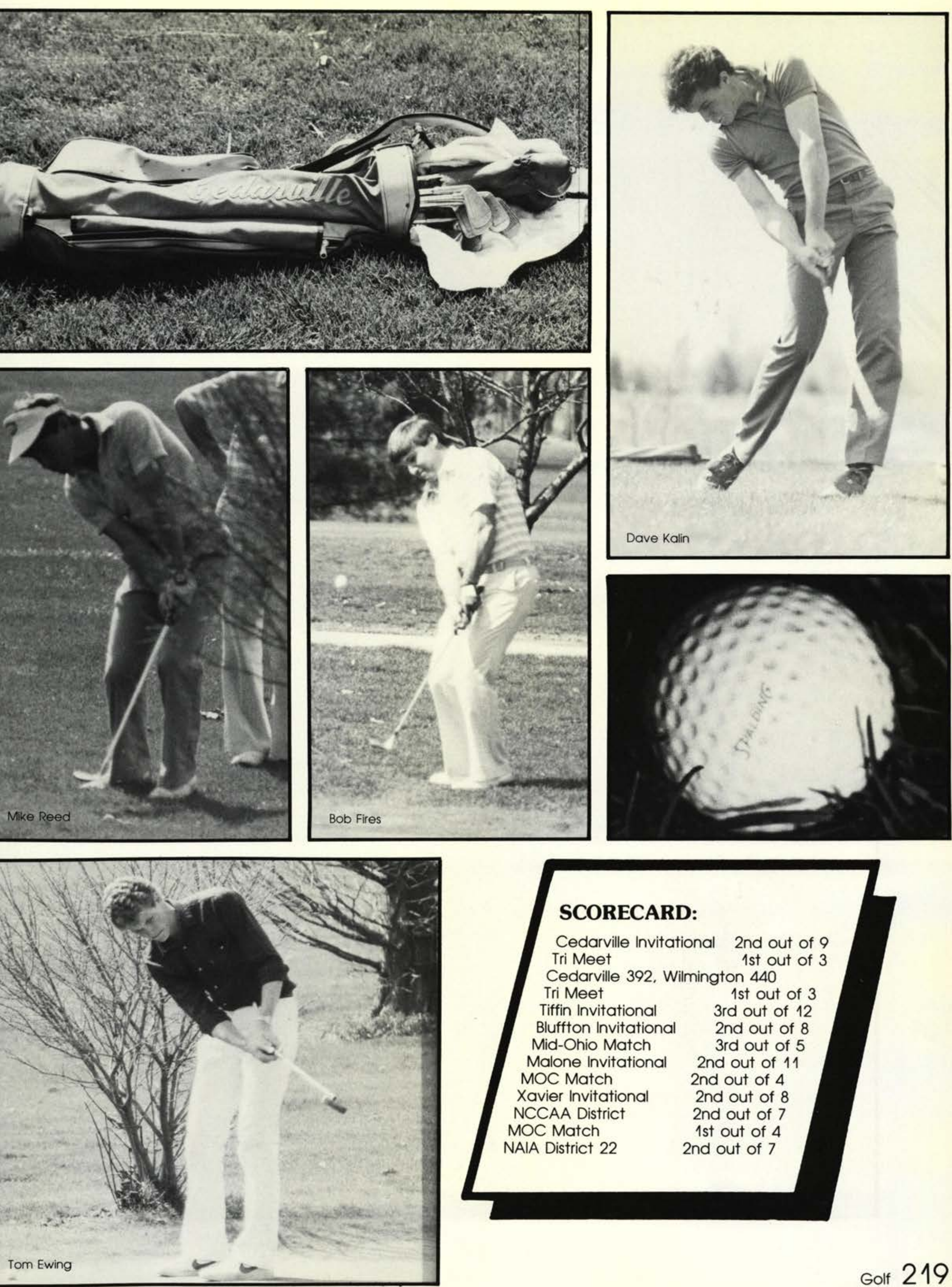


\section{The Year In Review}

T. he 1984 sports season at Cedarville College would have to be labeled as another banner year for the Yellow Jacet teams and individuals alike. There were several conference and district championships as well as some athletes that earned All-American status.

In the fall, both the men's and women's cross country teams placed second in the NCCAA Nationals at John Bryan State Park. Freshman Rob Moore and sophomores Jane Romig and Sue Vaughan were NCCAA All-Americas. The men's team qualified for the NAIA Nationals for the first time ever.

The Yellow Jacket soccer squad posted a 10-6-2 record as co-champions of the Mid-Ohio Conference. Senior goalkeeper became Cedarville's second player to be named to the

"There were several confer. nece and district champion. ships as well as some athletes that earned All.American sta. tus."

NAIS Academic All-American soccer team. The women's volleyball team was 16-22 and participated in the NCCAA District III tournament.

The winter season saw the men's basketball team have a winning season for the seventh year in a row with a 16-13 mark. The Yellow Jackets were the NCCAA District III runner-up and an NAIA District 22 qualifier. Senior all-district performer Tim Danube became the 18th C.C. player to reach 1,000 career points.

The women's roundball squad had a 10-12 slate and won the Cedarville Invitational. Sophomore Lisa Campbell was all-conference, all-district, and an NAIA honorable mention All-American with a school record season field goal percentage of 60.2 . Wrestlers Ron Comfort and Perry DeFelice both placed fifth in their weight classes in

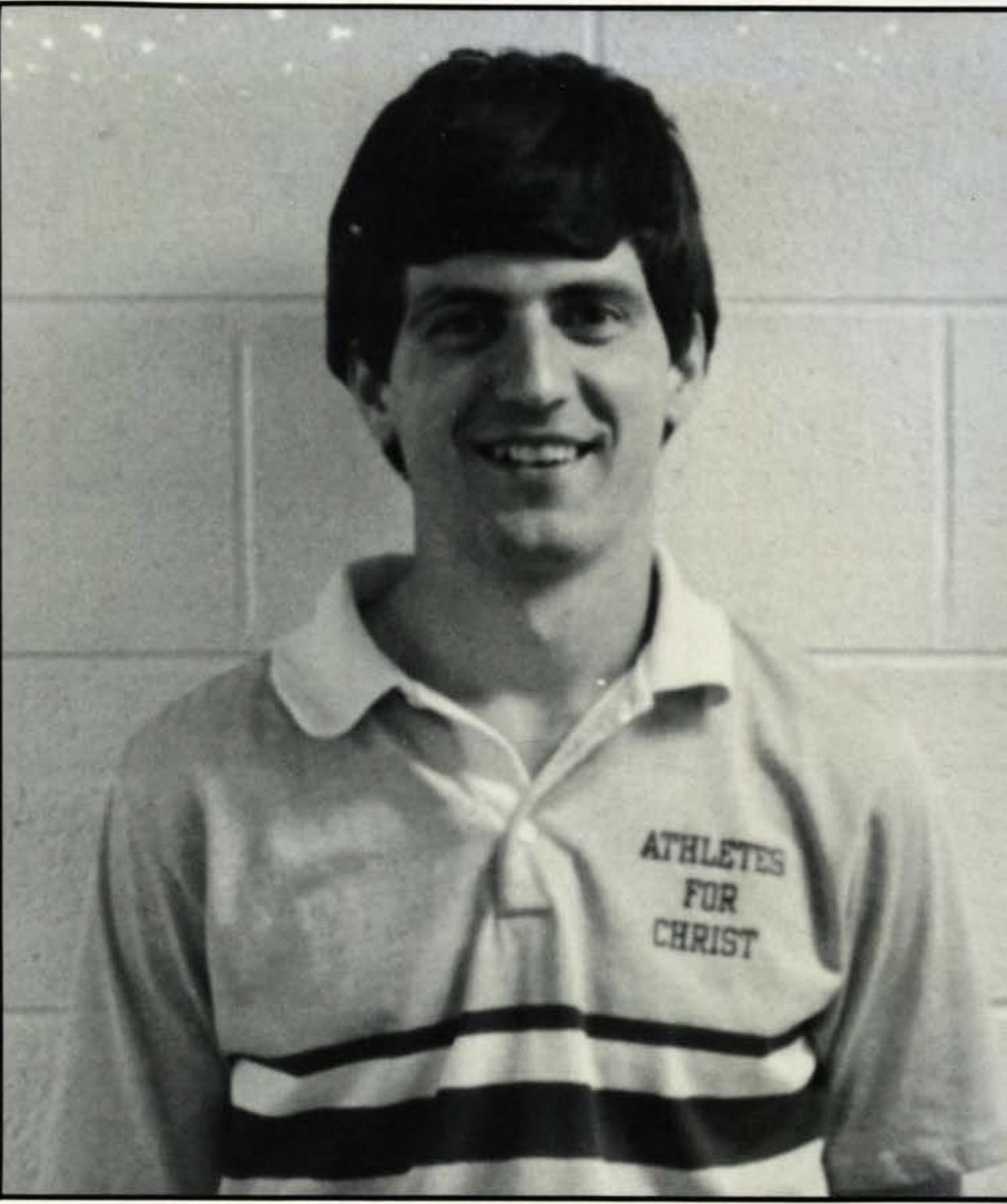

the NCCAA Nationals.

The spring campaign was highlighted by the men's track team winning the NCCAA national championship for the fourth time. Junior Gary Anderson won the Wheeler Award for being the outstanding Christian track and field "Athlete of the Year." Tom Hill, Rob Moore, Clarence Eddy, and Clancy

\section{"The men's tennis team won the MOC and the NAIA District 22 tournaments for the 13th year in a row."}

Cruise won All-American honors. Elvin King was named "Coach of the Year" in the NCCAA. The 1984 track squad was only beaten by one school during the entire year.

The women tracksters won the WBVV and finished third in the NCCAA. Jane Romig was the only Lady Jacket
All-American,

The men's tennis team won the MOC and NAIA District 22 Tournaments for the 13th year in a row. The women's squad won the district tournament for the first time ever.

In the final year of slow-pitch softball, Cedarville went 25-11 as there will be a change to fast-pitch next spring. The golf team had a 12-3 record as $\mathrm{MOC}$ co-champions, and the baseball team hit a school record 21 home runs during a 10-23 season.

Seniors Ann Berger and Steve Sagraves were named the female and male "Athletes of the Year" by the Yellow Jacket Club. Berger had a 13-1 singles record for the women's tennis team and won the conference and district titles. Sagraves batted .390 for the baseball team and set a new school mark in homers with 11. He was an all-conference and all-district firstbaseman.

by Mark Womack 


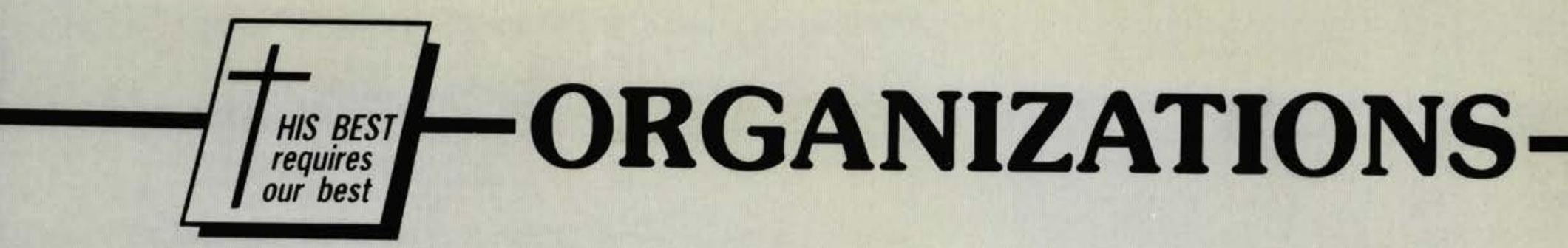

\section{EXPANDING HORIZONS}

nvolvement" is a key to a reI warding college experience. and Cedarville College offers dozens of opportunities to expand the horizons and broaden the interests of its students. Troups and clubs of all shapes, and sizes, and colors vie for a student's attention. Many seek out the men's and women's service organizations, while others find a niche in student government or in the group organized by students in their major. Whatever the interest or ability, there is something for everyone to do.

by Bill Thomas

\section{Layout By:}

- Tracy Holtzmann

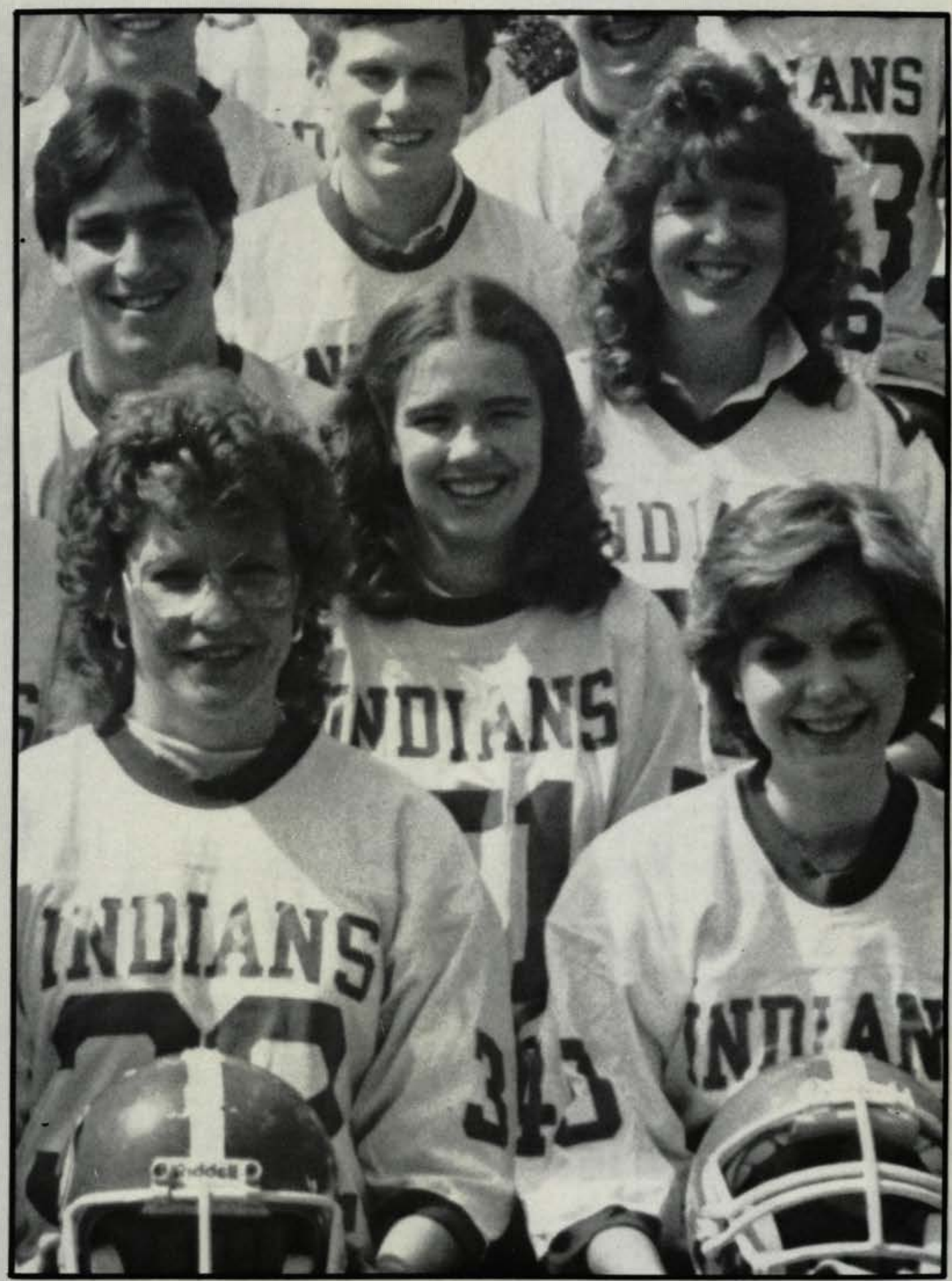




\section{Campus Organizations}

Academic Advisory Board

Def. Ardent academic enthusi-

asts who supply suggestions (and a probing analysis) to the administration. They also select the staff and faculty members of the year.

Sara Beattie. Colin Lord, Don Wagner. Pau Hayes (Chrmn). Mark Price, Bill Jaquis: Irene Farley, Jeff Bolyard. On couch: Dean Johnson:

Advisory Seven

Det. The "deacons" of the college fellowship who co-ordinate the Sunday and Wednesday services and function to serve the spiritual needs of the college campus.

First row: Brod Rickard. Chris Tupps. Keith Holt, Second row: Bob Beikert. Dave Blackstone, Tom Carr, Kirk Farhurst.
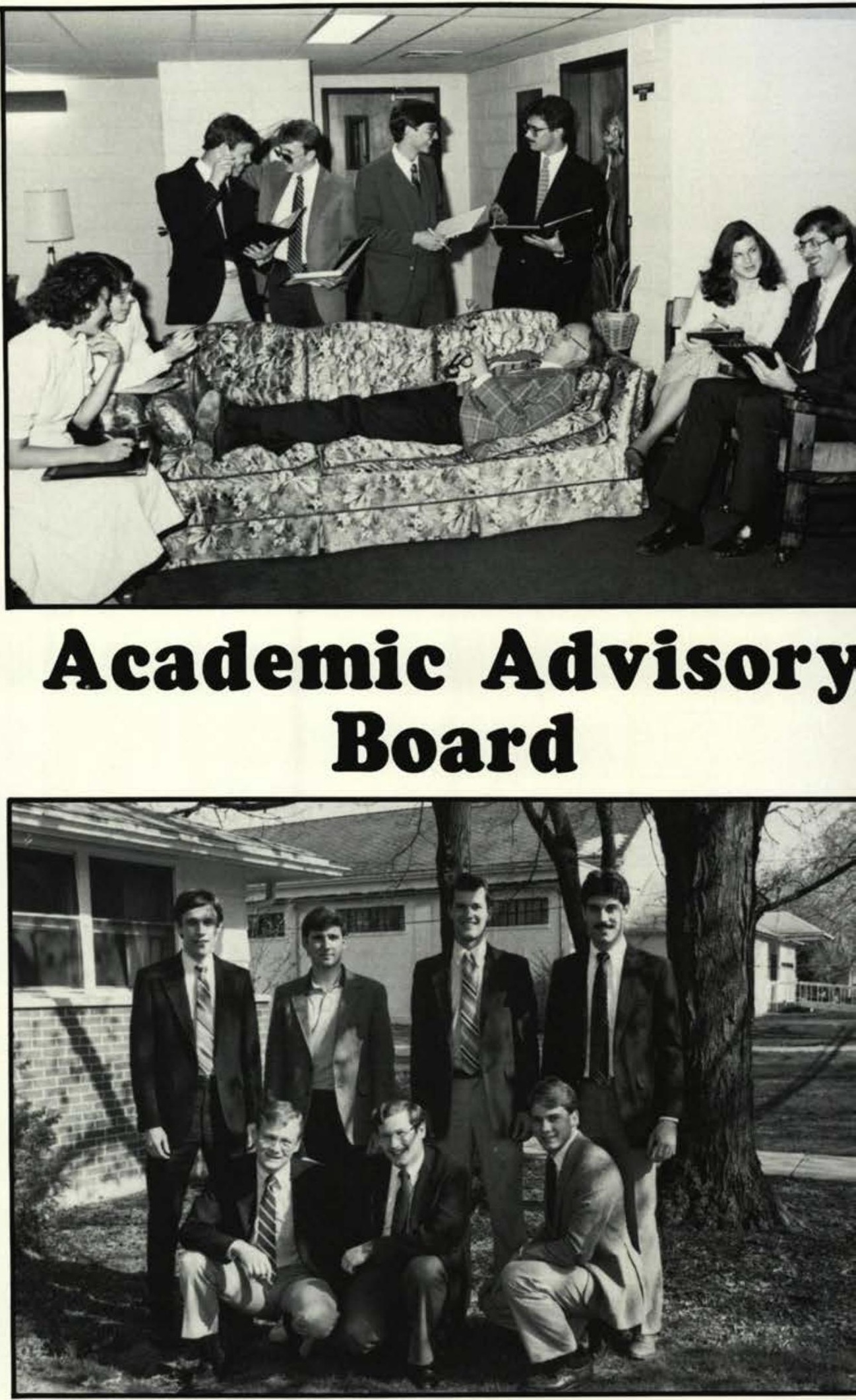

\section{Advisory Seven}


Alpha Mu Chi (Alfə Mōo Ki)

Def. A fellowship for those fortunate few engaged women.

First row: Leda Tenney, Dawn Foster (Pres:) Second row Carol MCDaniels. Kelly Slaughter. Mrs. Printy (Advisor)

Cedars Editorial

Det. The gubernatorial members of the college newspaper staff.

Seated: Jane Owen (Editor), Standing: Shelle Beaman (Copy Editor), Deborah Horner (Advisor), Jay Highman (Bus Mgr.), Jill Parks (Assigning Editor), Karen Troyer (Layout). Not pletured: Birgit Kass (Office Mgr.)

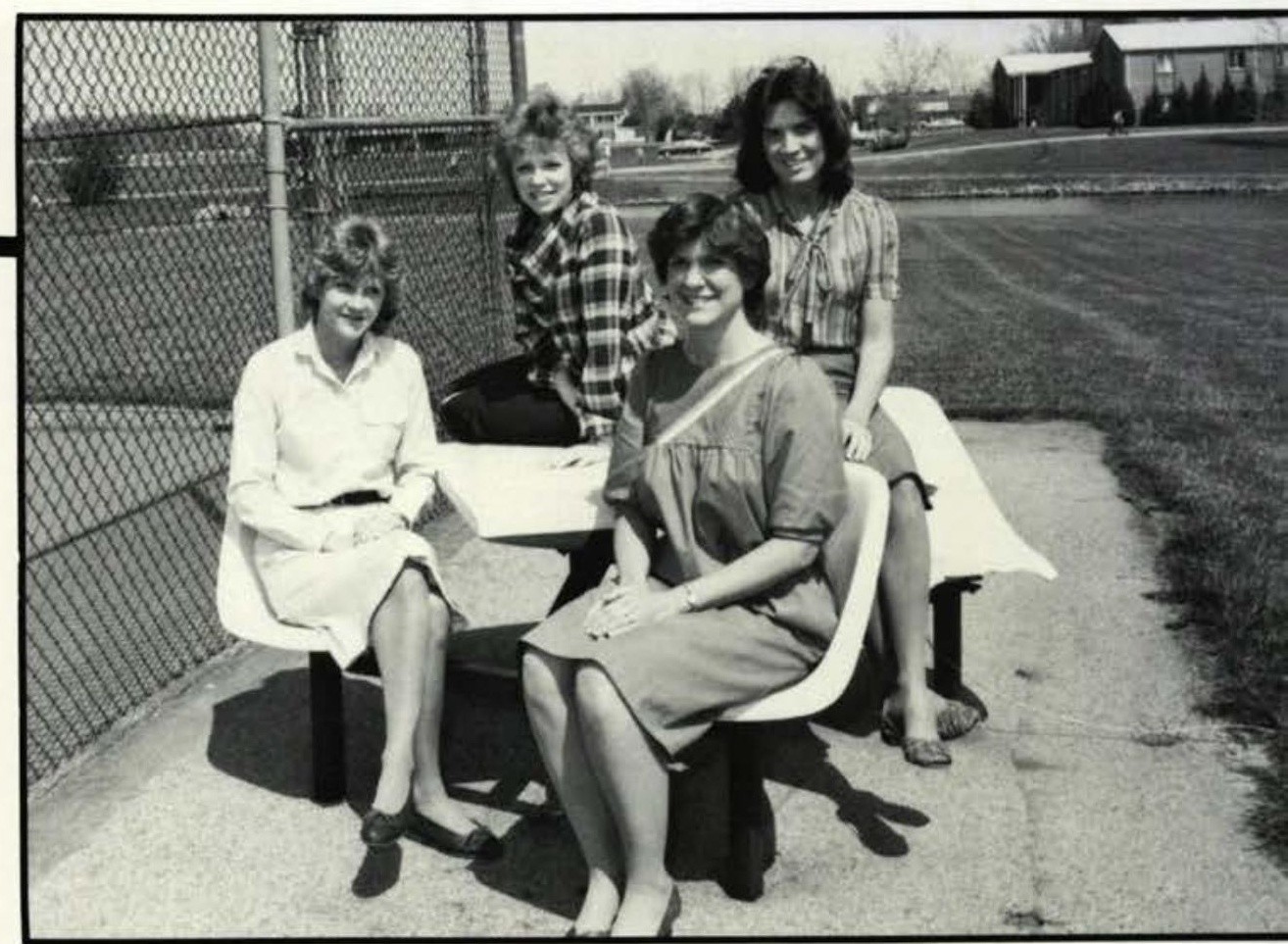

\section{Alpha Mu Chi}

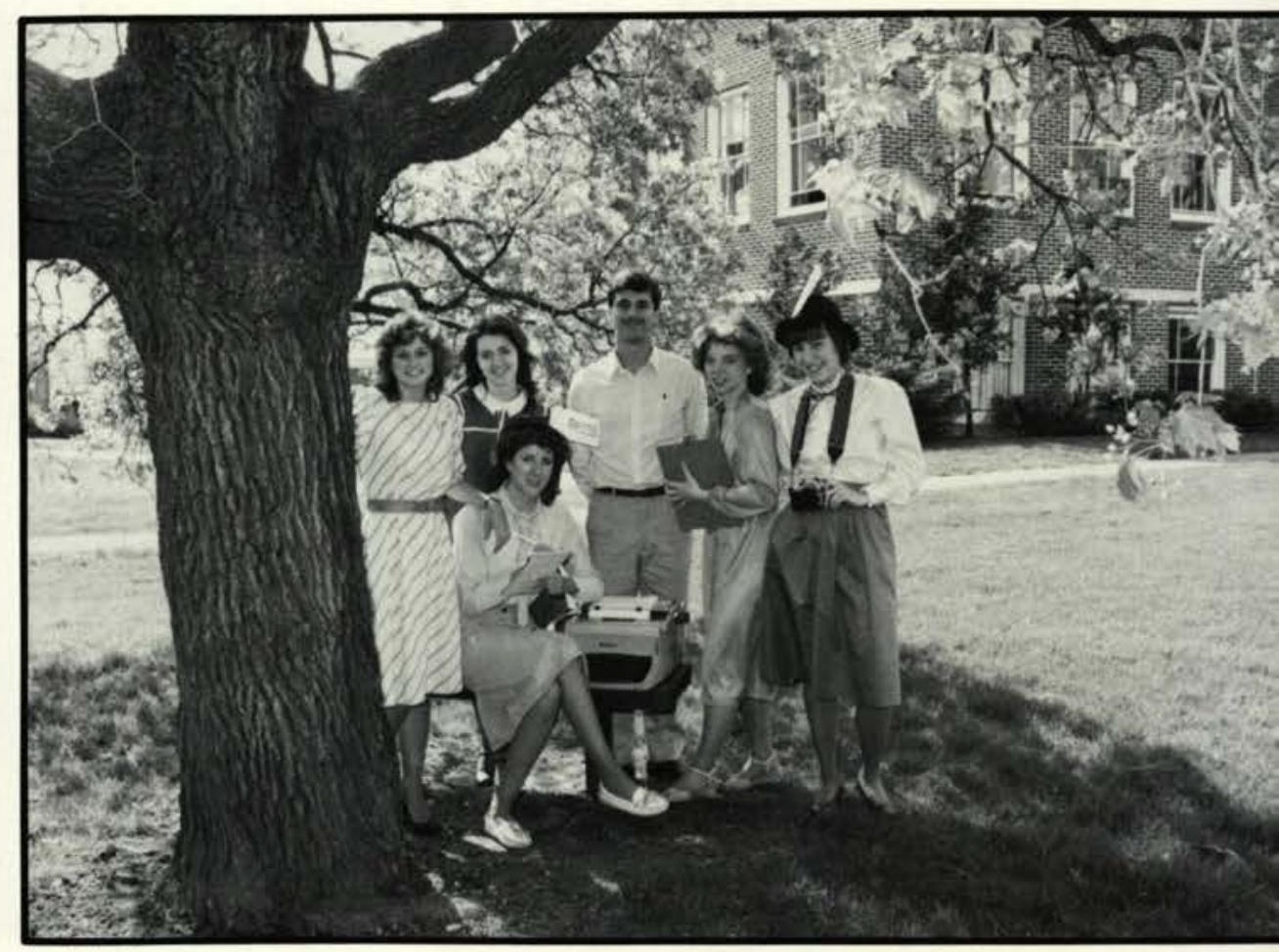

Cedars Editorial 


\section{Campus Organizations}

\section{Cedarville Elementary \\ Education Club}

First row: Lori Hess (Pres.). Ellen Spencer (Vice Pres.). Second row: Jodi Fisher. Kathy Clayton. Pamela Woods, Jenny Boer (Treas). Debbie Richardson (Rep.) Third row: Kelly Slaughter. Chris Dail. Karen Sunderman. Not Picfured: Cynthia Reed (Sec.).

Def. Cedarville Elementary Education Club. The Creative Research Society which meets to bombard one another with fresh ideas on teaching methods.
Cedarville College

Republicans

Kneeling: Jim Koerber, John Polson. Matt Biggs (Founder and Treas.). Scott Zimpfer (Pres.), Standing: Amy Jo Guest (Sec.), Kendall Herrick. Rachel Wilson (Senate Rep.). Marsha McNeish. Joel Hoskinson. Kathy Reynoids (Membership. co-ordinator). Tracy Roy, Carol Herriman, Robin Stockham. Susan Biake Sally Cochran, In free: Dave Edwards. Scott Moyer. Di Rex Rogers (Advisor) Dan Mulholland. Tim Davis, Byron Mullet. Stephen Harper

Def. Political activists of Cedarville who stimulate greater awareness of and involvement in political issues.

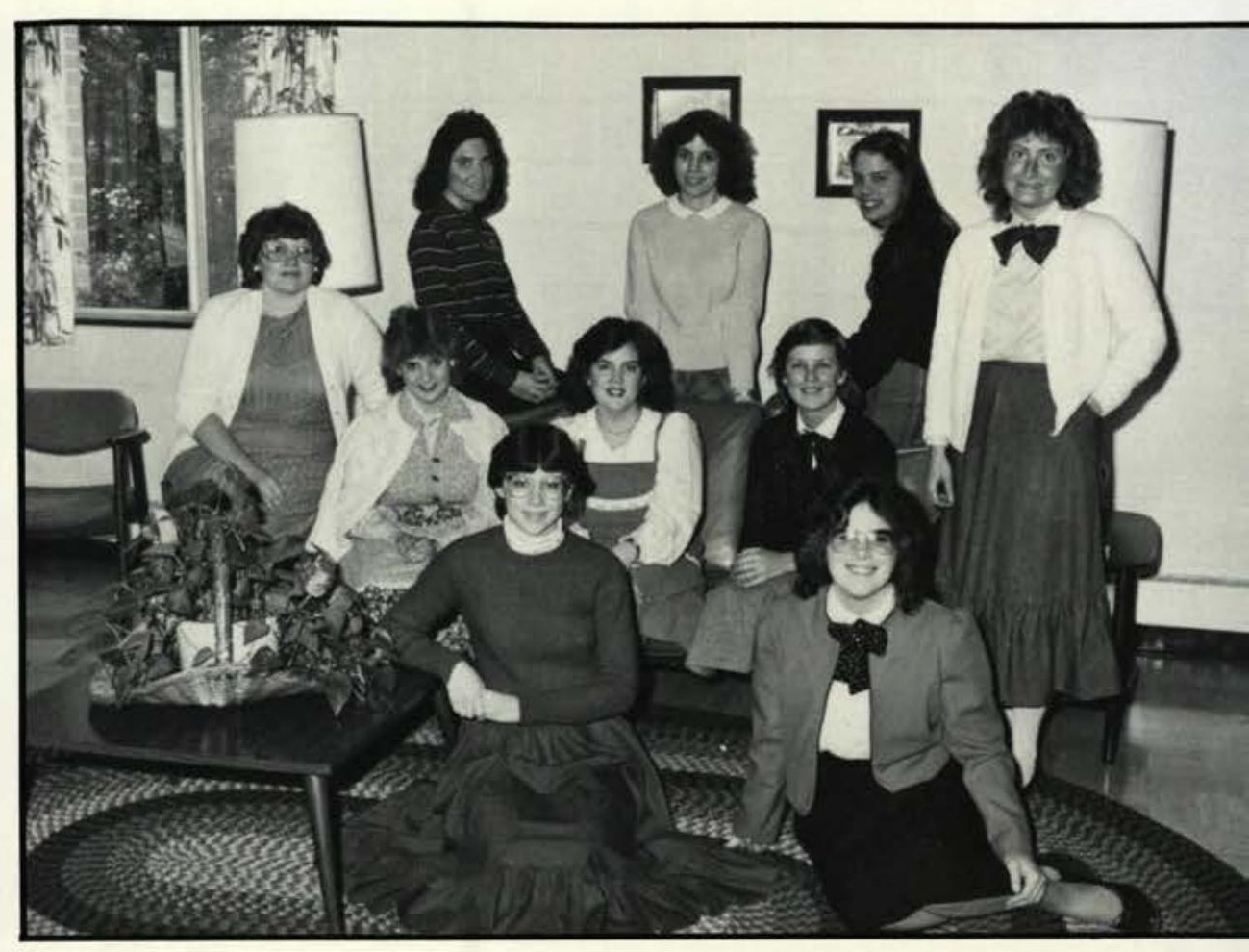

\section{C.E.E.C.}

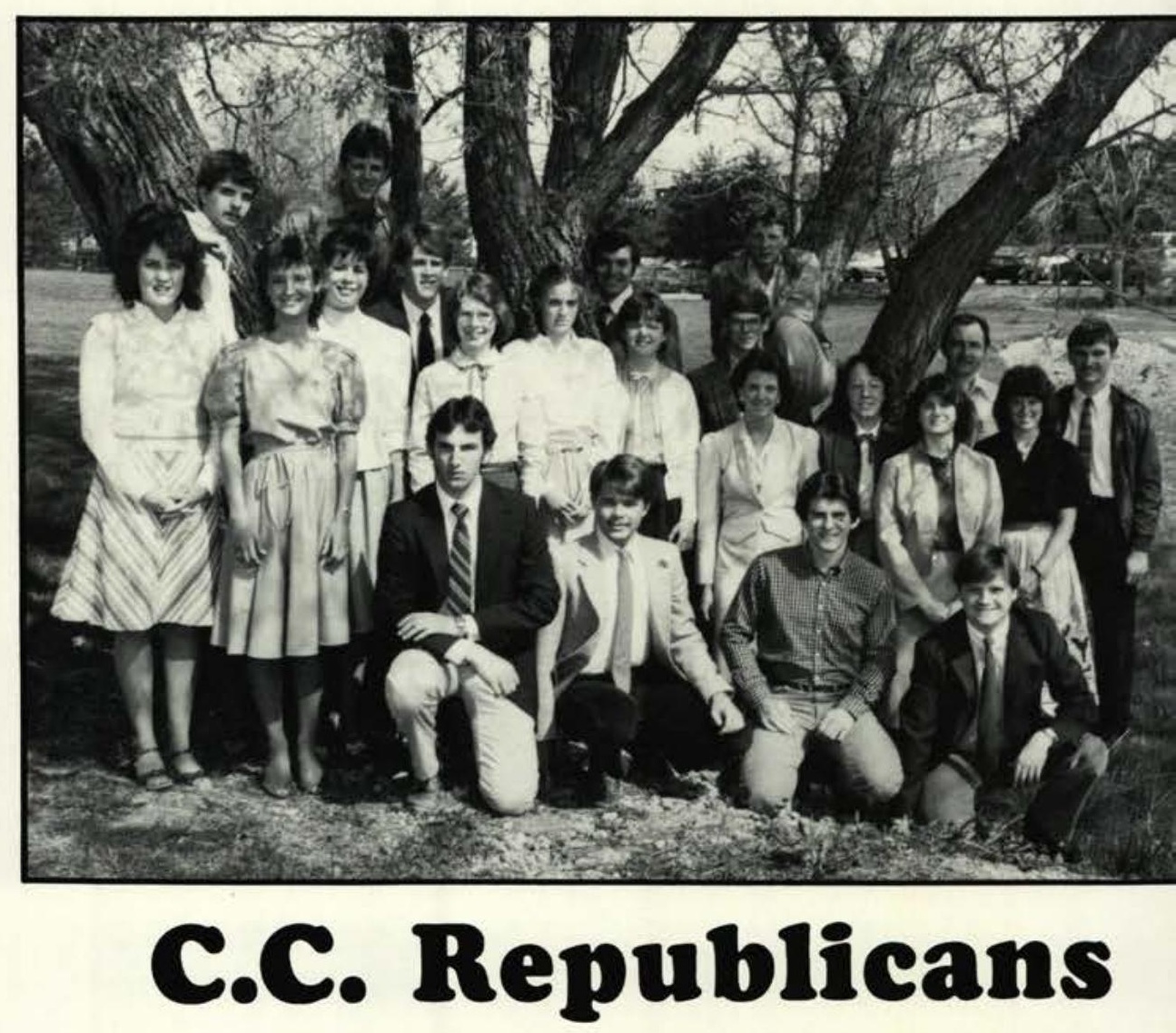




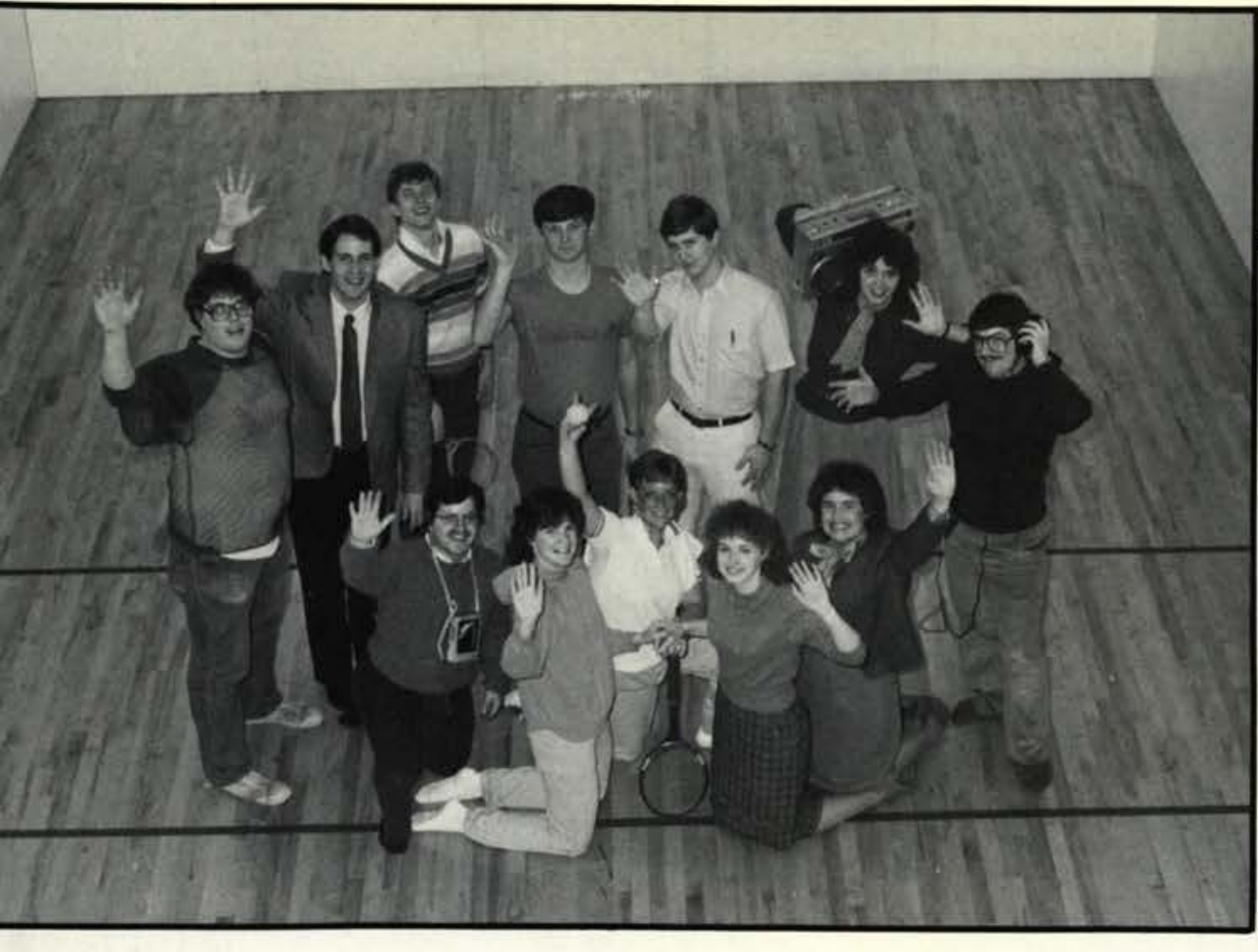

Communications Club

First row: Rick Horsfall, Jennifer

Matthews (Sec.). Judy Heppe, Jennifer

Robinson. Lyn Butcke (Treas.). Second

row: Mark Tinner, Jeff Lyle (Pres.). Chad

Bresson (Vice Pres.). Pete Wright. Todd

Rhoades, Melanie Coleman. Perry

Chiarelli.

Def. Peppy conclomerate of people whose expertise lies in semantic escapades.

\section{Communications Club}

\section{FWM}

First row seated on floor: Jacqueline King. Jennifer King, Second row seated:

Marcia Golike. Evan Parks. Joy Hart

(Vice Pres.). Third row seated: Sylvic Rinder Knecht, Rachel Cook. David

Ketcham. Sally Cochran, Standing: Alise Alexander, Bob Ward. Annegrat Grosse. Aaron Bowes (Pres.), Steve DeCook

Mark Duquette (Prayer letter sec.), Jane Baughman. Mr. and Mrs. Durham.

Def. Diligent students who meet weekly at 7:00 AM to pray for and discuss missions. 
Forensics

Def. Exercisers of mind and mouth. This speech team competes in areas of dramatic interpretation along with extemporaneous and persuasive speaking.

Mr. David Robey (Advisor). Jim Liebler. Gary Barker. Kathy Bachelder, Elena Michaels, Melissa Marshall. John Sidle.

Freshman Class Officers

Def. Officers of the youngest $\mathrm{Ce}$ darvillans.

First row: John Papp (Vice-Pres.), Kathi Harris (Senate rep.). Second row: Larry Harris (Senate rep.). Rusty King (Pres.). Third row: Mike and JoAnne Dicuirci (Advisors), Eric Shrum (Chaplain), John Adkins (Senate rep.). Ruth Gorman (Senate rep.). Isa Velasco (Sec.)
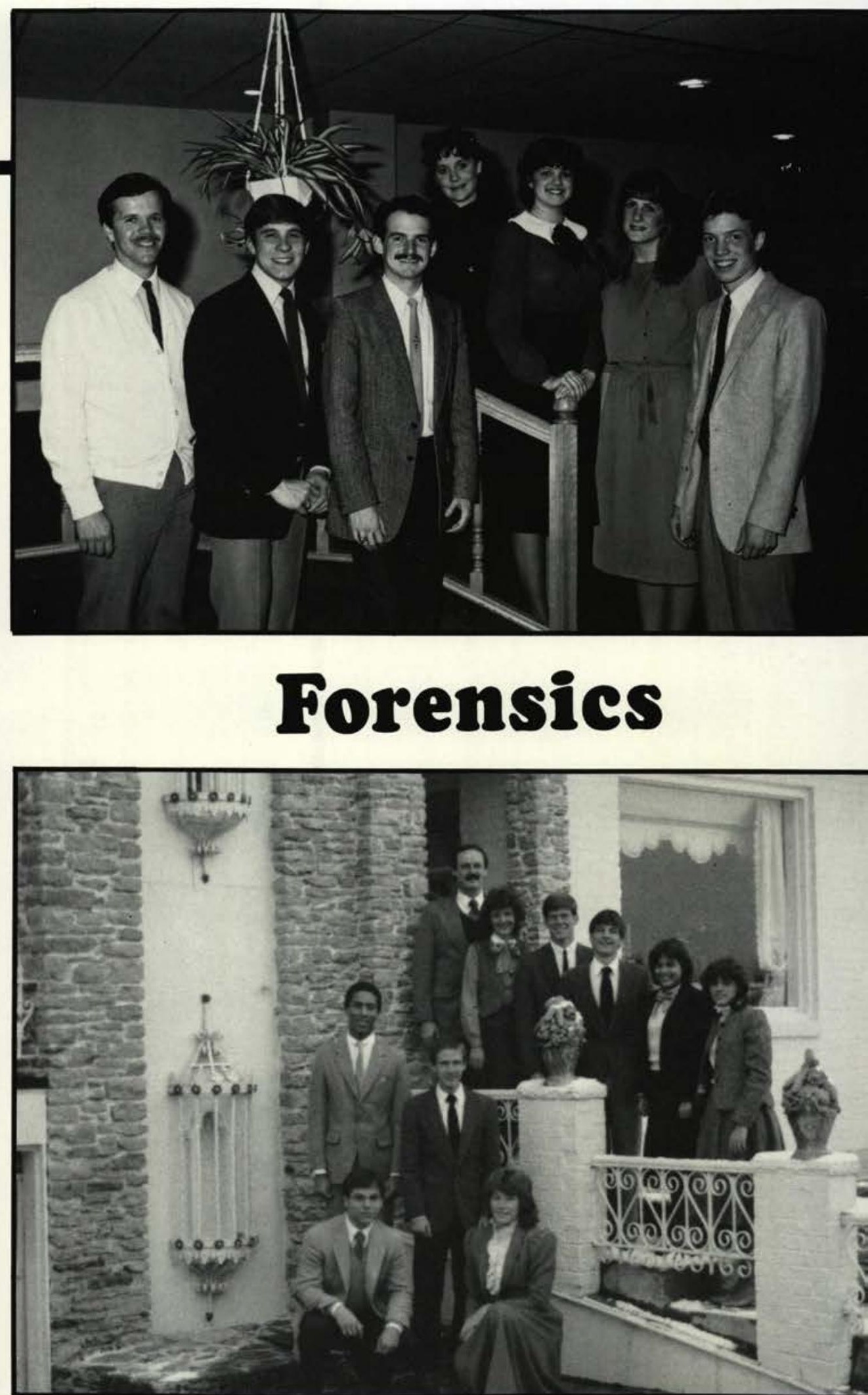

\section{Freshman Class Officers}




\section{Campus Organizations}

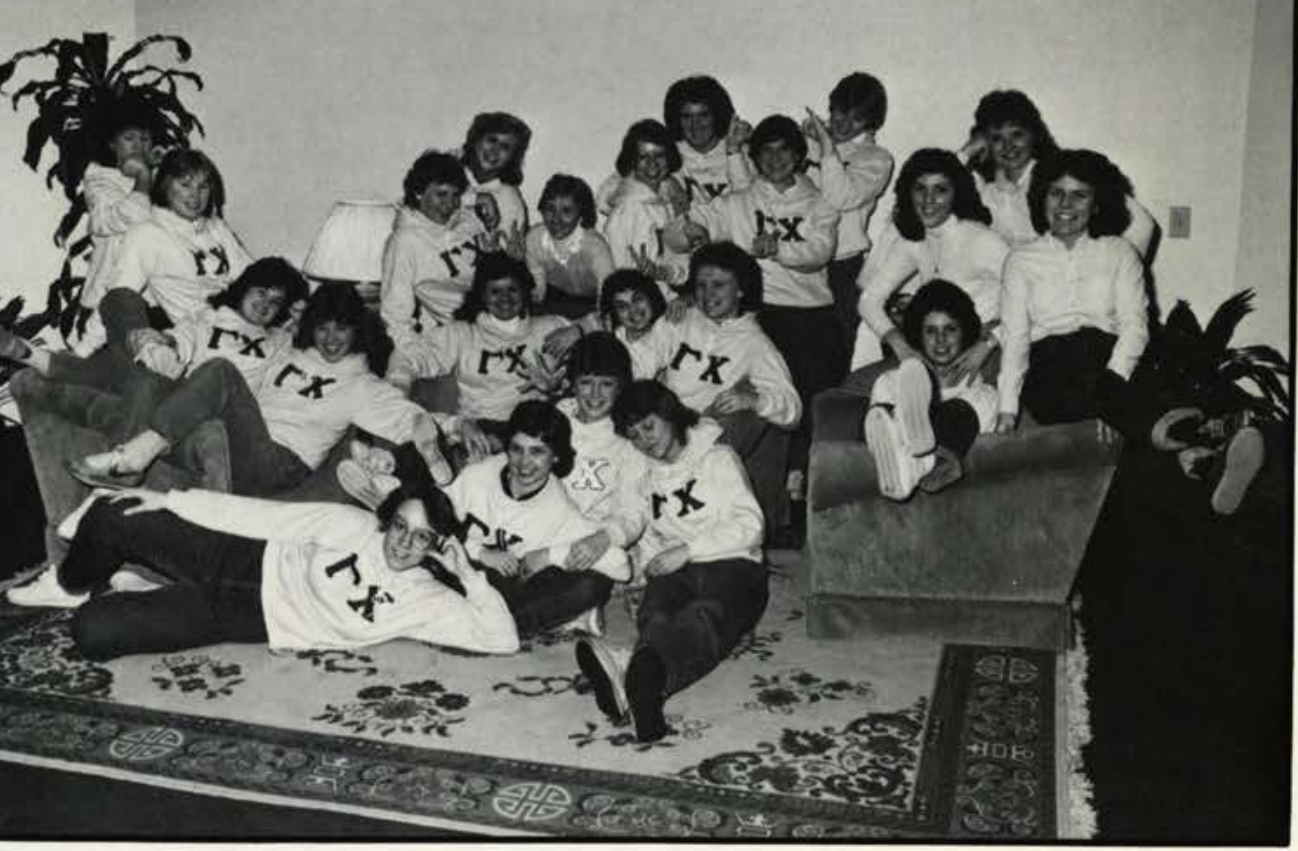

\section{Gamma Chi}

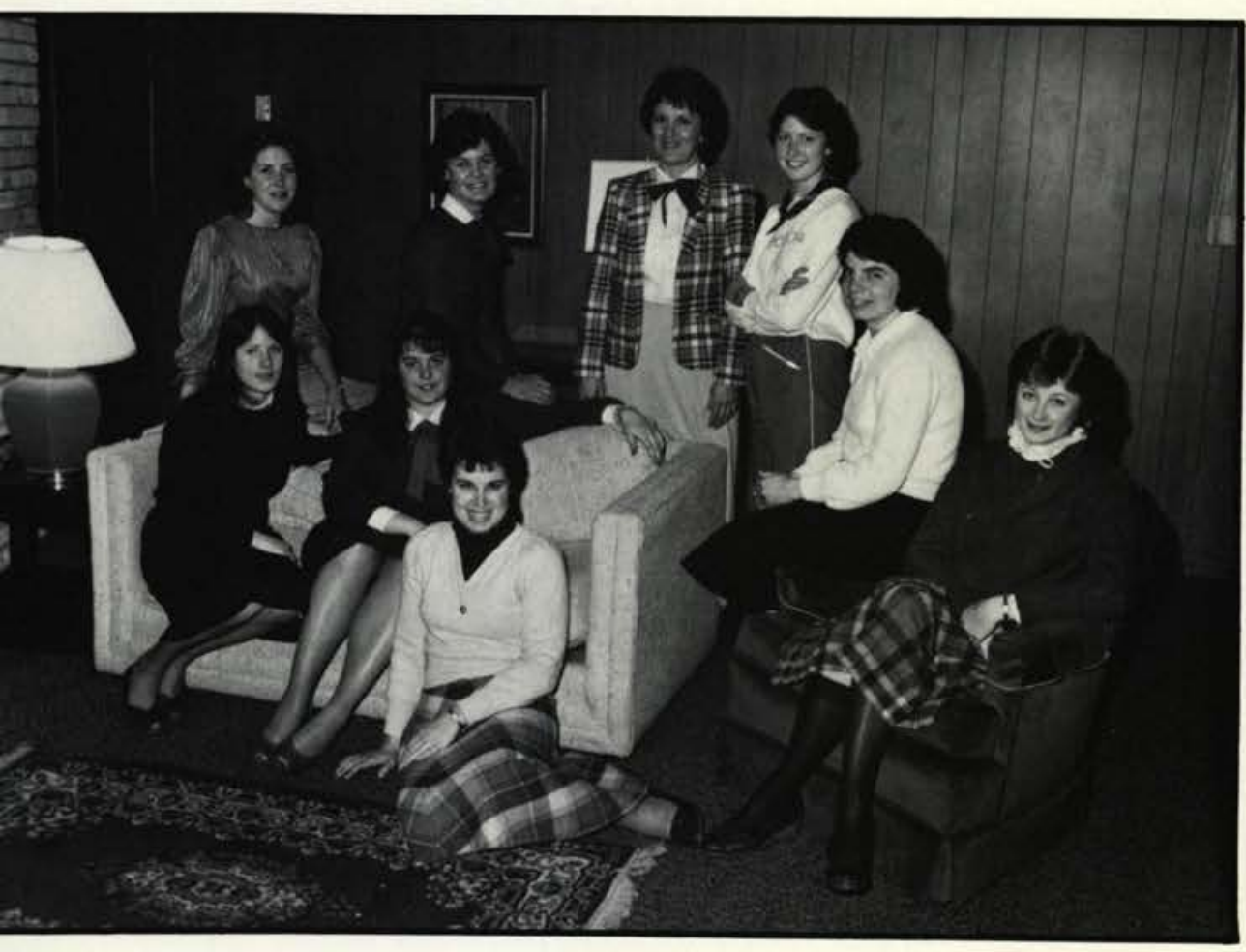

Gamma Chi (Gammə Ki)

Def. A sophisticated society exclusively for women which seeks to develop the poise and ease of c cultured lady.

First row seated on floor: Robin Stockham. Christina Hart. Sherrie Davis (Pres). Leda Tenney. Second row seated: Tanya Kirchner. Tammy Barton. Amy Lydo, April Ames (Chpl), Chris McCauley, Third row: Julie Mears ( $\mathrm{Sec}$ ). Lorene Fornell, Kay Wilson. Marsha McNeish. Dawn Fisher. Betty Smith. Tina Ashley, Lori Leach, Standing: Liz Stutesman, Marilyn Bean. Kristina Parsell. Marsha Jones: Joanne Major. Not Pictured: Janet Wilson (Vice Pres.). Beth Ruff (Treas.). Terry Gray (Senate Rep). Deanne Rice (Social Chrmn.)

Gamma Zeta Theta

(Gammə Zātə Theta)

Def. "Women living for God." Functions include community service, eating. selling Valentine cookie-grams, caroling, eating. taking children to the zoo, cleaning houses and yards, and eating.

Seated: Lorene Norton (Sec), Deb Tinner (Pres), Ruth Snook, Lisa Howard. Teresa Carter. Standing: Cami McGraw. Shelley Clements. Mrs. Ager. Cheryl Phillips. Not Plctured: Julie Murray (Vice Pres.), Lisa Swanson (Treas), Teresa Cnter (Chipin).

\section{Gamma Zeta Theta}




\section{Campus Organizations}

Junior Class Officers

Def. Officers of the class of rising seniors.

Bob Beikert (V.P.). Dave Smyth (Senate Rep.). Mr. Spencer (advisor), Dave Kammeyer (Treas.), Keith Holt (Pres.). Jay Benson (alt Senate Rep.), Dennis Papp (chaplain), Not pictured: Esther Bucklew (Sec.), Jill Parks (Senate Rep.)

Kappa Epsilon Alpha (Kappa Epsilon Alfə)

Def. Business oriented collegians who sponsored the Students in Free Enterprise conference.

First row: Ed Keeley. Susan Patton Timothy Reiter (SOC. Chrmn). Second row: Debbie Cornelius ( $\mathrm{Sec}$.). Lisa Steele. Rhoda Wagner, Laurie Colas. Third row: Kevin Carder. Sydney Caruthers, Greg Moffitt, Dave Dever. Don Booher, Karl Fetzer, Byron Clemens. Diane Auckland, Linda Lons. Not Pictured: Mike Pitts (Pres.). Mark Kaisand (Vice Pres.), Lori Greenwalt (Treas.). Sherie Pinkerton (S.IF.E. Chrmn.)

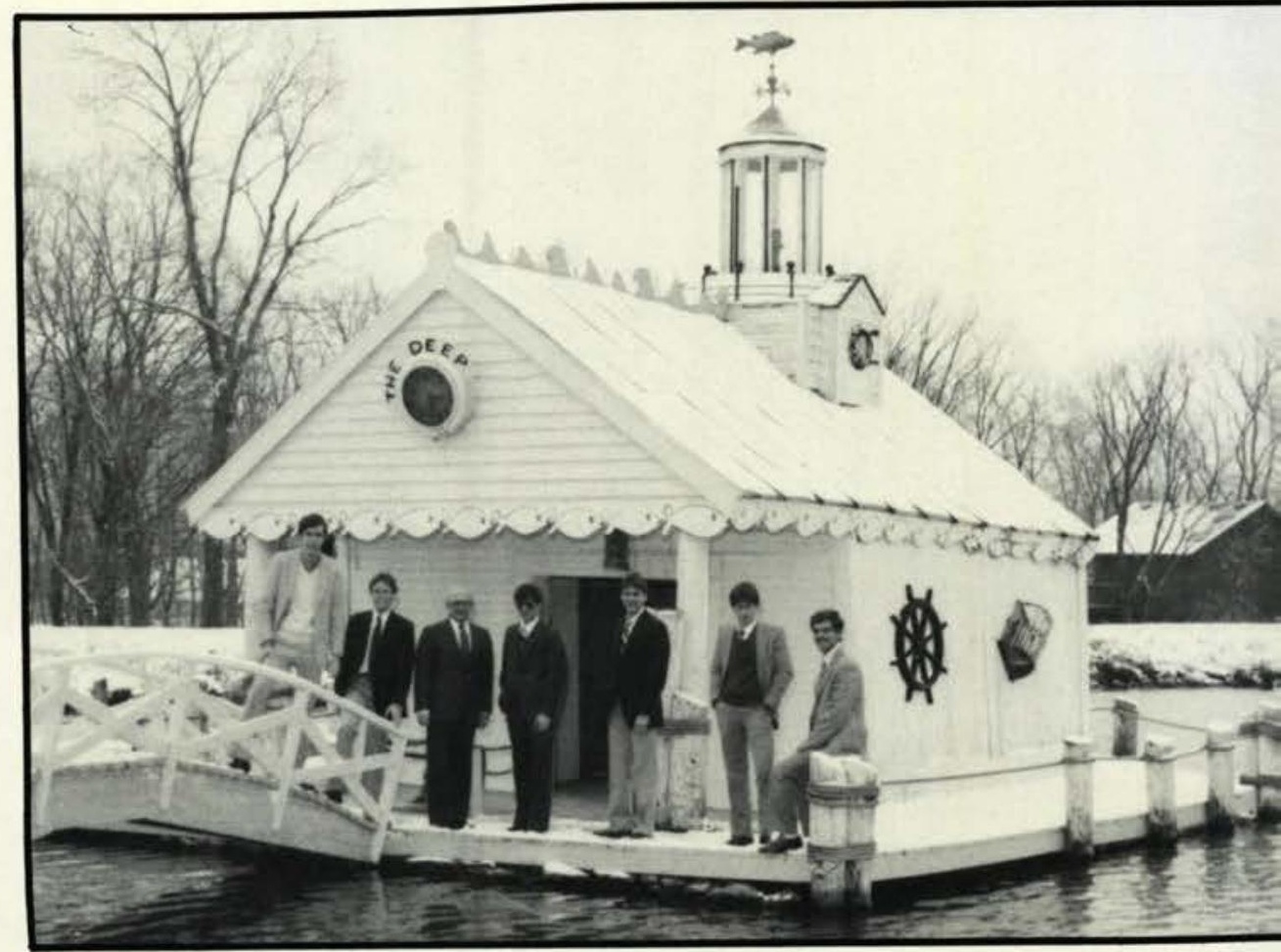

\section{Junior Class Officers}

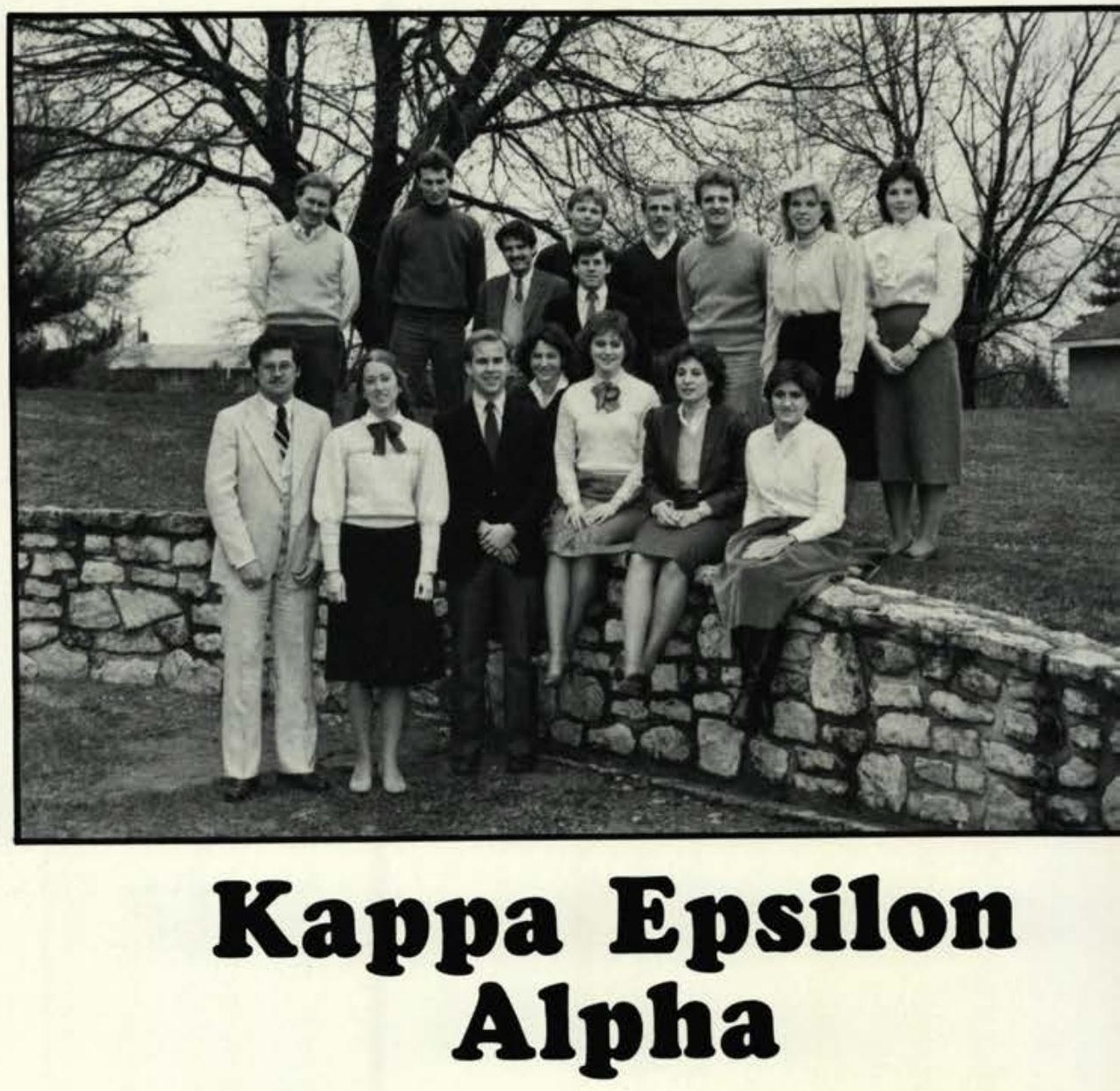




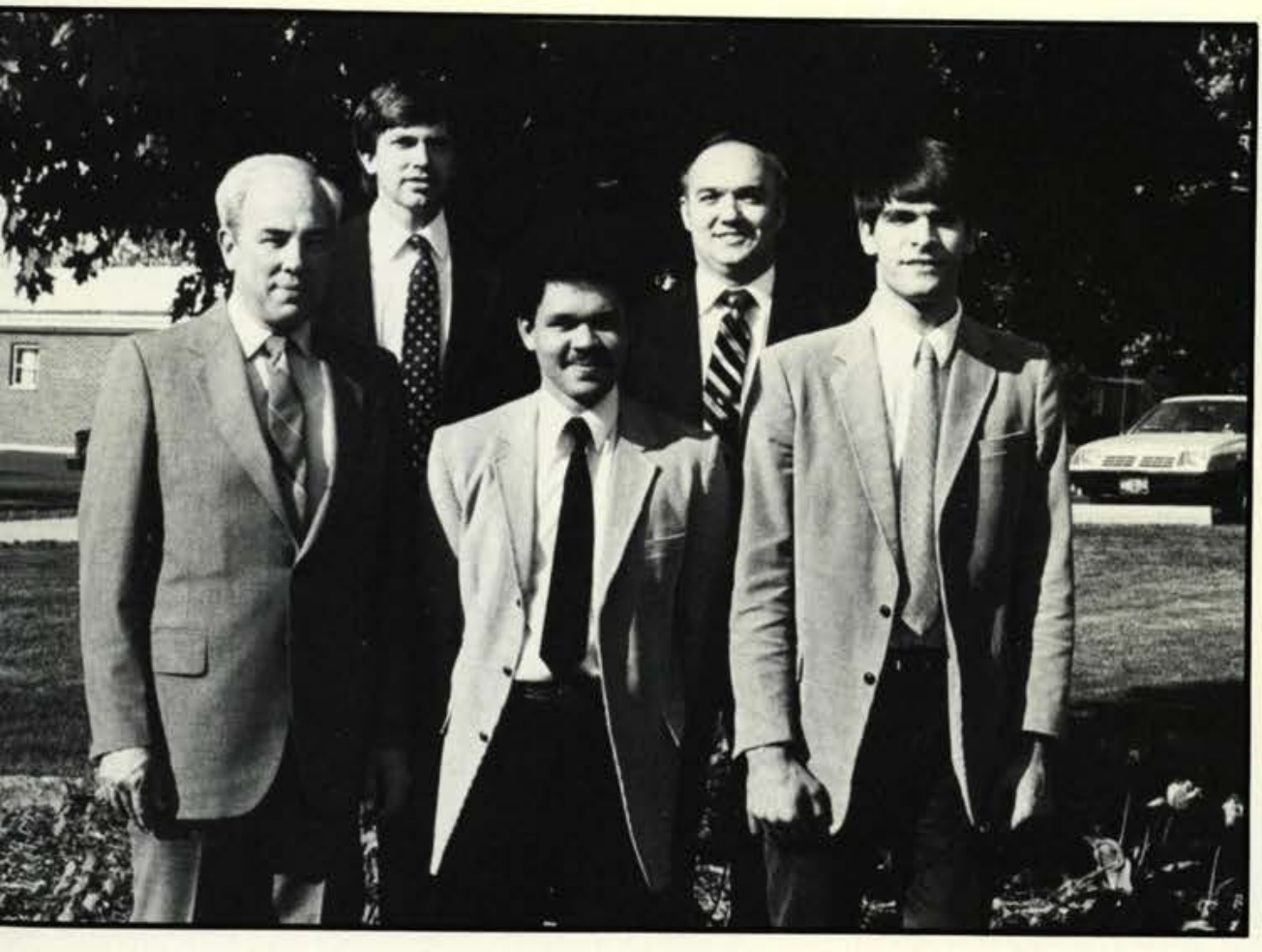

Married Student Fellowship

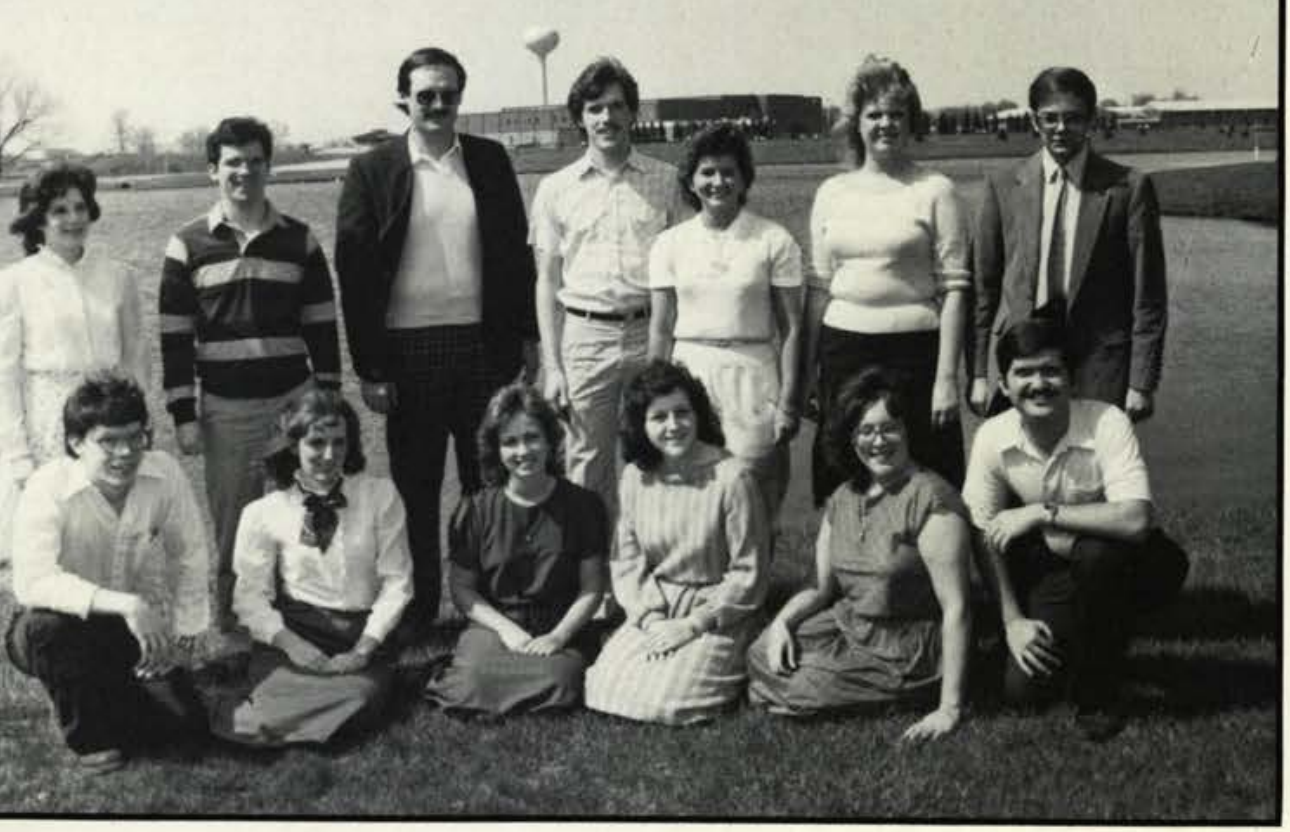

\section{MENC}

Married Student

Fellowship

Def. A club exclusively designed for wedded Cedarvillans.

First row: Dr. Riggs (Advisor), Lewis Kyle (Pres.), Tim Danube (Student Body Rep.), Second row: Kevin Crowell (Vice-

Pres.), Gary Brewer (Treas:)

\section{M.E.N.C.}

Def. Cedarville's chapter of Music Educators National Conference; activities include attending concerts and going Christmas caroling, plus participation in anything flavored with tasteful music.

First row: Colin Lord (Act. Co-ord.), Joy

Burr, Linda Coldren, Julie English (Vice Pres-), Judy Walters (Sec), Bill Bany. Second row: Terri Lymn Mackenzie, Ed Lanning, Mr. Dicuirci (Advisor), Dan Price (Pres.), Julie Kolkman (Senate rep.), Jill Camplell (Treas.) 
Miracle Staff

Def. A stupendous assembly of layout artists, copy writers, photographers, and graphic designers who arduously labor throughout the academic year to create Miracles.

First row: Scott Jones, Keith Beres, Rob Reichard, Rodney N. Smith, Mike Walton, Perry Chiarelli, Tracy Holtzmann, Donna Thomas, Janel Wallace, Second row: Jeff Wassenaar, Tracy McCoy, Jeff Mullinix, Jacqui Ward, Ann Hunter, Bill Thomas, Charlene Hunt, Shelley Frank, Karen Beattie, Laurie Colas, Mrs. Dixon, Third row: Dave McClure, Chad Bresson, Becky Payton, Connie Kirby, Jon Beight, Robin Stockham, Cami McGraw, Tami Eimers

Physical Education Majors and Minors

Def. Sponsors of activities like swimming parties to become better acquainted with other PE majors.

First row: Karen Harrington, Kevin Wallace, Steve Cox, Marsha Peterson, Lynette Wiseman, Second row: Julie Erdmann. Marianne Hiner, Gary Wallace, Don Wagner (Pres.), Kristy Vance, Marsha McNeish, Third row: Tip Link (Senate Alt.), Jim Robinson, Cathy Eekam, Tim Davis, Shawn Dexter, Neil Black, Cliff Fawcett, Chervl Rendale, Steve Emmons, David Sallee, Not pictured: Carla Womack (Vice Pres.), Tracy Turner (Sec./ Treas.), Crissie Gorges (Senate Rep.), Dr. Pam Diehl (Advisor).

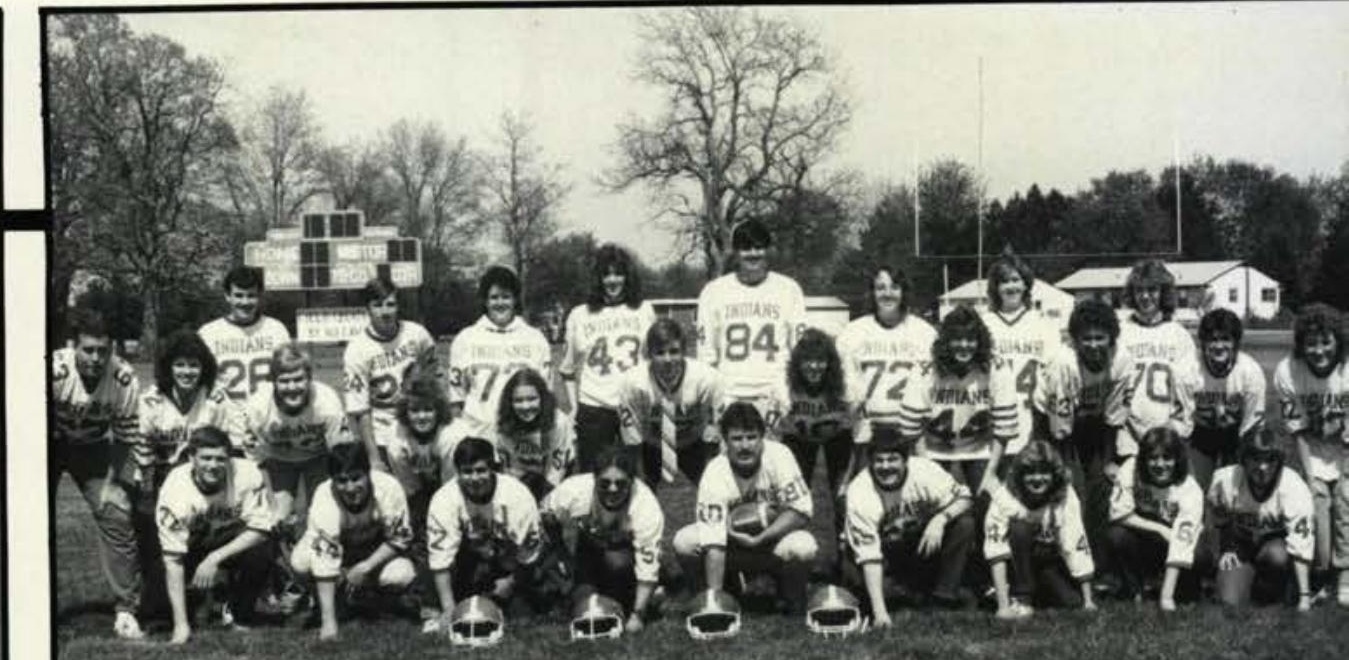

Miracle Staff

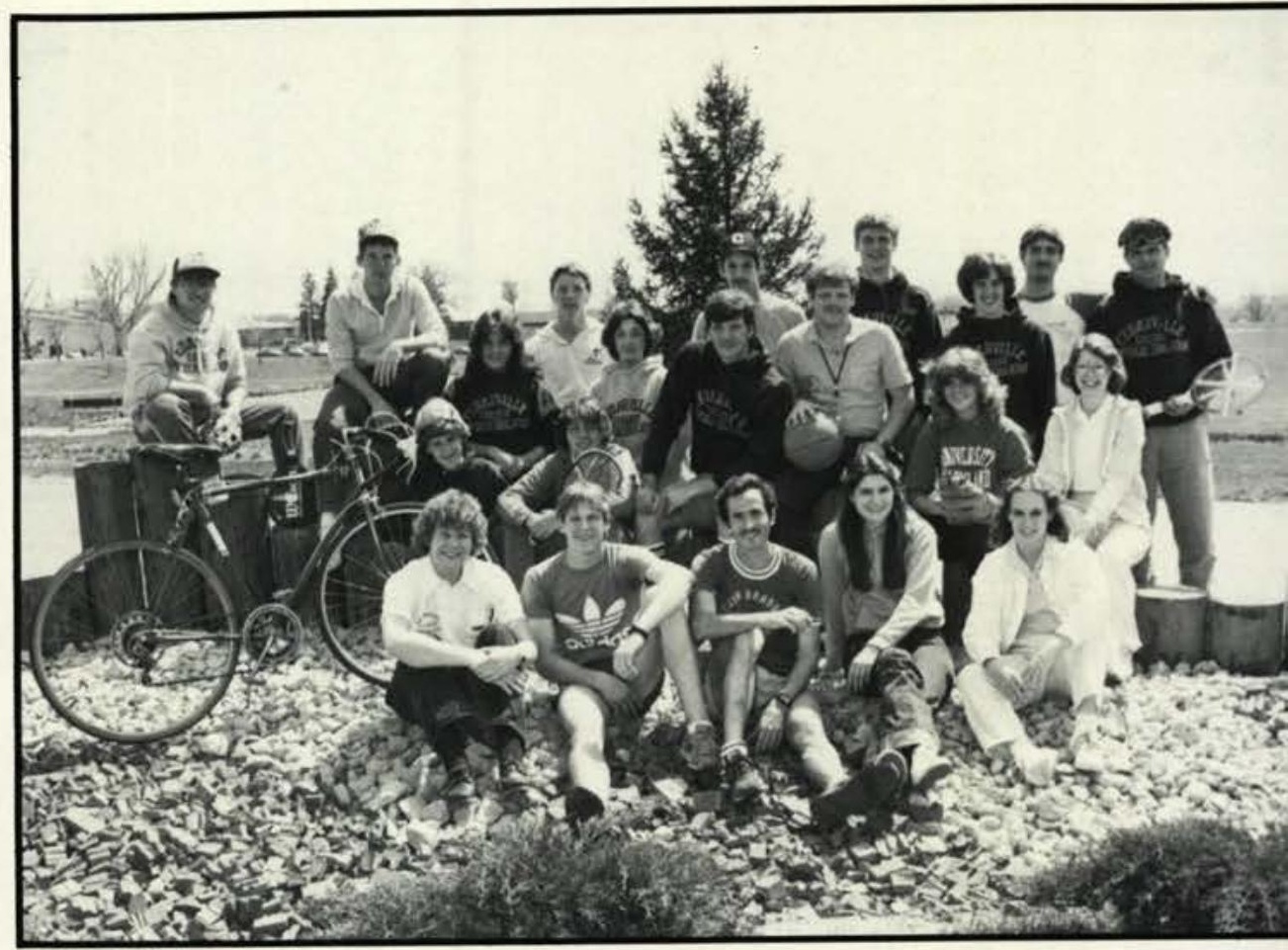

\section{P.E.M.M.}




\section{Campus Organizations}

\section{Pi Sigma $\mathrm{Nu}$ \\ Sigma Noo}

Def. Male collegians who devise extensive initiation procedures, sponsor a softball tournament, host a skating party, and plan a Spring chapel series.

First row: Jim Atkinson, Dave Clark, Brent Long, Dave Ormsbee (Advisor), Jeff Krueger, John Powell (Treas.), Tom Fite, Brent Coeling, Dave Bowser (Pres.). Second row - Jerry Gorham, DeMaurice Smith, Wayne Anderson, Mike Morgan, Jeff Dilley (Vice Pres.), Barry Kane, Tim Woodard, Todd Gueist, John Madderman, Not pietured: Joe Walker (Sec.), Brian Hellwig

\section{Pre-Law Society}

Def. All alliance for those aspiring to careers in law. Insight in gleaned from hosting special speakers and collecting facts on law schools.

Jill Stebbins, Richard Haywood, Dan Mulholland, Lorene Norton (Sec.), Scott Haynes (Vice Pres.), Joe Halsey (Sponsor), Cheryl Phillips (Pres.), David Hale, Susan Blake, Matt Henderson.
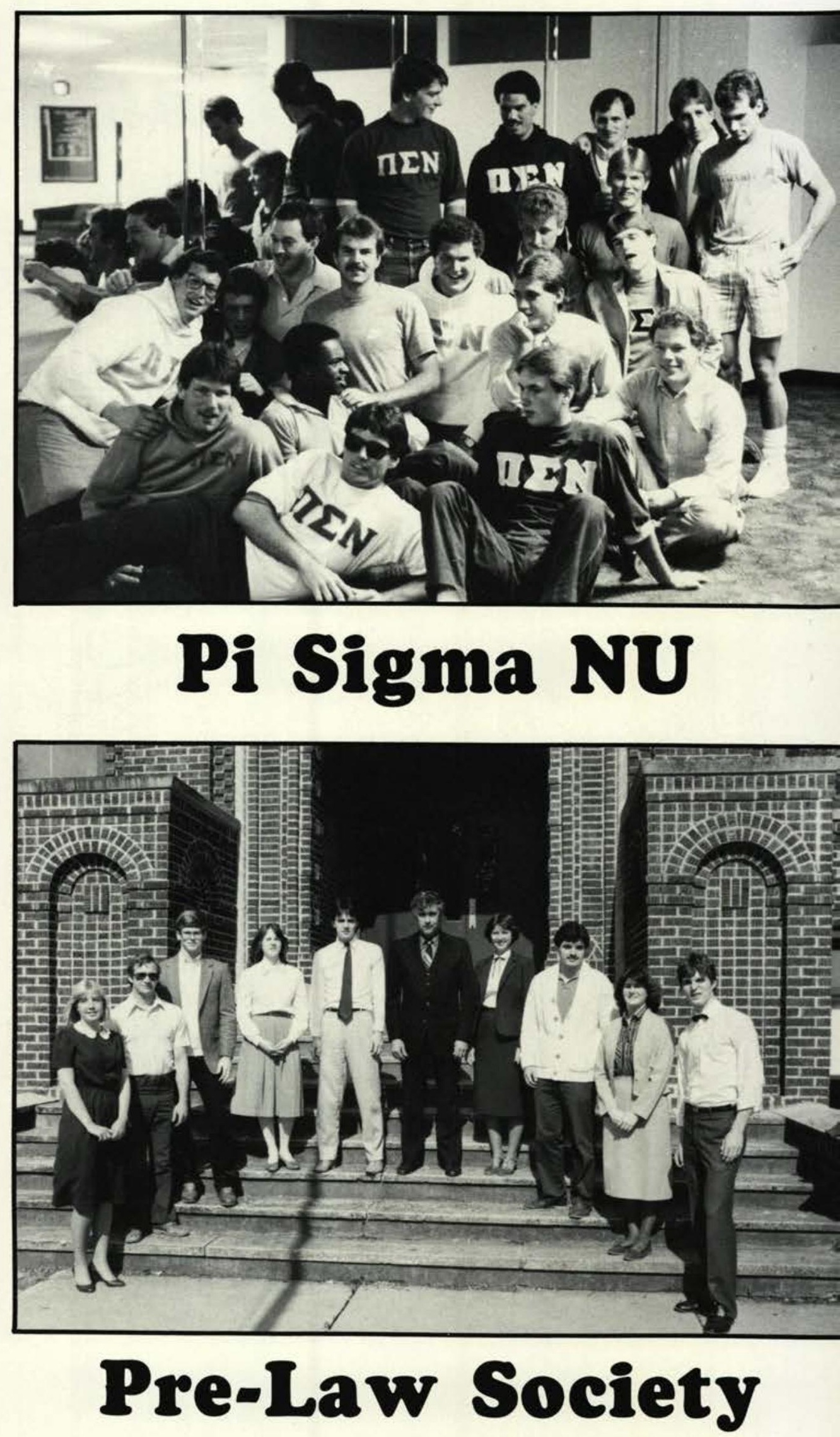


\section{Student Senate}

Def. Student legislatures of $\mathrm{Ce}$ darville College.

First row: Jill Stebbins, Rohin Campbell, Gary Cooke, Connie Kirby, Gillis West (Chap.), Robin Bowling (Sec.). John Jackson (Pres.). Jim Liebler. Tammy Cox, Dave Smyth, Flaine Stone, Jay Benson (Proj. Chrmn.). Second row: David Edwards, Amy Jo Guest, Pete Bishop, Julie Kolkman, Ben Smith. Julie Mears, Paul Jones, Carol Herriman, Rod Smith, Tim Bishop, Third row: John Little, Joy Hart, John Adkins, Ruth Withrow, Paul Hayes, Rachel Wilson, Matt Biggs, Kathleen Kirby, Dan Mulholland, Fourth row: Joe Walker. Heidi Hemphel, Andy Wilson, Catherine Farley, Jim Barber (Vice Pres.), Sonya Nichols, Mark Horne. Kim Murphy. Ted Towne, Kathi Harris, Gary Barker. Not pictured: Larry Schweinsburg (Treas.).

Swordbearers

Def. Students who minister to area churches through their services.

First row: Angela Zaugg. Dawn Baughman, Sherry Frank, Dave Piper (President), Joy Harden, Kim Searles, Judy Runge, Second row: Karen Dubbal, Jenni Cranich, Kristin Weber, Donna Birch, Lorene Barram, Third row: Larry Reichard. David Johnson, Bryan Crump, Sonya Nichols, Jeff Piper, Fourth row: Jon Beight, Steve Emmons, Brian Hedges

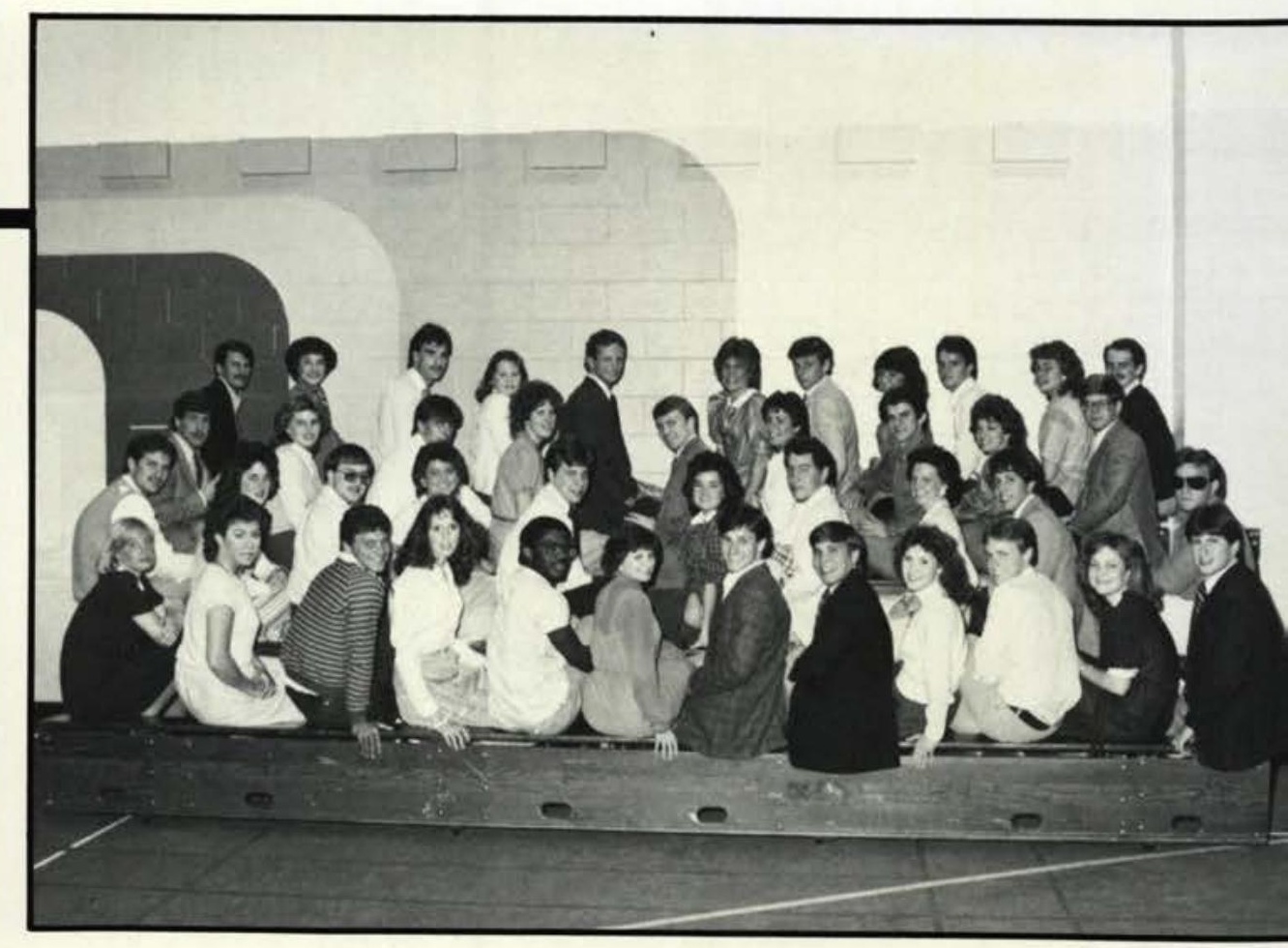

\section{Student Senate}

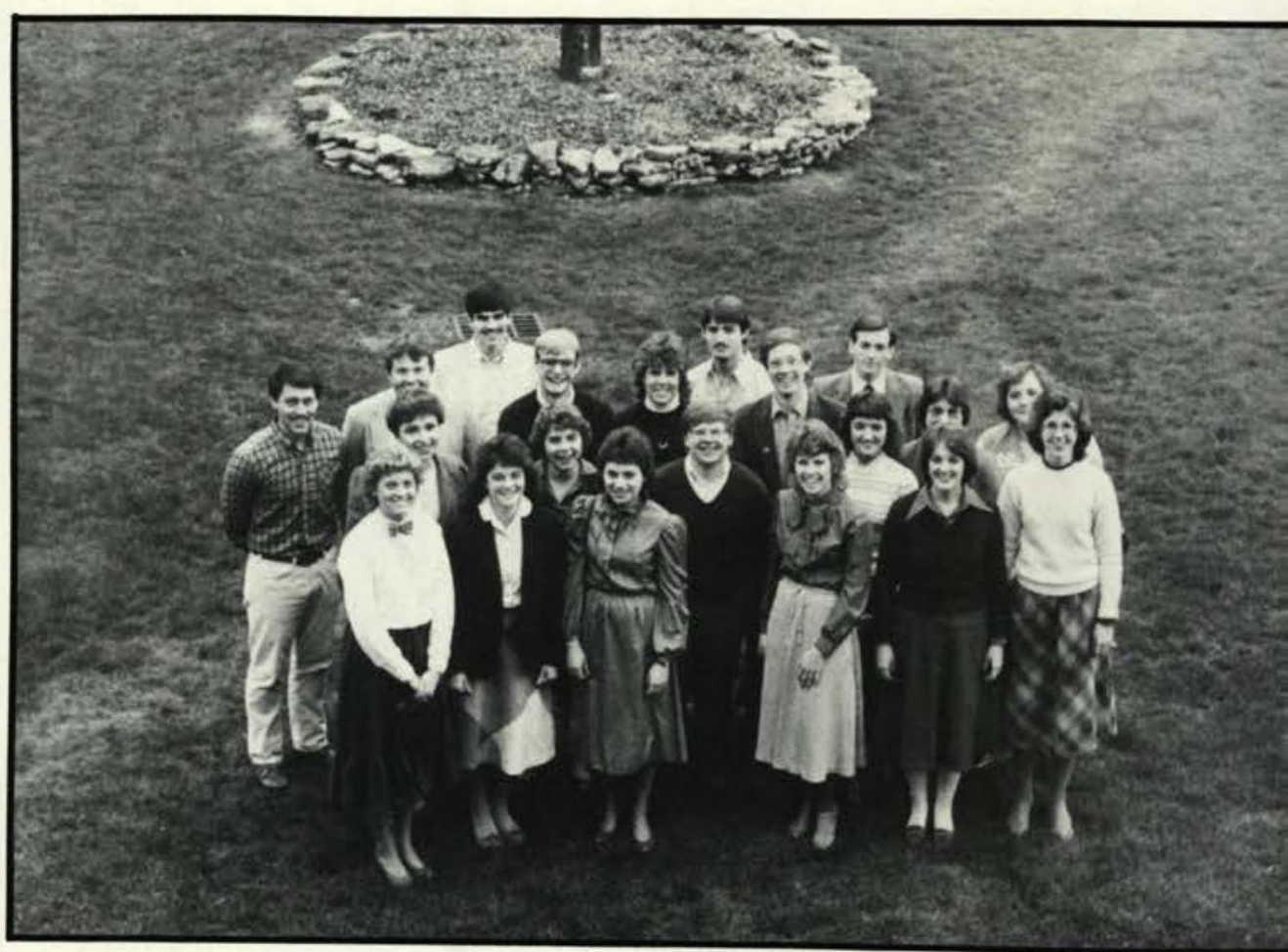

\section{Swordbearers}




\section{Campus Organizations}
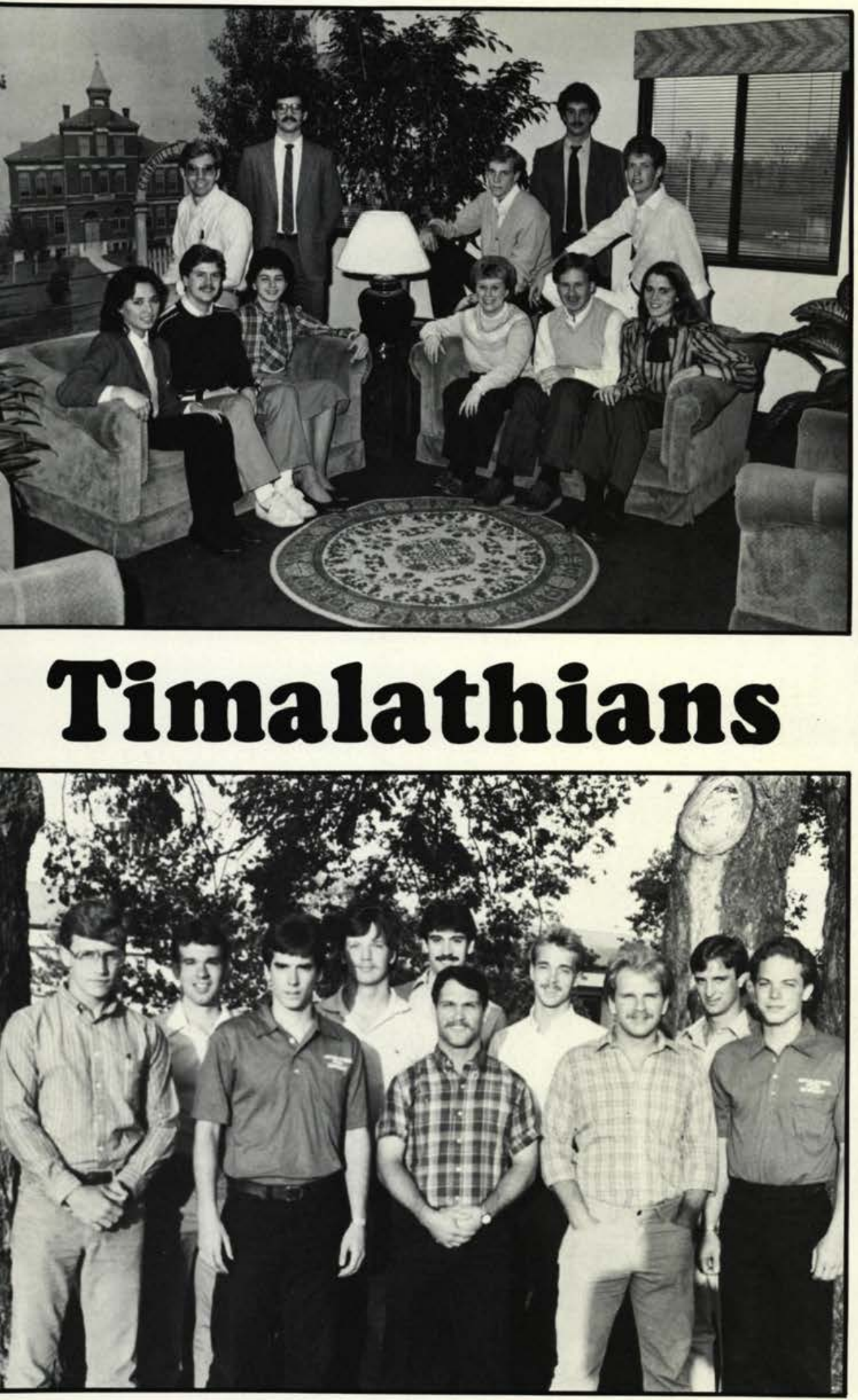

Varsity "C" Club

Def. Cedarville athletes of the male gender who have lettered in. a varsity sport.

First row: Steve Sagraves, Dave Moody, Gary Mills, Jay Brewin, Noel Hack, Second row: Tom Greve, Gary Wallace, Kirk Fairhurst, Dave Jones, Greg Clemmons

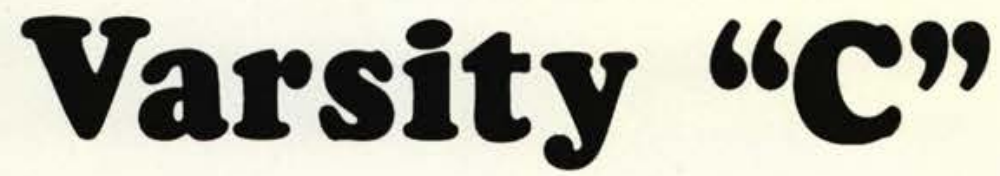




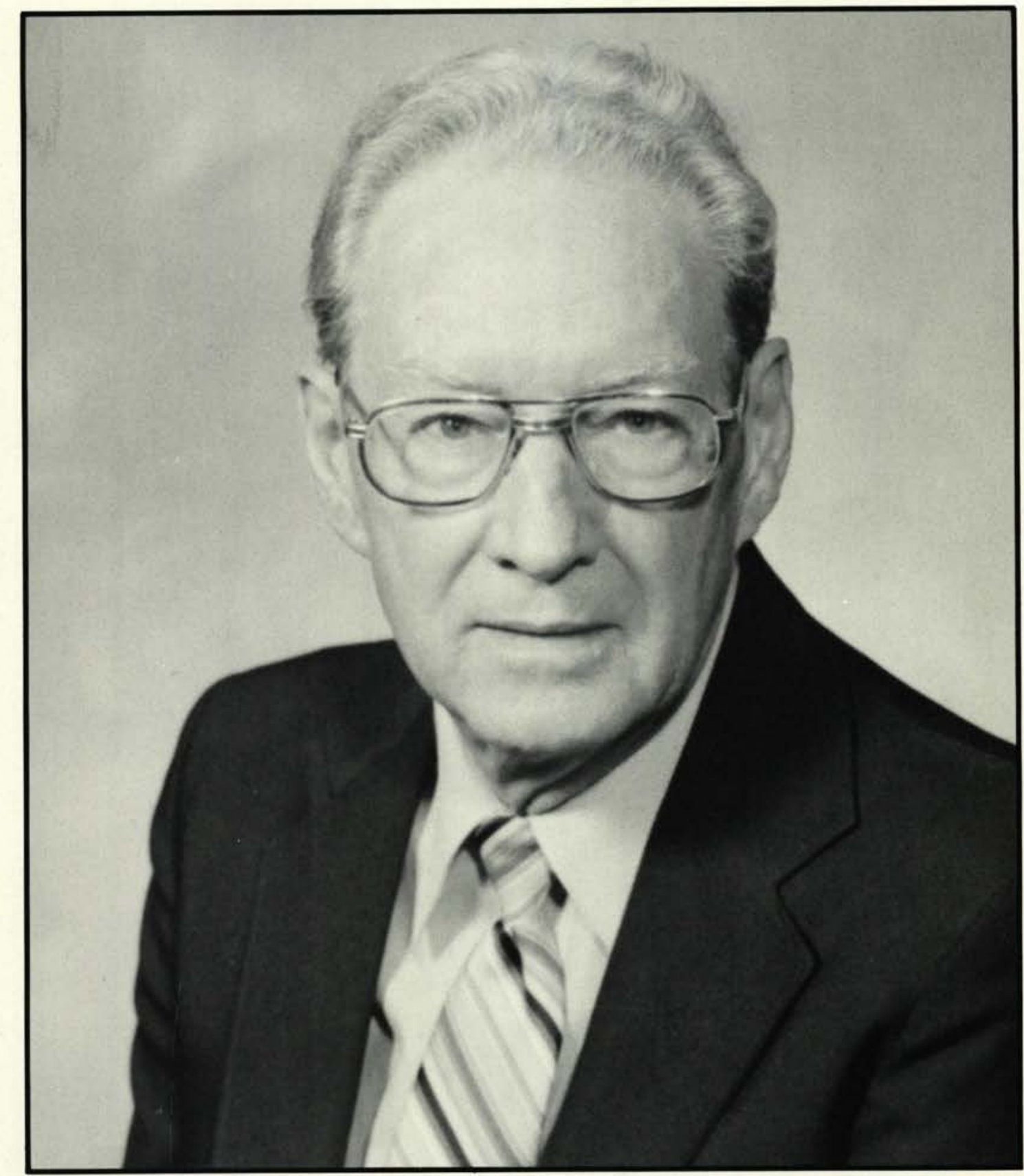

\section{Dr. Mead Armstrong,}

Professor Emeritus Of Bible

June 9, 1907-November 12, 1983

$\mathbf{W}$ arm. Loving. Personable. That is Mr. Armstrong. That is how recall him. He knew your name, your hometown, your church. He cared enough to find out and to remember.

He loved theology and he loved to teach it. Hundreds, yes thousands, can still recall doctrinal statements and Scriptural passages which were learned under his wise guidance.

Life has its strange, yet beautiful, cycles. Mr. Armstrong was my first theology teacher back in 1951. Years later, we taught together. In addition I had his grandchildren in some of my classes. What a circle of transmission: From him to me and back to his family.

Mr. Armstrong. He was never Dr. Armstrong or Mead to me. He had to be $\mathrm{Mr}$. because he was an unassuming, fatherly person. I loved and respected him. I still do.

by Robert Gromacki 


\section{Church Patrons}

BEREA BAPTIST CHURCH

250 WEST STREET

BEREA, OH 44017

PASTOR: KENNETH J. SPINK

BEREAN BAPTIST CHURCH AND CHRISTIAN SCHOOL

702 ATASCOCITA ROAD

HUMBLE, TX. 77396

PASTOR: MARK J. KEOUGH

\section{CALVARY BAPTIST CHURCH}

$\triangle 01$ CENTER ST

ASHLAND, OH 44805

PASTOR: WILLIAM L. MOSER

CALVARY BAPTIST CHURCH

MARION ROAD AND BEAL AVENUE

BUCYRUS, OH. 44820

PASTOR: J. HOWARD JONES

CALVARY BAPTIST CHURCH

$636 \mathrm{~N}$. BEST STREET

FOREST CITY, IA 50436

PASTOR: DOUGLAS P. DOMOKOS

CALVARY BAPTIST CHURCH

1527 S. CUSTER RD

MONROE, MI 48161

PASTOR: MORTIN COSSINS

DISCOVERY BAPTIST CHURCH

6120 51st AVENUE N.W

GIG HARBOR, WA 98335

PASTOR: MARK SUKO

FAITH BAPTIST CHURCH

$\triangle 50$ THELMA ST. P.O. BOX 596

HUDSON, IA. 50643

FAITH BAPTIST CHURCH

2205 LANC-CIRC, RD

LANCASTER, OH. 43130

PASTOR: E. ALLEN KRAEMER

\section{FIRST BAPTIST CHURCH}

P.O. BOX 383

MONROE, IA 50170

PASTOR: GREG BOYLE

\section{FIRST BAPTIST CHURCH}

39 E. MAIN STREE

RANDOLPH, NY 14772

PASTOR: LEE EINFELDT

\section{FIRST BAPTIST CHURCH}

530 MEADOW DRIVE

NORTH TONAWANDA, NY

PASTOR: WOODROW W. MCCALEB

ASSOCIATE: JOHN MILAM

\section{FIRST BAPTIST CHURCH}

HICKSVILLE ROAD AND CLARK STREET MASSAPEGVA, NY 11758
PASTOR: FREDRICK W. THOMAS

FAITH BAPTIST CHURCH

603 AIRPORT AVENUE

VAN WERT. OH. 45891

PASTOR: REV. FRED D. JENSEN

FIRST BAPTIST CHURCH

1001 N. LINCOLN

CRESTON, IA. 50810

PASTOR: NORMAN HOOG

FIRST BAPTIST CHURCH

445 N. MARKET STREET

GALION. OH 44833

FIRST BAPTIST CHURCH OF ENFIELO

253 BRAIKARD ROAD

ENFIELO. CT 06082

PASTOR: REV. GEORGE H. HEII.AND

\section{GRACE BAPTIST CHURCH}

109 N. MAIN STREET

CEDARVILLE, OH 45314

PASTOR: PAUL JACKSON BYRON SHEARER

HUNTSBURG BAPTIST CHURCH

16419 MAYFIELD ROAD

HUNTSBURG, OH 44046

PASTOR: REV. BEN H. GARLICH

\section{LANGHORNE TERRACE BAPTIST CHURCH \\ 1249 WEST MAPLE AVENUE \\ LANGHORNE, PA. 19077 \\ PASTOR: REV. DONALD E. MCCALL REV WARREN SAUL}

\section{LEABITTSBURG BAPTIST CHURCH}

$\triangle 150$ KINCAID ROAD

WARREN, OH 44481

PASTOR: REV. VIRGIL R. WOLFORD

\section{MARANATHA BAPTIST CHURCH}

MARANATHA VILLAGE

SEBRING, FL. 33870

PASTOR: ROY G. HAMMAN, D.D.

\section{MEMORIAL BAPTIST CHURCH}

2435 EAKIN ROAD

COLUMBUS, OH 43204

PASTOR: REV. TOM WRIGHT, JR.

ASSOCIATE: DENNIS GEORGE

\section{MIDWAY BAPTIST CHURCH}

7517 RED ARROW HWY

WATERVLIET, MI 49091

PASTOR: REV. HAROLD KNICKERBOCKER

MOUND TAHOMA BAPTIST CHURCH 5220 W. 74th STREET

TACOMA, WA. 98467

PASTOR: REV. ELVON M. NELSON
NORWOOD BAPTIST CHURCH

2037 COURTLAND AVENUE

NORWOOD, OH 45212

PASTOR: LEE FULMER

OAK GROVE BAPTIST CHURCH AND SCHOOL

5500 WOODEND

KANSAS CITY, KS 66106

PASTOR: JAMES R. GRAY

YOUTH: KEITH MACKINTOSH

ADMIN: JOHN TILSON

\section{PARSIPPANY BAPTIST CHURCH}

1179 LITTLETON ROAD BOX 165

PARSIPPANY, NJ 07054

PASTOR: DAVID NETTLETON

\section{PERRY BAPTIST CHURCH}

2425 PERRY DRIVE, SW

CANTON. OH. 44706

PASTOR: REV GORDON H. ROLOFF

\section{PLEASANT HEIGHTS BAPTIST}

\section{CHURCH}

1817 MONTANA AVENUE

EAST LIVERPOOL. OH 43920

PASTOR: J.E. BECKLEY, JR.

\section{SAYLORVILLE BAPTIST CHURCH}

6429 NW SIXTH DRIVE

DES MOINES, IA 50313

PASTOR: REV. JOSEPH F. HAYES, JR.

SHAWNEE HILLS BAPTIST CHURCH 3490 JASPER ROAD

JAMESTOWN, OH. 4.5335

PASTOR: DENNIS L. HENDERSON

\section{SILVIS HEIGHTS BAPTIST CHURCH}

900 MIDDLE ROAD

SILVIS, IL. 61282

PASTOR: REV. EDWARD A. THOMPSON

\section{SOUTHGATE BAPTIST CHURCH}

2111 S. CENTER BLVD

SPRINGFIELD, OH 45506

PASTOR: JOHN R. GREENING

SOUTHSIDE BAPTIST CHURCH

397 S. COMMERCE STREET

SEBRING, FL. 33870

PASTOR: RUSSFLL E. LETHBRIDGE, JR.

\section{TEMPLE BAPTIST CHURCH}

1148 GALLIA STREET

PORTSMOUTH, OH 45662

PASTOR: REV. JOHN GOWDY

TRINITY BAPTIST CHURCH

R.R. 1, BOX 285

BLOOMFIELD, IN. 47424

PASTOR: JAMES W. GRIMES 


\section{Who's Who???}

The students chosen as members of this year's Who's Who in American Colleges and Universities were selected by faculty members and the Student Services Committee. This year's committee consisted of Donald Rickard, Charles Clevenger, Kurt Moreland, Debbie Battaglia, and Karl Fetzer.

Each department selects two or three of the most qualified students in their respective departments, while the remaining members are chosen by the committee.

The students, who are to be Junior or Seniors, are selected according to their academic re- cord, extra-curricular activity, honors, and Chritian Service involvement. Also, one of the most vital qualifications was the students Critian Testimony consisting of adherence to the standards of the school, and more importantly, the positive manifestation of scriptural standards in the students own life.

These young people have demonstrated the ability to excel in that which has been placed before them during their college life, and have exibited a degree of leadership which is necessary and essential for today's youth to possess. by Karl Fetzer

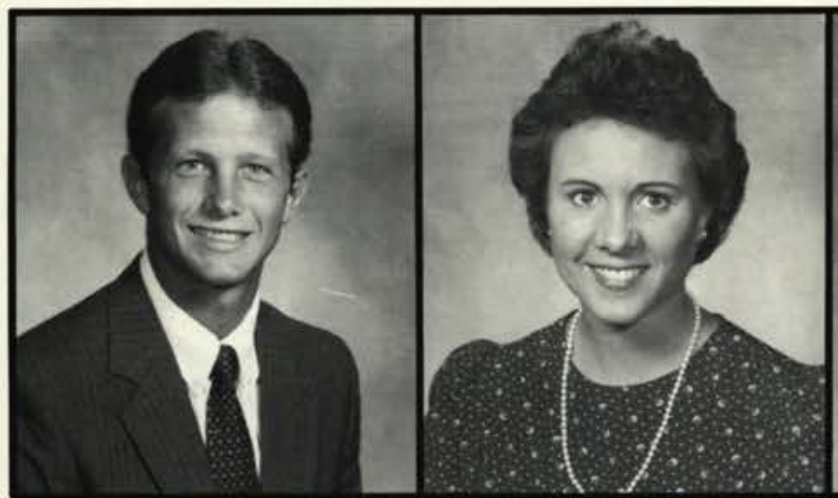

James Barber

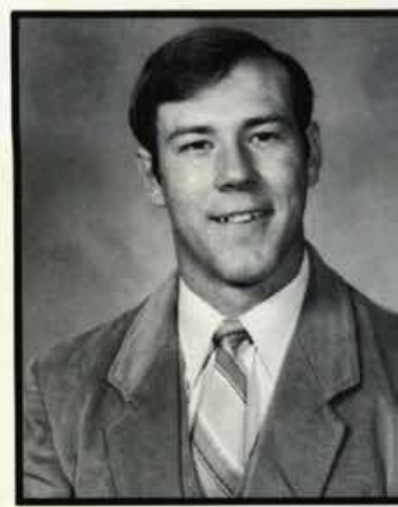

Kenneth Alford

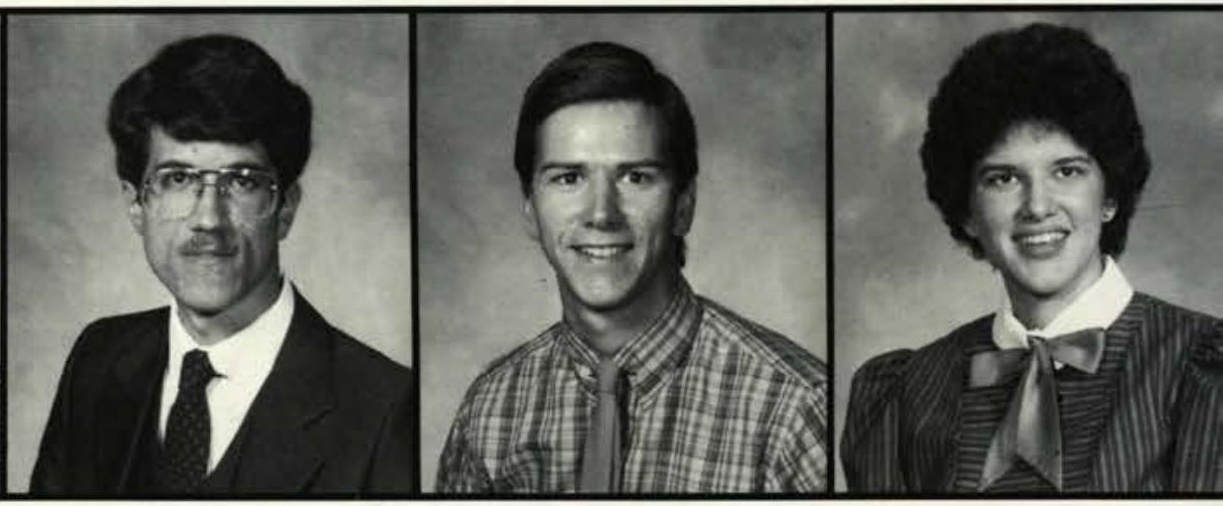

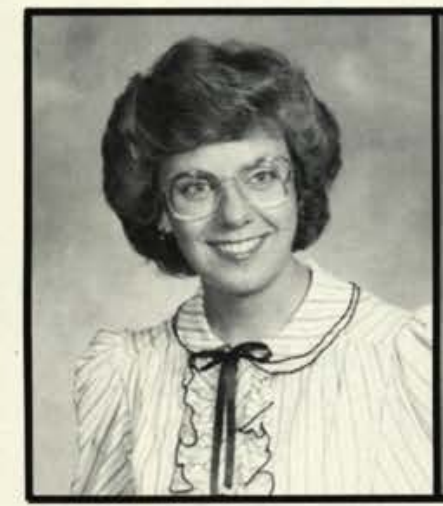

Cheryl Clayton

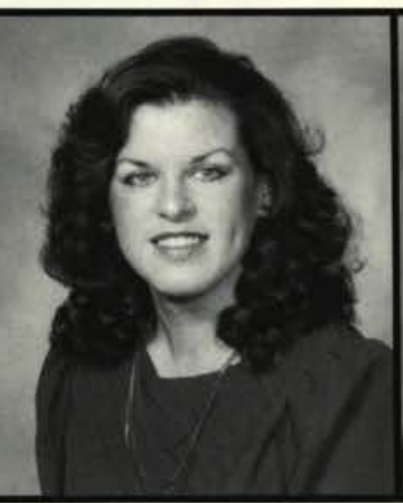

Irene Farley

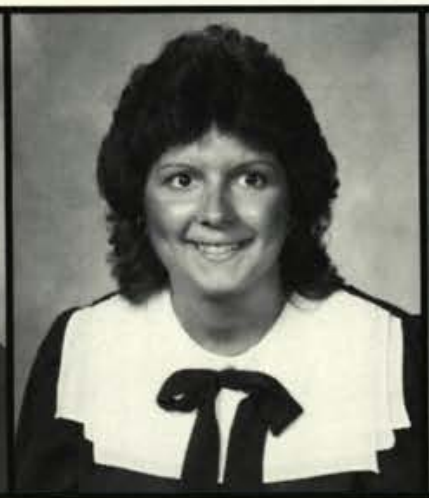

Lori Greenawalt

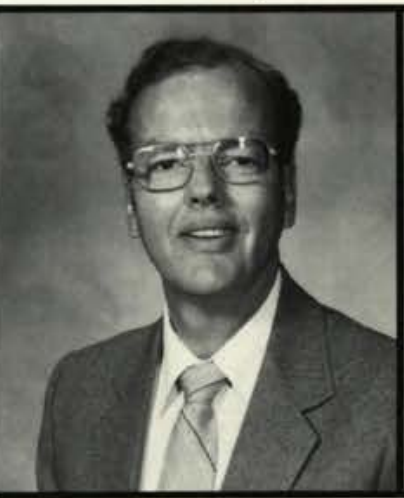

Benjamin Harrison

\section{Lynette Chezik}

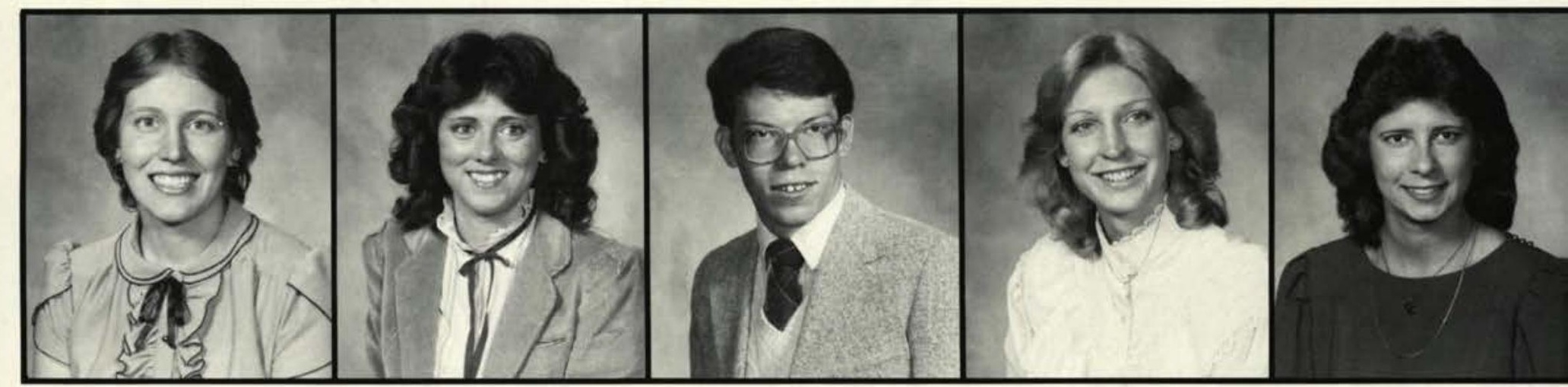

Linda Ladygo

Carol Lewis

Colin Lord

Dawn Matthews

Julie Merck 


\section{Creating Miracles}

C cared?!?! You bet. Being a transfer student in charge of the yearbook has, to say the least, been a real learning experience. At times, as with all editors I suppose, it seemed as if this book would never be completed. It was during these "down times" that the Lord seemed to be telling me that "His grace was sufficient for me." Now here at the end of this book I can certainly tell you that His grace is totally sufficient.

Wait a minute! Before you go to put this book on some forgotten shelf I want to let you know that it's our hope as staff that you might pull this yearbook down sometime later in life and be reminded of your year at the 'Ville. Not only the "good" times, but of our theme and of His desire for your best.

Lastly, a genuine thanks to all who have disciplined and dedicated your time, and who desired to give their best to their school and Lord. Thank you for the opportunity I have had to learn, grow and enjoy. JEFFREY $\mathrm{H}$. WASSENAAR 1983-84 MIRACLE Editor

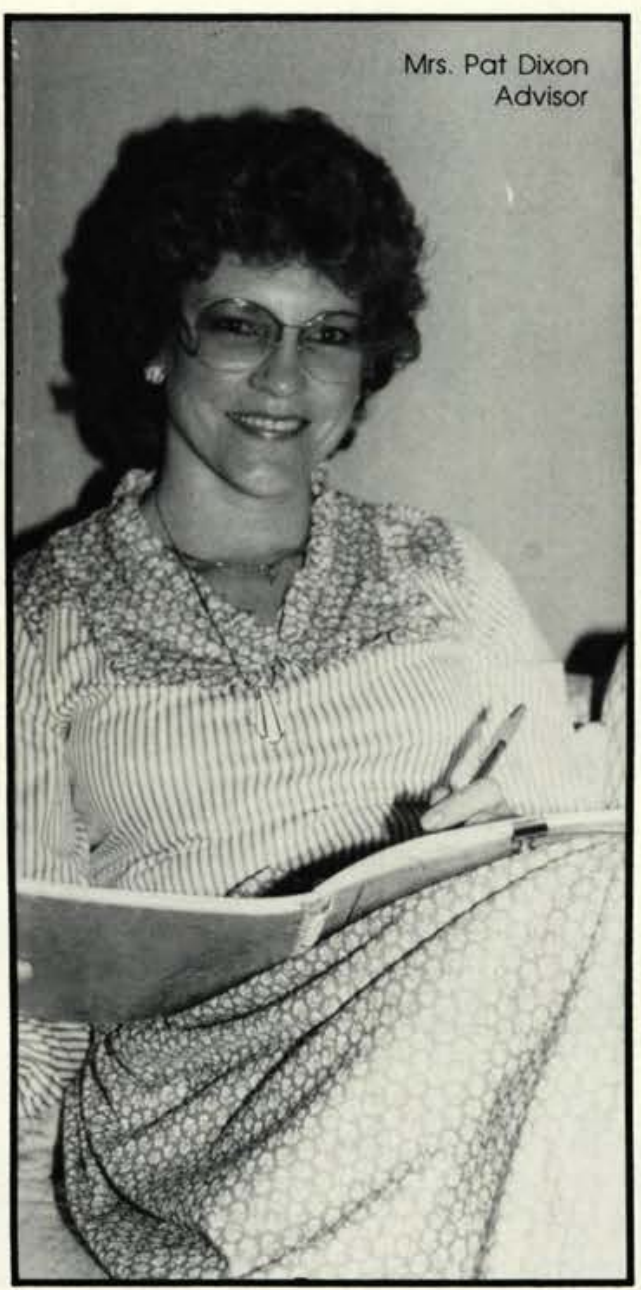

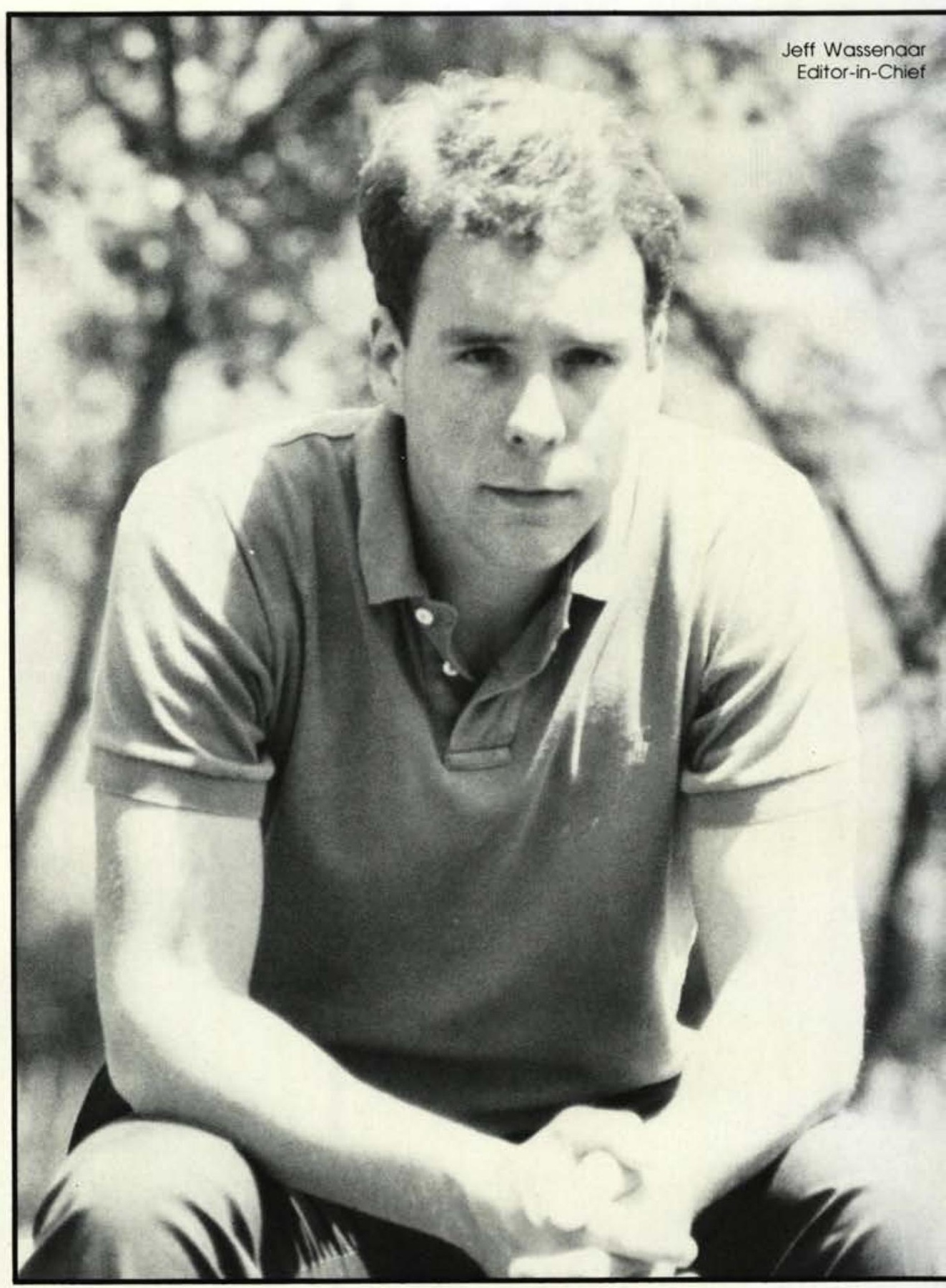
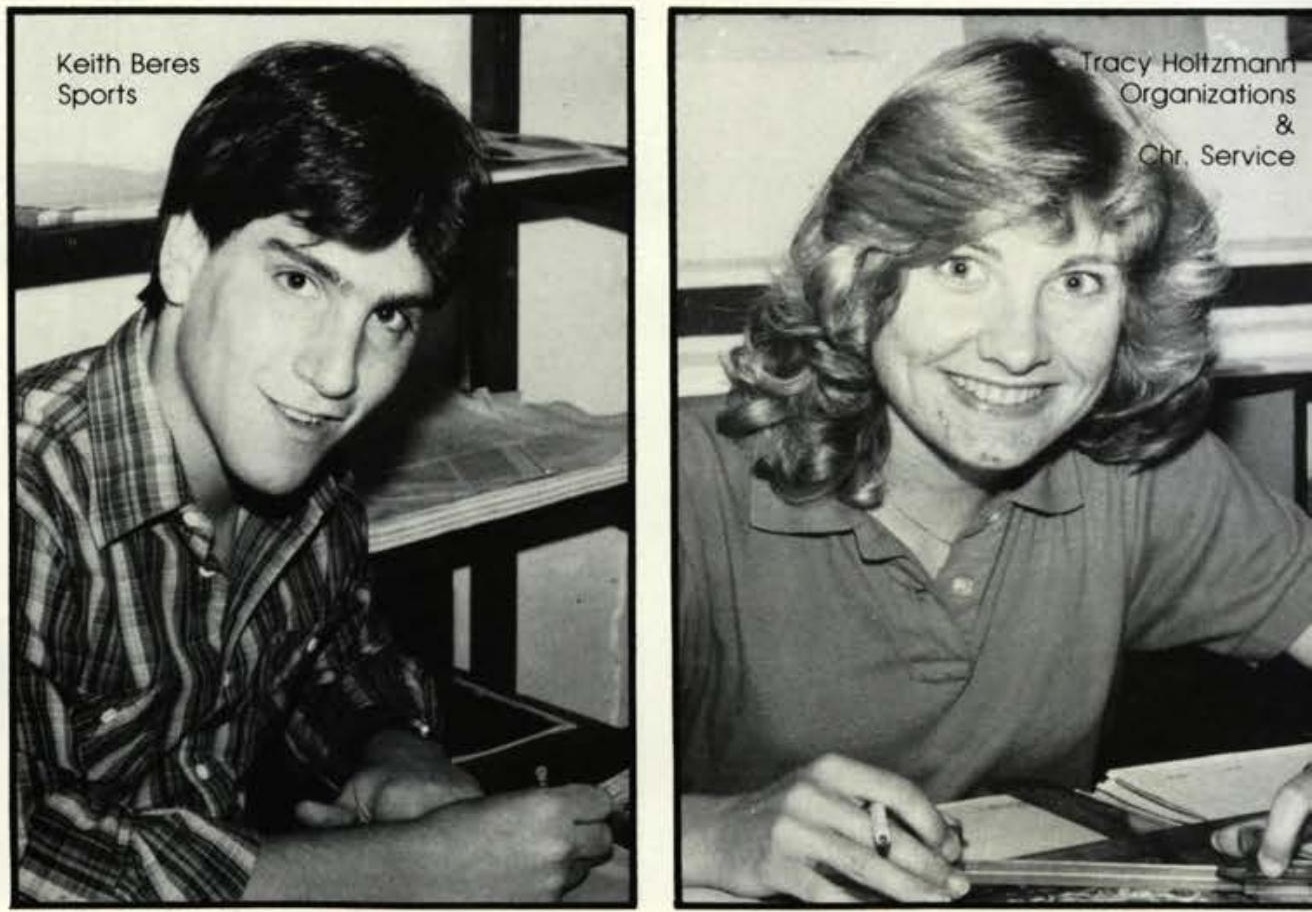


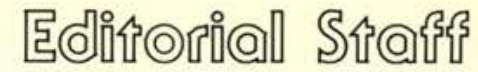
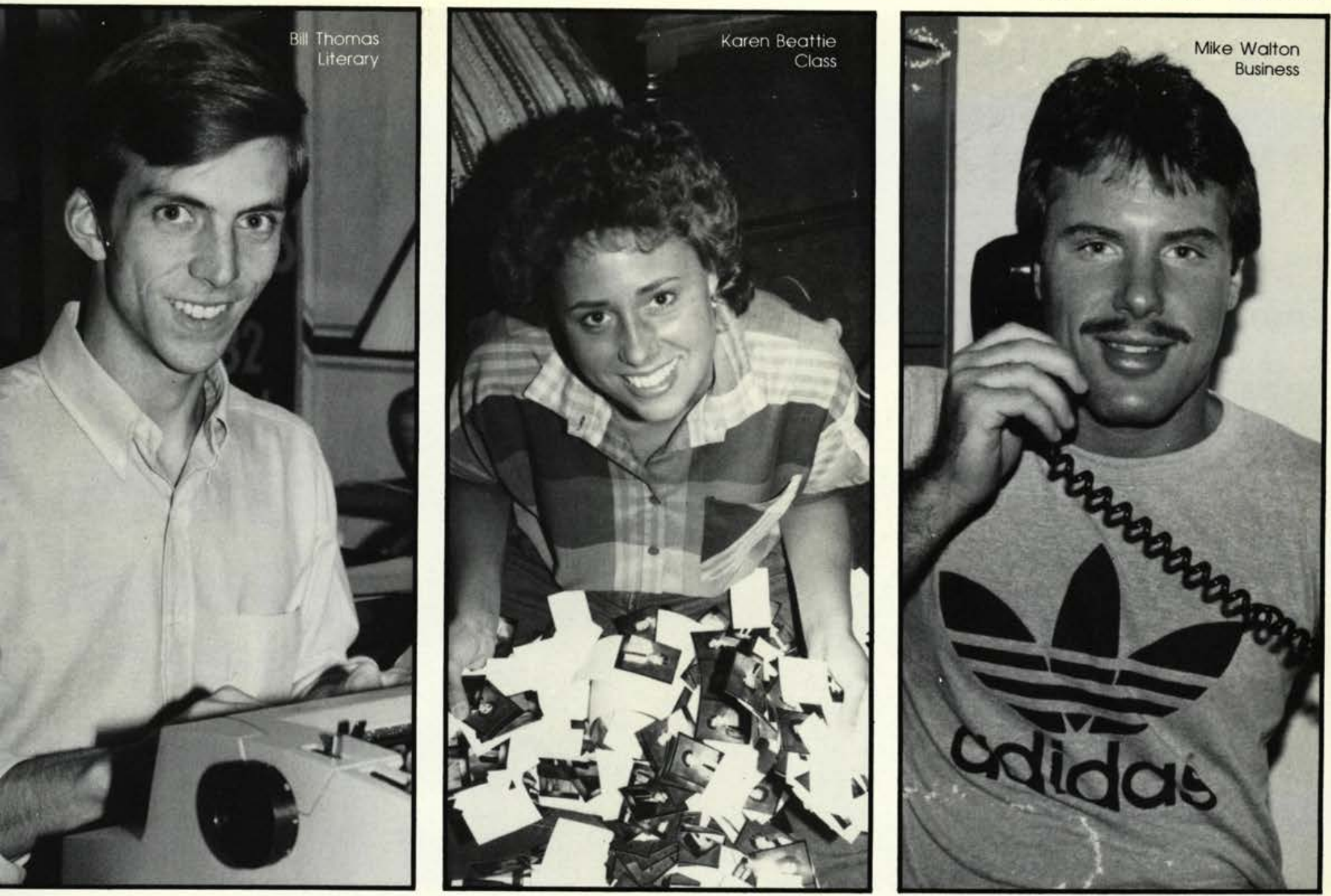

Jon Beight
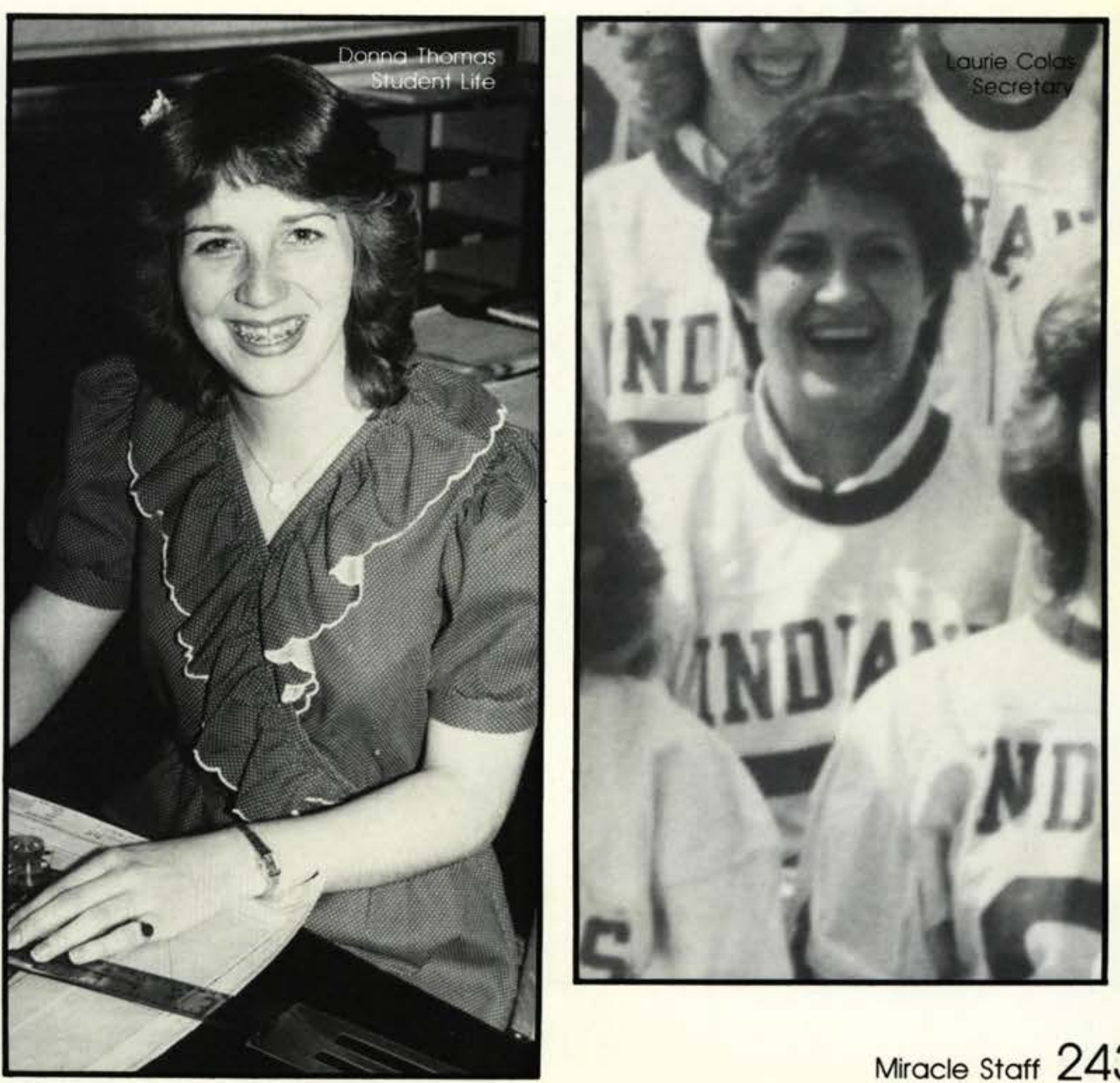

Miracle Staff 243 
Abel, Joyce A. 88

Abel, Nancy L. 50

Abresch. Cheri A, 110

Acker, Joel D, 110
Ackley, Becky L, 110

Ackley. Becky L. 110
Ackley. Melinda S. 110

Adams, Jane M. 50

Adkins, John V. 110

Adkins, Kathy M. 50

Alexander, Alise H. 98

Alexander, Alise H. 98
Alford. Kenneth L. 51

Allen, Amy S. 110

Allen, Cathy G. 110

Altimus, Shari L. 88

Ames, April L 88

Anderson, Gary B. 88

Anderson. Gary B. 88
Anderson. Hugh M. 88

Anderson, Jerald R. 98

Anderson, Jonathan L. 51

Anderson, Kurt D. 110

Anderson, Leslie M. 110

Anderson, Linda K. 110

Anderson, Lorelei 110

Anderson. Mark D. 110

Anderson, Nancy E. 110

Anderson. Regina M. 51

Anderson, Robinette 51

Anderson. Sarah J 98

Anderson. Sharon A. 110

Anderson. Wayne P. 88

Andrews. Barbara L. 110

Andrus, Tamara $L, 9$

Angell, Dawn M. 88

Anthony. Marc R. 98

Armor, Debble C. 88

Armstrong. Cynthia L. 5

Ash. Kimberlyn S. 98

Ashley. Tina L. 88

Atchley, Darrell K. 51

Atkinson. James A, 98

Auckland. Denise A. 110

Auckland. Diane M. 51
Augustus. April S. 98

Augustus. Aprit S. 98
Averill, Becky J. 110

Averill, Becky J. 110
Avery, Aprill L. 98

Ayres, Kimra L. 88

Bachelder. Kathy L. 51

Bailey. Jeffrey R. 52

Baise. Cynthia L. 11

Baidis, Susan M, 98

Baker, Katherine L. 88

Bandy. Kenneth E. 52

Bane, Kenneth D. 88

Bantle. David R. 98

Bany. William W. 98

Banzhof, Sharon L. 88

Barber. James R. 88

Barber, Robert D. 98

Barker. Gary W. 98

Barnard. Bret A. 110

Barnes, Robert W. 98

Barr. Sarah A. 110

Barram. Lorene F. 8

Barrand, Lori A. 88

Barton. Tammy J. 110

Bartus, John E. 88

Bashline. Amy E. 52

Baster, Michaelia, Debbie A. 88

Baver, Robert A. 8

Baughman, Dawn E. 98

Baughman, Dawn E. 98
Baughman, Jane M. 110

Baumgard, Gina E. 110

Beach. Melissa J. 98

Beaman, Rick A. 110

Beaman. Shellie L. 88

Beardsley, Margret L. 110

Beardsley, Margret
Bears. Judy L. 88

Beattie. Karen L. 98

Beattie, Jora J 110

Beebe, Jo A. 110

Beight. James D.

Beight. Jon D. 88

Belford, David A. 98

Bell, Debra J. 88

Bell. Tim A 88

Beltz. Jodi L. 8

Benedict, James R. 88

Benedict, Laurie A, 88

Benevides. Prudence L. 98

Bennett. Becky J. 110

Bennett. Dave J. 110

Bennett, James A.

Bennett. Rick W. 98

Bennett. Ronald L. 98

Benson, Bethany K. 52

Benson, Jay P. 88

Bensink. Kimberly J.
Berdy, Debbi L. 110

Beres, Keith A. 110

Berger. Ann C. 52

Bergman, Julie M. 88
Bernard, Jennifer D. 86

Best. David R. 110

Beste, Jeffery S. 98
Beveridge. Thomas G. 52

Beveridge. Thomas G. 5
Bickel, Deborah S. 110

Bigelow, John R. 110

Biggs. Matthew B. 9

Birch. Donna S. 52

Bires, Lee A. 52 Birtch, Donna L. 98

Birtch, Donna L. 98

Bishop. Lori E. 88

Bishop. Peter C. 98

Bishop. Timothy D. 52

Bitier, Kathieen M. 98

Bitterman, Carol S. 98

Bxier. Melissa J. 111

Black. Neil J 98

Block Suelen M. 111

Black. Suellen M. 111

Blackbum, John C. 52

Blackburn, Sara J 88

Blockburn, Thomos A. 53

Blackbum, Thomas A. 53

Blake, Susan D, 98

Blasdel. Diane L 89

Blass, Brenda L. 89

Blaylock. Valerie A. 111

Blessing. Amn E. 98

Bletzinger. Christina M. 111

Bliss, Carolyn R. 53

Bliss, Nancy J. 98

Block, Dorenda A. 111

Bloxham, Annette J. 114

Bode, Douglas A. 98

Boer, Jenny A. 53

Boersma, Joy C. 111

Boice. Lisa M. 98

Bolyard. Jeffrey S. 89

Bonenberger, Joyce I. 53

Bonning. Theresa D. 11

Booher, Don W. 53

Borden. Roy W. 53

Bose. Mark G. 11

Boulet. Jan M. 99

Bowen, Renee A. 111

Bowers, Ricky C. 99

Bowersox, Jonathan W. 53

Bowes. Aaron T. 89

Bowling. Lisa A. 111

Bowing. Robin R. 89

Bowser, David S. 53

Boyd, Alice P. 53

Boyer. Colleen R. 89

Bradey. Melinda L. 111

Brogg. Phil M. 111 .

Bragg. Stephen E. 53

Brandi. Sara J. 99

Braun. Michelle A. 99

Bresson. Chad R. 9

Bresson. Jon F. 114

Brewin. Gary Ls 5

Briggs, Laurie 111

Briggs, Laurie 111

Briggs. Linda L. 54

Briggs. Susan B. 99

Britock, Elisabeth A.

Brock, Teftrey D. 54

Brock. Timothy A. 111
Brocker, L. Down 111

Broughton. Shelly A. 111

Brown. Glen C. 89

Brown. Luke S. 111

Brown. Sandra A. 54

Brown, Tracy L. 89

Browne, Shelley L. 89

Brueilly. Kevin E. 54

Brugger, Jennifer $G$. $\varphi$

Brumm, Terri L. $\phi 9$

Buck. Martha 99

Buckholz. John R. 111

Bucklew, Elizabeth A. 99

Bucklew, Esther K. 89

Bugno. Joy E. 111

Bullock, Timothy A. 54

Bunting, Jolon D, 111

Burchett, Brenda $\infty$

Burdick. Cynthia E. 89

Burdick, Dale J. 89

Burghon. David C. 8

Burk, Steve M. 54

Burke, Holly J. 111

Burkett, Dankart, Richard D, 111

Burr, Joycelyn R.

Burtis. M. Scott 89

Burton. Mary K. 111

Butke. D. Lynn 89

Butier, Cynthia L. 86

Buter Stacey $\mathrm{L} 89$

Butier, Stacey L. 89

Butr. 54

Butzlat, Jeanne L. 11

Byrd. Warren W. 54

Byrnes, Heather $L .89$

Calhoun, Antoinette J. 111

Calisti, Lynne B. 11

Callan, Jon D. 89

Calvert, Susan K. 111

Calvin, Tana A. 111

Campbell, Jill M. 89

Campbell, Lisa A. 9

Campbell, Lyle 111

Campbell, MikeA. 99

Campbell. Steven M. 111

Carano. Darleen L. 54

Carder, Kevin L. 89

Carey. Daniel W. 89

Carmichael, Wendy E. 111

Carothers, Chris A. 55

Carpenter, Sandra S. $\phi$

Carr. Thomas A. 99

Carter, Jeffery P. 112

Carter, Teresa L. 99

Carver. Sheryll A. 55

Casteel, Lisa M. 89

Casteel. Lon R. 112

Cater, Lori L. 99

Chamberlain, Jonathan C. $\varphi$

Chance. Stephen M.

Chapman. Theodore J. 112

Charter, Melody D. 112

Chase, Christina A. $\varphi$

Chasse, Richard D 9

Cherry. Douglas E. 112

Chester, David A. 112

Chiarelli, Perry E. 112

Chitwood. Marc D. $\phi$

Christ. Charles S. 55

Christina, Amy L. 99

Christmas, David K. 99

Clark, David M. 55

Clark, Jon F. 55

Clark. Kevin M. 112

Clarkson, Becky L 9

Clyton. Cheryl L. 89

Clayton, Kathleen M. 8

Clemens, Byron C. 55

Clemens, Greg S. 99

Clements. Shelley L. 89

Clifford, Phillp E. 112

Cline, Kristine E. 112
Cobb, Jeannette D. 9

Cobine, Joseph P. 55

Cochran, Solly J. 89

Coeling. Brent W. 55

Cochran, Brent W. 55

Colfey, Maria G. 112

Coftmon, Eura 55

Colfman, Laura $L$.

Colas, Launie D.

Coleman, Melanie L. 112

Collins. Daniel N. 99

Collins. Meredith B. $\varphi$

Colon, Eduardo N. 112

Colthorp. Rebecca J.

Colvin, Tana A. 112

Comfort, Ronald D, 89

Conley, Jomes B. 89

Coniey. James B. 89

Conner, Kevin S. 11

Cook. Mary R. 100

Cook, Pamela S. 55

Cooke. Angela F. 55

Cooke, Cregan S. 100

Cooke, Gary S. 89

Cooley. Cynthia K. 112

Coons. Mary E. 112

Cooper, Diane R. 100

Corchado, Luis A. 89

Corchado. Ralph E. 90

Cornelius, Deborah A. 56

Cornish. Jerry W. 112

Corry, David M. 112

Coston. Williom T. 112

Cotton, Craig R. 90

Cotton. Traci L. 90

Cowser, Dan B. 90

Cox, Joseph L. 50

Cox, Norm D. 100

Cox, Steve M. 100
Cox, Tamarah D. 100

Cox, Tamarah D. 100

Coy, Kevin C. 56

Cramer Mark A. 90

Crampton. Teresa M. 90

Cranick, Jennifer E. 90

Craw. Cheryl L. 56 
Ely. Mitchell D. 90

Emmons, Sricia M. 90

Engdahi, David A. 100

England, Elang L 58

Engle. Sally $J 113$

English, Julia L 58

Enman, Judith A. 113

Enman, Michael 191

Ensminger. Brian S.

Entingh, Karen E. 58

Entwistle. Robert C. 58

Erdmann, Julie D. 90

Erikson, Keith M. 101

Eriandson, Dawn E. 86

Essier, Carol L. 58

Estes, Donna M. 58

Evans. Gene M. 101

Evans, Tammy A. 113

Eubank. Rhonda K. 59

Everett, Dan D. 113

Ewing. Cynthia L.

Ewing. Poul T. 91

Exiey. Jonathan L. 113

Fairhurst, Kirk A. 101

Farley. Catherine E. 91

Farley, rene J. 59

Farrow, Patricia A. 59

Fast. Denise D. 59

Fawcett, Clifford W. 113

Fawcett. Lisa C. 114
Felker, Joyce A. 59

Fernandez. Michael L. 59

Ferris, Michelle J. 114

Fetzer, Karl L. 59

Fiedler, Jan M. 114

Fields. Susan E. 59

Fields, Virginia L. 59

Fieleke, Kimberly A. 114

Figary, Wendi A. 114

Fllinger, Roderick H. 101

Fires, Robert W. 101

Firman, Debra A. 10

Fish, Laura M. 114

Fisher, Brandi 101

Fisher, Brenda J. 101

Fisher, Calvin J. 114

Fisher, Dawn A. 59

Fisher. Jody K. 114

Fisher, Lisa L. 101
Fitch. Constance L. 60

Fite. Thomas A. 10

Flach, Jodi L. 114

Fleetwood, Mark W. 101

Fleetwood. Teena M. 10

Foge, Philip R. 114

Ford. Andrew S. 114

Ford. Donna M. 91

Ford. Virginia 114

Fornell. Lorene L. 91

Forrer, Andrea L. 101

Forrest. Henry J. 101

Forter. Claire A. 114

Foulke. Samantha K. 114

Fowler, C. Tadd 91

Frank. Shelly L. 101

Frank. Sherry L. 101

Fraser, Andrew L. 101

Frazer, Andrew Vicki J. 1014

Fread, Robert 114

Freed, Todd I 114

Freeburger. Donna M. 91

Freeman, Steven E. 01

Freiger, Kevin F, 114

Frey, David C, 114

Friedland, Renee L 91

Fugett, Janice 114

Fuller. Marla S. 114

Fuler, Terri R. 101

Fultz, Joseph R. 10

Gaff. Joyce A. 101

Gainey, Daniel F. 114

Galland. Cynthia A. 91

Garbig. Darci M. 114

Carmatter, Janet S. 114

Garton, Bradiey A, 104

Gaston, Renee S. 101

Geist, Toresa A.

George, Daniel A. 91

George, Daniel A. 91

Gephart, Diane L. 114

Gerzman, Melanie A. 60

Getz, Sarn $M$.

Gibson, Jill R. 101

Gibson, Jir R. 101

Glesel, Timothy D. 101

Giesman. Kenneth A. 114

Gifford. Cathy J. 114
Gifford, Jodean M. 114

Gilbert, Jeftrey W. 114

Gles, Nancy L. 60

Goidsmith, Beth A. 101

Golemba. Brenda L. 114

Golike, Morcia M 80

Goocey. Anthony V. 101

Good. Greg L. 101

Goode, Jeriann 114

Goodman, Leslie D. 60

Gordon, Glenn T. 60

Gorham, Jerry T. 60

Gorman, Ruth E. 114

Gornewich, Theresa L. 114

Grady. Wendy J.11

Grasley. Michelle A, 101

Graybeal, Mitzi L. 115

Green, Sandra L. 10

Greenawalt, Lori A \&O

Greenley, Sarah M. 115

Greenwood, Jonathan E. 01

Greenwood. Thomas J 01

Greetham, Susan L 101

Grennel. Cynthia A. 10

Greve. Tom A. 91

Griffith, Christine R. 115

Grimes. Tracy E. 115

Grinnell, Michael D. 115

Grooms, Maxine L. 6

Grosh, Esther E. 101

Groski. William G. 115

Gruenberg. James R. 61

Gruet. Thomas J. 91

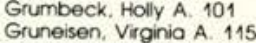

Guest. Amy J. 115

Gunther. Stocy 1115

Gust. Brenda J. 115

Haberi. Lori R. 115

Habermehl, Filizabeth A. 91

Hack. Noel M. 101

Hackbarth, John R. 115

Hackenberry. Lyn M. 115

Haines, Karen D. 115

Hale, David C. 102

Hale, Gregory A. 115

Halladay. Judson W, 61

Hammond. Dean R. 115

Hammond. Michael F. 102

Hancock. Crystal A, 102

Hancock, Keith L. 91

Hancock. Laure S. 115

Hankins. Jonda S. 115

Hannay. Scott R. 115

Happe. Judy E. 102

Harden, Joy A. 102

Hardwick, Bradley R. 115

Hardwick. Bradley R. 115

Harklerood, Joy E. 61

Harrington. Karen J. 9

Harris, Kathi J. 115

Harris, Larry L. 115

Harris, Nadine S. 9

Harris. Shelly L. 115

Harrison, Benjamin D. 6

Harsh. David E. 61

Hart. Christina J. 10

Hart. Joy A. 91

Hartsough, David A. 91

Hartsough. Laura A. 11

Harvey. Doris E. 102

Haskins, Kevin S 102

Haskowich, Anna K. 115

. 115

Hassier. Joe G. 91

Hause, Gregory E. 01

hause, Gregory E, 61

awk, Daniel 102

Hayes, Beverly D.

Haywood, Richard G. 115

tazen donet $\mathrm{L}$.

Heacox, Lary $L$ it

Headdings, Karen $Y$ Q 91

Hedges, Brian T, 102

Hedges, Rachei 101

Hedrick. Jerry C. 102

Heffelfinger, Jeffrey L. 115

Hefick. Heather M. 91

Heiland, Jefferson S 115

Helland. Kenneth D. 91

Heitzman, Diana L. 115

Helman, Kelley L. 102

Helmick. Carol L. 91

Helmick, Cynthia J. 115

Helmick, Kelly L. 102

Heimuth, Eric D. 115

Hellwig. Eric V. 6

elwig. Brian M.

Hempel, Heidi E, 102

Henderson, Matthew L. 115

Henderson. Nadeen K. 115
Henderson. Rebecca K. 02

Hennessee, Emily A, 62

Henry. Debbie K.

Henry. Lisa 8. 110

Henry. Patricia E. 80

Henry. Saundra A. 116

Herbert, Kelly J. 94

Herr. Benjamin J 91

Hert: Suzanne M. 102

Herrick, Kendall L. 110

Hershnerger. Tom 102

Hershberger. Tamra E. 91

Hess, Linda A 91 .

Hess, Lori A 01

Hess, Ruth E o

Homan . 02

Hil. Grace L 62

Hill, Joeleah J. 10

Hill, Tom C 102

Himes. Richard R. 62

Hinson, Shawn M. 9

Hippard, Lori A. 91

Hirer. Morianne J, 102

Hite, Valerie C. 116

Hobar, Karen A, 22

Hobby. Richard D. 116

Hochstettler. Virginia M. 116

Hock, Lori A. 62

Hodge, Candace S. 110

Hoecke, Beth J. 116

Holliday. Kimberly J. 91

Hoiman. Anga L 110

oiman, Kathi J. 92

Holmes. Deboran C. 102

Holt. Jeffrey T.

Holt, Keith W 92

Holtzmann, Tracy A. 63

Hood. Barbara L. 92

Hood, Robert G. 92

Hopper, Philip D. 116

Hornbeck, Bethel E. 92

Horne. Mark N. 102

Horner. Jack A. 92

Horner, Lori A. 92

Horstall, Richard G 92

Horvath, Jill L. 116

Hoskins, Barbara A. 102

Hoskinson, Joel M. 110

Howard. Ann L. 63

Howard, Lloydene C 116

Howder. Scott J. 116

Howdyshell, Dorothy E. 110

Hubbard. Catrina L. 63

Hubrard Stephen 63

Hubbard, stephen

Huddleston, Nancy A. 102

Hudlet Steven

Hudnall, Lisa J. 03

Hugan, James B. 63

Augan, Robert G. 110

Hughes, Poul R. 116

Hull, Joan M. 116

Huil, Joan $M .110$

Hunt Charlene $K$

Hunt, Judy M 116

Hunter An 110

Hunter, Corolyn A Q

Hyatt, Kristine K A. $K 2$

Hysong. Pamela L. 102

Irvin, Fayetta L. 63

Irving. John T. 116

iverson. Douglas S. 116

Jackson, Christine L. 110

Jackson, John A. 63

Jackson, Lloyd C. 110

Jackson, Melinda A. 63

Jackson, Susan R. 102

Jacobs, Becky S. 102

Jacobs, Julie M. 63

Jacobs, Robert A 102

ames. Richard D, 116

ameson, David D. 63

Jameson, Peter R. 116

Jantzi. Charles D. 102

Jaquis, Wiliom P. o4

Jayne, Leah R. 64

Jefson, Todd K. 92

Jenney. Ronald L. 6

Jennings, Lisa J. 64

Jennings, Timothy A. 92

Jessop. Connie S. 116

Jewell, Martha L. 64

Jewell, Rebekah J. 64

Jillson, Katherine J., 92

Johns, Karen A. 64 
Lane. Carl W 92

Lane, Michael C. 117

Lanham. Carla J. 60

Lanning. Edward G. 103

Laub. Andrew S. 603

Lauterbach. Sandra M. 118

Law, Michael D. 11

Lay. Kathy S. 118
Leach, Jeffrey A. 118

Leach, Jeffrey A. 11

Leach, Lori A. 93
Lee, Bill D. 118

Lee, Marc E. 103

Lee. Teresa L. 103

Lee, Todd E. 103

Leffier. William S. 55

Lewis, Carol A 60

Libby. Lynette D. o7

Libby, Lynette D. 07
Lickider, Trent E 93

Liebler. James M. 103

Lindaberry, R. Frank 118

Lindberg. Michael R. 6 ?

Lindley, Doris A. 118

Lindiner. David $\mathrm{H}$. 67

Lindsey, Lori A. 103

Link. Francis A. 93

Little. John W. 93

Liftle. Darryl C. 93

Livingston, Michele B. 118

Lombard, Catherine M. 118

Lombard. Catherine

Long. Annette M.

Long. Cyndia L. 93

Long. Linda A. 93
Longnecker. Patti S. 103
Longnecker. Sharon A. 93

Lons, Linda A. 118

Lopez. Alberto 118

Lopez. Pamela 104

Lord. Colin W. 93

Lord, Timothy C. 93

Love. Rebecca E. 93

Lowe, Denise I. 104

Loy. Kimberly A. 118

Loy. Rob D. 104

Lunstrum, Beth A. 93
Luttrell, Roger D. 93

Lydic. Amy L. 118

Lyle, Jeffrey D. 93

Lyon, Andrew P. 118

Maas, Brian E. 118

Mackenzie, Terri L. 118

MacMichael. Melissa A. 104

MacQuarrie, Debbie J. 67

Maddox, Brian D. 118

Major. Joanne K. 93

Malott, Leslie R 104

Mangrum, Vicki 104

Mangrum, Vicki 119

Manioy, James P 93

Mantz, JoAnne L. 118

Manuel, Richard C 93

Maresh, Lori A of

Marhugh, Patricia H. 104

Markey, Brett A. 104

Markley. Diana F, 67

Marling. Will H. 104

Marnott. William R. 93

Marshall, Holly S. 118

Marshall, Melissa A. 104

Marshall. William P. 104

Martin. Apri D, 118

Martin, Jay W. 104
Martin. Michele J. 93

Martin, Wes C. 118

Martin. Willam S. 118

Mcson, Rodney M. 104

Mason, Ruth M. 104

Massie, Kristi E. 104

Mast. Clifford L. 104

Masters. Lois K. 104

Masters, Lynda L. 118
Mathews. Bryan K. 118

Mathews, Dawn K. 67

Mathews. Karen L. 93

Mathewson. Melanie A. 93

Mathewson, Melanie
Mathis, Kelly R. 118

Matson, Steven J. 104

Matthes, Jennifer L. 104

Masxon, Lauren D. 118

Mazey, Willam J. 93

McAllester, Sharon R. 118

McAllster, Michael S. 104

McBrayer, Ball 93

McBrayer, Terry G. 118

McBrayer, Terry G. 118

MCColl, Donold A. 93

McCauley Did A 93

McCauley, Diane R. 118

McConnell, Dione L 118

McCormick, Lois I. 67

McCoy. Jit 93

McCoy, Tracy L 118
McDaniels, Carol J. 93

McDonald. Lisa K. 104

McElroy. Laura C. 93

McGhee, Fath A, 104

McGill, Richard D. 104
McGilivray, Margaret E 118

McGilivray, Margaret E

McGraw, Camile A. 104

McGraw, Edwina L. O

Mc Guire. Sara 104

Mclaughin. Michael J. 119

MCMillan, Diane L. 67

McNabb, Bruce R. 104

McNeish, Marilyn J. 104

McNeish, Marsha A o7

McVey, David J. 10

Mead John P 68

Meadows, Karen S. 119

Mears, Gregory S. 93

Mears. Julie K. 86

Meeks. Charies R, 68

Meoak. Robert P. 119

Merchant, Brad C.

Merck, June L. 08

Messick. Don w 93

Messinger Dano 93

Mever, Ruth L 93

Meyer, Stephen A 119

Michael, Elena M 104

Michel, Britt C 119

Mlevoi, Suzanne 58

Miler, Annette M. 58

Niller, Douglas J 94

Milier, Larry E, 104

Miler, Philip $G$ o 8

Miller, Rebecca S. 94

Milliken. Jill A. 80

Mils, gory L. 94

Milis. Susan G. 94

Mitchell, John G. 110

Mitchell, Mark J. 104

Mitchell, Scott D. 119

Moats, Diane M. 86

Modderman. John R. 105

Modesty. Bonnie 105

Moeser. Jean M. 105

Motfitt, Greg A 68

Mohr, Judith L. 88

Moll, Jim B. 105

Moncriet, Mary L. 68

Monroe, Randall C. 94

Montross. Bryan E. 119

Moody, David L. 94

Moore, Dale D. 105

Moore, Danny L. 94

Moore, Reda A. 68

Moore. Robert L. 119

Moore. William S. 68

Moran, Gregory S. 119

Morgan, Michael B. 68

Morgan, Victor M 60

Morris, Dan L. 119

Morton, James W.R. 105

Morton, James WIR.

Moser. Susan J. 105

Moses. Mark A. 105

Mosher, Canla A. 89

Mosher, Chanies H. 105

Mosiey. Dana J 69

Mossman. Jeff A. 89

Motzer, Lisa A 1 ,

Mowry, David H. 94

Mover. Chad V. 119

Moyer, W. Scon 105

Muebscher. Mark D. 119

Mukes. Cicero C. 94

Mulholiand. Dan E. 105

Mullen, Lori L. 119

Mulligan, Steve J. 94

Munson, Robert H. 119

Murdoch, James M. 119

Murphy. Deborah J. 119

Murphy. Kimbra K. 94

Murphy. Sharon L. 69

Murray, Julie D 69

Murray. Michael H. 69

Murrin. Alicia M. 105

Musselman, Rex A. 94

Myers, Kim A. 94

Mytelt. Dwight D. 94

Magy. Charon J. 69

Nash. Deborah L. 69

Neal. Shella L. 119

Nelson, Andrew R. 119

Nemitz, Mark A. 119

Nemecek. RoseAnn 105

Nesport. Jill M. 105
Nester, Beth A. 119

Neudeck, Edward W. 105

Neudeck. Melanie J. 94

Newman. Nancy M. 69

Newton. C Laniya 69

Nicholas. John A. 94

Nichols, Kenneth N. 119

Nichols, Senneth R. 105

Niehoff. Cindy J. 119

Nckel, Sue E. 105

Nickell, Kenneth A. 94

Nickoson, Krista

Nissen, Robin S. 119

Nonnemacher. Gary S, 105

Norden, Greg S. 119

Norrick. Sherri L 119

Norris. Lisa S. 119

Norvell. William B. 105

Norvell, Wiliam B. 105

Noyes, Linda S. 94

Nuet. Tamra $k, 4$

Nuss, Randy S 94

Oakes, Judith E. 105

Oberle, Connie B. 119

O'Boyle, Sandra J. 120

O'Conner, Rebecca E, 105
O'Donnell, Patrick A. 94

O'Neal. Joseph R. 70

O'Wade, Daneen J. 86

Olinger, Danny E,

Oljace. Kim E. 94
Olson, Barbara J. 105

Olson, Brian E. 70

Olson, David S, 69

Ottaway. Diane S. 105

Owen. Jane E. 70

Oyes, Nathanael G, 120

Page. Russel S. 120

Pagnotti, Patricia C. 105

Palmer. Arlan E. 70

Palmer. Teresa J. 120

Paolino. Paul I. 70

Papp, Dennis M. 94

Papp. John J. 120

Park. Martyn R. 94

Parker. Jerry A. 105

Parks. Jill M. 9

Parman, Kristine K. 105

Parris. James A. 70

Parsel. Kristina D. 120

Parsons, Joan E. 94

Pate, Deborah C. 120

Patterson. Dennis 94

Patton. Susan E. 70

Pauley, Max O. 120

Payton. Rebecca D. 70
Payton. Thurman R. 120

Pearson, Helen M. 94

Pearson, Marianne 94

Pedersen, Ellen M. 94

Pensworth. Donald L. 105

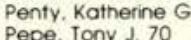

Pepe. Tony J. 70 Merkins, Rhonda M. 120

Perks, in 94

Perry, Lynn B. 94

Petek, Daniel C. 120

Peters, Jo-Ellyn M. 105

Peters, Steven A. 94

Peters, Timothy B. 70

Peterson, Heidi S. 94

Peterson, James E. 70

Peterson. Joan E. 94

Peterson, Marsha L 70

Peterson, Steve R. 120

Peterson, Teri L. 94

Peterson, Thomas L. 120

Pfuelb. James M. 94

Phillips, Amy L. 120

Philips, Charie E. 71

Philips, Cheryl A. 94

Phillips, Imothy S 105

Phillips. Tod L. 94

Pitonyar, Lori J. 94

Plaga. Gladys C. 120

Plett, Stanley K. 105

Plunket. Keith A. 94

Polsdarfer. Shelley M. 105

Polsdorfer, Wesley D. 71

Polson, John M. 120

Ponzani. Chrissy J. 105

Posey. Deborah L. 120

Porter, Frank H. 94

Powell, John T. 71

Powell, Rae A. 120

Power, Kathryne D. 94

Powers, Rick A. 94

Potts. Kim E. 120

Pickering. David J. 71
Pierce. Stephen M. 120 


\section{Index}

Roy. Tracy A, 105 Ruby, Darren L. 121 Ruft. Mary E. 121

Range, Judy L. 106
Russell, Kimberly D. 121

Saathoff. April J. 73

Sadler, Gregg C. 121

Sagraves. Stephen E. 7

Saliee. Glen W. 105

Sand, Robert M. 105

Sandy. Jill A. 121

Sanford, Barbora A. 95

Santee. Scott A. 121

Sargent, Mark L. 73

Saucier, Jean M. 73

Sounders. Shannon M. 121

Schaedel, Jan M. 95

Schakat, Timothy M. 121

Schellhase, Mary L. 121

Schneider, Barbara A. 121

Schneppe, Shirley J. 105

Schanfeid, Deborah S. 95

Schramm, Kay L. 95

Schrock. Ariin O. 74

Schrock, Loretta B. 74
Schroder, Jewel K. 95

Schroder, Jewel K. 95
Shultz, Melody A. 122

Shultz, Melody A. 122

Schulze, Warren D. 74

Shuttenberg. Monica L. 122

Schwartz, BonnieA. 95

Schwartz, Deborah S. 122
Schweinsburg. Larry W. 95

Scott. Gloria B. 74

Scott, Robert A. 12

Scott. Susan J. 74

Scouten. Sharon R. 95

Seager, Keith A. 100

Searies. Daniel R, 122

Seevers, Shawn D. 122

Seidel, Erick J. 122

Seipelt, E. Yvonne 106

Selden, Annette J. 74

Sellers, Forrest R. 122

Sewal, Suzanne $M 74$

Shaffer, Linda $L$, 122

Shannan, Todd E 105

Shannan, Todd E. 105

Sharper. Richard P. Kevin A 122

Shawbock, Margaret A. 122

Sheldrake. Theodore J 122

Shelkey. J. Dovid 122

Shepard. Tina L 122

Shepherd, Charles E. 95

Shepherd, cavid M. 106

Sherman, Michael H 95

Shomo. Robert E. 74

Shrum, Eric L. 122

Shulse, David F 95

Shupert, Teena Y. 95

Sidle. John E. QS

Siefert, Marlene K. 105

Siegle, Connie M. 74

Silver, Carol A. 74

Silver, Holly L. 105

Simkins. Douglas S. 122

Simpson. Karen J. 95

Simpson. Kent N. 74

Simpson, Sydney M. 122

Sjoquist, Sandra F. 74

Slater, Craig W. 75

Sloughter, Kelly E. 75

Staon, Tammy W. 106

Sloop. Kim L. 122

Slyby. Dave M. 106
Skiles. David M. 122

Skinner. Nora K. 95
Smallman. David A. 122

Smallman, David A.

Smart, Linda A. 95

Smith, Benjamin P. 107

Smith, Benjamin P,
Smith, Betty M 107

Smith, Bob J 122

Smith, Bob J. 122

Smith, Carmon G. 107

Smith, Carol S. 75

Smith. Charles W. 122

Smith. Cheryl 122

Smith, Kelly S, 107

Smith, Laura i. 122

Smith, Laura L. 122

Smith, Marcia 122

Smith Pamela $M$

Smith, Phonda $\mathrm{K} .122$

Smith, Rodney N. 95

Smith, Ronald D 95

Smith, Ronald M 122

Smith, W. Martin 75

Smyth, Dave A. 95

Snare, Karen M. 75

Snider, Gregory A. 122

Snodgrass, Rust A., 122

Snook. David H. 75

Snook. Ruth L. 95
Snyder. David R. 95

Snyder, Dianna K. 95

Snyder, Jayne M. 107

Snyder, Rebecca L. 107

Sober, Rebecca J. 122

Sober. Stan D. 107

Soliz, Antonio R. 122

Sommers, Rhoda C. 75

Sorgius, Melinda J. 107

Sparks, Jeftery W. 95

Sparing. Jane M. 95

Spear, Laurie A. 75

Spencer, Ellen R., 95

Spradin Andrea G

Sprodin, Andrea G. 95

Sproding. Cheryl 75

Springer Somut 1

Springer, Samuel T, 122

Sprowis, John P. 95

Stackhouse, Julie L. 122

Stagg. Karen S 107

Staley, Karen S. 107

Stamm, Diane E, 123

Starks. Charles T, 75

Starr. Crystal $L$ 107

Stautfer, Deiores I. 123

Stebbins, Gay L 123

Stebbins, Jill M 123

Steinbruegge, Brian E. 123

Stewart, Timothy L. 75

Stith, Wendy A. 123

Stockham, Robin M. 107

Stoltzfus, Cindy M 107

Stone, Christine L. 107

Stone. Elaine E. 95

Stone, Jon W. 107

Storer, Jil K. 123

Stork, Jennifer L. 76

Stover. Lynn B. 76

Stover. Verion C 123

Stowell. Ronald L. 123

Strait. Andrew R. 107

Strock, Loretta M. 75

Stuebe. Denice L. 107

Stuber. Vicki L. 107

Sturgis. Barty L. 96

Stutesman, Elizabeth A. 107

Summerville. Kurt L. 123

Sunderman, Karen S 107

Supplee, Edward R. 95

Swander. Allen S. 75

Swander. Mark A. 123

Swanson, Lisa A. 76

Swanson. Lisa A. 76

Swanson, Pam M. 12

Swayze. Jil A. 123

Tatt. William G. 107

ait. Steven P. 123

Tancred, Todd N. 96

tavierne, Richard S. 10

Taylor, Allison K. 123

Taylor. Barbara J. 96

Taylor, Brian K. 96

Taylor. Diane 107

Taylor, Gayle A. 107

taylor. Janet E. 75

Taylor. Joel K. 96

Taylor. Walter L. 123

Teall, Thomas W. 75

Tedford. Rujeana B, 10

Templin. Mike J. 70

Tenney, Leda J. 76

Terkelsen, Franklin L. 107
Terpenning. Darrel W. 107

Terpstra, Steven K.

Teril. Nadine L. 123

hacker. Don 107

Thane. Brent D. 96

Thane. Michael A. 77

Thibo. Connie L. 96

Thomas. Amy R. 123

homas, Donna J. 123

Thomas, Judith A. 77

Thompson, David K, 107

Thompson, John 107

Thompson Jil A. 123

Thorton Lydio B. 123

Tice, Sheri G 107

ilford Sheri G. 107

Iinner. Deboroh 177

inner. Deborah Li, 77

Iinner, Mark A. 107

Iifus, Alan D, 123

Tood. Edward M. 123

Todd. Kevin J, 96

Tom, Donald E, 10

Iome, Debra J. 96

Towne, Theodore D. 77

Irautman, Michoel L. 77

Irautman. Wayne C. 107

Treese, Cindy L. 7 7

rrexier. Im S 107

Trivett, Phylls. M. 123

Trueman. Rhonda R. 107

Trupp. Elaine Y 107

Tucker. Alvin D. 96

Tupps. Christopher S. 96

turner. Robert J. 123

Turner. Tracy L. 90

Tyson, Lisa $L 123$

Uimer, Jeffrey T. 96
Unger, James A. 96

Van Meter, Scott W. 123

Van Wingerden. Robert J. 123

van Wingerden. Rober

Vander Heide, Jeffrey C: 108

Vanness, Barbara K. 108

Vantrease, Cindy R. 96

Vantrease, Kathy D. 123

Vaughn. Beth A 123

Vaughn, Susan C. 108

Venman. Kimberlee S. 108

Vigor. Ginger M. 98

Vissman. Bridgot $K$ 108

$V$ oth, John D 96

Wagner, Dean 77

Wagner, Donald A. 77

Wagner. Joy M. 108

Wagner, Rhoda G. 96

Wainwright, James H. 77

Waldo, Jeff A. 78

Walker, Cynthia D. 124

Walker, Cynthia D. 124

Woker. Joseph A, 78

Waker, Laura है. 108

Waker, Michoel A. 108

Wallace, Daniel F, 78

Walace Gerald $C$ 12

Wallace, Gerald C. 12

Wallace, Janel M.

Walse. Kevin L 124

Walter

Walter Daniel $t$

Walter. Daniel L 124

Walter Mank H. 96

Walter. Ronald E. 108

Walter. Steven P, 124

Walters, David $M$.

Walton. Judy A, 96

Waltrip, Elizabeth A. 124

Waltz. Brenda T. 124

Ward. Jacqui C. 85

Ward, Kelly S o5

Ward. Robert K. 10

Wartle, Brian 108

Warner. Ted D 124

Warren, Janice 124

Wossencar, Jett $H .96$

Wasson, Debra E. 108

Watson, Robert K. 124

Watson, Sherri L. 108

Veaver, Diane L 108

Webb. Karen S. 78

Webb. Kayla R. 78

Webber, Bruce R. 96

Weber, Kristin R. 124

Wedge. Thomas W.

Weidman. Christine R. 108

Weindort, Jason J. 108

Weisenflun, Kurt V. 108

Welch, Mary E. 108

Welsher, Mark R. 96

Wells, Mary L 108

Wemett. James W. 108

Wemett, Steve M 108

Wenrick, Jettrey S. 78

Wenz. Poul S. 124

Weston Judith J 10

Weston, Judith J. 108

Welzel, Stephen A. 79

Whispler. Anita k. 108 


\section{Faculty:}

Abbas, Robert 20

Ager, Merlin F. 20

Alyn, Irene B. 20

Anderson, Lyle J. 20

Baker, J. Wesley 20

Baker, Sue H. 20

Baldwin, Richard E. 20

Ballard, Stanley 20

Bartholomew, Ray E. 20

Bates, Patricia L. 20

Bauer, Janet A. 20

Bauman, Donald P. 20

Bergen, Harmon 20

Biddle, James R. 20

Biddle, Sharon 20

Bonenberger, Omer E. 20

Bosma, Jan M. 20

Braithwaite, Edwin S. 20

Brock, Lynn A. 20

Brown, Debra L. 20

Brown, Elaine L. 20

Brown, Stephen P. 20

Callan, Donald E. 20

Clark, Martin E. 20

Clevenger, Charles 21

\section{Staff:}

Ager, Ruth A. 25

Angela, John 26

Auckland, Mary 26

Auckland, Robert C. 26

Baldwin, Martha M. 26

Beikert, Grace A. 26

Beikert, Robert 26

Bergen, Audrey L. 26

Berger, Curtis E. 26

Bertschinger, Betty 26

Blackburn, Beth E. 26

Boley, Brenda 27

Bowersox, Richard 27

Brown, Mark A. 27

Burrichter, Margaret 27

Cagwin, Deboah 27

Campbell, Fran 27

Campbell, Jack N. 27

Carr, Alberta M. 27

Cato, James D. 27

Cato, Melody J. 27

Chaffe, Stuart 27

Cole, Harry E. 27

Compton, Deborah J. 27

Conklin, Emily C. 27

Conklin, Wilma J. 27

Coriell, Ron J. 27

Couch, Robert 27

Coy, Sherry G. 27

Cunningham, Jeffery 27
DiCuirci, Michael 20

Diehl, Pamela S. 21

Dillon, Charles A. 21

Dixon, Pat L. 21

Dolph, Charles D. 21

Durham, Richard D. 22

Eimers, Lee 22

Eimers, Sharon L. 22

Eillington, Charles L. 22

Fawcett, Clifford W. 22

Fisher, Jean R. 22

Flentge, Dennis R. 22

Frank, Dwayne I. 22

Glanville, Ellen E. 22

Greenwood, Edward L. 22

Gromacki, Robert 22

Grosh, Ronald M. 22

Hall, Helen L. 22

Halsey, Joseph G. 22

Harner, Sandra W. 22

Helmick, Larry S. 22

Horner, Deborah L. 22

Hunt, Karol 22

Danube, Derena L. 27

Day, Jeannie 27

DeMeester, John R. 27

Divan, Linda A. 27

Elmore, Marabeth 28

Farrow, Patricia A. 28

Fires, Judith A. 28

Fissel, Nancy 28

Gaffner, David C. 28

Gathany, Paul H. 28

Gidley, David L. 28

Gidley, Irene J. 28

Green, Margaret M. 28

Greenwood, May E. 28

Grooms, Dewayne 28

Hall, Hugh T. 28

Halladay, Lorraine A. 28

Howell, Agnes C. 28

Huber, Trish J. 28

Hubler, Sherry L. 28

Hubler, Stephen A. 28

Hunt, Helen R. 28

Hunt, Leigh R. 28

Johnson, Judy A. 28

Kendall, Harold D. 28
Johnson, Martha J. 22

Phipps, James R. 25

Phipps, Terry L. 25

Kempf, Betsy L. 22

Killian, Lawrence N. 22

King, Elvin R. 22

Klimek, Mark R. 22

Larson, H. Mark 22

Leightenheimer, James

O. 23

Loach, Barbara 23

Matson, David L. 23

McClure, Philip 23

McGillivray, John 23

McGoldrick, James E. 24

Mclntosh, Richard T. 24

Monroe, Allen L. 24

Monroe, Beverly S. 24

Moreland, Kurt D. 24

Murdoch, J. Murray 25

Pagnard, Charles M. 25

Parr, Robert G. 25

Parvin, Donald A. 25

Percesepe, Gary J. 26

Kendall, JoAnne E. 28

King, Helen T. 28

Knauff, Nancy A. 28

Kolar, Michelle L. 29

Kuhn, Gary P. 29

Kunkel, Matt E. 29

Larson, Susan D. 29

Lee, Patricia J. 29

Lichtensteiger, Diane L. 29

Liddle, Sheryl D. 29

Maddox, Bruce 29

Mathews, Mark E. 29

Matson, Rebecca 29

McDougal, Mark 29

McIntosh, Barbara 30

Mick, Bernice M. 30

Miller, Cheryl A. 30

Murdoch, Emma 30

Ormsbee, David M. 30

Potter, John 30

Printy, Beatrice H. 30

Purrington, David R. 30

Rawson, Sharon R. 30

Rayburn, Ethel J. 30
Rayburn, Marlin L. 25

Rich, Anne N. 25

Riggs, Jack R. 25

Robey, David H. 25

Rogers, Rex M. 25

Seaman, James 25

Seaman, Lila M. 25

Silvus, John E. 25

Slocum, Ruth E. 25

Smith, Galen P. 25

Smith, Sarah H. 25

Spencer, Edward E. 25

Stahl, Karl N. 25

Walker, Ronald J. 25

Warren, W. David 25

Wetzel, Daniel E. 25

Young, Stephen W. 25

Samuel, David W. 30

Shirey, Deborah 31

Simpson, Lynne M. 31

Sjoquist, Douglas W. 31

Smith, Michele M. 31

Smith, Roscoe F. 31

Spencer, Dorthy 31

Stahl, Mary E. 31

St. Clair, Ida B. 31

Street, Joan L. 31

Sturgis, Kathleen 31

Taylor, Virginia M. 31

Tocknell, John 31

Vickman, Bonnie J. 31

Vickman, Jeffrey A. 31

Vine, Allan 31

Walker, Dick 31

Ware, Paul 31

Witzel, Phyllis A. 31

Wilcox, Faye 31

Wolfli, Cynthia Y. 31

Womack, Amy 31

Womack, Glenda J. 31

Womack, Mark E. 31

Youngman, Myron L. 31 
$\vec{b}$ 


"Whatever You Do.

Work At it With All Your Heart, As Working For The Lord, Not For Men."

Col 3:23

N.I.V. 